EURYCIBIADES BARRA ROSA

\title{
INDICADORES DE DESEMPENHO E SISTEMA ABC O USO DE INDICADORES PARA UMA GESTÃO EFICAZ DO CUSTEIO E DAS ATIVIDADES DE MANUTENÇÃO.
}

Tese apresentada à Escola Politécnica da Universidade de São Paulo para obtenção do título de Doutor em Engenharia

v.1 


\section{INDICADORES DE DESEMPENHO E SISTEMA ABC O USO DE INDICADORES PARA UMA GESTÃO EFICAZ DO CUSTEIO E DAS ATIVIDADES DE MANUTENÇÃO.}

Tese apresentada à Escola Politécnica da Universidade de São Paulo para obtenção do título de Doutor em Engenharia

Área de Concentração:

Engenharia de Produção

Orientador:

Prof. Dr. Israel Brunstein 
Este exemplar foi revisado e alterado em relação à versão original, sob responsabilidade única do autor e com a anuência de seu orientador.

São Paulo, de maio de 2006.

Assinatura do autor

Assinatura do orientador

FICHA CATALOGRÁFICA

Rosa, Eurycibiades Barra

Indicadores de Desempenho e sistema ABC: O Uso de Indicadores para uma Gestão Eficaz do Custeio e das Atividades de Manutenção / E. B. Rosa - ed.rev. - São Paulo, 2006.

2v.

Tese (Doutorado) - Escola Politécnica da Universidade de São Paulo. Departamento de Engenharia de Produção.

1.Manutenção industrial 2.Indicadores de desempenho 3.Custeio baseado em atividades 4.Gestão por indicadores 5.Planejamento e Controle I. Universidade de São Paulo. Escola Politécnica. Departamento de Engenharia de Produção II.t. 
Aos meus filhos Rogério, Marilia, Léo e Lucas, ao meu neto Michel e à memória de minha mãe Ana que voltou aos braços de Deus, após 90 anos de uma vida produtiva. 


\section{AGRADECIMENTOS}

Em primeiro lugar a Deus, fonte de toda sabedoria, pela força, coragem e inspiração, permanecendo fiel ao meu lado em todo o percurso desta etapa importante de minha vida.

Ao amigo e orientador, Prof. Dr. Israel Brunstein, pelas diretrizes seguras e permanente incentivo para que este trabalho chegasse a um resultado definitivo.

Ao Prof. Dr. Antonio Rafael Namur Muscat, pelas preciosas sugestões e contribuições para o enriquecimento do texto.

Ao Prof. Dr. Edson de Oliveira Pamplona, pelas sugestões oportunas no desenvolvimento do trabalho, apoio e estímulo.

Ao Prof. Dr. José Arnaldo Barra Montevechi, pelas palavras de força e de apoio moral nos momentos mais difíceis.

Ao Prof. Dr. Luiz Gonzaga Mariano de Souza que, através do Instituto de Produção e Gestão da Universidade Federal de Itajubá, ofereceu esta preciosa oportunidade.

Aos colegas e amigos da IMBEL e da AREVA pela colaboração, incentivo e estímulo.

Aos amigos e colaboradores da MAHLE, particularmente aos Engenheiros João Vitor Zanesco, José Maurício Torneli e, especialmente, ao estagiário Adriano Fernandes Carvalho que emprestaram um irrestrito apoio para que este trabalho pudesse ter sido levado a termo.

A minha esposa Rosângela, pelo estímulo, paciência e incansável apoio.

A todos que, direta ou indiretamente, colaboraram na execução deste trabalho. 


\section{RESUMO}

Os rumos atuais da competição e da tecnologia justificam a crescente utilização de indicadores para a gestão dos recursos produtivos nas organizações industriais. Nesta linha de pensamento, o presente trabalho discorre sobre as principais abordagens relacionadas com gestão competitiva, construção de indicadores e métodos de custeio, disponíveis na literatura. Com base no modelo gerencial do Prof. Nigel Slack, para agregar vantagem competitiva na manufatura, é desenvolvido um sistema de indicadores integrados para a gestão do custeio e das atividades de manutenção. $\mathrm{O}$ modelo de gestão é validado por intermédio de um estudo de caso real e os resultados obtidos demonstram a eficácia do sistema de indicadores no monitoramento das atividades de manutenção nas empresas industriais. 


\begin{abstract}
The current trend in terms of world-wide competition and technological skills justify the increasing utilization of constant up-to-date information and decision-making data in manufacturing organizations. Accordingly, this work discusses the major contributions related to a world-class management, performance metrics and costing methods. Based on Nigel Slack's management model proposed to increase competitiveness, an inter-related performance metrics system is developed, aiming to reduce maintenance cost and to improve the overall maintenance activities management. The management techniques proposed in this research is validated by its application in a real manufacturing company, selected for a case-study. This research shows that the data collected allows statistical analysis and helps a plant management team to get important conclusions about the effectiveness of the performance metrics proposed for maintenance management.
\end{abstract}




\section{SUMÁRIO}

LISTA DE TABELAS

LISTA DE FIGURAS

LISTA DE QUADROS

LISTA DE ANEXOS

\section{LISTA DE SIGLAS}

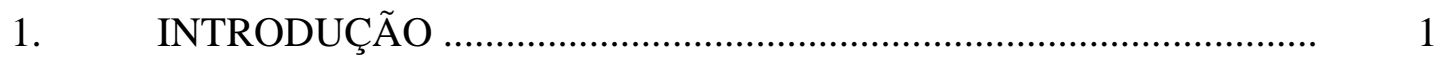

1.1. Considerações Iniciais ....................................................................... 1

1.2. O Projeto de Pesquisa ....................................................................... 3

1.2.1. Objetivos Geral e Específico .................................................................. 4

1.2.2. Hipóteses - Indicadores Gerenciais .................................................... 5

1.2.3. Variáveis de Pesquisa ........................................................................ 6

1.3. Justificativas .............................................................................. 6

1.3.1. Gestão dos Processos Produtivos ......................................................... 7

1.3.2 Melhoria do Desempenho da Função Manutenção ................................ 7

1.3.3. Utilização das Políticas de Manutenção ................................................ 8

1.3.4. Apuração dos Custos de Manutenção ................................................... 10

1.4. Organização do Relatório Final ........................................................... 12

2. AS TEORIAS DE BASE .............................................................. 14

2.1. A Avaliação do Desempenho ............................................................ 14

2.1.1. Considerações Iniciais ..................................................................... 14

2.1.2. O Desempenho e seus Componentes .................................................. 16

2.1.3. O Modelo de Avaliação Segundo Sink e Tuttle ..................................... 18

2.1.4. O Modelo de Avaliação Segundo Slack ................................................. 22

2.1.5. Considerações Finais ............................................................................ 24

2.2 A Construção de Indicadores Gerenciais ............................................. 26

2.2.1. Considerações Iniciais ..................................................................... 26

2.2.2. Indicadores, Parâmetros e Medidas ...................................................... 27

2.2.3. Requisitos Operacionais ................................................................. 28

2.2.4. Utilização de Padrões ............................................................................ 34

2.2.5. Seleção de Indicadores ....................................................................... 36 
2.2.6. Considerações Finais ..................................................................... 42

2.3. A Função Manutenção na Indústria ..................................................... 43

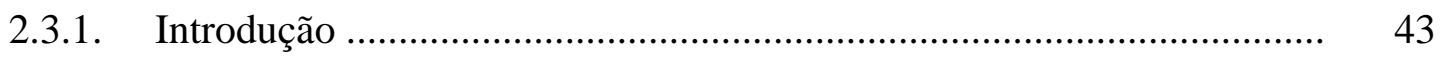

2.3.2. Histórico ............................................................................................ 44

2.3.3. O Conceito de Manutenção .................................................................. 48

2.3.4. Confiabilidade, Manutenibilidade e Disponibilidade ........................... 51

2.3.5. Prevenção e Recuperação das Falhas ................................................... 66

2.3.6. As Políticas de Manutenção .................................................................. 76

2.3.7. Gestão da Manutenção Industrial ...................................................... 85

2.3.8. O Uso de Indicadores na Gestão da Manutenção ................................. 95

2.3.9. Considerações Finais ..................................................................... 109

2.4. $\quad$ A Gestão dos Custos Industriais ........................................................ 113

2.4.1. Considerações Iniciais .................................................................... 113

2.4.2. O Sistema Tradicional de Custos ........................................................ 115

2.4.3. Limitações dos Sistemas Tradicionais de Custos ................................ 119

2.4.4. O Método de Custeio ABC - Activity Based Costing ......................... 122

2.4.5. Gestão Total dos Custos ................................................................. 140

2.4.6. Considerações Finais ...................................................................... 142

2.5. Conclusões .................................................................................. 143

3. O REFERENCIAL TEÓRICO ….................................................... 145

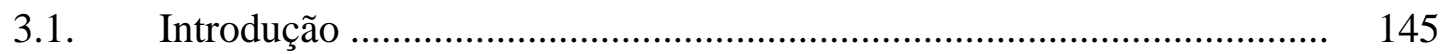

3.2. Indicadores para a Gestão da Manutenção ......................................... 150

3.2.1. A Qualidade dos Serviços de Manutenção ........................................... 151

3.2.2. A Velocidade dos Serviços de Manutenção ......................................... 156

3.2.3. A Confiabilidade dos Serviços de Manutenção ................................... 158

3.2.4. A Flexibilidade dos Serviços de Manutenção ........................................ 163

3.2.5. Os Custos das Atividades de Manutenção ............................................. 166

3.3. Considerações Finais ........................................................................... 174

4. METODOLOGIA _....................................................................... 176

4.1. Considerações Iniciais .................................................................. 176

4.2. Métodos de Abordagem e de Procedimentos ...................................... 179

4.2.1. Métodos de Abordagem ................................................................... 179 
4.2.2. Métodos de Procedimentos ................................................................... 182

4.3. Delimitação do Universo da Pesquisa ................................................. 186

4.4. As Técnicas de Pesquisa ....................................................................... 187

4.5. Os Instrumentos de Pesquisa .............................................................. 191

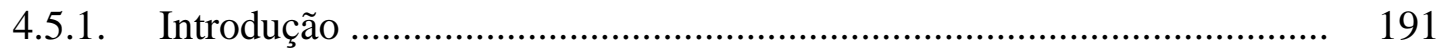

4.5.2. Formulário Padronizado de Entrevista ................................................. 191

4.5.3. Quadros de Análise Documental ........................................................ 219

4.6. Consideração Final ............................................................................ 219

5. APRESENTAÇÃO DAS EMPRESAS .......................................... 220

5.1. Introdução ............................................................................. 220

5.2. As Empresas ........................................................................... 220

5.2.1. Areva T\&D Brasil ........................................................................ 221

5.2.2. Imbel - Fábrica de Itajubá ................................................................ 224

5.2.3. Mahle Componentes de Motores do Brasil .......................................... 229

5.2.4. Conclusões Parciais ........................................................................ 232

5.3 O Perfil da Manutenção nas Empresas ............................................... 232

5.4 Conclusões Finais ....................................................................... 234

6. APRESENTAÇÃO DOS RESULTADOS ......................................... 237

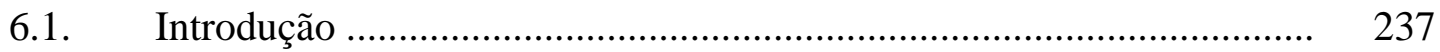

6.2. $\quad$ Composição dos Indicadores ............................................................. 240

6.2.1. Indicadores de Qualidade .................................................................. 240

6.2.2. Indicadores de Velocidade ............................................................... 243

6.2.3. Indicadores de Confiabilidade ........................................................ 245

6.2.4. Indicadores de Flexibilidade ............................................................. 250

6.2.5. Indicadores de Custos ...................................................................... 253

6.3. $\quad$ Análise de Correlação .......................................................................... 260

6.3.1. Considerações Iniciais ...................................................................... 260

6.3.2. Resultados das Análises ....................................................................... 262

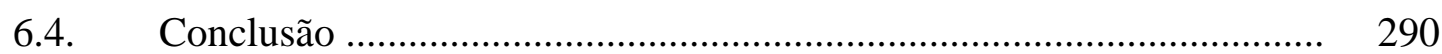

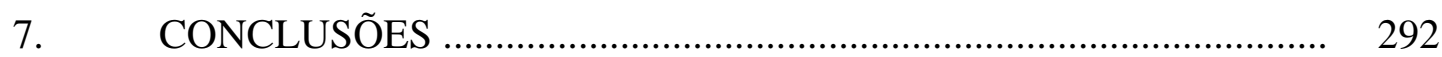

7.1. Considerações Gerais ..................................................................... 292

7.2. Contribuição do Trabalho ..................................................................... 293 
7.2.1. Contribuição Acadêmica ..................................................................... 293

7.2.2. Contribuição Empírica .................................................................... 297

7.2.3. Contribuição Imediata para a Empresa .............................................. 298

7.3. Conclusão Final ........................................................................... 299

7.4. Sugestões para Trabalhos Futuros …................................................... 300

REFEREANCIAS ..................................................................... 302

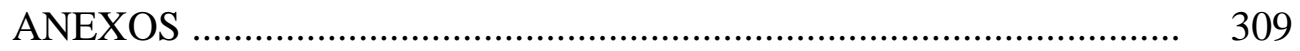

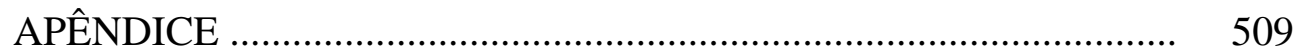




\section{LISTA DE TABELAS}

Tabela 2-1 $\quad$ Elementos de Desempenho e Indicadores Associados ............. $\quad 37$

Tabela 2-2 Parâmetros de Desempenho e Indicadores Associados ............. 38

Tabela 2-3 $\quad$ Escalas de Avaliação para FMEA ………………………........... $\quad 70$

Tabela 2-4 Indicadores de Gestão .............................................................. 95

Tabela 2-5 Organização das Operações de Manutenção ............................. 100

Tabela 2-6 Fatores de Percepção do Valor para as Operações de Manutenção .......................................................................... 101

Tabela 2-7 Processos Empresariais Genéricos …........................................ 128

Tabela 2-8 Categoria de Custos x Direcionador de Recurso ........................ 133

Tabela 2-9 Medidas de Atividades ............................................................ 133

Tabela 2-10 Critérios de Seleção de Direcionadores de Atividades .............. 136

Tabela 3-1 Gestão do Custeio e das Atividades de Manutenção ................. 149

Tabela 3-2 Indicadores para a Gestão da Manutenção ................................ 150

Tabela 4-1 Auto Avaliação da Função Manutenção nas Empresas ............ 218

Tabela 5-1 Tabela Comparativa _................................................................ 232

Tabela 5-2 $\quad$ Pontual Global das Empresas .................................................... 233

Tabela 6-1 Distribuição dos Ativos ………............................................... 239

Tabela 6-2 Indicadores para a Gestão da Qualidade ................................... 240

Tabela 6-3 Dados para a Composição dos Indicadores de Qualidade ........ 240

Tabela 6-4 Valores dos Indicadores de Qualidade no Período .................... 241

Tabela 6-5 Valores dos Indicadores de Qualidade pelos Equipamentos da Célula ................................................................................... 242

Tabela 6-6 Indicadores para a Gestão da Velocidade ................................. 243

Tabela 6-7 Dados para a Composição dos Indicadores de Velocidade ....... 243

Tabela 6-8 Valores dos Indicadores de Velocidade no Período .................. 244

Tabela 6-9 Valores dos Indicadores de Velocidade pelos Equipamentos da Célula ........................................................................... 245

Tabela 6-10 Indicadores para a Gestão da Confiabilidade ........................... 245

Tabela 6-11 Valores dos Indicadores de Confiabilidade no Período ............. 246 
Tabela 6-12 Apuração do Índice de Risco de Equipamento (IRE) da Célula para o Mês 12/2004

Tabela 6-13 Quadro Resumo de Apuração do Índice de Risco de

Equipamento (IRE)

Tabela 6-14 Valores dos Indicadores de Confiabilidade pelos

Equipamentos da Célula

Tabela 6-15 Indicadores de Flexibilidade para a Gestão da Manutenção ..... 250

Tabela 6-16 Quadro Geral das Intervenções: Equipamentos x Funcionários 251

Tabela 6-17 Indicadores de Custos para a Gestão da Manutenção ................ 253

Tabela 6-18 Apuração dos Indicadores de Custos CHA, CAA, CMC e CMP

Tabela 6-19 Apuração do Custo de Paralisação da Produção (CPP) ............. 256

Tabela 6-20 Apuração do Custo Total de Manutenção (CTM) .................... 256

Tabela 6-21 Apuração dos Indicadores de Custos (CTMUP, CMUP CRO, CMUP MET e CHS) 258

Tabela 6-22 Valores dos Indicadores de Custos 259

Tabela 6-23 Funcionários participantes da OS MP 02T40365 ..................... 282

Tabela 6-24 Funcionários Participantes da OS MC 02R85942 _................... 285 


\section{LISTA DE FIGURAS}

Figura 1-1 Utilização das Políticas de Manutenção .....................................

Figura 1-2 Pressuposto do Processo Gerencial ........................................... 5

Figura 1-3 Objetivo Específico do Trabalho de Pesquisa .......................... 5

Figura 1-4 Disponibilidade (t) ............................................................... 11

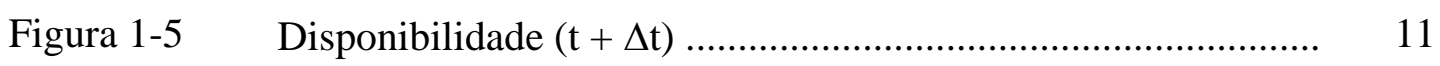

Figura 2-1 Desempenho de um Sistema Organizacional ........................... 17

Figura 2-2 Visão Holística de um Sistema Organizacional ......................... 18

Figura 2-3 Modelo Gerencial de Avaliação de Sink \& Tuttle ................... 19

Figura 2-4 Modelo Gerencial de Avaliação de Slack .................................. 23

Figura 2-5 Aumento da Expectativa em Relação à Manutenção ................ 47

Figura 2-6 Evolução das Técnicas de Manutenção ..................................... 47

Figura 2-7 Confiabilidade e Custos ......................................................... 53

Figura 2-8 Curva Característica da Vida de Equipamentos ....................... 56

Figura 2-9 Tipos de Curvas de Falhas ........................................................ 57

Figura 2-10 Tempos de Paralisação da Produção .......................................... 59

Figura 2-11 Caracterização da Disponibilidade .......................................... 61

Figura 2-12 Tempos Disponíveis (T) e Tempos em Manutenção (t) ............ 62

Figura 2-13 Fatores que Afetam a Produção da Fábrica ............................... 65

Figura 2-14 Relação entre Esforço e Resistência ......................................... 66

Figura 2-15 Análise de Árvore de Falhas .................................................... 71

Figura 2-16 Etapas da Metodologia do MASP …........................................ 72

Figura 2-17 Classificação dos Modos de Falha pela Criticidade .................. $\quad 75$

Figura 2-18 Fluxograma Lógico para a Escolha da Política de Manutenção 83

Figura 2-19 Utilização das Políticas de Manutenção ..................................... 84

Figura 2-20 Seleção das Políticas de Manutenção na MCC ......................... 84

Figura 2-21 Gestão do Planejamento e Programação da Manutenção .......... 87

Figura 2-22 Estágios de Vida de um Equipamento ..................................... 90

Figura 2-23 Sistema de Gerenciamento de Manutenção .............................. 94

Figura 2-24 As Seis Grandes Perdas ........................................................... 107

Figura 2-25 $\quad$ Rendimento Operacional Global ............................................ 109 
Figura 2-26 Custeio Total ou Custeio por Absorção Integral ....................... 116

Figura 2-27 Custeio por Absorção Ideal .................................................... 117

Figura 2-28 Custeio Direto ou Variável .......................................................... 117

Figura 2-29 Fluxo do Sistema de Custo Tradicional ................................... 118

Figura 2-30 Visão Econômica de Custeio ..................................................... 125

Figura 2-31 Relacionamento entre ABC e BPA …....................................... 127

Figura 2-32 Modelo Genérico de Processo Empresarial .............................. 128

Figura 2-33 Processos, Subprocessos e Atividades da Empresa .................. 129

Figura 2-34 Visão de Aperfeiçoamento de Processos .................................. 139

Figura 2-35 Relacionamento entre ABM e ABC ......................................... 141

Figura 3-1 Modelo para a Gestão do Custeio e das Atividades de

Manutenção .......................................................................... 146

Figura 3-2 Objetivos de Desempenho ..................................................... 148

Figura 3-3 Eficácia Global dos Equipamentos ......................................... 155

Figura 3-4 Fluxograma para a Gestão dos Custos de Manutenção ............. 167

Figura 5-1 Classificação das Empresas .................................................... 233

Figura 6-1 Organograma da Planta de Itajubá .......................................... 238

Figura 6-2 Taxa de Polivalência das Equipes ............................................. 252

Figura 6-3 $\quad$ Custo Total de Manutenção ....................................................... 274

Figura 6-4 Custo da Manutenção Preventiva .............................................. 274

Figura 6-5 Custo da Paralisação da Produção ............................................. 274

Figura 6-6 Indisponibilidade Operacional ............................................. 275

Figura 6-7 Horas Paralisadas ................................................................ 275

Figura 6-8 Horas de Manutenção Preventiva Realizadas ........................... 276

Figura 6-9 Tempo Médio de Reparo ........................................................ 276

Figura 6-10 Indisponibilidade Programada ................................................. 277

Figura 6-11 Horas Consumidas nas Intervenções ......................................... 277

Figura 6-12 Disponibilidade Programada ...................................................... 277

Figura 6-13 Velocidade de Atendimento ..................................................... 278

Figura 6-14 Custo da Manutenção Corretiva ................................................ 282

Figura 6-15 Horas de Manutenção Corretiva .............................................. 283

Figura 6-16 Indisponibilidade Forçada ......................................................... 283 
Figura 6-17 Número de Falhas ................................................................ 284

Figura 6-18 Índice de Risco de Equipamento ............................................ 284

Figura 6-19 Disponibilidade Forçada ....................................................... 284 


\section{LISTA DE QUADROS}

Quadro 6-1 Organização dos Indicadores ................................................... 262

Quadro 6-2 Resumo Análise Intra Indicadores .......................................... 263

Quadro 6-3 Resumo Análise Entre Indicadores ........................................... 269

Quadro 6-4 Quadro Geral de Dados: Outubro de 2004 ................................ 279

Quadro 6-5 Anexo 4: Quadro Resumo de Dados (28/10/2004) ................... 280

Quadro 6-6 Quadro das Ordens de Serviço: OS MP 02T40365 .................. 281

Quadro 6-7 Quadro Geral de Dados: Julho de 2004 ..................................... 286

Quadro 6-8 Quadro de Ocorrência de Falhas: 07/2004 ............................... 287

Quadro 6-9 Quadro das Ordens de Serviço: OS MC 02R85942 .................. 288

Quadro 6-10 Análise dos Equipamentos .................................................... 289 


\section{LISTA DE ANEXOS}

Anexo 1 Instrumentos de Pesquisa …....................................................... 309

Anexo 2 Questionário de Avaliação ......................................................... 329

Anexo 3 Quadro Geral de Dados .............................................................. 350

Anexo 4 Quadro Resumo de Dados ........................................................... 365

Anexo 5 Dados de Produção .................................................................... 377

Anexo 6 Quadro das Ordens de Serviço .................................................... 380

Anexo 7 Quadro de Ocorrência de Falhas ................................................. 402

Anexo 8 Quadro de Recursos Consumidos ............................................... 444

Anexo 9 Resultados dos Indicadores de Qualidade .................................. 445

Anexo 10 Resultados dos Indicadores de Velocidade ................................. 450

Anexo 11 Resultados dos Indicadores de Confiabilidade ........................... 455

Anexo 12 Resultados dos Indicadores de Flexibilidade .............................. 459

Anexo 13 Resultados dos Indicadores de Custos ......................................... 461

Anexo 14 Análise Intra Indicadores - Qualidade ....................................... 465

Anexo 15 Análise Intra Indicadores - Velocidade ....................................... 470

Anexo 16 Análise Intra Indicadores - Confiabilidade ................................ 474

Anexo 17 Análise Intra Indicadores - Custos .............................................. 481

Anexo 18 Análise Entre Indicadores - Qualidade/Custos ........................... 488

Anexo 19 Análise Entre Indicadores - Qualidade/Velocidade .................... 493

Anexo 20 Análise Entre Indicadores - Qualidade/Confiabilidade .............. 495

Anexo 21 Análise Entre Indicadores - Velocidade/Confiabilidade ............. 497

Anexo 22 Análise Entre Indicadores - Velocidade/Custos .......................... 499

Anexo 23 Análise Entre Indicadores - Custos/Confiabilidade .................... 504 


\section{LISTA DE SIGLAS}

$\begin{array}{ll}\text { ABC } & \text { "Activity Based Costing” } \\ \text { ABM } & \text { "Activity Based Mangement” } \\ \text { ABRAMAN } & \text { Associação Brasileira de Manutenção } \\ \text { BPA } & \text { "Business Process Analysis” } \\ \text { BVQI } & \text { "Bureau Veritas Quality International” } \\ \text { CAM-I } & \text { "Consortium for Advanced Manufacturing International” } \\ \text { COFAP } & \text { Companhia Fabricadora de Peças } \\ \text { CPM } & \text { "Critical Path Method” } \\ \text { DQS } & \text { "Deustch Quality Systems” } \\ \text { FE } & \text { Fábrica da Estrela } \\ \text { FI } & \text { Fábrica de Itajubá } \\ \text { FJF } & \text { Fábrica de Juiz de Fora } \\ \text { FMCE } & \text { Fábrica de Material de Comunicações e Eletrônica } \\ \text { FMEA } & \text { "Failure Mode and Effect Analysis” } \\ \text { FPV } & \text { Fábrica Presidente Vargas } \\ \text { FTA } & \text { "Failure Tree Analysis” } \\ \text { IMBEL } & \text { Indústria de Material Bélico do Brasil } \\ \text { ISO } & \text { "International Organization for Standartization” } \\ \text { JIT } & \text { "Just-in-Time” } \\ \text { JUSE } & \text { "Japanese Union of Scientists and Engineers” } \\ \text { MASP } & \text { "Tototodologia Aplicada à Solução de Problemas } \\ \text { MCC } & \text { Manutenção Centrada na Confiabilidade } \\ \text { MRP } & \text { "Materials Resources Planning” } \\ \text { OHSAS } & \text { "Ocupational Health and Safety System” } \\ \text { PCM } & \text { Planejamento e Controle da Manutenção } \\ \text { PDCA } & \text { "Plan Do Check Action” } \\ \text { PERT } & \text { "Program Evaluation and Review Technique” } \\ \text { RCFA } & \text { Sindicato das Indústrias Metalúrgicas, Mecânicas e de Material } \\ \text { TIMMMEI } & \text { "Total Management” }\end{array}$




\section{Capítulo 1}

\section{Introdução}

O presente capítulo discute os aspectos relevantes do tema da Tese. Justifica a importância do assunto e apresenta o problema de pesquisa e os objetivos geral e específico do trabalho. O tema e a sua delimitação estão aqui definidos, assim como também o objeto de estudo, as hipóteses, o mérito e a organização estrutural do relatório final.

\subsection{CONSIDERAÇÕES INICIAIS}

A produção de bens de consumo e de serviços vem sofrendo importantes mudanças nos últimos trinta anos. O comportamento dos consumidores face aos novos padrões de preço e de qualidade dos produtos e serviços, o rápido avanço das novas tecnologias da informação e, também, o questionamento da forma taylorista de organização do trabalho nas organizações são vetores representativos dessa evolução.

SALERNO (1991) sustenta que as mudanças no panorama econômico, político e social apontam novos critérios de competitividade e padrões de produção que contemplam esforços na direção de uma produção mais integrada e flexível. Tais esforços remetem para uma discussão relacionada com mudanças organizacionais que podem ser entendidas em quatro níveis distintos: na relação entre empresas, na organização geral da empresa, na organização da produção e na organização do trabalho. As mudanças nas relações entre as empresas podem ser vistas, segundo o autor, por meio de acordos cooperativos, parcerias entre clientes e fornecedores e subcontratações. A criação de unidades de negócios, a redução de níveis hierárquicos e a gestão por atividades e processos são exemplos das mudanças na organização geral das empresas. A migração do layout funcional da produção por processos para a manufatura celular, como forma de reduzir estoques, aumentar o giro do capital e melhorar a taxa de utilização dos equipamentos, retrata mudanças na organização da 
produção. ZARIFIAN (1990) alega que se os postos de trabalho deixam de ser seqüenciais para se tornarem células produtivas, o trabalho acaba se tornando uma atividade de coordenação e supervisão e o conceito de posto de trabalho perde a sua pertinência. Na verdade a organização do trabalho migra de uma carga prescritiva para uma organização sócio-técnica (grupos semi-autônomos) onde tal carga prescritiva é questionada. Assim, a avaliação do desempenho também migra de resultados individuais para um conceito mais sistêmico e abrangente de resultados de processos.

O conceito da qualidade tem abrangência mundial e por este motivo torna-se um balizador da concorrência cada vez mais acirrada entre os setores produtivos. Assim, dentro desse ambiente competitivo, o conceito de qualidade expande-se e incorpora o da produtividade. Juntos formam as novas regras do mercado. Administrar com qualidade e produtividade passa a não ser mais um privilégio dos países do primeiro mundo. O avanço das práticas gerenciais japonesas e a formação de blocos comerciais sinalizam a dimensão atual da concorrência.

Produtos e serviços melhores precisam ser obtidos em tempos cada vez menores, com menos recursos e ainda atender às exigências de demanda do mercado. É a produção de bens e de serviços sendo colocada no ambiente competitivo. Assim, o tempo, um recurso absolutamente escasso, passa a refletir a flexibilidade dos sistemas produtivos. Flexibilidade para que os sistemas sintam o mercado, desenvolvam ou alterem modelos, produzam e comercializem novos produtos e serviços. Flexibilidade para melhorar métodos, processos, gestão de recursos, movimentar materiais, dentro e fora das organizações e ainda atender de forma efetiva às exigências dos clientes. Enfim, melhorar a capacidade de produzir e de atender. A sobrevivência das empresas no futuro é, seguramente, dependente de seus desempenhos atuais, relacionados com a qualidade e produtividade.

SLACK (1993) defende que produção de bens e de serviços desempenha um papel significativo no sucesso competitivo das organizações. Afirma, ainda, que a função produção não deve gerenciada sem um direcionamento estratégico, presa tão somente às suas próprias rotinas. Para o autor, a importância da função produção é de tal ordem que o seu direcionamento estratégico deve ser conduzido para dois pólos 
principais: consumidores e concorrentes. Os primeiros, porque de fato representam o juízo daquilo que deve ser importante. Os segundos, porque o desempenho da organização deve refletir a competitividade da concorrência.

O autor também alega que uma das formas de construir metas e objetivos para a produção de bens e serviços é trabalhar em cima das necessidades reais e potenciais dos consumidores. Tal trabalho deve envolver decisões sobre aquilo que é mais importante para os consumidores. Em outras palavras, o autor sugere pesquisar como os consumidores valorizam determinados aspectos tais como preço, prazo, qualidade e confiabilidade na entrega, através dos quais é possível contribuir para o desempenho da organização.

Resumindo, a contribuição da produção de bens e serviços para o desempenho da organização pode ser vista sob dois aspectos intimamente ligados. $\mathrm{O}$ mercado e a concorrência são os pontos centrais que as empresas devem enfocar para alcançar a vantagem competitiva. Satisfazer o mercado e ser melhor que os concorrentes devem ser as metas de qualquer organização bem sucedida. É justamente neste contexto que a importância maior da função manutenção, nas organizações industriais, está inserida. A relevância da função está calcada no processo produtivo da organização, que por sua vez depende do bom desempenho de seus equipamentos. As falhas e, muitas vezes, as quebras dos ativos geram perdas de produção, riscos de acidentes, danos ao meio ambiente, além de exercerem forte impacto na gestão dos custos da organização.

\subsection{O PROJETO DE PESQUISA}

O presente projeto de pesquisa tem como linha de ação desenvolver uma pesquisa de natureza exploratória. A idéia é investigar a realidade prática da gestão do custeio e das atividades de manutenção para dar uma resposta ao questionamento (problema de pesquisa) sempre presente no dia-a-dia operacional das organizações industriais: por que o setor de manutenção é avaliado em função das paralisações e dos crescimentos de seus custos? Assim, o objeto de estudo do projeto de pesquisa é o setor de manutenção de empresas industriais produtoras de bens de consumo e o tema básico, foco do trabalho, está relacionado com a gestão da manutenção. O 
projeto ainda delimita o tema concentrando esforços na gestão do custeio e das atividades de manutenção industrial

\subsubsection{OBJETIVOS GERAL E ESPECÍFICO}

As políticas de manutenção em uma empresa de produção industrial são circunstanciadas por variáveis relacionadas com custos, segurança dos equipamentos, instalações, produto e pessoas que operam e intervêm nos mesmos. A durabilidade e a disponibilidade dos ativos são também variáveis que impactam na administração das políticas e dos recursos da manutenção (ver Figura 1-1).

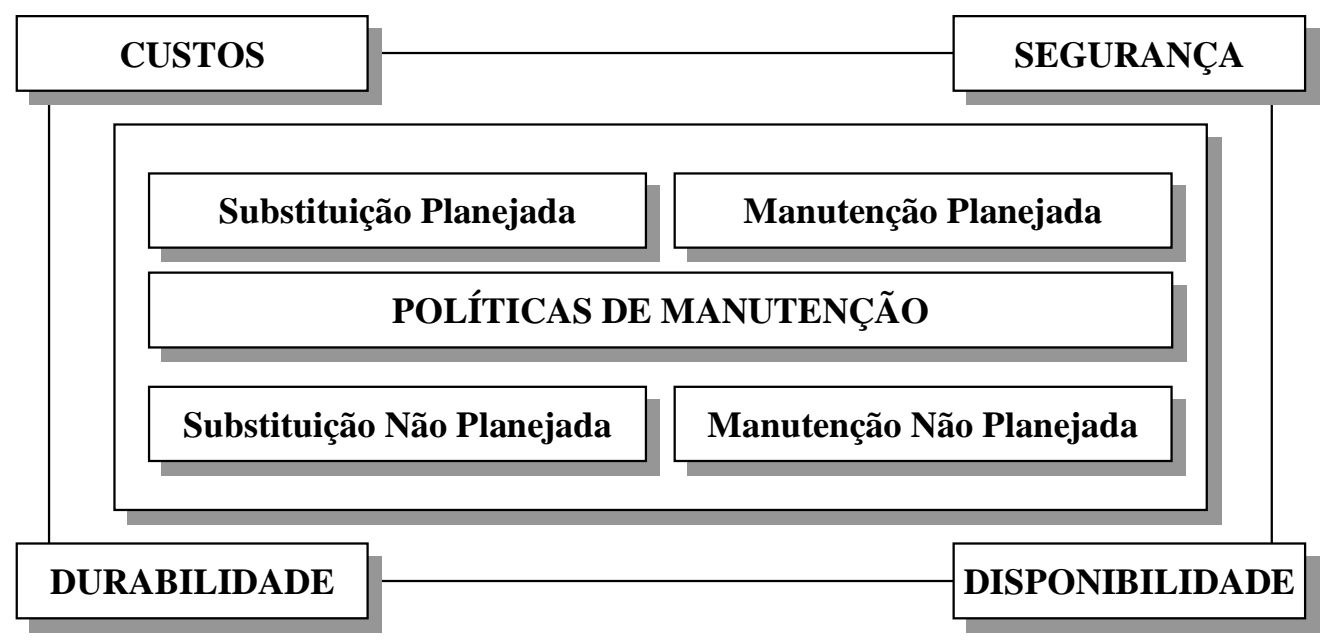

Figura 1-1 - Utilização das Políticas de Manutenção.

Assim, o objetivo geral do trabalho está na identificação dos fatores que interligam a utilização das políticas de manutenção e a gestão dos custos de suas atividades.

Por outro lado, o pressuposto do processo gerencial das atividades de manutenção, ilustrado na Figura 1-2 a seguir, é a avaliação da situação real através de monitoração sistemática e contínua e interferência gerencial por ações corretivas e preventivas. Desta forma, o objetivo específico do trabalho de pesquisa é: desenvolver um conjunto de indicadores integrados capaz de gerenciar o custeio, 
as ocorrências de falhas dos ativos e as atividades de manutenção, como se pode ver ilustrado pela Figura 1-3.

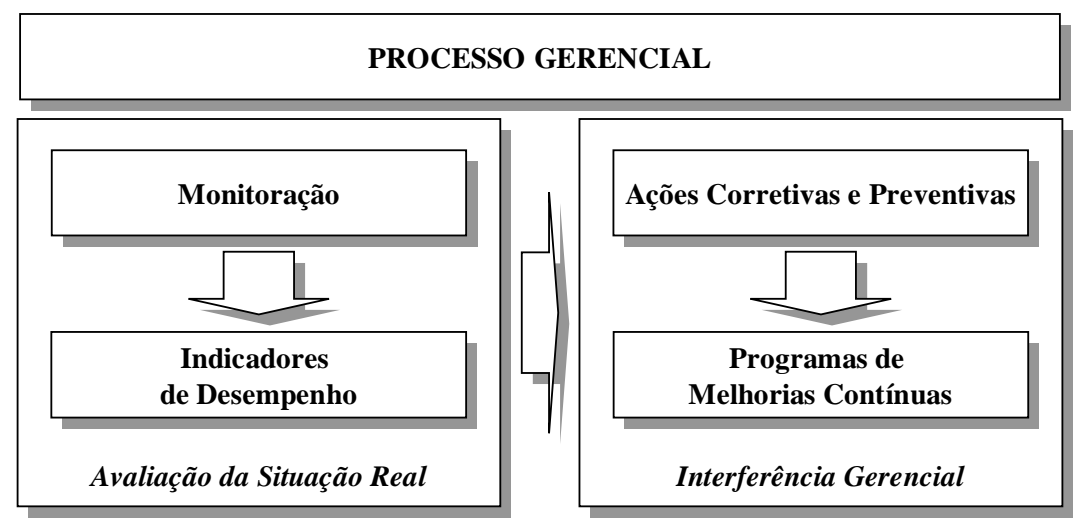

EXCELÊNCIA OPERACIONAL

Figura 1-2 - Pressuposto do Processo Gerencial.

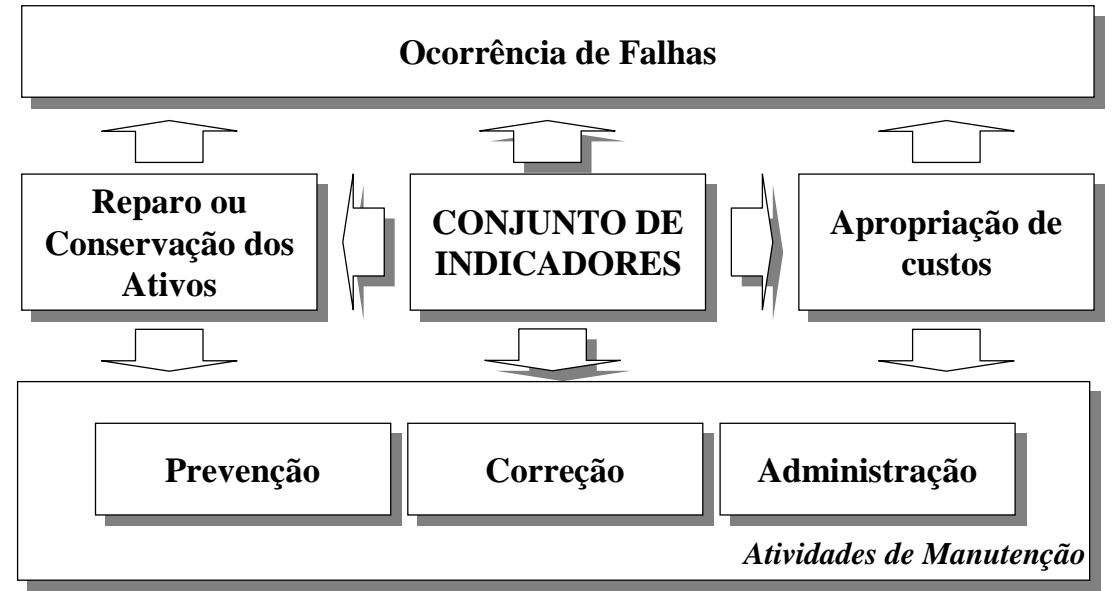

Figura 1-3 - Objetivo Específico do Trabalho de Pesquisa.

\subsubsection{HIPÓTESES - INDICADORES GERENCIAIS}

A proposição de um conjunto de indicadores integrados é, em princípio, dependente do sistema produtivo e do sistema de informação disponíveis. Entretanto, dentro dos diferentes modelos e lógicas, presentes na literatura, para a construção de 
índices gerenciais, pretende-se apresentar um modelo específico. Tal modelo organizará um conjunto de indicadores, integrados dentro de uma lógica consistente e coerente, para a gestão do custeio e das atividades de manutenção. Nestas condições, as hipóteses formuladas têm por finalidade conduzir o trabalho na busca de respostas que satisfaçam o problema de pesquisa proposto:

1) Se não houver um conjunto de indicadores, então o custeio e as atividades de manutenção nãa serão gerenciadas;

2) Se houver um conjunto de indicadores, então o custeio e as atividades de manutenção serão gerenciadas de forma eficiente e produtiva; e

3) Se houver um modelo gerencial integrado de indicadores específicos para a função manutenção, então o custeio e as atividades de manutenção corretivas e preventivas serão conduzidas de forma eficaz.

Se estas hipóteses não forem verificadas empiricamente e não respondem de modo satisfatório ao problema apresentado, deverão ser revistas. Tal reformulação ocorrerá de forma adequada para manter a coerência do estudo e apresentar respostas satisfatórias ao questionamento original.

\subsubsection{VARIÁVEIS DE PESQUISA}

São variáveis dependentes e independentes de pesquisa:

- Variáveis Independentes: Custos das falhas e das atividades de manutenção;

- Variáveis Dependentes: Custeio e utilização das políticas de manutenção.

\subsection{JUSTIFICATIVAS}

A relevância do assunto pode ser alinhavada das seguintes formas: na gestão dos processos produtivos, na melhoria do desempenho da própria função manutenção, na utilização das políticas e apuração dos custos das atividades de manutenção. 


\subsubsection{GESTÃO DOS PROCESSOS PRODUTIVOS}

NAGAO (1998) relata que a função manutenção tem se destacado a cada dia que passa como uma área fundamental para o sucesso das organizações que possuem uma base fortemente industrial. O autor cita os comentários de KLETZ (1993) sobre inúmeros relatos onde problemas de manutenção propiciaram acidentes graves e colocaram em risco o meio ambiente, o ser humano e a integridade da instalação industrial. Assim, é perfeitamente válido inferir que o impacto de uma manutenção inadequada e ineficiente, pelo aumento crescente dos custos e das paralisações, pode influir na rentabilidade do negócio e na sobrevivência da própria organização. Pelo o que foi exposto anteriormente pode-se justificar o fato do setor de manutenção de uma empresa desempenhar um papel cada vez mais importante na dinâmica dos sistemas de produção.

MONCHY (1989) argumenta que a função manutenção apresenta influência direta no desempenho da organização, particularmente em termos de produtividade e de qualidade. Para o autor, há uma tendência em superar o paradigma instituído que a função é tão somente uma fonte de custos e migrar para um conceito mais direto: sobre o setor de manutenção pesa a responsabilidade de minimizar as perturbações e imprevistos, decorrentes da função produção. Portanto, a função manutenção representa um potencial considerável para a melhoria do desempenho da empresa.

\subsubsection{MELHORIA DO DESEMPENHO DA FUNÇÃO MANUTENÇÃO}

A função manutenção é uma fonte de custo cara e complexa e como tal precisa ser bem administrada. Deve ser entendida como uma atividade meio por excelência que deve existir, para propiciar à área operacional, o cumprimento das metas de produção. Sendo assim, o desempenho da manutenção acaba sendo avaliado em termos de custos e das paralisações dos equipamentos e instalações (KELLY \& HARRIS, 1980).

MONCHY (1989) sustenta que o setor de manutenção, a cada dia que passa, vem ocupando uma posição de maior destaque dentro do organograma das organizações produtoras de bens e serviços. Relata que a finalidade da função é 
proteger o alto investimento feito nas instalações, assim como assegurar altos padrões de confiabilidade e qualidade de seus serviços. Nestas condições, a atuação do setor, seguramente, afeta o desempenho global da organização. A função manutenção passa a ser vista, não mais como uma simples fonte de custos, mas como um setor importante sobre o qual pesa a responsabilidade de minimizar perturbações, imprevistos e custos operacionais no retorno dos equipamentos e instalações à sua prontidão funcional. Sendo assim, a melhoria do desempenho da função manutenção justifica também a utilização de indicadores para o gerenciamento das suas atividades e de seu custeio.

\subsubsection{UTILIZAÇÃO DAS POLÍTICAS DE MANUTENÇÃO}

A manutenção pode ser considerada como uma combinação de ações conduzidas para substituir, revisar ou modificar componentes ou grupos identificáveis de componentes de um equipamento. Tudo isto, para que este opere dentro de uma disponibilidade especificada em um intervalo de tempo também especificado. A função dos equipamentos é produzir, durante um determinado período de tempo, proporcionando portanto uma saída planejada.

Essa saída vai depender da demanda vendida e, em longo prazo, das previsões de venda, com as flutuações normais do processo. Portanto a disponibilidade dos equipamentos deve propiciar a consecução do plano de produção. Assim, o conceito da função manutenção expande-se para um conjunto de atividades técnicas e administrativas que permitem à empresa atingir suas metas de disponibilidade operacional de forma econômica.

RODRIGUES (2000) defende que os bens de produção são projetados para não falhar e que a alta refratariedade às falhas implica em robustez. Produto robusto é caro e muitas vezes a sua aquisição é inviabilizada por razões financeiras ou por outras de cunho intangível. Como os bens de produção mais acessíveis, portanto, mais baratos, são mais carentes de robustez e mais suscetíveis às falhas, então o papel de uma política de manutenção é conjugar vantagens econômicas e técnicas que permitam manter a prontidão funcional do ativo a serviço da organização que o adquiriu. 
As funções manutenção e produção em uma organização industrial moderna estão inter-relacionadas e não é possível, nem desejável, considerar cada uma isoladamente. Esforços para reduzir custos de qualquer uma destas funções podem facilmente aumentar os custos de outra. Tudo o que for economizado em uma pode ser perdido na outra. É importante que ambas sejam planejadas em uma base unificada com o objetivo de obter o menor custo global. Qual é então o melhor caminho de se conduzir estas funções de modo a atingir o objetivo pretendido?

Existem quatro alternativas, políticas ou estratégias de manutenção segundo GALLIMORE \& PENLESKY (1988):

I. Substituição não-planejada - utilizar o equipamento até o momento em que este falhe irreversivelmente, transformá-lo então em sucata e comprar um novo;

II. Substituição planejada (equipamento idêntico ou de última geração) utilizar o equipamento e vendê-lo antes que o custo de sua conservação se torne mais importante que o benefício por ele propiciado, ou seja, desfazerse do bem no momento em que sua vida econômica for ultrapassada;

III. Manutenção não-planejada (corretiva ou de emergência - utilizar o equipamento até o momento em este falhe e então repará-lo;

IV. Manutenção planejada (sistemática ou preditiva) - realizar manutenções regulares, planejadas cuidadosamente, juntamente com as exigências da produção de forma a prevenir a ocorrência de falhas que prejudiquem o andamento do plano de produção;

A decisão entre estas alternativas será considerada como parte integrante da estratégia global da empresa e, por esta razão, é influenciada por fatores externos e internos. Os externos (interferência em longo prazo), são representados pela obsolescência dos equipamentos, nível de vendas da corporação, custo do capital investido e diversificação do mercado. Já os fatores internos (interferência em curto prazo) podem ser considerados como o custo da indisponibilidade dos equipamentos e o custo dos recursos de manutenção. A análise do impacto de cada um destes fatores nos custos globais de manutenção acaba determinando a estratégia indicada para cada equipamento tendo em vista a obtenção de um custo global mínimo. 


\subsubsection{APURAÇÃO DOS CUSTOS DE MANUTENÇÃO}

RODRIGUES (2000) analisa a interferência dos custos fixos e variáveis nas políticas de manutenção centrando suas observações na confiabilidade dos equipamentos e apresenta dados que permitem visualizar como os períodos planejados para a intervenção nos mesmos interferem nos custos globais das atividades de manutenção. Tal abordagem sugere apenas uma visão parcial do problema. A confiabilidade é uma das variáveis envolvidas na questão e é geralmente medida pelo TMEF - Tempo Médio Entre Falhas, e reflete, em última análise, a freqüência das intervenções nos equipamentos e apenas uma parcela da disponibilidade do equipamento.

A outra é necessariamente definida pela sua manutenibilidade, que traduz a maior ou menor facilidade de executar as atividades de intervenção nos equipamentos e pode ser medida pelo TMDR - Tempo Médio de Reparo, incluindo aí os atrasos decorrentes da falta de informações e de recursos materiais e humanos. Como se pode ver, a disponibilidade dos ativos fica configurada através das variáveis confiabilidade e manutenibilidade.

Por outro lado, a definição dos períodos de intervenção passa a ter uma melhor acuracidade (precisão objetiva), se os custos da disponibilidade podem ser apropriados através das atividades necessárias para manter a prontidão funcional dos equipamentos e instalações. Portanto, torna-se importante a adoção de indicadores para a gestão do custeio e das atividades de manutenção.

Nestas condições, num dado instante será possível obter uma representação gráfica da disponibilidade como função dos custos associados às atividades de manutenção.

Entretanto, na medida em que as atividades de manutenção são monitoradas e ações gerenciais corretivas e preventivas são implementadas, será possível observar uma melhoria na disponibilidade, sempre relacionada a um custo global mínimo, como se pode observar nas Figura 1-4 e Figura 1-5. 


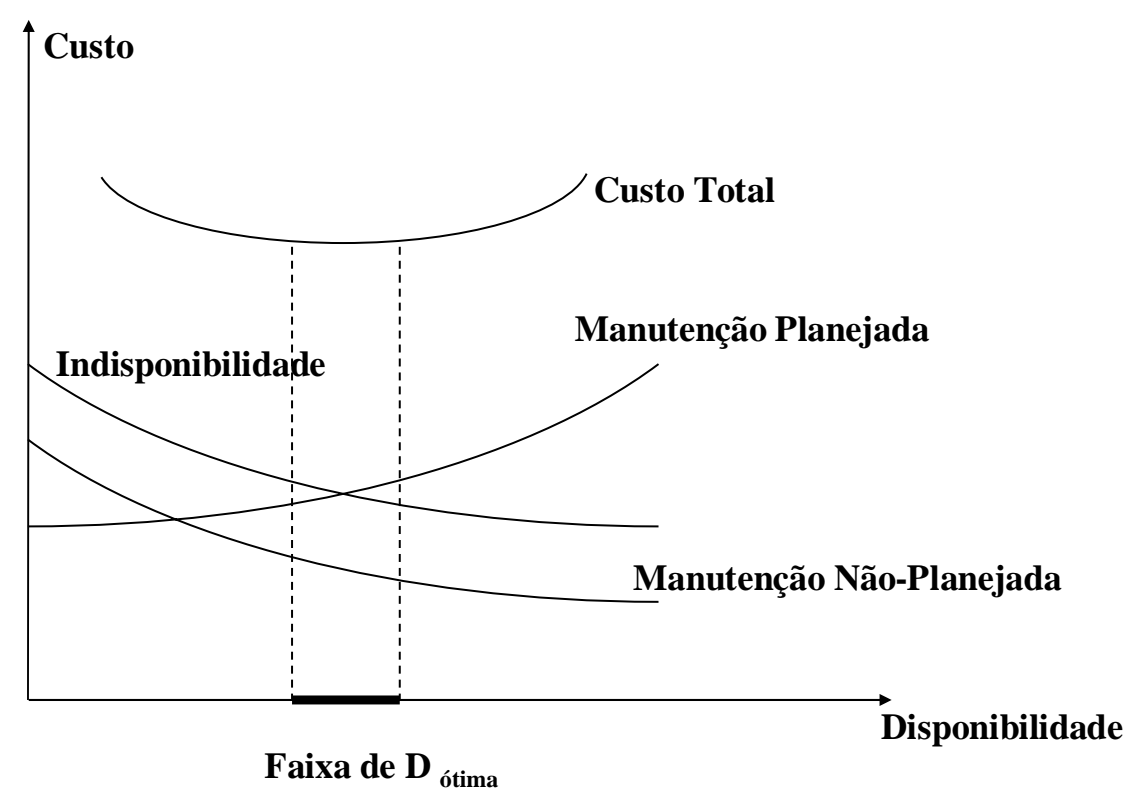

Figura 1-4 - Disponibilidade (t).

Fonte: Adaptada de MONCHY (1989).

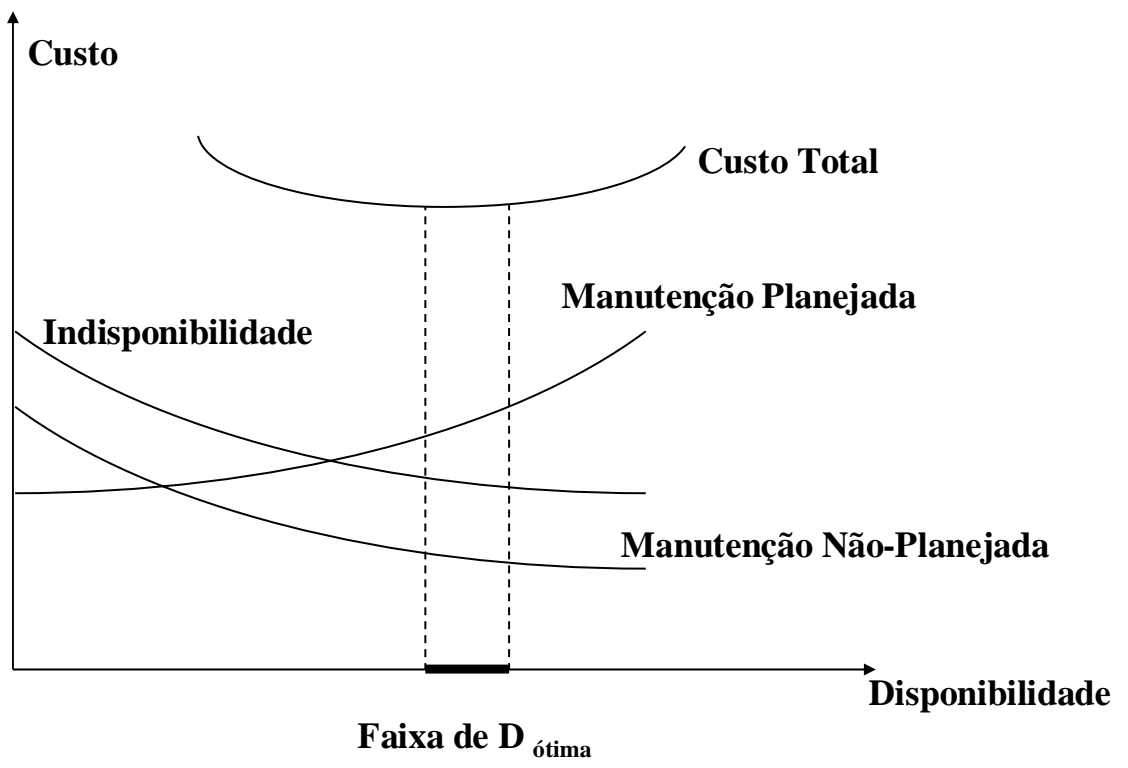

Figura 1-5 - Disponibilidade $(\mathrm{t}+\Delta \mathrm{t})$.

Fonte: Adaptada de MONCHY (1989). 
É preciso deixar claro que o grande desafio da gestão da manutenção é gerar uma disponibilidade compatível com as necessidades do plano de produção. As causas de uma reduzida confiabilidade ou manutenibilidade podem significar, também, responsabilidades além do departamento de manutenção.

\subsection{ORGANIZAÇÃO DO RELATÓRIO FINAL}

No Capítulo 2 é conduzida uma revisão bibliográfica com a finalidade maior em produzir um texto detalhado onde são discutidas as questões pertinentes ao tema do trabalho de pesquisa. Tais discussões permitem a construção de um referencial teórico que serve de base para o desenvolvimento da Tese. Essas questões foram pesquisadas na literatura nacional e internacional disponíveis.

São considerados autores clássicos tais como CLIFTON (1974), COKINS (1996), MOUBRAY (1997), MONCHY (1989), GALLIMORE \& PENLESKY (1988), MARTINS (2003) e WESTWICK (1981). Os autores que ainda estão discutindo tais questões, como por exemplo, PAMPLONA (1997), NAGAO (1998), ANHESINE (1999), RODRIGUES (2000), PINTO \& XAVIER (2001), FURMANN (2002), MENDES (2002), BORNIA (2002) e CONTADOR (2004) entre outros, também são levados em conta na revisão da bibliografia.

São considerados os vários pontos-de-vista relacionados com a avaliação do desempenho de empresas e a construção de indicadores. Também são levadas em conta as questões relativas ao processo gerencial dos recursos produtivos, particularmente aquelas pertinentes à gestão da manutenção nas empresas de produção de bens de consumo.

No Capítulo 3 é apresentado o referencial teórico que consubstancia a construção dos indicadores gerenciais utilizados para a gestão do custeio e das atividades de manutenção e dá suporte ao desenvolvimento da pesquisa.

O Capítulo 4 descreve os diferentes métodos de pesquisa citados na literatura e justifica aqueles adotados para o desenvolvimento do trabalho. O texto delimita o universo da pesquisa e apresenta os critérios utilizados para justificar a escolha dos objetos de estudo. Discorre sobre as técnicas de pesquisa e explica aquela adotada 
para dar sustentação metodológica ao trabalho. O fechamento do capítulo dá-se pela apresentação dos instrumentos de pesquisa utilizados na coleta de dados.

A apresentação das empresas que delimitam o universo da pesquisa está presente no Capítulo 5. O texto justifica a escolha das empresas para os estudos de caso e faz uma avaliação das mesmas por meio de critérios padronizados para empresas de classe mundial. A conclusão do capítulo se faz pelas justificativas da adoção daquela empresa sobre a qual o trabalho de pesquisa concentra os esforços para validar os indicadores do modelo de gestão.

O Capítulo 6 apresenta os resultados das aplicações práticas do sistema de indicadores integrados desenvolvido. O texto ainda leva em conta uma discussão minuciosa e detalhada desses resultados. Tal discussão tem por finalidade a validação dos indicadores propostos na gestão do custeio e das atividades de manutenção, nas empresas consideradas nos estudos de casos.

As considerações gerais e finais, a contribuição acadêmica e empírica do trabalho e as sugestões para trabalhos futuros estão alinhavadas no Capítulo 7 como fechamento da Tese. 


\section{Capítulo 2}

\section{As Teorias de Base}

As Teorias de Base propiciam uma revisão bibliográfica que tem por finalidade produzir um texto detalhado, onde são discutidas as questões relativas ao tema do trabalho. Tais questões permitem a seleção dos conceitos que dão forma ao referencial teórico utilizado como suporte para o desenvolvimento da Tese. Os diferentes pontos-de-vista relacionados com a avaliação do desempenho de empresas e a construção de indicadores são discutidos de forma ampla e objetiva. Também são levadas em conta as questões pertinentes aos processos de gestão dos recursos produtivos. Particularmente aquelas relacionadas com os diferentes métodos de custeio e as pertinentes ao processo de gestão da função manutenção, em empresas produtoras de bens de consumo.

\subsection{A AVALIAÇÃO DO DESEMPENHO}

\subsubsection{CONSIDERAÇÕES INICIAIS}

É grande o interesse de muitas empresas e até mesmo de profissionais das mais diversas áreas sobre a questão do desempenho das organizações humanas. $\mathrm{Na}$ verdade, o termo é bastante amplo e pode apresentar uma certa ambigüidade, dependendo do contexto onde esteja inserido. Há uma deficiência nas definições operacionais do termo desempenho e seus componentes, na prática atual das organizações. Encontra-se o campo cheio de acadêmicos que estão tentando abordar a medição e melhoria de sistemas organizacionais com modelos conceituais fracos e sem definições operacionais. Em contrapartida, também é possível encontrar o campo cheio de práticos, sem modelos conceituais e definições operacionais fracas. O resultado é confusão, tanto na literatura como na prática (SINK \& TUTTLE, 1993). 
Os rumos atuais da competição, da tecnologia e do gerenciamento dos recursos exigem mudanças. Este cenário justifica novas formas para as organizações poderem medir e administrar seus custos e novos atributos para a avaliação de seu desempenho. Tais atributos devem efetivamente refletir a integração e flexibilidade de seus recursos. A falta de sensibilidade a tais exigências poderá diminuir a capacidade competitiva das empresas, face aos concorrentes do mercado (PORTER, 1985; ROSA, 2003; ROSA ET AL, 2003; SUMANTH, 1984).

A ausência de medidas além de inibir a monitoração do desenvolvimento do trabalho nas organizações, também dificulta a identificação de falhas que poderiam ser analisadas e eliminadas. Sem medidas, não há como comparar o desempenho real com padrões preestabelecidos e implementar medidas corretivas ou preventivas, quando for o caso. Com elas, haverá possibilidade de identificar desempenhos que darão suporte às decisões relacionadas a recursos, planos, políticas, esquemas e estruturas. Sem medidas, os funcionários de todos os níveis não têm base para compreender claramente o que se espera deles. Nem os gerentes conseguem fundamentar argumentos para especificar, com clareza, quais os resultados esperados dos subordinados. As medidas propiciam informações preciosas para o aprimoramento do processo de gestão das organizações.

Entretanto, com medidas inconsistentes a tendência é avaliar de forma distorcida o desempenho da organização. Nestas condições, RUMMLER \& BRACHE (1992) alegam que a eficiência de um sistema de medidas de desempenho está diretamente ligada a metas preestabelecidas. Relatam que as organizações sempre principiam a medição de seu desempenho por intermédio de medidas de cunho financeiro. Ao lado delas, aparecem conjuntos de novas medidas, quase sempre decorrentes de antigos problemas gerados pela burocracia, ou novas posturas originárias de novos gerentes e novos programas. Os autores afirmam que, na maioria das vezes, tais medidas, além de contra producentes, não são interrelacionáveis e, por conseguinte, não gerenciáveis.

As comparações de receitas com custos, em períodos arbitrariamente curtos, propiciam a inclusão de despesas de períodos passados nos custos do período corrente. As despesas do período corrente acabam por incluir benefícios que somente 
serão concretizados em períodos futuros. Assim sendo, os indicadores de cunho financeiro passam a não refletir o desempenho recente da organização. Eles também podem ser contestados pela evolução rápida da tecnologia, pelos ciclos de vida, cada vez mais reduzidos, dos produtos e pelas inovações na gestão das operações de produção. JOHNSON \& KAPLAN (1987) relatam a inadequação de indicadores financeiros de curto prazo e a sua substituição por indicadores de desempenho compatíveis com a estratégia da empresa. Para os autores, indicadores financeiros de curto prazo como lucratividade e taxa de retorno terão que ser substituídos por indicadores não financeiros. No curto prazo, lucros mais elevados podem ser originários mais da recuperação de preços dos produtos, do que de uma maior produtividade, por exemplo. Num prazo mais longo, os produtores de baixo custo precisam garantir o sucesso através dos ganhos de produtividade. Afinal, a situação favorável dos preços também estará disponível para a concorrência.

NEELY (1999) argumenta que inúmeros autores discutem as questões relacionadas com as medidas de desempenho das organizações. Relata que os indicadores financeiros tradicionais são criticados em virtude das seguintes razões: incentiva decisões imediatistas; não possui foco estratégico, além de ser inadequado para quantificar dados sobre qualidade, responsabilidades e flexibilidade; motiva os gerentes a minimizar as variações dos processos para obter otimizações locais, em detrimento da melhoria contínua; as medidas financeiras não refletem as necessidades dos consumidores e nem informam sobre o desempenho dos concorrentes. Por fim, a medida do desempenho de um sistema organizacional é importante, na medida em que direciona ações e recursos para aqueles processos que estão aquém de suas potencialidades. Assim, a medição do desempenho só se justifica no sentido de aprimorá-lo (SINK \& TUTTLE, 1993; DEMING, 1986).

\subsubsection{O DESEMPENHO E SEUS COMPONENTES}

ROSA (1996) constata uma variedade de definições para o termo desempenho e seus componentes na prática operacional dos sistemas organizacionais. Segundo o autor, há empresas que confundem conceitos como produtividade com produção, avaliam a eficiência por meio de medidas que 
explicitam o rendimento e assim por diante. O presente título pretende sistematizar tais conceitos e fornecer uma definição apropriada para o desempenho de um sistema organizacional de tal modo que a tarefa de sua medição possa se tornar factível.

Os recursos de um sistema organizacional podem ser reunidos em três grupos básicos, segundo CAMPOS (1992). O primeiro pode ser definido como os recursos materiais (hardware), compreendendo máquinas, equipamentos e instalações. Em seguida vem o dos recursos técnicos e administrativos que representam todos os procedimentos responsáveis (software) pelo funcionamento da organização. Finalmente o terceiro é composto pelos recursos humanos da organização (humanware). Neste contexto, ROSA (1996) formula um conceito para o desempenho de um sistema organizacional.

O autor entende que o desempenho está ligado ao gerenciamento simultâneo destes três grupos de recursos e será tanto melhor quanto mais integrado estiverem dentro da própria organização, conforme apresentado na Figura 2-1(a). Dessa forma é possível inferir que um sistema organizacional apresentando um desempenho ideal pode ser representado pela Figura 2-1(b). Em contrapartida, um sistema em que o desempenho é nulo apresentaria uma ausência completa de integração de seus recursos, como se pode ver na Figura 2-1(c).

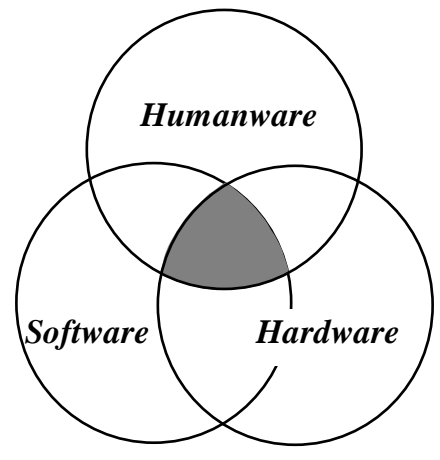

(a) - Desempenho

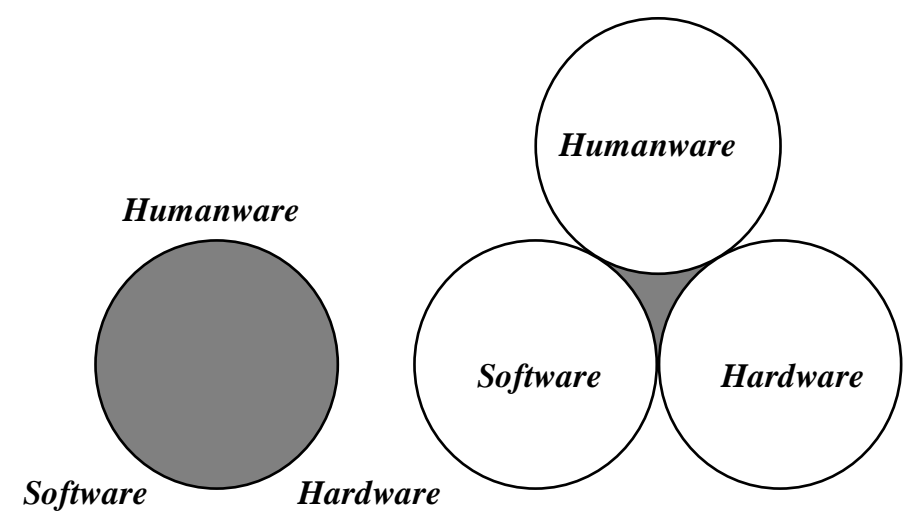

(b) - Desempenho Ideal (c) - Ausência de Desempenho

Figura 2-1 - Desempenho de um Sistema Organizacional.

Fonte: ROSA (1996). 
Por outro lado, vários autores sugerem uma visão holística para o sistema organizacional que se quer avaliar. Assim, um sistema é constituído por vários outros, sendo possível identificar sistemas à montante e à jusante daquele que está sendo observado e, naturalmente, as suas respectivas interfaces (CAMPOS, 1992; SINK \& TUTTLE, 1993; SLACK, 1993; DEMING, 1986).

Assim, um sistema organizacional possui inputs, atividades ou processos de transformação que agregam valor aos inputs que recebe e, outputs (resultados), que provocam efeitos nos sistemas à jusante.

A Figura 2-2 exemplifica o modelo do enfoque.
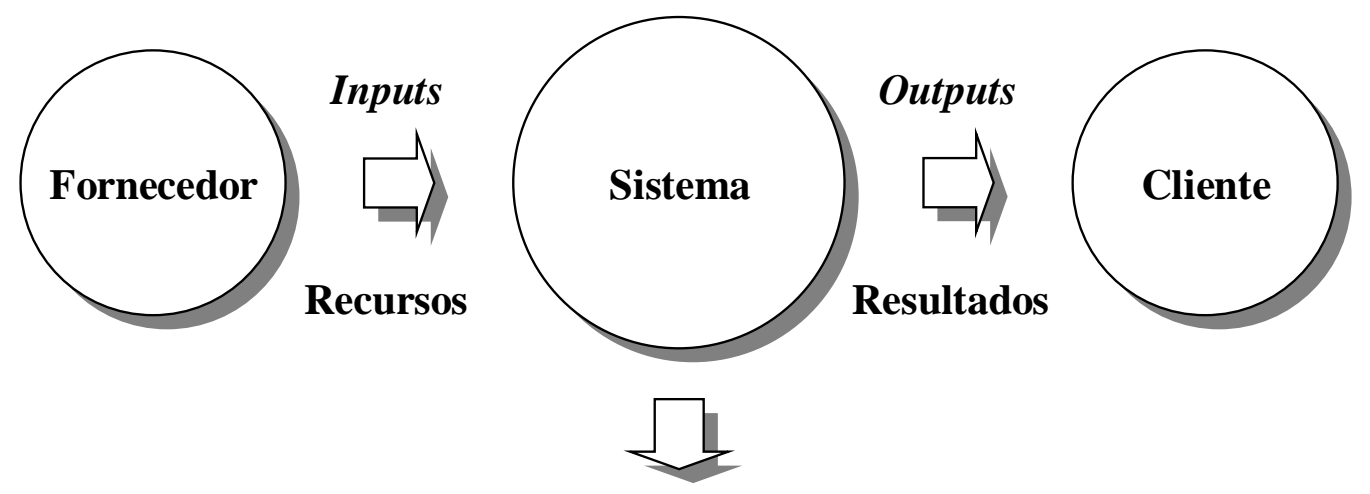

Transformações que agregam valor

Figura 2-2 - Visão Holística de um Sistema Organizacional.

Fonte: CAMPOS (1992).

\subsubsection{O MODELO DE AVALIAÇÃO SEGUNDO SINK E TUTTLE}

O modelo proposto por SINK \& TUTTLE (1993) estabelece que o desempenho de um sistema organizacional é composto por um complexo interrelacionamento de vários parâmetros ou critérios de desempenho, assim denominados: eficácia, eficiência, produtividade, qualidade, qualidade de vida no trabalho, inovação e lucratividade, para os centros de lucro, ou orçamentalidade 
para os centros de custo e organizações sem fins lucrativos. A Figura 2-3 representa a esquematização do modelo

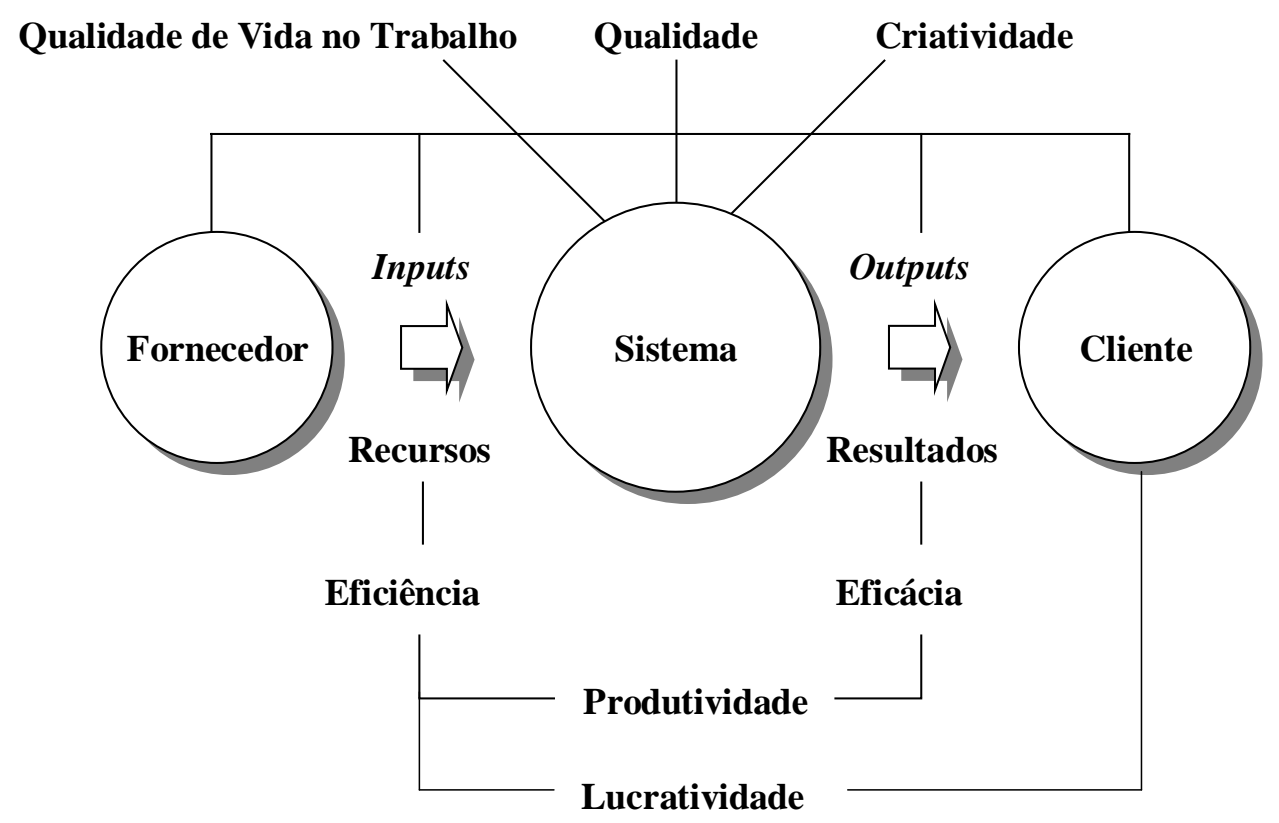

Figura 2-3 - Modelo Gerencial de Avaliação de SINK \& TUTTLE.

Fonte: SINK \& TUTTLE (1993).

O grau de eficácia de um sistema deve traduzir a forma pela qual o sistema realiza aquilo a que se propôs, bem como refletir os objetivos corretos por ele alcançados. Obviamente, o conceito de objetivo correto estará sempre sujeito a interpretação, critério, julgamento e percepção de pessoas ou grupo de pessoas. Em outras palavras, a eficácia pode ser entendida como sendo a realização efetiva das coisas certas, pontualmente e dentro dos requisitos de qualidade especificados. O modelo estabelece uma medida operacional para a eficácia pela relação entre resultados obtidos e previstos. O conceito de ser mais ou menos eficaz depende do resultado da relação proposta. É uma medida comparativa que deve ser observada ao longo de períodos subseqüentes.

A eficiência deve estar associada ao consumo de recursos e pode ser visualizada no lado referente aos inputs. Uma definição operacional para a eficiência pode ser estabelecida pela relação entre consumo previsto de recursos e consumo 
efetivo de recursos. Se maior que um, então o sistema foi mais eficiente do que se esperava, uma vez que consumiu menos recursos do que o previsto; se menor que um, o sistema foi menos eficiente. Espera-se, também, que a eficiência tenha uma correlação positiva com o tempo. Neste ponto, é possível refletir o relacionamento que existe entre os critérios eficácia e eficiência. O resultado esperado do sistema é conseqüência da quantidade prevista de recursos para a sua realização. Por outro lado, o resultado obtido é também função da quantidade efetiva de recursos consumida pelo próprio sistema. Assim, a relação entre eficiência e eficácia pode ser percebida através da produtividade.

Na visão do modelo, a produtividade é uma relação entre os resultados gerados pelo sistema e os recursos que propiciaram a geração desses resultados. O conceito da produtividade, como um importante parâmetro de desempenho, pode ser ampliado, uma vez que incorpora os conceitos de eficácia, eficiência e qualidade.

Enquanto a eficiência está relacionada ao consumo de recursos e à eficácia aos resultados, a qualidade, como parâmetro de desempenho, é mais difusa no sistema organizacional em função de sua importância em todos os estágios de gerenciamento do sistema. O parâmetro de desempenho qualidade deve ser definido operacionalmente com pelo menos cinco pontos de verificação, no sistema organizacional.

O gerenciamento do primeiro ponto de verificação compreende um conjunto de atividades que garantam a efetividade dos recursos. O segundo ponto enfoca a confirmação de que o sistema organizacional efetivamente está recebendo os recursos que necessita. O terceiro aborda uma parte importante do gerenciamento da qualidade total: a criação de qualidade no produto ou serviço realizado pelo sistema organizacional e tem relações profundas com as percepções e o potencial criativo das pessoas. O quarto ponto de verificação da qualidade garante que os resultados, gerados pelo sistema organizacional, satisfazem às especificações e requisitos estabelecidos. Finalmente, o quinto ponto de verificação enfoca os sistemas à jusante e reflete a compreensão detalhada e significativa daquilo que os clientes querem, precisam, esperam e exigem e de como estão reagindo à entrega dos bens e serviços que o sistema organizacional está fornecendo. 
A qualidade de vida no trabalho enfoca um aspecto particular do processo de transformação e é caracterizado pelas pessoas que compõem o sistema organizacional. Na visão esquemática para a definição operacional do parâmetro, observa-se que ele apresenta relações com o terceiro ponto de verificação de qualidade em que o sistema constrói a qualidade do produto ou do serviço.

A criatividade ou inovação também é um parâmetro de desempenho que guarda relações com o terceiro ponto de verificação de qualidade. A inovação pode ser entendida como um processo criativo capaz de mudar aquilo que o sistema organizacional faz e, também, o modo de fazer. Este processo deve incluir mudanças importantes na estrutura da organização, na tecnologia, nos produtos, nos serviços, nos métodos de procedimentos, nas políticas e outros aspectos julgados necessários. Essas mudanças devem afetar de modo positivo a flexibilidade do sistema organizacional e permitir uma reação, com êxito, a pressões, oportunidades, desafios e ameaças internas e externas.

A definição operacional da lucratividade ou orçamentalidade é proposta como sendo a relação existente entre o resultado financeiro alcançado pelo sistema organizacional e os custos que propiciaram alcançá-lo. A lucratividade é, todavia, diferenciada da orçamentalidade, pois que a primeira é associada aos centros de lucros e definida como uma medida ou conjunto de medidas que relacionam receitas com custos. Já a orçamentalidade é associada aos centros de custos e definida como uma medida ou conjunto de medidas que relacionam orçamentos, metas, entregas, custos e prazos.

Embora todos os parâmetros sejam relevantes para todos os sistemas organizacionais, sua importância relativa varia em função do tipo de sistema que está sendo observado. Nesse sentido, SINK \& TUTTLE (1993) classificam os sistemas organizacionais em três tipos, de acordo com seus objetivos: resultados diretos, resultados indiretos e resultados desconhecidos.

Nos sistemas de resultados diretos, tais como a fabricação automatizada, oficina de consertos de aparelhos e caixas bancárias, não existe uma variabilidade de outputs. Neste tipo de sistema, a eficiência torna-se um parâmetro relevante porque a organização preocupa-se com a habilidade de seus recursos em produzir uma 
quantidade de outputs num período de tempo apropriado. A qualidade é também outro parâmetro importante uma vez que a satisfação do cliente está associada ao grau em que o output corresponde aos requisitos do cliente. A eficácia - entendida como o output adequado - não é uma preocupação significativa, segundo os autores, porque as pessoas que atuam no sistema têm pouca possibilidade de exercer sua influência nos outputs produzidos.

Empresas de projetos, softhouses e firmas de consultoria são exemplos de sistema de resultados indiretos, onde o grau de variabilidade dos outputs é bem maior. Neste tipo de sistema, a eficácia, entendida como resultado desejado, é um importante parâmetro de desempenho. Somente depois de ter os outputs claramente especificados, é que o sistema irá se concentrar na melhoria da eficiência e produtividade com as quais esses outputs são produzidos

Para os autores, o terceiro tipo de sistema - sistema de resultados desconhecidos está sempre em preparação para poder desempenhar uma dada missão, mas existe a possibilidade de nunca ter que efetivamente desempenhá-la em um ambiente operacional.

As Organizações Militares, a Defesa Civil, as Instituições Educacionais e de Serviços Sociais são entidades representativas desta categoria. As Instituições Educacionais podem até mesmo acompanhar o progresso dos formandos, porém os resultados finais são geralmente desconhecidos. Na área militar existem exercícios simulados, batalhas e catástrofes simuladas. Para essas organizações a medida crítica é justamente a eficácia, que não chega a ser conhecida. Em conseqüência, tendem a resistir a medições de eficiência e produtividade, uma vez que não se podem comparar recursos previstos e consumidos em face do resultado do sistema ser desconhecido.

\subsubsection{O MODELO DE AVALIAÇÃO SEGUNDO SLACK}

Existem cinco elementos básicos de desempenho considerados pelo modelo de SLACK (1993): qualidade, velocidade, confiabilidade, flexibilidade e custos. Através deles, a produção de bens ou de serviços contribui de forma significativa 
para o desempenho global do sistema e cada um deles incorpora uma vantagem competitiva para a organização. A Figura 2-4 representa o esquema do modelo.

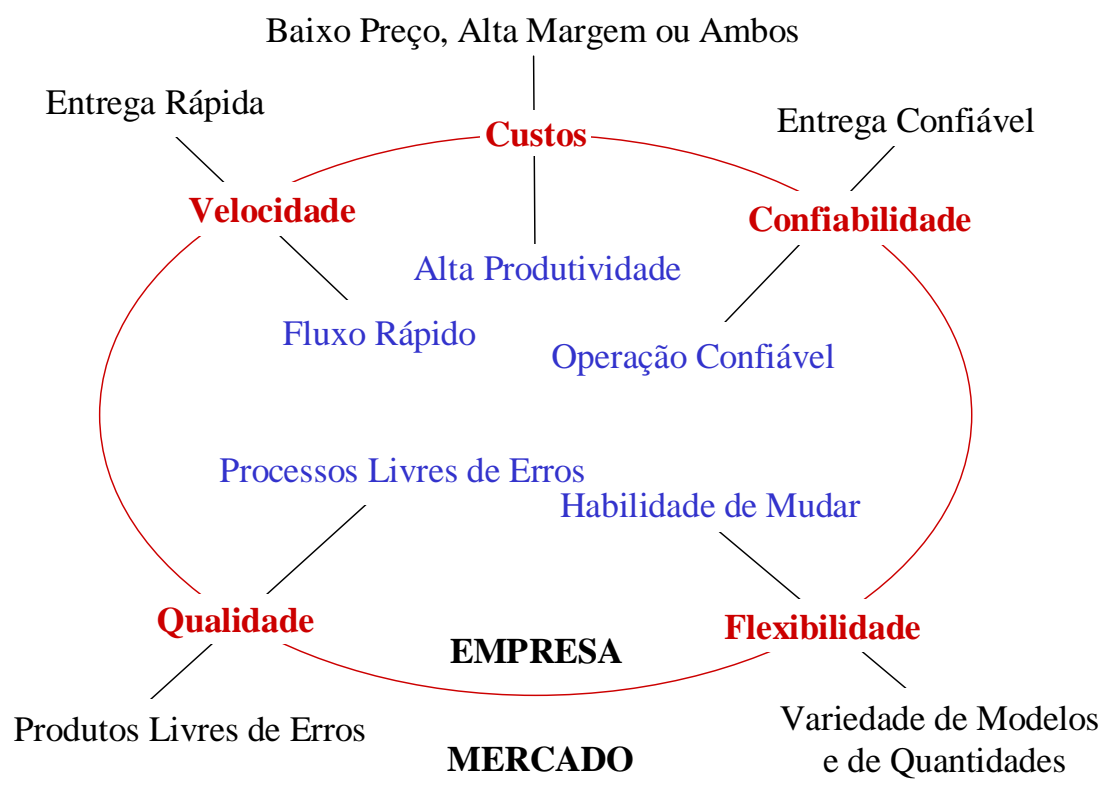

Figura 2-4 - Modelo Gerencial de Avaliação de SLACK.

Fonte: SLACK (1993).

A qualidade é entendida como ausência de erros, isto é, não cometer erros na conformação dos produtos. Produtos livres de erros significam processos livres de erros. A velocidade significa trabalhar rápido. Fazer com que o intervalo de tempo entre o início do processo de fabricação e a entrega do produto ao cliente seja pequeno. Menor do que aquele oferecido pela concorrência. Significa reduzir o lead time da empresa, ou seja, fluxo de informações, de materiais e de operações também reduzidos. Manter a promessa dos prazos de entrega é o sentido do elemento confiabilidade. Entrega confiável significa operação confiável.

A flexibilidade deve ser entendida como a capacidade da manufatura migrar de uma configuração para outra. Adaptar a operação, ou porque as necessidades dos clientes foram alteradas, ou os processos de produção sofreram modificações, ou mudanças ocorreram nos canais de suprimentos. Flexibilidade significa estar apto para mudar toda vez que for necessário e com rapidez suficiente. A vantagem de custos é fazer barato. Significa conformar os produtos com custos mais baixos que aqueles dos concorrentes. Seja pela aquisição de recursos mais baratos ou através de 
processos de transformação mais eficientes. Em outras palavras, baixo preço, alta margem ou ambos significam alta produtividade da organização.

\subsubsection{CONSIDERAÇÕES FINAIS}

Tendo em vista o que foi exposto anteriormente, pode-se inferir que a importância dos parâmetros é dependente da situação e das peculiaridades do próprio sistema. Um laboratório de pesquisa e desenvolvimento, por exemplo, dará, certamente, a cada um dos parâmetros uma importância diferente do que faria um departamento de produção de uma empresa industrial. É improvável que dois sistemas organizacionais ou gerentes distintos dêem o mesmo peso aos mesmos parâmetros. É possível que um mesmo sistema pondere de forma diferente os mesmos parâmetros, em épocas distintas.

O tempo, associado à resposta rápida do sistema, explicita a velocidade das operações como uma medida de eficiência. O tempo de processamento associado ao tempo planejado representa o recurso em tempo previsto para o processamento. O tempo de fluxo total traduz o tempo efetivamente gasto para o processamento. Pelo que se pode avaliar, a vantagem de velocidade da operação pode ser vista como medida de eficiência porque compara recursos previstos e consumidos.

A confiabilidade também pode ser expressa em termos da definição operacional de eficiência proposta por SINK \& TUTTLE (1993), na medida em que se pode comparar a data de entrega prevista com a data de entrega realizada.

A qualidade tem um grande poder motivacional. Um alto nível de desempenho de qualidade interna assegura produtos livres de erros para os consumidores. Melhora outros aspectos do desempenho interno tais como velocidade, confiabilidade e custos. A forma de a organização poder garantir a satisfação do consumidor externo é assegurar a satisfação de seus próprios consumidores internos. O gerenciamento da qualidade total implica não somente no aprimoramento contínuo dos níveis de qualidade. Significa também envolvimento no processo global de eliminação de defeitos. Não só monitorar o processo e registrar o seu desempenho, mas analisar o seu comportamento ao longo do tempo. Qualidade 
significa também implantar melhorias e acompanhar seus efeitos sobre o desempenho.

Observa-se que o conceito de flexibilidade como elemento de desempenho, proposto por SLACK (1993), está intimamente ligado à definição operacional de inovação defendida por SINK \& TUTTLE (1993). Ambas as propostas estão ligadas à habilidade de fazer mudanças, de usar a criatividade para melhorar métodos e processos. SALERNO (1991) ainda salienta que a questão da flexibilidade está centrada nos critérios adotados para a sua avaliação. Nestas condições propõe indicadores que contemplem inovações de produtos, processos, marketing, lançamento de novos produtos e de estrutura organizacional que promovam um menor lead time e qualidade centrada no processo, como um dos critérios para avaliar a flexibilidade da organização.

Todos os elementos de desempenho, propostos por SLACK (1993), apóiam o custo da organização. Assim, os custos são reduzidos pela velocidade das operações. O fluxo de materiais que se move rapidamente pelos diferentes estágios do processo despende menos tempo em filas ou em estoques intermediários. Isto significa menos despesas indiretas e previsões mais fáceis. A habilidade da operação em propiciar fluxo mais rápido é dependente de operações livres de erros.

A qualidade mais alta funciona como um redutor de custos. Menos erros dentro das operações refletem na redução direta dos refugos, retrabalhos e desperdícios. Menos erros também significam menos surpresas na operação e mais confiabilidade interna e externa.

A confiabilidade de entrega é decorrente de um fluxo mais rápido, principalmente porque pequenos desvios na programação podem ser mais facilmente acomodados. A confiabilidade interna também reduz custos. Se todas as partes, materiais e informações fluem, dentro da operação, conforme foi planejado, as despesas indiretas com o seguimento das entregas atrasadas serão eliminadas. Da mesma forma são eliminadas as despesas indiretas com o esforço das reprogramações. A flexibilidade operacional reduz custos. A redução dos tempos de setup reduz despesas indiretas, além de incrementar a confiabilidade interna. A 
flexibilidade permite a opção por roteiros alternativos de processo de forma a evitar indisponibilidades inevitáveis de máquinas, o que reduz custos.

Como se pode observar, os modelos apresentados conjugam-se no sentido de dar um direcionamento metodológico ao processo de avaliação de desempenho e demonstrar que por intermédio deles, a administração da competitividade de sistemas organizacionais torna-se factível.

\subsection{A CONSTRUÇÃO DE INDICADORES GERENCIAIS}

\subsubsection{CONSIDERAÇÕES INICIAIS}

Os parâmetros e os elementos de desempenho, apresentados respectivamente nos modelos de SINK \& TUTTLE (1993) e SLACK (1993), representam um conjunto de informações necessárias para que os gerentes administrem o sistema organizacional de forma adequada. Eles não representam indicadores específicos de desempenho. Na verdade, a tarefa dos gerentes é identificá-los. Os parâmetros e os elementos de desempenho funcionam como instrumentos, cujos mostradores são representados pelos indicadores específicos. Devem ser capazes de sinalizar se o sistema organizacional está sendo confiável, veloz, flexível, eficaz, eficiente e produtivo. Se a qualidade está sendo gerenciada em seus cinco pontos de verificação, se é lucrativo ou se a orçamentalidade está sendo corretamente administrada.

WESTWICK (1989) define indicadores como ferramentas essenciais para a monitoração do desempenho das organizações e da própria concorrência. O autor relata que a análise dos indicadores propicia às gerências o estudo e o entendimento, de forma sistemática, do desempenho dos processos internos e externos da empresa.

SUMANTH (1984) aponta diversos benefícios da medição do desempenho para as organizações produtoras de bens e de serviços. Dentre eles, pode-se citar:

- A medição mostra a direção para comparações dentro da organização e de seu mercado e cria ação competitiva;

- A organização pode avaliar a eficiência da conversão de seus recursos na produção de bens ou serviços; 
- A medição facilita o planejamento de recursos de curtos e longos prazos; o planejamento de metas de desempenho para o futuro pode ser mais realístico;

- Os objetivos econômicos e não econômicos da empresa podem ser reorganizados por prioridade;

- A medição determina estratégias para cobrir a diferença entre os níveis de desempenho planejados e os medidos;

- Auxilia no planejamento dos lucros da organização; e

- Propicia a execução mais racional de acordos coletivos.

\subsubsection{INDICADORES, PARÂMETROS E MEDIDAS}

SINK \& TUTTLE (1993) sistematizam os conceitos para indicadores, parâmetros e medidas e alegam que estes termos por muitas vezes se alternam, podendo ter o mesmo significado, conforme o contexto ou entendimento. Para os autores, parâmetro pode ser considerado como um critério ou um meio de julgamento para que se defina o que deve ser medido. Já a medida é a operacionalização do parâmetro, ou seja, é a definição precisa das circunstâncias que envolvem a sua quantificação, enquanto que indicador é uma relação que possibilita a quantificação do parâmetro.

Na visão de WESTWICK (1989), um indicador expressa simplesmente um número para um resultado de uma comparação entre duas situações. Para o autor, tecnicamente um indicador deve ser expresso por uma fração. Aquilo que se quer avaliar fica alocado no numerador da fração, para que possa ser relacionado a um outro fator que está indicado no denominador da fração. Uma das vantagens do uso de indicadores é justamente a importância, ou foco, que se pode dar tanto no numerador como no denominador da fração. Tal foco ajuda escapar das armadilhas inerentes ao uso absoluto dos números. 


\subsubsection{REQUISITOS OPERACIONAIS}

KAYDOS (1988) alega que existem requisitos técnicos e culturais em um eficiente sistema de medidas de desempenho e que são fundamentais para prover os gerentes de informações acuradas, relevantes e oportunas. Argumenta que um sistema de medida pode ser tecnicamente perfeito, mas não será efetivo se os requisitos culturais e sociais da empresa não forem atendidos. Esses requisitos podem ser conflitantes com a cultura da empresa.

O autor relata as características técnicas e culturais de um sistema de medidas, da seguinte forma:

\section{1) Requisitos Técnicos}

$\checkmark \quad$ Inteireza (Integridade) - necessário para prover um quadro completo do desempenho de forma que não parecerá melhor ou pior do que na realidade é;

$\checkmark$ Explicar a Lacuna de Desempenho - o sistema de medidas deve poder explicar de $80 \%$ a $90 \%$ das diferenças entre o previsto e o encontrado. Deve basear-se no fato de que $\pm 20 \%$ das causas correspondem por $\pm 80 \%$ dos desvios de desempenho. As outras $\pm 80 \%$ das causas respondem pela minoria dos desvios. O autor relata que 95\% das lacunas de desempenho normalmente não são difíceis de encontrar;

$\checkmark$ Detalhes Suficientes - o sistema de indicadores deve ter detalhes suficientes por três importantes razões: (a) para isolar a causa do problema no ponto onde uma ação pode ser tomada; para a resolução de um problema geral é necessário descobrir o problema específico que o causa; (b) estar apto a estabelecer responsabilidades pelo problema; deve-se determinar quem é o responsável pela melhoria da medida de desempenho ou por resolver o problema; se suficientes detalhes são providos para identificar a causa do problema, então as responsabilidades podem ser atribuídas com maior segurança, seja em nível de departamento, de grupo de trabalho ou de indivíduo; (c) ser 
capaz de ver todos os problemas e oportunidades com um controle adequado; negócios são sistemas muito complexos e para um controle apropriado suas medidas de desempenho devem refletir esta complexidade;

$\checkmark$ Acurácia - é a precisão objetiva na reportagem dos dados. Assim, qualquer mudança em uma medida de desempenho é um indicador confiável de uma mudança no desempenho;

$\checkmark$ Oportunidade - a análise dos dados deve ser circunstanciada pelos eventos que ocorreram durante a coleta dos mesmos, ou seja, não deve haver demora entre a coleta e a análise dos dados, pois algum fato importante pode ser esquecido;

$\checkmark \quad$ Freqüência - a freqüência da coleta e análise dos dados deve ser compatível com a velocidade das mudanças na organização. Utilizar um número elevado de medições num ambiente de mudanças lentas significa aumentar os custos de medição e de análise desnecessariamente. Por outro lado, medir pouco em um ambiente de mudanças rápidas pode significar uma imagem distorcida da realidade;

$\checkmark$ Ciclo de Aprendizagem - algumas ações decorrentes da análise dos dados coletados podem ter seus resultados avaliados em pouco tempo, dias ou semanas. Outras podem demorar anos. Isto precisa ser levado em conta na hora de se estabelecer o que será medido. Caso contrário pode-se pensar que o resultado não corresponde às expectativas, quando na verdade está ocorrendo só uma acomodação do processo. Assim, o ciclo de aprendizagem corresponde ao tempo decorrido entre a medida inicial, análise dos dados, implementação das ações corretivas ou preventivas e a coleta de novos dados para verificação dos efeitos no processo;

Operação Sistemática - o sistema de medida deve ser parte integral do negócio e não alguma coisa de caráter meramente eventual. A coleta sistemática serve não só para medir, mas para rever as 
informações em uma base regular que auxilie na mudança de prioridades, procedimentos e alocação de recursos;

$\checkmark$ Consistência de Longo Prazo - as mudanças nas medidas no curto prazo são importantes para serem analisadas. Entretanto, deve-se prestar atenção naquelas de longo prazo, onde o mix de produtos, volume de produção e o nível de vendas podem sofrer alterações. Portanto, estes fatores precisam ser isolados para se evitar erros de análise. Assim, devem-se procurar indicadores que possam ser válidos ao longo do tempo; e

$\checkmark$ Medidas Financeiras e Requisitos Operacionais - medidas financeiras e operacionais são complementares e não devem ser utilizadas isoladamente para analisar a situação do negócio. As medidas financeiras não são adequadas para gerenciar ou medir as operações do negócio, da mesma forma que as medidas operacionais não devem ser utilizadas para gerenciar o seu lado financeiro.

\section{2) Requisitos Culturais}

$\checkmark$ Ausência de Medo - é um dos 14 pontos da proposta de DEMING (1986) em seus conhecidos princípios. Para a avaliação do desempenho existem dois medos específicos que tornam um sistema de medidas completamente inútil. O primeiro é o medo pessoal de ser repreendido por apresentar maus resultados. Se existem conseqüências negativas, há a possibilidade de que os dados sejam distorcidos. O segundo é o medo de colocar um colega ou amigo em má situação por reportar um resultado que possa indicar um desempenho ruim. No meio operacional, os problemas são muitas vezes reportados voluntariamente por quem os encontra. Assim, se houver o medo de represálias por resultados ruins haverá o receio de reportar os dados;

$\checkmark$ Responsabilidade - a responsabilidade deve ser atribuída de forma integral. Responsabilidades partilhadas tendem a incorrer em problemas. Isso não invalida a participação das partes na 
responsabilidade do todo. Normalmente as pessoas não têm dificuldades em assumir responsabilidades pelos problemas ocorridos, quando elas possuem a autoridade para interferir nas causas geradoras dos mesmos;

$\checkmark \quad$ Validade - as medidas de desempenho devem ser aceitas por todos na organização. Se não estiverem sendo, dois possíveis problemas podem estar ocorrendo: ou as medidas não são compreendidas ou existem falhas no sistema de medidas. Em ambos os casos o problema deve ser eliminado seja, pelo treinamento adequado, seja pela modificação do sistema de medidas. A ação deve ser precisa e rápida para que as medidas não caiam no descrédito;

$\checkmark$ Facilmente Compreendidas e Relevantes para o Usuário - se as medidas não são fáceis de terem sua importância entendidas pelos usuários, poderão ser mal usadas ou até mesmo não usadas. Daí a necessidade de se empregar termos que sejam familiares e do treinamento, para a discussão da relevância das medidas, com os envolvidos;

$\checkmark \quad$ Fácil de Usar - reportar dados deve ser uma atividade simples e fácil para todos os envolvidos. Da mesma forma, a análise dos dados deve ser elaborada de forma a ser de fácil compreensão por todos;

SUMANTH (1984) relata que não há uma concordância expressa quanto à definição e à utilização de indicadores entre os diversos atores nos sistemas organizacionais. Quanto mais se tenta chegar a um denominador comum, mais confusão se cria. Isso se deve ao fato de que usuários de diferentes formações e origens tentam criar indicadores que atendam às suas expectativas. $\mathrm{O}$ autor relata $\mathrm{a}$ diversidade dos pontos de vista sobre medidas de desempenho, nas organizações:

1) Visão dos Contabilistas - Utilizam normalmente a taxa de retorno do capital como medida de desempenho;

2) Visão dos Economistas - Usam medidas parciais de produtividade, principalmente a produtividade do trabalho, para avaliar o desempenho; 
3) Visão Comportamentalista - Avaliam o desempenho pela utilização do tempo pelas pessoas na realização das tarefas, tomando como base de comparação o tempo disponível. Na verdade, esta visão pode induzir a erros de interpretação, pois utilizar bem o tempo disponível não dá garantias que a realização da tarefa foi de forma eficiente ou produtiva.

4) Visão dos Engenheiros - Os engenheiros, geralmente, buscam medidas de ativos físicos e outros recursos, tais como produção por hora, homens/hora por unidade e assim por diante.

5) Visão dos Gerentes - Normalmente interessados em medidas que indiquem a lucratividade a partir de indicadores da contabilidade.

GOLD (1985) relata os requisitos gerenciais que um sistema de análise de desempenho deve possuir:

- As medidas devem cobrir mudanças em cada input que contribui para o efetivo desempenho;

- As medidas devem identificar melhorias e atrasos específicos de desempenho dentro de cada departamento operacional ou centro de custo;

- O sistema não deve somente medir as mudanças ocorridas no desempenho, mas também buscar identificar as suas causas. Isto serve para estabelecer diferenças entre os efeitos causados por mudanças nas condições do mercado, alterações na planta industrial e modificações operacionais;

- O sistema deve também facilmente traçar os efeitos, desde o setor de custos, propiciado por alguma inovação que resulte em alteração no desempenho, até ao produto final;

- As medidas devem facilitar as respostas do planejamento estratégico aos impactos externos que afetam a competitividade e lucratividade da organização. Inclusos, neste contexto, encontram-se as reduções nos preços dos produtos, os acréscimos nos fatores de preços, as mudanças no suprimento ou na qualidade dos produtos e o proveito da inovação tecnológica; 
- Os gerentes devem usar os recursos do sistema de medição de forma regular e efetiva. Isto envolve aprendizado em participar com os subordinados da avaliação das causas e efeitos das mudanças passadas no desempenho.

Finalmente, SINK \& TUTTLE (1993) complementam o ponto-de-vista de KAYDOS (1988) sobre requisitos técnicos e culturais, quando relatam alguns paradigmas que dificultam o uso eficaz de sistemas de medição:

- A medição é ameaçadora - A imensa maioria dos funcionários de uma organização tende a manter na memória um dado indicador que foi utilizado para constranger alguém. Estes casos acabam por ser incorporados à cultura da empresa e dificultam a introdução de novos indicadores. Não é a medição em si que incomoda as pessoas, mas sim a forma como as informações, dela decorrentes, são usadas;

- Enfoque em único indicador - A análise do desempenho tomando por base um único indicador geralmente conduz a decisões equivocadas. Por mais simples que seja uma empresa, ela é fruto da composição de vários fatores complexos. Uma empresa pode ser muito eficiente na utilização de seus recursos e não sobreviver no mercado, em face da concorrência;

- Ênfase excessiva na produtividade da mão-de-obra - Toda vez que uma organização enfoca a produtividade como uma das dimensões mais importantes do desempenho, tende a dar excessiva ênfase à produtividade da mão-de-obra. Nestas condições, o desempenho passa a ser imputado única e exclusivamente na responsabilidade das pessoas. Os fatores políticos, econômicos conjunturais que, sem dúvida, em muito afetam o desempenho das empresas, são esquecidos. Além disso, indicadores dessa natureza geram perdas no clima organizacional da empresa devido à incerteza de permanência no emprego, em face de um resultado ruim; 


\subsubsection{UTILIZAÇÃO DE PADRÕES}

SLACK ET AL (1999) explicam que normalmente as empresas utilizam padrões para julgar seu próprio desempenho medido por meio de indicadores. Relatam que existem quatro tipos de padrões comumente usados: padrões históricos, padrões de desempenho alvos, padrões de desempenho da concorrência e padrões de desempenho absolutos.

\section{A. PADRÕES HISTÓRICOS}

Comparar o desempenho atual com desempenhos anteriores é uma forma de utilizar padrões históricos. Tais padrões são efetivos na medida em que julgam que uma dimensão do desempenho está melhorando ou piorando com o tempo, porém não dão uma indicação se o desempenho em questão está satisfatório ou não. Se o lead-time de uma empresa, para atendimento de um pedido, era de sete semanas e atualmente é de cinco semanas, pode-se dizer, com segurança, que a empresa evoluiu historicamente. Entretanto, não se pode afirmar que este desempenho foi satisfatório sem antes analisar o lead-time da concorrência que poderia ser, por exemplo, de duas semanas. O passado da própria empresa, na maioria dos casos, é o referencial mais vantajoso e normalmente o mais utilizado, segundo SIQUEIRA (1999). Entretanto, não é tão fácil a sua obtenção em uma empresa que está iniciando suas atividades ou não teve o devido cuidado em manter registros de seus resultados. A empresa que utiliza padrões históricos está comparando produtos, métodos e processos idênticos ou no mínimo similares. Contudo, algumas desvantagens existem quando as organizações utilizam o passado para analisar o desempenho atual, conforme salienta o autor:

- Os padrões encontrados no passado podem não ter sido os mais adequados. Se forem utilizados podem conduzir a uma análise distorcida da realidade;

- Uma melhoria aparente pode ser decorrência mais de um efeito da mutação da economia do que um incremento na eficiência do processo produtivo; 
- Como a tecnologia está em constante aperfeiçoamento, é possível que um nível de realização, perfeitamente satisfatório no passado, pode ser inaceitável nas condições tecnológicas atuais; e

- Um indicador de desempenho que traga valores monetários em sua definição, como por exemplo, vendas por empregados, pode sofrer um desgaste pelos efeitos da inflação. Nestas condições, qualquer comparação é inviável;

\section{B. PADRÕES DE DESEMPENHO ALVOS}

Os padrões de desempenho alvos são arbitrariamente estabelecidos para refletir um nível de desempenho, definido como adequado ou razoável, segundo SLACK ET AL (1999). Os autores citam orçamentos, metas e previsões como exemplos típicos de padrões de desempenho alvos. Afirmam que todas as previsões, sem exceções, pertencem a uma rota de falhas uma vez que a racionalidade é limitada. Tal fato gera um potencial de fraqueza quanto ao uso de orçamentos, metas e previsões como um padrão de comparação. Entretanto, WESTWICK (1989) argumenta que orçamentos, metas e previsões são, provavelmente, os melhores padrões-alvo que uma empresa pode ter. Apresentam-se vantajosos quando confrontados com padrões históricos, desde que se considerem as seguintes circunstâncias: variações no nível da economia, no estado da tecnologia e no valor da moeda.

\section{PADRÕES DE DESEMPENHO DA CONCORRÊNCIA}

Os padrões de desempenho da concorrência comparam o desempenho atingido por uma organização com o dos seus concorrentes no mercado. Em termos de melhoramentos de desempenho estratégico, os padrões da concorrência seguramente são os mais úteis. Entretanto, a utilização de tais padrões deve levar em conta que as comparações somente são factíveis se estiverem considerando organizações nas mesmas condições de mercado (SLACK ET AL, 1999; WESTWICK, 1989; SIQUEIRA, 1999). 


\section{PADRÕES DE DESEMPENHO ABSOLUTOS}

Os padrões absolutos, ideais ou utópicos adotam seus valores em limites teóricos. Os padrões defeito zero e estoque zero são bons exemplos de padrões ideais. Tais padrões ilustram o quanto as organizações poderiam melhorar teoricamente.

\subsubsection{SELEÇÃO DE INDICADORES}

Para WESTWICK (1973), a seleção de indicadores de desempenho deve ser posterior à definição das metas e objetivos da organização. Acrescenta que os indicadores somente agregam valor na medida em expressam o caminho que uma organização deseja traçar. Neste sentido, o autor propõe um conjunto de características que devem balizar a sua seleção:

- Os gerentes devem sempre que possível adotar indicadores fáceis de avaliar o sucesso de sua organização. Tais indicadores devem estar subsidiados por outros que ajudam a explicar como este sucesso pode ser alcançado ou mantido. Deve haver uma lógica inter-relacionando os indicadores de modo que possa ter uma análise sustentada durante a avaliação dos dados;

- Pseudo-indicadores devem ser evitados, pois levam a interpretações ambíguas. Geralmente não apresentam uma relação matemática real para com os fatos. Por exemplo, o indicador vendas por empregados deveria ser analisado somente em relação aos funcionários diretamente ligados a essa atividade. Os empregados que não têm qualquer tipo de envolvimento com a área de vendas não deveriam ser contabilizados;

- Todo indicador selecionado dever dar ao gerente uma orientação para uma ação de melhoria. Deve medir um fato relacionado com as atividades da organização e não situações triviais ou ocasionais. Todo gerente deve sempre considerar o custo envolvido na obtenção de um indicador antes de sua implementação. Indicadores que geram informações para somente um gerente devem ser evitados e mantidos em números mínimos; e 
- Diferentes empresas requerem indicadores distintos, assim como também são diversas as formas de sua coleta. Dentro de uma organização, diferentes níveis de gerência requerem indicadores distintos, mas o tratamento dispensado aos mesmos deve ser uniforme.

ROSA (1996) apresenta as principais características que os indicadores de desempenho devem atender: não ambigüidade, facilidade de levantamento, facilidade de compreensão e facilidade de comparação.

Por outro lado, SLACK ET AL (1999) sugerem uma relação de indicadores, associados aos cinco elementos de desempenho em seu modelo para avaliação gerencial do desempenho e que podem ser vistos na Tabela 2-1.

\begin{tabular}{|c|c|}
\hline Elementos de Desempenho & Indicadores Associados \\
\hline \multirow{2}{*}{ Qualidade } & Nível de reclamação de consumidor \\
& Nível de refugo \\
& Alegações de garantia \\
Tempo médio de falhas
\end{tabular}

Tabela 2-1 - Elementos de Desempenho e Indicadores Associados.

Fonte: SLACK ET AL (1999). 
Para SINK \& TUTTLE (1993), os indicadores escolhidos devem proporcionar medidas que gerem informações. Tais informações, por sua vez, devem ser capazes de oferecer possibilidades de melhorias. Com base nas definições propostas pelos autores, em seu modelo de avaliação gerencial, é possível estabelecer um quadro que relacione exemplos de indicadores aos parâmetros de desempenho, como se pode verificar na Tabela 2-2.

\begin{tabular}{|c|c|}
\hline Parâmetros de Desempenho & Indicadores Associados \\
\hline \multirow{2}{*}{ Eficiência } & Tempo de máquina parada \\
& $\begin{array}{c}\text { Prazo de entrega médio } \\
\text { Utilização de espaço }\end{array}$ \\
& Horas planejadas/horas trabalhadas \\
Custos previstos/custos obtidos
\end{tabular}

Tabela 2-2 - Parâmetros de Desempenho e Indicadores Associados.

KAYDOS (1998) enfatiza que é importante medir com foco em resultados ou com base no consumo de recursos. Apresenta uma lista ampla de indicadores 
utilizados em diversas empresas, compilada de vários artigos, estudos de casos, consultorias e outras publicações. Tais indicadores estão agrupados por categorias e algumas delas não são exatas, porque dependem de especificações de processos, produtos e clientes:

- Desenvolvimento de negócios:

$\checkmark$ Novo negócio para produtos, penetração geográfica, penetração demográfica;

$\checkmark$ Certificação para clientes - porcentagem de negócios feitos com certificado de abastecimento; e

$\checkmark$ Proporção da melhoria da qualidade.

- Satisfação e insatisfação do cliente:

$\checkmark$ Expectativa do cliente versus desempenho da empresa - pela inspeção; e

$\checkmark$ Desempenho da empresa versus competição - pela inspeção.

- Atendimento ao cliente:

$\checkmark$ Chamadas não respondidas em xx segundos;

$\checkmark$ Chamadas em espera além de xx segundos; e

$\checkmark$ Chamadas transferidas para outra parte.

- Desenvolvimento de funcionários:

$\checkmark$ Funcionários que completaram um plano de desenvolvimento pessoal;

$\checkmark$ Funcionários completando um plano de desenvolvimento pessoal; e

$\checkmark$ Horas de treinamento por funcionário por ano.

- Satisfação dos funcionários:

$\checkmark$ Avaliação da satisfação com relação às questões de políticas salariais, chefes, superior imediato, condições de trabalho, horas de treinamento etc. 
$\checkmark$ Hora extra, voluntária ou não por problema específico; e

$\checkmark \quad$ Razões das faltas.

- Engenharia - Projeto:

$\checkmark \quad$ Tempo de ciclo de projeto;

$\checkmark$ Mudanças após o projeto estar completo; e

$\checkmark$ Ordens para mudanças - pelas razões.

- Impacto ambiental:

$\checkmark$ Consumo de água por unidade de produto, por funcionário ou por dólar vendido;

$\checkmark$ Desperdício de água por unidade de produto, por funcionário ou por dólar vendido;

$\checkmark$ Obediência à reformas - variadas auditorias; e

$\checkmark$ Porcentagem de material reciclado reaproveitado.

- Flexibilidade:

$\checkmark \quad$ Número de padrões, conformidades e partes únicas;

$\checkmark \quad$ Número de diferentes capacidades do processo; e

$\checkmark \quad$ Médias dos lotes produzidos.

- Inovação e desenvolvimento de produto:

$\checkmark \quad$ Número de melhorias em produto existente;

$\checkmark \quad$ Número de novos produtos introduzidos por ano; e

$\checkmark \quad$ Número de sucessos por novo produto.

- Manutenção:

$\checkmark$ Tempo perdido por diferentes tipos de problemas em equipamentos;

$\checkmark$ Manutenção planejada versus não planejada; e

$\checkmark$ Perdas por testes de manutenção. 
- Inventário:

$\checkmark$ Percentagem das ordens cumpridas; e

$\checkmark$ Variações no inventário físico.

- Mercado:

$\checkmark$ Participação das vendas; e

$\checkmark$ Crescimento das vendas versus crescimento do setor.

- Desenvolvimento organizacional:

$\checkmark$ Participação de funcionários e gerentes em equipes;

$\checkmark$ Funcionários em equipes autogerenciáveis; e

$\checkmark$ Economias advindas de sugestões.

- Produtividade:

$\checkmark \quad$ Vendas por funcionário;

$\checkmark$ Dólar produzido por funcionário; e

$\checkmark \quad$ Valor total de produtos acabados pelos seus custos.

- Compras:

$\checkmark$ Mudanças nas ordens de compra - pelas razões; e

$\checkmark$ Economias relativas aos custos anuais previstos.

- Qualidade externa - o que o cliente vê:

$\checkmark$ Reclamações e elogios;

$\checkmark$ Ordens perdidas - pelas razões; e

$\checkmark \quad$ Tempo perdido por falhas.

- Qualidade interna - quão bem estão os processos internos:

$\checkmark$ Custos da qualidade - retrabalhos, rejeições, garantias, retornos e refugos;

$\checkmark$ Perdas - de todos os tipos - má utilização da capacidade, tempo ocioso, perda de tempo, excesso de produção, etc.; e 
$\checkmark$ Processos abaixo do controle estatístico.

- Qualidade em liderança - quão bem os executivos lideram as melhorias na qualidade:

$\checkmark$ Tempo destinado para passar os valores de qualidade aos funcionários;

$\checkmark \quad$ Tempo destinado para melhorar a qualidade das atividades; e

$\checkmark$ Funcionários que aderem aos valores de qualidade e seus conceitos.

- Qualidade nas vendas:

$\checkmark$ Serviço, responsabilidade, conhecimento, empatia - pela satisfação do cliente;

$\checkmark$ Acurácia e especificações completadas como ordenadas; e

$\checkmark$ Acurácia do preço.

- Produtividade nas vendas:

$\checkmark \quad$ Tempo destinado nas vendas versus atividades administrativas;

$\checkmark$ Vendas por proporção do custo da venda; e

$\checkmark$ Vendas por funcionários envolvidos no processo de vendas.

- Eficácia na programação:

$\checkmark \quad$ Percentagem de itens em atraso versus média de produção diária; e

$\checkmark$ Alteração na programação - controlados e não controlados.

\subsubsection{CONSIDERAÇÕES FINAIS}

Os indicadores, em última análise, têm a finalidade precípua de quantificar os resultados decorrentes das atividades dos serviços ou da produção. Permitem uma percepção clara e definitiva não só do direcionamento gerencial da empresa, mas também dos eventuais desvios em relação às metas e objetivos estabelecidos.

O sucesso de um sistema de indicadores gerenciais para administrar a competitividade de uma organização não está associado tão somente ao conjunto de 
indicadores selecionados e nem a um sistema de medidas tecnicamente perfeito. O fator humano desempenha um peso considerável na efetividade do sistema de indicadores. Um sistema de medição de desempenho deve ser usado como um instrumento que possibilite o aprimoramento da organização.

Um processo de avaliação consistente permite ao corpo gerencial uma compreensão mais clara da sua realidade de desempenho e dos obstáculos presentes no dia a dia operacional. E por fim, cabe ressaltar que os indicadores devem dar uma idéia nítida dos ganhos pontuais e globais, decorrentes dos esforços de melhoria e qual é a inter-relação entre eles.

\subsection{A FUNÇÃO MANUTENÇÃO NA INDÚSTRIA}

\subsubsection{INTRODUÇÃO}

As modernas células de fabricação com centros de usinagem dotados de alto rendimento produtivo representam uma das formas de tornar o produto cada vez mais barato e acessível em um mercado cada vez mais competitivo. Tais ativos, quando utilizados e tendo em vista a complexidade das funções que deles são exigidas, estão sujeitos a mecanismos de falhas. Se uma falha ocorre durante o tempo de operação, pode-se pensar em perdas consideráveis para a produção, em termos de atrasos na entrega dos produtos, até que seja descoberto e substituído o componente danificado (MONCHY, 1989).

RODRIGUES (2000) afirma que existe uma cultura instituída no sentido de prevenir ou substituir um componente na iminência de falhar, mantendo a inevitável paralisação da produção sob controle. Em condições controladas as paralisações da produção por falhas nos equipamentos causam menores contratempos, segundo o autor.

Dentro deste contexto, uma questão fundamental se coloca: qual deve ser a freqüência das intervenções nos ativos de produção com vistas a maximizar a sua utilização? Se for alta, o risco de falha é pequeno, mas em contra partida o custo alto dessa medida irá reduzir a freqüência de intervenções e, como decorrência, correr o 
risco do ativo falhar. Deixar falhar, pagando o ônus que isto representa, ou prevenir a falha, auferindo as vantagens decorrentes, são os extremos entre os quais se deve procurar a melhor forma de manter um ativo dentro da prontidão funcional necessária.

Neste sentido, a função deve alavancar os cinco elementos básicos de competitividade propostos por SLACK (1993), para poder contribuir de forma significativa para o desempenho da empresa. A gestão da função manutenção com base em qualidade, velocidade, confiabilidade, flexibilidade e custos é, sem dúvida, um elemento decisivo para a competitividade da organização.

CONTADOR (2004) lembra que a função manutenção dentro de uma organização representa um alto potencial de contribuição para o aumento de desempenho, à luz de seu relacionamento com a função produção.

\subsubsection{HISTÓRICO}

A história da manutenção acompanha o desenvolvimento técnico industrial da humanidade, conforme relatam ARIZA (1978), MONCHY (1989), BAZOVSKY (1971), NAGAO (1998), MOUBRAY (1997) e NEPOMUCENO (1989).

No fim do século XIX, com o surgimento da mecanização das indústrias nasceu a necessidade dos primeiros reparos. Até 1914, a manutenção tinha importância secundária e as indústrias praticamente não possuíam equipes para a execução deste tipo de serviço. Os reparos eram trabalhados pelo mesmo efetivo da produção. Até essa época as equipes de manutenção praticamente não existiam e a maior parte dos cuidados com o equipamento era no sentido de trocar partes que se gastavam. Evitar que o desgaste ocorresse em curto prazo era também um cuidado que se tomava em relação aos equipamentos. Para isso, passava-se gordura de origem animal nas partes móveis e sujeitas a cargas mecânicas, onde o desgaste era notado com facilidade e contornado com esta simples providência. Neste período praticavase a manutenção acidental reativa da quebra - conserta sem nenhum planejamento na execução das tarefas. 
Com o advento da $1^{\text {a }}$ Guerra Mundial, as fábricas passaram a ter que manter uma produção mínima para fins bélicos e criaram equipes que pudessem corrigir as falhas dos equipamentos no menor tempo possível. Desta forma surge um órgão subordinado à produção, com uma função típica de manutenção. Esta situação mantém-se até a década de 30, quando advém a $2^{\text {a }}$ Guerra Mundial. A alta administração das fábricas preocupava-se em aumentar a produtividade. Não só em corrigir as falhas, mas também em evitar o seu aparecimento. Havia grande interesse que que os artefatos de guerra cumprissem a sua missão com sucesso e mesmo que apresentassem problemas na linha de combate o reparo deveria ser rápido e fácil.

Tal situação levou técnicos de manutenção a desenvolverem processos de prevenção de falhas (evolução dos conceitos de confiabilidade), que juntamente com a correção (manutenibilidade) completavam o quadro geral de manutenção. Forma-se uma estrutura de manutenção tão importante quanto à de produção. A história de engenharia da confiabilidade remonta a essa época, mais precisamente a Peenemunde, local das pesquisas bélicas alemãs. Daí surgem relatos das experiências com os foguetes $\mathbf{V} \mathbf{1}$ e a utilização dos conceitos de confiabilidade na melhoria do desempenho de tais artefatos.

De 1940 a 1966, com o avanço da indústria aeronáutica, ocorre a expansão dos critérios de manutenção preventiva, pois não é possível efetuar reparos na maior parte dos equipamentos de uma aeronave em vôo. Para garantir o funcionamento do equipamento surge então, dentro do órgão de manutenção, uma equipe altamente especializada preocupada em definir os níveis de confiabilidade dos equipamentos. Não só definir, mas também aumentá-la. Os conceitos de manutenção preventiva e de inspeção são estruturados para diminuir os riscos de acidentes. São realizados estudos em torno de como reduzir os tempos de reparo, aumentar a eficiência das equipes e melhorar os métodos de trabalho de manutenção, por intermédio do sistema PERT-CPM.

O dimensionamento da quantidade de sobressalentes necessários e o estudo das características das falhas passaram a ser desenvolvidos e agrupados em torno do título Engenharia de Manutenção. Devido as suas características peculiares as indústrias de processo também adotaram a manutenção de prevenção de falhas, 
principalmente nas áreas de geração de energia, petroquímicas, químicas, siderúrgicas e na indústria de papel. A partir de 1966, com a expansão da indústria, a Engenharia de Manutenção passa a desenvolver processos mais sofisticados de controle e análise, com vistas a pré-determinar os períodos mais econômicos de execução da manutenção. O início dos anos sessenta testemunha o aparecimento de diversos livros e trabalhos técnicos sobre confiabilidade.

Em junho de 1967 foi apresentado um artigo na conferência da American Industry Aeronautical Association sobre projetos e operações comerciais de aeronaves. Este documento deu origem a um programa de manutenção programada para os aviões Boeing 747, baseado nos princípios de confiabilidade, utilisado pelo pessoal da Federal Aviation Administration. Este programa viria a se tornar mais tarde a MCC - Manutenção Centrada na Confiabilidade. Os conceitos de manutenção preditiva ou manutenção sob condição são introduzidos na década de 70. Nesta mesma época os conceitos e as práticas do TPM - Total Productive Maintenance são introduzidos no Japão.

RODRIGUES (2000) APUD MARTINA (1997) e ANHESINE (1999) relatam a evolução das práticas de manutenção que passaram por três etapas ou gerações, sistematizadas por MOUBRAY (1997), conforme pode ser visto nas Figura 2-5 e Figura 2-6. A Primeira Geração cobre o período relacionado com o fim da Segunda Guerra Mundial. As indústrias tinham então poucas máquinas, simples e fáceis de reparar. Os tempos de paralisação não ofereciam qualquer tipo de contratempo porque os níveis de produção eram baixos. A prevenção era julgada dispensável. Eram os tempos da manutenção corretiva, sem sombra de dúvida. A Segunda Geração traz consigo as várias mudanças provocadas pela Guerra. A indústria incorpora um parque produtivo bastante complexo em face do aumento generalizado de mecanização das plantas industriais, conseqüência direta do aumento de demanda de bens. Nestas condições, as falhas e as paralisações tornam-se críticas. Fortalece-se a idéia de maior disponibilidade das plantas e confiabilidade dos processos, como forma de reduzir custos com a perda de produtividade. Esta nova faceta gera a manutenção preventiva, ou seja, paradas programadas em intervalos de tempo fixos, as recuperações globais programadas e os sistemas para planejamento e controle dos trabalhos de manutenção. 


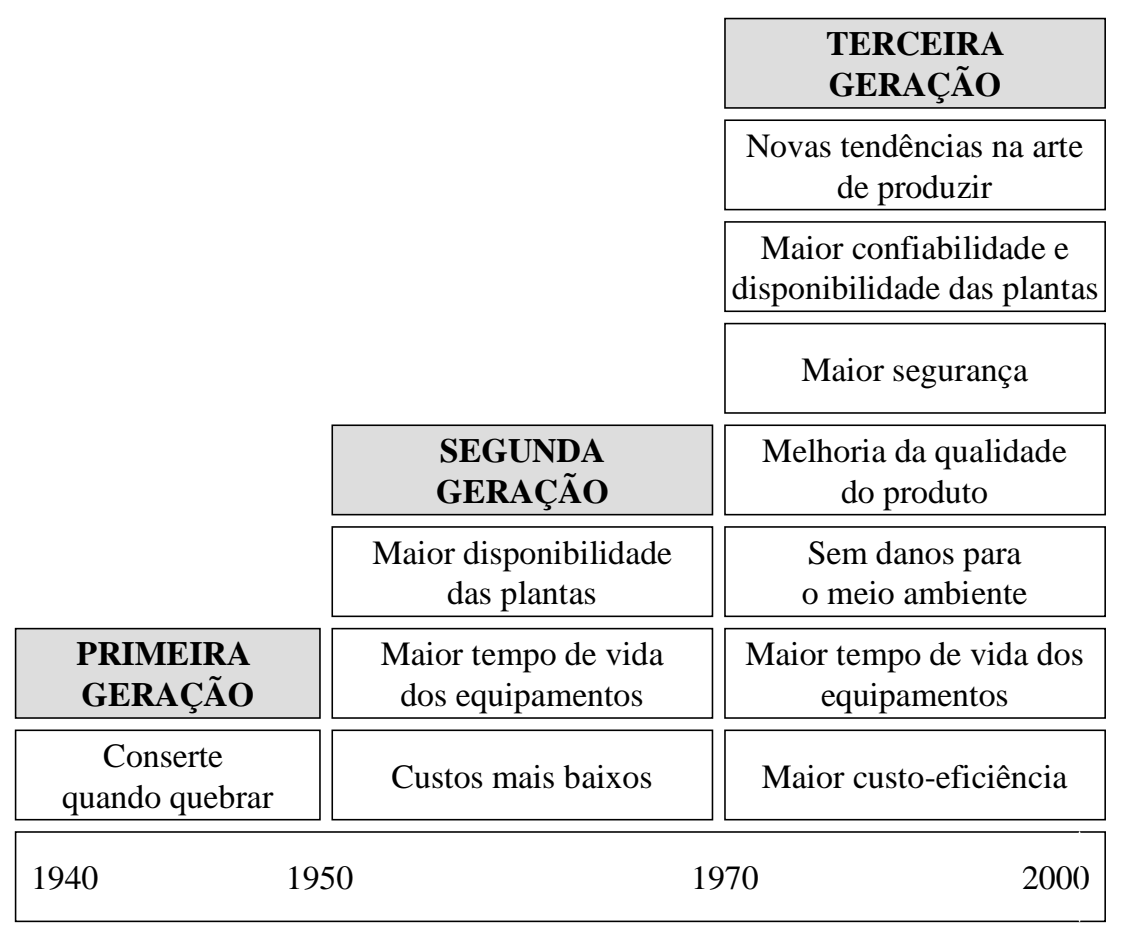

Figura 2-5 - Aumento da Expectativa em Relação à Manutenção.

Fonte: MOUBRAY (1997)..

\begin{tabular}{|c|c|c|}
\hline & & $\begin{array}{l}\text { TERCEIRA } \\
\text { GERAÇÃO }\end{array}$ \\
\hline & & $\begin{array}{c}\text { Monitoramento na } \\
\text { condução do trabalho }\end{array}$ \\
\hline & & $\begin{array}{c}\text { Projeto com confiabilidade } \\
\text { e manutenibilidade }\end{array}$ \\
\hline & & $\begin{array}{c}\text { Computadores } \\
\text { pequenos e ágeis }\end{array}$ \\
\hline & $\begin{array}{l}\text { SEGUNDA } \\
\text { GERAÇÃO }\end{array}$ & $\begin{array}{c}\text { Polivalência } \\
\text { e trabalho em equipe }\end{array}$ \\
\hline & $\begin{array}{c}\text { Recondicionamentos } \\
\text { programados }\end{array}$ & Sistemas especialistas \\
\hline $\begin{array}{r}\text { PRIMEIRA } \\
\text { GERAÇÃO }\end{array}$ & $\begin{array}{l}\text { Computadores } \\
\text { grandes e lentos }\end{array}$ & $\begin{array}{c}\text { Análise do modo e do } \\
\text { efeito das falhas (FMEA) }\end{array}$ \\
\hline Quebra - Conserta & $\begin{array}{c}\text { Planejamento e } \\
\text { controle do trabalho }\end{array}$ & Estudos sobre riscos \\
\hline 1940 & & 2000 \\
\hline
\end{tabular}

Figura 2-6 - Evolução das Técnicas de Manutenção.

Fonte: MOUBRAY (1997). 
Na década de 70 tem início a Terceira Geração, conseqüência das mudanças dos mercados, da arte de fabricar e da economia, onde produtividade e redução de custos tornam-se preocupações constantes. As paralisações não programadas devido a falhas aleatórias passam a ter sérios desdobramentos. As mudanças tecnológicas demandam novas posturas para a função manutenção. Além da disponibilidade das plantas e da confiabilidade dos processos, há grande preocupação com a qualidade do produto, segurança e meio ambiente, maximização da vida útil dos equipamentos e do custo-benefício.

Novas técnicas como FMEA (Failure Mode and Effect Analysis) e FTA (Failure Tree Analysis) são utilizadas. O conceito de manutenção preventiva por condição (manutenção preditiva) é reforçado. A implantação de um sistema produtivo conduz a projetos mais preocupados com a manutenibilidade (facilidade de manutenção) e confiabilidade. Estudos de risco, análises sobre o modo e efeito das falhas, a clara identificação das causas geradoras de falhas e a sua eliminação na fonte (manutenção pró-ativa) sinalizam as novas tendências para a função manutenção.

\subsubsection{O CONCEITO DE MANUTENÇÃO}

De acordo com o Dicionário Aurélio Básico da Língua Portuguesa de 1995, a manutenção é definida como “as medidas necessárias para a conservação ou a permanência de alguma coisa ou de uma situação" ou ainda como “os cuidados técnicos indispensáveis ao funcionamento regular e permanente de motores $e$ máquinas”. XENOS (1998) cita a NBR 5462 (1994) e define manutenção como a “combinação de ações técnicas e administrativas, incluindo as de supervisão, destinadas a manter ou recolocar um item em um estado no qual possa desempenhar uma função requerida”. Para o autor, “manter significa fazer de tudo o que for preciso para assegurar que um equipamento continue a desempenhar as funções para as quais foi projetado, num nível de desempenho exigido”.

As atividades de manutenção existem para evitar a degradação dos equipamentos e instalações, normalmente causada pelo desgaste natural e pelo uso. Tal degradação pode se manifestar das mais variadas formas, indo desde uma 
aparência externa ruim dos ativos até perdas de desempenho, paralisações da produção, fabricação de produtos de má qualidade e poluição ambiental. Num sentido restrito, as atividades de manutenção estão limitadas ao retorno de um ativo a sua prontidão funcional. Já num sentido mais amplo, as atividades de manutenção devem estar preocupadas em introduzir melhorias nos equipamentos e na racionalização do trabalho. As melhorias servem para minimizar a ocorrência ou a reincidência de falhas. A racionalização minimiza o tempo da intervenção nos equipamentos, seja para reparo ou conservação. De qualquer modo, ambas reduzem custos e melhoram a produtividade.

Assim, XENOS (1998) complementa que as atividades de manutenção têm focos distintos. De um lado, observam-se as atividades de manutenção propriamente ditas, preocupadas em manter as condições originais de funcionamento dos equipamentos e com a restauração das mesmas, em caso de eventuais deteriorações. De outro, colocam-se as atividades de melhoria dos equipamentos que modificam as condições originais de operação, introduzindo novos patamares de produtividade. O autor finaliza seu pensamento considerando um sentido bem mais abrangente para o conceito de manutenção. O objetivo da função não é somente o de manter ou até mesmo restaurar as condições físicas dos ativos (o que o equipamento é), mas de também manter suas capacidades funcionais (o que o equipamento pode fazer).

KELLY \& HARRIS lembram que a função manutenção pode ser definida como um conjunto de ações essenciais de modo a tornar permanente, ou restaurar por ocasião da falta, uma dada condição operacional de um ativo. Já RODRIGUES (2000) argumenta que manutenção é administrar, controlar e executar com qualidade todas as atividades que assegurem níveis ótimos de disponibilidade e um desempenho adequado dos ativos industriais. Para o autor, a disponibilidade e o desempenho dos ativos devem estar consistentes com os objetivos da empresa. Portanto, tal definição permite inferir que a disponibilidade ótima e o desempenho adequado refletem os esforços da organização em otimizar seus custos.

MONCHY (1989) alega que a manutenção deve aplicar os conceitos de correção e prevenção, quantificando níveis de desempenho para os ativos e assegurando que as atividades requeridas otimizem o custo global da propriedade. 
Como pressuposto, o autor estabelece que manter é dominar. Diferente, portanto, de conservar que significa consertar ou reparar um equipamento para assegurar a continuidade da produção. MOUBRAY (1997), entretanto, sugere uma abordagem conceitual um tanto diferente definindo a manutenção como um conjunto de técnicas destinadas a atuar nos ativos físicos para que cumpram ou preservem suas funções específicas.

SLACK ET AL (1999) utilizam o termo manutenção para abordar a forma como as empresas tentam evitar as falhas, cuidando de suas instalações físicas. Tal cuidado é uma função importante nas atividades de produção, principalmente aquelas cujas instalações físicas têm um papel fundamental na produção de bens e serviços. $\mathrm{O}$ autor aponta os seguintes benefícios de uma manutenção bem gerenciada:

- Segurança melhorada - Instalações bem mantidas têm pouca probabilidade de se comportar de forma não previsível ou não padronizada;

- Confiabilidade aumentada - Baixa freqüência de falhas conduz a menores interrupções das atividades normais de produção;

- Qualidade maior - Instalações bem cuidadas têm pouca possibilidade de afetar a qualidade do produto, por ocasião de sua fabricação;

- Custos de operações mais baixos - Os processos funcionam de forma mais eficiente quando recebem manutenção de forma sistemática;

- Tempo de vida mais longo - Cuidados regulares, limpeza ou lubrificação podem prolongar a vida efetiva dos ativos; e

- Valor final mais alto - Ativos bem conservados recebem melhores preços no mercado de segunda mão.

PINTO \& XAVIER (2001) ampliam o conceito de manutenção, incluindo a necessidade de preservação do meio ambiente. Para os autores, a missão da manutenção é "garantir a disponibilidade da função dos equipamentos e instalações de modo a atender a um processo de produção ou de serviço, com confiabilidade, segurança, preservação do meio ambiente e custos adequados”. 
Tendo em vista o que foi anteriormente exposto é perfeitamente válido estabelecer que a abrangência do conceito de manutenção se estende através das atividades que efetivamente exerce. Ou seja: conservar a disponibilidade das instalações; reparar danos com pessoal competente; fornecer peças de reposição necessárias; registrar danos e defeitos, analisá-los e eliminar a causa fundamental dos mesmos; informar sobre as experiências realizadas, evitando erros futuros na padronização de procedimentos, na realização de projetos, na operação dos equipamentos e na própria manutenção; e finalmente, controlar a instalação quanto à capacidade instalada, segurança dos equipamentos, meio ambiente, consumo de energia e domínio tecnológico.

\subsubsection{CONFIABILIDADE, MANUTENIBILIDADE E DISPONIBILIDADE}

PINTO \& XAVIER (2001) relatam que os termos confiabilidade, manutenibilidade e disponibilidade fazem parte do cotidiano da manutenção. Até porque a conceituação moderna da função prevê a garantia da disponibilidade da função dos equipamentos e instalações, através da melhoria de sua confiabilidade.

MONCHY (1989) amplia o conceito de manutenção para um conjunto de atividades técnicas e administrativas que permitem à empresa atingir suas metas de confiabilidade, disponibilidade e manutenibilidade de forma econômica. Assim, a função manutenção pode ser entendida como uma combinação de ações conduzidas para substituir, revisar ou modificar componentes ou grupos de componentes de um equipamento. Tais ações têm a finalidade de fazer com que o ativo opere dentro de uma disponibilidade específica, em um intervalo de tempo também definido.

\section{A. A CONFIABILIDADE}

Para SLACK ET AL (1999), produtos e serviços confiáveis são formas de propiciar vantagem competitiva para as organizações. Os autores citam as empresas japonesas que muito ampliaram sua participação no mercado de automóveis e de bens elétricos por meio de sua reputação por produtos de alta confiabilidade. Os gerentes, na maioria das vezes, estão preocupados com a melhoria da confiabilidade dos serviços e produtos que produzem. Nestas condições tentam manter em 
funcionamento as estratégias que possibilitem a minimização da probabilidade de falhas e ainda procuram aprender com elas, quando as mesmas ocorrem, segundo o autor.

PINTO \& XAVIER (2001), assim como RODRIGUES (2000) e MONCHY (1989), alegam que confiabilidade é a probabilidade de um equipamento cumprir sua missão sob dadas condições operacionais, em um intervalo de tempo estabelecido. Assim:

- A confiabilidade é a probabilidade estatística de não ocorrer falha, de um determinado tipo, para certa missão com um nível dado de confiança;

- Cumprir a missão é o mesmo que realizar o serviço esperado;

- Condições operacionais dadas são aquelas às quais o equipamento está submetido. Um mesmo ativo funcionando em condições operacionais diferentes apresentará confiabilidades distintas;

- O período de tempo estabelecido para que o equipamento cumpra a sua missão é fundamental, uma vez que a confiabilidade varia com o tempo.

Para os autores, todo ativo é projetado segundo a função básica que irá desempenhar e nestas condições é possível reconhecer dois tipos distintos de desempenho relacionados com o ativo. O primeiro é o desempenho inerente que o equipamento é capaz de fornecer. O segundo é o desempenho requerido que se quer obter o ativo. O trabalho básico da manutenção é restaurar o desempenho inerente do equipamento. Se o desempenho não é o desejado, ou se reduz a expectativa ou se introduzem modificações. Assim, quando um dado ativo não apresenta o desempenho previsto, o termo falha é usado para caracterizar essa situação.

PINTO \& XAVIER (2001) estabelecem que "a falha pode ser definida como a cessação da função de um item ou a incapacidade de satisfazer a um padrão de desempenho previsto". Portanto, quanto maior o número de falhas, menor a confiabilidade do equipamento. Quanto maior a confiabilidade, os resultados para o usuário do ativo também serão melhores. Entretanto, o lado financeiro da confiabilidade precisa ser levado em questão. As curvas da Figura 2-7 explicitam os 
custos de manutenção e de produção como dependentes da confiabilidade, segundo os autores.

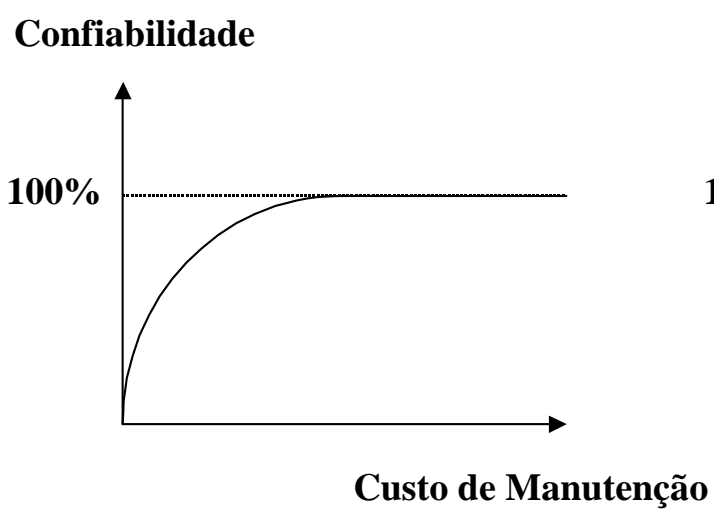

\section{Confiabilidade}

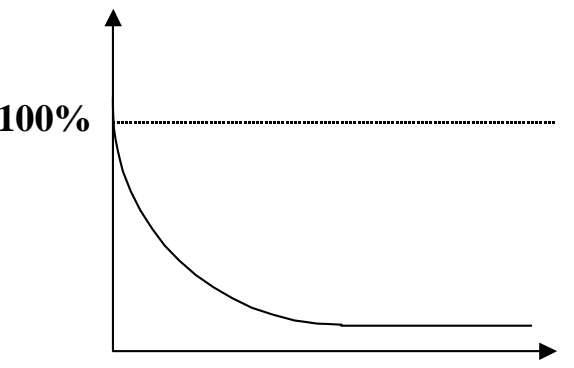

Custo de Produção

Figura 2-7 - Confiabilidade e Custos.

Fonte: PINTO \& XAVIER (2001).

Para SLACK ET AL (1999) as falhas na produção podem ocorrer por razões muito distintas umas das outras e nesse contexto classifica as falhas da seguinte forma:

- Falhas da Produção - Falhas que têm sua origem dentro da produção, seja porque seu projeto global não é adequado ou porque as instalações (máquinas, equipamentos e edifícios) ou pessoal não funcionam da forma prevista; estas falhas são subdivididas em:

$\checkmark$ Falhas de Projeto - Algumas falhas de projeto acontecem porque, por exemplo, uma característica da demanda não foi bem observada ou foi mal calculada. Assim, uma linha de produção pode não dar conta de lidar com as demandas que lhe são solicitadas. Outras falhas de projeto podem ocorrer porque as condições sobre as quais a linha de produção foi projetada para trabalhar não são as esperadas;

$\checkmark$ Falhas das Instalações - São manifestadas por uma interrupção total e repentina na produção já que as máquinas, equipamentos, edifícios e acessórios têm probabilidade de quebrar, dada a sua confiabilidade inerente; 
$\checkmark$ Falhas do Pessoal - As falhas das pessoas ocorrem ou por erro de julgamento ou através de atos que são claramente contrários a um procedimento operacional estabelecido. Por exemplo, o operário que deixar de cumprir os procedimentos prescritos para limpeza e lubrificação de seu equipamento, certamente afetará a confiabilidade do mesmo.

- Falhas de suprimentos - São decorrentes das falhas no material ou nas informações fornecidas à operação. Quanto mais uma produção depende de fornecedores de materiais e de serviços, tanto mais a confiabilidade da operação é comprometida, seja por uma falha no prazo de entrega ou na qualidade dos bens ou serviços fornecidos; e

- Falhas do Cliente - São causadas por ações dos próprios clientes. Os clientes podem usar mal os produtos e serviços que a operação produziu. Assim, para reduzir a probabilidade deste tipo de falha, a maioria das organizações assume a responsabilidade de educar e treinar os clientes na forma eficiente de usar seus produtos.

Para o autor, a taxa de falhas e a confiabilidade são diferentes formas usadas para medir falhas. Na verdade, medem a tendência de uma produção, ou parte dela, de incorrer em falha. A taxa de falha mede a freqüência de ocorrência da falha e a confiabilidade, a probabilidade de uma falha ocorrer. Assim, a taxa de falhas $(\lambda)$ pode ser definida a partir da porcentagem do número total de produtos testados, ou como o número total de falhas ocorridas em um dado tempo de operação:

$$
\begin{aligned}
& \lambda=\frac{\text { Número de Falhas }}{\text { Número Total de Produtos Testados }} \times 100, \\
& \text { ou: } \\
& \lambda=\frac{\text { Número de Falhas }}{\text { Tempo de Operação }} .
\end{aligned}
$$

SLACK ET AL (1999) ainda oferecem uma medida alternativa de falhas através do tempo médio de bom funcionamento do equipamento, conhecido como 
TMEF - Tempo Médio Entre Falhas. O TMEF é o recíproco da taxa de falhas, como apresentado na expressão:

$$
\mathrm{TMEF}=\frac{1}{\lambda}=\frac{\text { Tempo de Operação }}{\text { Número de Falhas }} .
$$

Pelo que se pode observar, o TMEF sinaliza a freqüência de falhas no ativo. Quanto maior o TMEF, tanto menor será a taxa de falhas e, por conseguinte, maior também será a confiabilidade do equipamento. Os autores ainda acrescentam que confiabilidade, em última análise, mede a habilidade de desempenho de um ativo em funcionar da forma como se espera dele, ao longo do tempo. Os componentes de um ativo são todos interdependentes e, nestas condições, uma pane em um componente individual pode causar a falha de todo o sistema. Assim, a confiabilidade do equipamento é dependente da confiabilidade de seus componentes e será tanto menor quanto maior for o número de seus componentes interdependentes.

PINTO \& XAVIER (2001) acrescentam que a confiabilidade de um equipamento ou produto pode ser expressa pela seguinte equação, segundo a distribuição exponencial (taxa de falhas constante):

$$
R(t)=e^{-\lambda t},
$$

em que:

- $\mathrm{R}(\mathrm{t})$ - Probabilidade de sobrevida ou confiabilidade;

- $\lambda$ - Taxa de falhas (número de falhas por período de operação); e

- $\mathrm{t}$ - Tempo previsto de operação.

SLACK ET AL (1999), PINTO \& XAVIER (2001), RODRIGUES (2000) e MONCHY (1989) alegam que a maioria dos componentes de um ativo tem probabilidades de falhas diferentes em diferentes etapas de sua vida útil. A curva que descreve a probabilidade de falha em função do tempo é denominada de curva característica de vida de equipamentos ou de curva da banheira, tendo em vista a sua forma, como apresentado na Figura 2-8. 


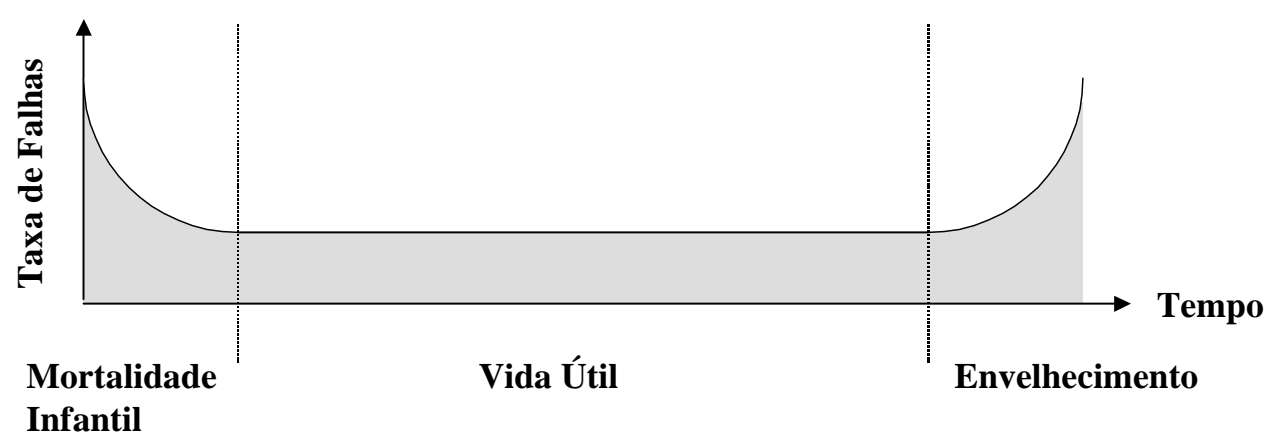

Figura 2-8 - Curva Característica da Vida de Equipamentos.

Fonte: Adaptado de PINTO E XAVIER (2001).

A curva apresenta três períodos distintos:

- Mortalidade Infantil ou a etapa da Vida Inicial - Há grande incidência de falhas causadas por componentes com defeitos de fabricação, deficiência de projeto ou oriundas de problemas de instalação;

- Vida Útil ou Etapa de Vida Normal - Quando a taxa de falhas é normalmente baixa, razoavelmente constante ao longo do tempo e causada por fatores aleatórios normais. Isto é, a ocorrência de falhas é decorrente de fatores menos controláveis, como fadiga ou corrosão acelerada, fruto das interações dos materiais com o meio; e

- Envelhecimento ou Degradação - Há um aumento sensível na taxa de falhas, decorrente do desgaste natural e será tanto maior quanto mais o tempo passar.

Os autores acrescentam que esta curva foi considerada durante muito tempo, como um padrão para o comportamento de equipamentos e sistemas. Entretanto, em função da evolução dos estudos sobre confiabilidade e avanços da própria $\mathbf{M C C}$ Manutenção Centrada na Confiabilidade foram adotados seis diferentes curvas para caracterizar a vida dos equipamentos. Tais curvas são apresentadas na Figura 2-9. 

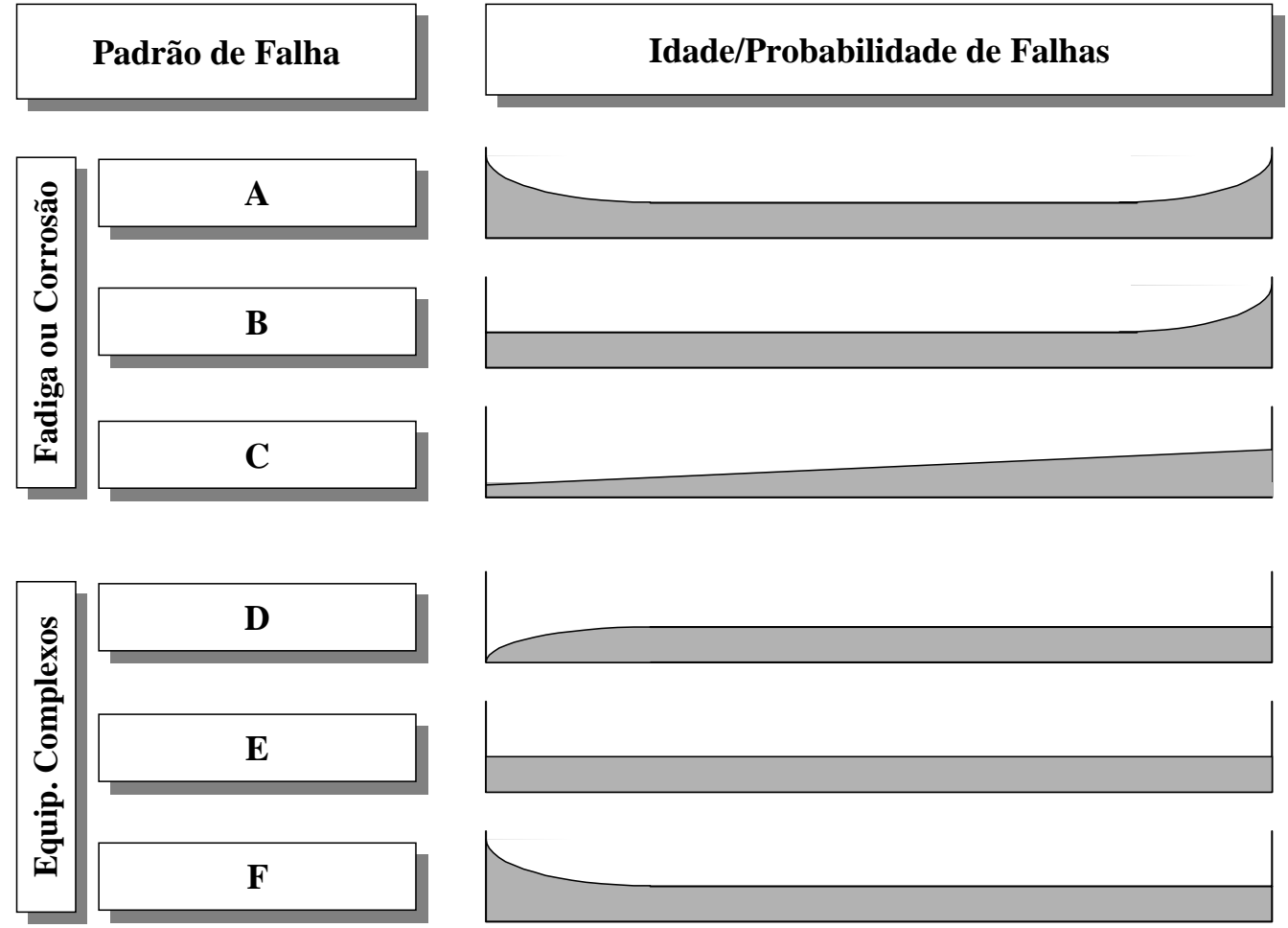

Figura 2-9 - Tipos de Curvas de Falhas.

Fonte: Adaptado de PINTO \& XAVIER (2001).

Uma análise rápida das curvas indica que:

- O padrão $\boldsymbol{A}$ é o da curva da banheira. Há uma elevada ocorrência de falhas no início da operação do ativo (mortalidade infantil ou falhas de início de funcionamento), seguida de uma freqüência de falha constante e um aumento da probabilidade de falha devido ao envelhecimento ou desgaste do equipamento;

- O padrão B apresenta probabilidade constante de falha seguida de uma zona de desgaste no final da vida útil do equipamento;

- Já o padrão $C$ tem um aumento gradual e lento na taxa de falhas e não há uma idade definida ou claramente identificada para o desgaste;

- O padrão $\boldsymbol{D}$ indica uma baixa probabilidade de falha no início de operação do equipamento, seguida de um rápido acréscimo até atingir um patamar de taxa de falhas constante; 
- O padrão $\mathbf{E}$ indica probabilidade de falha constante em qualquer idade do equipamento; e

- O padrão $\boldsymbol{F}$ apresenta alta mortalidade infantil para o início da operação, para cair em uma situação de probabilidade de falha constante para as outras idades.

Os padrões A, B e C representam falhas típicas por fadiga ou corrosão, enquanto que os padrões D, E e F representam falhas típicas de ativos complexos, tais como equipamentos hidráulicos e eletrônicos (PINTO \& XAVIER, 2001).

\section{B. A MANUTENIBILIDADE}

A manutenibilidade ou mantenabilidade está relacionada com a facilidade de executar a intervenção no equipamento, restaurando a sua prontidão funcional. É na verdade uma característica intrínseca ao equipamento que permite um maior grau de facilidade na execução dos serviços de manutenção. Assim, a manutenibilidade é a probabilidade de um equipamento retornar a sua condição operacional, com recursos de manutenção determinados e dentro de um período de tempo também especificado (MONCHY, 1989).

De modo análogo à taxa de falhas, PINTO \& XAVIER (2001) definem a taxa de reparos $(\mu)$ de um ativo em função do número de reparos efetuados, em relação ao tempo total dos reparos efetuados no equipamento. Caracterizam o TMDR Tempo Médio de Reparo como sendo o inverso da taxa de reparos.

$$
\begin{aligned}
& \mu=\frac{\text { Número de Reparos Efetuados }}{\text { Tempo Total dos Reparos Efetuados }}, \\
& \text { TMDR }=\frac{1}{\mu} .
\end{aligned}
$$

Os autores também propõem a seguinte expressão para explicitar a manutenibilidade:

$$
M(t)=1-e^{-\mu t}
$$


em que:

- $\quad \mathrm{M}(\mathrm{t})$ - Probabilidade de duração do reparo;

- $\mu$ - Taxa de reparos; e

- $\mathrm{t}$ - Tempo previsto de reparo

O TMDR reflete a habilidade das equipes de manutenção em efetuar o reparo propriamente dito, com recursos de manutenção perfeitamente determinados e dentro de um período de tempo também previamente especificado.

Por outro lado, CONTADOR (2004) relata que é necessário fazer distinção entre tempo de interrupção da produção e o tempo de duração do reparo. O tempo de reparo envolve todas as atividades efetivamente realizadas com a intenção de restaurar a prontidão funcional do ativo.

Todos os demais tempos, causados por esperas de ferramentas, sobressalentes e tempos mortos são tempos de interrupção da produção. Muitas vezes o tempo de interrupção da produção começa antes mesmo do reparo ser deflagrado. Normalmente, os tempos que ocorrem entre a parada e o retorno do equipamento à operação, estão indicados na Figura 2-10.

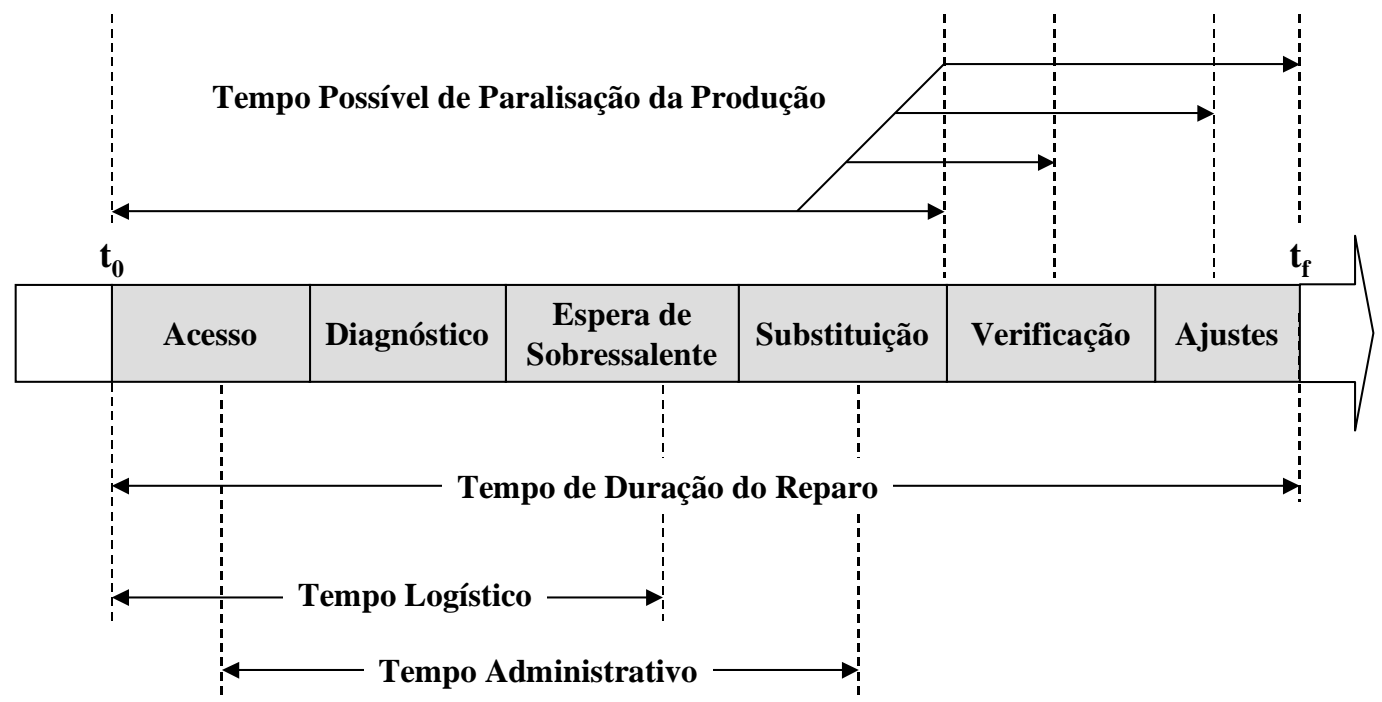

Figura 2-10 - Tempos de Paralisação da Produção.

Fonte: Adaptado de PINTO \& XAVIER (2001) e CONTADOR (2004). 
A figura considera os seguintes elementos de tempo:

- $\boldsymbol{t}_{0}$ - Instante em que se verifica a falha ou momento em que a falha se torna evidente;

- Acesso - Período de tempo dedicado à localização do defeito, incluindo a remoção de tampas, blindagens e protetores;

- Diagnóstico - Análise da falhas através das relações de causa e efeito, utilização de instrumentação de testes e interpretação das informações obtidas que levem à decisão da ação corretiva;

- Tempo de espera de sobressalente - Tempo eventualmente necessário para a equipe ter em mãos as peças sobressalentes necessárias para efetuar o reparo;

- Substituição - Tempo que envolve a remoção da peça defeituosa, colocação da sobressalente e a remontagem das tampas, blindagens e protetores;

- Verificação - Tempo necessário para verificar se a condição de falha é inexistente e que o equipamento tem suas funções operacionais perfeitamente restabelecidas. Há casos em que a prontidão funcional do ativo é restaurada, antes mesmo do término da verificação. Como se pode ver, o tempo em questão não implica necessariamente na interrupção da atividade produtiva;

- Ajustes - Inserção de novas peças ou módulos implica em ajustes e regulagens para o perfeito funcionamento do ativo. Da mesma maneira que no tempo de verificação, parte ou a totalidade do tempo de ajustes pode não interromper a atividade produtiva;

- Tempo Logístico - Tempo que envolve a espera de peças, de equipamentos de testes, de ferramentas adicionais e de mão de obra que devem ser transportados até o ativo objeto de reparo. Compreende o tempo de acesso, o tempo para diagnóstico e o tempo de espera das peças sobressalentes; 
- Tempo Administrativo - Reflete a agilidade do próprio sistema de manutenção. É o tempo consumido desde o registro da falha, distribuição das tarefas de reparo, substituição de equipes, intervalos formais, etc. Compreende parte do tempo logístico e parte do tempo de substituição; e

- $\boldsymbol{T}_{\boldsymbol{f}}$ - Instante de retorno do equipamento à operação.

\section{A DISPONIBILIDADE}

MONCHY (1989) alega que um equipamento disponível está apto para ser utilizado. A partir desta evidência, a disponibilidade de um ativo é dependente do número de falhas que ocorrem (confiabilidade), da rapidez com que elas são reparadas (manutenibilidade), dos métodos e processos utilizados no exercício das políticas de manutenção e das atividades de apoio efetivas (logística).

PINTO \& XAVIER (2001) argumentam que a disponibilidade pode ser claramente compreendida pela Figura 2-11.

\section{Capacidade Instalada (Tempo Total)}

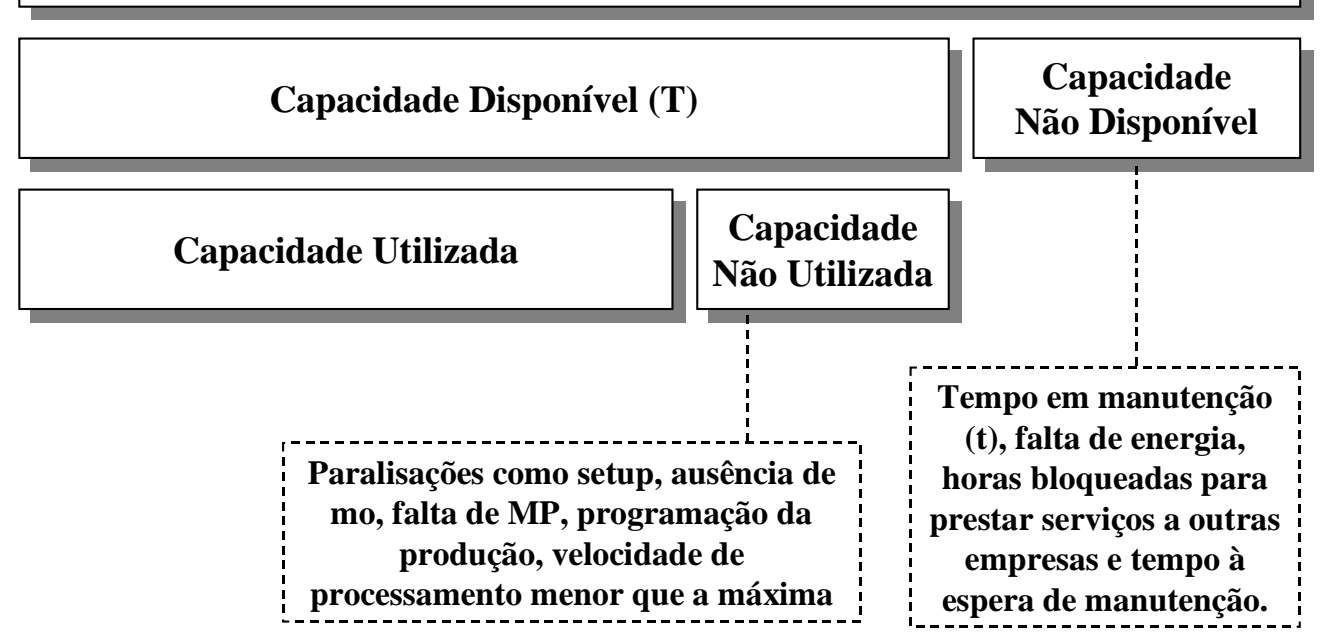

Figura 2-11 - Caracterização da Disponibilidade.

Fonte: Adaptado de MUSCAT (1987) e PINTO \& XAVIER (2001). 
A figura compreende os seguintes conceitos:

- Tempo Total ou Capacidade Instalada - Tempo em que o ativo poderia ficar disponível para a operação. Este tempo reflete a capacidade instalada para realizar produção;

- Capacidade Disponível ou Tempo Disponível (T) - Parcela da capacidade instalada que pode ser aproveitada para realizar produção;

- Capacidade não Disponível ou Tempo não Disponível - Parcela da capacidade instalada não disponível para realizar produção. Nesta capacidade não disponível incluem-se os tempos em manutenção (t), ou seja, os tempos destinados às intervenções de manutenção preventiva ou corretiva. Outras indisponibilidades tais como falta de energia, horas bloqueadas para prestar serviços a outras empresas e tempos à espera de manutenção também podem ser aqui incluídas;

- Tempo de Funcionamento ou Capacidade Utilizada - Parcela da capacidade disponível, efetivamente utilizada para gerar produção;

- Tempo de não Funcionamento ou Capacidade não Utilizada Representam as paralisações decorrentes de setup, ausência de mão-deobra, falta de matéria-prima, programação da produção e uso de velocidade de processamento menor que a máxima.

Pelo que se pode observar, tem-se ao longo do tempo normal os tempos disponíveis para gerar produção (T) e os tempos em que o ativo está em manutenção (t), portanto indisponível para a produção, conforme apresentado na Figura 2-12.

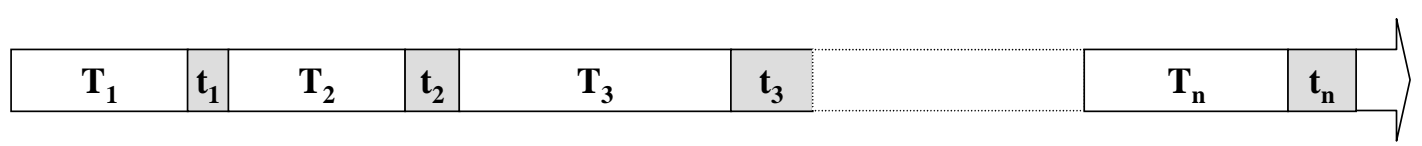

Figura 2-12 - Tempos Disponíveis (T) e Tempos em Manutenção (t).

Fonte: Adaptado de PINTO \& XAVIER (2001).

Assim, fica caracterizado o tempo médio de bom funcionamento do equipamento, conhecido como TMEF - Tempo Médio Entre Falhas: 


$$
\mathrm{TMEF}=\frac{\mathrm{T}_{1}+\mathrm{T}_{2}+\mathrm{T}_{3}+\ldots+\mathrm{T}_{\mathrm{n}}}{\mathrm{n}}
$$

Já o tempo médio sem produção está associado à falha e é refletido pelo TMDR - Tempo Médio de Reparo:

$$
\operatorname{TMDR}=\frac{\mathrm{t}_{1}+\mathrm{t}_{2}+\mathrm{t}_{3}+\ldots+\mathrm{t}_{\mathrm{n}}}{\mathrm{n}}
$$

Para SLACK ET AL (1999), a disponibilidade reflete o grau de aptidão de um sistema ou de um ativo para funcionar. Assim, a disponibilidade é caracterizada pela iminência da falha ou pelo tempo destinado ao reparo. Há diversas maneiras de se medir a disponibilidade, dependendo das várias razões que justifiquem a não operação do ativo, segundo os autores. Poderia, por exemplo, ser incluída a falta de disponibilidade devido a tempos de espera de manutenção.

Pelo que se pode observar, a duração do tempo de reparo, da forma como está representada na Figura 2-12, pode ser interpretada das seguintes formas:

1) A intervenção da manutenção está condicionada especificamente pela falha do ativo, caracterizando uma política de manutenção não planejada. Nestas condições, o tempo de não funcionamento do ativo é devido a uma intervenção de reparo. Assim, o TMDR está associado às intervenções após a falha do equipamento;

2) A intervenção da manutenção é resultante de uma ação planejada, caracterizando uma estratégia de manutenção planejada. Assim, o tempo de não funcionamento do equipamento é devido a uma intervenção de prevenção. Nestas condições, o TMDR está associado às intervenções de prevenção; e

3) O tempo de não funcionamento do equipamento é devido à espera de manutenção. Assim, o TMDR deve incluir também o tempo de espera da ação de manutenção.

Considerando os argumentos anteriormente expostos, os equipamentos ou algumas partes deles, dentro de uma planta industrial, podem estar em uma das seguintes condições: 
- Condição A - Produzindo normalmente;

- Condição B - Produzindo, porém disponível para a manutenção, de acordo com o plano anual de manutenção preventiva;

- Condição C - Sob manutenção planejada;

- Condição D - Sob manutenção não planejada; e

- Condição $\boldsymbol{E}$ - À espera de manutenção.

A disponibilidade, então, pode ser também definida, segundo PINTO \& XAVIER (2001) como sendo a probabilidade do equipamento estar apto a produzir, no momento em que é solicitado e que pode ser expresso na forma:

Disponibilidade $=\frac{\mathrm{A}+\mathrm{B}}{\mathrm{A}+\mathrm{B}+\mathrm{C}+\mathrm{D}+\mathrm{E}}=\frac{\text { Tempo de Operação }}{\text { Tempo Total }}$,

- sendo C + D + E o tempo de paralisação do ativo.

Os autores afirmam que a disponibilidade é afetada pela freqüência de manutenção - confiabilidade, e facilidade na execução da manutenção manutenibilidade.

A confiabilidade e a manutenibilidade são incorporadas na fase de projeto do ativo e acabam por caracterizar a carga de trabalho da manutenção. Nestas condições é possível medir três tipos de disponibilidades:

- Disponibilidade Inerente - Considera somente as intervenções no equipamento após a falha do mesmo:

$$
\begin{aligned}
& \mathrm{D}_{\mathrm{i}}=\frac{\mathrm{TMEF}}{\text { TMEF }+ \text { TMDR }}, \\
& \checkmark \quad \text { TMEF - Tempo Médio Entre Falhas; e } \\
& \checkmark \quad \text { TMDR - Tempo Médio de Reparo. }
\end{aligned}
$$

- Disponibilidade Atingida - Considera também as intervenções antes da falha do equipamento:

$$
\mathrm{D}_{\mathrm{a}}=\frac{\mathrm{TMEM}}{\mathrm{TMEM}+\mathrm{TMDI}},
$$


$\checkmark$ TMEM - Tempo Médio Entre Manutenções; e

$\checkmark$ TMDI - Tempo Médio de Intervenção.

- Disponibilidade Operacional - Inclui as interrupções devido à logística de suprimentos ou de pessoal que implica na espera pela manutenção:

$\mathrm{D}_{\mathrm{o}}=\frac{\mathrm{TMEM}}{\mathrm{TMEM}+\mathrm{TMDP}}$

$\checkmark$ TMEM - Tempo Médio Entre Manutenções; e

$\checkmark$ TMDP - Tempo Médio de Paralisação.

As causas de uma baixa disponibilidade podem estar além do departamento de manutenção. Por esta razão, CONTADOR (2004) afirma que o “desafio da produtividade, no que depende da manutenção reside em planejamento e controle operacional na demanda de serviços em determinado período”.

A Figura 2-13 apresenta as relações entre os fatores que contribuem para a produção da fábrica e os fatores que interferem na paralisação das máquinas.

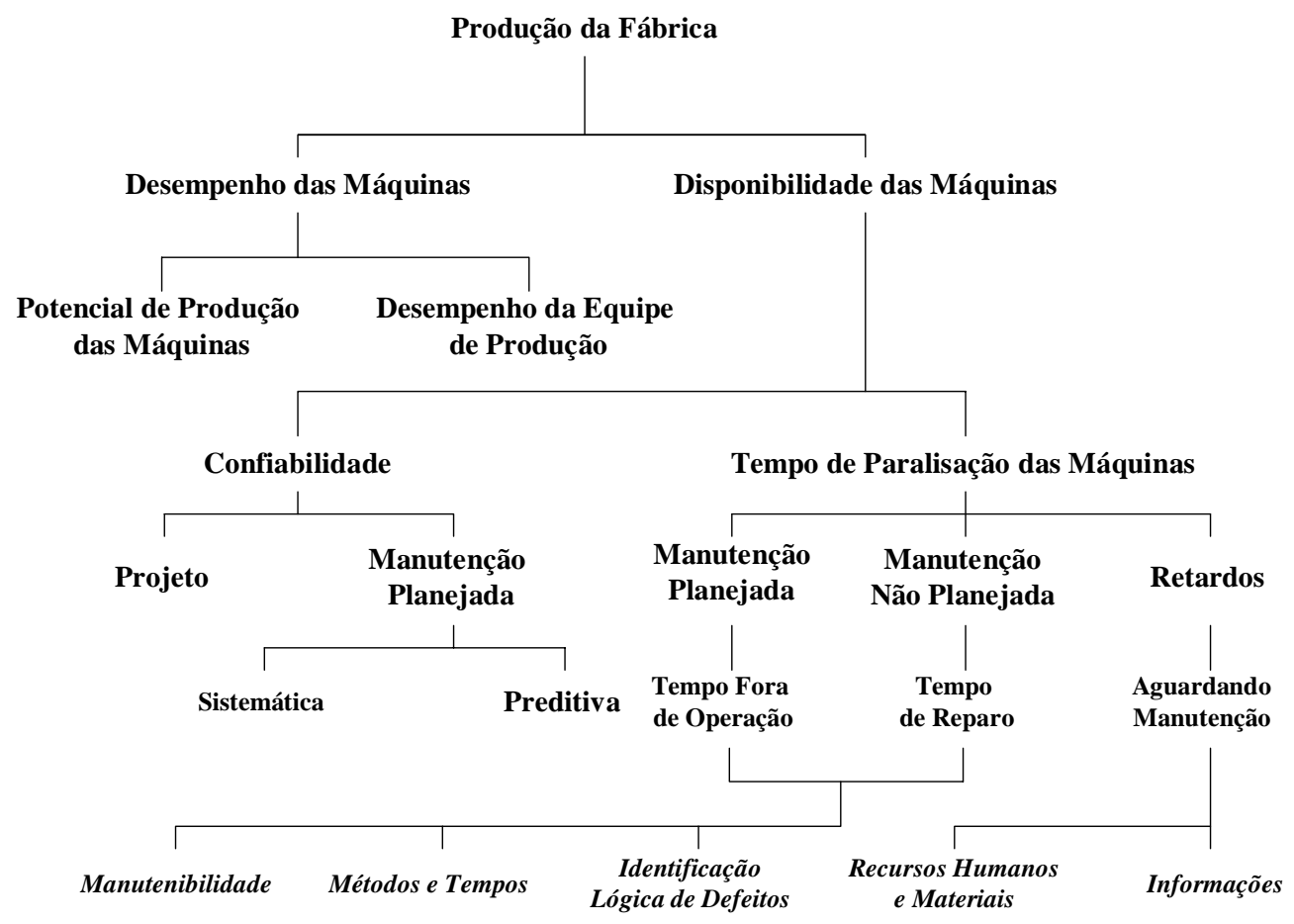

Figura 2-13 - Fatores que Afetam a Produção da Fábrica.

Fonte: Adaptado de CONTADOR (2004). 


\subsubsection{PREVENÇÃO E RECUPERAÇÃO DAS FALHAS}

XENOS (1998) relata que existem três grandes categorias de causas para as falhas dos ativos:

- falta de resistência (robustez);

- uso inadequado; e

- manutenção inadequada, como se pode ver na Figura 2-14.

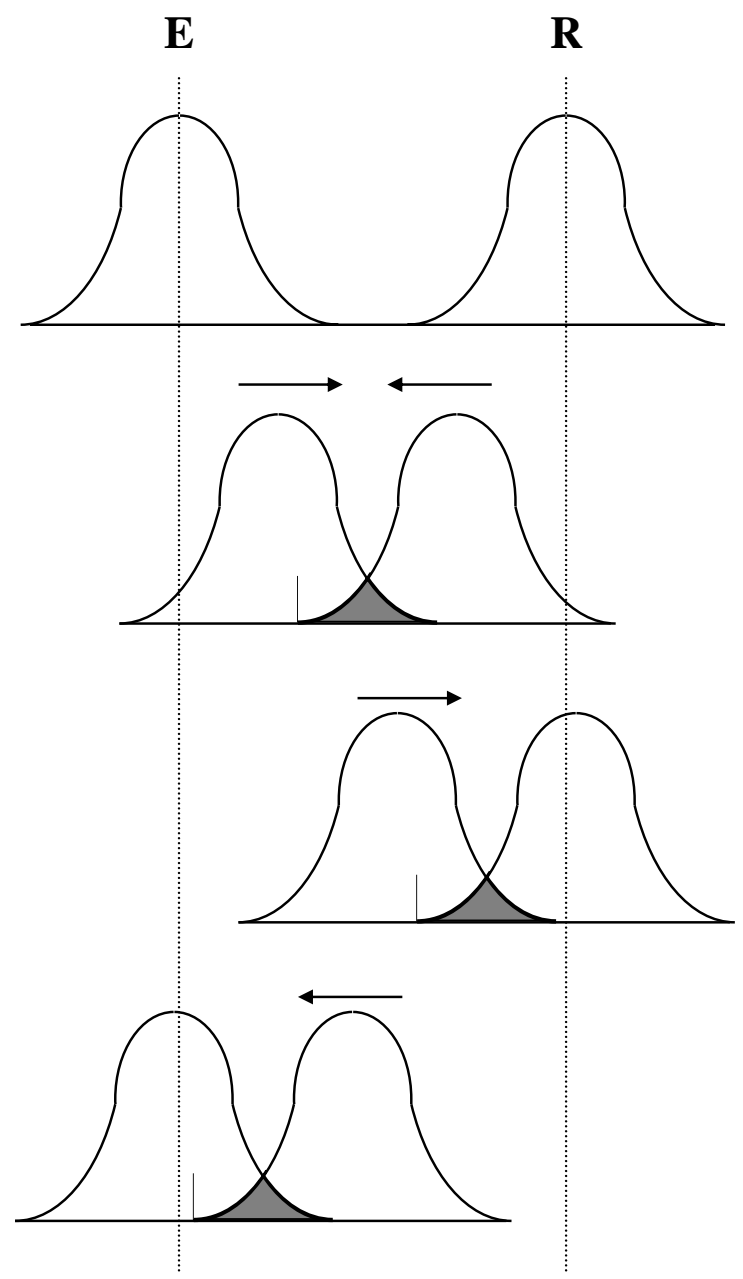

O projeto do equipamento está correto. Não ocorrem falhas, pois o maior esforço é menor que a resistência mais baixa.

Falha por deficiência de projeto. A resistência e o esforço foram avaliados de forma incorreta.

Falha por operação incorreta do equipamento, causando aumento do esforço.

As áreas hachuradas indicam que o esforço (E) ultrapassou a resistência (R), resultando em falha do equipamento.

Figura 2-14 - Relação Entre Esforço e Resistência

Fonte: Adaptado de XENOS (1998) 
A falta de resistência é inerente ao equipamento e decorre das deficiências do projeto. Neste caso, a falha ocorre em virtude do esforço normal aplicado estar além da resistência ou robustez do ativo. O uso inadequado é entendido como sendo a aplicação de esforços que estão fora da capacidade do equipamento e pode resultar em erros, durante a sua operação. A manutenção inadequada significa que as atividades de prevenção, para evitar a degradação do ativo, não são suficientes ou não estão sendo corretamente tomadas. Os equipamentos em operação estão sujeitos a um grande número de esforços que provocam a sua degradação ao longo do tempo. Como conseqüência, a sua robustez também diminui segundo o autor. A falha sempre ocorrerá quando a resistência do ativo cair abaixo dos esforços a que estiver submetido.

Na Figura 2-14, o esforço (E) e a resistência (R) são variáveis e estão representadas por suas respectivas distribuições estatísticas, em torno de uma média. Não havendo sobreposições das distribuições, não haverá falhas, dado que a resistência será maior que o esforço. Entretanto, o autor alega que nem sempre a resistência apresenta um valor médio constante e tende a diminuir devido à degradação do equipamento, por fadiga, corrosão ou outros fatores. Por conseguinte, a distribuição estatística da resistência varia ao longo do tempo. Por outro lado, o esforço tende a aumentar em função das condições operacionais e ambientais desfavoráveis. O resultado disso é a aproximação das duas distribuições estatísticas (E) e (R) e o conseqüente aumento da probabilidade de falha.

PINTO \& XAVIER (2001) afirmam que as boas práticas de manutenção devem estar ligadas à dinâmica dos negócios da empresa. Devem contribuir, de forma efetiva, para levar a organização a uma posição de liderança no mercado. Neste contexto, SLACK ET AL (1999) apontam para três conjuntos de atividades que se relacionam com a prevenção e recuperação de falhas:

- Análise e deteção de falhas - diz respeito ao entendimento da natureza das falhas, isto é, compreender com clareza quais as falhas que estão ocorrendo e porque elas ocorrem; 
- Melhoria da confiabilidade das operações - analisa as formas de melhorar a confiabilidade das operações ou minimizar as conseqüências das falhas;

- Adoção de políticas e estratégias de manutenção ${ }^{1}$ - elabora políticas, estratégias e procedimentos que trabalhem em benefício da produção para se recuperar das falhas, quando elas ocorrerem.

\section{A. ANÁLISE E DETEÇÃO DE FALHAS}

SLACK ET AL (1999), PINTO \& XAVIER (2001), RODRIGUES (2000) e FURMANN (2002) apontam as seguintes técnicas utilizadas na análise e detecção de falhas:

- Análise do Efeito e Modo de Falhas (FMEA - Failure Mode and Effect Analysis);

- Análise das Causas-Raízes de Falhas (RCFA - Root Cause Failure Analysis);

- Análise de Árvore de Falhas; e

- Metodologia de Análise e Solução de Problemas (MASP)

\section{1) ANÁLISE DO EFEITO E MODO DE FALHAS (FMEA)}

SLACK ET AL (1999) definem a Análise do Efeito e Modo de Falhas (FMEA) como sendo uma técnica que ajuda a identificar e priorizar falhas em equipamentos, sistemas e processos. É um sistema lógico que hierarquiza as falhas potenciais e fornece recomendações para as ações preventivas. É um meio de identificar falhas antes que aconteçam, por meio de um procedimento construído em cima de três questões chaves. Assim, para cada causa possível de falha:

\footnotetext{
${ }^{1}$ A discussão em torno das questões pertinentes às políticas e estratégias de manutenção será objeto do Título 2.3.6.
} 
- Qual é a freqüência de ocorrência da falha?

- Qual o grau de gravidade da falha, ou em outras palavras, qual o dano que a falha causa ao usuário ou cliente?

- Qual a facilidade da falha ser detectada, ou qual é a detectabilidade da falha?

Baseado em uma avaliação quantitativa dessas três questões, os autoesr calculam o IRF - Índice de Risco da Falha para cada causa potencial de falha. Nestas condições, as ações que visam prevenir falhas são então priorizadas e aplicadas às causas que apresentarem os maiores IRF's.

$$
\mathrm{IRF}=\mathrm{O} \times \mathrm{G} \times \mathrm{D},
$$

em que:

- O - Freqüência de ocorrência da falha. Maior ocorrência, maior peso no Índice de Risco da Falha;

- G - Grau de gravidade da falha. Quanto maior o dano que a causa falha no usuário ou no cliente, tanto maior é o peso no índice; e

- D - Facilidade de deteção da falha, antes que aconteça. Quanto maior a facilidade, menor é o peso no IRF.

Os autores recomendam um processo de sete passos para a aplicação efetiva da técnica de FMEA:

- Passo 1 - Identificar todas as partes componentes dos ativos, sistemas ou processos;

- Passo 2 - Listar todas as formas possíveis segundo as quais os componentes podem falhar (os modos de falhas);

- Passo 3 - Identificar os efeitos possíveis das falhas (paralisações, segurança, necessidade de reparo, efeitos para os clientes);

- Passo 4 - Identificar todas as causas possíveis das falhas para cada modo de falha; 
- Passo 5 - Para cada causa potencial de falha avaliar a ocorrência, gravidade e detectabilidade da falha;

- Passo 6 - Calcular o IRF (Índice de Risco da Falha) multiplicando as três avaliações; e

- Passo 7 - Instigar ações preventivas que minimizem as falhas que apresentem um alto IRF.

PINTO \& XAVIER (2001) e SLACK ET AL (1999) recomendam os pesos para as parcelas que compõem o IRF, de acordo com a Tabela 2-3.

\begin{tabular}{|c|c|c|}
\hline Componente do IRF & Classificação & Peso \\
\hline \multirow{4}{*}{ Ocorrência (O) } & Muito Baixa & 1 \\
\cline { 2 - 3 } & Baixa & 2,3 \\
\cline { 2 - 3 } & Moderada & $4,5,6$ \\
\cline { 2 - 3 } & Alta & 7,8 \\
\cline { 2 - 3 } & Muito Alta & 9,10 \\
\hline \multirow{5}{*}{ Gravidade (G) } & Muito Baixa & 1 \\
\cline { 2 - 3 } & Baixa & 2,3 \\
\cline { 2 - 3 } & Moderada & $4,5,6$ \\
\cline { 2 - 3 } & Alta & 7,8 \\
\cline { 2 - 3 } & Muito Alta & 9,10 \\
\hline \multirow{5}{*}{ Detectabilidade (D) } & Muito Fácil & 1 \\
\cline { 2 - 3 } & Fácil & 2,3 \\
\cline { 2 - 3 } & Moderada & $4,5,6$ \\
\cline { 2 - 3 } & Difícil & 7,8 \\
\cline { 2 - 3 } & Muito Difícil & 9,10 \\
\hline
\end{tabular}

Tabela 2-3 - Escalas de Avaliação para FMEA.

Fonte: Adaptado de PINTO \& XAVIER (2001) e SLACK ET AL (1999).

\section{2) ANÁLISE DAS CAUSAS-RAÍZES DE FALHAS (RCFA)}

Este tipo de análise era aplicado somente para os equipamentos mais importantes e críticos, segundo PINTO \& XAVIER (2001). Atualmente, tendo em vista o potencial de ganho que a técnica apresenta para a manutenção, o autor recomendam o seu uso mais generalizado, principalmente em problemas crônicos. A essência da técnica consiste na pesquisa da relação causa-e-efeito, através do questionamento dos "Por Quếs". O método recomenda que se faça tantas vezes a pergunta até que a questão não tenha mais sentido, indicando que se chegou à causa 
fundamental (causa raiz) do efeito pesquisado. OHNO (1997) descreve a técnica como uma prática gerencial efetiva na melhoria das atividades de produção.

\section{3) ANÁLISE DE ÁRVORE DE FALHAS}

SLACK ET AL (1999) descrevem a técnica da Análise de Árvore de Falhas como um procedimento lógico. O método parte para a análise de uma falha potencial, trabalhando "para trás”, com vistas a identificar todas as possíveis causas e origens da falha em estudo. A construção da árvore de falhas é feita através de ramificações que são conectadas por dois tipos de nós: nós $\boldsymbol{E}$ e nós $\boldsymbol{O U}$. Nestas condições, é necessária a ocorrência de todas as ramificações abaixo de um nó $\boldsymbol{E}$ para garantir que ocorra um evento acima do nó. Basta apenas a ocorrência de uma das ramificações abaixo de um nó $\boldsymbol{O U}$ para que o evento acima do nó possa ocorrer. A Figura 2-15 esquematiza a utilização da técnica.

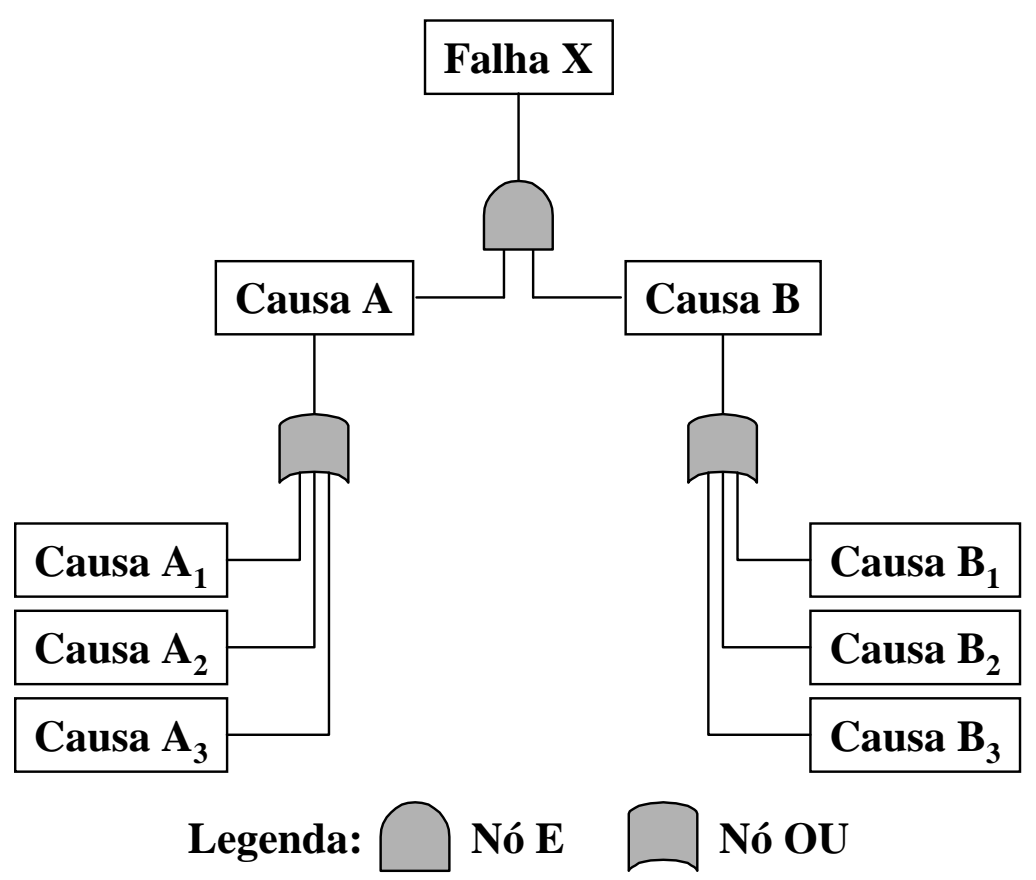

Figura 2-15 - Análise de Árvore de Falhas.

Fonte: Adaptado de SLACK ET AL (1999). 


\section{4) METODOLOGIA DE ANÁLISE E SOLUÇÃO DE PROBLEMAS}

CAMPOS (1992) descreve a Metodologia de Análise e Solução de Problemas como um processo que pesquisa as relações de causa-e-efeito presentes nos problemas de produção. É uma prática gerencial eficiente, dado que se fundamenta em procedimentos lógicos, com base em fatos e dados, que procura localizar a causa fundamental dos problemas. É uma técnica utilizada pela Gestão da Qualidade Total, adotada pela JUSE - Union of Japanese Scientists and Engineers e conhecida como QC Story. A Figura 2-16 explicita as principais etapas do método, associadas ao ciclo PCDA - Plan (Planejar), Do (fazer), Check (Verificar) e Action (corrigir) para o gerenciamento do processo, segundo o autor.

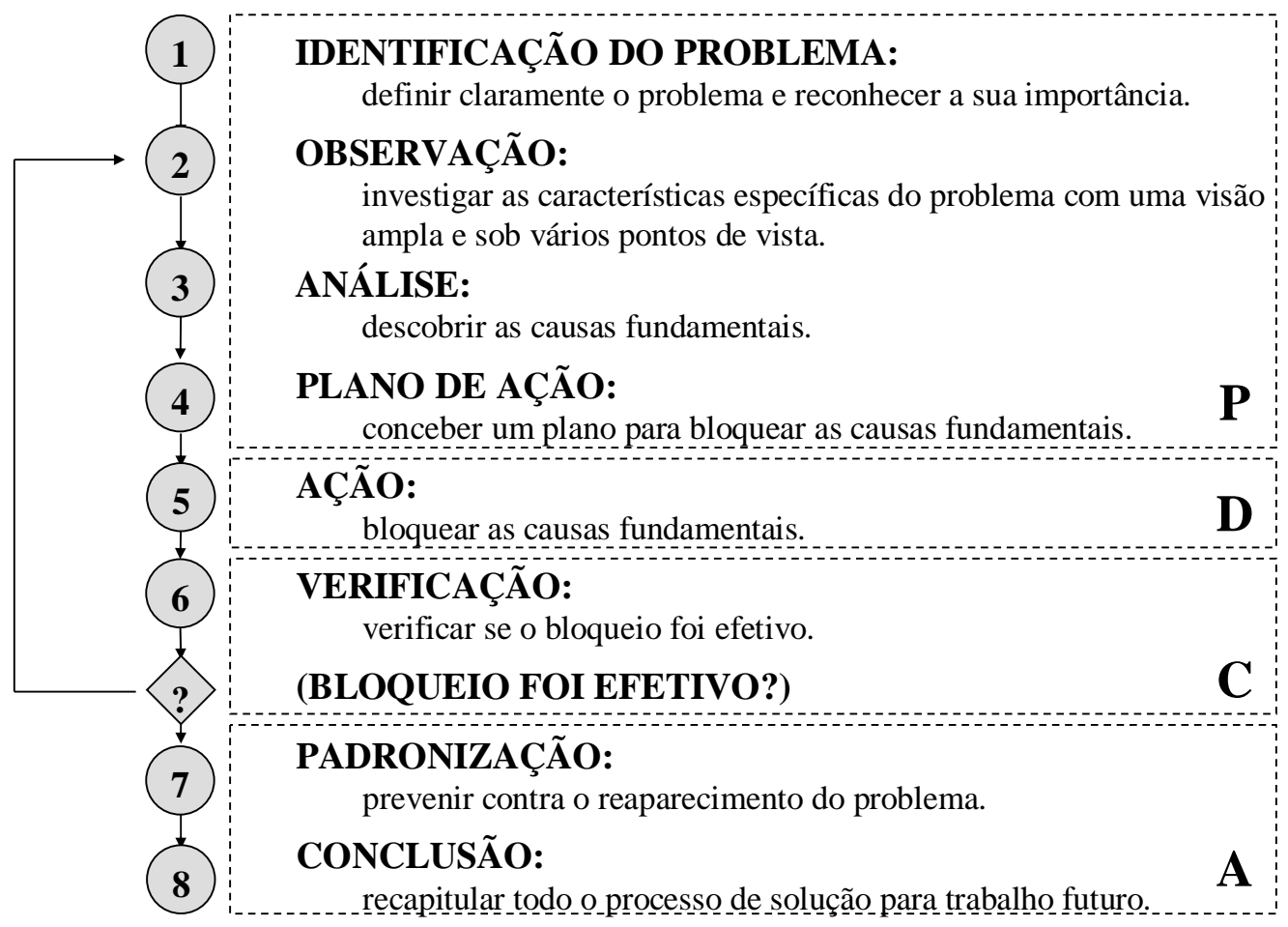

Figura 2-16 - Etapas da Metodologia do MASP.

Fonte: Adaptado de CAMPOS (1992). 


\section{B. MELHORIA DA CONFIABILIDADE DAS OPERAÇÕES}

FURMANN (2002), RODRIGUES (2000), PINTO \& XAVIER (2001), SLACK ET AL (1999) e ANHESINE (1999) indicam as seguintes técnicas, como as mais utilizadas na melhoria da confiabilidade dos ativos:

- Utilização de Redundâncias;

- Dispositivos à Prova de Falha; e

- MCC - Manutenção Centrada na Confiabilidade.

\section{1) UTILIZAÇÃO DE REDUNDÂNCIAS}

Introduzir redundância em uma produção é ter sistemas ou componentes de reserva em casos de falha, segundo SLACK ET AL (1999). Alegam que esta é uma solução cara para melhorar a confiabilidade dos ativos, sistemas e instalações. Mas, mesmo sendo cara ainda é utilizada quando a interrupção do funcionamento pode ter um impacto crítico. Citam exemplos de usinas nucleares, prédios públicos e hospitais que possuem geradores de eletricidade redundantes para operar, em caso de falha no fornecimento da energia. Alguns componentes redundantes podem ser usados o tempo todo para melhorar a confiabilidade e, por conseguinte, reduzir a probabilidade de falha. As luzes de freio em traseiras de ônibus e caminhões contêm duas lâmpadas para reduzir a probabilidade de não mostrar luz vermelha, quando o freio é acionado, segundo o autor.

\section{2) DISPOSITIVOS À PROVA DE FALHAS}

Os dispositivos à prova de falhas foram também utilizados por OHNO (1997), na descrição das práticas gerenciais utilizadas no Sistema Toyota de Produção. A essência desses dispositivos é baseada no fato de que os erros humanos são inevitáveis até certo grau. São denominados de Poka-Yokes, que significam prevenir a desatenção. São, em princípio, dispositivos simples, baratos, que são incorporados em um processo para evitar falhas decorrentes da falta de atenção dos operadores. São exemplos típicos de dispositivos poka-yokes: 
- Sensores ou interruptores em máquinas que somente permitem a sua operação se a peça estiver posicionada corretamente;

- Sinais sonoros nos caixas eletrônicos dos bancos para assegurar que os clientes retiraram seus cartões; e

- Barras de altura em divertimentos de parques de diversões, para assegurar a entrada de clientes que não excedam determinada altura.

\section{3) MCC - MANUTENÇÃO CENTRADA NA CONFIABILIDADE}

ANHESINE (1999) considera a Manutenção Centrada na Confiabilidade um processo que envolve consideração sistemática das funções de um ativo, o seu modo de falhas e um critério de priorização com base em fatores econômicos e de segurança, para a aplicação de uma política de manutenção adequada e eficaz. Neste sentido, o autor destaca a MCC como uma metodologia de lógica disciplinada. A técnica é usada para identificar as tarefas de manutenção preventiva necessárias para realizar e aprimorar a confiabilidade inerente ao equipamento, a um custo mínimo de recursos.

NAGAO (1998) e FURMANN (2002) caracterizam a metodologia da MCC pela utilização da técnica da Análise dos Efeitos e Modos de Falha (FMEA). Isto é, acompanhamento sistemático para identificar os modos e efeitos das falhas, e suas respectivas causas, que podem levar o ativo a não cumprir a sua função operacional. Depois dessa identificação, é feita uma análise de criticidade para cada modo de falha com base na ocorrência, gravidade e detectabilidade da falha. Com essas informações é possível compor um procedimento de manutenção adequado ao equipamento. Como se pode ver a MCC é uma ferramenta de suporte à decisão gerencial.

FURMANN (2002) e PINTO \& XAVIER (2001) acrescentam que a abordagem clássica da Manutenção Centrada na Confiabilidade inclui as seguintes etapas:

- E1 - Escolha do equipamento, sistema ou instalação, definindo com clareza as suas fronteiras, interfaces e necessidades de modernização; 
- E2 - Definição das funções e dos padrões de desempenho no contexto operacional atual;

- E3 - Análise dos efeitos e dos modos de falha, coletando informações sobre a ocorrência, gravidade e detectabilidade das falhas;

- E4 - Decisão sobre a criticidade dos modos de falha e sobre a seleção das tarefas, conforme pode ser observado na Figura 2-17; e

- E5 - Determinação de ações de manutenção, através da elaboração de políticas, estratégias, tarefas e freqüência de intervenção. A Figura 2-17 apresenta um fluxograma de decisão para a seleção de políticas de manutenção com base na MCC.

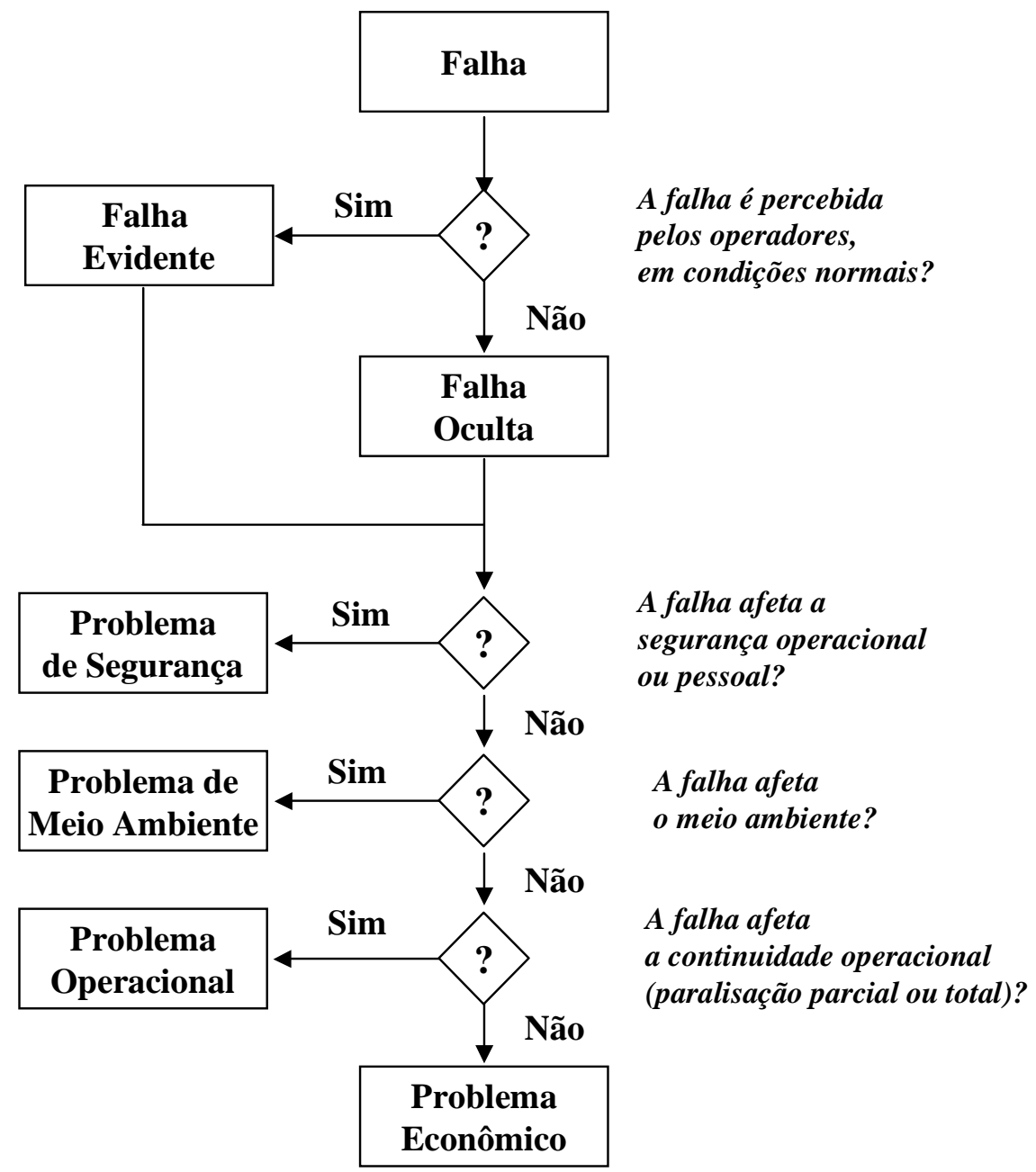

Figura 2-17 - Classificação dos Modos de Falha pela Criticidade.

Fonte: Adaptado de PINTO \& XAVIER (2001). 
Assim, é possível concluir que a análise e a deteção de falhas através da MCC apresentam os seguintes benefícios:

- Aprimoramento da compreensão do funcionamento e da utilização dos ativos, o que leva a uma ampliação do conhecimento dos operadores e manutentores das mais diversas especialidades;

- Melhoria do trabalho em grupo com conseqüências bastante positivas na análise, solução de problemas e na definição de programas de trabalho;

- Desenvolvimento de mecanismos ou de dispositivos à prova de falhas, com base na experiência adquirida na análise dos efeitos e modos de falha; e

- Aprimoramento do planejamento das atividades de manutenção com vistas a garantir a operação do ativo em um nível de desempenho desejado. O planejamento, nestas condições, inclui, além das atividades de prevenção, procedimentos operacionais e melhorias necessárias para que o equipamento atinja ou se mantenha no nível de desempenho desejado.

\subsubsection{AS POLÍTICAS DE MANUTENÇÃO}

RODRIGUES (2000) APUD KAPUR \& LAMBERSON (1977) e O'CONNOR (1989) alegam que os bens de produção são projetados para não falhar. Entretanto, os bens com menores freqüências de falhas têm uma robustez mais acentuada, são mais duráveis e caros. Bens mais acessíveis e mais baratos são carentes de robustez e mais predispostos às falhas. Nestas condições, a falha surge como uma perspectiva inerente ao ativo. Assim, surge a política de manutenção no sentido de conjugar vantagens econômicas e técnicas, seja na aquisição do ativo ou na manutenção de sua prontidão funcional a serviço da empresa.

Existem três formas de uma empresa prevenir-se contra as paralisações da produção, decorrentes de falhas, na visão de GALLIMORE E PENLESKY (1988):

1) Providenciar meios auxiliares que possam exercer a função dos ativos que estão sendo reparados; 
2) Praticar políticas de manutenção de forma criteriosa e eficaz com vistas a reduzir a taxa de falhas; e

3) Agregar elementos e cuidados suplementares aos componentes dos ativos de forma que se tornem mais confiáveis, mais fáceis de serem operados e de serem reparados.

Inúmeros são os termos destinados a caracterizar as diferentes estratégias ou políticas de manutenção. A maioria deles é decorrente do momento de atuação das equipes de manutenção diante da ocorrência da falha funcional do ativo. Basicamente, dois são os momentos que caracterizam a atuação da manutenção: antes das ocorrências das falhas (atividades de prevenção) e após as ocorrências das falhas (atividades de correção).

KELLY \& HARRIS (1980), GALLIMORE \& PENLESKY (1988), MONCHY (1989), MOUBRAY (1997), XENOS (1998), SLACK ET AL (1999) e mais recentemente autores tais como RODRIGUES (2000), PINTO \& XAVIER (2001) e FURMANN (2002) relatam as diferentes estratégias ou políticas de manutenção, discutidas nos parágrafos subseqüentes.

\section{A. SUBSTITUIÇÃO NÃO PLANEJADA}

A organização produtiva que utiliza equipamentos pequenos, facilmente substituíveis, pode chegar à conclusão que o reparo é mais caro que a substituição. Nestas condições a estratégia preconiza a utilização do ativo até o momento em que falhe irreversivelmente para em seguida efetuar a sua substituição.

Alternativamente, avanços tecnológicos acabam por gerar a obsolescência de muitos dos equipamentos que estão sendo utilizados nas plantas industriais, em um curto espaço de tempo. Em conseqüência, tais ativos são candidatos a uma substituição por outros mais modernos. É a política de substituição não planejada focada na aquisição de tecnologia.

Além dessas possibilidades, existem componentes que são impossíveis de reparar, dado que são projetados para uma única vida. Assim, ativos que se 
enquadrem também nesta categoria podem ser objetos de uma estratégia de substituição não planejada.

\section{B. SUBSTITUIÇÃO PLANEJADA}

O mérito dessa política está na utilização do equipamento até o momento em que sua vida econômica é ultrapassada. Os custos de sua conservação tornam-se mais importantes que os benefícios por ele gerados. Tal estratégia é freqüentemente utilizada nos processos onde o ativo funciona como uma unidade individual, sem comprometer o fluxo da produção.

Quando aplicada nas condições adequadas, a substituição planejada pode trabalhar no sentido de reduzir o tempo de paralisação, prevenir revisões onerosas e minimizar as ações de manutenção. Isto torna a organização capaz de obter, continuamente, as vantagens de equipamentos de última geração, que é particularmente importante nas indústrias em que a tecnologia e os métodos são constantemente alterados, para o atendimento efetivo das necessidades do mercado.

\section{MANUTENÇÃO NÃO PLANEJADA}

A manutenção não planejada é realizada após a ocorrência da falha no equipamento com o objetivo básico de recompor as suas funções requeridas.

Divide-se em duas categorias: manutenção corretiva e de emergência. É importante ressaltar, nesse ponto, as diferenças entre os termos manutenção corretiva e de emergência, visto que são freqüentemente utilizados de uma forma intercambiável.

Na realidade, o termo manutenção de emergência deve ser usado quando não há uma análise antecipada da falha ocorrida. Há a necessidade da intervenção da engenharia de manutenção para diagnosticar a causa da quebra.

Por outro lado, o termo manutenção corretiva é utilizado nos casos em que a falha foi considerada antecipadamente. Há um planejamento do método de reparo bem como a preparação do ferramental necessário, se for o caso. Como se pode ver, 
o tempo de reparo é maior nos casos de manutenção de emergência e, em decorrência, os custos também o são.

Ambas as categorias ainda podem ser subdivididas em manutenção paliativa e curativa dependendo da intenção da equipe de manutenção no momento da intervenção no ativo.

Se o objetivo é restaurar provisoriamente a prontidão funcional do equipamento, antes do reparo definitivo, a manutenção é dita paliativa. Se a intenção é retirar definitivamente a condição de falha, restaurando a função requerida do ativo, então a manutenção é dita curativa.

A manutenção não planejada é uma estratégia que pode ser aplicada em equipamentos operando como unidades individuais ou separados do processo de fabricação. A falha, nestes casos, não compromete o fluxo da produção.

A política também pode ser aplicada naqueles ativos que, historicamente, nem apresentem falhas catastróficas, nem tão freqüentes, que ensejem verificações regulares. Uma instalação industrial que opera com vários equipamentos com funções semelhantes e recondicionados pode também utilizar esta estratégia. É mais fácil e rápido substituir um equipamento com falha, por outro recondicionado. O equipamento é então recuperado e mantido à disposição para futuras utilizações.

\section{MANUTENÇÃO PLANEJADA OU PREVENTIVA}

Em processos contínuos ou altamente automatizados os custos das perdas de produção decorrentes das falhas dos ativos podem ser extremamente altos. A falha de um dado componente pode arruinar todo o processo e ainda causar danos irreparáveis nas relações da produção com o mercado.

Assim, a manutenção planejada ou preventiva tem como objetivo prevenir a falha do equipamento durante a operação. É uma intervenção planejada, pró-ativa, uma vez que pretende atuar nas causas geradoras das falhas. Portanto pode ser programada e ter a sua execução preparada, antes mesmo da caracterização do estado de falha. A forma de antecipação às falhas pode ser feita das seguintes formas: 
manutenção sistemática, assistemática ou preditiva e manutenção por ronda e testes (detectiva).

\section{1) MANUTENÇÃO SISTEMÁTICA}

A manutenção sistemática é uma intervenção realizada com base no conhecimento e domínio da lei de degradação do equipamento, normalmente condicionada ao tempo de funcionamento ou ao número de operações (partidas).

É uma política bastante eficaz quando o mecanismo de falha é típico de desgaste. Os períodos de intervenção são predeterminados e resultam de cuidadosa consideração de fatores relacionados com a confiabilidade do equipamento.

Há duas razões principais que tornam esta política inadequada para componentes ditos de reposição complexa. A primeira é que quanto mais complexo o componente, tanto menos provável de apresentar um padrão de falha típico de desgaste. A segunda é que componentes complexos são, via de regra, de reparo ou substituição bastante onerosa.

\section{2) MANUTENÇÃO ASSISTEMÁTICA OU PREDITIVA}

A manutenção assistemática ou preditiva tem a sua intervenção realizada com base no acompanhamento da condição e/ou desempenho do ativo, através da análise do comportamento de parâmetros representativos da situação do equipamento em relação a referenciais máximos ou mínimos predeterminados.

Esta abordagem reduz o elemento probabilístico da falha, e maximiza a vida útil do bem. Este acompanhamento requer o domínio de técnicas preditivas adequadas a cada situação em particular e deve ser realizado com o equipamento em serviço. Pode-se assim definir o ponto ótimo da intervenção, aumentando a disponibilidade operativa do ativo.

A adoção dessa estratégia independe da lei de degradação do equipamento e traz uma série de vantagens, entre as quais: 
- Redução de acidentes causados pelo equipamento. A manutenção preditiva permite uma parada segura quando não for possível a paralisação instantânea. A condição do equipamento pode ser indicada por um alarme, caso seja possível a parada instantânea;

- Maior disponibilidade da máquina pelo maior tempo de operação. Permite ajustar as paradas de máquina à programação da produção, evitando perdas resultantes das paralisações inesperadas;

- Maior disponibilidade da máquina pelo menor tempo de manutenção. Permite a parada de máquina antes que ocorram maiores danos que requeiram um tempo de reparo excessivo;

- Maior produção líquida. Algumas máquinas podem ser operadas com mais carga e/ou maior velocidade e é possível detectar reduções da eficiência da máquina ou um consumo maior de energia; e

- Melhor qualidade do produto ou serviço. Possibilita um melhor planejamento para reduzir o efeito das paralisações sobre os clientes do produto ou do serviço. Permite a redução da incidência de produtos ou de serviços abaixo do nível de qualidade exigido.

\section{3) MANUTENÇÃO POR RONDA E TESTES (DETECTIVA)}

A manutenção por ronda e testes ou detectiva é uma inspeção realizada periodicamente quando ainda não se conhece a lei de degradação do equipamento. A estratégia tem por finalidade a deteção de mau funcionamento de um bem e desenvolver uma atitude pró-ativa do inspetor, permitindo a sua pronta atuação no sentido de restaurar as condições de bom funcionamento do ativo.

\section{E. MODIFICAÇÃO DE PROJETO}

As políticas já citadas visam, em última análise, minimizar o efeito da falha. Já a estratégia de modificação de projeto tem como objetivo maior a eliminação das causas das falhas através das atividades de melhorias exercidas pela manutenção. Essas atividades visam aprimorar as condições originais de operação, desempenho e 
confiabilidade intrínseca dos ativos, pela incorporação de modificações ou alterações no seu projeto ou configuração original.

Essa política é usualmente adotada em equipamentos de elevado custo de manutenção. Exige um grande intercâmbio de informações entre os departamentos de engenharia, manutenção e a empresa fornecedora do bem. As modificações de projeto podem dar origem a componentes ou sistemas mais modernos, peças mais resistentes e outras medidas concretas para aumentar a confiabilidade intrínseca ou a capacidade funcional dos ativos.

A Figura 2-18 apresenta o fluxo lógico para a escolha das políticas de manutenção. Entretanto, a decisão entre estas alternativas deve ser considerada no contexto da estratégia global da empresa e sofre a influência de fatores externos e internos à organização. Como fatores externos podem ser citados a obsolescência dos equipamentos, o nível de vendas da corporação, custo do capital investido e a diversificação do mercado. O custo da indisponibilidade dos ativos e o dos recursos de manutenção representam os fatores internos.

SLACK ET AL (1999) argumentam que cada estratégia para a manutenção é adequada para diferentes circunstâncias, como está apresentado na Figura 2-19.

A política de manutenção não planejada, mais especificamente a manutenção corretiva, é usada com freqüência em três situações:

1) Quando o reparo é fácil, logo a conseqüência da falha é pequena;

2) Quando a manutenção preventiva é muito dispendiosa; e

3) Quando a falha não é previsível de nenhuma forma; logo, não há vantagem em se utilizar a manutenção preventiva, porque a falha apresenta a mesma probabilidade de acontecer antes ou depois do reparo.

A manutenção planejada ou preventiva tem sua utilização recomendada nos casos em que o custo da falha não prevista é alto, devido às paralisações da produção e quando a falha não é totalmente aleatória. O momento da intervenção pode ser programado antes que a falha se torne muito provável.

A manutenção preditiva é usada quando o custo da falha tem um valor significativamente alto, incluindo-se aí os custos da atividade de manutenção para 
restaurar a função do ativo mais o custo da não produção, decorrente de sua indisponibilidade. É a estratégia freqüentemente usada nos ativos que ocupam uma posição crítica no processo produtivo. Os autores alegam que é muito comum a adoção de combinações dessas políticas em face das diferentes características dos equipamentos das empresas.

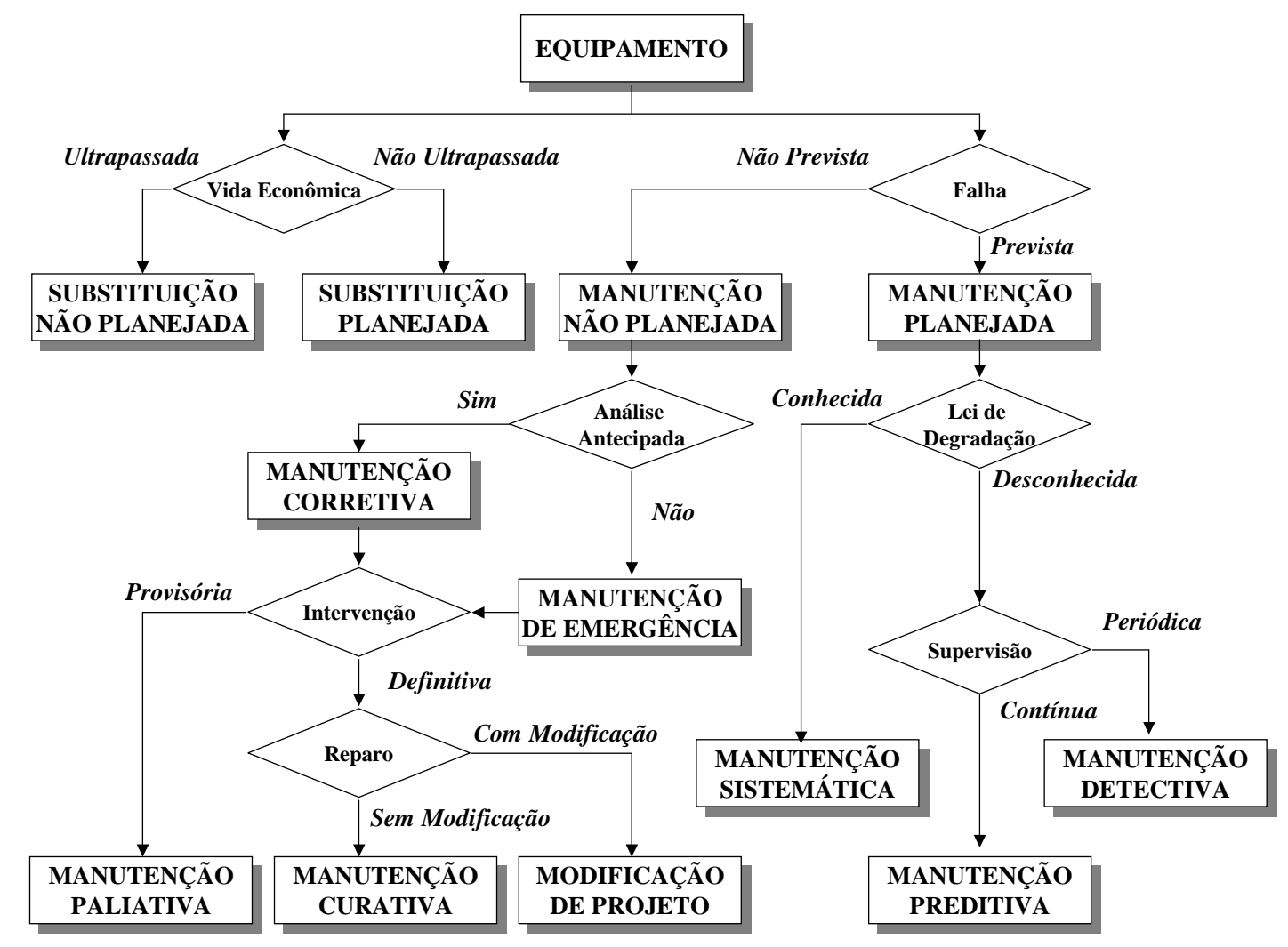

Figura 2-18 - Fluxograma Lógico para a Escolha da Política de Manutenção.

Fonte: Adaptado de MONCHY (1989) \& FURMANN (2002). 

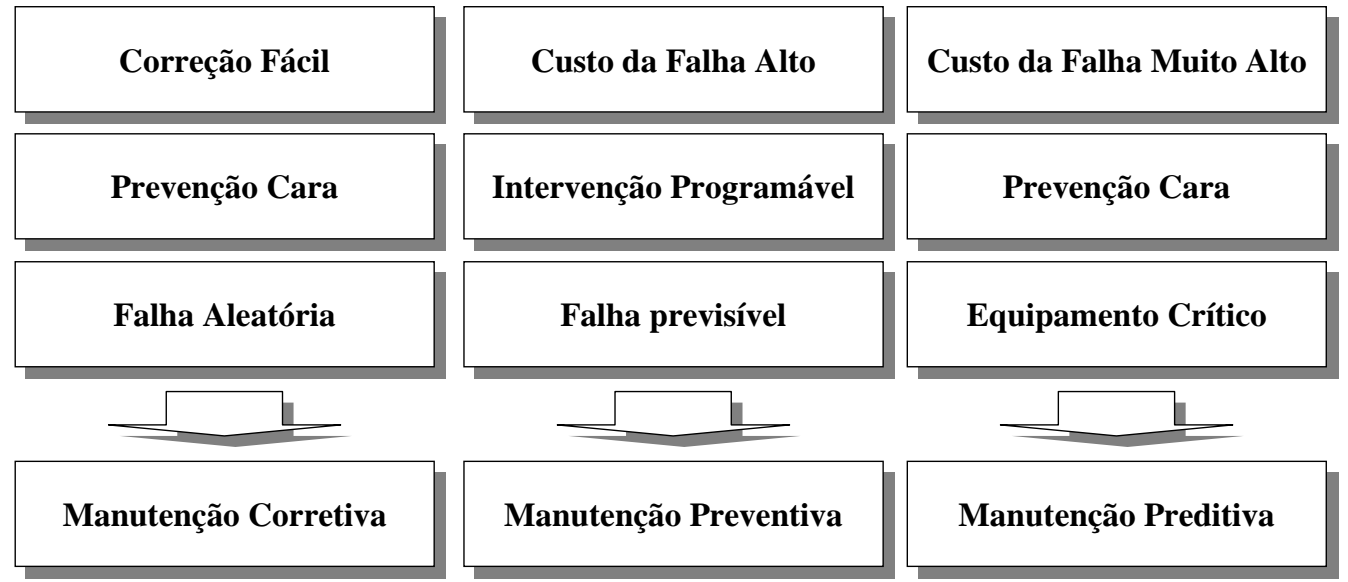

Figura 2-19 - Utilização das Políticas de Manutenção.

Fonte: Adaptado de SLACK ET AL (1999).

PINTO \& XAVIER (2001) apresentam um fluxograma de decisão para a seleção das políticas de manutenção, com base na metodologia da MCC Manutenção Centrada na Confiabilidade (Figura 2-20).

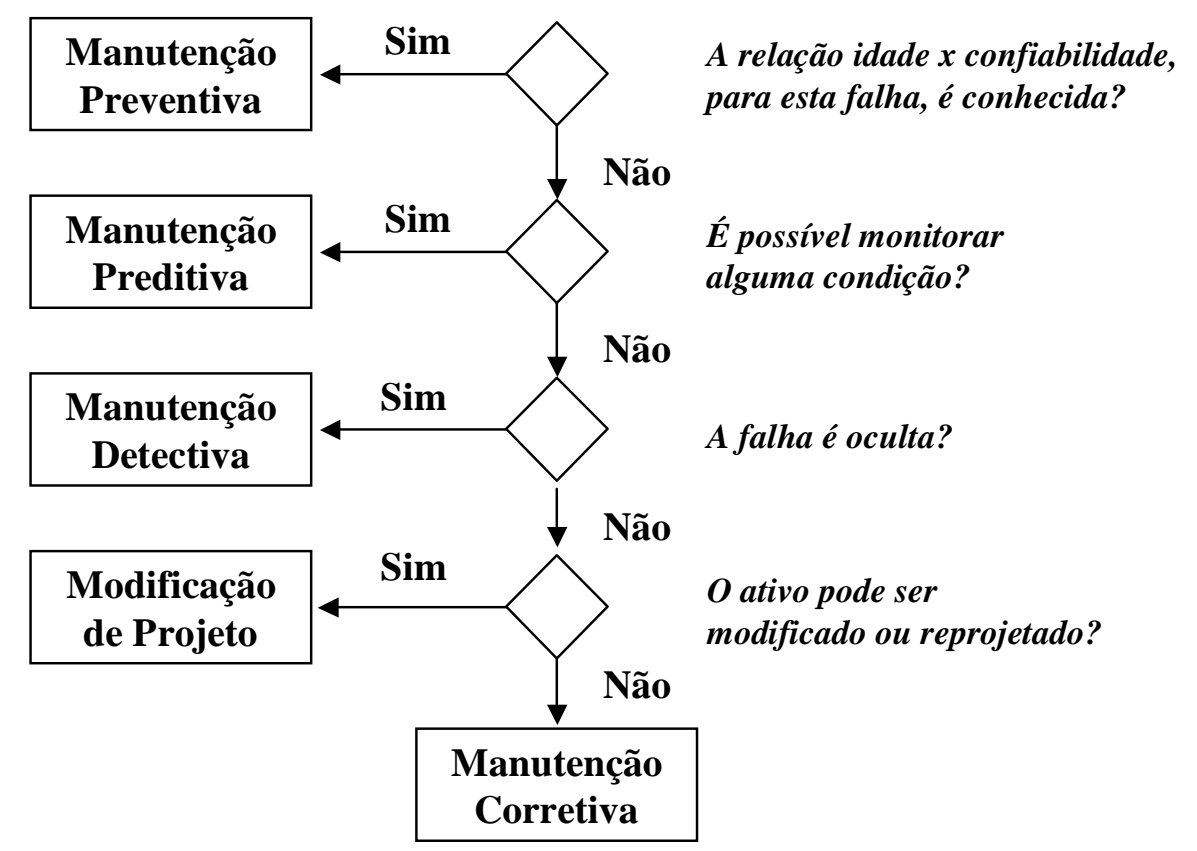

Figura 2-20 - Seleção das Políticas de Manutenção na MCC.

Fonte: Adaptado de PINTO \& XAVIER (2001). 


\subsubsection{GESTÃO DA MANUTENÇÃO INDUSTRIAL}

\section{A. INFORMATIZAÇÃO DA MANUTENÇÃO}

NAGAO (1998), APUD DECARLI ET AL (1991), argumenta que os softwares desenvolvidos para dar suporte ao Gerenciamento da Manutenção Industrial são fundamentais para a melhoria do desempenho da manutenção.

Assim, um Sistema de Gerenciamento de Manutenção deve incluir os módulos específicos de Gestão de Equipamentos, Gestão de Planejamento e Programação, Gestão de Materiais e Gestão de Custos.

\section{1) GESTÃO DE EQUIPAMENTOS}

O módulo de gestão de equipamentos deve trabalhar com dois conceitos fundamentais: o da matrícula do equipamento e o do posto de serviço. A matrícula do equipamento identifica as suas características tais como os seus dados técnicos, o registro dos componentes, das peças reservas, dados dos equipamentos reserva (equipamentos similares ou alternativos). A matrícula deve incluir também o seu histórico de falhas, a sua localização e os custos da intervenção (custos de mão-deobra, serviços e materiais). A análise dos efeitos e modos de falha, além dos dados referentes às inspeções de rotina, deve fazer parte da matrícula do equipamento.

Os dados dos postos de serviço devem abranger as características técnicas do próprio posto, dados relativos ao processo produtivo, além das condições de operação. É também importante incluir os dados do produto, as medidas de segurança relativas aos riscos da intervenção de manutenção e as medidas preventivas contra paralisações da produção. Finalmente, os dados do posto de serviço devem conter o histórico do posto, o processo de lubrificação, os processos de intervenção em ações corretivas e preventivas e os custos associados. 


\section{2) PLANEJAMENTO E PROGRAMAÇÃO DOS SERVIÇOS}

A otimização dos recursos de manutenção parte do pressuposto de uma estrutura adequada para planejar, programar, alocar e executar os serviços. O planejamento dos serviços deve compreender as fases de emissão do pedido de manutenção pelo solicitante do serviço e a geração da ordem de serviço com o detalhamento completo da execução dos serviços solicitados. Este detalhamento deve incluir os recursos necessários para a execução do serviço, isto é, mão-de-obra, materiais e serviços complementares. O detalhamento deve descrever todas as tarefas pertinentes à execução dos serviços, além da seqüência das mesmas. Também fazem parte do detalhamento a duração das tarefas, as prioridades, as datas e as horas previstas para início e término dos serviços. É importante que estejam registradas as medidas de segurança necessárias para a liberação dos serviços e outras informações complementares para a execução dos mesmos.

Para que a gestão do planejamento da manutenção seja eficaz, os seguintes pontos devem ser observados com atenção:

- O planejador deve ter autoridade ou acesso a ela para tomar decisões que influenciem a carga de trabalho ou os recursos disponíveis, bem como para a designação de prioridades;

- O planejador deve dispor de informações corretas e atualizadas, sejam da carga de trabalho, sejam dos recursos disponíveis; e

- As áreas de responsabilidades e as linhas de comunicação entre os níveis de planejamento devem ser definidas com clareza.

A fase de programação consiste na preparação dos serviços, cadastro e alocação da mão-de-obra, apropriação das horas trabalhadas além da avaliação do desempenho das equipes designadas para a execução dos serviços. A programação das grandes paradas pode significar um período intenso de atividades que envolvem o trabalho conjunto de pessoal próprio e de prestadores de serviços. Por esta razão depende de uma área de coordenação bastante eficaz, onde custos, qualidade e prazos são essenciais. Assim, a gestão do planejamento e programação da manutenção deve considerar as seguintes atividades como premissas básicas para a gestão: 
- Determinar de um programa de trabalho de manutenção preventiva, ao longo do ano e em cargas semanais;

- Atender aos pedidos de modificação e melhoria dos equipamentos; e

- Atender às paralisações e serviços de emergência.

Nestas condições, a gestão do planejamento e programação da manutenção pode ser sistematizada pela Figura 2-21, onde se podem observar as três premissas para o planejamento e programação da manutenção dando entrada no PCM Planejamento e Controle da Manutenção através das solicitações de serviços (SS). Na figura também é vista a alocação das equipes para a realização dos trabalhos, por meio das ordens de serviço (OS). Observa-se, também, a realimentação de dados de custo, de modos e efeitos das falhas e de desempenho das equipes para posterior avaliação global do desempenho da manutenção.

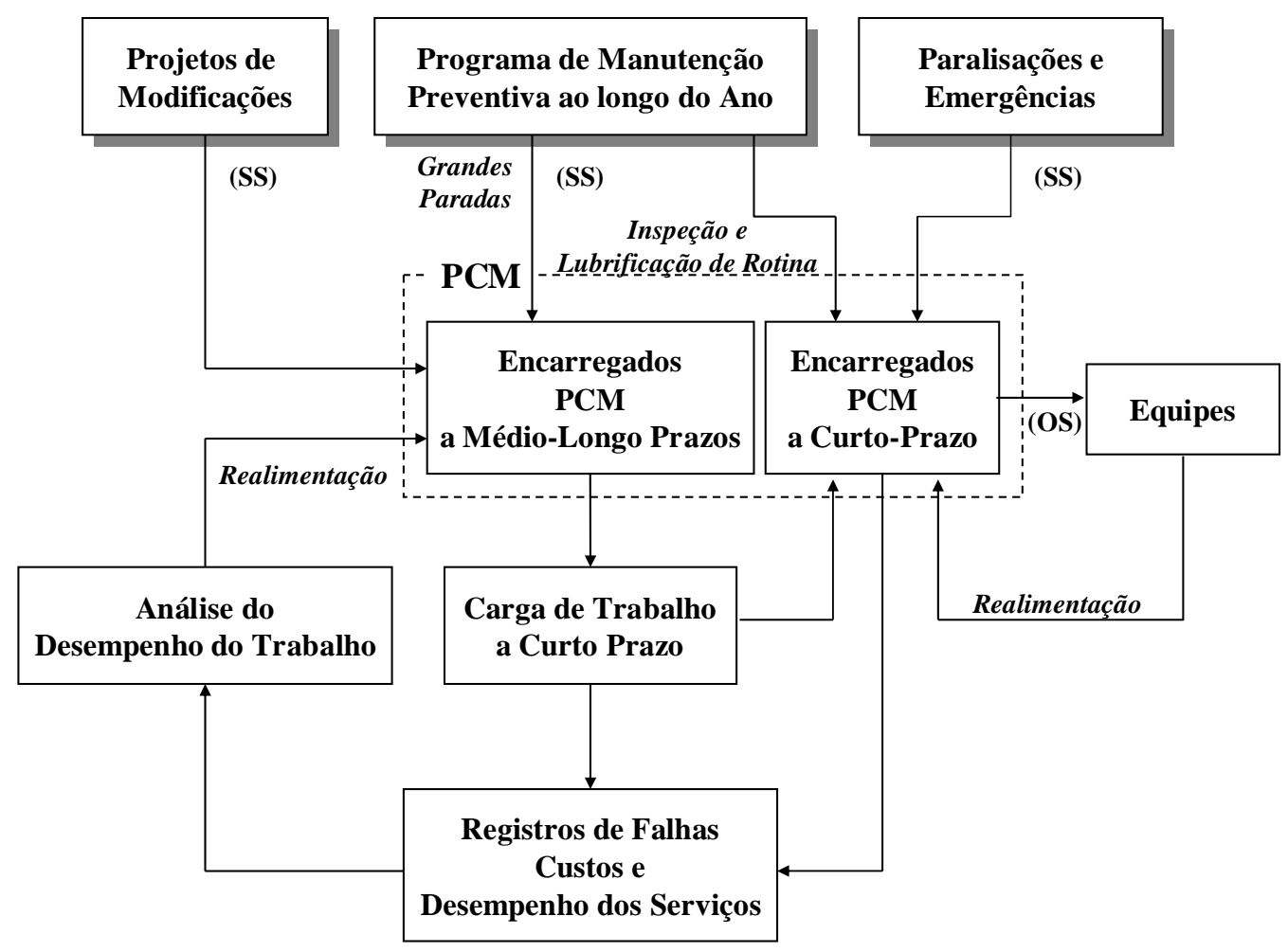

Figura 2-21 - Gestão do Planejamento e Programação da Manutenção.

Fonte: Adaptado de KELLY \& HARRIS (1980). 


\section{3) GESTÃO DE MATERIAIS}

A gestão de materiais para os serviços de manutenção tem importância fundamental, dado que devem estar disponíveis para a intervenção de manutenção no momento adequado. Assim, o módulo de gestão de materiais deve levar em conta os seguintes pontos:

- Política da empresa para a gestão de materiais, incluindo aí a análise de risco para a definição dos estoques de segurança e sistemas de armazenamento e controle de estoques;

- Padronização de materiais, incluindo a sua especificação técnica, dados do fornecedor e até mesmo os materiais substitutos;

- Padronização de procedimentos para a armazenagem, entrega e inspeção de materiais; e

- Contratos de parceria, estoques sob consignação e redes de almoxarifados.

\section{4) GESTÃO DE CUSTOS}

A gestão de custos da manutenção deve estar integrada com os sistemas de alocação de mão-de-obra, aquisição de serviços e materiais. Estes dados devem estar consolidados tanto para a pesquisa quanto para o acompanhamento dos custos e servem para diversas finalidades. Dentre elas podem-se citar a preparação e acompanhamento do orçamento da manutenção, as pesquisas sobre custos da intervenção para um direcionamento dos trabalhos de melhoria e a verificação dos impactos causados pelas ações de melhoria.

A exploração dos dados poderá ser realizada por:

- Equipamento;

- Posto de Serviço;

- Tipo de Falha;

- Tipos de Intervenção; 
- Linha de Produção;

- Unidades de Produção;

- Planta Industrial; e

- Empresa.

\section{B. ABORDAGENS PARA O GERENCIAMENTO DA MANUTENÇÃO}

RODRIGUES (2000) e NAGAO (1998) relatam três abordagens, consideradas canônicas, na arte de gerenciar a manutenção: Terologia, TPM Manutenção Produtiva Total e Logística. Os autores também comparam tais abordagens com a metodologia da MCC - Manutenção Centrada na Confiabilidade na detecção e prevenção de falhas.

\section{1) TEROLOGIA}

Reflete o pensamento inglês na gestão da função manutenção e cuja finalidade precípua da abordagem é a ampliação do ciclo de vida dos ativos através da melhoria de suas especificações, segundo KELLY \& HARRIS (1980). A definição de Terologia vem do grego "tero", que significa "ter cuidado", “preservar”. Assim, a abordagem está relacionada com a aplicação de habilidades técnicas, administrativas e financeiras no sentido de otimizar os custos do ciclo de vida de peças, componentes, conjuntos, prolongando o ciclo de vida do ativo. Observa-se então uma contribuição multidisciplinar para o prolongamento do ciclo de vida dos bens físicos da empresa, maximizando o retorno dos investimentos realizados.

Para os autores, a Terologia cobre aspectos relativos a especificação, projeto, fabricação, instalação, partida, operação e substituição do equipamento, como se pode verificar na Figura 2-22, que ilustra os estágios de vida de um ativo. 


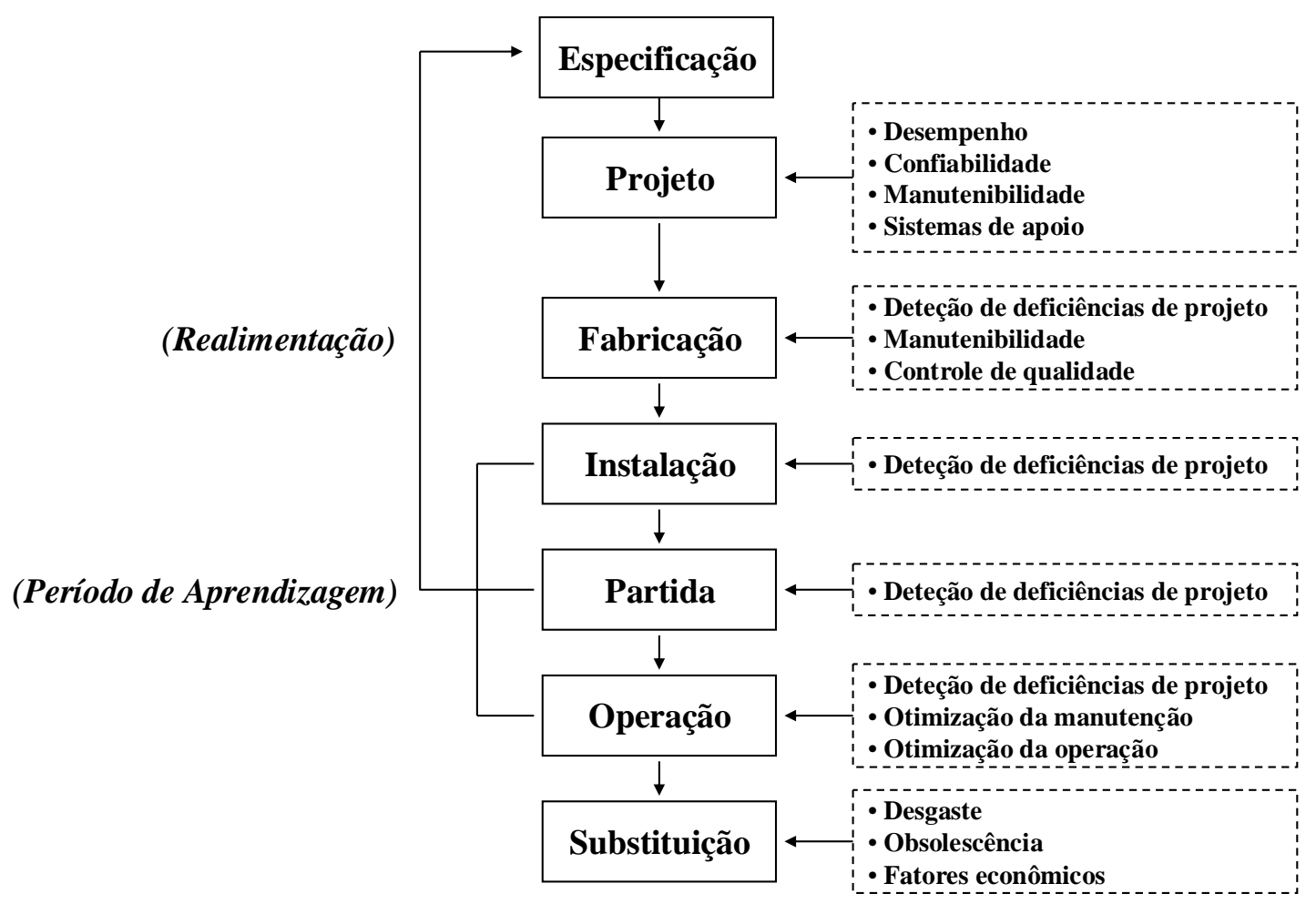

Figura 2-22 - Estágios de Vida de um Equipamento.

Fonte: Adaptado de KELLY \& HARRIS (1980).

Na fase de projeto, a ênfase é colocada na confiabilidade que por sua vez deve ser correlacionada com o custo inicial, desempenho do ativo e custo operacional. Na fase de fabricação, a manutenibilidade continua a ser considerada, dado que justamente nesse ponto começa a se revelar a natureza multidisciplinar da maioria dos problemas de manutenção.

As etapas seguintes de instalação, partida e operação não são apenas partes de um período de teste do desempenho do equipamento. É uma etapa de aprendizagem, onde as principais deficiências do projeto são identificadas e analisadas. A função dessa fase é reunir dados e fatos que propiciem a otimização da manutenção e da operação. Essas informações devem servir de realimentação para a melhoria das especificações do equipamento.

Este modelo de gerenciamento da manutenção acaba por refletir um maior envolvimento da empresa no processo de tomada de decisões. Principalmente 
aquelas concernentes a investimentos em bens de capital. O modelo também vai demandar um compartilhamento de responsabilidades pela especificação, aquisição, instalação, operação e acompanhamento dos ativos inseridos nos processos da empresa.

Como já foi mencionada anteriormente, a MCC - Manutenção Centrada na Confiabilidade é uma metodologia lógica e estruturada, associada a um programa de manutenção preventiva. Tal programa é especialmente elaborado com vistas a preservar a confiabilidade inerente de um ativo, isto é, o nível de desempenho por ele incorporado a partir do projeto. Já a preservação da confiabilidade do equipamento requer uma análise lógica das conseqüências técnicas e econômicas dos modos e efeitos das falhas. Por outro lado, o período de aprendizagem, segundo a Terologia, é o momento onde se configuram dois aspectos significativamente importantes. $\mathrm{O}$ primeiro diz respeito à atuação multidisciplinar para a deteção dos defeitos de projetos e aprimorar a especificação do ativo. O segundo identifica as semelhanças entre a Terologia e a metodologia da MCC.

A reunião de dados e fatos que permitem a melhoria da manutenção e a da própria operação necessariamente vai refletir no aprimoramento da confiabilidade inerente do equipamento, de acordo com o objetivo prioritário da MCC.

\section{2) TPM (MANUTENÇÃO PRODUTIVA TOTAL)}

A Manutenção Produtiva Total ou TPM² é uma prática gerencial na gestão da manutenção. O foco do programa está na maximização do rendimento operacional dos ativos por meio da operação básica dos mesmos e no envolvimento de toda a escala organizacional para atingir tal objetivo. Está baseada na manutenção voluntária por parte dos operadores e na introdução de melhorias para minimizar as falhas dos equipamentos.

\footnotetext{
2 Total Productive Maintenance, conforme NAKAJIMA (1988).
} 
Como pano de fundo dessa abordagem percebe-se a existência de um mercado exigente, obrigando as empresas a se tornarem mais competitivas. O TPM apresenta-se como uma prática gerencial com objetivos bem definidos de:

- Eliminar desperdícios;

- Obter o melhor desempenho dos equipamentos;

- Reduzir as paralisações da produção por quebras ou intervenções;

- Redefinir o perfil de conhecimento e habilidades dos recursos humanos, principalmente aqueles lotados na produção e manutenção;

- Modificar a sistemática de trabalho; e

- Melhorar o ambiente de trabalho.

Os objetivos citados remetem aos esforços da organização em cumprir as exigências dos clientes externos e internos e sugere um modelo de gestão participativa. Não há mais a separação entre operadores e manutentores. Todos são responsáveis pela conservação e funcionamento dos ativos, para que a empresa atinja seus objetivos operacionais. A responsabilidade é distribuída entre as pessoas que operam, supervisionam, administram e controlam o processo.

Para o programa, o foco está na operação dos ativos. O operador de máquina é o centro das atenções. Os operadores passam a executar tarefas mais simples que antes eram exclusivas dos manutentores. Como exemplos podem ser citadas as tarefas de lubrificação, limpeza, ajustes e setups, medição de temperatura e de vibração, troca de lâmpadas e inspeções, entre outras. Aquelas de maior complexidade permanecem, ainda, na responsabilidade da equipe de manutenção.

A MCC e o TPM apresentam muitos pontos em comum, como por exemplo, o trabalho em equipe, senso de propriedade, multidisciplinaridade, indicadores de desempenho, análise de falhas e melhorias nos equipamentos, entre outros. Existe também uma complementaridade visível entre essas metodologias. O TPM apresenta uma visão mais sistêmica do processo. Preocupa-se com o treinamento e a educação dos recursos humanos, com o engajamento da alta gerência nas atividades operacionais, com a melhoria do ambiente de trabalho e com a utilização das ferramentas da qualidade. O programa procura dar visibilidade aos processos através 
de painéis de atividades com indicadores de desempenho, melhorias implementadas e cronogramas de implantação. A MCC por outro lado apresenta uma abordagem mais pontual e profunda nas questões concernentes à confiabilidade e à utilização da metodologia de análise dos efeitos e modos de falha.

\section{3) LOGÍSTICA}

A finalidade da Logística é assegurar a efetividade e o funcionamento econômico de equipamentos, sistemas e instalações, através de atividades de apoio efetivas como fluxo maior e mais rápido das informações e utilização de recursos computacionais.

A Logística também apresenta pontos comuns com a MCC, já que a sustentação logística abrange a fase das especificações e projetos dos ativos. O funcionamento econômico dos equipamentos, sistemas e instalações passa pela redução dos custos necessários para manter o ativo em funcionamento. Tais custos têm origens na confiabilidade, manutenibilidade, qualidade e segurança deficientes.

O conceito de gerenciamento da manutenção está intrinsecamente ligado a uma atividade de caráter departamental, conforme atesta ANHESINE (1999). Esta definição, por sua vez, tem fortes relações com a Logística e a eficiência no planejamento dos trabalhos, a saber:

- Planejamento das ordens de serviços;

- Fornecimento de materiais e serviços;

- Manuseio de materiais;

- Acompanhamento dos custos; e

- Administração do Histórico da Manutenção;

A Figura 2-23 apresenta os principais elementos de um sistema de gerenciamento da manutenção, conforme relata XENOS (1998). A missão da manutenção, as metas de melhoria e o plano de manutenção formam a espinha dorsal do sistema, com destaque maior para o plano de manutenção. 


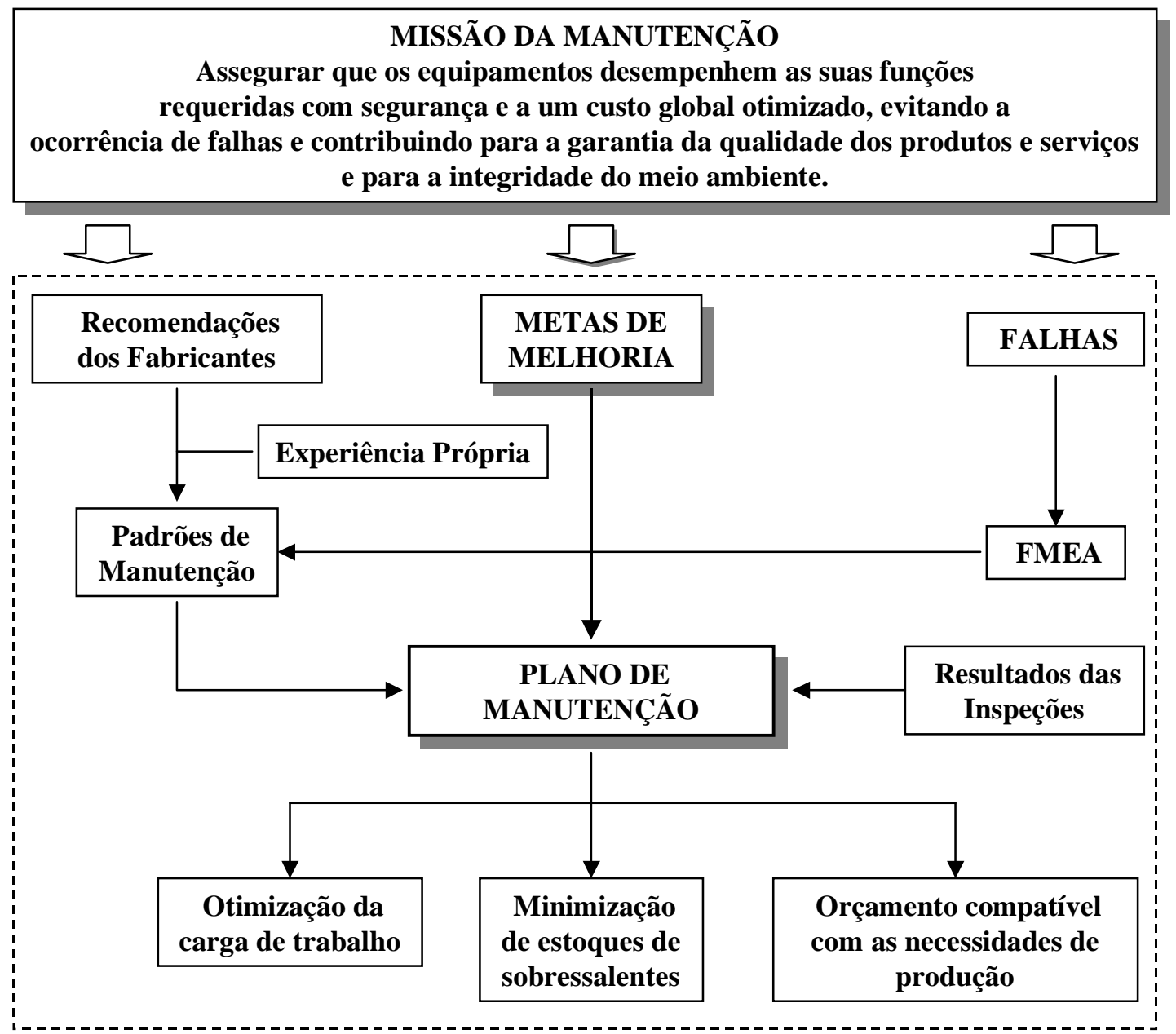

Figura 2-23 - Sistema de Gerenciamento de Manutenção.

Fonte: XENOS (1998).

O plano de manutenção deve ser elaborado a partir das recomendações dos fabricantes e incorporar a experiência acumulada da empresa. Todo este conhecimento é consolidado nos padrões de manutenção e origens das informações do plano. A sustentação logística do sistema é identificada pela efetividade e rapidez das informações que realimentam e modificam o plano de manutenção. Os dados e fatos resultantes das inspeções, reformas, troca de componentes e análise de falhas são informações essenciais para a elaboração e revisão periódica do plano de manutenção. O plano de manutenção é a base para a otimização da carga de trabalho, dos custos e dos materiais da manutenção, sem que isso acarrete qualquer tipo de prejuízo para a disponibilidade dos equipamentos, segundo o autor. 


\subsubsection{O USO DE INDICADORES NA GESTÃO DA MANUTENÇÃO}

FURMANN (2002) sugere um conjunto de indicadores, publicado em documento nacional da ABRAMAN - Associação Brasileira de Manutenção, para a gestão da manutenção em empresas industriais. Os indicadores podem ser observados na Tabela 2-4

\begin{tabular}{|c|c|}
\hline \multicolumn{2}{|c|}{} \\
\hline \multirow{4}{*}{$\begin{array}{c}\text { Indicadores } \\
\text { de } \\
\text { Disponibilidade }\end{array}$} & Disponibilidade Operacional [\%] \\
\cline { 2 - 2 } & Indisponibilidade Programada [\%] \\
\cline { 2 - 2 } & Indisponibilidade Forçada [\%] \\
\cline { 2 - 2 } & Taxa de Falhas [falhas/ano] \\
\cline { 2 - 2 } & Tempo Médio de Reparo [h] \\
\hline \multirow{3}{*}{$\begin{array}{c}\text { Indicadores } \\
\text { de }\end{array}$} & Taxa de Incidentes [incidentes/ano] \\
\cline { 2 - 2 } Custos & Custo Médio Anual da Manutenção Corretiva [US\$/ano] \\
\cline { 2 - 2 } & Custo Acumulado de Falha [US\$] \\
\cline { 2 - 2 } & Custo Médio Anual de Exploração [US\$/ano] \\
\cline { 2 - 2 } & Custo Médio Anual de Manutenção por Faturamento [\%] \\
\hline
\end{tabular}

Tabela 2-4 - Indicadores de Gestão.

Fonte: Adaptado de FURMANN (2002).

Além da identificação dos indicadores, o autor define critérios para padronizar a seleção das ocorrências (incidentes) de manutenção que farão parte do cálculo dos indicadores, bem como a sua própria formulação.

Assim, os principais indicadores de disponibilidade podem ser listados:

1) Disponibilidade Operacional:

$$
\mathrm{DO}=\frac{\mathrm{HS}+\mathrm{HPCO}}{\mathrm{HP}} \times 100
$$

em que:

- DO - Disponibilidade Operacional [\%];

- HS - Horas em Serviço [h];

- HPCO - Horas Paradas por Conveniência Operativa [h]; e 
- HP - Horas do Período Considerado.

2) Indisponibilidade Programada:

$\mathrm{IP}=\frac{\mathrm{HMP}}{\mathrm{HP}} \times 100$

onde:

- IP - Indisponibilidade Programada (Manutenção Preventiva) [\%];

- HMP - Horas em Manutenção Preventiva; e

- HP - Horas do Período Considerado [h].

3) Indisponibilidade Forçada:

$\mathrm{IF}=\frac{\mathrm{HMC}}{\mathrm{HP}} \times 100$

onde:

- IF - Indisponibilidade Forçada (Manutenção Corretiva) [\%];

- HMC - Horas em Manutenção Corretiva [h]; e

- HP - Horas do Período Considerado [h].

4) Taxa de Falhas:

$\mathrm{TF}=\frac{\mathrm{NF}}{\mathrm{HS}}$,

onde:

- $\mathrm{TF}$ - Taxa de Falhas [falhas/período];

- NF - Número de Falhas no Período Considerado [falhas/período];

- HS - Horas de Serviço no Período Considerado [h];

- Os critérios, para padronizar a seleção de ocorrências, definem que serão levados em contas os seguintes casos, para o equipamento em análise:

$\checkmark$ Falhas durante a operação em vazio e carga do equipamento; 
$\checkmark \quad$ Falhas na partida do equipamento;

$\checkmark \quad$ Falhas durante ensaio no equipamento;

$\checkmark$ Falhas em equipamento externos que implicam em falhas para o equipamento, objeto da análise; e

$\checkmark$ Falhas em equipamentos auxiliares que implicam em falhas para o equipamento, objeto da análise.

5) Tempo Médio de Reparo:

$\mathrm{TMR}=\frac{\mathrm{HMC}}{\mathrm{NF}}$,

onde:

- $\quad$ TMR - Tempo Médio de Reparo [h];

- HMC - Horas de Manutenção Corretiva no período considerado [h];

- NF - Número de Falhas no período considerado;

- O critério de padronização para o levantamento do tempo de reparo, considera as seguintes as seguintes atividades como parte do tempo em questão:

$\checkmark$ Emissão de documentos;

$\checkmark$ Preparação de material, ferramentas e dispositivos;

$\checkmark$ Deslocamentos;

$\checkmark$ Isolação do equipamento;

$\checkmark \quad$ Reparo propriamente dito;

$\checkmark$ Recomposição do equipamento; e

$\checkmark \quad$ Baixa de documentos.

6) Taxa de Incidentes:

$\mathrm{TI}=\frac{\mathrm{NI}}{\mathrm{HM}}$

onde: 
- TI - Taxa de Incidentes [incidentes/período];

- NI - Número de Incidentes no período considerado [Incidentes/período];

- HM - Horas de Manutenção corretiva e preventiva no período considerado [h]; e

- Como critério para padronizar a seleção de ocorrências, consideram-se os incidentes relacionados com a segurança do trabalho e meio ambiente

O autor ainda relata os principais indicadores de custos utilizados na gestão da manutenção industrial:

- Custo médio anual da manutenção preventiva [US\$/ano];

- Custo médio anual da manutenção corretiva [US\$/ano];

- Custo acumulado de falha [US\$] - utilizado na análise da vida útil do equipamento;

- Custo médio anual de exploração do equipamento [US\$/ano] - utilizado na análise da vida útil do equipamento;

- Relação entre o custo médio anual de manutenção e o faturamento [\%]; e

- Obviamente estes custos incluem:

$\checkmark$ A mão-de-obra;

$\checkmark$ Os gastos gerais do serviço de manutenção;

$\checkmark$ As ferramentas e equipamentos usados para a manutenção;

$\checkmark$ Os produtos e os materiais consumidos;

$\checkmark$ O custo de posse do estoque para a manutenção;

$\checkmark$ O custo de subcontratações; e

$\checkmark$ Diversos outros custos (custo de transporte, instalações, energia utilizada, garantias, etc.) 
XENOS (1988) argumenta que a monitoração das atividades de manutenção pode ser realizada através de itens de controle simples e relevantes e que possam ser úteis para gerar alguma ação concreta.

Para o autor, o resultado da manutenção pode ser medido pelos seguintes indicadores:

1) Número de falhas por período de tempo;

2) Tempo de interrupção da produção por período de tempo; e

3) Custo de manutenção por período de tempo.

NAGAO (1998) utiliza o modelo gerencial de avaliação de SINK \& TUTTLE (1993) para sugerir indicadores que permitam gerenciar os fatores críticos de sucesso da manutenção.

Para o autor, tais fatores são representados pela disponibilidade operacional, confiabilidade das instalações, aliadas à otimização de seus custos.

Nesse sentido, recomenda adoção de indicadores que contemplem os parâmetros de desempenho do modelo. Ou seja, indicadores de eficiência, eficácia, produtividade, inovação, qualidade, qualidade de vida no trabalho e de acompanhamento do orçamento.

O autor também afirma a necessidade da utilização de indicadores macro para a manutenção. É importante efetuar comparações externas com empresas similares, que permitam analisar tendências e elaborar estratégias de médio e longo prazos.

Cita como exemplo os seguintes indicadores (também acompanhados pela Associação Brasileira de Manutenção Industrial - ABRAMAN):

- Relação de horas extras por horas disponíveis;

- Relação da mão-de-obra contratada pela mão-de-obra própria;

- Relação do efetivo da manutenção sobre o efetivo total;

- Indisponibilidade operacional média anual da unidade de produção;

- Custo da Manutenção sobre o faturamento da empresa; e

- Custo da manutenção sobre o valor de reposição da planta. 
MENDES (2002) organiza as operações de manutenção em diferentes níveis de atividades, conforme evidenciado na Tabela 2-5.

\begin{tabular}{|c|c|c|c|}
\hline Atividades & Nível & Responsabilidade & Operação \\
\hline $\begin{array}{c}\text { Manutenção Autônoma: } \\
\text { Limpeza } \\
\text { Inspeções (usando os sentidos) } \\
\text { Ajustes } \\
\text { Pequenos reparos } \\
\end{array}$ & 2 & $\begin{array}{l}\text { Operadores de } \\
\text { Produção }\end{array}$ & \multirow{2}{*}{$\begin{array}{l}\text { Operação de } \\
\text { Manutenção } \\
\text { de linha de } \\
\text { frente } \\
\text { “front-office” }\end{array}$} \\
\hline $\begin{array}{c}\text { Intervenções: } \\
\text { Manutenção não planejada } \\
\text { Manutenção planejada }\end{array}$ & 3 & Manutentores & \\
\hline $\begin{array}{l}\text { PCM - Planejamento e Controle da } \\
\text { Manutenção: } \\
\text { Análise da confiabilidade } \\
\text { Plano de manutenção preventiva } \\
\text { Lista de sobressalentes }\end{array}$ & 4 & \multirow{2}{*}{$\begin{array}{l}\text { Engenharia de } \\
\text { Manutenção }\end{array}$} & \multirow{2}{*}{$\begin{array}{l}\text { Operação de } \\
\text { Manutenção de } \\
\text { retaguarda } \\
\text { "back-office" }\end{array}$} \\
\hline $\begin{array}{c}\text { Apoio às Operações: } \\
\text { Especialização técnica } \\
\text { Padronização de sobressalentes } \\
\text { Definição de políticas }\end{array}$ & 5 & & \\
\hline
\end{tabular}

Tabela 2-5 - Organização das Operações de Manutenção.

Fonte: Adaptado de MENDES (2002).

O autor relata que as operações de manutenção contribuem de forma significativa no valor de transformação de recursos em bens e dependem de recursos humanos e dos materiais envolvidos.

Na medida em que o valor das transformações dos insumos em bens é dependente das atividades de manutenção, o autor propõe transformar os custos de tais atividades em vantagem competitiva para a empresa. Assim, um modelo de gestão do valor do serviço de manutenção é proposto.

O modelo organiza os fatores de percepção de valor ( "value-drivers”) para as operações de manutenção com os respectivos indicadores associados, conforme apresentado na Tabela 2-6. 


\begin{tabular}{|c|c|}
\hline $\begin{array}{c}\text { Fatores de Percepção do Valor } \\
\text { para as Operações de } \\
\text { Manutenção }\end{array}$ & Indicadores Usuais Associados \\
\hline Velocidade de Atendimento & TMDR - Tempo Médio de Reparo \\
& Taxa de Intervenções Programadas \\
\hline Confiabilidade & Número de Falhas \\
& TMEF - Tempo Médio Entre Falhas \\
& Disponibilidade Inerente \\
Competência & Rendimento Operacional \\
\hline Consistência & Taxa de Competência \\
& Plano de Treinamento \\
& Taxa de Rotatividade \\
\hline Custos & Taxa de Manutenção Preventiva \\
& Quantidade de Falhas Reincidentes \\
\hline Flexibilidade & Custo Total de Manutenção \\
\hline Acessibilidade & Total de Manutenção por unidade produzida \\
& Perdas de Produção \\
\hline & Taxa de Polivalência \\
\hline
\end{tabular}

Tabela 2-6 - Fatores de Percepção do Valor para as Operações de Manutenção.

Fonte: Adaptado de MENDES (2002).

As definições e conceitos, estabelecidos pelo autor, tanto para os fatores de percepção de valor quanto para os indicadores associados, podem ser vistos nos parágrafos seguintes.

1) Velocidade de Atendimento - Diz respeito à prontidão da manutenção para restaurar o estado de funcionamento do equipamento e, principalmente, às paralisações decorrentes de ações corretivas. A velocidade de atendimento também se relaciona com a eficiência nas intervenções planejadas. Ou seja, relação entre o tempo previsto e o efetivamente gasto nas atividades programadas de manutenção. Os indicadores associados são: 
$\checkmark$ TMDR (Tempo Médio de Reparo) - Tempo médio para restabelecer as condições de funcionamento de um equipamento, sistema ou instalação; e

$\checkmark$ Taxa de Intervenções Programadas - Relação entre o prazo previsto e o executado das atividades programadas de manutenção, de natureza corretiva e de melhorias.

2) Confiabilidade - A confiabilidade dos serviços de manutenção é traduzida pela disponibilidade e desempenho dos equipamentos, sistemas e instalações. A disponibilidade, por sua vez, é decorrente das condições de projeto e de manutenção dos ativos. Depende, portanto, da confiabilidade inerente dos equipamentos e de sua manutenibilidade (facilidade de efetuar a intervenção). A confiabilidade das operações de manutenção pode ser expressa por:

$\checkmark$ Número de Falhas - Número de ocorrências de falhas em um equipamento, sistema ou instalação, em um período considerado ou relativo a uma quantidade produzida;

$\checkmark$ TMEF (Tempo Médio Entre Falhas) - Diz respeito ao intervalo de tempo entre as ocorrências de falhas;

$\checkmark$ Disponibilidade Inerente - Exprime, em valores percentuais, o quanto um equipamento, sistema ou instalação está disponível para a produção, dentro dos limites de segurança e qualidade de fabricação. As diferentes questões pertinentes à disponibilidade já foram discutidas no Título 2.3.4.

$\checkmark$ Rendimento Operacional - É a relação entre o volume efetivamente produzido e a capacidade de produção de um equipamento, sistema ou instalação. As perdas de rendimento podem ter várias origens tais como, perdas por não qualidade, por logística, por falta de mão-deobra e por deslocamentos entre outras.

3) Competência - A competência para as operações de manutenção está relacionada ao grau de conhecimento técnico e experiência, necessários 
ao planejamento, organização e execução das atividades de manutenção.

Os indicadores associados são:

$\checkmark$ Taxa de Competência - Relação entre o estado atual da competência e as necessidades de treinamento para a manutenção e pode ser medida pelas horas de treinamento realizadas em relação às horas relacionadas com as necessidades;

$\checkmark$ Plano de Treinamento - Estabelecido pelas necessidades de treinamento (competência a ser adquirida) e medido através do cumprimento do mesmo em relação aos prazos; e

$\checkmark$ Taxa de Rotatividade - Diz respeito ao percentual de recursos humanos substituídos nas equipes de manutenção, durante um determinado período.

4) Consistência - Para o serviço de manutenção a consistência é percebida pela ausência ou não-reincidência das falhas. A ausência significa que as ações preventivas programadas foram realizadas e são consistentes. A não-reincidência das falhas indica eficácia nas ações tomadas. São indicadores associados:

$\checkmark$ Taxa de Manutenção Preventiva - Relação entre o número de intervenções previstas e o de intervenções efetivamente realizadas;

$\checkmark$ Quantidade de Falhas Reincidentes - Número de panes ocorridas nos mesmos equipamentos decorrentes das mesmas causas, em um período de tempo considerado.

5) Custos - São os gastos envolvidos nas operações de manutenção que podem ser explicitados pelos seguintes indicadores associados:

$\checkmark$ Custo Total de Manutenção - Contabilizados pelos gastos totais de peças sobressalentes, ferramentas, ferramental, instrumentos, consumíveis, bem como os gastos com recursos humanos, direta e indiretamente envolvidos nas atividades de manutenção;

$\checkmark$ Custo Total de Manutenção por Unidade Produzida - Utilizado para expressar a contribuição da manutenção nos custos de produção; e 
$\checkmark$ Perdas de Produção - É o custo decorrente da paralisação da produção e medido monetariamente pelas unidades que deixaram de ser produzidas e conseqüentemente faturadas.

6) Flexibilidade - A flexibilidade das operações de manutenção pode ser percebida pela capacidade de adaptação das equipes às necessidades mutantes dos diversos clientes. Assim, a flexibilidade está diretamente associada à polivalência das equipes de manutenção. $\mathrm{O}$ indicador associado é:

$\checkmark$ Taxa de Polivalência das Equipes - Diz respeito ao grau de homogeneidade da competência das diferentes equipes.

7) Acessibilidade - A acessibilidade ao serviço de manutenção tem implicação sobre o tempo de resposta das equipes, principalmente aquele relacionado com as intervenções corretivas. Neste sentido, a acessibilidade tem fortes correlações com a velocidade de atendimento. É medida através do indicador:

$\checkmark$ Tempo de Reatividade - Tempo decorrido entre a constatação da pane e chamada do serviço de manutenção e a sua chegada ao local da intervenção.

MIRSHAWKA \& OLMEDO (1993) remetem a discussão, sobre indicadores, para o TPM - Manutenção Produtiva Total, cujo foco, para a gestão da manutenção, está centrado na maximização do rendimento operacional dos ativos.

Nesta direção, os autores propõem a adoção do indicador de Rendimento Operacional Global - ROG, ou Eficácia Global dos Equipamentos - EGE, como forma de monitorar o desempenho dos serviços de manutenção.

Na visão dos autores, o rendimento operacional é a relação entre o volume efetivamente produzido e a capacidade de produção de um ativo, dentro de um período de tempo considerado, ou seja:

$$
\mathrm{ROG}=\frac{\mathrm{Q}_{\text {Efetiva }}}{\mathrm{Q}_{\text {Pr evista }}}
$$


É fácil observar que o conceito de rendimento operacional global, proposto por MIRSHAWKA \& OLMEDO (1993), coincide com o de eficácia, na definição de SINK E TUTTLE (1993). Isto é, a eficácia global de um equipamento, sistema ou instalação pode ser medida pela relação entre os resultados obtidos e os esperados, dentro de um período de tempo considerado.

$$
\mathrm{EGE}=\frac{\text { Resultados Obtidos }}{\text { Resultados Previstos }}=\frac{\mathrm{Q}_{\text {Efetiva }}}{\mathrm{Q}_{\text {Prevista }}}=\mathrm{ROG}
$$

Nos parágrafos seguintes constam as observações e relatos dos autores MIRSHAWKA \& OLMEDO (1993), no que concerne à formulação do ROG Rendimento Operacional Global ou EGE - Eficácia Global dos Equipamentos.

A formulação da EGE ou do ROG é dependente das perdas ou fontes de diminuição da produção que podem ser agrupadas em seis grandes categorias:

1) Perdas por quebra do equipamento - Esta categoria é a mais contribui para a queda de rendimento ou da eficácia do equipamento. Existem dois tipos de perdas que podem ser consideradas dentro desta categoria. O primeiro tipo refere-se à quebra repentina do equipamento. O segundo tem relação com a quebra decorrente da degeneração gradativa do ativo, que o torna inadequado ao uso;

2) Perdas por ajustagens nas preparações - Este tipo de perda é decorrente das mudanças de linha, com a interrupção do ciclo para a preparação do produto subseqüente;

3) Perdas por paradas temporárias - A parada temporária não constitui uma quebra e sim uma interrupção momentânea da produção. Essa paralisação pode ser decorrente da operação em vazio (interrupção da alimentação das matérias primas) e da detecção de um produto com defeito (o ciclo é interrompido para evitar a propagação do defeito);

4) Perdas por queda da velocidade de produção ou da capacidade produtiva - Este tipo de perda abrange a produção não realizada proveniente de uma menor velocidade de trabalho; 
5) Perdas pela geração de produtos defeituosos e por retrabalho - São perdas de produção decorrentes da geração de defeitos e também pelo retrabalho para a correção dos mesmos, quando isso é possível; e

6) Perdas para a entrada em regime de processo ou por queda de rendimento - O tempo gasto para entrar em regime de produção propicia uma queda no rendimento no processo. Dentre os fatores que atrasam a estabilização do processo, pode-se citar o equipamento operando fora de suas características nominais, tensão, alinhamento e vibrações, entre outros. Nestas condições, o produto final acaba por incorporar as imperfeições do processo, gerando perdas.

Pelo o que se pode observar, essas seis grandes categorias de perdas também podem ser agrupadas, duas a duas:

- Perdas por parada:
a) Quebras imprevistas; e
b) Mudanças de linha ou regulagem das máquinas;

- Perdas por queda de velocidade ou da capacidade produtiva:

c) Operação em vazio ou parada momentânea; e

d) Queda de velocidade

- Perdas devido a defeitos:
e) Produção defeituosa; e
f) Queda no rendimento. 
Nestas condições, torna-se possível associar tais perdas, em termos de tempos perdidos, em relação ao tempo total disponível dos equipamentos para gerar produção, conforme pode ser visto na Figura 2-24.

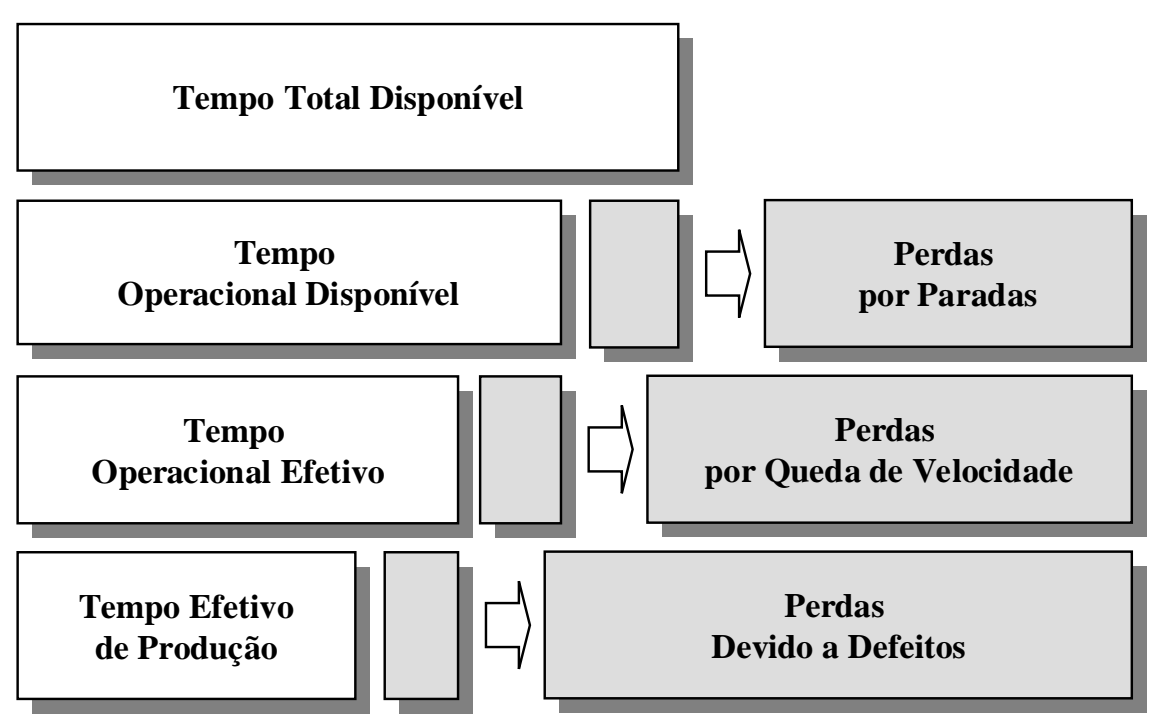

Figura 2-24 - As Seis Grandes Perdas.

Fonte: Adaptado de MIRSHAWKA \& OLMEDO (1993).

Portanto, o ROG ou EGE para um dado período de tempo ou quantidade de produção realizada é uma relação percentual que pode ser calculado através das expressões:

$$
\mathrm{ROG}=\mathrm{ITO} \times \mathrm{IPO} \times \mathrm{IPA},
$$

onde:

- $\quad$ ITO - Índice de Tempo Operacional Disponível;

- IPO - Índice de Performance Operacional;

- IPA - Índice de Produtos Aprovados

O ITO - Índice de Tempo Operacional Disponível é calculado pela expressão [2-24] e referido à Figura 2-24.

Assim: 


$$
\text { ITO }=\frac{\text { Tempo Total Disponível }- \text { Tempo de Paradas }}{\text { Tempo Total Disponível }} \times 100
$$

O IPO - Índice de Performance Operacional é composto por dois outros índices. O primeiro, denominado de IVO - Índice de Velocidade Operacional, explicita a relação entre a velocidade teórica e a efetiva do equipamento.

Assim:

$$
\text { IVO }=\frac{\text { Ciclo Teórico }}{\text { Ciclo Efetivo }} \times 100 \text {. }
$$

O segundo índice que compõe o IPO é o IOE - Índice de Operação Efetiva, que tem por objetivo verificar a constância do nível de produção realizada, na unidade de tempo.

Assim:

$$
\mathrm{IOE}=\frac{\text { Q }_{\text {Produzida }} \times \text { Ciclo Efetivo }}{\text { Tempo Operacional Disponível }} \times 100 .
$$

Nestas condições, tem-se:

$$
\mathrm{IPO}=\mathrm{IVO} \times \mathrm{IOE}=\frac{\mathrm{Q}_{\text {Produzida }} \times \text { Ciclo Teórico }}{\text { Tempo Operacional Disponível }} \times 100 .
$$

O IPA - Índice de Produtos Aprovados mede o percentual de defeitos na produção realizada e é dado por:

$$
\mathrm{IPA}=\frac{\mathrm{Q}_{\text {Produzida }}-\text { Defeituosos }}{\mathrm{Q}_{\text {Produzida }}}
$$

A Figura 2-25 resume toda a metodologia de cálculo do ROG - Rendimento Operacional Global ou EGE - Eficácia Global dos Equipamentos. 


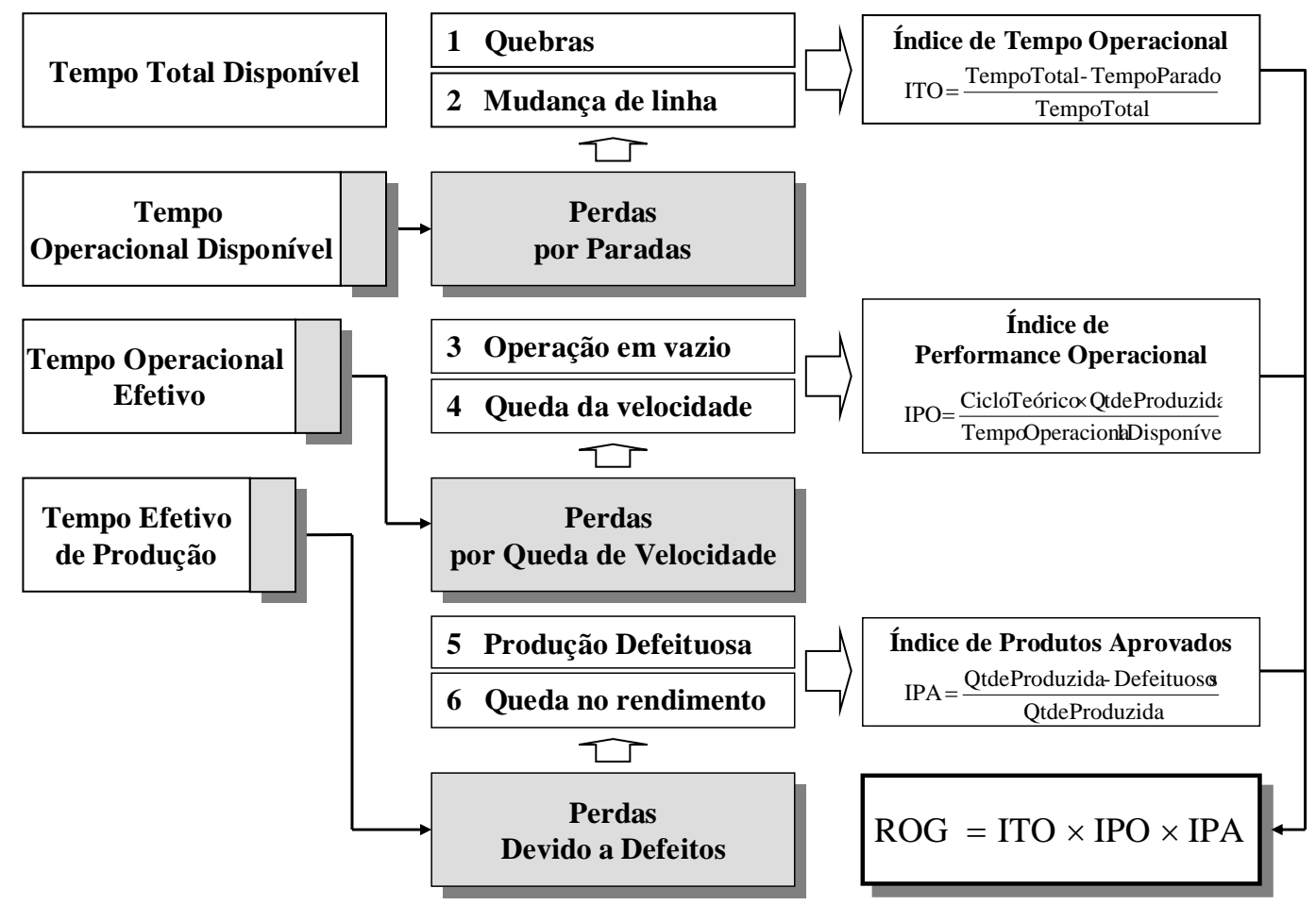

Figura 2-25 - Rendimento Operacional Global.

Fonte: Adaptado de MIRSHAWKA \& OLMEDO (1993).

\subsubsection{CONSIDERAÇÕES FINAIS}

XENOS (1998) afirma que os profissionais de manutenção precisam adquirir novas habilidades, compatíveis com a complexidade, cada vez mais crescente dos equipamentos. Para o autor, não é mais suficiente saber somente como desmontar e reformar ativos. Na verdade, é preciso conhecê-los em detalhes. É necessário entender como os seus sistemas funcionam e porque estão funcionando de determinada maneira. É preciso saber como e porque as falhas estão ocorrendo e o que fazer para preveni-las.

PINTO \& XAVIER (2001) complementam afirmando que o novo papel da manutenção é o grande desafio gerencial destes novos tempos. A visão sistêmica do negócio, a mudança de paradigmas e os novos conceitos de gerenciamento, ligados à competitividade do mercado, são os objetos deste novo desafio. Portanto, a gestão da manutenção deve estar centrada em questões de qualidade, produtividade e competitividade. 


\section{A. MANUTENÇÃO COMO VISÃO DA QUALIDADE}

Planejar manutenção também significa planejar qualidade. Assim, o espaço para ações improvisadas ou para decisões com base na intuição e no subjetivismo, certamente estará reduzido. Este é o ponto de partida para que a manutenção apresente um produto de qualidade e adequado ao uso (FURMANN, 2002).

A qualidade pode ser entendida como a forma pela qual os serviços são julgados pelos usuários. Neste sentido, CAMPOS (1992) propõe um conjunto de dimensões que afetam diretamente a satisfação dos usuários de um dado serviço:

- Qualidade - Afeta diretamente a satisfação do usuário. Pode ser medida pela da qualidade intrínseca dos serviços finais ou intermediários da manutenção;

- Custos - Devem refletir os gastos intermediários de todo o sistema de manutenção:

$\checkmark$ A mão-de-obra;

$\checkmark$ Os gastos gerais do serviço de manutenção;

$\checkmark$ As ferramentas e equipamentos usados para a manutenção;

$\checkmark$ Os produtos e os materiais consumidos;

$\checkmark$ O custo de posse do estoque para a manutenção;

$\checkmark$ O custo de subcontratações; e

$\checkmark$ Outros custos (custos de transporte, instalações, energia utilizada, garantias, etc.)

- Atendimento - Diz respeito às condições de execução dos serviços de manutenção. Considera a prontidão ou tempo de resposta das equipes em restaurar o estado de funcionamento dos ativos, particularmente aqueles decorrentes das intervenções corretivas. O atendimento leva em conta, também, a competência (conhecimento técnico e experiência) das equipes e a sua flexibilidade para abordar os diferentes problemas de manutenção. 
- Moral - Reflete o nível de satisfação dos usuários e equipes de manutenção; e

- Segurança - Considera a segurança das equipes, dos usuários, dos produtos e dos equipamentos, sistemas ou instalações.

A combinação dessas dimensões reflete o valor do serviço, percebido pelo usuário. O serviço terá tanto mais valor para os clientes, quanto mais favorável for a combinação dessas dimensões.

FURMANN (2002) APUD JURAN \& GRINA (1991) relata a disponibilidade, confiabilidade e manutenibilidade como parâmetros de adequação ao uso para produtos duráveis, tais como equipamentos, sistemas ou instalações. A disponibilidade, como função da confiabilidade e manutenibilidade, representa a dimensão pela qual o usuário pode ter o serviço assegurado quando dele precisar.

\section{B. MANUTENÇÃO COMO VISÃO DA PRODUTIVIDADE}

CONTADOR (2004) argumenta que a função manutenção é parte integrante do esforço de produção na empresa. A parcela pertinente à manutenção depende da tecnologia, responsável pelo nível de desempenho para a empresa funcionar. Tal desempenho seguramente está vinculado à freqüência de falhas e à duração das intervenções de manutenção. Neste contexto, a manutenção representa um alto potencial para o aumento da produtividade da empresa, em função de seu relacionamento com a função produção.

Para NAGAO (1998), a manutenção voltada para a produtividade passa, necessariamente, por uma visão sistêmica que interrelaciona máquina, homem, processo e ambiente de trabalho. O conhecimento das máquinas tem sua importância fundamentada na implementação de melhorias, redução de perdas e quebras. A capacitação das pessoas leva à formação de grupos participativos para a solução de problemas e, também, introdução de melhorias nos equipamentos e processos, A revisão constante dos processos permitirá a utilização de recursos informatizados, além do acompanhamento de custos e atualização dos registros técnicos. Finalmente, um ambiente de trabalho participativo, aberto a novas idéias e à inovação, 
certamente, contribui para a transparência no processo de comunicação e segurança no fluxo de informações.

\section{MANUTENÇÃO COMO VISÃO DE COMPETITIVIDADE}

PORTER (1992) afirma que a tecnologia desempenha um papel muito importante no desempenho dos negócios. A tecnologia altera a estrutura do próprio negócio, cria novas oportunidades e vantagens competitivas. Dentro desse ponto de vista, a tecnologia pode ser vista como um vetor de apoio à competitividade e pode se apresentar de variadas formas. Dentre elas, podem ser citadas a tecnologia de materiais, da informação e de processos, produtos, transportes e de manutenção.

Por outro lado, toda organização precisa conhecer os fatores críticos de seu sucesso competitivo. Tais fatores são, a bem da verdade, os atributos que a empresa deve concentrar sua atenção, para ser bem sucedida no exercício de suas atividades. Obviamente, a manutenção está inserida neste contexto. Conforme já mencionado anteriormente, NAGAO (1998) aponta a disponibilidade operacional, confiabilidade das instalações e otimização de custos, como fatores críticos de sucesso para a função manutenção.

\section{CONCLUSÕES FINAIS}

Para o fechamento dessas considerações finais, é importante deixar registrado que o melhor sistema de manutenção é aquele adequado a sua própria instalação industrial. Nesta direção, a abordagem terológica dá uma contribuição importante. É fundamental que a manutenção participe de todo o ciclo de vida da instalação. Desde o projeto inicial até o fim de sua vida útil. A manutenibilidade dos equipamentos deve ser incorporada na fase de projeto e aprimorada na de exploração industrial. Nestas condições, são possíveis as definições de políticas de manutenção que otimizem recursos e resultados.

NAGAO (1998) complementa e aponta os seguintes fatores como fundamentais na determinação de uma política de manutenção eficaz:

- Criticidade do equipamento dentro do processo produtivo; 
- Estratégia da empresa a curto, médio e longo prazo;

- Adequação dos ativos ao processo;

- Custos das intervenções de correção, prevenção, assim como também os custos decorrentes da não produção;

- Impacto causado pela falha ao meio ambiente e à segurança industrial; e

- Políticas de peças sobressalentes e de equipamentos reservas.

Assim, por tudo o que foi discutido pode-se resumir que a função primordial da manutenção em uma empresa é antecipar-se às falhas. Ou, como diz PINTO \& XAVIER (2001), “a principal função da manutenção é diminuir a necessidade de fazer manutenção".

\subsection{A GESTÃO DOS CUSTOS INDUSTRIAIS}

\subsubsection{CONSIDERAÇÕES INICIAIS}

Num mercado competitivo, seja ele industrial, comercial ou de serviços, os custos são altamente relevantes para a tomada de decisão. Neste sentido, as organizações já não podem mais definir seus preços de acordo com os custos incorridos, mas sim com base nos preços praticados no mercado em que atuam (MARTINS, 2001).

PAMPLONA (1997), por sua vez, afirma que os sistemas tradicionais de custos estão fora de sintonia do ambiente atual de competitividade, além de terem acompanhado a evolução das técnicas de gestão dos processos produtivos. Por esta razão, tais sistemas não levam em conta os custos da não produção representados, por exemplo, pelo tempo de paralisação de máquinas. Ou seja, ignoram as indisponibilidades dos ativos no processo de produção.

Por outro lado, POZZI (1995) relata que o impacto do avanço tecnológico dáse de forma bastante clara. As novas tecnologias de gestão, tais como $M R P-$ Materials Resources Planning, JIT-Just-in-Time, TQM-Total Quality Management e 
TPM-Total Productive Maintenance, fazem com que as despesas indiretas cresçam significativamente em relação às diretas.

Os custos diretos relativos às operações de equipamentos têm uma participação menor na presença dos custos indiretos relativos à manutenção, programação das máquinas, administração de materiais e etc. A integração da manufatura reduz custos de uma forma global, mas cria novos custos indiretos de investimentos, operação e manutenção do sistema integrador.

JOHNSON \& KAPLAN (1987) argumentam que este ambiente gera impacto na acuracidade dos sistemas de gerenciamento de custos. Em outras palavras, as metodologias convencionais de custos estão, cada vez mais, gerando informações incorretas com relação aos custos unitários dos produtos e serviços.

Nestas condições é possível observar uma tendência para a adoção de sistemas de custos baseado em atividades, com vistas à eliminação das principais distorções $^{3}$ da contabilidade de custos tradicional, como se pode ver nos parágrafos seguintes.

FURMANN (2002) afirma que o custeio baseado em atividades proporciona vantagens qualitativas na análise aprimorada das despesas de uma estrutura. A primeira diz respeito ao direcionamento da atenção dos gerentes paras as atividades, dado que elas geram custos. A segunda está relacionada com a acuracidade das informações de suporte para as decisões estratégicas da empresa.

Um sistema de apropriação de custos com base em atividades e processos é o mais adequado para a medição precisa do custo unitário de processamento de transações e de produção, segundo KAPLAN \& NORTON (1997). Os autores indicam o $A B C$ - Activity Based Costing como a metodologia apropriada para medir e gerenciar os custos dos serviços e os de produção na medida em que consomem recursos dos vários departamentos da empresa.

NAKAGAWA (1994) complementa, definindo o ABC como a metodologia certa para a análise estratégica dos custos relacionados com as atividades que mais

\footnotetext{
${ }^{3}$ Serão objetos de discussão no próximo título.
} 
consomem os recursos da empresa. Ou seja, os recursos são consumidos pelas atividades e não pelos produtos que a empresa produz. Resumindo, os produtos consomem as atividades e estas consomem recursos, gerando os custos.

Entretanto, para a distribuição dos custos das atividades aos produtos, o ABC faz uso do conceito de Costs Drivers, direcionadores de custos, definidos como transações determinantes dos custos das atividades, segundo BORNIA (2002).

Nestas condições, os indicadores aparecem como um meio de aprimoramento do custeio das atividades de manutenção e do gerenciamento da prontidão funcional dos ativos dos sistemas produtivos.

\subsubsection{O SISTEMA TRADICIONAL DE CUSTOS}

O sistema tradicional de custos tem como característica a utilização de princípios e métodos de custeio, segundo BORNIA (2002). Os princípios identificam o tratamento que o sistema dá aos custos indiretos. Avaliam o que e quanto foi consumido de recursos na geração de uma dada produção. Já os métodos de custeio indicam onde os recursos foram consumidos, isto é, definem os critérios para a alocação dos custos indiretos aos produtos e para a análise dos mesmos. BORNIA (2002) e MARTINS (2003) organizam os princípios e métodos de custeio da seguinte forma:

- Princípios de Custeio:

$\checkmark$ Custeio Total ou Absorção Integral;

$\checkmark$ Custeio por Absorção Ideal; e

$\checkmark$ Custeio Direto ou Variável;

- Métodos de Custeio:

$\checkmark$ Centros de Custos;

$\checkmark$ Custo-Padrão; e

$\checkmark \quad$ ABC-Activity Based Costing 


\section{A. PRINCÍPIOS DE CUSTEIO}

\section{1) CUSTEIO TOTAL OU ABSORÇÃO INTEGRAL}

Nesta filosofia, a totalidade dos custos, fixos e variáveis é alocada aos produtos. Os custos indiretos são distribuídos aos produtos através de bases de rateio, tais como: quantidade produzida, horas de mão-de-obra direta, valor da mão-de-obra direta, área ocupada, valor da produção, potência das máquinas, etc. A Figura 2-26 representa, de forma simplificada, a essência do princípio.

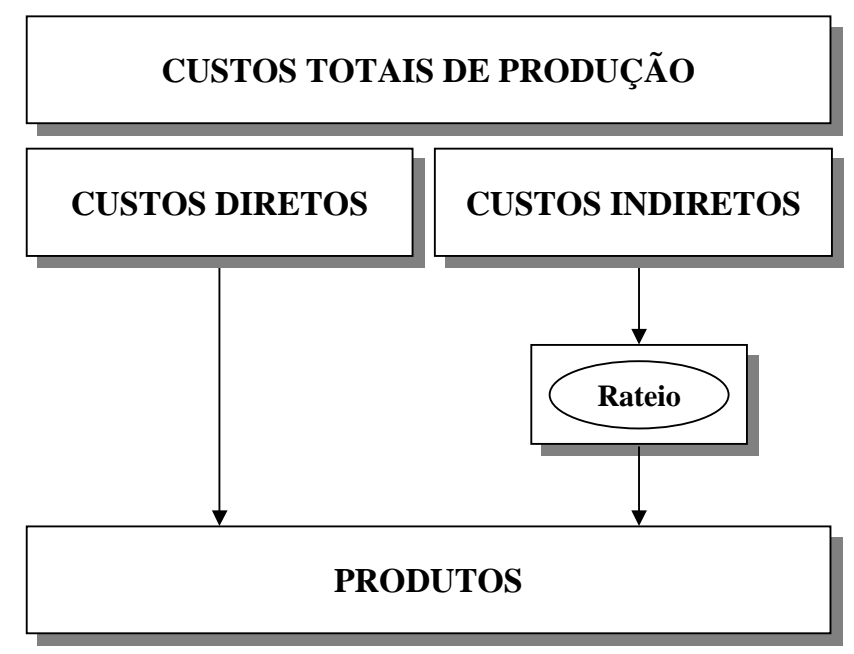

Figura 2-26 - Custeio Total ou Custeio por Absorção Integral.

\section{2) CUSTEIO POR ABSORÇÃO IDEAL}

Da mesma maneira que o princípio anterior, todos os custos também são computados como custos dos produtos. Entretanto, os custos relacionados com o consumo não eficiente (desperdícios) dos insumos não são alocados aos produtos. Assim, a separação entre custos e desperdícios é fundamental para medir as perdas dos processos produtivos e possibilitar a implementação de melhorias para a redução dos desperdícios. Os custos indiretos, resultantes do consumo eficiente dos recursos também são distribuídos aos produtos nas bases de rateio citadas anteriormente.

A Figura 2-27 representa o esquema simplificado do princípio. 


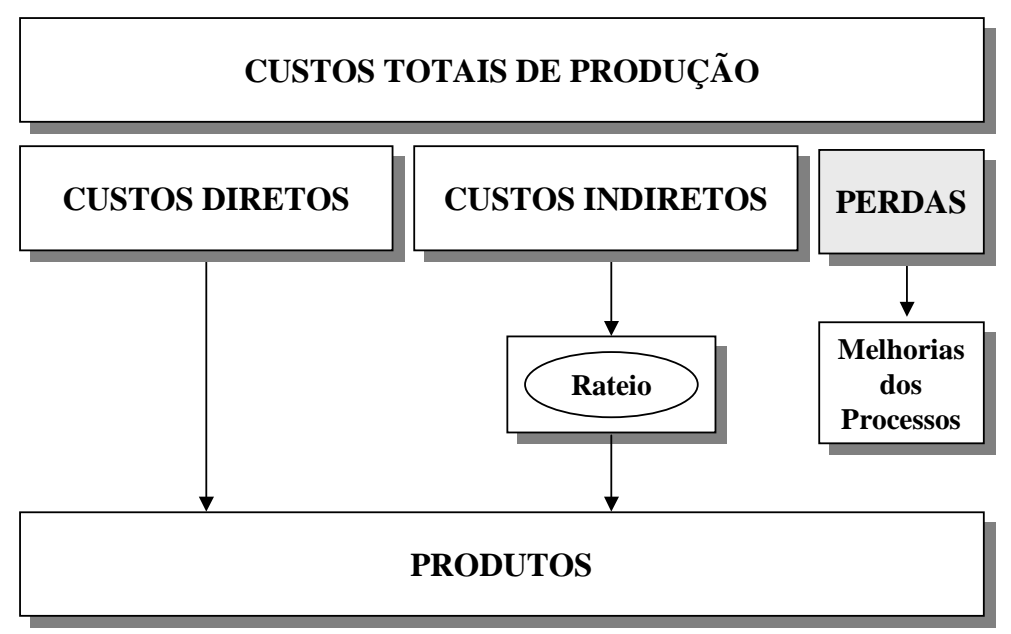

Figura 2-27 - Custeio por Absorção Ideal

\section{3) CUSTEIO DIRETO OU VARIÁVEL}

Neste princípio, apenas os custos variáveis diretos são relacionados aos produtos. Os custos indiretos são considerados como custos do período, conforme pode ser visto na Figura 2-28;

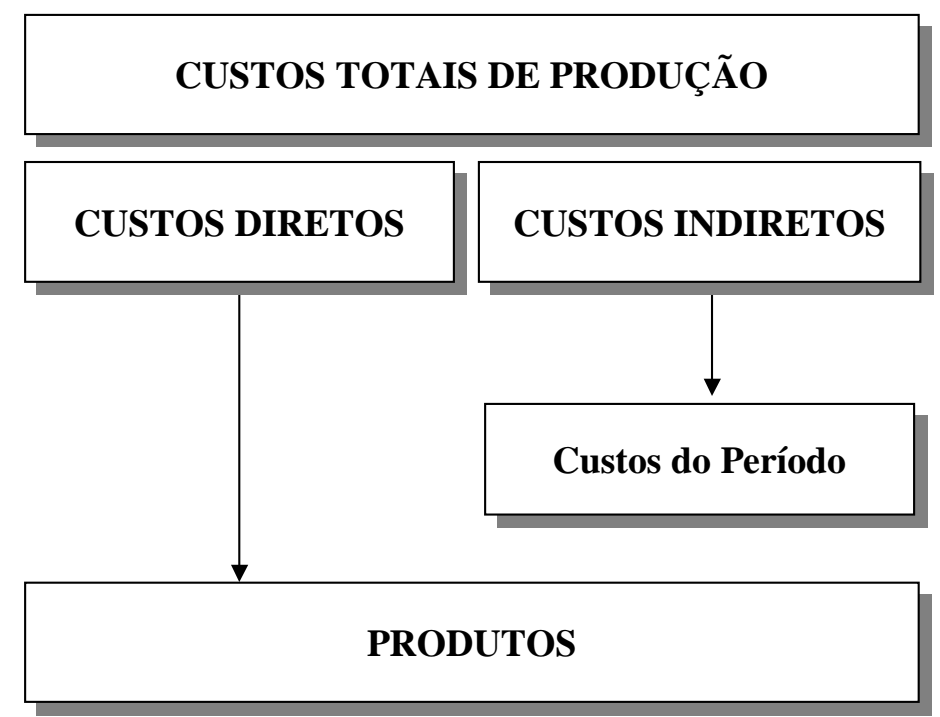

Figura 2-28 - Custeio Direto ou Variável 


\section{B. MÉTODOS DE CUSTEIO}

\section{1) CENTROS DE CUSTOS}

É o método mais utilizado na prática industrial e reflete a contabilidade de custos tradicional. O método consiste em ratear os custos indiretos dos centros comuns aos centros de apoio e destes aos centros produtivos que possuem uma relação direta com os produtos, conforme se pode ver na Figura 2-29.

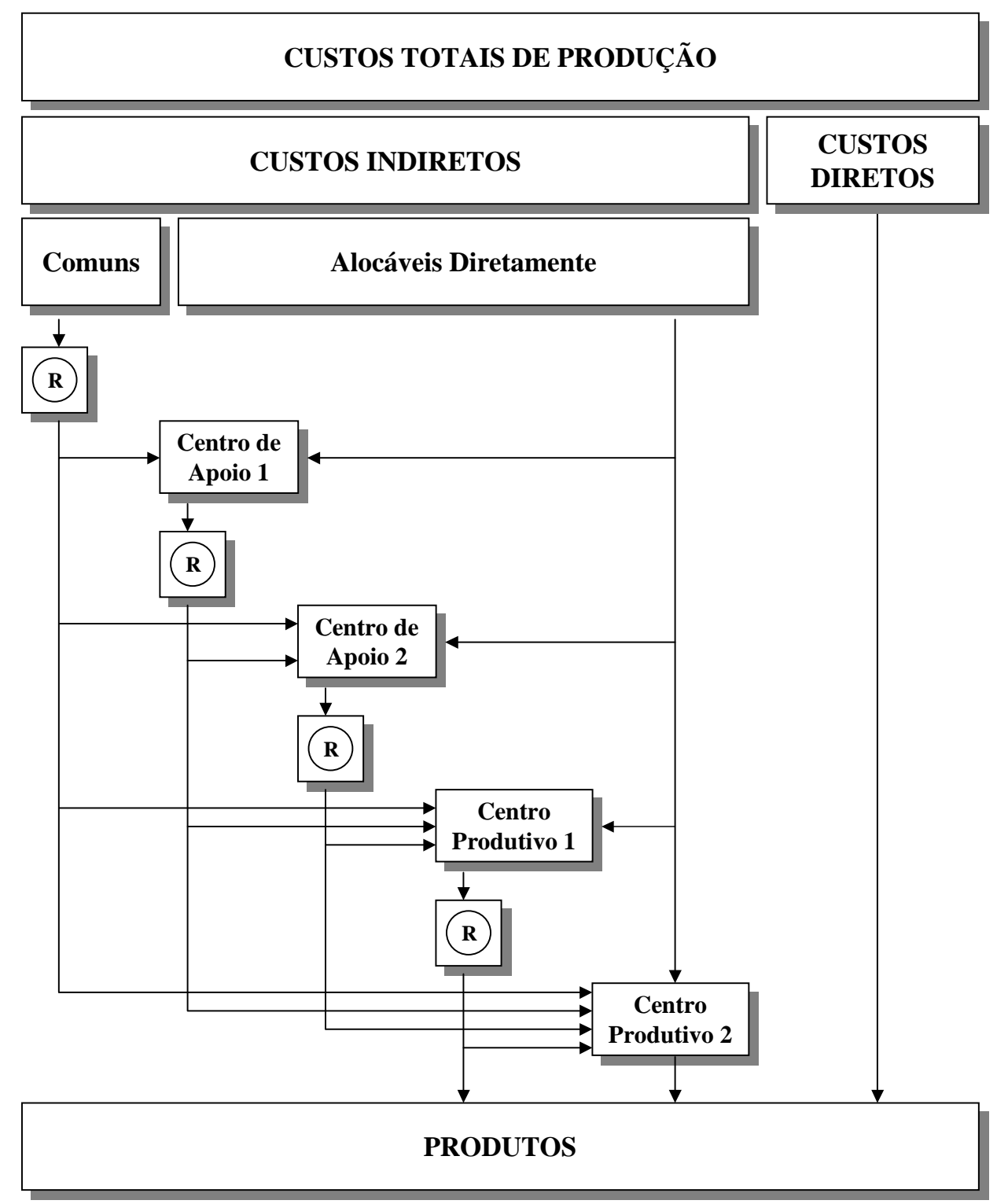

Figura 2-29 - Fluxo do Sistema de Custo Tradicional Fonte: Adaptado de MARTINS (2003) e PAMPLONA (1997) 


\section{2) CUSTO PADRÃO}

O objetivo principal da metodologia do custo-padrão é fornecer suporte para o controle de custos da empresa. A idéia básica do método é estabelecer padrões de consumo de recursos no sentido de avaliar a eficiência de sua utilização, pelos meios de produção. Tal avaliação é conduzida através das variações ocorridas entre o padrão e o real. A finalidade é buscar as causas (motivos) que deram origens a tais desvios.

\subsubsection{LIMITAÇÕES DOS SISTEMAS TRADICIONAIS DE CUSTOS}

MARTINS (2003) relata que os sistemas tradicionais de custos vêm perdendo relevância, em função das necessidades de informações que os gerentes precisam neste novo ambiente competitivo. Assim, para o autor, as principais deficiências dos sistemas tradicionais são:

- Distorções no custeio dos produtos, provocadas por rateios arbitrários dos custos indiretos;

- Utilização de reduzido número de bases de rateio;

- Não mensuração dos custos das atividades que não agregam valor;

- Não utilização do conceito de Custo-Meta ou Custo- Alvo que em síntese procura definir o custo máximo de um produto, em face das limitações de preço de mercado, para que se consiga uma rentabilidade mínima atrativa;

- Não considera medidas de desempenho de natureza não financeira, conhecidas por indicadores físicos de produtividade.

PAMPLONA (1997), por sua vez, discute as inadequações do sistema tradicional de custos, diante do novo ambiente de negócio, pela apropriação dos custos indiretos baseada na mão-de-obra direta, da filosofia do custeio variável e da “variabilidade” dos custos fixos. 


\section{A. APROPRIAÇÃO BASEADA NA MÃO-DE-OBRA DIRETA}

A apropriação dos custos indiretos com base na mão-de-obra direta introduz distorções na medida em que apresenta incorreções e, a cada dia que passa, se torna menos confiável como base de rateio.

Os custos indiretos cresceram em função da automação dos centros produtivos. Este crescimento deu-se por conta das atividades de apoio pertinentes e a mão-de-obra direta passou a ter uma participação cada vez menor no esforço para gerar produção. Assim, os cálculos dos custos dos produtos com base neste tipo de apropriação tornam-se incorretos. Produtos provenientes das linhas de produção com mão-de-obra direta intensiva acabam por ter os seus custos sobrecarregados. Tal sobrecarga é devida aos custos indiretos resultantes das linhas altamente automatizadas.

Por outro lado, a polivalência atual da mão-de-obra direta propicia a execução de vários produtos ao mesmo tempo. Nestas condições, a apuração correta das horas trabalhadas em relação aos diferentes produtos fica muito difícil de ser concretizada. O que torna a mão-de-obra direta cada vez mais, menos confiável como base de apropriação dos custos indiretos.

\section{B. A FILOSOFIA DO CUSTEIO VARIÁVEL}

O custeio variável ou direto trata os custos indiretos como custos do período e não como custos do produto. Nestas condições, a filosofia apresenta as seguintes desvantagens que limitam a sua utilização como sistema único:

- Do ponto de vista de tomada de decisões, o custeio direto propicia muito mais rapidamente informações vitais para a empresa. Entretanto, os princípios contábeis atuais não admitem o uso de demonstrações de resultados e de balanços avaliados com base no custeio variável. Isto porque o custeio direto fere os princípios contábeis, principalmente no que concerne ao regime de competência e confrontação. Segundo estes, devem-se apropriar as receitas e delas deduzir todos os sacrifícios envolvidos para a sua obtenção; 
- Custos de fabricação menores não significam, necessariamente, preços menores de vendas. A margem de contribuição deve continuar cobrindo os custos indiretos. Como o custo unitário pode ter uma correlação negativa com o volume de produção, podem surgir situações em que vendas maiores no período podem resultar em lucros menores. Situações desta natureza podem trazer confusão ao departamento comercial, menos habituado com a metodologia da contabilidade de custos; $\mathrm{e}$

- A participação dos custos indiretos nos custos totais da produção tem sido cada vez maior neste novo ambiente automatizado da produção. Na medida em que são considerados como custos do período passam a ser tratados como custos incontroláveis e não administráveis. Nestas condições a apuração correta dos custos dos produtos fica prejudicada, assim como também as ações de melhorias, para minimizar as variações dos custos indiretos.

\section{A “VARIABILIDADE” DOS CUSTOS FIXOS}

Os custos fixos são provocados pela posse dos ativos e colocação dos fatores de produção em prontidão funcional em um dado período de tempo e independem do volume específico de atividades do mesmo período. Sejam elas, atividades produtivas, comerciais ou administrativas. Por esta razão, são comumente conhecidos como custos de capacidade. Os custos fixos podem ter origem em duas vertentes principais. Em primeiro lugar vêm os custos fixos decorrentes de decisões administrativas tomadas em períodos anteriores. Depreciação, seguros e impostos são exemplos destes custos. Em segundo lugar surgem os custos fixos provenientes de decisões administrativas de curto prazo. Salários dos supervisores, despesas de publicidade e pesquisa enquadram-se nessa segunda vertente. Assim, os custos fixos podem variar em função da alteração da estrutura básica da empresa e, também, em decorrência das modificações arbitrárias das políticas administrativas (BRUNSTEIN \& MIORI, 1988).

Portanto, na medida em que a participação dos custos fixos nos custos de produção aumenta, a sua apropriação em bases relacionadas com o volume de 
atividades do período propiciam distorções nos custos dos produtos. Na verdade encobrem o principal determinante da variabilidade dos mesmos que é a complexidade da estrutura produtiva e não o volume de atividades.

\section{CONCLUSÕES}

Em razão do anteriormente exposto pode-se concluir que a principal causa da obsolescência dos sistemas de custos tradicionais está na constante redução na participação da mão-de-obra direta no esforço de produção. Com as novas tecnologias de automatização dos recursos produtivos, os custos indiretos passaram a ter uma proporção significativa nos custos totais de produção. As ações gerenciais direcionadas para a melhoria dos processos também justificam a inadequabilidade dos sistemas tradicionais de custos ao novo ambiente produtivo. A prevalência da busca e a eliminação de desperdícios, geralmente escondidos pela complexidade da organização, são os focos principais das novas técnicas de gestão. Em contra partida, a contabilidade de custos tradicional direciona seus esforços tão somente para a avaliação de estoques

\subsubsection{O MÉTODO DE CUSTEIO ABC - “ACTIVITY BASED COSTING”.}

\section{A. INTRODUÇÃO}

O custeio baseado em atividades, $A B C$ - Activity based Costing, é uma metodologia que tem por finalidade reduzir as distorções provocadas pelo rateio arbitrário dos custos indiretos, nos sistemas tradicionais de custos. A alocação dos custos indiretos aos produtos através de bases de rateio tais como mão-de-obra direta, horas-máquinas e volume de produção eram relevantes no passado. Nessa época, os processos produtivos eram mais simples, o mix de produção era reduzido e o custo da mão-de-obra tinha um peso significativo nos processos de transformação. Com o avanço tecnológico, a crescente complexidade dos sistemas produtivos e uma maior variedade de produtos no mix de produção, a participação da mão-de-obra direta nos custos de transformação é cada vez menor. Assim, a alocação dos custos indiretos 
com base no custo da mão-de-obra direta acaba por distorcer os custos dos produtos, conforme já discutido anteriormente.

O ABC pode também ser aplicado aos custos diretos, principalmente à mãode-obra direta. Não haverá, neste caso, diferenças importantes, com relação aos sistemas tradicionais. A diferença fundamental está no tratamento dado aos custos indiretos, segundo MARTINS (2003). Na visão do autor, o ABC é, na verdade, uma ferramenta de gestão de custos, muito mais do que de custeio de produto.

BORNIA (2002) complementa afirmando que alguns autores consideram que o ABC tem o foco centrado no cálculo dos custos (o lado do método). Outros, consideram o $\mathrm{ABC}$ voltado para as decisões de âmbito estratégico e se referem ao ABM - Activity Based Management, com o intuito de explicitar uma técnica muito mais ampla do que simplesmente um método de custeio, segundo o autor

Inicialmente, a presente revisão irá tratar o $\mathrm{ABC}$ enquanto método, para depois tecer as considerações pertinentes à gestão estratégica dos custos.

\section{B. HISTÓRICO}

NAKAGAWA (1994) afirma que "segundo alguns autores, o ABC já era conhecido e utilizado por contadores em 1800 e no início de 1900. Outros registros históricos mostram que o ABC já era bastante conhecido e utilizado na década dos anos 60". BORNIA (2002) APUD DE ROCCHI (1994) relata as origens do ABC nos trabalhos de Alexander Hamilton Church, nas primeiras décadas do século XX. O autor também cita o Platzkosten de Konrad Mellerowics na década de 50, o livro Activity Costing and Input-Output Accounting de George J. Staubus publicado em 1971 e o Transaction Based Costing de Jeffrey G. Miller e Thomas E. Vollmann em 1985.

Para o autor, a ampla divulgação do ABC se deu a partir de 1986 com a publicação dos trabalhos do CAM-I (Consortium for Advanced Manufacturing International). Tal consórcio foi formado por empresas industriais, de consultorias, professores e agências governamentais. O objetivo era estudar a problemática dos custos no novo ambiente de negócios. As conclusões dos estudos, publicadas em 
1988, deram conta que o sistema de custos da empresa moderna deve levar em consideração conceitos de custos que não agregam valor, medidas não financeiras de desempenho e contabilidade por atividades, entre outros. Assim, o conceito mais divulgado, tanto na literatura quanto nas empresas foi o do custeio baseado em atividades. Entretanto, marcos importantes na história do ABC foram as seguintes publicações, segundo BORNIA (2002):

- O artigo “The Hidden Factory” de Jeffrey Miller e Thomas Vollmann em 1985. O trabalho discute o conceito de custos e suas relações com a complexidade da estrutura produtiva;

- O livro "Relevance Lost: The Rise and Fall of Management Accounting” de Thomas Johnson e Robert Kaplan em 1987. A obra discorre sobre a evolução da contabilidade gerencial no tempo e a tendência ao uso da contabilidade financeira como base para as decisões da empresa;

- O artigo “Measure Costs Right: Make the Right Decisions”, publicado em 1988 por Robin Cooper e Robert Kaplan menciona o ABC - Activity Based Costing como um novo enfoque para o cálculo dos custos. A paternidade do ABC ficou desta forma, caracterizada.

\section{A LÓGICA DO ABC}

MARTINS (2003) afirma que o custeio por atividades parte do pressuposto que as atividades da empresa consomem recursos, gerando custos. Os produtos, objetos de custeio, utilizam atividades para a sua geração, absorvendo seus custos. Assim, na visão do autor, a lógica do ABC foi concebida no sentido de possibilitar a análise dos custos sob dois pontos de vista:

- Visão Vertical ou Visão Econômica de Custeio - Apropriação dos custos aos produtos através das atividades realizadas em cada departamento funcional da empresa;

- Visão Horizontal ou Visão de Aperfeiçoamento de Processos Apropriação dos custos dos processos através das atividades realizadas nos diversos departamentos funcionais da empresa. 


\section{1) VISÃO ECONÔMICA DE CUSTEIO}

Na visão vertical, a apropriação dos custos no sistema $A B C$ é feita em dois estágios, conforme relatam MARTINS (2003), BORNIA (2002), POZZI (1995) e PAMPLONA (1997). No primeiro estágio ocorre o custeio das atividades, ou seja, os recursos são alocados às atividades através dos direcionadores de recursos ou direcionadores de primeiro estágio (resources drivers). No segundo, tem-se a ocorrência do custeio dos produtos, isto é, os custos das atividades são alocados aos produtos através dos direcionadores de atividades ou direcionadores de segundo estágio (activity drivers). As fases para o cálculo dos custos dos produtos são as seguintes: mapeamento das atividades, alocação dos custos às atividades, identificação e seleção dos direcionadores de custos (cost drivers) e atribuição dos custos das atividades aos produtos. A Figura 2-30 apresenta um modelo esquemático da visão vertical do método $\mathrm{ABC}$.

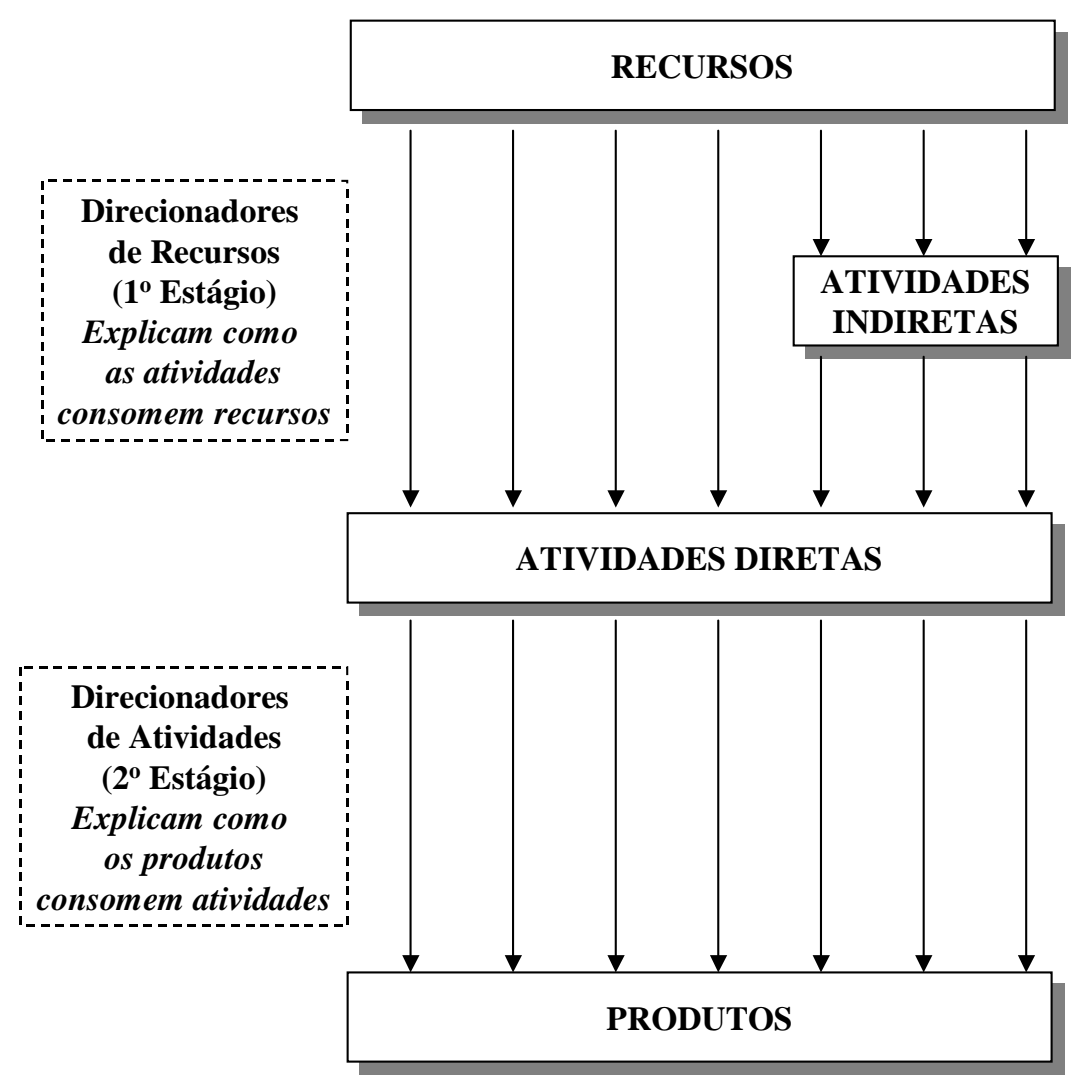

Figura 2-30 - Visão Econômica de Custeio.

Fonte: Adaptado de BORNIA (2002). 


\section{A) MAPEAMENTO DAS ATIVIDADES}

Uma atividade é o resultado da combinação de recursos humanos, materiais, tecnológicos e financeiros utilizado na produção de bens e serviços, segundo MARTINS (2003). Para NAKAGAWA (1994), a atividade descreve a maneira como a empresa utiliza seu tempo e recursos para cumprir sua missão, objetivos e metas. Portanto, a principal finalidade de uma atividade é a conversão de recursos em produtos ou serviços.

Assim, como bem lembra BORNIA (2002), a empresa deve ser modelada em atividades que, devidamente encadeadas, irão formar seus processos e subprocessos. O autor também recorda a existência de atividades diretas e indiretas nestes processos e subprocessos. Como atividades diretas cita o PCP - Planejamento e Controle da Produção e a Administração de Materiais que podem ter os seus custos alocados diretamente aos produtos. Já as atividades indiretas sempre existirão nos processos e subprocessos da empresa e podem ser mais identificáveis com outras atividades diretas do que com os próprios produtos.

PAMPLONA (1997) observa que as atividades podem ser mapeadas a partir do detalhamento dos processos e subprocessos da empresa. Para o autor, as atividades não devem ter uma especificação tão detalhada a ponto de gerar informações irrelevantes, nem tão genéricas que não possam gerar as informações necessárias.

OSTRENGA ET AL (1997) sugere a utilização da Análise de Processo de Negócio (BPA - Business Process Analysis), como uma forma de identificar as atividades que serão utilizadas no ABC. A análise de processo de negócio procura identificar dos processos e subprocessos da empresa, para depois dividi-los em atividades.

O relacionamento da Análise de Processo de Negócio com o método ABC pode ser visto na Figura 2-31. A análise tem início na divisão dos processos em subprocessos e estes em atividades. Estas, por sua vez, tornam-se o foco principal tanto para identificar as oportunidades de melhorias dos processos, quanto para o custeio dos produtos. 


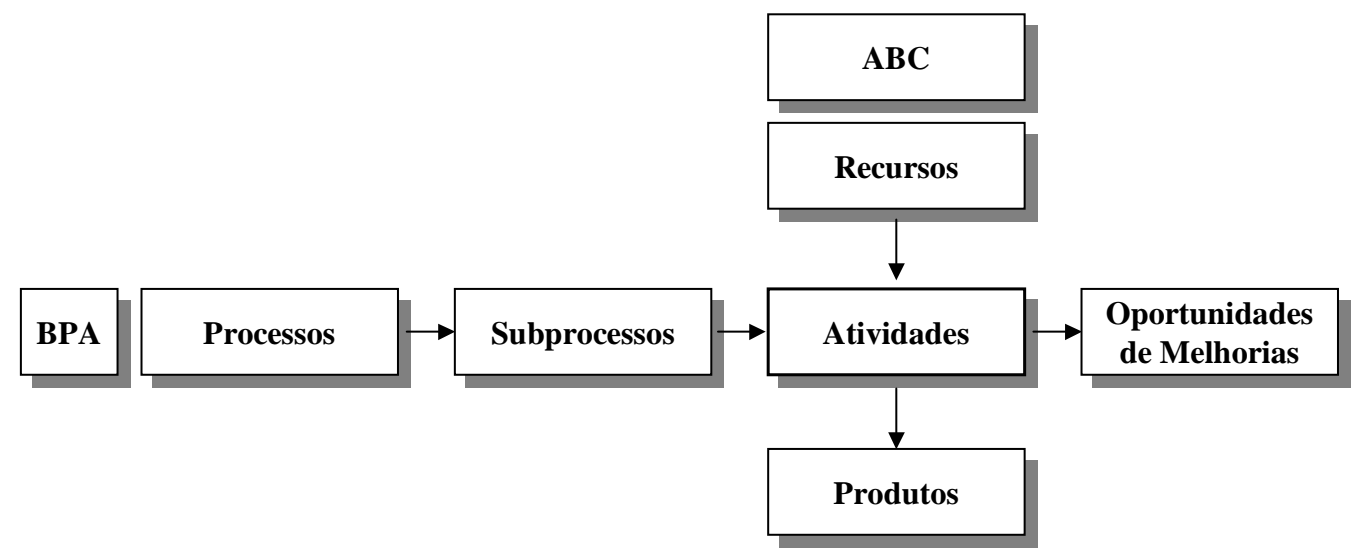

Figura 2-31 - Relacionamento entre ABC e BPA.

Fonte: Adaptado de OSTRENGA ET AL (1997).

O autor relata que a visão de processo é uma das maneiras de se enxergar a empresa. Contrasta com a tradicional visão funcional, baseada em uma estrutura organizacional departamentalista e pode ser representada pela Figura 2-32.

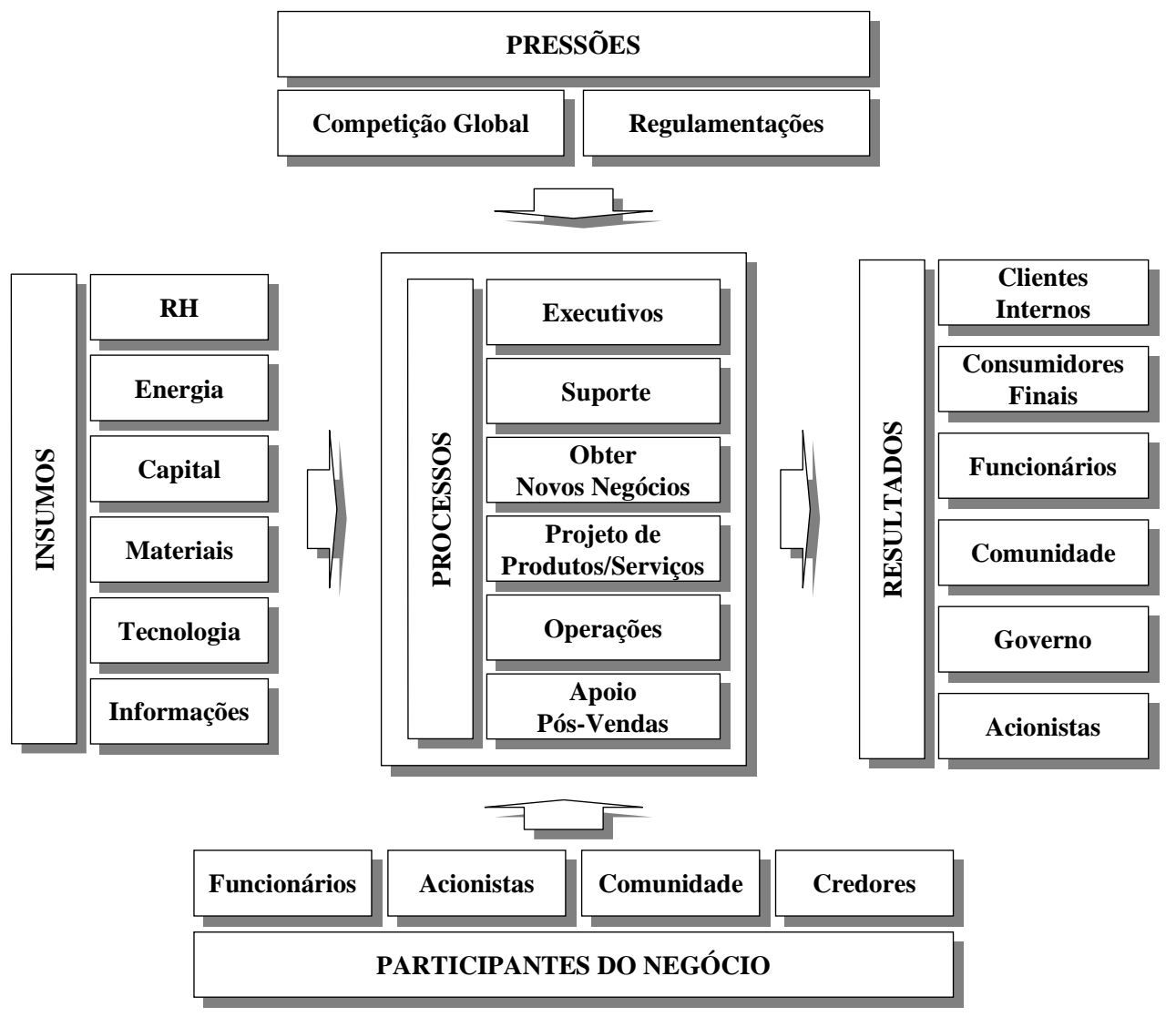

Figura 2-32 - Modelo Genérico de Processo Empresarial.

Fonte: Adaptado de OSTRENGA ET AL (1997). 
A análise de processo de negócio procura gerenciar os processos de alto nível da empresa, para que ela funcione. A condução desses processos empresariais sofre influências de fatores regulatórios, competitivos e dos próprios participantes do negócio. Seus resultados são direcionados para os clientes da organização, consumidores finais, funcionários, acionistas, comunidade e governo. Os processos empresariais são divididos em subprocessos (ver Tabela 2-7) e estes em atividades que são o foco principal de toda a análise, segundo OSTRENGA ET AL (1997).

\begin{tabular}{|c|c|}
\hline Processos & Subprocessos \\
\hline Processos Executivos & $\begin{array}{c}\text { Planejamento Estratégico; } \\
\text { Alocação de Capital; } \\
\text { Orçamentação. }\end{array}$ \\
\hline Suporte & $\begin{array}{c}\text { Relações com Recursos Humanos; } \\
\text { Controle Financeiro; } \\
\text { Treinamento de Pessoal; } \\
\text { Apoio Administrativo } \\
\text { Sistemas de Informação; } \\
\text { Gestão de Caixa. }\end{array}$ \\
\hline Obter Novos Negócios & $\begin{array}{c}\text { Promoção de Vendas/Publicidade; } \\
\text { Treinamento em Vendas de } \\
\text { Produtos/Serviços; } \\
\text { Preparação de Propostas; } \\
\text { Apreçamento/Cotações; } \\
\text { Obtenção de Pedidos. }\end{array}$ \\
\hline Projeto de Produto/Serviços & $\begin{array}{c}\text { Avaliação/Pesquisa de Mercado; } \\
\text { Planejamento de Produto; } \\
\text { Projeto de Produto/Processo; } \\
\text { Desenvolvimento de Produto; } \\
\text { Testes de Aceitação pelo Mercado. }\end{array}$ \\
\hline Operações & $\begin{array}{c}\text { Previsão de Produto/Serviço; } \\
\text { Aquisição de Insumos; } \\
\text { Planejamento de Instalações e } \\
\text { Equipamentos; } \\
\text { Conversão; } \\
\text { Manutenção. } \\
\end{array}$ \\
\hline Apoio Pós-Vendas & $\begin{array}{c}\text { Embalagem; } \\
\text { Logística Externa; } \\
\text { Educação/Treinamento de Clientes; } \\
\text { Consulta de Clientes; } \\
\text { Peças de Reposição/Conserto }\end{array}$ \\
\hline
\end{tabular}

Tabela 2-7 - Processos Empresariais Genéricos.

Fonte: Adaptado de OSTRENGA ET AL (1997).

O autor finaliza propondo três abordagens para a identificação dos processos, subprocessos e atividades da empresa, conforme apresentado na Figura 2-33. 


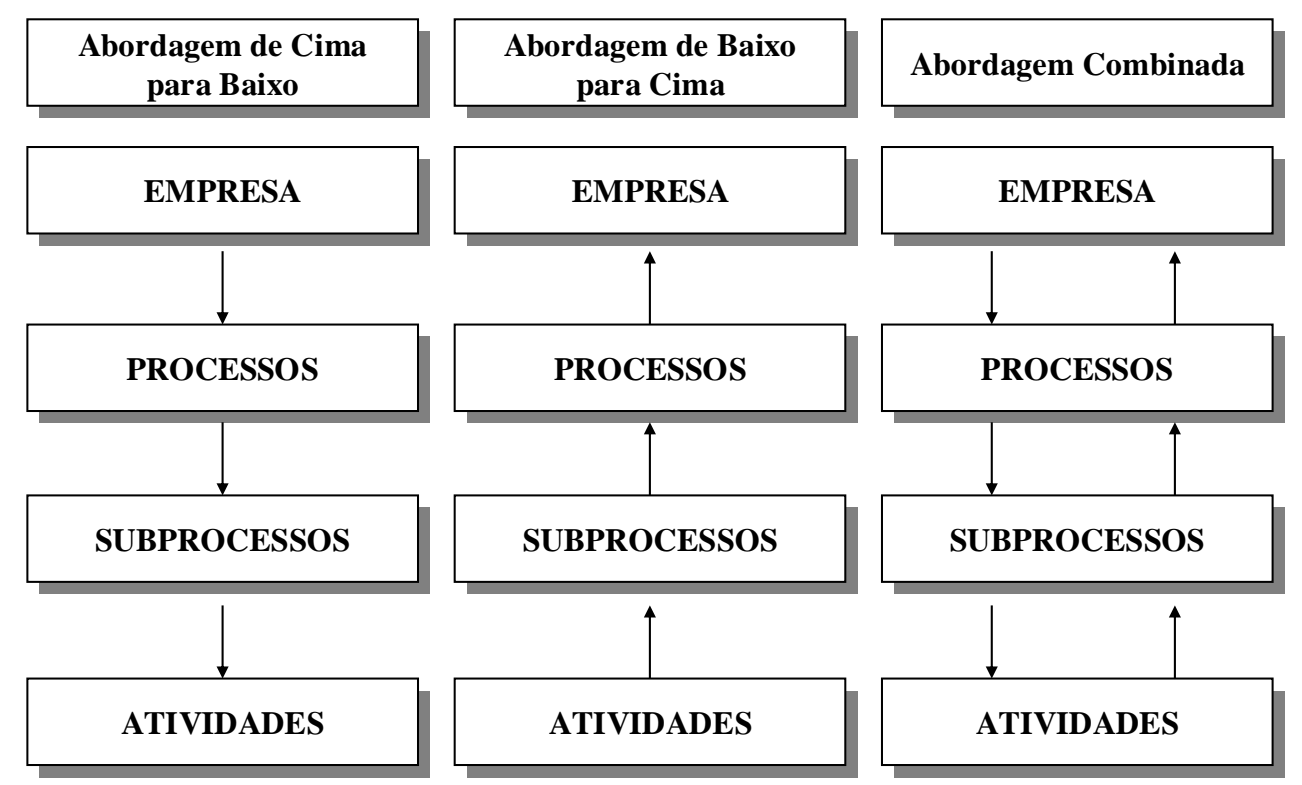

Figura 2-33 - Processos, Subprocessos e Atividades da Empresa.

Fonte: Adaptado de OSTRENGA ET AL (1997).

1) Abordagem de cima para baixo - Identificação inicial de todos os processos existentes na empresa, para uma posterior divisão em subprocessos e atividades. As vantagens dessa abordagem são a consistência e a simplicidade. A desvantagem, entretanto, reside no risco de desencadear algumas atividades de natureza genérica ou que já são executadas nos vários processos existentes;

2) Abordagem de baixo para cima - Ocorre inicialmente a identificação de todas as atividades existentes dentro da empresa. Em seguida, identificam-se os subprocessos em que estas atividades se encontram, ligando-os aos seus respectivos processos. Tal abordagem tem maior probabilidade de identificar todas as atividades, mas tende a provocar muita repetição de trabalho e de sintonia fina para alocar as atividades nos subprocessos e estes nos processos da empresa.

3) Abordagem combinada - Esta versão começa pela abordagem de cima para baixo. Uma vez identificados os processos e subprocessos da empresa, é feita uma primeira aproximação para a determinação das atividades. Em seguida, os subprocessos são revistos para verificar se 
alguma atividade foi desconsiderada, alocando a mesma de forma adequada em relação ao subprocesso. Esta abordagem possui vantagens em relação às demais. Todos os processos e atividades de nível mais baixo da empresa são mapeados para posterior refinamento.

\section{B) ALOCAÇÃO DOS CUSTOS ÀS ATIVIDADES}

BORNIA (2002) afirma que o cálculo dos custos das atividades corresponde à distribuição dos custos indiretos do método dos centros de custo. Assim a alocação destes custos às atividades deve representar todos os sacrifícios de recursos necessários para o seu desempenho.

Por outro lado, MARTINS (2003) lembra que a primeira fonte de dados para custear as atividades é o razão geral da empresa. Deste modo, a aplicação dos conceitos do $\mathrm{ABC}$ em sua plenitude implica na reorganização da contabilidade de custos, orientando os mesmos para as atividades.

O ABC trabalha com o conceito de centro de atividades. Os centros de atividades, por sua vez, representam processos homogêneos tais como usinagem e estampagem, ou então uma linha de produção, ou ainda processos de negócios como distribuição e marketing, como bem observa PAMPLONA (1997).

A distribuição dos custos às atividades deve ocorrer da forma mais criteriosa possível e de acordo com a seguinte prioridade, conforme a recomendação de MARTINS (2003): alocação direta, rastreamento e rateio. A alocação direta dá-se, quando são possíveis uma identificação clara, direta e objetiva do item de custo com a atividade. O rastreamento ocorre através da relação de causa e efeito entre a ocorrência da atividade e a geração de custos. Tal relação é expressa pelos direcionadores de recursos, objetos de discussão do próximo subtítulo. O rateio deve ser utilizado nos casos em que não há possibilidade de se usar nem a alocação direta e nem o rastreamento, segundo o autor.

OSTRENGA ET AL (1997) complementa que o processo de reorganização da classificação dos custos dos registros contábeis para as atividades deve levar em conta os seguintes passos: 
- O primeiro diz respeito ao exame global dos dados da contabilidade, no sentido de entender a estrutura do esquema de numeração das contas, assim como também o conteúdo de cada uma delas. É importante a elaboração de um mapa organizacional com base nas informações sobre os centros de custos. Através deste mapa será possível atualizar as discrepâncias entre o mapa geral da organização e a contabilidade;

- A tarefa seguinte é buscar oportunidades para condensar dados. Contas que apresentem categorias de custos semelhantes poderão ser combinadas;

- Na seqüência deve ocorrer o exame dos centros de custos. Tal exame deve considerar duas dimensões. A primeira diz respeito a possibilidade de transformar os centros de custos em centros de atividades. Os centros de custos que exercem tarefas semelhantes podem ser combinados para fins de custeio das atividades. A segunda dimensão deve levar em conta a seqüência dos centros de custos que, dentro do possível, deve refletir o fluxo do processo;

- O passo final é examinar as alocações ou rateios internos previamente feitos. Se estas alocações ou rateios foram realizados com base em serviços prestados ou demandas reais, então representam informações relevantes para o ABC. Caso contrário, precisam ser reformuladas para fins do custeio baseado em atividades.

\section{C) IDENTIFICAÇÃO E SELEÇÃO DOS DIRECIONADORES DE CUSTOS}

Os direcionadores de custos (cost drivers), segundo BORNIA (2002), podem ser definidos como aquelas transações que determinam os custos das atividades. Em outras palavras, são as causas principais dos custos das atividades. O método ABC tem por objetivo encontrar a origem dos custos das atividades, para, dessa forma, repassá-los aos produtos (objetos de custeio), com base no consumo das atividades, por parte dos mesmos. 
MARTINS (2003) lembra que os direcionadores de custos refletem a causa básica da atividade e, portanto, a da existência de seus custos. O autor distingue dois tipos de direcionadores (ver Figura 2-30). Os de primeiro estágio, direcionadores de recursos (resources drivers), e os de segundo estágio, direcionadores de atividades (activity drivers).

Os direcionadores de recursos definem as relações existentes entre os recursos consumidos e as atividades. Tais direcionadores procuram explicar como as atividades consumem os recursos. Já os direcionadores de atividades são usados para custear os produtos e indicam as relações existentes entre os mesmos e as atividades. Procuram explicar como os produtos consomem ou utilizam as atividades.

O exemplo a seguir, sugerido pelo autor, esclarece o conceito desses direcionadores. Assim, o número de requisições feitas ao almoxarifado explica como a atividade comprar materiais consome o recurso material de escritório. Portanto, o direcionador do recurso material de escritório é o número de requisições feitas ao almoxarifado. Já o número de cotações ou pedidos de compra relacionados com um dado produto explica como este utiliza a atividade comprar materiais. Assim, o numero de cotações ou pedidos de compra relacionados com um dado produto é um direcionador da atividade comprar materiais.

Alguns exemplos de direcionadores de recursos são apresentados por PAMPLONA (1997) na Tabela 2-8. O autor também sugere o uso das medidas de atividades como forma de direcionar os recursos para as atividades, dado que a medida é simples de ser entendida, fácil de ser medida e obtida nas fontes de dados da organização.

Exemplos dessas medidas de atividades podem ser vistas na Tabela 2-9. Entretanto, é recomendado que as medidas de atividade sejam sempre reavaliadas diante de mudanças na empresa que venham a afetar a tecnologia, vendas e outros fatores de produção, segundo o autor. 


\begin{tabular}{|l|l|}
\hline Categoria de Custo & Direcionador de Recurso \\
\hline $\begin{array}{l}\text { De Ocupação (aluguéis, arrendamento, } \\
\text { impostos prediais, seguros contra fogo) }\end{array}$ & Área (metros quadrados) \\
\hline Depreciação & Depreciação por Localização \\
\hline Setor de Pessoal & Número de Empregados \\
\hline Encargos Sociais & \% do Custo de Mão-de-Obra \\
\hline Segurança e Limpeza & Área (metros quadrados) \\
\hline Manutenção Preventiva & $\begin{array}{l}\text { Número de Máquinas do Programa } \\
\text { Registros nos Cartões de Tempo } \\
\text { Número de Quebras }\end{array}$ \\
\hline Ferramentaria & Número de Ferramentas \\
\hline Utilidades & Medições \\
\hline Inspeção & $\begin{array}{l}\text { Número de Inspeções } \\
\text { Designações de Departamento }\end{array}$ \\
\hline Armazenagem & Número de Recebimentos e Remessas \\
\hline Controle de Chão de Fábrica & Número de Movimentos \\
\hline Engenharia Industrial & $\begin{array}{l}\text { Ordem de Trabalho } \\
\text { Mudanças de Rota } \\
\text { Estudos, Levantamentos }\end{array}$ \\
\hline Engenharia da Qualidade & $\begin{array}{l}\text { Defeitos } \\
\text { Especificações de Processos } \\
\text { Planos de Testes }\end{array}$ \\
\hline
\end{tabular}

Tabela 2-8 - Categoria de Custo x Direcionador de Recurso.

Fonte: PAMPLONA (1997).

\begin{tabular}{|l|l|}
\hline \multicolumn{1}{|c|}{ Atividades } & \multicolumn{1}{c|}{ Medidas de atividades } \\
\hline Contas a Pagar & $\begin{array}{l}\text { Faturas } \\
\text { Cheques }\end{array}$ \\
\hline Contas a Receber & $\begin{array}{l}\text { Pedidos de Clientes } \\
\text { Número de Clientes }\end{array}$ \\
\hline Controle de Estoques & Número de Itens \\
\hline Planejamento e Controle de Materiais & Número de Itens \\
\hline Compra & Número de Pedidos de Compra \\
\hline $\begin{array}{l}\text { Recebimento e Armazenagem de } \\
\text { Componentes }\end{array}$ & Número de Pedidos de Compra \\
\hline Inspeção de Entrada & Número de Inspeções \\
\hline Controle da Qualidade & Número de Inspeções \\
\hline Avaliação de Vendedores & Número de Vendedores \\
\hline Certificação de Vendedores & Número de Vendedores \\
\hline
\end{tabular}

Tabela 2-9 - Medidas de Atividades.

Fonte: PAMPLONA (1997). 


\section{D) ATRIBUIÇÃO DOS CUSTOS DAS ATIVIDADES AOS PRODUTOS}

Uma vez identificadas as atividades relevantes, seus direcionadores de custos e respectivos custos, a próxima etapa é repassar os custos das atividades aos produtos ou outros objetos de custeio que podem ser tanto serviços como lotes, linhas, peças, clientes e outras atividades, conforme o interesse da administração.

MARTINS (2003) alega que os sistemas tradicionais utilizam poucas bases de rateio (normalmente medidas de volume) para atribuir custos aos produtos. O $\mathrm{ABC}$ dá mais transparência à análise de custos dado que utiliza vários direcionadores para rastrear o consumo de atividades pelos produtos.

PAMPLONA (1997), assim como OSTRENGA ET AL (1997) indicam duas tarefas fundamentais para atribuir custos aos objetos: formação dos grupos de custos de atividades e especificação dos direcionadores de custos de segundo estágio.

Para a formação dos grupos de custos de atividades, os autores sugerem levar em consideração os seguintes fatores:

- Os grupos de atividades devem ser formados levando-se em conta que serão usados como possíveis bases para posterior atribuição de custos aos objetos;

- As atividades, com as mesmas causas básicas de geração de custos, são candidatas prováveis à consolidação;

- Atividades que agregam e não agregam valor não devem ser combinadas no mesmo grupo de atividades. Em outras palavras, atividades de categorias diferentes não devem ser combinadas;

- Atividades que reflitam um custo relativamente insignificante devem ser combinadas com atividades correlatas.

Os autores advertem que a formação dos grupos de custos de atividades é de suma importância na implementação do custeio baseado em atividades. Principalmente no que concerne às informações que serão geradas para a administração dos custos. 
Grupos de custos de atividades mal formados introduzem erros e distorções no custeio dos produtos, conforme será discutido mais adiante.

Na especificação dos direcionadores de segundo estágio, OSTRENGA ET AL (1997) relata que existem três características críticas que devem ser consideradas:

1) Um direcionador deve refletir a demanda que um objeto de custo coloca sobre a atividade em relação a outros objetos. Ou seja, objetos diferentes utilizam diferentemente as diversas atividades, dada a complexidade dos processos que geram tais objetos. O direcionador de atividades deve refletir essas diferentes demandas;

2) O direcionador de atividades deve refletir ou estar relacionado às causas básicas geradoras de custos das atividades; e

3) A quantificação do direcionador de atividades deve ser possível e prática.

Nesta linha, o autor apresenta sugestões no sentido de possibilitar a especificação de direcionadores de segundo estágio que atendam às características críticas definidas anteriormente:

- Resistir ao impulso de especificar "qualquer coisa” como direcionador de custos somente porque dispõe de dados sobre ela;

- Ao considerar distintas alternativas de direcionadores de custos de segundo estágio, deve-se levar em conta o custo da coleta de dados em relação a acurácia que cada um oferece;

- A Tabela 2-10 mostra exemplos de direcionadores de atividades avaliados em relação a quatro critérios distintos; e

- As contribuições mais valiosas com relação à especificação dos direcionadores de segundo estágio são aquelas advindas das pessoas diretamente envolvidas nas próprias atividades. 


\begin{tabular}{|c|c|c|c|c|}
\hline $\begin{array}{c}\text { Possíveis direcionadores } \\
\text { de atividades }\end{array}$ & $\begin{array}{c}\text { Relação com } \\
\text { as causas } \\
\text { básicas }\end{array}$ & $\begin{array}{l}\text { Fácil de } \\
\text { medir }\end{array}$ & $\begin{array}{c}\text { Dados } \\
\text { Disponíveis }\end{array}$ & Quantificável \\
\hline Distância entre operações & 3 & 3 & 4 & 5 \\
\hline Número de movimentos & 4 & 3 & 4 & 4 \\
\hline Número de veículos & 2 & 5 & 5 & 5 \\
\hline $\begin{array}{l}\text { Horas de mão-de-obra } \\
\text { direta }\end{array}$ & 2 & 5 & 5 & 5 \\
\hline $\begin{array}{l}\text { Horas de máquinas } \\
\text { disponíveis }\end{array}$ & 4 & 4 & 4 & 4 \\
\hline $\begin{array}{l}\text { Número de unidades } \\
\text { produzidas }\end{array}$ & 3 & 5 & 5 & 5 \\
\hline $\begin{array}{l}\text { Número de unidades boas } \\
\text { produzidas }\end{array}$ & 4 & 4 & 4 & 4 \\
\hline Horas de máquina orçadas & 3 & 4 & 4 & 4 \\
\hline Número de inspeções & 3 & 2 & 3 & 2 \\
\hline $\begin{array}{l}\text { Número de unidades } \\
\text { reprocessadas }\end{array}$ & 2 & 2 & 2 & 2 \\
\hline $\begin{array}{l}\text { Número de mudanças na } \\
\text { engenharia }\end{array}$ & 3 & 3 & 3 & 2 \\
\hline $\begin{array}{c}\text { Número de peças para } \\
\text { montar }\end{array}$ & 5 & 4 & 4 & 4 \\
\hline $\begin{array}{l}\text { Número de unidades } \\
\text { rejeitadas }\end{array}$ & 3 & 2 & 2 & 3 \\
\hline Obs.: as ava & ões vão de 1 & 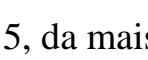 & ixa para a m & \\
\hline
\end{tabular}

Tabela 2-10 - Critérios de Seleção de Direcionadores de Atividades. Fonte: OSTRENGA ET AL (1997).

PAMPLONA (1997) aprofunda a discussão analisando as questões relativas às distorções decorrentes das agregações de custos baseadas em atividades diferentes. Assim, o autor analisa o nível de distorção provocada pela utilização de um único 
direcionador para rastrear duas ou mais atividades agregadas. Neste sentido, indica três fatores determinantes da aceitabilidade de um direcionador de custos de segundo estágio: a diversidade de produtos, os custos relativos das atividades agregadas e a diversidade de volume de produção.

A diversidade de produtos - Produtos diversos são aqueles que utilizam as atividades em proporções diferentes. Isto é, a complexidade dos processos determina para os diferentes produtos, diversos consumos de atividades de apoio. Portanto, é improvável que dois produtos diferentes consumam as mesmas atividades e na mesma proporção. Assim, haverá sempre alguma distorção na formação dos grupos de custos de atividades e quanto maior a diversidade dos produtos tanto maior é a distorção da alocação dos custos das atividades para os produtos;

Os custos relativos das atividades agregadas - A participação relativa do custo de cada atividade no processo produtivo influencia a formação dos grupos de atividades que são representados por um único direcionador de custos. Não havendo a diversidade de produtos não ocorre distorção no custo do produto apenas pelo fato de uma atividade apresentar maior participação relativa nos custos. Se dois produtos consomem, cada um, as atividades de um grupo em uma mesma proporção, o efeito da participação relativa dos custos de cada atividade neste grupo também não irá provocar distorções nos custos dos produtos. Assim, dado que sempre irá ocorrer maior ou menor diversidade de produtos, é recomendável que as atividades que participem de um grupo sejam de baixo custo relativo. Se tais atividades tiverem alto custo relativo, a formação dos grupos de atividades deve ser repensada para que menores distorções sejam introduzidas nos custos dos produtos.

A diversidade de volume - Ocorre quando os produtos são fabricados em lotes de tamanhos diferentes. Supondo que o direcionador de custos adotado tem relações com o volume de produção. Considerando, também, que os produtos consomem, com maior intensidade, atividades não relacionadas com o volume de produção. Então, a distorção na distribuição dos custos das atividades aos produtos terá um peso significativo.

O autor conclui que a formação dos grupos de atividades é de fundamental importância na metodologia de custeio. $\mathrm{O}$ agrupamento de atividades que provoquem 
as menores distorções possíveis, determinam a quantidade necessária de direcionadores e, como decorrência, os custos de implantação e operação do sistema ABC.

MARTINS (2003) complementa que a alta proporção dos custos indiretos nas atividades de apoio, a complexidade dos processos e os diferentes volumes de produção influenciam os custos dos produtos. Tal influência é mais marcante no sistema $\mathrm{ABC}$ que nos tradicionais. Produtos mais complexos fabricados em baixos volumes apresentam-se, pelo $\mathrm{ABC}$, menos lucrativos do que se apresentavam, considerando os sistemas tradicionais. Inversamente, os produtos menos complexos, mais simples, fabricados em altos volumes apresentam margens maiores. Isto ocorre, porque as bases para rateio, nos sistemas tradicionais, não refletem o consumo real de recursos pelos produtos. Em sendo os custos indiretos relativamente baixos e a produção padronizada, não há sensíveis diferenças entre os métodos de custeio. $\mathrm{O}$ ABC não se restringe somente ao custeio do produto. $\mathrm{O}$ método permite que os processos da empresa sejam também custeados.

\section{2) VISÃO DE APERFEIÇOAMENTO DE PROCESSOS}

Para MARTINS (2003), a visão de aperfeiçoamento de processos (visão horizontal) admite que um conjunto de atividades que se encadeiam e são exercidas pelos diferentes departamentos da empresa caracterizam um processo. Em outras palavras, os processos são compostos por atividades que se inter-relacionam e, dentro dessa visão, podem ser aprimoradas, reestruturadas ou até mesmo eliminadas.

O autor ainda complementa que os sistemas tradicionais de custos refletem os custos da estrutura funcional da empresa. O ABC, na visão do aperfeiçoamento de processos, vai além desta estrutura, dado que os processos são interdepartamentais. Nestas condições, o método pode ser visto como uma ferramenta de análise de fluxo de custos, permitindo que os processos da empresa sejam custeados e aperfeiçoados.

Portanto, é possível construir um modelo para a visão horizontal de aperfeiçoamento de processos, de acordo com a Figura 2-34. 


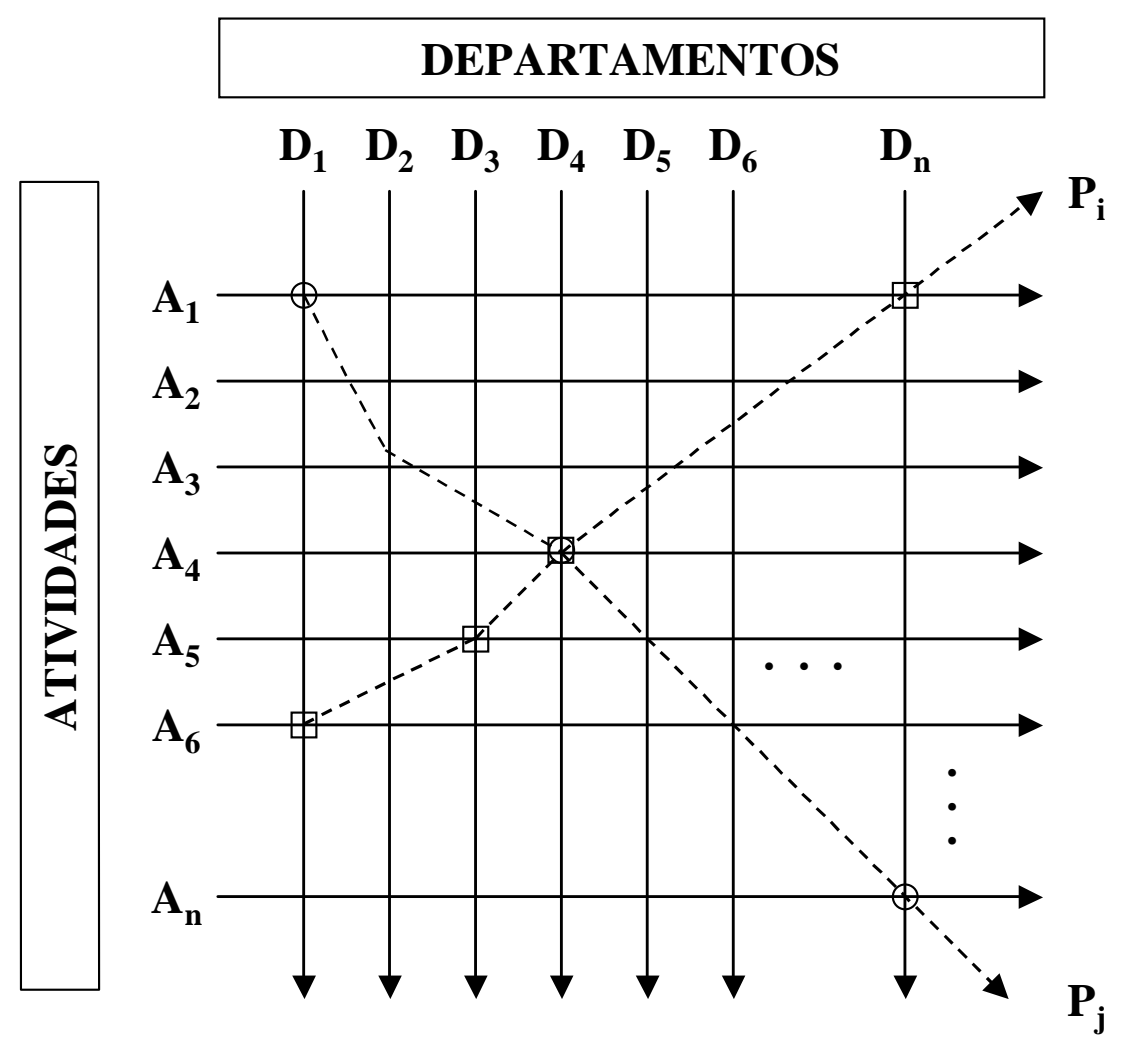

Figura 2-34 - Visão de Aperfeiçoamento de Processos.

Fonte: Adaptado de LORINO (1991).

Na vertical, a empresa é caracterizada pelos seus diversos departamentos $\left(D_{1}\right.$, $\left.D_{2}, D_{3}, \ldots, D_{n}\right)$. As atividades $\left(A_{1}, A_{2}, A_{3}, \ldots, A_{n}\right)$ que a organização executa podem ser vistas nas linhas horizontais da figura. Assim, os processos $\left(\mathrm{P}_{1}, \mathrm{P}_{2}, \ldots, \mathrm{P}_{\mathrm{i}}, \mathrm{P}_{\mathrm{j}}, \ldots, \mathrm{P}_{\mathrm{n}}\right)$ são identificados pela seqüência das atividades realizadas pelos diferentes departamentos. É possível uma determinada atividade não ser executada em apenas um departamento. Nesta situação, a atividade deve ser dividida em subatividades, cada uma delas identificadas com os departamentos onde se realizam. Assim, para se conhecer o custo do processo, somam-se os custos das atividades envolvidas. O autor lembra que pode ocorrer uma dada situação em que uma atividade venha a fazer parte de mais de um processo. Nesta condição, será necessária uma análise para verificar o quanto cada processo se utiliza desta atividade, para que o custo seja alocado, de forma consistente, aos processos que dela compartilham. 


\subsubsection{GESTÃO TOTAL DOS CUSTOS}

OSTRENGA ET AL (1997) relatam que a Gestão Total dos Custos (TCM Total Cost Management) é uma filosofia gerencial abrangente que propicia uma gerência pró-ativa de todos os recursos da empresa e das atividades que os consome. É um processo permanente de planejamento e aperfeiçoamento das questões táticas e operacionais da empresa. Entretanto, ao mesmo tempo, provê as bases necessárias para o direcionamento estratégico da organização. As principais características do sistema TCM, segundo o autor, podem ser assim alinhavadas:

- O foco do sistema está na prevenção dos custos e não nos relatórios de custos;

- O sistema está sempre fazendo a conexão direta entre os desempenhos operacionais e os objetivos estratégicos;

- Efetua medidas da lucratividade e dos fluxos de caixa dos produtos, serviços e dos fluxos e acumulação de custos e leva em conta os custos das atividades comerciais e administrativas;

- Considera a tecnologia com um fator importante tanto para a redução de custos, como para a melhoria da lucratividade;

- O sistema leva em conta os custos indiretos com base em análises de causa-e-efeito; e

- O sistema não é apenas uma função contábil. É, primordialmente, uma forma de fazer negócios.

A flexibilidade, abrangência e pró-atividade do TCM são decorrentes da natureza de seus três princípios básicos, segundo o autor:

- Análise do Processo do Negócio (BPA);

- Custeio Baseado em Atividades (ABC); e

- Aperfeiçoamento Contínuo.

A Gestão Total dos Custos (TCM), como bem lembra PAMPLONA (1997), engloba a Gestão Baseada em Atividades ( $A B M$ - Activity Based Management). De um lado o ABC fornece as informações sobre as atividades da empresa. De outro, o 
ABM utiliza tais informações em análises que propiciam a melhoria contínua das atividades e, na seqüência, a dos processos e a da organização.

O relacionamento entre o $\mathrm{ABC}$ e o $\mathrm{ABM}$ pode ser visto na Figura 2-35 a seguir.

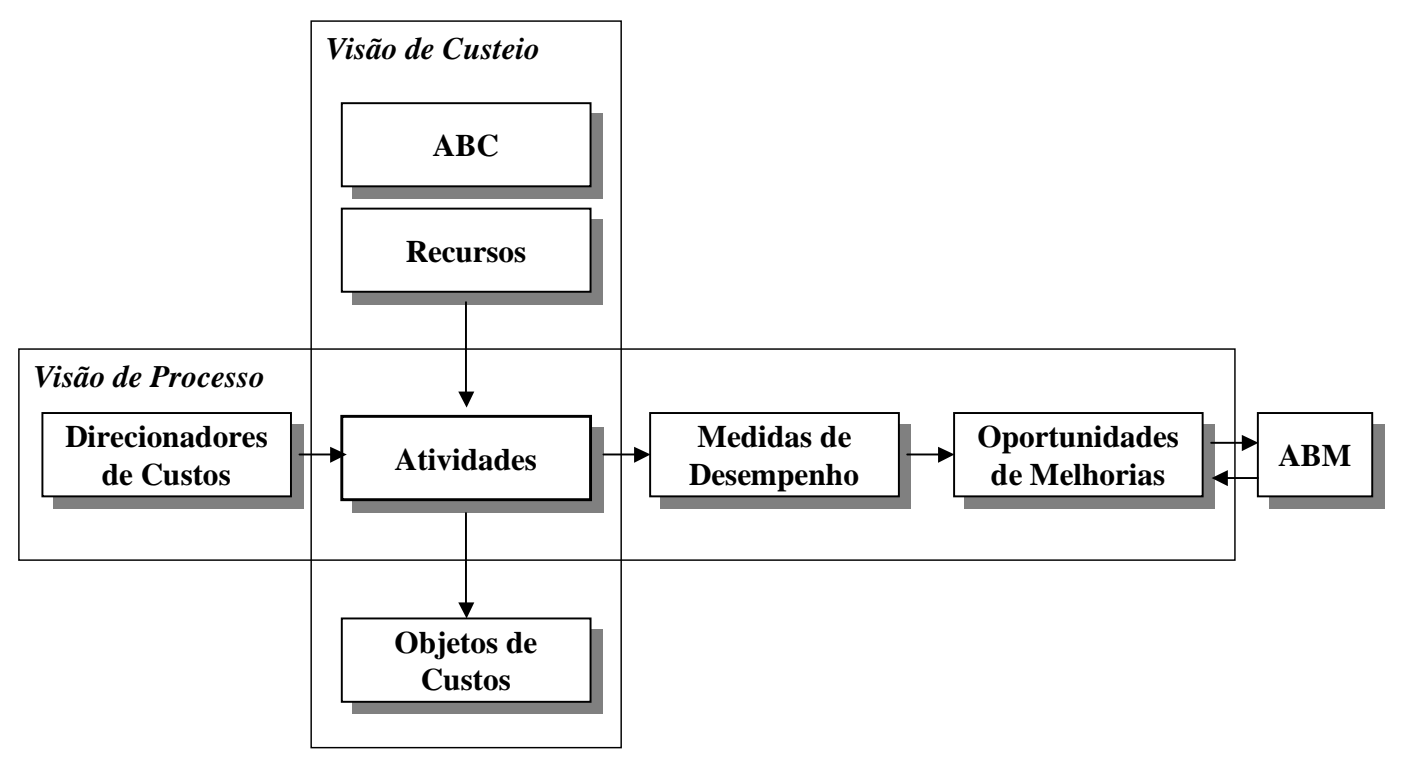

Figura 2-35 - Relacionamento entre ABM e ABC.

Fonte: Adaptado de PAMPLONA (1997).

Esta figura reflete as visões vertical e horizontal relatadas por MARTINS (2003) na formulação da lógica do Sistema ABC.

A primeira diz respeito à visão econômica de custeio e é usada para a tomada de decisões que envolvem levantamentos de preços, informações sobre produtos e projeto de produtos e priorização de esforços de melhoria.

A segunda analisa o aperfeiçoamento dos processos através das informações relativas ao desempenho das atividades que favorecem a identificação das oportunidades de melhorias. 


\subsubsection{CONSIDERAÇÕES FINAIS}

Pelo o que foi exposto e discutido nos títulos precedentes, pode-se concluir que o Sistema $\mathrm{ABC}$ tem uma conotação bem mais acentuada para a gestão dos custos industriais do que, simplesmente, de custeio de objetos de custos. O método permite identificar com clareza as atividades que estão impactando nos custos das empresas. Uma vez identificadas, tais atividades poderão ser aprimoradas ou até mesmo eliminadas dos processos da empresa. Como se pode ver, o método ABC contribui efetivamente para a melhoria do desempenho da organização.

BORNIA (2002) lembra que as atividades, em última análise, representam os vetores que direcionam os custos para os produtos e processos e fornecem informações preciosas para a eliminação de desperdícios. Assim, o trabalho efetivo que agrega valor e o trabalho adicional, necessário, porém que agrega somente custos, ficam claramente identificados. Os custos unitários das atividades podem servir como uma medida de desempenho das mesmas, além de gerar facilidades nas simulações e orçamentação. Permitem, ainda, um acompanhamento preciso de onde ocorrem as variações de custos. Da mesma forma, a identificação e a eliminação dos desperdícios podem ser efetuadas diretamente sobre a atividade, independentemente dos custos dos produtos. O autor recorda que os desperdícios são decorrentes dos processos e não dos produtos.

MARTINS (2003) encerra essas considerações finais afirmando que os conceitos e a metodologia do custeio baseado em atividades também podem ser aplicados nas empresas prestadoras de serviços. Atividades e objetos de custos não são exclusivos de empresas industriais e podem ser encontrados em todas as organizações, inclusive naquelas sem fins lucrativos.

Desta forma, o ABC encaixa-se perfeitamente no processo de análise do desempenho das atividades de manutenção, na gestão de seus custos, além de produzir informações acuradas para a apreciação do desempenho global da organização. 


\subsection{CONCLUSÕES}

As Teorias de Base propiciam uma revisão bibliográfica detalhada e completa onde são discutidas as questões pertinentes ao trabalho de pesquisa. Os diferentes pontos de vista relacionados com a avaliação de desempenho de empresas e a construção de indicadores gerenciais são analisados de forma ampla e objetiva. As questões ligadas às necessidades de se medir o desempenho das empresas são apresentadas de forma clara e consistente. Os principais modelos de avaliação, presentes na literatura, são também apresentados e discutidos. O texto infere que através deles é possível dar um direcionamento metodológico ao processo de avaliação de desempenho de sistemas organizacionais.

A revisão relativa à construção de indicadores gerenciais leva a conclusões importantes e atuais. Os indicadores permitem uma percepção do direcionamento gerencial da organização. Este trabalho analisa os requisitos técnicos e culturais que os indicadores devem possuir para gerar informações acuradas, relevantes e oportunas. Considera que o fator humano tem um peso significativo na sua efetividade.

Na sequiência, o texto faz uma apresentação completa e detalhada das questões relativas ao exercício da função manutenção dentro das organizações industriais. Considera, primeiramente, a estruturação da função com base nos elementos de competitividade e relata, em seguida, a história de sua evolução. O conceito da própria função manutenção é discutido de forma criteriosa e eficaz. As questões relativas à disponibilidade dos ativos, assim como as diferentes técnicas de prevenção e recuperação de falhas são consideradas com bastante profundidade. $\mathrm{O}$ texto ainda contempla as políticas de manutenção. Passa pelas diferentes abordagens para o gerenciamento da função e pelo uso de indicadores para este mister. O texto é finalizado com a análise da gestão da função com focos centrados na qualidade, produtividade e competitividade da empresa.

A gestão dos custos industriais, sistemas tradicionais de custeio e suas limitações são também objetos da discussão das Teorias de Base. O Sistema ABC é contemplado com um texto amplo e objetivo, onde a sua lógica é apresentada levando-se em conta tanto a visão econômica de custeio como a de aperfeiçoamento 
de processos. Toda a problemática relacionada com o mapeamento das atividades, especificação de direcionadores de custos e alocação de custos a objetos é discutida de modo criterioso e amplo. O texto também leva em conta os aspectos do relacionamento entre aos Sistemas ABC e ABM, dentro da visão da Gestão Total dos Custos (TCM). A finalização do texto relata a adequabilidade do Sistema ABC para o custeio e aprimoramento das atividades de manutenção nas empresas industriais.

Finalmente, considerando que o foco do trabalho de pesquisa está relacionado com métodos de custeio. Ou mais precisamente ainda com métodos de custeio das atividades da manutenção industrial. Considerando também que o objetivo do trabalho é o desenvolvimento de indicadores gerenciais. Considerando, ainda, que tais indicadores devem ser capazes de administrar não só o custeio, mas também as falhas e as atividades da manutenção. Pode-se perceber claramente que o texto apresentado, nas Teorias de Base, dá o suporte adequado para a construção do referencial teórico do trabalho de pesquisa que será apresentado e discutido no próximo capítulo deste trabalho. 


\section{Capítulo 3}

\section{O Referencial Teórico}

O referencial teórico aqui apresentado consubstancia a construção dos indicadores gerenciais utilizados para a gestão do custeio e das atividades de manutenção e dá suporte ao desenvolvimento do trabalho

\subsection{INTRODUÇÃO}

A gestão do custeio e das atividades de manutenção obedecerá ao pressuposto do processo gerencial ilustrado pela Figura 1-2. Isto é, avaliação da situação real através de monitoração sistemática e contínua e interferência gerencial por meio de ações corretivas e preventivas, via implementação de programas de melhorias contínuas.

Já o referencial teórico, ilustrado na Figura 3-1, construído para a gestão do custeio e das atividades de manutenção, toma por base o modelo de avaliação de desempenho segundo SLACK (1993) e discutido no Título 2.1.4 do Capítulo 2 (As Teorias de Base).

O modelo explica como a função manutenção pode ser estruturada e gerida, dentro de uma organização industrial, para contribuir de forma efetiva para o desempenho global da empresa.

Além disso, através dele, é possível observar que a função manutenção oferece vantagens competitivas para a operação por intermédio dos cinco elementos básicos de desempenho: qualidade, velocidade, confiabilidade, flexibilidade e custos. 


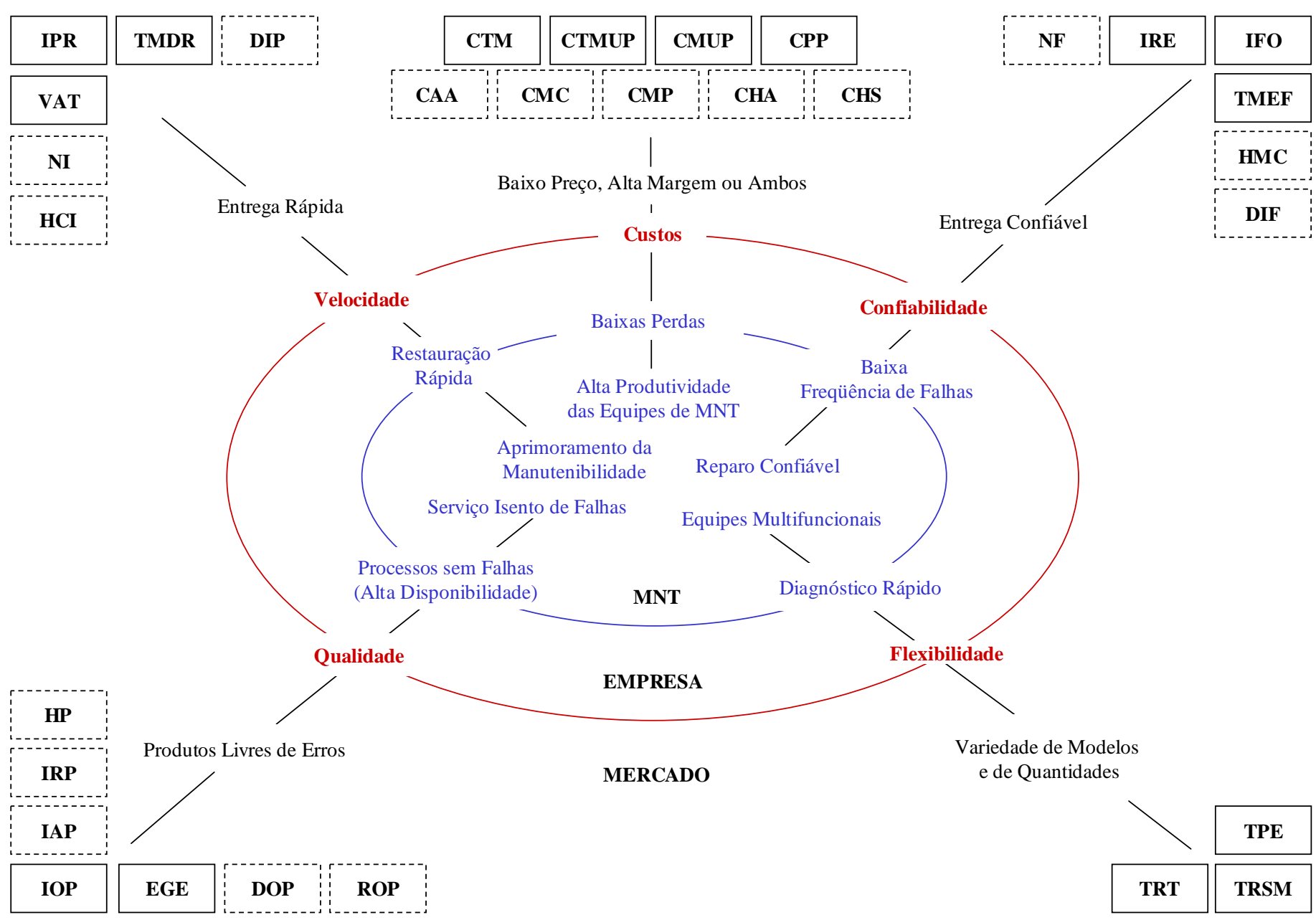

Figura 3-1 - Modelo para a Gestão do Custeio e das Atividades de Manutenção. 
A qualidade é vista como ausência de erros na conformação dos produtos. Processos sem falhas e operações sem interrupções com alta disponibilidade. Implica na inexistência de erros ou de falhas nos processos produtivos e, por decorrência, serviços de manutenção também isentos de falhas.

A velocidade para o mercado significa trabalhar rápido, reduzir o lead time da empresa. Menor do que aquele oferecido pela concorrência. Significa, também, restaurar rapidamente a prontidão funcional dos ativos sob intervenção. Em outras palavras, aprimorar a manutenibilidade dos equipamentos pela diminuição do tempo de reparo.

Manter a promessa dos prazos de entrega é o sentido maior da confiabilidade. Uma operação confiável, com baixa freqüência de falhas, permite respeitar os prazos de entrega compromissados. A baixa incidência de falhas, por sua vez, é obtida através do aprimoramento da confiabilidade inerente dos ativos.

A flexibilidade pode ser entendida como a capacidade da operação migrar de uma configuração para outra. Reflete a capacidade de adaptação da produção em face da alteração das necessidades dos clientes, das modificações dos processos produtivos e das mudanças que podem ocorrer nos canais de suprimentos.

A flexibilidade para a manutenção pode ser vista como a habilidade necessária para efetuar as intervenções nos equipamentos. Tal habilidade naturalmente incorre no diagnóstico rápido das causas das falhas e explicita a existência de equipes altamente capazes e multifuncionais.

A vantagem de custos é conformar os produtos com gastos menores que os da concorrência. Fazer barato pode significar aquisição de recursos em melhores condições de preços ou processos de transformação mais eficientes.

Para a manutenção, a vantagem de baixos custos pode ser conseguida pela redução das perdas decorrentes das paralisações da produção e dos gastos referentes às atividades de manutenção. Em última análise, significa alta produtividade das equipes de manutenção. 
A Figura 3-2 é uma outra forma de explicitar os objetivos de desempenho, propostos por SLACK (1993), que servem de base para a gestão do custeio e das atividades de manutenção, assim como as suas inter-relações com as funções produção manutenção e mercado.

\begin{tabular}{|c|c|c|c|c|c|c|}
\hline Manutenção & & Produção & & $\begin{array}{l}\text { Objetivos de } \\
\text { Desempenho }\end{array}$ & & Mercado \\
\hline Serviço Isento de Falhas & h & $\begin{array}{l}\text { Processos sem Falhas } \\
\text { (Alta Disponibillidade) }\end{array}$ & $\mapsto$ & Qualidade & 4 & $\begin{array}{l}\text { Produtos Livres } \\
\text { de Erros }\end{array}$ \\
\hline $\begin{array}{l}\text { Aprimoramento da } \\
\text { Manutenibilidade }\end{array}$ & b & Restauração Rápida & $h$ & Velocidade & 4 & Entrega Rápida \\
\hline $\begin{array}{c}\text { Aprimoramento da } \\
\text { Confiabilidade Inerente }\end{array}$ & h & $\begin{array}{c}\text { Baixa Freqüência } \\
\text { de Falhas }\end{array}$ & $h$ & Confiabilidade & $\sqrt{1}$ & Entrega Confiável \\
\hline $\begin{array}{l}\text { Multifuncionalidade e } \\
\text { Diagnóstico Rápido }\end{array}$ & h & Habilidade de Mudar & h & Flexibilidade & 4 & $\begin{array}{l}\text { Variedade de Modelos } \\
\text { e de Quantidades }\end{array}$ \\
\hline $\begin{array}{l}\text { Alta Produtividade das } \\
\text { Equipes de Manutenção }\end{array}$ & h & $\begin{array}{c}\text { Baixas Perdas de } \\
\text { Produção e Manutenção }\end{array}$ & $\beta$ & Custos & $\sqrt{4}$ & $\begin{array}{c}\text { Baixo Preço, } \\
\text { Alta Margem ou Ambos }\end{array}$ \\
\hline
\end{tabular}

Figura 3-2 - Objetivos de Desempenho.

Conforme o que já foi discutido no Título 2.1.5 do Capítulo 2 (As Teorias de Base) há uma interligação nítida e consistente entre os elementos ou objetivos de desempenho propostos por SLACK (1993).

O aprimoramento de uns afeta e contribui para a melhoria dos outros e viceversa. Dessa forma a integração dos indicadores propostos dá-se através desses elementos de desempenho, também de forma nítida e consistente, como se poderá ver nos próximos títulos.

A Tabela 3-1 resume os indicadores, principais e complementares, adotados e os relaciona com os processos de manutenção pelos objetivos de desempenho já citados. 


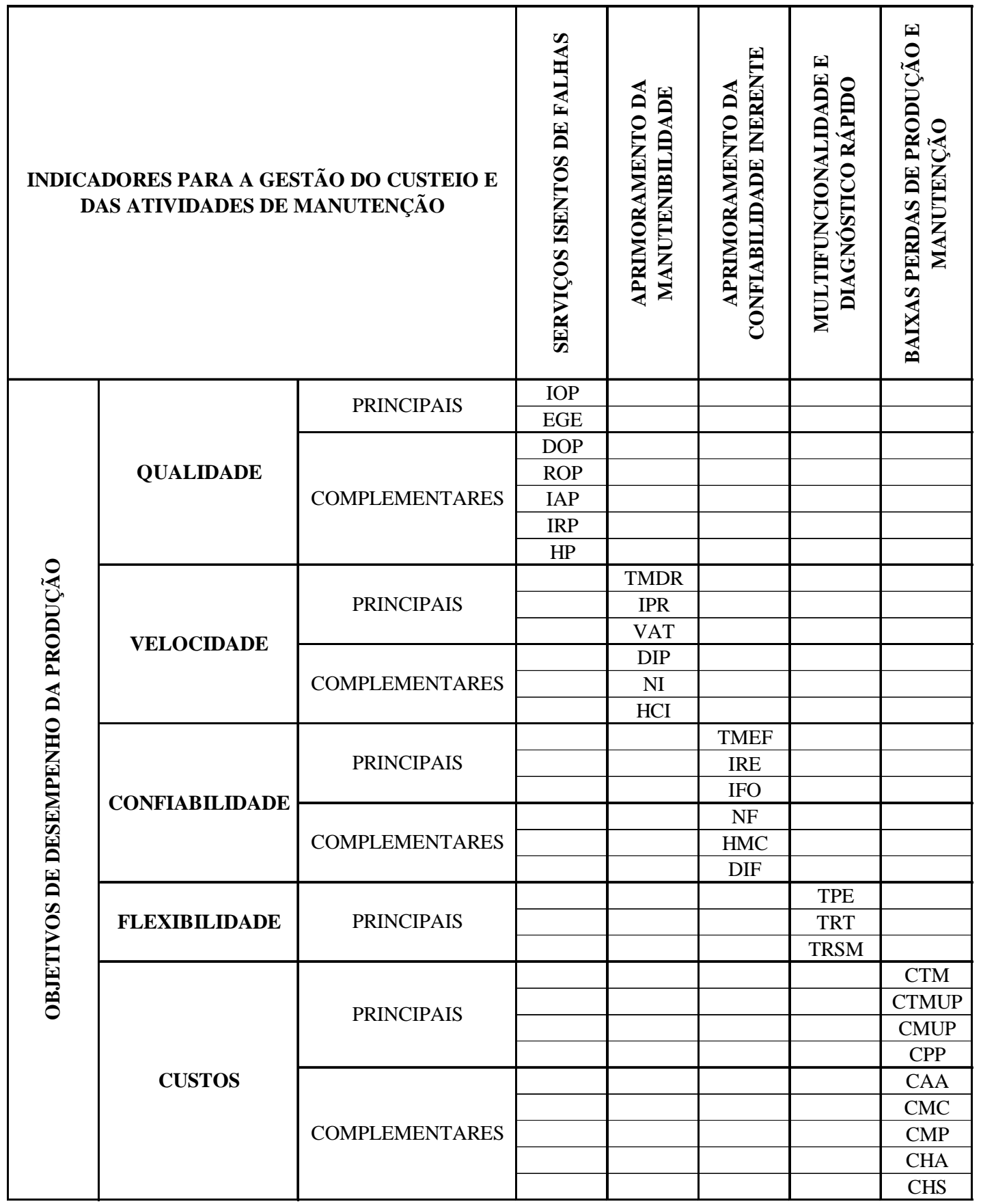

Tabela 3-1 - Gestão do Custeio e das Atividades de Manutenção. 


\subsection{INDICADORES PARA A GESTÃO DA MANUTENÇÃO}

Convém esclarecer, neste ponto, que o foco do trabalho está centrado na definição de indicadores para a gestão do custeio e das atividades de manutenção. A finalidade é a verificação das hipóteses formuladas no 1.2.2 do Capítulo 1 (Introdução). O trabalho não irá acompanhar a implementação de programas de melhorias contínuas nas empresas que delimitam o universo da pesquisa (ver Título 4.3 do Capítulo 4 (Metodologia)).

Nestas condições, a Tabela 3-2 explicita os indicadores adotados para a gestão da manutenção de acordo com os critérios propostos por SLACK (1993) que serão discutidos nos títulos que se seguem.

\begin{tabular}{|c|c|c|c|}
\hline \multicolumn{2}{|c|}{ OBJETIVO DE DESEMPENHO } & SIGLA & DESCRIÇÃO \\
\hline \multirow{7}{*}{ Qualidade } & \multirow{2}{*}{ Principais } & IOP & Indisponibilidade Operacional \\
\hline & & EGE & Eficácia Global dos Equipamentos \\
\hline & \multirow{5}{*}{ Complementares } & DOP & Disponibilidade Operacional \\
\hline & & ROP & Rendimento Operacional \\
\hline & & IAP & Índice de Aprovação \\
\hline & & IRP & Índice de Reprovação \\
\hline & & HP & Horas Paralisadas \\
\hline \multirow{6}{*}{ Velocidade } & \multirow{3}{*}{ Principais } & TMDR & Tempo Médio de Reparo \\
\hline & & IPR & Indisponibilidade Programada \\
\hline & & VAT & Velocidade de Atendimento \\
\hline & \multirow{3}{*}{ Complementares } & DIP & Disponibilidade Programada \\
\hline & & $\mathrm{NI}$ & Número de Intervenções \\
\hline & & HCI & Horas Consumidas nas Intervenções \\
\hline \multirow{6}{*}{ Confiabilidade } & \multirow{3}{*}{ Principais } & TMEF & Tempo Médio Entre Falhas \\
\hline & & IRE & Índice de Risco de Equipamento \\
\hline & & IFO & Indisponibilidade Forçada \\
\hline & \multirow{3}{*}{ Complementares } & NF & Número de Falhas \\
\hline & & HMC & Horas de Manutenção Corretiva \\
\hline & & DIF & Disponibilidade Forçada \\
\hline \multirow{3}{*}{ Flexibilidade } & \multirow{3}{*}{ Principais } & TPE & Taxa de Polivalência das Equipes \\
\hline & & TRT & Taxa de Realização de Treinamento \\
\hline & & TRSM & Taxa de Reatividade dos Serviços de Manutenção \\
\hline \multirow{9}{*}{ Custos } & \multirow{4}{*}{ Principais } & CTM & Custo Total de Manutenção \\
\hline & & CTMUP & Custo Total de Mnt por Unidade Produzida \\
\hline & & CMUP & Custo de Mnt por Unidade de Produto \\
\hline & & CPP & Custo de Paralisação da Produção \\
\hline & \multirow{5}{*}{ Complementares } & CAA & Custo das Atividades de Apoio \\
\hline & & CMC & Custo da Manutenção Corretiva \\
\hline & & CMP & Custo da Manutenção Preventiva \\
\hline & & $\mathrm{CHA}$ & Custo Horário das Atividades de Manutenção \\
\hline & & CHS & Custo da Hora em Serviço dos Equipamentos \\
\hline
\end{tabular}

Tabela 3-2 - Indicadores para a Gestão da Manutenção. 


\subsubsection{A QUALIDADE DOS SERVIÇOS DE MANUTENÇÃO}

A Qualidade na visão de SLACK (1993), conforme já discutido no Título 2.1.4 do Capítulo 2 (As Teorias de Base), é entendida como ausência de erros na conformação dos produtos, além de possuir um grande poder motivacional.

Nestas condições, um alto nível de desempenho de qualidade interna assegura processos sem falhas e produtos livres de erros para os consumidores. A qualidade, segundo o autor, é capaz de melhorar outros aspectos do desempenho interno tais como velocidade, confiabilidade e custos.

A gestão da qualidade não é tão somente direcionada para o aprimoramento contínuo dos níveis de qualidade. Envolve também o processo global de eliminação de defeitos, operações sem interrupções e a inexistência de erros ou falhas nos serviços e intervenções de manutenção.

A gestão deste importante elemento de desempenho, dentro da função manutenção, pode ser efetuada por meio dos indicadores:

- Principais:

$\checkmark$ IOP - Indisponibilidade Operacional;

$\checkmark$ EGE - Eficácia Global dos Equipamentos;

- Complementares:

$\checkmark$ DOP - Disponibilidade Operacional;

$\checkmark$ ROP - Rendimento Operacional;

$\checkmark$ IAP - Índice de Aprovação;

$\checkmark$ IRP - Índice de Reprovação;

$\checkmark$ HP - Horas Paralisadas

\section{A. IOP - INDISPONIBILIDADE OPERACIONAL}

A IOP - Indisponibilidade Operacional dos ativos pode ser medida através da expressão: 


$$
\mathrm{IOP}=\frac{\sum_{1}^{\mathrm{i}}(\mathrm{HP})_{\mathrm{i}}}{\sum_{1}^{\mathrm{i}}(\mathrm{HS})_{\mathrm{i}}},
$$

onde,

- IOP - Indisponibilidade Operacional no período [\%];

- $\quad$ i - Indicador Referencial do Equipamento;

- HP - Horas Paralisadas do equipamento no período considerado [h]. As horas paralisadas incluem todas as paralisações devidas às intervenções (de reparo e/ou de prevenção) e à logística de suprimentos ou de pessoal:

$\checkmark$ Emissão de documentos;

$\checkmark$ Preparação de materiais, ferramentas e dispositivos;

$\checkmark$ Isolação do equipamento;

$\checkmark$ Intervenção de reparo, ou de prevenção, propriamente dita;

$\checkmark$ Recomposição do equipamento;

$\checkmark \quad$ Baixa de documentos.

- HS - Horas em Serviço do equipamento no período considerado [h].

A IOP afeta diretamente a satisfação do cliente interno. A sua redução implica em menos interrupções nos processos produtivos, maior agilidade na restauração da prontidão funcional dos ativos e as decorrentes economias de custos.

\section{B. EGE - EFICÁCIA GLOBAL DOS EQUIPAMENTOS}

A EGE - Eficácia Global dos Equipamentos, conforme discussão já efetuada no Título 2.3.8 do Capítulo 2 (As Teorias de Base) é um indicador abrangente. Leva em consideração as seis grandes perdas observadas na utilização dos ativos para gerar produção. 
Assim, para uma dada produção realizada ou período de observação considerado, a EGE poderá ser formulada pela expressão:

$\mathrm{EGE}=\mathrm{DOP} \times \mathrm{ROP} \times \mathrm{IAP}$,

onde,

- EGE - Eficácia Global dos Equipamentos [\%];

- DOP - Disponibilidade Operacional [\%]:

$$
\mathrm{DOP}=1-\mathrm{IOP}=1-\frac{\sum_{1}^{\mathrm{i}}(\mathrm{HP})_{\mathrm{i}}}{\sum_{1}^{\mathrm{i}}(\mathrm{HS})_{\mathrm{i}}},
$$

$\checkmark$ DOP - Disponibilidade Operacional decorrente da Indisponibilidade Operacional no período;

$\checkmark$ IOP - Indisponibilidade Operacional, calculada de acordo com a expressão [III-1] e com as mesmas observações pertinentes;

$\checkmark \quad$ i - Indicador Referencial do Equipamento;

$\checkmark$ HP - Horas Paralisadas do equipamento no período considerado [h];

$\checkmark$ HS - Horas em Serviço do equipamento no período considerado [h].

- ROP - Rendimento Operacional [\%]:

$$
\mathrm{ROP}=\frac{\sum_{1}^{\mathrm{i}}(\mathrm{HPL})_{\mathrm{i}}}{\sum_{1}^{\mathrm{i}}(\mathrm{HS})_{\mathrm{i}}},
$$

$\checkmark$ ROP - Rendimento Operacional no período;

$\checkmark \quad$ i - Indicador Referencial do Equipamento;

$\checkmark$ HPL - Horas Planejadas para o equipamento produzir Q unidades de Produção no período considerado [h]; 
$\checkmark$ HS - Horas em Serviço do equipamento para produzir as Q unidades de produção [h]

- IAP - Índice de Aprovação [\%]:

$$
\mathrm{IAP}=\frac{\sum_{1}^{\mathrm{i}}(\mathrm{Q}-\mathrm{q})_{\mathrm{i}}}{\sum_{1}^{\mathrm{i}}(\mathrm{Q})_{\mathrm{i}}}
$$

- IRP - Índice de Reprovação [\%]:

$$
I R P=1-I A P=1-\frac{\sum_{1}^{i}(Q-q)_{i}}{\sum_{1}^{i}(Q)_{i}}=\frac{\sum_{1}^{i}(q)_{i}}{\sum_{1}^{i}(Q)_{i}}
$$

$\checkmark \quad$ IRP - Índice de Reprovação no Período

$\checkmark \quad$ IAP - Índice de Aprovação no período;

$\checkmark \quad$ i - Indicador Referencial do Equipamento;

$\checkmark$ Q - Quantidade total produzida pelo equipamento no período [u];

$\checkmark$ q-Quantidade de defeitos gerados pelo equipamento no período [u].

Assim, a EGE passa a ter a seguinte formulação definitiva:

$$
\mathrm{EGE}=\left[1-\frac{\sum_{1}^{\mathrm{i}}(\mathrm{HP})_{\mathrm{i}}}{\sum_{1}^{\mathrm{i}}(\mathrm{HS})_{\mathrm{i}}}\right] \times\left[\frac{\sum_{1}^{\mathrm{i}}(\mathrm{HPL})_{\mathrm{i}}}{\sum_{1}^{\mathrm{i}}(\mathrm{HS})_{\mathrm{i}}}\right] \times\left[\frac{\sum_{1}^{\mathrm{i}}(\mathrm{Q}-\mathrm{q})_{\mathrm{i}}}{\sum_{1}^{\mathrm{i}}(\mathrm{Q})_{\mathrm{i}}}\right] .
$$

A Figura 3-3 ilustra a formulação da EGE: 


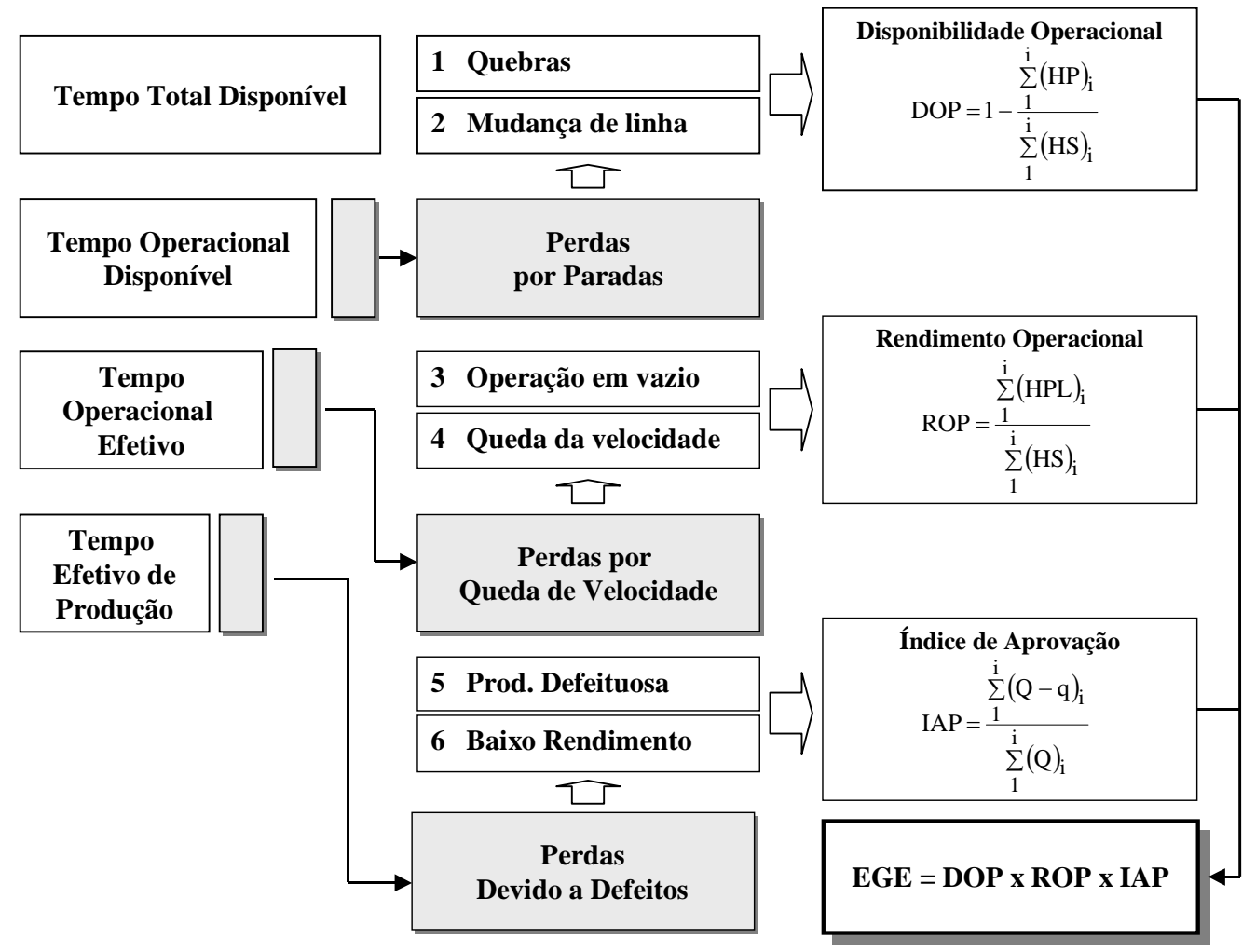

Figura 3-3 - Eficácia Global dos Equipamentos.

Fonte: Adaptado de MIRSHAWKA \& OLMEDO (1993).

Nestas condições e de acordo com a figura anterior pode-se ainda ilustrar:

$$
\begin{aligned}
& \text { DOP }=\frac{\text { Tempo Operacional Disponível }}{\text { Tempo Total Disponível }} \quad[\%] ; \\
& \text { ROP }=\frac{\text { Tempo Operacional Efetivo }}{\text { Tempo Operacional Disponível }} \quad[\%] ; \text { e } \\
& \text { IAP }=\frac{\text { Tempo Efetivo de Pr odução }}{\text { Tempo Operacional Efetivo }} \quad[\%] .
\end{aligned}
$$

Assim, multiplicando membro a membro as equações, tem-se:

$$
\text { EGE }=\frac{\text { Tempo Efetivo de Produção }}{\text { Tempo Total Disponível }}[\%] \Rightarrow \frac{\text { Re sultados Obtidos }}{\text { Resultados Previstos }}
$$

O que vale dizer que a eficácia global dos equipamentos está consistente com a proposta de SINK E TUTTLE (1993) para a sua definição e reflete a relação entre resultados obtidos e esperados dentro de um período de observação. 


\subsubsection{A VELOCIDADE DOS SERVIÇOS DE MANUTENÇÃO}

A velocidade tem o significado maior da entrega rápida ou, em outras palavras, entregar os produtos para os consumidores em prazos menores que aqueles oferecidos pela concorrência. Significa, portanto, restaurar rapidamente a prontidão funcional dos ativos sob intervenção. Isto é, aprimorar a manutenibilidade dos equipamentos pela diminuição do tempo de reparo. Nestas condições, a velocidade dos serviços de manutenção pode ser gerenciada através dos seguintes indicadores:

- Principais:

$\checkmark$ TMDR - Tempo Médio de Reparo;

$\checkmark \quad$ IPR - Indisponibilidade Programada;

$\checkmark$ VAT - Velocidade de Atendimento;

- Complementares:

$\checkmark$ DIP - Disponibilidade Programada;

$\checkmark$ NI - Número de Intervenções;

$\checkmark$ HCI - Horas Consumidas nas Intervenções.

\section{A. TMDR - TEMPO MÉDIO DE REPARO}

O TMDR - Tempo Médio de Reparo tem por finalidade monitorar a rapidez com que as equipes de manutenção restauram a prontidão funcional dos equipamentos. Pode ser medido pela equação:

$$
\text { TMDR }=\frac{\sum_{1}^{\mathrm{i}}(\mathrm{HCI})_{\mathrm{i}}}{\sum_{1}^{\mathrm{i}}(\mathrm{NI})_{\mathrm{i}}},
$$

onde,

- TMDR - Tempo Médio de Reparo do período [h];

- $\quad$ i - Indicador Referencial do Equipamento; 
- HCI - Horas Consumidas pelas Intervenções. Horas efetivamente consumidas para a realização das intervenções no equipamento, no período considerado [h]. São consideradas as intervenções de correção e de prevenção que implicam na paralisação da produção;

- NI - Número de Intervenções realizadas no equipamento, no período considerado;

\section{B. IPR - INDISPONIBILIDADE PROGRAMADA}

A IPR - Indisponibilidade Programada reflete antecipação às falhas, de tal modo que o fluxo produtivo não seja interrompido por uma falha inesperada e venha a comprometer a velocidade de entrega. A IPR pode ser formulada através da expressão:

$$
\mathrm{IPR}=\frac{\sum_{1}^{\mathrm{i}}(\mathrm{HMP})_{\mathrm{i}}}{\sum_{1}^{\mathrm{i}}(\mathrm{HS})_{\mathrm{i}}} .
$$

Na seqüência pode-se calcular a DIP - Disponibilidade Programada pela expressão:

$$
\mathrm{DIP}=1-\mathrm{IPR}=1-\frac{\sum_{1}^{\mathrm{i}}(\mathrm{HMP})_{\mathrm{i}}}{\sum_{1}^{\mathrm{i}}(\mathrm{HS})_{\mathrm{i}}},
$$

onde,

- DIP - Disponibilidade Programada no período [\%];

- IPR - Indisponibilidade Programada no período [\%];

- $\quad$ i - Indicador Referencial do Equipamento;

- HMP - Horas em Manutenção Preventiva do equipamento no período considerado [h];

- HS - Horas em Serviço do equipamento no período considerado [h]. 


\section{VAT - VELOCIDADE DE ATENDIMENTO}

A VAT - Velocidade de Atendimento reflete a prontidão das equipes de manutenção para restaurar o estado de funcionamento dos equipamentos.

A Velocidade de Atendimento também se relaciona com a eficiência das equipes de manutenção, na medida em que compara os tempos planejados e os efetivamente consumidos nas atividades de manutenção.

A VAT pode ser formulada através da expressão:

$$
\mathrm{VAT}=\frac{\sum_{1}^{\mathrm{i}}(\mathrm{HPI})_{\mathrm{i}}}{\sum_{1}^{\mathrm{i}}(\mathrm{HCI})_{\mathrm{i}}},
$$

onde,

- VAT - Velocidade de Atendimento no período [\%];

- i - Indicador Referencial do Equipamento;

- HPI - Horas Previstas para as Intervenções. Horas planejadas para a realização das intervenções no equipamento, no período considerado [h];

- HCI - Horas Consumidas pelas Intervenções em [h].

\subsubsection{A CONFIABILIDADE DOS SERVIÇOS DE MANUTENÇÃO}

A confiabilidade dos serviços de manutenção é traduzida pela disponibilidade e desempenho dos equipamentos, sistemas e instalações.

A disponibilidade, por sua vez, é dependente das condições de projeto dos ativos (confiabilidade inerente) e da facilidade de efetuar a intervenção (manutenibilidade).

O modelo de gestão propõe os seguintes indicadores para a gestão da confiabilidade dos ativos de uma empresa industrial:

- Principais:

$\checkmark$ TMEF - Tempo Médio Entre Falhas; 
$\checkmark$ IRE - Índice de Risco de Equipamentos;

$\checkmark$ IFO - Indisponibilidade Forçada;

- Complementares

$\checkmark$ NF - Número de Falhas;

$\checkmark$ HMC - Horas de Manutenção Corretiva;

$\checkmark$ DIF - Disponibilidade Forçada.

\section{A. TMEF - TEMPO MÉDIO ENTRE FALHAS}

O TMEF - Tempo Médio entre falhas sinaliza a freqüência de falhas nos equipamentos da operação, num dado período de observação. Quanto maior o TMEF, menor será taxa de falhas dos equipamentos e, por conseguinte, maior também será a confiabilidade dos mesmos. Na verdade, o TMEF reflete o tempo médio de bom funcionamento dos equipamentos da produção e pode ser medido pela expressão [3-14]:

$$
\mathrm{TMEF}=\frac{\sum_{1}^{\mathrm{i}}(\mathrm{HS})_{\mathrm{i}}}{\sum_{1}^{\mathrm{i}}(\mathrm{NF})_{\mathrm{i}}},
$$

onde,

- TMEF - Tempo Médio Entre Falhas no período[h];

- i - Indicador Referencial do Equipamento;

- HS - Horas em Serviço do equipamento no período considerado [h];

- NF - Número de Falhas que ocorreram no equipamento, no período considerado.

Convém assinalar que serão levados em conta os seguintes critérios para a padronização da seleção de ocorrências para os equipamentos em análise:

- Falhas durante a operação em vazio e carga do equipamento;

- Falhas na partida do equipamento; 
- Falhas durante ensaio no equipamento;

- Falhas em equipamentos externos que implicam em falhas no equipamento objeto da análise;

- Falhas em equipamentos auxiliares que implicam em falhas para o equipamento objeto da análise.

\section{B. IRE - ÍNDICE DE RISCO DE EQUIPAMENTO}

O IRE - Índice de Risco de Equipamento tem a sua formulação calcada na Análise do Efeito e Modo de falhas (FMEA), tal como proposta por SLACK ET AL (1999). O indicador relata o risco potencial de um equipamento falhar e do dano que a falha pode representar, além de considerar a facilidade da falha ser detectada antes que aconteça. Assim, o índice representa um instrumento preventivo para avaliar o risco potencial dos equipamentos falharem.

O IRE monitora os equipamentos a partir de suas falhas e em termos dos seguintes fatores: nível de ocorrência, grau de gravidade e facilidade de detecção.

O nível de ocorrência designa a possibilidade de uma determinada falha ocorrer no equipamento. Reflete a freqüência da falha no equipamento. A falha que tiver um nível de ocorrência maior terá um maior peso no IRE.

O grau de gravidade da falha representa a extensão do dano que uma determinada falha causa no equipamento, no processo ou no produto, caso venha a ocorrer em vez de outra. Quanto maior o dano causado pela falha, tanto maior será o seu peso no índice.

A facilidade de deteç̧ão expressa a possibilidade da falha ser detetada antes que efetivamente aconteça e, portanto, não provocar dano ao equipamento, processo ou produto. Quanto maior a facilidade de a falha ser detetada tanto menor será seu peso no índice.

O indicador hierarquiza os equipamentos que apresentam os maiores riscos potenciais de falhas e assinala as falhas mais importantes a eles relacionadas. São duas análises seguidas, com grau de detalhamento crescente. Em primeiro lugar, aponta para o equipamento com o maior risco potencial de falha e, em seguida, para 
a falha de maior ocorrência, de maior grau de gravidade e de menor facilidade de deteç̧ão.

Assim, o IRE enseja atividades de manutenção preventiva. Permite ao planejador priorizar ações no sentido de monitorar, mais de perto, aqueles equipamentos que apresentam os maiores riscos potenciais. Será possível, também, definir procedimentos que eliminem a possibilidade de ocorrência da falha, uma vez que foi avaliado à priori, o seu dano, a sua freqüência e a sua dificuldade de detecção.

Com essa sistemática, o gerente saberá então onde concentrar seus esforços. Qual equipamento com maior potencial de risco? Qual falha com maior potencial de risco no equipamento?

A equação [3-15] expressa o indicador relatado:

$$
\operatorname{IRE}=\sum_{1}^{\mathrm{i}}(\mathrm{IRF})_{\mathrm{i}}=\sum_{1}^{\mathrm{i}}\left(\sum_{1}^{\mathrm{j}}(\mathrm{O} \times \mathrm{G} \times \mathrm{D})_{\mathrm{j}}\right)_{\mathrm{i}},
$$

onde:

- IRE - Índice de Risco de Equipamento;

- IRF - Índice de Risco da Falha no Equipamento;

- i - Indicador Referencial do Equipamento;

- j - Indicador Referencial da Falha;

- O - Nível de Ocorrência da Falha. Número de vezes que a falha ocorre no período de avaliação. Este número traduz a influência da ocorrência da falha no índice. Quanto maior a ocorrência, maior a influência;

- G - Grau de Gravidade da Falha. Avalia o efeito da falha no equipamento. Está caracterizada em dois níveis: torna o equipamento indisponível (peso 10) e não torna o equipamento indisponível (peso 1);

- D - Deteção. Expressa a dificuldade de detetar a falha antes que ela ocorra. Está caracterizado em três níveis: nenhuma dificuldade (peso 1), média dificuldade (peso 5) e grande dificuldade (peso 10). 
Convém salientar que a apuração do IRE é dependente de uma providência acessória e anterior: padronização das falhas. Tal padronização compreende a classificação e a codificação das falhas de tal modo que garanta total clareza na sua identificação nos registros de ocorrências.

\section{IFO - INDISPONIBILIDADE FORÇADA}

A IFO - Indisponibilidade Forçada reflete o tempo de não funcionamento dos ativos devido às intervenções de reparo, relatada por FURMANN (2002). Reflete a confiabilidade inerente dos equipamentos. Correlaciona-se negativamente com a disponibilidade que é afetada pela freqüência de manutenção (confiabilidade) e pela facilidade de execução da intervenção (manutenibilidade). Assim, a disponibilidade aumenta e, portanto, aumenta também a confiabilidade na medida em que a indisponibilidade forçada dos ativos diminui.

A IFO pode ser formulada pela equação:

$$
\mathrm{IFO}=\frac{\sum_{1}^{\mathrm{i}}(\mathrm{HMC})_{\mathrm{i}}}{\sum_{1}^{\mathrm{i}}(\mathrm{HS})_{\mathrm{i}}} .
$$

Na seqüência, a DIF - Disponibilidade Forçada pode ser calculada pela expressão:

$$
\mathrm{DIF}=1-\mathrm{IFO}=1-\frac{\sum_{1}^{\mathrm{i}}(\mathrm{HMC})_{\mathrm{i}}}{\sum_{1}^{\mathrm{i}}(\mathrm{HS})_{\mathrm{i}}},
$$

onde,

- DIF - Disponibilidade Forçada do período [\%];

- IFO - Indisponibilidade Forçada do período, devida às intervenções corretivas [\%];

- i - Indicador Referencial do Equipamento; 
- HMC - Horas em Manutenção Corretiva do equipamento no período considerado [h];

- HS - Horas em Serviço do equipamento no período considerado [h]

\subsubsection{A FLEXIBILIDADE DOS SERVIÇOS DE MANUTENÇÃO}

A flexibilidade deve ser vista como a habilidade das equipes de manutenção para efetuar qualquer tipo de intervenção nos equipamentos. Tal habilidade reflete rapidez nos diagnósticos das causas das falhas, além de explicitar a existência de equipes altamente capazes e multifuncionais.

Desta forma, a gestão da flexibilidade dos serviços de manutenção pode ser feita pelos dos seguintes indicadores:

- TPE - Taxa de Polivalência das Equipes;

- TRT - Taxa de Realização de Treinamentos;

- TRSM - Taxa de Reatividade dos Serviços de Manutenção.

\section{A. TPE - TAXA DE POLIVALÊNCIA DAS EQUIPES}

A percepção da flexibilidade dos serviços de manutenção pode ser sentida pela adaptação das equipes às necessidades, sempre mutantes, dos diversos clientes. Nesta linha, a flexibilidade está diretamente relacionada à polivalência das diversas equipes de manutenção e o indicador associado pode ser a TPE - Taxa de Polivalência das Equipes de manutenção.

O indicador diz respeito ao grau de homogeneidade da competência das diferentes equipes. Assim, a equipe de maior polivalência é aquela capaz de intervir em um número maior de equipamentos. Nestas condições, a TPE pode ser formulada pela equação:

$$
\mathrm{TPE}=\frac{\sum_{1}^{\mathrm{i}}(\mathrm{NIRE})_{\mathrm{i}}}{\sum_{1}^{\mathrm{i}}(\mathrm{NTIR})_{\mathrm{i}}},
$$


onde,

- TPE - Taxa de Polivalência de uma dada equipe no período [\%];

- $\quad$ i - Indicador Referencial do Equipamento;

- NIRE - Número de Intervenções Realizadas pela Equipe no equipamento, no período considerado;

- NTIR - Número Total de Intervenções Realizadas no equipamento, no período considerado.

Como se pode observar, o crescimento da TPE significa que a equipe é capaz de intervir em um maior número de equipamentos.

\section{B. TRT - TAXA DE REALIZAÇÃO DE TREINAMENTOS}

A existência de equipes altamente capazes e multifuncionais está condicionada ao grau de conhecimento técnico e experiência necessária ao planejamento, organização e execução das atividades de manutenção.

O indicador relacionado pode ser a TRT - Taxa de Realização de Treinamentos. A TRT estabelece as necessidades de treinamentos (competência a ser adquirida) para as diferentes especialidades e o cumprimento das mesmas dentro de um período considerado. Assim, a TRT é formulada pela expressão:

$$
\mathrm{TRT}=\frac{\mathrm{HTR}}{\mathrm{HTP}},
$$

onde,

- TRT - Taxa de Realização de Treinamentos para uma dada especialidade no período considerado [\%];

- HTR - Horas de Treinamento Realizadas para a especialidade, no período considerado [h];

- HTP - Horas de Treinamento Previstas para a especialidade, no período considerado [h]. 
É possível perceber que na medida em que a TRT cresce maior é o número de treinamentos realizados para a especialidade e, portanto, a competência da equipe também cresce.

Assim, é de se esperar que a polivalência da equipe também aumente. Caso contrário, a gerência deverá rever o conteúdo dos treinamentos para as reais necessidades da manutenção.

\section{TRSM - TAXA DE REATIVIDADE DOS SERVIÇOS DE MNT}

A flexibilidade dos serviços de manutenção tem implicação sobre as horas paralisadas de produção. Principalmente aquelas relacionadas com as intervenções corretivas.

As horas paralisadas de produção, conforme já mencionado no Título 2.1.1, necessariamente incluem os tempos destinados a: emissão de documentos; diagnóstico da causa das falhas; preparação de materiais, ferramentas e dispositivos; deslocamentos; isolação do equipamento; reparo propriamente dito; recomposição do equipamento; baixa de documentos.

O indicador associado é a TRSM - Taxa de Reatividade dos Serviços de Manutenção, formulada pela equação:

$$
\mathrm{TRSM}=\frac{\mathrm{NORR}}{\mathrm{NSRR}},
$$

onde,

- TRSM - Taxa de Reatividade dos Serviços de Manutenção no período considerado [\%];

- NORR - Número de Ordens de Reparo Realizadas pela manutenção no período considerado;

- NSRR - Número de Solicitações de Reparo Recebidas pela manutenção no período considerado. 
Pode-se perceber que, à medida que a TRSM diminui, significa que os serviços de manutenção não conseguem cumprir as solicitações de reparos em um mesmo período.

Em conseqüência, tal fato denota um crescimento das paralisações da produção, além de comprometer a flexibilidade dos serviços e influir negativamente nos custos, confiabilidade, qualidade e velocidade das atividades de manutenção.

\subsubsection{OS CUSTOS DAS ATIVIDADES DE MANUTENÇÃO}

Em função de toda a discussão conduzida no Título 2.4.4 do Capítulo 2 (As Teorias de Base), a metodologia do ABC será a adotada para a gestão do custeio dos serviços de manutenção. Isto porque o Sistema ABC tem uma conotação bem mais acentuada para a gestão de custos do que simplesmente para o custeio de objetos.

São duas visões presentes no método. A visão econômica de custeio (visão vertical) explica que as atividades consomem recursos (gerando custos) e os produtos utilizam ou consomem as atividades, absorvendo seus custos. O modelo da visão econômica de custeio pode ser vista na Figura 2-30.

Já a visão de aperfeiçoamento de processos (visão horizontal) considera que os processos são formados por atividades que se inter-relacionam. Explica como tais processos absorvem os custos das atividades interdepartamentais que os compõem.

O modelo da visão horizontal está apresentado na Figura 2-34.

Desta forma, a lógica do Sistema ABC encaixa-se perfeitamente no processo de gestão dos serviços de manutenção. Tal processo naturalmente inclui o gerenciamento de seus custos, além de produzir informações acuradas para a apreciação do desempenho global da organização.

Assim, a Figura 3-3 apresenta um fluxograma básico para a determinação dos custos e dos indicadores associados para a gestão dos custos dos serviços de manutenção em um período de tempo considerado. 


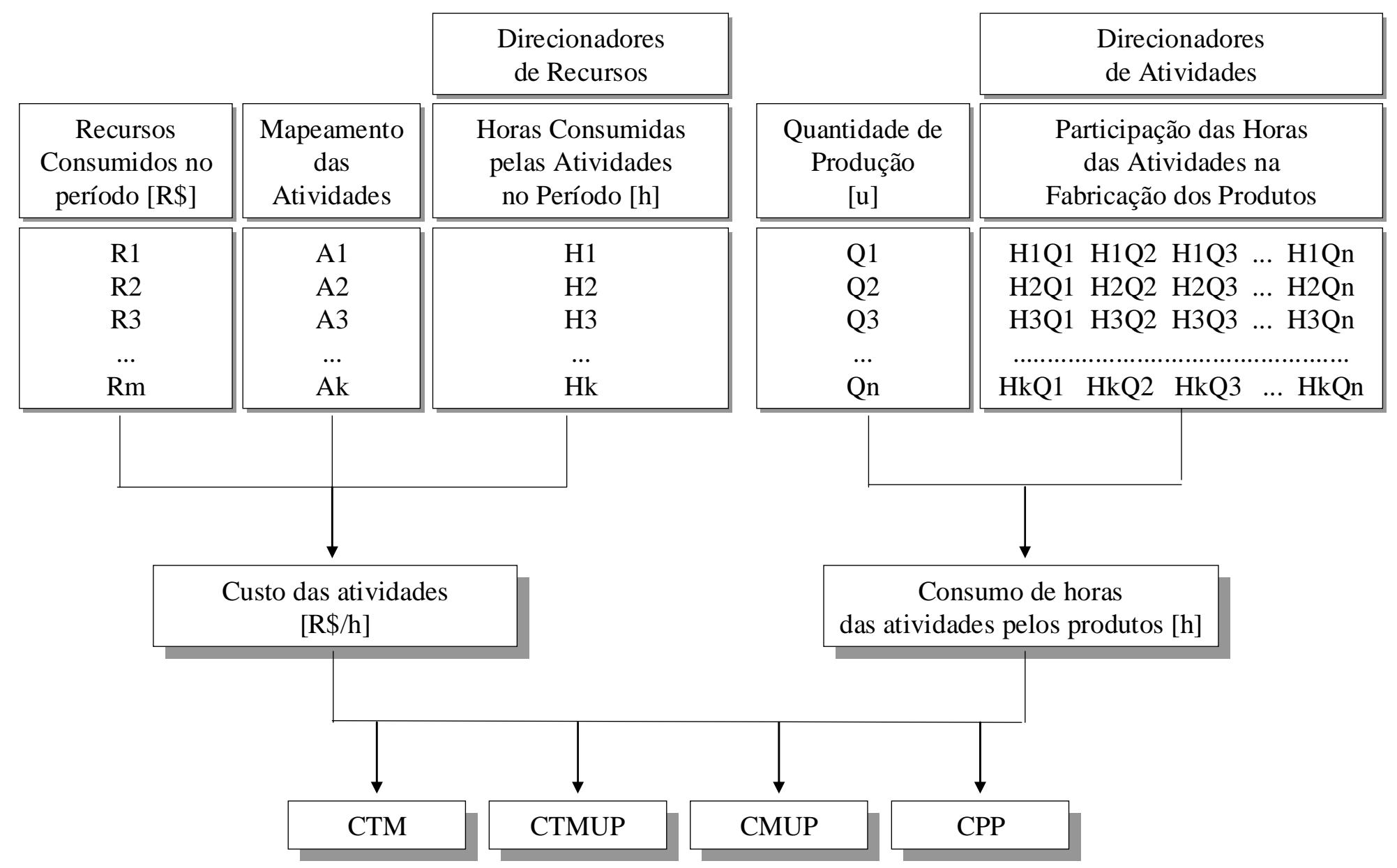

Figura 3-4 - Fluxograma para a Gestão dos Custos de Manutenção. 
Nestas condições, a gestão dos custos dos serviços de manutenção poderá ser feita pelos indicadores:

- Principais:

$\checkmark$ CTM - Custo Total de Manutenção;

$\checkmark$ CTMUP - Custo Total de Manutenção por Unidade Produzida;

$\checkmark$ CMUP - Custo de Manutenção por Unidade de Produto;

$\checkmark$ CPP - Custo das Paralisações da Produção;

- Complementares:

$\checkmark$ CAA - Custo das Atividades de Apoio;

$\checkmark$ CMC - Custo da Manutenção Corretiva;

$\checkmark$ CMP - Custo da Manutenção Preventiva;

$\checkmark$ CHA - Custo Horário das Atividades de Manutenção;

$\checkmark$ CHS - Custo da Hora em Serviço dos Equipamentos.

\section{A. CTM - CUSTO TOTAL DE MANUTENÇÃO}

É contabilizado pelos gastos totais das atividades presentes nos serviços de manutenção, no período considerado. O CTM - Custo Total de Manutenção é calculado através da expressão:

$\mathrm{CTM}=\mathrm{CAA}+\mathrm{CMC}+\mathrm{CMP}+\mathrm{CPP}$

onde, para o período considerado, tem-se:

- CTM - Custo Total de Manutenção [R\$];

- CAA - Custo das Atividades de Apoio em [R\$], ver Título 2.5.2;

- CMC - Custo da Manutenção Corretiva em [R\$], ver Título 2.5.3;

- CMP - Custo da Manutenção Preventiva em [R\$], ver Título 2.5.4;

- CPP - Custo da Paralisação da Produção em [R\$], ver Título 2.5.5. 


\section{B. CAA - CUSTO DAS ATIVIDADES DE APOIO}

O CAA - Custo das Atividades de Apoio reflete o esforço despendido pelas atividades de apoio à manutenção. Representa aquelas atividades que não estão diretamente envolvidas com a restauração da prontidão funcional dos ativos, mas que são imprescindíveis para que tal prontidão possa ser restaurada. Dentre elas podemse citar as atividades de planejamento, programação e controle da manutenção, atividades de engenharia e atividades relacionadas com o setup dos processos produtivos. O CAA - Custo das Atividades de Apoio é calculado pela expressão:

$\mathrm{CAA}=\mathrm{CHA} \times \mathrm{HAA}$,

onde,

- CHA - Custo Horário das Atividades de Manutenção em [R \$h];

$\mathrm{CHA}=\frac{\sum_{1}^{\mathrm{m}}(\mathrm{R})_{\mathrm{m}}}{\mathrm{H}}$,

$\checkmark$ R-Recurso Consumido no período;

$\checkmark$ m - Indicador Referencial do Recurso;

$\checkmark$ H - Horas do período considerado;

- HAA - Horas das Atividades de Apoio à manutenção realizadas no período considerado, em [h].

Assim, a expressão definitiva do CAA - Custo das Atividades de Apoio é escrita da seguinte maneira:

$$
\mathrm{CAA}=\left[\frac{\sum_{1}^{\mathrm{m}}(\mathrm{R})_{\mathrm{m}}}{\mathrm{H}}\right] \times \mathrm{HAA}
$$

\section{CMC - CUSTO DA MANUTENÇÃO CORRETIVA}

O CMC - Custo da Manutenção Corretiva é obtido pela expressão: 


$$
\mathrm{CMC}=\mathrm{CHA} \times \sum_{1}^{\mathrm{i}}(\mathrm{HMC})_{\mathrm{i}} ;
$$

onde,

- CHA - Custo Horário das Atividades de Manutenção, calculado conforme a equação [3-25], em [R\$/h];

- HMC - Horas de Manutenção Corretiva do período [h];

- $\quad$ i - Indicador Referencial do Equipamento.

Assim, o Custo da Manutenção Corretiva (CMC) é definitivamente formulado na forma:

$$
\mathrm{CMC}=\left[\frac{\sum_{1}^{\mathrm{m}}(\mathrm{R})_{\mathrm{m}}}{\mathrm{H}}\right] \times\left[\sum_{1}^{\mathrm{i}}(\mathrm{HMC})_{\mathrm{i}}\right] .
$$

\section{CMP - CUSTO DA MANUTENÇÃO PREVENTIVA}

O CMP - Custo da Manutenção Preventiva é calculado pela equação:

$$
\mathrm{CMP}=\mathrm{CHA} \times \sum_{1}^{\mathrm{i}}(\mathrm{HMP})_{\mathrm{i}},
$$

onde,

- CHA - Custo Horário das Atividades de Manutenção em [R $\$ / h]$, conforme já definido pela equação [3-25];

- HMP - Horas de Manutenção Preventiva do período [h];

- $\quad$ i - Indicador Referencial do Equipamento.

Assim, o Custo da Manutenção Preventiva (CMP) é definitivamente formulado como: 


$$
\mathrm{CMP}=\left[\frac{\sum_{1}^{\mathrm{m}}(\mathrm{R})_{\mathrm{m}}}{\mathrm{H}}\right] \times\left[\sum_{1}^{\mathrm{i}}(\mathrm{HMP})_{\mathrm{i}}\right]
$$

\section{E. CPP - CUSTO DAS PARALISAÇÕES DA PRODUÇÃO [R\$]}

O CPP - Custo das Paralisações da Produção é contabilizado pelo custo da não produção. Isto é, pelo custo de oportunidade das vendas das unidades que deixaram de ser produzidas durante as horas paralisadas. Reflete o que a empresa deixou de ganhar, como bem lembra MARTINS (2001). O custo de oportunidade é realmente um lucro cessante. Assim, o CPP é formulado pela expressão:

$$
\mathrm{CPP}=\sum_{1}^{\mathrm{i}}(\mathrm{CNP})_{\mathrm{i}}
$$

onde,

- CPP - Custo das Paralisações da Produção [R\$];

- i - Indicador Referencial do Equipamento;

- CNP - Custo da Não Produção do equipamento em [R\$]:

$$
\mathrm{CNP}=\sum_{1}^{\mathrm{n}}(\mathrm{LU} \times \mathrm{QNP})
$$

$\checkmark \mathrm{n}$ - Indicador Referencial do Produto;

$\checkmark$ LU - Lucro Unitário do produto [R \$/u];

$\checkmark$ QNP - Quantidade Não Produzida de produto durante as horas paralisadas [u].

Logo, a expressão definitiva do CPP é:

$$
\mathrm{CPP}=\sum_{1}^{\mathrm{i}}\left[\sum_{1}^{\mathrm{n}}(\mathrm{LU} \times \mathrm{QNP})_{\mathrm{n}}\right]_{\mathrm{i}}
$$

As horas paralisadas incluem todas as paralisações devidas às intervenções e à logística de suprimentos ou de pessoal, como já discutido no Título 2.1.1: 
$\checkmark$ Emissão de documentos;

$\checkmark$ Preparação de materiais, ferramentas e dispositivos;

$\checkmark$ Isolação do equipamento;

$\checkmark$ Intervenção de reparo, ou de prevenção, propriamente dita;

$\checkmark$ Recomposição do equipamento;

$\checkmark$ Baixa de documentos.

Assim, pelo o que descrito nos títulos anteriores, o CTM - Custo Total de Manutenção pode ser definitivamente expresso pela equação:

$$
\mathrm{CTM}=\left[\frac{\sum_{1}^{\mathrm{m}}(\mathrm{R})_{\mathrm{m}}}{\mathrm{H}}\right] \times\left[\mathrm{HAA}+\sum_{1}^{\mathrm{i}}(\mathrm{HMC}+\mathrm{HMP})_{\mathrm{i}}\right]+\sum_{1}^{\mathrm{i}}\left[\sum_{1}^{\mathrm{n}}(\mathrm{LU} \times \mathrm{QNP})_{\mathrm{n}}\right]_{\mathrm{i}}
$$

Em que,

- $\mathrm{R}$ - Recurso consumido no período em [R $\$ / \mathrm{h}]$;

- m - Indicador Referencial do Recurso;

- HAA - Horas das Atividades de Apoio à manutenção realizadas no período considerado, em [h];

- $\quad$ i - Indicador Referencial do Equipamento;

- HMC - Horas de Manutenção Corretiva do período [h];

- HMP - Horas de Manutenção Preventiva do período [h];

- $\mathrm{n}$ - Indicador Referencial do Produto;

- LU - Lucro Unitário do Produto em [R \$/u];

- QNP - Quantidade Não Produzida de produto durante as horas paralisadas [u]. 


\section{F. CTMUP - CUSTO TOTAL DE MNT POR UNIDADE PRODUZIDA}

É contabilizado pelo CTM - Custo Total de Manutenção e pelas quantidades de produtos fabricados no período considerado. O CTMUP - Custo Total de Manutenção por Unidade Produzida é expresso pela equação:

$$
\text { CTMUP }=\frac{\text { CTM }}{\sum_{1}^{n}(Q)_{n}},
$$

onde,

- CTMUP - Custo Total de Manutenção por Unidade Produzida [R\$/u];

- CTM - Custo Total de Manutenção no período considerado em [R\$], calculado de acordo com a equação [3-34];

- $\mathrm{n}$ - Indicador referencial do produto;

- Q - Quantidade de produtos fabricada no período considerado [u].

\section{G. CMUP - CUSTO DE MANUTENÇÃO POR UNIDADE DE PRODUTO}

É contabilizado pelo custo das atividades envolvidas na fabricação da quantidade de determinado produto, no período considerado. O CMUP - Custo de Manutenção por Unidade de Produto pode ser calculado pela expressão:

$$
\mathrm{CMUP}_{\mathrm{n}}=\frac{\mathrm{CHA} \times \mathrm{HS}_{\mathrm{n}}}{\mathrm{Q}_{\mathrm{n}}},
$$

onde,

- $\mathrm{CMUP}_{\mathrm{n}}$ - Custo de Manutenção por Unidade do Produto n [R\$/u];

- $\mathrm{n}$ - Indicador Referencial do Produto;

- CHA - Custo Horário das Atividades de Manutenção, no período considerado [R $\$ / \mathrm{h}]$, calculado de acordo com a equação [3-25];

- $\mathrm{HS}_{\mathrm{n}}$ - Horas em Serviço consumidas na fabricação das unidades do produto n, no período considerado [h]; 
- $\mathrm{Q}_{\mathrm{n}}$ - Unidades fabricadas do produto $\mathrm{n}$, no período considerado [u].

Logo, a expressão definitiva do CMUP é:

$$
\mathrm{CMUP}_{\mathrm{n}}=\left[\frac{\sum_{1}^{\mathrm{m}}(\mathrm{R})_{\mathrm{m}}}{\mathrm{H}}\right] \times\left[\frac{\mathrm{HS}_{\mathrm{n}}}{\mathrm{Q}_{\mathrm{n}}}\right] .
$$

\section{H. CHS - CUSTO DA HORA EM SERVIÇO DOS EQUIPAMENTOS}

O CHS - Custo da Hora em Serviço dos Equipamentos reflete o esforço da função manutenção em manter os equipamentos funcionando. Representa a participação do esforço do setor na geração de riqueza da organização. O CHS pode ser apurado através da equação:

$$
\mathrm{CHS}=\frac{\mathrm{CTM}}{\sum_{1}^{\mathrm{i}}(\mathrm{HS})_{\mathrm{i}}},
$$

onde,

- CHS - Custo da Hora em Serviço dos Equipamentos em [R $\$ / h]$;

- CTM - Custo Total de Manutenção no período considerado em [R\$], calculado de acordo com a equação [3-34];

- HS - Horas em Serviço do equipamento no período considerado em [h];

- $\quad$ i - Indicador Referencial do Equipamento.

\subsection{CONSIDERAÇÕES FINAIS}

O Modelo de Gestão adotado dá sustentação para se atingir aos objetivos gerais e específicos do trabalho, conforme relatado no Título 1.2.1 do Capítulo 1 Introdução. Primeiramente, porque os elementos de desempenho considerados explicam de forma clara e consistente como a função manutenção deve ser estruturada e gerida. Explicam também como o setor pode contribuir para o desempenho global da organização. 
Em segundo lugar, os indicadores propostos gerenciam os objetivos de desempenho da função manutenção que produzem impactos na função produtiva da organização. Além disso, os indicadores não apresentam qualquer tipo de ambigüidade. São de fácil compreensão, levantamento e uso.

A lógica de sua formulação promove o inter-relacionamento entre eles, por intermédio dos elementos de desempenho considerados. Assim, qualidade, confiabilidade, velocidade, flexibilidade e custos circunstanciam a gestão da função manutenção na empresa. Enfim, os indicadores propostos, além de interligados, subsidiam-se uns aos outros. Através deles é possível avaliar o desempenho da função manutenção e permitem explicar como o sucesso do setor pode ser alcançado e mantido. 


\section{Capítulo 4}

\section{Metodologia}

O título descreve os diferentes métodos de pesquisa citados na literatura e justifica aqueles adotados para a abordagem e procedimentos no desenvolvimento do trabalho. O texto delimita o universo da pesquisa e apresenta os critérios utilizados para justificar a escolha das empresas, objetos de estudo. Discorre sobre as diferentes técnicas de pesquisa e justifica aquela adotada para dar sustentação metodológica ao trabalho. O fechamento do capítulo se dá pela apresentação dos instrumentos de pesquisa que serão utilizados.

\subsection{CONSIDERAÇÕES INICIAIS}

Na definição de LAKATOS \& MARCONI (2000) o método científico é considerado como sendo um conjunto de atividades racionais e sistemáticas que permitem alcançar um dado objetivo (conhecimento válido e verdadeiro) com segurança e economia. O método delineia um caminho a ser seguido no processo investigatório, detecta erros e auxilia as decisões do investigador. Os autores discorrem sobre o desenvolvimento histórico do método, enquanto sistematização das atividades, que sofreu transformações na medida em que o conhecimento científico também evoluiu.

Relatam que somente no século XVI teve início uma linha de pensamento que propunha buscar o conhecimento calcado em bases mais garantidas, na procura do real. Não havia mais interesse em buscar as causas absolutas ou a natureza íntima das coisas. Pelo contrário, procurava-se compreender as relações entre elas. Os acontecimentos eram explicados mediante a observação científica, aliada ao raciocínio. Citam Galileu como o primeiro teórico do método experimental e relatam os principais passos de seu método como sendo: 
1) Observação dos fenômenos;

2) Análise dos elementos que constituem tais fenômenos, buscando estabelecer uma relação quantitativa entre eles;

3) Indução de certo número de hipóteses, fundamentada na análise da relação dos elementos que constituem os fenômenos;

4) Verificação experimental das hipóteses formuladas;

5) Generalização do resultado experimental para casos similares;

6) Confirmação das hipóteses e estabelecimento das leis gerais.

Os autores, na descrição do desenvolvimento histórico do método, ainda relatam os conceitos de Francis Bacon e na seqüência, o Discurso sobre o Método de Descartes. Bacon critica a lógica de Aristóteles - dedução formal de uma conclusão com base em duas premissas - porque não conduzem a um conhecimento completo do universo. Para ele, o caminho seguro para a verdade dos fatos deve acompanhar os seguintes passos:

1) Experimentação - observação e registro de todas as informações possíveis a respeito do objeto de investigação;

2) Formulação de hipóteses - explicar a relação causal entre os fatos com base na análise dos resultados obtidos da experimentação;

3) Repetição experimental - em outros lugares e por cientistas diferentes com a finalidade de acumular dados que servirão de base para a formulação de hipóteses;

4) Teste das hipóteses - repetição experimental para a confirmação das hipóteses através de novas evidências;

5) Generalização - com bases nas evidências que obteve, o cientista generaliza suas explicações para todos os fenômenos da mesma espécie.

Descartes, por sua vez, afasta-se dos processos indutivos de Galileu e Bacon para dar origem ao método dedutivo e postula quatro regras, com base na razão (princípio absoluto do conhecimento humano), para se chegar à verdade nas ciências: 
1) Evidência - "não acolher jamais como verdadeira uma coisa que não se reconheça evidentemente como tal, isto é, evitar a precipitação e o preconceito e não incluir juízos, senão aquilo que se apresenta como tal clareza ao espírito que torne impossível a dúvida”;

2) Análise - “dividir cada uma das dificuldades em tantas partes quantas necessárias para melhor resolvê-las”;

3) Síntese - “conduzir ordenadamente os pensamentos, principiando com os objetos mais simples e mais fáceis de conhecer, para subir, em seguida, pouco a pouco, até o conhecimento dos objetos que não se disponham, de forma natural, em seqüências de complexidade crescente”;

4) Enumeração - "realizar sempre enumerações tão cuidadas e revisões tão gerais que se possa ter certeza de nada haver omitido” (HEGENBERG, 1976).

Segundo BUNGE (1980) APUD LAKATOS \& MARCONI (2000) o conceito moderno do método coincide com a teoria da investigação, que alcança seus propósitos, de forma científica, quando cumpre as seguintes etapas:

1) Identificação de um problema ou uma lacuna existente em um conjunto de conhecimentos;

2) Colocação precisa do problema ou a recolocação de um velho problema na visão de novos conhecimentos;

3) Busca de conhecimentos ou instrumentos que permitam a solução do problema;

4) Tentativa de solucionar o problema através dos meios disponíveis identificados;

5) Desenvolvimento de hipóteses, teorias ou técnicas ou produção de dados empíricos que possibilitem a solução do problema;

6) Obtenção de uma solução, exata ou aproximada, para o problema por meio do instrumental conceitual ou empírico disponível; 
7) Investigação das conseqüências da solução obtida em outras teorias, ou os prognósticos que possam ser feitos a partir dela;

8) Comprovação da solução no confronto das teorias e informações empíricas pertinentes;

9) Se o resultado é satisfatório, a pesquisa é dada como concluída;

10) Se o resultado não é satisfatório um novo ciclo de investigação recomeça através da correção das hipóteses, das teorias, procedimentos e dados empregados na obtenção da solução incorreta.

\subsection{MÉTODOS DE ABORDAGEM E DE PROCEDIMENTOS}

Há uma distinção entre métodos de abordagem e de procedimentos na condução de um processo investigatório. Tal distinção é decorrente dos diferentes níveis de inspiração filosófica, graus de abstração, finalidades, fases da investigação, bem como do momento em que os métodos se inserem na condução da pesquisa. Os métodos de abordagem caracterizam-se por um grau mais elevado e amplo de abstração dos fenômenos da natureza e da sociedade. Já os métodos de procedimentos sugerem etapas mais concretas do processo investigatório, com uma finalidade mais restrita e menos abstratos no que concerne às explicações gerais dos fenômenos (LAKATOS \& MARCONI, 2000).

\subsubsection{MÉTODOS DE ABORDAGEM}

\section{A. O MÉTODO INDUTIVO}

O método indutivo, na visão de CERVO \& BERVIAN (1978) APUD LAKATOS \& MARCONI (2000), é um processo mental, através do qual, partindo de dados particulares, satisfatoriamente constatados, deduz-se uma verdade geral ou universal, que não estava contida nas partes observadas (conexão ascendente). O objetivo dos argumentos indutivos é propiciar conclusões de conteúdo muito mais amplo do que os pressupostos nas quais se baseiam. Os autores relatam que é preciso 
levar em conta três elementos fundamentais no processo de indução: em primeiro lugar está a observação dos fenômenos com a finalidade precípua de descobrir as causas de sua manifestação, pela formulação de hipóteses; em uma segunda etapa procura-se descobrir a relação existente entre eles, por intermédio da comparação de fatos e dos fenômenos observados; em último lugar está a generalização da relação encontrada para fatos e fenômenos da mesma espécie ainda não observados. LAKATOS \& MARCONI (2000) deixam claro que a amostra investigada é importante para caracterizar a força do argumento indutivo. Casos existem que podem não legitimar a indução: a generalização indutiva feita a partir de dados insuficientes ou baseada em uma amostra não representativa da população.

\section{B. O MÉTODO DEDUTIVO}

O método dedutivo, utilizado por René Descartes (1596-1650), segundo SALMON (1978), apresenta duas características básicas que o distingue do indutivo. Em primeiro lugar, para o argumento dedutivo, se todas as premissas são verdadeiras, a conclusão deve ser verdadeira. Já para o argumento indutivo a conclusão não é necessariamente verdadeira, se as premissas são verdadeiras. Em segundo, o argumento dedutivo parte do princípio que toda informação ou conteúdo fatual da conclusão fazem parte, pelo menos implicitamente das premissas. Em contra partida, para o argumento indutivo a conclusão contém informações que não fazem parte, nem implicitamente das premissas.

Para o autor, os dois tipos de métodos têm propósitos diversos. Enquanto o dedutivo tem a finalidade de explicitar as premissas, o indutivo busca ampliar o alcance dos conhecimentos. O método dedutivo não admite graduações intermediárias: os argumentos dedutivos ou estão corretos ou não, em outras palavras, ou as premissas sustentam de forma completa a conclusão ou não a sustentam. Já os argumentos indutivos admitem diferentes graduações de para que as premissas dêem sustentação à conclusão. Assim, se de um lado os argumentos indutivos ampliam o conteúdo das premissas com o sacrifício da precisão, do outro, os dedutivos limitam o conteúdo das mesmas, para obter precisão. 


\section{O MÉTODO HIPOTÉTICO-DEDUTIVO}

O método hipotético-dedutivo é apresentado por POPPER (1975). O autor relata que toda discussão científica parte de um problema surgido, em geral de conflitos diante de expectativas e teorias existentes. Em seguida, uma espécie de solução provisória é oferecida. Tal solução proposta consiste de uma conjectura (nova teoria) é em seguida criticada, com vistas à eliminação de erros e por meio de testes de falseamento, isto é, tentativas de refutação, entre outros meios, pela observação e experimentação. Dessa forma, tal como no caso da dialética, esse processo se auto-renovaria, dando oportunidade ao aparecimento de novos problemas. Caso a conjectura apresentada seja refutada, haverá nova reformulação para o problema, novas hipóteses, novas conjecturas e novos testes de refutação e, se aprovada, tem-se uma nova teoria. Esta nova teoria conduzirá necessariamente a novas contradições ou problemas que serão objeto de novas investigações.

\section{O MÉTODO DIALÉTICO}

O método dialético tem suas referências assinaladas na Grécia Antiga através de filósofos como Heráclito, Parmênides e Aristóteles. Passa por Montaigne no século XVI, Diderot no século XVII chegando até Hegel, Marx e Engel. O método tem seus princípios baseados em quatro leis fundamentais: (a) Lei da ação recíproca - a dialética concebe o mundo como um conjunto de processos, onde tudo se relaciona. (b) Lei da mudança dialética - o mundo é concebido como um conjunto de processos em constante transformação. Para a dialética nada é definitivo, absoluto ou sagrado que não possa sofrer transformações. (c) Lei da mudança qualitativa - para a dialética as transformações dos processos não são indefinidamente quantitativas. Transformando-se, em determinados momentos os processos sofrem mudanças qualitativas. A quantidade transforma-se em qualidade. (d) Lei da interpenetração dos contrários - A dialética pressupõe que todos os objetos e fenômenos da natureza apresentam contradições internas. Há o lado positivo e negativo. Há o passado e o futuro. Há o que nasce e o que morre. Assim, a luta entre o velho e o novo, entre o 
elemento que desaparece e o que se desenvolve representa o conteúdo interno das transformações quantitativas em qualitativas (LAKATOS \& MARCONI, 2000).

Assim, considerando as características específicas dos diversos métodos de abordagem anteriormente detalhados, o método indutivo é escolhido como o mais adequado para dar sustentação ao projeto de pesquisa e respostas ao problema de pesquisa proposto.

\subsubsection{MÉTODOS DE PROCEDIMENTOS}

A literatura disponibiliza diferentes métodos de procedimentos para construir uma pesquisa científica conforme relatam vários autores (NAKANO \& FLEURY, 1996; LAKATOS \& MARCONI, 2000).

\section{A. MÉTODO HISTÓRICO}

O método histórico parte do pressuposto que as formas atuais da vida social, instituições e costumes têm suas raízes no passado e que é preciso investigar suas origens para melhor compreender sua natureza e função. Assim, a essência da metodologia está na investigação de acontecimentos, processos e instituições do passado para constatar sua influência na sociedade de hoje.

\section{B. MÉTODO COMPARATIVO}

A filosofia central do método é realizar comparações com a finalidade precípua de verificar similitudes e explicar diferenças. O método considera que por meio do estudo das semelhanças e divergências, entre diversos tipos de grupos, sociedades ou povos, pode se ter uma melhor compreensão do comportamento humano. 


\section{SURVEY - MÉTODO ESTATÍSTICO}

O método estatístico tem seus fundamentos na teoria das probabilidades. Permite comprovar as relações que os fenômenos guardam entre si e obter generalizações sobre sua natureza, significado ou ocorrência. O método preconiza o uso de um único instrumento de coleta de dados (em geral um questionário), aplicado a amostras de tamanho grande, pelo emprego de técnicas de amostragem e análise estatística. Tem por objetivo a coleta de dados, por entrevista ou questionário projetados para esse fim; mas, ao contrário do que ocorre na pesquisa experimental, o pesquisador não intervém em nenhum momento no processo investigatório.

\section{PESQUISA EXPERIMENTAL}

É o estudo da relação causal entre duas variáveis de um sistema sob condições controladas pelo pesquisador. O pesquisador faz o teste das hipóteses por meio de um experimento controlado, projetado de forma a produzir os dados necessários, podendo ser realizado em laboratório ou no próprio campo.

\section{E. ESTUDO TEÓRICO CONCEITUAL}

Fundamenta-se em discussões conceituais a partir da literatura, revisões bibliográficas e modelagens conceituais, baseadas na percepção e experiência do pesquisador.

\section{F. MODELAGEM}

Emprega técnicas matemáticas para descrever o funcionamento de um sistema ou de parte de um sistema produtivo.

\section{G. SIMULAÇÃO}

Emprega técnicas computacionais para simular o funcionamento de sistemas produtivos, a partir de modelos matemáticos. 


\section{H. MÉTODO FUNCIONALISTA}

O método funcionalista foi utilizado por Bronislaw Malinowski (1884-1942) e tem uma conotação mais interpretativa do que investigatória. O método leva em consideração que a sociedade funciona como um sistema organizado de atividades. De um lado a sociedade apresenta uma estrutura complexa de grupos ou indivíduos que se reúnem numa trama de ações e reações. De outro, apresenta um sistema de instituições que estão correlacionadas entre si, agem e interagem umas com as outras. A análise funcionalista envolve a integração funcional de toda a sociedade. Cada parte tem uma função específica a desempenhar no todo.

\section{MÉTODO ESTRUTURALISTA}

O método foi desenvolvido por Lévi-Strauss e sugere que o processo investigatório deve partir de um fenômeno concreto seguido de uma abstração pela construção de um modelo que represente o objeto de estudo. Em seguida, retorna-se ao real, desta vez com uma realidade estruturada e relacionada com o sujeito da investigação. O método considera que a linguagem abstrata propiciada pelo modelo do real é indispensável para comparar experiências. Assim, o método caminha do concreto para o abstrato e vice-versa, porém com um modelo para analisar a realidade concreta dos diversos fenômenos.

\section{J. PESQUISA E AÇÃO}

Trata-se de uma metodologia mais adequada a projetos de pesquisa que visem diretamente à realização do processo com uma forma inovadora e geralmente instrumental. A pesquisa aparece como um exercício compartilhado por todos os implicados e chega a confundir-se com um processo de aprendizagem coletiva. Seu resultado é um novo processo iniciado, conhecido e realizado pelos participantes. 


\section{K. MÉTODO MONOGRÁFICO - ESTUDO DE CASO}

O método foi criado por Le Play que o utilizou para estudar famílias operárias na Europa. A metodologia pressupõe que qualquer caso que se estude em profundidade pode ser considerado representativo de muitos outros. A metodologia sugere uma análise aprofundada de um ou mais objetos (casos), com o uso de múltiplos instrumentos de coleta de dados (LAKATOS \& MARCONI, 2000).

A adoção de tal metodologia em um processo investigatório remete às considerações de YIN (1994). Segundo o autor, a investigação de um fenômeno contemporâneo dentro do seu contexto real, através de múltiplas fontes de evidência tais como entrevistas, arquivos, documentos e observação, estudando situações onde as fronteiras entre o fenômeno e seu contexto não são claras, é a proposta do estudo de caso como método de pesquisa. Por outro lado, LAZZARINI (1995) assinala como vantagem da pesquisa, com base em estudo de caso, justamente essa possibilidade de utilizar várias fontes de evidência.

O estudo de caso não deve se restringir única e exclusivamente à fase exploratória de um processo investigatório, podendo mesmo ser utilizado em pesquisas descritivas ou até explanatórias. É desta forma que YIN (1994) contesta a concepção bastante difundida, de que a metodologia em apreço seria apropriada apenas para a fase exploratória de uma pesquisa. Por outro lado, RIEGE (2003) apresenta como argumento fundamental, para utilizar o estudo de caso como metodologia, o problema de pesquisa em si. Em outras palavras: a proposta de pesquisa por si só valida a utilização do método.

Os estudos de caso representam a estratégia de pesquisa que mais se ajusta a situações em que o pesquisador tem pouco controle sobre os eventos, ou quando o foco da análise está restrito a fenômenos contemporâneos, ou ainda quando são colocadas questões do tipo “como” e "por quê" (LAZARINI, 1995; YIN, 1994).

Considerando que as questões de pesquisa propostas neste trabalho buscam respostas para as questões do tipo por que o custeio e as atividades de manutenção não podem ser gerenciados sem um conjunto de indicadores? Ou, como um conjunto de indicadores gerenciais integrados pode propiciar um gerenciamento mais eficaz 
para o custeio e atividades de manutenção? Considerando ainda, que os fenômenos que serão investigados são de natureza predominantemente contemporânea, além do fato do investigador não ter controle sobre os eventos que circunstanciam o problema de pesquisa proposto. Então, em face das explanações anteriores, justifica-se adoção do Estudo de Caso como a metodologia de procedimento mais adequada para dar sustentação ao projeto de pesquisa e respostas ao problema de pesquisa proposto.

Em que pese toda a argumentação favorável de adequação do método às questões de pesquisa propostas neste trabalho, é fundamental ter sempre presente as limitações que são peculiares ao Estudo de Caso. Dentre elas podem-se citar a falta de rigor científico nos procedimentos de pesquisa, necessidade de grande habilidade do pesquisador para controlar potenciais distorções, tamanho reduzido da amostra e ausência de critérios amostrais rigorosos (VOSS, TSIRITSIS \& FROHLICH, 2002; LAZZARINI, 1995; YIN, 1994).

\subsection{DELIMITAÇÃO DO UNIVERSO DA PESQUISA}

O universo da pesquisa está restrito aos Gerendes das Áreas de Vendas, Logística, Contabilidade e Custos, Produção e Manutenção das três maiores empresas industrias produtoras de bens de consumo do distrito industrial de Itajubá, Estado de Minas Gerais, que realizaram o maior faturamento em 2004.

Além do critério do maior faturamento, a escolha das empresas para os estudos de casos foi orientada no sentido de atender a determinadas características tais como, dinamismo, líder do mercado em seu segmento e constância no seu processo de evolução. Outra característica importante levada em conta na escolha das empresas foi a sua contribuição, dentro da realidade própria de cada uma, para a modernização do país gerando tecnologia e produzindo riquezas. Outro critério considerado foi a atuação sempre presente delas, como geradoras de novas soluções para atender ao mercado em que atuam, criando empregos e integrando-se perfeitamente junto à comunidade. E, por fim, por que apresentam uma magnitude de 
dados e informações que as tornam exemplificadoras das questões pertinentes a este projeto de pesquisa, além de permitir e facilitar o acesso aos mesmos.

\subsection{AS TÉCNICAS DE PESQUISA}

Método e técnica são os componentes fundamentais que devem estar presentes em um processo investigatório. O método orienta o caminho, isto é, as fases da proposta de estudo. Com as técnicas, a maneira como a pesquisa será conduzida fica estabelecida de forma clara e simples. As técnicas, nestas condições, são as normas utilizadas nos diferentes tipos de estudos e em qualquer área do conhecimento humano. Elas se dividem em documentação direta e documentação indireta. Na documentação indireta incluem-se as pesquisas bibliográficas, pesquisas documentais e estudos exploratórios, isto é, todos os tipos de documentos escritos tais como livros, jornais, revistas, periódicos, filmes, fotografias e outros registros. Já a documentação direta faz uso de todo tipo de observação direta do fenômeno em estudo e são classificadas em observação direta intensiva e observação direta extensiva (ANDRADE, 1997; SANTOS, 2003).

LAKATOS \& MARCONI (2002) relatam as diferentes técnicas para a realização da observação direta extensiva e intensiva.

A observação direta intensiva é realizada através das seguintes técnicas:

1) Observação - os sentidos são usados na obtenção de determinados aspectos da realidade. Não se trata apenas de ver e ouvir, mas também de examinar os fatos ou fenômenos em estudo e existem as seguintes formas para a sua realização:

$\checkmark$ Observação sistemática - quando é planejada, estruturada e controlada;

$\checkmark$ Observação assistemática - quando for ocasional e sem qualquer controle;

$\checkmark$ Observação participante - quando o observador participa dos fatos observados; 
$\checkmark$ Observação não participante - quando o observador se limita a observar os fatos;

$\checkmark$ Observação individual - quando é realizada por apenas um observador;

$\checkmark$ Observação em equipe - quando realizada por um grupo definido de observadores;

$\checkmark$ Observação na vida real - quando os fatos são observados no campo, na vida real;

$\checkmark$ Observação em laboratório - quando os fatos são observados em um ambiente que procura reproduzir o ambiente natural

2) Entrevista - quando ocorre um diálogo face a face com um determinado entrevistado com o objetivo de colher dados relevantes para a pesquisa proposta; a técnica pressupõe uma preparação prévia por parte do pesquisador e uma seleção precisa do entrevistado e pode ser realizada das seguintes formas:

$\checkmark$ Entrevista padronizada ou estruturada - as perguntas que são feitas à fonte selecionada obedecem a um roteiro preestabelecido;

$\checkmark$ Entrevista despadronizada ou não estruturada - perguntas abertas que ocorrem dentro de uma conversa informal; quando existe um roteiro geral informal diz-se que a entrevista é focalizada; quando há perguntas específicas não estruturadas diz-se que a entrevista é clínica; quando há o relato livre do entrevistado a entrevista é dita não dirigida;

$\checkmark$ Painel - A finalidade desse tipo de entrevista é avaliar a evolução das opiniões em períodos curtos de tempo. Assim sendo, há uma repetição das perguntas às mesmas pessoas. As perguntas, por sua vez, devem ser feitas de maneira diversa para que as respostas não sejam distorcidas em virtude das repetições. 
Já a observação direta extensiva é, segundo os autores, realizada com as seguintes técnicas:

1) Formulário - consiste em uma série de perguntas que são formuladas para a fonte pelo pesquisador e as respostas anotadas por ele;

2) Questionário - consiste num conjunto de perguntas que são respondidas pela fonte, sem a presença do pesquisador;

3) Testes - técnica quantitativa que permite avaliar rendimento, freqüência, capacidade ou conduta;

4) Sociometria - técnica quantitativa que procura explicar as relações pessoais entre indivíduos de um grupo;

5) Análise de conteúdo - técnica que permite a descrição sistemática, objetiva e quantitativa de conteúdo de comunicação;

6) Pesquisa de mercado - técnica que permite a obtenção de informações sobre o mercado, de forma organizada e sistematizada.

Levando-se em conta as características do presente estudo concernentes ao problema de pesquisa proposto, objetivo geral e específico e objeto de estudo. Considerando, também, os métodos de abordagem e procedimento selecionados para o processo investigatório em questão, a coleta de dados adquire um papel preponderante. Seja pela documentação indireta, via pesquisa documental, ou pela prática da documentação direta nas duas formas usuais de observação direta intensiva e extensiva.

Com relação à pesquisa documental, foram examinados os dados relevantes concernentes a identificação da empresa, ramo das atividades, capital, área da empresa, área construída, número de funcionários e descrição de seus produtos ou serviços. Serão, também, examinados os dados pertinentes às suas metas globais para os próximos cinco anos. Os dados das metas globais incluem as metas de produção e de vendas, de redução de preço e de prazo de entrega, metas de qualidade, de produtividade, de lucratividade e de disponibilidade financeira. 
Foi utilizada a técnica da observação direta intensiva através de entrevistas padronizadas . Foi conduzida uma conversação face a face com os gerentes responsáveis pelas áreas críticas das empresas, selecionadas para a pesquisa empírica, obedecendo a um mesmo roteiro de entrevista. O objetivo central das entrevistas foi o de obter uma visão integrada da empresas e com foco particular no setor de manutenção. Pretende-se dar um direcionamento preciso do trabalho de pesquisa, através de um entendimento claro das dificuldades operacionais que o setor está vivenciando e que de alguma forma podem afetar o desempenho das atividades que executa.

Os objetivos das entrevistas foram: identificar os problemas gerais e específicos que podem estar comprometendo o desempenho do setor de manutenção das empresas; conhecer o seu funcionamento rotineiro, suas dificuldades, seus problemas e como tais aspectos podem influenciar nas atividades do setor; identificar as ferramentas básicas de trabalho diário; travar conhecimento com o pessoal operacional do setor, sua formação, suas tarefas básicas, seus métodos de trabalho e como enfrentam os problemas diários.

A técnica da observação direta extensiva foi utilizada pelo emprego de formulários específicos com um roteiro de questões preenchido pelo pesquisador, com dados e informações fornecidas pelo entrevistado. Nestas condições, os principais dados existentes sobre falhas de equipamentos, utilização de políticas de manutenção e custos das suas atividades foram examinados. Os formulários analisaram a consistência de anotação dos dados e a forma como os mesmos estão direcionando o gerenciamento diário do setor. Identificaram, também, as carências de conhecimentos técnicos e comportamentais nas técnicas de manutenção para que se possibilite uma futura atividade de treinamento e conscientização, efetivamente direcionada para as reais necessidades do setor. 


\subsection{OS INSTRUMENTOS DE PESQUISA}

\subsubsection{INTRODUÇÃO}

A pesquisa empírica proposta no presente estudo fou efetivada conforme a metodologia descrita nos títulos anteriores e cronograma de trabalho relatado no título seguinte. A pesquisa foi realizada com a utilização dos seguintes instrumentos, aplicados nas gerências das áreas de vendas, logística, contabilidade, custos, produção e manutenção das empresas que delimitam o universo de pesquisa:

- Formulário Padronizado de Entrevista; e

- Quadros de Análise Documental.

\subsubsection{FORMULÁRIO PADRONIZADO DE ENTREVISTA}

O formulário, organizado por MIRSHAWKA \& OLMEDO (1993), foi utilizado nas entrevistas com o gerente da área de manutenção. O objetivo deste questionário foi realizar um levantamento de dados suficientes para se ter um perfil do estado atual de desempenho da função manutenção das empresas pesquisadas. O questionário foi desenvolvido, segundo os autores, para avaliar se a uma organização de manutenção pode ser classificada como manutenção de classe mundial.

\section{“IDENTIFICAÇÃO DA EMPRESA}

Razão Social:

Sigla: CGC: $|\cdot|+1-1 \cdot \mid$ $-|+|$

Endereço:

CEP: Cidade: UF: DDD: |___ Telefone:|_|_|_|_|-_____ Fax: 
Setor de Atividade:

Pessoa de Contato:

E-mail:

O nome de sua empresa poderá ser divulgado como participante do presente trabalho de pesquisa junto à Escola Politécnica da Universidade de São Paulo?
( ) $\operatorname{Sim}$
( ) Não

A empresa possui várias unidades fabris com organizações de manutenção independentes?
( ) Sim
( ) Não

Em caso afirmativo, informar o órgão/unidade responsável pelo preenchimento deste questionário.

Órgão/Unidade:

\section{ASPECTOS ORGANIZACIONAIS DA MANUTENÇÃO}

1) O organograma de sua manutenção pode ser considerado:
a) Atualizado e completo;
b) Atualizado, mas incompleto;
c) Completo, mas desatualizado;
d) Desatualizado e incompleto, porém existente;
e) Não existe organograma.

2) Cadernos de Encargos (job descriptios) estão disponíveis para:
a) Todas as posições de manutenção, incluindo os supervisores;
b) Todas as posições de manutenção, excluindo os supervisores;
c) Somente para os supervisores ou mais de $50 \%$ das posições;
d) Menos que 50\% de todas as posições da manutenção; 
e) Não existem Cadernos de Encargos.

3) Relação supervisor/funcionários diretos da manutenção:
a) 1 para 8-12;
b) 1 para $13-16$;
c) 1 para menos de 8 ;
d) 1 para mais de 16;
e) Não existe supervisor.

4) Relação planejador de manutenção/funcionários diretos da manutenção:
a) 1 para $15-20$;
b) 1 para $10-14$;
c) 1 para $21-25$;
d) 1 para 26-30;
e) Não existe planejador de manutenção ou qualquer relação diferente das citadas.

5) Mandato da gerência de manutenção:
a) Responsabilidades plenamente documentadas - completa autonomia;
b) Responsabilidades claras - boa autonomia;
c) Supervisão e coordenação informais - autonomia restrita;
d) A manutenção reporta à produção/operação;
e) Linhas de autoridade e jurisdição indefinidas.

6) Esforços e atitudes do grupo de manutenção:

a) Excelente, orgulhosos de seu profissionalismo em todos os níveis, grupo motivado;

b) Executam seu trabalho de forma profissional, constante e sem comprometimento; 
c) Trabalham na média de aceitação mas com reclamações esporádicas;

d) Freqüentes atrasos de serviços com muitas reclamações - raramente se esforçam;

e) Constantes atritos dentro do próprio grupo de manutenção e com outras áreas de operação.

7) Localização das áreas de escritórios/oficinas de manutenção:
a) Perfeita;
b) Boa (possível pequena melhoria);
c) Razoável (possível grande melhoria);
d) Sofrível (necessária grande melhoria);
e) Inadequado ou inexistente.

8) Layouts dos escritórios/oficinas de manutenção:
a) Perfeito;
b) Bom (possível pequena melhoria);
c) Razoável (possível grande melhoria);
d) Sofrível (necessária grande melhoria);
e) Inadequado ou inexistente.

9) Qualidade e quantidade das ferramentas e equipamentos de manutenção:
a) Perfeita;
b) Boa (possível pequena melhoria);
c) Razoável (possível grande melhoria);
d) Sofrível (necessária grande melhoria);
e) Inadequada ou inexistente. 
10) Qual a porcentagem do pessoal de manutenção que recebe bônus baseado no desempenho do grupo/empresa?
a) $100 \%$;
b) Acima de 90\%;
c) Entre $75 \%$ e $90 \%$;
d) Entre $50 \%$ e $75 \%$;
e) Menos que $50 \%$.

\section{PROGRAMAS DE TREINAMENTO EM MANUTENÇÃO}

1) Treinamento para supervisores:

a) Todos são treinados de acordo com plano regular e, obrigatoriamente, se treinamento adicional for necessário;

b) Todos são treinados. Treinamento adicional é oferecido de forma opcional;

c) A maioria é treinada. Treinamento regular;

d) A maioria é treinada. Treinamento não regular;

e) Poucos são treinados ou o treinamento é inexistente.

2) Treinamento para planejadores:

a) Todos os planejadores/programadores atendem a um ou mais seminários externos referentes a sua especialidade;

b) Todos os planejadores/programadores dispõem de material escrito para treinamento sobre suas atividades;

c) Todos os planejadores/programadores recebem treinamento individual, assistidos no local de trabalho durante um mês, no mínimo;

d) Planejadores/programadores aprendem trabalhando, parcialmente assistidos;

e) Não há programa de treinamento; 
3) Quais dos quatro assuntos abaixo estão incluídos no conteúdo do treinamento dado aos planejadores de manutenção de sua empresa?

1 - Planejamento de materiais;

2 - Práticas de programação;

3 - Planejamento e execução - ordens de serviço;

4 - Planejamento de projetos.

a) Inclui todos os quatro assuntos acima;

b) Inclui três dos assuntos acima;

c) Inclui dois dos assuntos acima;

d) Inclui um dos assuntos acima;

e) Não existe treinamento para planejadores.

4) Treinamento sobre produtividade e qualidade inclui:

a) Todos. Gerência, supervisores, horistas e pessoal de suporte;

b) Todos, menos pessoal de suporte;

c) Somente gerentes e supervisores;

d) Somente gerência;

e) Não há programas nesta área ou existe somente para horistas.

5) Treinamento para especialistas em manutenção:

a) Está associado a incrementos salariais, conforme avanço no programa existente;

b) Experiência anterior é necessária antes da contratação. É dado treinamento no trabalho;

c) Basta experiência anterior antes de contratar. Já inicia produzindo;

d) Treina no local após ter sido contratado. Não requer experiência;

e) Não existe treinamento formal nem pré-requisitos na contratação. 
6) Intervalos de treinamento na manutenção. Treinamento formal é ministrado a todos especialistas com a seguinte freqüência:
a) Menos que 12 meses;
b) Entre 12 e 18 meses;
c) Entre 18 e 24 meses;
d) Treinamento apenas para alguns especialistas. Qualquer freqüência acima;
e) Não há treinamento.

7) Composição do treinamento de manutenção:
a) Treinamento é todo mesclado com teoria e prática reais;
b) Treinamento é todo teórico (sala-de-aula);
c) Treinamento é todo prático (em laboratório);
d) Todo treinamento é feito no serviço real;
e) Não há programa de treinamento;

8) Instrutores do programa de treinamento:
a) Conduzido por especialistas externos;
b) Conduzido pelo especialista do "staff";
c) Conduzido pelos supervisores;
d) Conduzido pelos horistas;
e) Não existe programa de treinamento.

9) A qualidade, nível de conhecimento/habilidade do grupo de especialistas da manutenção é:
a) Perfeito;
b) Bom (possível pequena melhoria);
c) Razoável (possível grande melhoria);
d) Sofrível (necessária grande melhoria); 
e) Inaceitável.

10) A qualidade, nível de conhecimento/habilidade do grupo de supervisores é:
a) Perfeito;
b) Bom (possível pequena melhoria);
c) Razoável (possível grande melhoria);
d) Sofrível (necessária grande melhoria);
e) Inaceitável.

\section{ORDENS DE SERVIÇO DA MANUTENÇÃO}

1) Que porcentagem aproximada dos homens.hora de manutenção é alocada em ordens de serviço?
a) $100 \%$;
b) $75 \%$;
c) $50 \%$;
d) $25 \%$;
e) Menos que $25 \%$.

2) Que porcentagem aproximada de materiais de manutenção é alocada em ordens de serviço?
a) $100 \%$;
b) $75 \%$;
c) $50 \%$;
d) $25 \%$;
e) Menos que $25 \%$.

3) Que porcentagem dos serviços de manutenção é coberta por ordens de serviço?
a) $100 \%$; 

b) $75 \%$;
c) $50 \%$;
d) $25 \%$;
e) Menos que $25 \%$.

4) Que porcentagem de ordens de serviço, incompletas ou de backlog ${ }^{1}$ é mantida arquivada por número/código do equipamento?
a) $100 \%$;
b) $75 \%$;
c) $50 \%$;
d) $25 \%$;
e) Menos que $25 \%$.

5) Que porcentagem de ordens de serviço é arquivada por número/código do equipamento após concluídas as intervenções?
a) $100 \%$;
b) $75 \%$;
c) $50 \%$;
d) $25 \%$;
e) Menos que $25 \%$.

6) Que porcentagem das ordens de serviço está disponível para análise dos dados históricos dos equipamentos?
a) $100 \%$;
b) $75 \%$;

${ }^{1}$ É o montante de serviços de manutenção a realizar num determinado momento. Normalmente é medido em homens-hora, podendo ser dividido por especialidades. Serviços pendentes (MIRSHAWKA \& OLMEDO, 1993). 
c) $50 \%$;

d) $25 \%$;

e) Menos que $25 \%$.

7) Que porcentagem das ordens de serviço é conferida pelo supervisor nos aspectos de qualidade e efetiva a conclusão do serviço?
a) $100 \%$;
b) $75 \%$;
c) $50 \%$;
d) $25 \%$;
e) Menos que $25 \%$.

8) Que porcentagem das ordens de serviço é encerrada dentro de oito semanas a contar da requisição dos serviços?
a) $100 \%$;
b) $75 \%$;
c) $50 \%$;
d) $25 \%$;
e) Menos que $25 \%$.

9) Que porcentagem das ordens de serviço é gerada por serviços de manutenção preventiva?
a) Entre $80 \%$ e $100 \%$;
b) Entre $60 \%$ e $80 \%$;
c) Entre $40 \%$ e $60 \%$;
d) Entre 20\% e 40\%;
e) Menos que $20 \%$. 
10) Considere as quatro informações abaixo e assinale quais as que estão contidas na ordem de serviço de sua manutenção?

1 - Tempo de desligamento;

2 - Homens.hora de especialistas necessários;

3 - Materiais necessários;

4 - Nome do requisitante/local.

a) A ordem de serviço contém as quatro informações acima;

b) Contém três das informações acima;

c) Contém duas das informações acima;

d) Contém uma das informações acima;

e) Não registra essas informações.

\section{PLANEJAMENTO E PROGRAMAÇÃO DA MANUTENÇÃO}

1) Que porcentagem de ordens de serviço, não em emergência, é executada dentro de quatro semanas a contar da solicitação dos serviços?

a) Acima de 90\%;

b) Entre $75 \%$ e $90 \%$;

c) Entre $60 \%$ e $75 \%$;

d) Entre 40\% e 60\%;

e) Menos que $40 \%$.

2) Considere o planejamento de uma ordem de serviço de sua manutenção e identifique quantos dos pontos abaixo ela inclui:

1 - Especialistas necessários;

2 - Materiais a serem utilizados;

3 - Ferramentas/equipamentos necessários; 
4 - Instruções específicas/plano de trabalho.

a) Inclui todos os quatros itens acima mencionados;

b) Inclui três dos itens acima mencionados;

c) Inclui dois dos itens acima mencionados;

d) Inclui um dos itens acima mencionados;

e) Não há planejamento.

3) Qual a porcentagem de ordens de serviço planejadas que sofreram atrasos devido à deficiências no planejamento?
a) Menos que $10 \%$;
b) Entre $10 \%$ e $20 \%$;
c) Entre $20 \%$ e $40 \%$;
d) Entre $40 \%$ e $50 \%$;
e) Mais que $50 \%$.

4) Quem é o responsável pelo planejamento das ordens de serviço?
a) Um planejador de manutenção 100\% dedicado a este trabalho;
b) Um supervisor de manutenção;
c) O gerente de manutenção;
d) Cada especialista de manutenção;
e) Não há planejamento.

5) A programação dos trabalhos é emitida com a freqüência:
a) Semanal;
b) Cada duas semanas;
c) Entre 3 e 7 dias
d) Diariamente;
e) Qualquer outra freqüência. 
6) Reuniões de manutenção com o pessoal de produção são realizadas:
a) Semanalmente
b) Cada duas semanas;
c) Entre 3 e 7 dias
d) Diariamente;
e) Qualquer outra freqüência.

7) O backlog de serviços de manutenção é possível de ser listado pelas categorias abaixo? Por quantas categorias é possível listar na sua empresa?

1 - Por especialista;

2 - Por área/departamento;

3 - Por requisitante;

4 - Por data a executar.

a) Disponível nas quatro categorias;

b) Disponível em três categorias;

c) Disponível em duas categorias;

d) Disponível em uma categoria;

e) Não controla backlog.

8) Quando o trabalho de manutenção é concluído, o tempo real gasto, o material, o tempo de desligamento e outras informações são anotados pelo:
a) Especialista que fez o serviço;
b) Supervisor do grupo;
c) Qualquer um do grupo de trabalho;
d) Planejador
e) Informações não registradas. 
9) Qual a porcentagem de acerto do planejamento comparando tempos reais com estimados?
a) Acima de $90 \%$;
b) Entre $75 \%$ e $90 \%$;
c) Entre $60 \%$ e $75 \%$;
d) Entre 40 e 60\%;
e) Menos que $40 \%$.

10) Qual a relação de chefia entre os planejadores e supervisores de manutenção?
a) Ambos se reportam ao mesmo gerente de manutenção;
b) O planejador reporta ao supervisor;
c) O supervisor reporta ao planejador;
d) O supervisor reporta à manutenção, o planejador à produção;
e) Ambos se reportam à produção.

\section{MANUTENÇÃO PREVENTIVA}

1) Um programa de manutenção preventiva inclui pontos, como:

1 - Checklist detalhado para equipamentos importantes;

2 - Lista de lubrificação dos equipamentos;

3 - Pessoal dedicado 100\% a programas de manutenção preventiva;

4 - Programas dedicados de manutenção preventiva; análise de vibrações; análise de óleo; termovisão etc.

a) Todos os quatro itens acima estão no programa de manutenção preventiva;

b) A manutenção preventiva inclui três dos itens acima;

c) A manutenção preventiva inclui dois dos itens acima;

d) A manutenção preventiva inclui um dos itens acima; 
e) Não há programa de manutenção preventiva;

2) Que porcentagem das tarefas de programa de manutenção preventiva é efetivamente realizada?

a) Acima de $90 \%$;

b) Entre $75 \%$ e $90 \%$;

c) Entre $60 \%$ e $75 \%$;

d) Entre 40\% e 60\%;

e) Menos que $40 \%$.

3) Que porcentagem dos equipamentos críticos da planta está coberta pelo programa de manutenção preventiva;

a) Acima de $90 \%$;

b) Entre $75 \%$ e $90 \%$;

c) Entre $60 \%$ e $75 \%$;

d) Entre $40 \%$ e $60 \%$;

e) Menos que $40 \%$.

4) Que porcentagem dos programas de manutenção preventiva é avaliada anualmente contra dados históricos reais conseguidos para assegurar sua eficácia?

a) Acima de $90 \%$;

b) Entre $75 \%$ e $90 \%$;

c) Entre $60 \%$ e $75 \%$;

d) Entre 40\% e 60\%;

e) Menos que $40 \%$.

5) Que porcentagem das manutenções preventivas é concluída dentro de até uma semana da data para a qual foi programada?

a) Acima de $90 \%$; 
b) Entre $75 \%$ e $90 \%$;

c) Entre $60 \%$ e $75 \%$;

d) Entre 40\% e 60\%;

e) Menos que $40 \%$.

6) O que determina a freqüência de inspeção de manutenção preventiva ou intervalos de serviços?

a) Programa baseado na condição do equipamento;

b) Programa baseado numa combinação de tempo de funcionamento do equipamento e intervalos de calendários pré-fixados;

c) Programa baseado somente no tempo de funcionamento do equipamento;

d) Programa baseado somente em intervalos de calendário;

e) Programa dinâmico, baseado na última inspeção/serviço executado.

7) Que porcentagem das inspeções/tarefas de manutenção possui mais que cinco linhas escritas de detalhes ou instruções?

a) Acima de 90\%;

b) Entre $75 \%$ e $90 \%$;

c) Entre $60 \%$ e $75 \%$;

d) Entre 40\% e 60\%;

e) Menos que $40 \%$.

8) O tempo médio para concluir uma inspeção completa de manutenção preventiva em um equipamento importante é:
a) 4 horas;
b) 4 a 8 horas;
c) 2 a 4 horas;
d) Menos que 2 horas; 
e) Qualquer outro tempo.

9) Que porcentagem do programa de manutenção preventiva é checada anualmente, comparando resultados reais com as estimativas de tempo e material?
a) Acima de 90\%;
b) Entre $75 \%$ e $90 \%$;
c) Entre $60 \%$ e $75 \%$;
d) Entre 40\% e 60\%;
e) Menos que $40 \%$.

10) Quem é responsável pela execução das tarefas de manutenção preventiva?
a) Pessoal dedicado 100\% à manutenção preventiva;
b) Pessoas específicas em cada grupo de trabalho;
c) Qualquer pessoa do grupo de manutenção;
d) Os especialistas mais novos;
e) Pessoal de operação.

\section{COMPRAS E ESTOQUES DE MANUTENÇÃO}

1) Que porcentagem de vezes que o material requisitado é encontrado no estoque da manutenção?
a) Acima de 95\%;
b) Entre $80 \%$ e $95 \%$;
c) Entre $70 \%$ e $80 \%$;
d) Entre 50\% e 70\%;
e) Menos que $50 \%$.

2) Que porcentagem dos itens em estoque dispõe de uma lista atualizada na manutenção? 

a) Acima de $90 \%$;
b) Entre $75 \%$ e $90 \%$;
c) Entre $60 \%$ e $75 \%$;
d) Entre $40 \%$ e $60 \%$;
e) Menos que $40 \%$.

3) Quem controla o que é estocado como estoque da manutenção?
a) A gerência de manutenção ouvindo seus subordinados;
b) Os supervisores de manutenção;
c) Os planejadores de manutenção;
d) Manutenção conjuntamente com a produção;
e) Outros.

4) A lista de materiais de manutenção em estoque é produzida:
a) Por computador on line com diversas opções de listagem;
b) Por ordem alfabética e códigos do item - listagem diária;
c) Por ordem alfabética - listagem periódica;
d) Por código do item - listagem periódica;
e) Não existe listagem impressa.

5) A localização cartesiana (corredor - prateleira) é disponível para quais porcentagens de materiais em estoque?
a) Acima de 95\%;
b) Entre $90 \%$ e $95 \%$;
c) Entre $80 \%$ e $90 \%$;
d) Entre 70\% e 80\%;
e) Menos que $70 \%$. 
6) Que porcentagem dos itens m estoque é retirada e debitada diretamente nas ordens de serviço específicas?
a) Acima de 95\%;
b) Entre $90 \%$ e $95 \%$;
c) Entre $80 \%$ e $90 \%$;
d) Entre $70 \%$ e $80 \%$;
e) Menos que $70 \%$.

7) Qual a porcentagem de itens de estoque da manutenção é administrada através de níveis máximos e mínimos?
a) Acima de 95\%;
b) Entre $90 \%$ e $95 \%$;
c) Entre $80 \%$ e $90 \%$;
d) Entre $70 \%$ e $80 \%$;
e) Menos que $70 \%$.

8) A lista para repor estoque é enviada para o departamento de compras:
a) Diariamente;
b) Cada 1 a 3 dias;
c) Semanalmente;
d) Quinzenalmente;
e) Outra freqüência.

9) O recebimento de novos materiais no estoque requer uma atualização diária. A que porcentagem destes recebimentos é feita a atualização imediata?
a) Acima de 95\%;
b) Entre $90 \%$ e $95 \%$;
c) Entre $80 \%$ e 90\%; 
d) Entre $70 \%$ e $80 \%$;

e) Menos que $70 \%$.

10) Que porcentagem dos itens de estoque é checada para verificar retiradas nos últimos seis meses?
a) Acima de $90 \%$;
b) Entre $80 \%$ e $90 \%$;
c) Entre $70 \%$ e $80 \%$;
d) Entre 50\% e 70\%;
e) Menos que $50 \%$.

\section{RELATÓRIOS GERENCIAIS DE MANUTENÇÃO}

1) Que porcentagem de vezes os relatórios gerenciais de manutenção chegam ao destinatário dentro de um dia da emissão?
a) Acima de $90 \%$;
b) Entre $75 \%$ e $90 \%$;
c) Entre $60 \%$ e $75 \%$;
d) Entre 40\% e 60\%;
e) Menos que $40 \%$.

2) Do número de relatórios emitidos pela manutenção. Qual a porcentagem que você avalia como úteis, realmente atingindo as pessoas certas?
a) Acima de 90\%;
b) Entre $75 \%$ e $90 \%$;
c) Entre 60\% e 75\%;
d) Entre 40\% e 60\%;
e) Menos que $40 \%$. 
3) Considere os seguintes relatórios gerados por equipamentos importantes e verifique quais são disponíveis na sua manutenção:

1 - Indisponibilidade em número de horas por equipamento, preferencialmente da maior quantidade para a menor (semanal ou mensal);

2 - Perdas de produção em R\$ por indisponibilidade, listando em ordem decrescente os equipamentos responsáveis (semanal ou mensal);

3 - Custos de manutenção incorridos, preferencialmente por equipamento (semanal ou mensal) também em ordem decrescente;

4 - Número de horas aplicadas em Manutenção Preditiva (semanal ou mensal).

a) Todos os quatro relatórios acima são disponíveis;

b) Três dos relatórios acima são disponíveis;

c) Dois dos relatórios acima são disponíveis;

d) Um dos relatórios acima são disponíveis;

e) Não existem relatórios com esses conteúdos.

4) Considere os relatórios de manutenção preventiva abaixo e indique quantos são disponíveis em sua manutenção?

1 - Lista de manutenções preventivas vencidas na data mais antiga para a mais recente;

2 - Custos em R\$ de manutenção preventiva por equipamento em ordem decrescente;

3 - Índice de horas de manutenção preventiva, comparado com as horas totais de manutenção (em \%);

4 - Índice do custo de manutenção preventiva, comparado com os custos totais de manutenção (em \%).

a) São disponíveis todos os quatro relatórios acima ou equivalentes;

b) São disponíveis três dos relatórios acima; 
c) São disponíveis dois dos relatórios acima;

d) É disponível um dos relatórios acima;

e) Não existem relatórios.

5) Observe os relatórios de pessoal de manutenção mostrados abaixo e indique quantos são disponíveis na sua manutenção:

1 - Horas trabalhadas por empregado em cada serviço/área/departamento;

2 - Horas empregadas em manutenção de emergência, corretiva e preventiva;

3 - Porcentagem de horas extras sobre as horas normais de manutenção;

4 - Porcentagem de funcionários de manutenção sobre o total de funcioários da empresa.

a) São disponíveis todos os quatro relatórios acima ou equivalentes;

b) São disponíveis três dos relatórios acima;

c) São disponíveis dois dos relatórios acima;

d) É disponível um dos relatórios acima;

e) Não existem relatórios.

6) Relatórios de planejamento - Considere os quatro tipos de relatórios a seguir e assinale quantos são emitidos pela sua manutenção:

1 - Custos estimados versus custos reais ocorridos por ordem de serviço;

2 - Relatório de backlog - total de horas já identificadas versus a capacidade de horas disponível (por semana);

3 - Relatório de eficiência de planejamento, por planejador, mostrando todos os planejamentos concluídos com desvios superiores a $20 \%$ para cima ou para baixo;

4 - Porcentagem de serviços concluídos até a data para a qual foram programados.

a) Emitidos todos os quatro relatórios acima ou equivalentes; 
b) Emitidos três dos relatórios acima;

c) Emitidos dois dos relatórios acima;

d) Emitido um dos relatórios acima;

e) Não existem relatórios.

7) Relatórios de programação - Considere os quatro tipos de relatórios de programação abaixo e assinale quantos são emitidos pela sua manutenção:

1 - Porcentagem de horas programadas referidas ao total de horas reais utilizadas na manutenção;

2 - Capacidade em horas de trabalho da equipe de manutenção nos últimos quatro meses;

3 - Número de ordens de serviços planejadas comparadas com o número de ordens concluídas (periodicidade quinzenal);

4 - Número de horas programadas para manutenção preventiva e manutenção não planejada (corretiva e de emergência).

a) Emitidos todos os quatro relatórios acima ou equivalentes;

b) Emitidos três dos relatórios acima;

c) Emitidos dois dos relatórios acima;

d) Emitido um dos relatórios acima;

e) Não existem relatórios.

8) Relatórios de estoque - Analise os quatro tipos de relatórios abaixo e assinale quantos são gerados por sua manutenção:

1 - Lista de valorização do estoque total;

2 - Lista para consulta por ordem alfabética ou produto;

3 - Lista de itens de estoque com datas de entrada, tempo de estoque e movimentação;

4 - Lista onde são usadas as peças - uso geral ou para equipamentos específicos. 
a) Gerados todos os quatro relatórios acima ou equivalentes;

b) Gerados três dos relatórios acima;

c) Gerados dois dos relatórios acima;

d) Gerado um dos relatórios acima;

e) Não existem relatórios de estoque

9) Relatórios de compra - Considere os quatro tipos de relatórios abaixo e assinale quantos são disponíveis na sua manutenção:

1 - Desempenho de fornecedores com índice de pontualidade - data prometida e data de entregue;

2 - Valores totais adquiridos para estoque, investimentos e valores comprados direto para ordens de serviço (periodicidade mensal);

3 - Avaliação global dos fornecedores - analisando consistência de preços, documentação e presteza nas cotações;

4 - Lista de fornecedores qualificados por tipos de serviços.

a) Disponíveis todos os quatro relatórios acima ou equivalentes;

b) Disponíveis três dos relatórios acima;

c) Disponíveis dois dos relatórios acima;

d) Disponível um dos relatórios acima;

e) Não existem relatórios de compra

10) Relatórios administrativos - Analise os quatro relatórios apresentados abaixo e assinale quantos deles são disponíveis:

1 - Custos totais de manutenção por unidade de produção;

2 - Comparação dos custos de manutenção orçados versus custos reais acumulados até a data (periodicidade mensal);

3 - Porcentagem dos custos de mão-de-obra e de material, comparados com os custos totais de manutenção; 
4 - Porcentagem dos custos totais de manutenção sobre o faturamento da empresa.
a) Disponíveis todos os quatro relatórios acima ou equivalentes;
b) Disponíveis três dos relatórios acima;
c) Disponíveis dois dos relatórios acima;
d) Disponível um dos relatórios acima;
e) Não existem relatórios administrativos

\section{AUTOMAÇÃO NA MANUTENÇÃO}

1) Que porcentagem das operações de manutenção é feita por computador?
a) Acima de 90\%;
b) Entre $75 \%$ e $90 \%$;
c) Entre $60 \%$ e $75 \%$;
d) Entre 40\% e 60\%;
e) Menos que $40 \%$.

2) Que porcentagem das atividades de planejamento e programação é feita por computador?
a) Acima de $90 \%$;
b) Entre $75 \%$ e $90 \%$;
c) Entre $60 \%$ e $75 \%$;
d) Entre $40 \%$ e $60 \%$;
e) Menos que $40 \%$.

3) Que porcentagem das atividades de estoque e compras é feita por computador?
a) Acima de 90\%;
b) Entre $75 \%$ e $90 \%$; 
c) Entre $60 \%$ e $75 \%$;

d) Entre $40 \%$ e $60 \%$;

e) Menos que $40 \%$.

4) Existe interligação entre as informações da manutenção e as do planejamento da produção?

a) Sim, automaticamente pelos sistemas automatizados on line;

b) Há reuniões conjuntas para decisões;

c) A manutenção informa as necessidades de interferência à produção;

d) O planejamento da produção é que prioriza as tarefas de manutenção;

e) Não existem interligações - constantes atritos

5) Os sistemas mecanizados existentes na manutenção, principalmente as interligações com outros sistemas, apresentam precisão e confiabilidade:

a) Acima de 95\%;

b) Entre 90\% e 95\%;

c) Entre 80 e $95 \%$

d) Entre $70 \%$ e $80 \%$

e) Menos que $70 \%$ ou inexiste automação.

6) Qual o nível de interligação dos lançamentos de horas de manutenção e a folha de pagamentos no departamento de pessoal?

a) Sistemas on line completamente interligados;

b) A manutenção e o departamento de pessoal se informam por listas automatizadas;

c) Manutenção e departamento de pessoal usam o cartão de ponto como documento comum;

d) A manutenção gera lista especial só para atender o departamento de pessoal e vice-versa; 
e) A manutenção apropria as horas, independentemente das horas usadas para pagamento.

7) Como as informações de custos de manutenção chegam a contabilidade da empresa?

a) Sistema on line - manutenção e contabilidade;

b) As informações fluem por disquetes;

c) As ordens de serviço de manutenção são documentos que servem à manutenção e à contabilidade;

d) As informações migram por documentos manuais, só para atender ao sistema de custos;

e) Cada área usa informações independentes.

8) Que porcentagem do pessoal de manutenção (planejadores, supervisores e gerentes) usa a informática no seu trabalho?
a) Acima de $90 \%$;
b) Entre $75 \%$ e $90 \%$;
c) Entre $60 \%$ e $75 \%$;
d) Entre $40 \%$ e $60 \%$;
e) Menos que $40 \%$.

9) Qual o nível de cooperação existente dentro da empresa para que a manutenção contribua eficazmente no aumento da rentabilidade?
a) Cooperação irrestrita em todos os níveis;
b) Na grande maioria dos casos;
c) Cooperação em todos os níveis de supervisão;
d) Poucos casos;
e) Não existe cooperação; 
10) A manutenção é consultada quando uma decisão da alta gerência a afeta. Exemplo: compra de novos equipamentos etc?

a) Em todos os casos e antes de ocorrer;

b) Na maioria dos casos antes de ocorrer;

c) Em poucos casos antes de ocorrer;

d) Informada a posteriori para tomar providências;

e) Não é consultada nem informada.”

MIRSHAWKA \& OLMEDO (1993) relatam que o questionário foi produzido de modo que apresente sempre a mesma seqüência de respostas certas. Isto é, da mais adequada (valendo 4 pontos) para a menos adequada (valendo zero ponto).

Desta forma, os valores para cada tipo de resposta correspondem a: resposta “a“ vale 4 pontos; resposta “b“ vale 3 pontos; resposta “c“ vale 2 pontos; resposta “d“ vale 1 ponto e resposta “e“ vale zero ponto;

O total de pontos possíveis é de 320. Nestas condições, os autores propõem a seguinte tabela para a auto-avaliação da função manutenção nas empresas:

\begin{tabular}{|c|l|}
\hline Valores & \multicolumn{1}{c|}{ Observações } \\
\hline $320-288$ pontos & Manutenção qualificada como de classe mundial. \\
\hline $288-256$ pontos & Manutenção muito próxima da de classe mundial. \\
\hline $256-224$ pontos & A manutenção necessita ajustes em diversas áreas. \\
\hline Abaixo de 224 pontos & $\begin{array}{l}\text { A manutenção precisa reexaminar seus objetivos dentro } \\
\text { da empresa. }\end{array}$ \\
\hline
\end{tabular}

Tabela 4-1 - Auto Avaliação da Função Manutenção nas Empresas.

Fonte: MIRSHAWKA \& OLMEDO (1993). 


\subsubsection{QUADROS DE ANÁLISE DOCUMENTAL}

Os quadros constantes do Anexo 1 foram utilizados na coleta de dados das atividades dos serviços de manutenção nas empresas pesquisadas. Foram considerados todos os dados necessários para compor os indicadores propostos no modelo de gestão.

\subsection{CONSIDERAÇÃO FINAL}

Todos os formulários, tabelas e quadros apresentados no Anexo 1 foram adaptados às características organizacionais da empresa pesquisada, de forma a possibilitar maior facilidade na obtenção dos dados empíricos, sua estruturação e análise. Desta forma, foi possível a elaboração das conclusões necessárias à verificação das hipóteses estabelecidas no presente estudo e à validação do modelo de gestão que representa a contribuição proposta do trabalho de pesquisa. 


\section{Capítulo 5}

\section{Apresentação das Empresas}

O presente capítulo apresenta as empresas que delimitam o universo da pesquisa. Justifica os critérios para a escolha das mesmas como estudos de caso. O texto ainda descreve o resultado das suas avaliações, por meio de formulário padronizad, e com o auxílio de parâmetros que pontuam o perfil da manutenção em relação ao de classe mundial. O capítulo ainda justifica a adoção da empresa sobre a qual o trabalho de pesquisa concentra os esforços para validar os indicadores do modelo de gestão.

\subsection{INTRODUÇÃO}

Conforme relatado no Título 4.3 do Capítulo 4, o universo da pesquisa está restrito as três maiores empresas do distrito Industrial de Itajubá, Estado de Minas Gerais. Além do critério do maior faturamento anual, a escolha das empresas foi conduzida no sentido de atender determinadas características como liderança de mercado, dinamismo e constância em seu processo de evolução. As empresas selecionadas para os estudos de casos são, respectivamente,

- Areva Transmissão \& Distribuição de Energia Ltda. (Areva T\&D Brasil);

- Imbel - Fábrica de Itajubá; e

- Mahle Componentes de Motores do Brasil Ltda., Itajubá.

Outro critério importante levado em conta na escolha das empresas foi a sua contribuição, dentro da realidade própria de cada uma, para a modernização do País gerando riquezas e produzindo tecnologia. Outro parâmetro relevante considerado foi a atuação sempre presente delas, como geradoras de novas soluções para o mercado em que atuam, criando empregos e promovendo uma integração perfeita na comunidade. Tais características diferenciadoras podem ser constatadas nos títulos que se seguem para a apresentação das empresas. E, por fim, o critério mais 
significativo para a escolha das empresas reside na magnitude de dados e informações que as tornam exemplificadoras das questões pertinentes a este trabalho, além da permissão e facilitação do acesso aos mesmos.

\subsection{AS EMPRESAS}

\subsubsection{AREVA T\&D BRASIL}

O SIMMMEI - Sindicato das Indústrias Metalúrgicas e de Material Elétrico de Itajubá resume os dados relativos à empresa AREVA T\&D Brasil, como podem ser vistos nos títulos a seguir.

\section{A. HISTÓRICO}

A história da empresa remonta a maio de 1976 quando, sob a denominação de BALTEAU Produtos Elétricos Ltda., iniciou suas atividades no Brasil, em Itajubá. O trabalho inicial restringiu-se a estudos de viabilidade técnica e econômica para possibilitar a fabricação local de transformadores para instrumentos de média, alta e extra-alta tensões.

A implantação da unidade industrial em Itajubá deu-se em setembro de 1977, em uma área construída de $2.200 \mathrm{~m}^{2}$. Em junho de 1978 começou a produção de transformadores para instrumentos até $245 \mathrm{kV}$. O Grupo SCHLUMBERGER comprou as atividades do Grupo BALTEAU em janeiro de 1982. A construção da nova unidade industrial teve início em fevereiro de 1984 em uma área de $50.270 \mathrm{~m}^{2}$, já no Distrito Industrial de Itajubá. No mês de dezembro do mesmo ano transferiu suas atividades para o endereço atual. Em julho de 1988 foi adquirida pelo Grupo ALSTOM, líder mundial na área de energia e transporte ferroviário.

Em maio de 1989 foi incorporada pela Companhia MASA ALSTOM, passando a denominar-se CIA. MASA ALSTHOM - Divisão Balteau Produtos Elétricos. Em dezembro de 1993 recebeu a denominação GEC ALSTOM T\&D MASA S.A. - Divisão Balteau. Passou a denominar-se ALSTOM T\&D LTDA., em 
junho de 1998. Em março de 1999 incorporou as atividades industriais da ER Equipamentos Elétricos de Alta Tensão Ltda., passando a ter a denominação de ALSTOM BRASIL LTDA., a partir de dezembro do mesmo ano. Em dezembro de 2000 transferiu as atividades da fábrica de reatores e bobinas de bloqueio da empresa ER - Equipamentos Elétricos de Alta Tensão Ltda., de Betim para Itajubá.

A planta da fábrica foi ampliada com a transferência da unidade de disjuntores, chaves seccionadoras e pára-raios da ALSTOM BRASIL LTDA., planta Interlagos (SP), para a unidade de Itajubá, em junho de 2001. Em setembro de 2001, passou a denominar-se ALSTOM Transmissão \& Distribuição de Energia Ltda. e, em maio do mesmo ano, a planta foi certificada na ISO-9001/2000. No início de 2004 tornou-se uma divisão da AREVA, especialista mundial no setor energético, com presença marcante em vários países, denominando-se AREVA Transmissão \& Distribuição de Energia Ltda. (AREVA T\&D Brasil).

\section{B. MOMENTO ATUAL}

A AREVA T\&D Brasil de Itajubá conta hoje com $66.000 \mathrm{~m}^{2}$ de área total, 500 colaboradores e $17.000 \mathrm{~m}^{2}$ de área construída, que possibilita a fabricação de transformadores para instrumentos de média, alta e extra-tensões até $800 \mathrm{kV}$, reatores, bobinas de bloqueio, disjuntores e pára-raios. É possuidora da mais completa linha do mercado brasileiro. A AREVA é líder neste segmento, além de apresentar boa penetração no mercado mundial, estando presente nos cinco continentes.

A empresa tem sua reputação baseada na experiência, na qualidade dos seus serviços de suporte técnico e comercial e na disponibilidade de entender e responder aos seus clientes. O que faz da AREVA o parceiro ideal no suprimento de energia, colocando-a na dianteira do mercado mundial. É uma empresa de produção sob encomenda. Para a AREVA cada cliente é único, oferecendo serviços e soluções adaptadas às suas especificações e necessidades próprias. 


\section{MISSÃO DA EMPRESA}

"Busca permanente da satisfação total de seus clientes, acionistas, funcionários, fornecedores e de sua comunidade, e da melhoria contínua de suas atividades, produtos ou serviços, com o objetivo de eliminar ou reduzir seus impactos no meio ambiente, comprometendo-se integralmente em melhorar e manter os seus Sistemas de Gestão da Qualidade e de Gestão Ambiental.”

\section{CERTIFICAÇÕES}

A AREVA, unidade Itajubá, possui um Sistema de Gestão da Qualidade certificado conforme a norma ISO 9001, desde 1994, e um Sistema de Gestão Ambiental certificado conforme norma ISO 1400,1 desde 2000. Está em fase de implementação do Sistema de Gestão de Saúde Ocupacional e Segurança com base na especificação OHSAS 18001, com certificação prevista ainda para 2006.

Isto confirma a preocupação da empresa em fabricar produtos de qualidade que atendam às necessidades dos clientes, através da atuação de seus colaboradores de modo seguro, saudável e com responsabilidade ambiental.

\section{E. LINHA DE PRODUTOS}

A empresa possui a seguinte linha de produtos:

- Transformadores para Instrumentos de Alta Tensão:

$\checkmark$ Transformadores de potencial capacitivo, a óleo, classe de isolação até $550 \mathrm{kV}$;

$\checkmark$ Transformadores de potencial indutivo, a óleo, classe de isolação até $245 \mathrm{kV}$;

$\checkmark$ Transformadores de corrente, a seco, classe de isolação até $72,5 \mathrm{kV}$;

$\checkmark$ Transformadores de corrente, a seco, classe de isolação até $765 \mathrm{kV}$. 
- Transformadores para Instrumentos de Média Tensão:

$\checkmark$ Transformadores de potencial indutivo, uso interno e externo, a seco, classe de isolação até $36,2 \mathrm{kV}$;

$\checkmark$ Transformadores de corrente, uso interno e externo, a seco, classe de isolação até $36,2 \mathrm{kV}$.

- Reatores e Bobinas de Bloqueio:

$\checkmark$ Reatores, a seco, com núcleo de ar, potência até 35 Mvar por bobina, isolação 1300 kVp (Reator Série);

$\checkmark$ Bobinas de bloqueio para sistemas de ondas portadoras (Carrier).

- Disjuntores, Seccionadores e Pára-Raios:

$\checkmark$ Disjuntores SF6 até $800 \mathrm{kV}$ com comando a mola, para correntes de interrupção até $63 \mathrm{kA}$;

Seccionadores para sistemas elétricos até $800 \mathrm{kV}$, de abertura central, vertical, dupla abertura, semi-pantográfica e pantográfica, com comando manual ou motorizado;

Pára-Raios $\mathrm{ZnO}$ para sistemas até $800 \mathrm{kV}$, com invólucro de porcelana ou polimérico de corrente de descarga nominal até 20 kA.

\subsubsection{IMBEL - FÁBRICA DE ITAJUBÁ}

\section{A. HISTÓRICO DA IMBEL E DA FÁBRICA DE ITAJUBÁ}

RODRIGUES (2004) relata a história da Indústria de Material Bélico no Brasil, remetendo as suas origens à migração da Corte Portuguesa para o Brasil em 8 de março de 1808. Para o autor, a criação da Fábrica de Pólvora da Lagoa Rodrigo de Freitas em 13 de maio de 1808, pelo então príncipe regente D. João, e o incremento das atividades do atual Arsenal de Guerra do Rio de Janeiro constituíram-se nas bases para o desenvolvimento da indústria bélica nacional. 
O autor afirma que, ainda no século XIX, a Revolução Industrial fez surgir a necessidade de se criar estabelecimentos fabris mais sofisticados, capazes de lidar com novos materiais e novas técnicas nas áreas de metalurgia, química e mecânica, de grande interesse militar. Por outro lado, a Guerra do Paraguai, maior conflito ocorrido na América Latina, evidenciou a necessidade do Brasil ampliar seu parque de material bélico, libertando-o da dependência do fornecimento exterior.

Vários estabelecimentos foram então criados e na século passado, na década de 40, o Exército Brasileiro contava com nove fábricas com produção bastante diversificada. Segundo o autor, foram desativadas as Fábricas do Andaraí, do Realengo, de Bonsucesso e de Curitiba. Permanecem até hoje em atividade os complexos fabris relatados a seguir.

\section{1) FÁBRICA DA ESTRELA (FE)}

Fundada em 13 de maio de 1808 com o nome de Fábrica de Pólvora da Lagoa Rodrigo de Freitas, teve sua localização inicial na área do atual Jardim Botânico do Rio de Janeiro. Por razões de segurança foi transferida para a Vila Inhomirim, município de Magé-RJ, em 1824. A partir dessa data passou a denominar-se Real Fábrica de Pólvora da Estrela, por decreto de D. Pedro I.

A Fábrica da Estrela possui hoje uma área total de aproximadamente $6.800 .000 \mathrm{~m}^{2}$ e uma área construída de $22.175 \mathrm{~m}^{2}$. Seus principais produtos interessam tanto a área civil como a militar e podem ser assim relacionados: nitropenta, azida, espoletas, cordel detonante, cargas sismográficas, pólvora negra, estopim, artifícios pirotécnicos, reforçadores, artefatos e retardos para cordel detonante.

\section{2) FÁBRICA PRESIDENTE VARGAS (FPV)}

Foi inaugurada em 15 de março de 1909 com a presença do então Presidente Affonso Pena, com a denominação de Fábrica de Pólvoras Sem Fumaça, na cidade de Piquete (SP). Junto com a Fábrica da Estrela, forma um complexo químicoindustrial de relevante importância estratégica. A FPV produz uma variada gama de 
produtos, entre eles: pólvoras de base simples e de base dupla, propelentes para foguetes e mísseis, lamas e emulsões explosivas e o TNT (trotil). Possui uma área de 22.600.000 $\mathrm{m}^{2}$ e área construída de $112.879 \mathrm{~m}^{2}$.

\section{3) FÁBRICA DE JUIZ DE FORA (FJF)}

Criada pelo Decreto $\mathrm{n}^{0} 23.654$ de 20 de dezembro de 1933, com a denominação de Fábrica de Estojos e Espoletas de Artilharia, teve a sua inauguração oficial em 22 de março de 1938. Em 25 de abril de 1939 passou a denominar-se Fábrica de Juiz de Fora. Seus principais produtos são: munição de grosso calibre, facas, facões, machadinhas e ferramentas de produção e controle.

A FJF presta serviços de radiografia industrial, tratamento térmico e superficiais de metais, além de serviços laboratoriais, mecânicos, metalográficos e balísticos para clientes nacionais e estrangeiros. A qualidade de seus produtos está assegurada pelo Certificado de Sistema de Qualidade NBR ISO 9002 na produção e serviços associados ao material bélico aeroespacial, foguetes e munições de 40 a 120 mm e respectivas embalagens. Possui uma área total de $2.200 .612 \mathrm{~m}^{2}$ e área construída de $356.760 \mathrm{~m}^{2}$.

\section{4) FÁBRICA DE ITAJUBÁ (FI)}

Criada pelo Decreto 23.654 de 20 de dezembro de 1933 (o mesmo que instituiu a Fábrica de Juiz de Fora), com a denominação de Fábrica de Canos e Sabres para Armamento Portátil, teve sua construção iniciada em 16 de julho de 1934 e inaugurada um ano depois.

Desde a sua fundação a FI enfrentou e venceu importantes desafios ${ }^{1}$, produzindo armamentos que, na época, representavam o que havia de mais moderno no mundo. Inicialmente foi o fuzil Mauser, notável projeto alemão, o melhor fuzil de

\footnotetext{
${ }^{1}$ Informação disponível em < www.imbelfi.gov.br/historico/FIhisto.htm $>$ Acesso em: 19/01/2006.
} 
repetição até hoje concebido. Seguro, simples, rústico e preciso, demandava, entretanto, o domínio de difícil tecnologia para ser fabricado. Foi o primeiro grande desfio, vencido em 1940. O segundo viria a ser a fabricação da pistola .45M911A1BR1, derivada do projeto de maior sucesso em toda a história do armamento de porte, projetada para a Fábrica Colt , dos Estados Unidos da América do Norte. Mas, o maior desafio viria a acontecer em 1964 quando se decidiu produzir o FAL (Fuzil Automático Leve), o fuzil automático de maior aceitação mundial, chegando a ser adotado por mais de 90 países.

Atualmente, a FI está iniciando a produção do fuzil 5,56 mm e de novos tipos de pistola. A qualidade de seus produtos é atestada pela exportação de pistolas e FAL para o mercado norte-americano, o mais exigente do mundo, há mais de 15 anos. Principal vocação da FI é a produção de armas de porte e portáteis, tanto para o mercado externo como para o interno. Possui uma área total de $1.000 .000 \mathrm{~m}^{2}$, sendo $28.000 \mathrm{~m}^{2}$ de área edificada, com cerca de 1.000 funcionários.

\section{5) FÁBRICA DE MATERIAL DE COMUNICAÇÕES E ELETRÔNICA}

A Fábrica de Material de Comunicações e Eletrônica (FMCE) teve seu início nas oficinas do Serviço Telegráfico do Exército em 1931. Com o rápido avanço da utilização dos meios elétricos e eletrônicos para a transmissão de mensagens na área militar, surgiu a necessidade de um estabelecimento dedicado à produção de equipamentos de comunicações. Nestas condições, as redes de rádio e de telégrafo que interligavam as várias guarnições militares e as atividades de campanha do Exército Brasileiro teriam o devido suporte para o funcionamento adequado.

Assim, o Aviso do Ministro da Guerra n ${ }^{0} 961$ de 4 de outubro de 1939 criou a Fábrica de Material de Transmissões. A denominação mudou sucessivamente para Fábrica de Material de Comunicações, Centro de Pesquisa e Desenvolvimento Tecnológico e Telecomunicações e, finalmente, em 01 de janeiro de 1985, para Fábrica de Material de Comunicações e Eletrônica.

Atualmente a FMCE produz equipamentos de rádio, telefonia e informática, equipamentos eletrônicos para mísseis, sistemas computadorizados para comando e 
controle, incluindo a direção de tiro de artilharia e de morteiros. A FMCE ainda realiza pesquisa e desenvolvimento nos campos da eletrônica, mecânica e informática. Situa-se na cidade do Rio de Janeiro e possui área total de $17.927 \mathrm{~m}^{2}$, com $10.322 \mathrm{~m}^{2}$ de área construída.

RODRIGUES (2004) ainda relata que a capacidade instalada nas fábricas militares era muito acima das necessidades das Forças Armadas Brasileiras em tempos de paz. Tal capacidade ociosa poderia ser direcionada para o mercado interno e externo, gerando recursos adicionais e incentivando o desenvolvimento da indústria bélica nacional.

Assim, para viabilizar tal projeto a Lei 6.227 de 14 de julho de 1975 criou a Indústria de Material Bélico do Brasil (IMBEL). Empresa pública de direito privado vinculada ao Ministério da Defesa - Exército Brasileiro a IMBEL tem sua sede na cidade de Piquete (SP) e engloba as cinco fábricas militares existentes.

\section{B. MOMENTO ATUAL}

O Decreto ${ }^{2} \mathrm{n}^{0} 5338$, de 12 de janeiro de 2005 publica o novo Estatuto Social da IMBEL. Além da atividade principal da IMBEL que é a produção de material de defesa, está ela também autorizada a prestar serviços nas áreas de pesquisa e desenvolvimento, projetos, construção, logística e cartografia.

Para a consecução desses objetivos, a IMBEL iniciou uma reestruturação organizacional por meio da implementação de uma nova estratégia de atuação empresarial e de melhoria de gestão, de forma a aumentar o faturamento, a incrementar a competitividade, a reduzir custos e criar condições para que uma Empresa Pública de defesa possa apresentar equilíbrio de suas contas.

Segundo SILVEIRA (2005), depois de acertar as contas com o parcelamento de suas dívidas estaduais e federais a IMBEL começou a colocar em prática o seu plano de revitalização.

\footnotetext{
${ }^{2}$ Informação disponível em < http://www.imbel.gov.br/index > Acesso em: 19/01/2006
} 
A política de crescimento da empresa está fundamentada no incremento da venda de produtos militares com aplicação civil e no desenvolvimento de parcerias estratégicas. Atualmente, a IMBEL exporta 30\% da sua produção, envolvendo armas leves e munições, para os Estados Unidos da América, América Latina e o Sudeste Asiático. O FBI - Federal Bureau of Investigation dos Estados Unidos é o principal cliente das pistolas calibre .45 da IMBEL. A Indonésia é outro cliente importante da empresa, segundo o autor.

\subsubsection{MAHLE COMPONENTES DE MOTORES DO BRASIL}

A MAHLE Grupo Brasil resume as informações ${ }^{3}$ relativas ao grupo, nos títulos a seguir.

\section{A. INTRODUÇÃO}

Desde 1950 no Brasil, a MAHLE transformou-se em um modelo empresarial que conseguiu se destacar em um mercado altamente competitivo, concentrando esforços em tecnologia da qualidade e na formação de recursos humanos, contando com a participação real e efetiva de uma estrutura sólida financeira. Com 8 mil funcionários no País, a MAHLE vem buscando novas soluções e agregando tecnologia para satisfazer cada vez mais os seus clientes. A empresa hoje é símbolo de qualidade em seus produtos, serviços e atendimento, sendo certificada pelas normas ISO/TS 16949, ISO 9001 e ISO 14001.

No Brasil, a MAHLE fabrica pistões, anéis, bronzinas, bielas, componentes sinterizados, sistemas de trem de válvulas, filtros automotivos, além de componentes de motores. Com oito fábricas instaladas no Brasil, nas cidades de Mogi-Guaçu (SP), Indaiatuba (SP), São Paulo (SP), São Bernardo do Campo (SP), Mauá (SP) e Itajubá (MG), a empresa conta, ainda, com um Centro de Tecnologia em São Paulo (SP) além de um Centro de Distribuição, em Limeira (SP), que atende a todo o mercado

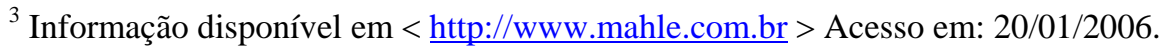


de reposição nacional e do exterior, especialmente a América Latina, África e Oriente Médio. Em Itajubá, a MAHLE Componentes de Motores Ltda. possui uma área total de $260.000 \mathrm{~m}^{2}$ com uma área construída de $50.200 \mathrm{~m}^{2}$ e cerca de 2.200 funcionários.

A MAHLE fornece produtos para as mais conceituadas montadoras, como Volkswagen, Audi, BMW, John Deere, Porsche, Opel, Toyota, Honda, Ford, General Motors, DaimlerChrysler, Fiat, Renault, Peugeot, MWM, Cummins, Scania, Volvo, International, Caterpillar e Perkins, entre outras, e 50\% de sua produção é exportada para montadoras nos Estados Unidos e Europa.

\section{B. HISTÓRICO}

- 1920 - Início das atividades da MAHLE, em Stuttgart.

- 1921 - Início da produção em série dos primeiros pistões de liga leve.

- 1929 - Início da produção em série de filtros de óleo, ar e combustível.

- 1950 - Ernst Mahle se estabelece no Brasil onde torna-se sócio fundador da Metal Leve - primeiro fabricante nacional de pistões.

- 1965 - Ernst Mahle retorna à Alemanha, sendo que a Metal Leve atua como licenciada da MAHLE GmbH, no País.

- 1978 - É adquirido o controle acionário da Cima Componentes Automotivos, de Santo André (SP), dando origem à Cima MAHLE.

- 1981 - Inauguração da fábrica de pistões em Mogi-Guaçu (SP), dando origem à MAHLE Pistões Ltda. Inauguração da planta da Metalúrgica Mogi-Guaçu Ltda. - "MMG”, em Mogi-Guaçu (SP). A razão social foi alterada em 1999 para MAHLE MMG Ltda..

- 1996 - A MAHLE adquire o controle acionário da Metal Leve S.A..

- 1997 - Em conjunto com a Magneti Marelli, adquire a Cofap Companhia Fabricadora de Peças. 
- 1998 - A MAHLE realiza uma "joint venture" para produtos sinterizados, com a empresa Miba, da Áustria.

- 1998/99 - Inauguração do centro logístico para o mercado da América Latina - Centro de Distribuição de Limeira (SP).

- 1999 - Através da cisão parcial da Cofap - Companhia Fabricadora de Peças, a MAHLE GmbH constituiu a MAHLE Cofap Anéis S.A.

- 2000 - Criação da MAHLE Sistemas de Filtração no Brasil.

- 2001 - Inauguração da fábrica de filtros, em Mogi-Guaçu (SP). Aquisição inicial de 33,3\% da empresa japonesa de filtros Tennex Corporation, com volume de vendas de 450 milhões de euros/ano e com filiais de produção no Japão, EUA, Grã-Bretanha, Filipinas e Tailândia. Em agosto, essa participação passou a 57,72\%, tornando-se majoritária.

\section{CERTIFICAÇÕES}

Com o objetivo de atender às expectativas de seus clientes, de promover a melhoria contínua dos produtos e processos, de adequar-se à legislação ambiental vigente, respeitando a natureza e a sociedade, o grupo MAHLE Brasil tem conquistado, ao longo sua história, a conformidade com padrões normativos de qualidade e de meio ambiente. O histórico das certificações da planta MAHLE Componentes de Motores do Brasil Ltda., pode ser observado a seguir:

- 2003 - ISO/TS 16949:2002 (BVQI $\left.{ }^{4}\right)$

- 2003 - ISO-14001:1996 (DQS $\left.{ }^{5}\right)$

- 2002 - ISO/TS 16949:1999 (BVQI)

- 1997 - QS 9000 (BVQI)

\footnotetext{
${ }^{4}$ Organismo certificador independente do Bureau Veritas Quality International.

${ }^{5}$ Associação Alemã para Certificação de Sistemas de Gestão.
} 
- 1994 - ISO 9001 (BVQI)

\subsubsection{CONCLUSÕES PARCIAIS}

Pelo que se depreende da leitura da apresentação das empresas, pode-se concluir que elas apresentam características diferenciadoras importantes que as tornam exemplos vivos das questões pertinentes a este trabalho de doutorado. Além, evidentemente, de permitir e facilitar o acesso aos dados de planejamento e controle de produção, manutenção, vendas, custos e logística para a validação dos indicadores desenvolvidos para o modelo de gestão.

As empresas atuam simultaneamente no mercado nacional e internacional, sendo cada uma delas líder em seu segmento. São organizações que apresentam evidente dinamismo e constante crescimento. São inovadoras e estão sempre gerando novas soluções nos mercados em que atuam, produzindo riquezas e novas tecnologias. São empresas de porte considerável no Distrito Industrial de Itajubá, conforme pode ser visto na Tabela 5-1. As empresas promovem uma integração notável com a comunidade itajubense, com inúmeras contribuições de natureza social. Atuam de forma concreta na melhoria da formação e qualidade de vida de seus funcionários.

\begin{tabular}{c|c|c|c}
\hline EMPRESAS & ÁREA TOTAL $\left[\mathbf{M}^{2}\right]$ & ÁREA CONSTRUÍDA [M $\left.{ }^{2}\right]$ & FUNCIONÁRIOS $^{\text {AUIO }}$ \\
\hline MAHLE & 260.000 & 50.200 & 2.200 \\
IMBEL-FI & 1.000 .000 & 28.000 & 1.000 \\
AREVA & 66.000 & 17.500 & 500 \\
\hline
\end{tabular}

Tabela 5-1 - Tabela Comparativa.

\subsection{O PERFIL DA MANUTENÇÃO NAS EMPRESAS}

O perfil do estado atual de desempenho da função manutenção das empresas pesquisadas foi levantado de acordo com o formulário organizado por MIRSHAWKA \& OLMEDO (1993) e descrito no Título 4.5.2 do Capítulo 4 Metodologia. O objetivo do questionário é classificar uma organização de manutenção como manutenção de classe mundial. O resultado das entrevistas com 
os gerentes das áreas de manutenção das respectivas empresas pode ser visto no Anexo 2. A pontuação global das empresas está resumida Tabela 5-2..

\begin{tabular}{l|l|c|c|c}
\hline \multicolumn{2}{c|}{ QUESITOS } & MAHLE & AREVA & IMBEL-FI \\
\hline 1 & Aspectos Organizacionais da Manutenção & 34 & 22 & 17 \\
2 & Programas de Treinamento em Manutenção & 29 & 24 & 19 \\
3 & Ordens de Serviço da Manutenção & 32 & 33 & 30 \\
4 & Planejamento e Programação da Manutenção & 32 & 32 & 26 \\
5 & Manutenção Preventiva & 28 & 23 & 19 \\
6 & Compras e Estoques de Manutenção & 38 & 16 & 23 \\
7 & Relatórios Gerenciais de Manutenção & 32 & 13 & 4 \\
8 & Automação na Manutenção & 33 & 18 & 24 \\
\hline \multicolumn{2}{r|}{ PONTUAÇÃO TOTAL } & 258 & 181 & 162 \\
\hline
\end{tabular}

Tabela 5-2 - Pontuação Global das Empresas.

A Figura 5-1 ilustra os resultados da pontuação.

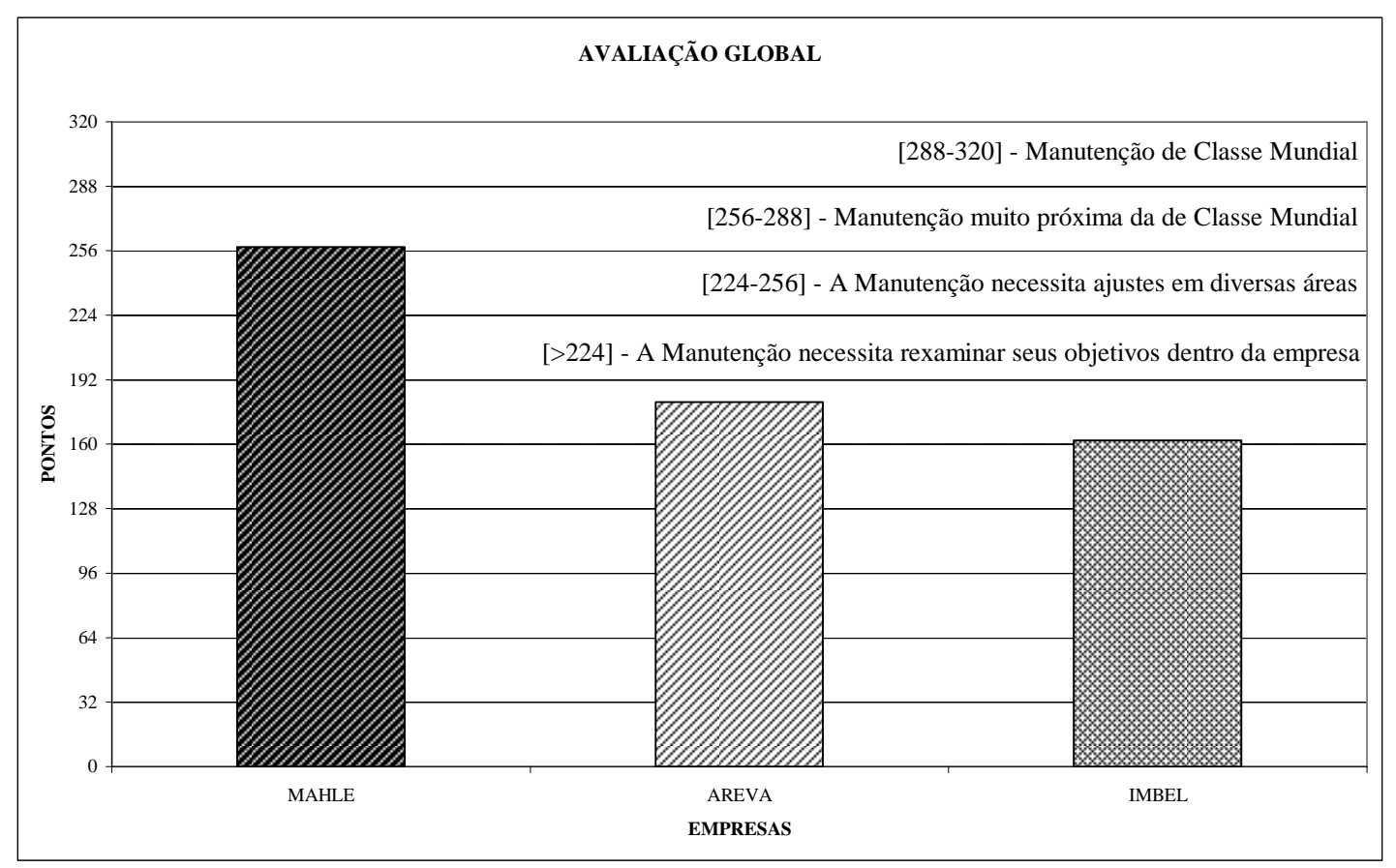

Figura 5-1 - Classificação das Empresas

Assim, de acordo com a Tabela 4-1, as empresas recebem a seguinte classificação: a MAHLE apresenta a sua função manutenção muito próxima da de 
classe mundial. Já a AREVA e a IMBEL-FI sugerem o setor de manutenção muito abaixo da pontuação classe mundial, necessitando rever os objetivos do setor dentro da própria organização.

\subsection{CONCLUSÕES FINAIS}

A IMBEL vive, desde 2005, um momento de redirecionamento de suas metas e objetivos, procurando equacionar e parcelar suas dívidas conforme já relatado anteriormente. Isto pode explicar o fraco desempenho da função manutenção da Fábrica de Itajubá (FI), na entrevista estruturada para classificar a sua manutenção como de classe mundial. Tal entrevista ocorreu no início de 2005, período coincidente com o realinhamento da empresa para superar a crise relatada por SILVEIRA (2005) e AMATO (2005).

Embora a IMBEL-FI tenha autorizado o acesso aos dados do setor de manutenção, as paralisações decorrentes das greves inviabilizaram completamente o acesso aos mesmos. Além disso, os dados necessários para validar os indicadores desenvolvidos neste trabalho ainda estavam registrados em arquivos manuais. A empresa tinha recém-adquirido um software para a gestão da manutenção e os dados históricos de seus ativos ainda seriam migrados dos arquivos manuais para o banco de dados do software.

Ainda que a empresa apresente um conjunto de ativos considerável, relevante para os propósitos do trabalho de pesquisa, as circunstâncias do momento impediram o acesso aos dados. Em conseqüência, a IMBEL-FI foi descartada como objeto de estudo do presente trabalho.

A AREVA também acabou sendo descartada como objeto de estudo em função da dificuldade de acesso e da organização dos dados de manutenção disponíveis na empresa. A classificação do perfil da sua manutenção também está muito afastada dos padrões da de classe mundial. A gerência da manutenção é acumulada pela gerência de produção e existe apenas um supervisor para dez manutentores em toda a fábrica. A manutenção tem, em conseqüência, uma 
autonomia restrita dado que a sua supervisão e coordenação são informais. O organograma do setor está desatualizado e incompleto.

É uma empresa montadora que recebe os componentes dos produtos de fornecedores do mercado nacional e internacional. O processo de produção industrial é manual e dependente apenas de poucas instalações de utilidades para a sua realização. A localização e o layout dos escritórios de manutenção, assim como também a qualidade e quantidade das ferramentas e equipamentos para a realização das atividades da função, são passíveis de grandes melhorias.

O planejamento da manutenção não está formalmente constituído. A responsabilidade pelo planejamento e programação das tarefas de manutenção recai sobre o supervisor de manutenção. Também é da sua responsabilidade o controle dos materiais de manutenção. Menos de $40 \%$ das atividades de manutenção estão automatizadas. As informações para custos migram da supervisão da manutenção para a contabilidade através de documentos manuais. Enfim, as respostas da empresa ao questionário padronizado para a classificação de sua manutenção como de classe mundial, deixam claro a insuficiência de dados específicos de manutenção e a descaracterizam como exemplificadora das questões tratadas neste trabalho.

Conseqüentemente, a MAHLE, em função de suas características já mencionadas anteriormente e principalmente pelo fato de sua manutenção estar muito próxima da de classe mundial, torna-se o principal e único objeto de estudo do trabalho, para a validação dos indicadores desenvolvidos para o modelo de gestão.

A função manutenção na empresa está adequadamente estruturada e com completa autonomia. Todas as responsabilidades do setor estão perfeitamente documentadas. Os treinamentos para o pessoal de manutenção ocorrem de forma regular e freqüente.

As informações contidas e extraídas nas ordens de serviços permitem a formação de banco de dados precisos e confiáveis e a emissão de relatórios gerenciais relevantes para a gestão do setor. A precisão e a confiabilidade dos bancos de dados de manutenção ultrapassam os 95\%, conforme podem ser vistos no anexo 2 . 
O controle dos estoques de materiais de manutenção é da responsabilidade dos planejadores e está integralmente automatizado. As informações de custos, dados de manutenção e contabilidade são compartilhados on line. Todas as atividades de planejamento, programação e execução das atividades da manutenção estão automatizadas e facilmente disponíveis para acesso e análise na empresa.

Enfim, as respostas dadas pela empresa ao questionário de classificação de sua manutenção evidenciam a riqueza dos dados disponíveis. A eficiente organização dos bancos de dados do setor, além de garantir o acesso com precisão e confiabilidade, permite a análise e a validação dos indicadores do modelo de gestão. Nestas condições e em função dos argumentos já relatados, a MAHLE caracteriza-se como um objeto de estudo notável, concreto e confiável. Por estas razões torna-se uma exemplificadora válida das questões pertinentes, discutidas neste trabalho.

Para finalizar a conclusão do capítulo, convém ainda acrescentar mais algumas observações. A classificação do perfil da manutenção das empresas AREVA e IMBEL-FI, com uma pontuação muito abaixo da de classe mundial, evidencia a necessidade de realinhar os objetivos e metas de seus respectivos setores de manutenção. Tal constatação por si só já justifica a adoção do modelo de gestão e seus indicadores na busca por melhorias. Além disso, ressalta também o seu grau de importância para uma gestão direcionada, objetiva e segura da função manutenção em tais organizações. 


\section{Capítulo 6}

\section{Apresentação dos Resultados}

O presente capítulo apresenta os resultados das aplicações práticas do sistema de indicadores integrados desenvolvido. O texto ainda leva em conta uma discussão minuciosa e detalhada desses resultados. Tal discussão tem por finalidade a validação dos indicadores propostos na gestão do custeio e das atividades de manutenção, na empresa considerada no estudo de caso.

\subsection{INTRODUÇÃO}

Em virtude das razões expostas na conclusão final do capítulo anterior, a MAHLE ficou então caracterizada como o objeto de estudo, capaz de exemplificar as questões discutidas nesta tese. Cabe aqui, neste momento, apresentar a estrutura organizacional da planta de Itajubá e a localização da célula de fabricação, denominada Retífica de Perfil, foco do objeto de estudo do trabalho.

Em primeiro lugar, a Figura 6-1 fornece uma localização precisa da célula em estudo, dentro da estrutura organizacional da empresa (planta de Itajubá). A Retífica de Perfil é uma célula de fabricação da mini-fábrica denominada Anéis com Cobertura, que pertence ao Setor de Usinagem.

O organograma evidencia que a gerência de operações da planta é dividida em setores ou fábricas. Alguns setores, por sua vez, subdividem-se em mini-fábricas e estas em células de fabricação. Outros setores são simplesmente compostos por células. Os setores subordinados à gerência de operações são assim denominados: Fundição, Pré-Usinagem, Usinagem, Prédio de Aço e Fábrica de Máquinas. O Setor de Usinagem congrega duas mini-fábricas: anéis com e sem cobertura. O setor denominado Prédio de Aço também compreende duas mini-fábricas: anéis de compressão nitretados e anéis de óleo. 

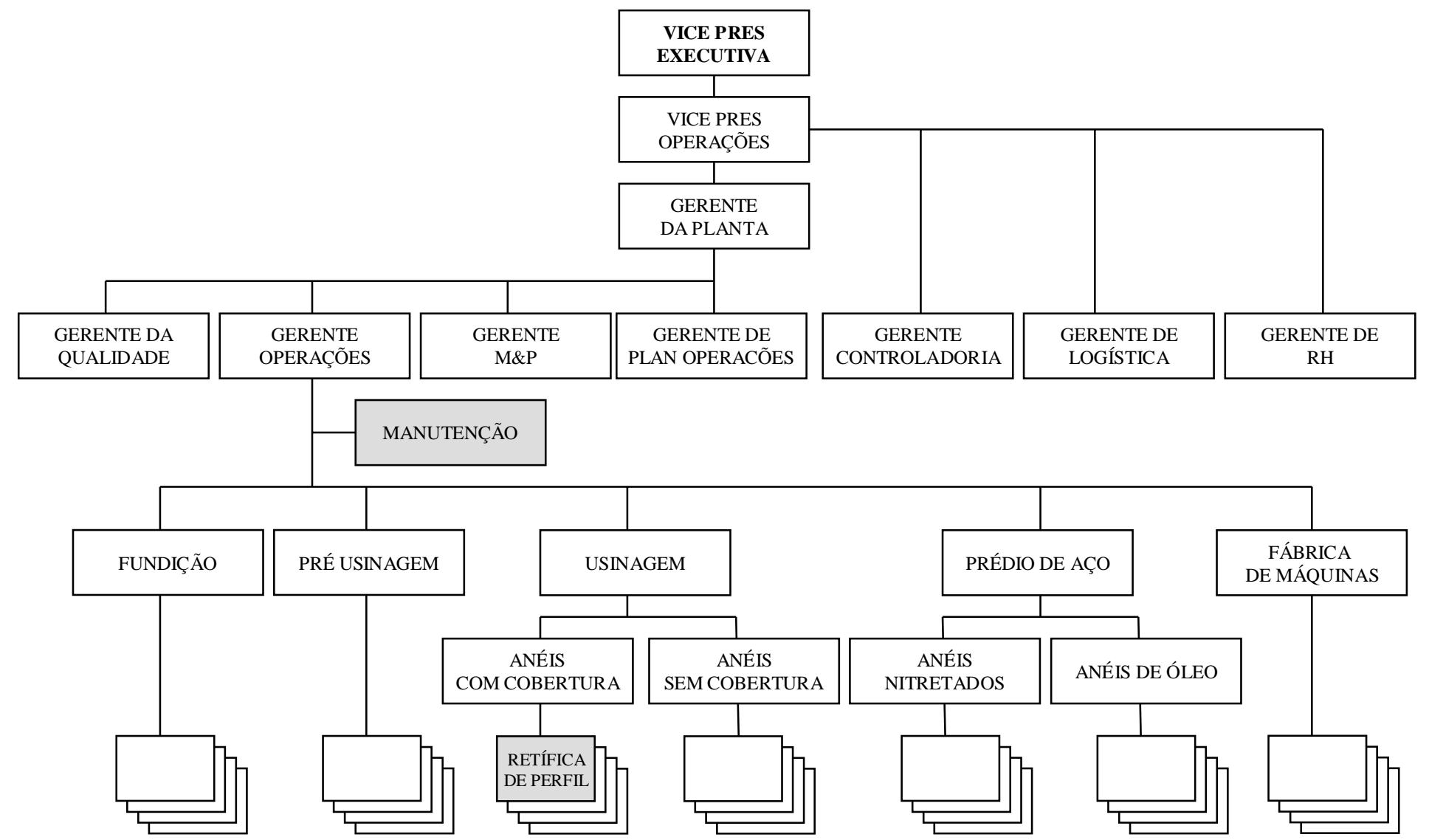

MANUTENÇÃO
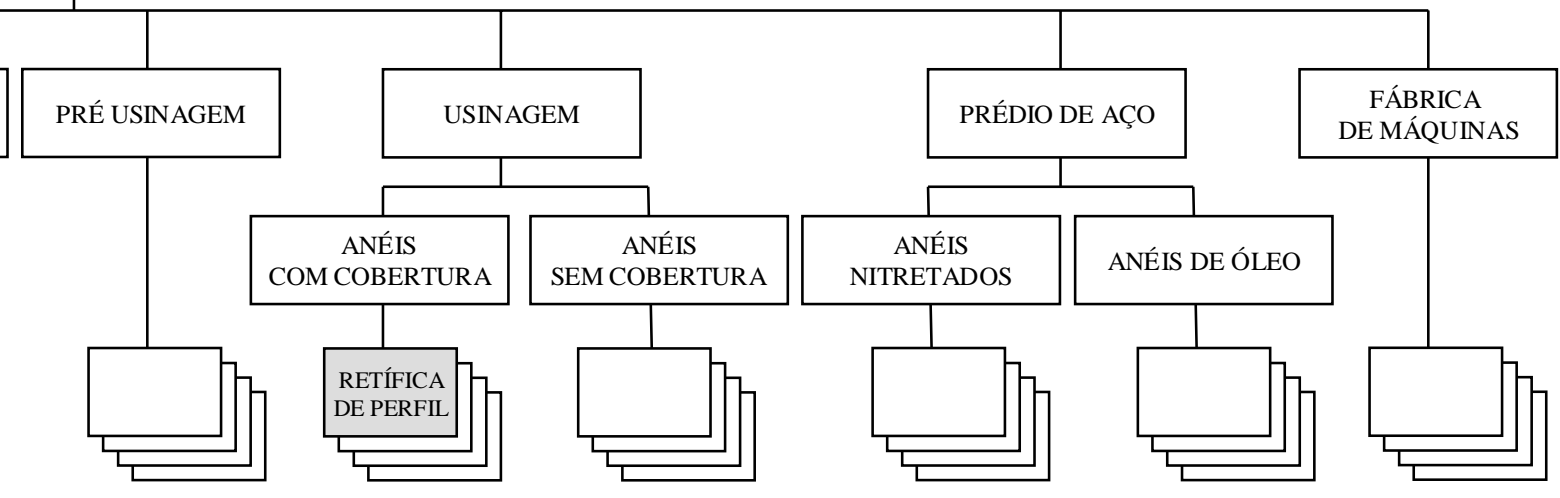

Figura 6-1 - Organograma da Planta de Itajubá.

Fonte: Setor de Manutenção da MAHLE (Cortesia MAHLE). 
A escolha da célula de fabricação Retífica de Perfil para ser o foco do objeto de estudo do trabalho se deu por várias razões. Em primeiro lugar por se tratar de uma célula representativa do Setor de Usinagem que congrega 53\% do esforço produtivo para a geração de riqueza da empresa, como se pode ver na Tabela 6-1, e que explicita a distribuição dos ativos pela planta de Itajubá.

\begin{tabular}{|c|c|c|}
\hline SETOR & No DE ATIVOS & PERCENTAGENS \\
\hline Fundição & 334 & 19 \\
\hline Pré-Usinagem & 149 & 9 \\
\hline Usinagem & 913 & 53 \\
\hline Prédio de Aço & 283 & 16 \\
\hline Fábrica de Máquinas & 44 & 3 \\
\hline Totais & 1.723 & 100 \\
\hline
\end{tabular}

Tabela 6-1 - Distribuição dos Ativos.

Fonte: Setor de Manutenção da MAHLE.

Em segundo lugar, porque a célula em apreço representa a fase mais delicada, complexa e de maior precisão mecânica da fabricação dos anéis com e sem cobertura, que apresentam a maior margem de contribuição para a empresa. O volume de dados, colhidos na célula, exemplifica as questões discutidas ao longo do trabalho. Propicia a validação dos indicadores desenvolvidos e, também, a do modelo de gestão proposto para a função manutenção. Os dados foram colhidos no período compreendido entre 01/06/2004 a 30/06/2005, a partir dos registros históricos das Áreas de Vendas, Logística, Contabilidade e Custos e Produção. As informações foram organizadas de forma a facilitar a construção dos indicadores.

Finalmente, como se apresenta adiante, os resultados obtidos explicitam a realidade prática da gestão das atividades de manutenção. Permitem demonstrar a consecução dos objetivos gerais e específicos pretendidos no trabalho de pesquisa, assim como também verificar as hipóteses formuladas que direcionaram o trabalho na busca de respostas ao problema de pesquisa proposto inicialmente. 


\subsection{COMPOSIÇÃO DOS INDICADORES}

\subsubsection{INDICADORES DE QUALIDADE}

A Tabela 6-2 resume a descrição dos indicadores desenvolvidos para a gestão da qualidade dentro da função manutenção. Com os dados organizados nos Anexos 3, 4 e 5, é possível compor a Tabela 6-3 para a construção dos mesmos.

\begin{tabular}{|c|l|l|c|}
\hline Classificação & Sigla & \multicolumn{1}{|c|}{ Descrição } & Referência \\
\hline \multirow{4}{*}{ Principais } & IOP & Indisponibilidade Operacional & Eq. [3-1] \\
\cline { 2 - 4 } & EGE & Eficácia Global dos Equipamentos & Eq. [3-2] \\
\hline \multirow{4}{*}{ Complementares } & DOP & Disponibilidade Operacional & Eq. [3-3] \\
\cline { 2 - 4 } & ROP & Rendimento Operacional & Eq. [3-4] \\
\cline { 2 - 4 } & IAP & Índice de Aprovação & Eq. [3-5] \\
\cline { 2 - 4 } & IRP & Índice de Reprovação & Eq. [3-6] \\
\cline { 2 - 4 } & HP & Horas Paralisadas & Anexo 3 \\
\hline
\end{tabular}

Tabela 6-2 - Indicadores para a Gestão da Qualidade.

\begin{tabular}{|c|c|c|c|c|c|c|c|}
\hline MÊS & H DISP & HP & HS & Q PREV & Q EXE & HPL & q \\
\hline & & & & & & & \\
jun/04 & 12.420 & 86,08 & $12.333,92$ & 1.505 .120 & 1.251 .039 & $10.323,37$ & 8.519 \\
jul/04 & 13.500 & 116,59 & $13.383,41$ & 1.649 .525 & 1.218 .930 & $9.975,94$ & 6.891 \\
ago/04 & 12.960 & 183,89 & $12.776,11$ & 1.649 .296 & 1.286 .292 & $10.107,55$ & 7.400 \\
set/04 & 12.420 & 144,24 & $12.275,76$ & 1.741 .100 & 1.370 .639 & $9.777,35$ & 9.718 \\
out/04 & 11.880 & 237,85 & $11.642,15$ & 1.598 .168 & 1.255 .947 & $9.336,10$ & 9.311 \\
nov/04 & 11.880 & 107,84 & $11.772,16$ & 1.564 .200 & 1.228 .387 & $9.329,52$ & 9.371 \\
dez/04 & 8.100 & 134,74 & $7.965,26$ & 1.049 .552 & 965.002 & $7.447,48$ & 8.285 \\
jan/05 & 12.420 & 93,81 & $12.326,19$ & 2.033 .200 & 1.398 .749 & $8.544,39$ & 12.707 \\
fev/05 & 11.880 & 177,25 & $11.702,75$ & 2.012 .428 & 1.527 .412 & $9.016,80$ & 15.836 \\
mar/05 & 12.420 & 190,76 & $12.229,24$ & 1.687 .740 & 1.542 .668 & $11.352,42$ & 13.434 \\
abr/05 & 12.420 & 103,42 & $12.316,58$ & 1.562 .022 & 1.330 .921 & $10.582,46$ & 10.492 \\
mai/05 & 12.420 & 196,92 & $12.223,08$ & 1.726 .380 & 1.336 .214 & $9.613,05$ & 10.691 \\
jun/05 & 12.960 & 205,01 & $12.754,99$ & 1.886 .520 & 1.548 .094 & $10.635,08$ & 13.441 \\
& & & & & & & \\
\hline MÉDIA & 12.129 & 152,18 & $11.977,05$ & 1.666 .558 & 1.327 .715 & $9.695,50$ & 10.469 \\
\hline
\end{tabular}

Tabela 6-3 - Dados para a Composição dos Indicadores de Qualidade. 
Onde,

- H DISP - Horas disponíveis no mês do período considerado [h];

- HP - Horas paralisadas no mês do período considerado [h];

- HS - Horas em serviço no mês do período considerado [h];

- Q PREV - Quantidade de produção prevista do mês do período considerado $[\mathrm{u}]$;

- Q EXE - Quantidade de produção executada no mês do período considerado $[\mathrm{u}]$;

- HPL - Horas planejadas associadas à produção executada no mês do período considerado [h];

$\checkmark \quad \mathrm{HPL}=(\mathrm{Q} E X E \times \mathrm{HDISP}) /(\mathrm{Q} P R E V) ;$

- q-Quantidade de refugos produzida no mês do período considerado [u].

Nestas condições, é possível construir a Tabela 6-4 que explicita os valores dos Indicadores de Qualidade no período considerado.

\begin{tabular}{|c|c|c|c|c|c|c|c|}
\hline MÊS & IOP & EGE & DOP & ROP & IAP & IRP & HP \\
\hline & & & & & & & \\
jun/04 & $0,70 \%$ & $82,55 \%$ & $99,30 \%$ & $83,70 \%$ & $99,32 \%$ & $0,68 \%$ & 86,08 \\
jul/04 & $0,87 \%$ & $73,47 \%$ & $99,13 \%$ & $74,54 \%$ & $99,43 \%$ & $0,57 \%$ & 116,59 \\
ago/04 & $1,44 \%$ & $77,53 \%$ & $98,56 \%$ & $79,11 \%$ & $99,42 \%$ & $0,58 \%$ & 183,89 \\
set/04 & $1,17 \%$ & $78,15 \%$ & $98,83 \%$ & $79,65 \%$ & $99,29 \%$ & $0,71 \%$ & 144,24 \\
out/04 & $2,04 \%$ & $77,97 \%$ & $97,96 \%$ & $80,19 \%$ & $99,26 \%$ & $0,74 \%$ & 237,85 \\
nov/04 & $0,92 \%$ & $77,93 \%$ & $99,08 \%$ & $79,25 \%$ & $99,24 \%$ & $0,76 \%$ & 107,84 \\
dez/04 & $1,69 \%$ & $91,13 \%$ & $98,31 \%$ & $93,50 \%$ & $99,14 \%$ & $0,86 \%$ & 134,74 \\
jan/05 & $0,76 \%$ & $68,17 \%$ & $99,24 \%$ & $69,32 \%$ & $99,09 \%$ & $0,91 \%$ & 93,81 \\
fev/05 & $1,51 \%$ & $75,09 \%$ & $98,49 \%$ & $77,05 \%$ & $98,96 \%$ & $1,04 \%$ & 177,25 \\
mar/05 & $1,56 \%$ & $90,59 \%$ & $98,44 \%$ & $92,83 \%$ & $99,13 \%$ & $0,87 \%$ & 190,76 \\
abr/05 & $0,84 \%$ & $84,53 \%$ & $99,16 \%$ & $85,92 \%$ & $99,21 \%$ & $0,79 \%$ & 103,42 \\
mai/05 & $1,61 \%$ & $76,76 \%$ & $98,39 \%$ & $78,65 \%$ & $99,20 \%$ & $0,80 \%$ & 196,92 \\
jun/05 & $1,61 \%$ & $81,33 \%$ & $98,39 \%$ & $83,38 \%$ & $99,13 \%$ & $0,87 \%$ & 205,01 \\
& & & & & & & \\
\hline MÉDIA & $1,29 \%$ & $79,63 \%$ & $98,71 \%$ & $81,31 \%$ & $99,22 \%$ & $0,78 \%$ & 152,18 \\
\hline
\end{tabular}

Tabela 6-4 - Valores dos Indicadores de Qualidade no Período.

Os dados colhidos no período (01/06/2004 a 30/06/2005) permitem visualizar a variação dos Indicadores de Qualidade por meio dos equipamentos que compõem a 
célula Retífica de Perfil. Cumpre, entretanto, deixar claro que a empresa não possui dados de produção e de refugos para cada um dos equipamentos da célula em apreço. Tal situação inviabiliza o cálculo do ROP (Rendimento Operacional), IAP (Índice de Aprovação) e conseqüentemente o do EGE (Eficácia Global de Equipamento) para cada um dos equipamentos que compõem a célula. Assim, numa tentativa de poder visualizar o EGE dos equipamentos da célula, adotou-se para cada um deles o valor médio anual do ROP e IAP declarados na Tabela 6-4. Então, a partir dos dados organizados nos Anexos 3, 4 e 5 pode-se construir a Tabela 6-5 que possibilita observar a variação dos indicadores na célula em questão.

\begin{tabular}{|c|c|c|c|c|c|c|}
\hline CÓDIGO $^{1}$ & IOP & DOP & ROP & IAP & EGE & HP \\
\hline 02200905 & $0,00 \%$ & $100,00 \%$ & $81,31 \%$ & $99,22 \%$ & $80,68 \%$ & 0,00 \\
02200906 & $0,18 \%$ & $99,82 \%$ & $81,31 \%$ & $99,22 \%$ & $80,53 \%$ & 12,11 \\
02200907 & $0,84 \%$ & $99,16 \%$ & $81,31 \%$ & $99,22 \%$ & $80,00 \%$ & 54,81 \\
02202537 & $0,46 \%$ & $99,54 \%$ & $81,31 \%$ & $99,22 \%$ & $80,31 \%$ & 29,86 \\
02202552 & $0,11 \%$ & $99,89 \%$ & $81,31 \%$ & $99,22 \%$ & $80,59 \%$ & 6,99 \\
02202560 & $0,04 \%$ & $99,96 \%$ & $81,31 \%$ & $99,22 \%$ & $80,65 \%$ & 2,57 \\
02203226 & $1,60 \%$ & $98,40 \%$ & $81,31 \%$ & $99,22 \%$ & $79,39 \%$ & 103,53 \\
02205701 & $0,00 \%$ & $100,00 \%$ & $81,31 \%$ & $99,22 \%$ & $80,68 \%$ & 0,00 \\
0220RP01 & $1,27 \%$ & $98,73 \%$ & $81,31 \%$ & $99,22 \%$ & $79,65 \%$ & 82,66 \\
0220RP02 & $1,75 \%$ & $98,25 \%$ & $81,31 \%$ & $99,22 \%$ & $79,26 \%$ & 113,29 \\
0220RP03 & $2,51 \%$ & $97,49 \%$ & $81,31 \%$ & $99,22 \%$ & $78,65 \%$ & 160,96 \\
0220RP04 & $3,98 \%$ & $96,02 \%$ & $81,31 \%$ & $99,22 \%$ & $77,47 \%$ & 251,29 \\
0220RP05 & $4,53 \%$ & $95,47 \%$ & $81,31 \%$ & $99,22 \%$ & $77,02 \%$ & 284,73 \\
0220RP12 & $0,91 \%$ & $99,09 \%$ & $81,31 \%$ & $99,22 \%$ & $79,94 \%$ & 59,21 \\
0220RP15 & $0,47 \%$ & $99,53 \%$ & $81,31 \%$ & $99,22 \%$ & $80,30 \%$ & 30,65 \\
0220RP18 & $0,71 \%$ & $99,29 \%$ & $81,31 \%$ & $99,22 \%$ & $80,11 \%$ & 46,32 \\
0220RP19 & $1,76 \%$ & $98,24 \%$ & $81,31 \%$ & $99,22 \%$ & $79,26 \%$ & 113,50 \\
0220RP21 & $0,56 \%$ & $99,44 \%$ & $81,31 \%$ & $99,22 \%$ & $80,23 \%$ & 36,27 \\
0220RP22 & $0,74 \%$ & $99,26 \%$ & $81,31 \%$ & $99,22 \%$ & $80,08 \%$ & 48,01 \\
0220RP23 & $3,07 \%$ & $96,93 \%$ & $81,31 \%$ & $99,22 \%$ & $78,20 \%$ & 195,51 \\
0220RP24 & $1,12 \%$ & $98,88 \%$ & $81,31 \%$ & $99,22 \%$ & $79,77 \%$ & 72,99 \\
0220RP27 & $1,61 \%$ & $98,39 \%$ & $81,31 \%$ & $99,22 \%$ & $79,38 \%$ & 103,99 \\
0220RP28 & $2,11 \%$ & $97,89 \%$ & $81,31 \%$ & $99,22 \%$ & $78,98 \%$ & 135,58 \\
0220RP29 & $0,51 \%$ & $99,49 \%$ & $81,31 \%$ & $99,22 \%$ & $80,26 \%$ & 33,57 \\
\hline MÉDIA & $1,28 \%$ & $98,72 \%$ & $81,31 \%$ & $99,22 \%$ & $79,64 \%$ & 82,43 \\
\hline
\end{tabular}

Tabela 6-5 - Valores dos Indicadores de Qualidade pelos Equipamentos da Célula.

\footnotetext{
${ }^{1}$ Código patrimonial do equipamento
} 
Os gráficos apresentados no Anexo 9 permitem uma visualização mais nítida da variação dos Indicadores de Qualidade na célula e no período considerado.

\subsubsection{INDICADORES DE VELOCIDADE}

A Tabela 6-6 resume a descrição dos indicadores para a gestão da velocidade dentro da função manutenção.

\begin{tabular}{|c|c|l|c|}
\hline Classificação & Sigla & \multicolumn{1}{|c|}{ Descrição } & Referência \\
\hline \multirow{4}{*}{ Principais } & TMDR & Tempo Médio de Reparo & Eq. [3-12] \\
\cline { 2 - 4 } & IPR & Indisponibilidade Programada & Eq. [3-13] \\
\cline { 2 - 4 } & VAT & Velocidade de Atendimento & Eq. [3-15] \\
\hline \multirow{4}{*}{ Complementares } & DIP & Disponibilidade Programada & Eq. [3-14] \\
\cline { 2 - 4 } & NI & Número de Intervenções & Anexo 3 \\
\cline { 2 - 4 } & HCI & Horas Consumidas nas Intervenções & Anexo 4 \\
\hline
\end{tabular}

Tabela 6-6 - Indicadores para a Gestão da Velocidade.

Assim, é possível compor a Tabela 6-7, a partir dos dados organizados nos Anexos 3, 4, e 6 e construir os indicadores. Nestas condições, a Tabela 6-8 apresenta os valores dos Indicadores de Velocidade no período considerado.

\begin{tabular}{|c|c|c|c|c|c|c|}
\hline MÊS & HS & HMC & HMP R & NF & NP & HPI \\
\hline & & & & & & \\
jun/04 & $12.333,92$ & 78,03 & 8,05 & 21 & 6 & 83,03 \\
jul/04 & $13.383,41$ & 116,12 & 0,47 & 33 & 1 & 117,12 \\
Ago/04 & $12.776,11$ & 53,04 & 130,85 & 31 & 14 & 119,04 \\
set/04 & $12.275,76$ & 63,99 & 80,25 & 33 & 15 & 97,99 \\
Out/04 & $11.642,15$ & 29,39 & 208,46 & 18 & 5 & 139,89 \\
Nov/04 & $11.772,16$ & 95,49 & 12,35 & 20 & 4 & 116,99 \\
Dez/04 & $7.965,26$ & 59,50 & 75,24 & 12 & 8 & 137,5 \\
jan/05 & $12.326,19$ & 39,91 & 53,90 & 26 & 13 & 83,91 \\
fev/05 & $11.702,75$ & 60,84 & 116,41 & 27 & 10 & 136,84 \\
Mar/05 & $12.229,24$ & 53,22 & 137,54 & 29 & 12 & 155,22 \\
abr/05 & $12.316,58$ & 91,15 & 12,27 & 30 & 3 & 112,15 \\
Mai/05 & $12.223,08$ & 41,04 & 155,88 & 22 & 6 & 169,04 \\
jun/05 & $12.754,99$ & 43,23 & 161,78 & 28 & 5 & 155,23 \\
& & & & & & \\
\hline MÉDIA & $11.977,05$ & 63,46 & 88,73 & 25 & 8 & 124,92 \\
\hline
\end{tabular}

Tabela 6-7 - Dados para a Composição dos Indicadores de Velocidade. 
Onde,

- HS - Horas em serviço do mês do período considerado [h];

- HMC - Horas de manutenção corretiva realizadas no mês do período considerado [h];

- HMP R - Horas de manutenção preventiva realizadas no mês do período considerado [h];

- NF - Número de falhas ou número de intervenções de natureza corretiva realizadas no mês do período;

- NP - Número de preventivas ou número de intervenções de natureza preventiva realizadas no mês do período.

\begin{tabular}{|c|c|c|c|c|c|c|}
\hline MÊS & TMDR & IPR & VAT & DIP & NI & HCI \\
\hline & & & & & & \\
jun/04 & 3,19 & $0,07 \%$ & $96,46 \%$ & $99,93 \%$ & 27 & 86,08 \\
jul/04 & 3,43 & $0,00 \%$ & $100,45 \%$ & $100,00 \%$ & 34 & 116,59 \\
Ago/04 & 4,09 & $1,02 \%$ & $64,73 \%$ & $98,98 \%$ & 45 & 183,89 \\
set/04 & 3,01 & $0,65 \%$ & $67,94 \%$ & $99,35 \%$ & 48 & 144,24 \\
Out/04 & 10,34 & $1,79 \%$ & $58,81 \%$ & $98,21 \%$ & 23 & 237,85 \\
Nov/04 & 4,49 & $0,10 \%$ & $108,48 \%$ & $99,90 \%$ & 24 & 107,84 \\
Dez/04 & 6,74 & $0,94 \%$ & $102,05 \%$ & $99,06 \%$ & 20 & 134,74 \\
jan/05 & 2,41 & $0,44 \%$ & $89,45 \%$ & $99,56 \%$ & 39 & 93,81 \\
fev/05 & 4,79 & $0,99 \%$ & $77,20 \%$ & $99,01 \%$ & 37 & 177,25 \\
Mar/05 & 4,65 & $1,12 \%$ & $81,37 \%$ & $98,88 \%$ & 41 & 190,76 \\
abr/05 & 3,13 & $0,10 \%$ & $108,44 \%$ & $99,90 \%$ & 33 & 103,42 \\
Mai/05 & 7,03 & $1,28 \%$ & $85,84 \%$ & $98,72 \%$ & 28 & 196,92 \\
jun/05 & 6,21 & $1,27 \%$ & $75,72 \%$ & $98,73 \%$ & 33 & 205,01 \\
& & & & & & \\
\hline MÉDIA & 4,89 & $0,75 \%$ & $85,92 \%$ & $99,25 \%$ & 33,23 & 152,18 \\
\hline
\end{tabular}

Tabela 6-8 - Valores dos Indicadores de Velocidade no Período.

Os dados colhidos no período permitem perceber a variação dos Indicadores de Velocidade pelos equipamentos que compõem a célula em estudo. A Tabela 6-9, construída a partir dos dados organizados nos Anexos 3, 4, e 6, evidencia esta afirmativa

Os gráficos apresentados no Anexo 10 possibilitam uma visualização mais nítida da variação dos Indicadores de Velocidade na célula e no período considerado. 


\begin{tabular}{|c|c|c|c|c|c|c|}
\hline CÓDIGO & TMDR & IPR & VAT & DIP & NI & HCI \\
\hline & & & & & & \\
02200905 & - & $0,00 \%$ & - & $100,00 \%$ & - & - \\
02200906 & 4,04 & $0,16 \%$ & $144,51 \%$ & $99,84 \%$ & 3 & 12,11 \\
02200907 & 7,83 & $0,75 \%$ & $101,82 \%$ & $99,25 \%$ & 7 & 54,81 \\
02202537 & 9,95 & $0,39 \%$ & $40,39 \%$ & $99,61 \%$ & 3 & 29,86 \\
02202552 & 1,75 & $0,00 \%$ & $100,00 \%$ & $100,00 \%$ & 4 & 6,99 \\
02202560 & 2,57 & $0,00 \%$ & $100,00 \%$ & $100,00 \%$ & 1 & 2,57 \\
02203226 & 5,45 & $0,23 \%$ & $101,11 \%$ & $99,77 \%$ & 19 & 103,53 \\
02205701 & - & $0,00 \%$ & - & $100,00 \%$ & - & - \\
0220RP01 & 2,43 & $0,50 \%$ & $91,57 \%$ & $99,50 \%$ & 34 & 82,66 \\
0220RP02 & 3,78 & $0,59 \%$ & $93,93 \%$ & $99,41 \%$ & 30 & 113,29 \\
0220RP03 & 3,93 & $1,26 \%$ & $66,52 \%$ & $98,74 \%$ & 41 & 160,96 \\
0220RP04 & 6,13 & $3,05 \%$ & $74,12 \%$ & $96,95 \%$ & 41 & 251,29 \\
0220RP05 & 8,37 & $3,53 \%$ & $69,26 \%$ & $96,47 \%$ & 34 & 284,73 \\
0220RP12 & 4,23 & $0,44 \%$ & $90,10 \%$ & $99,56 \%$ & 14 & 59,21 \\
0220RP15 & 2,79 & $0,26 \%$ & $119,02 \%$ & $99,74 \%$ & 11 & 30,65 \\
0220RP18 & 1,85 & $0,19 \%$ & $90,82 \%$ & $99,81 \%$ & 25 & 46,32 \\
0220RP19 & 3,78 & $1,05 \%$ & $71,30 \%$ & $98,95 \%$ & 30 & 113,50 \\
0220RP21 & 3,30 & $0,38 \%$ & $90,02 \%$ & $99,62 \%$ & 11 & 36,27 \\
0220RP22 & 3,00 & $0,42 \%$ & $89,27 \%$ & $99,58 \%$ & 16 & 48,01 \\
0220RP23 & 8,50 & $1,90 \%$ & $82,34 \%$ & $98,10 \%$ & 23 & 195,51 \\
0220RP24 & 7,30 & $0,32 \%$ & $101,82 \%$ & $99,68 \%$ & 10 & 72,99 \\
0220RP27 & 2,74 & $0,63 \%$ & $87,01 \%$ & $99,37 \%$ & 38 & 103,99 \\
0220RP28 & 4,37 & $1,53 \%$ & $80,31 \%$ & $98,47 \%$ & 31 & 135,58 \\
0220RP29 & 5,60 & $0,44 \%$ & $85,49 \%$ & $99,56 \%$ & 6 & 33,57 \\
& & & & & & \\
\hline MÉDIA & 4,71 & $0,75 \%$ & $89,58 \%$ & $99,25 \%$ & 18,00 & 82,43 \\
\hline
\end{tabular}

Tabela 6-9 - Valores dos Indicadores de Velocidade pelos Equipamentos da Célula.

\subsubsection{INDICADORES DE CONFIABILIDADE}

A descrição dos indicadores para a gestão da confiabilidade da função manutenção estão resumidas na Tabela 6-10.

\begin{tabular}{|c|c|l|c|}
\hline Classificação & Sigla & \multicolumn{1}{|c|}{ Descrição } & Referência \\
\hline \multirow{4}{*}{ Principais } & TMEF & Tempo Médio Entre Falhas & Eq. [3-16] \\
\cline { 2 - 4 } & IRE & Índice de Risco de Equipamento & Eq. [3-17] \\
\cline { 2 - 4 } & IFO & Indisponibilidade Forçada & Eq. [3-18] \\
\hline \multirow{4}{*}{ Complementares } & NF & Número de Falhas & - \\
\cline { 2 - 4 } & HMC & Horas de Manutenção Corretiva & - \\
\cline { 2 - 4 } & DIF & Disponibilidade Forçada & Eq. [3-19] \\
\hline
\end{tabular}

Tabela 6-10 - Indicadores para a Gestão da Confiabilidade. 
A variação dos valores dos Indicadores de confiabilidade pelos meses do período considerado está apresentada na Tabela 6-11

A Tabela 6-12 demonstra a obtenção do Índice de Risco de Equipamento (IRE) para o mês 12/2004. Os valores para os meses do período considerado estão relatados no Anexo 7. Já a Tabela 6-13 resume a apuração do IRE nos meses do período, a partir dos valores do Índice de Risco da Falha (IRF) no equipamento.

A variação dos valores dos Indicadores de Confiabilidade, através dos equipamentos da Célula Retífica de Perfil, está contida na Tabela 6-14. As três últimas tabelas foram construídas a partir dos dados organizados nos Anexos 3, 4 e 6.

Uma visualização mais nítida da variação dos valores destes indicadores está registrada nos gráficos apresentados pelo Anexo 11.

\begin{tabular}{|c|c|c|c|c|c|c|}
\hline MÊS & TMEF & IRE & IFO & NF & HMC & DIF \\
\hline & & & & & & \\
jun/04 & 587,33 & 2.117 & $0,63 \%$ & 21 & 78,03 & $99,37 \%$ \\
jul/04 & 405,56 & 3.309 & $0,87 \%$ & 33 & 116,12 & $99,13 \%$ \\
ago/04 & 412,13 & 3.106 & $0,42 \%$ & 31 & 53,04 & $99,58 \%$ \\
set/04 & 371,99 & 3.308 & $0,52 \%$ & 33 & 63,99 & $99,48 \%$ \\
out/04 & 646,79 & 1.806 & $0,25 \%$ & 18 & 29,39 & $99,75 \%$ \\
nov/04 & 588,61 & 2.006 & $0,81 \%$ & 20 & 95,49 & $99,19 \%$ \\
dez/04 & 663,77 & 1.203 & $0,75 \%$ & 12 & 59,50 & $99,25 \%$ \\
jan/05 & 474,08 & 2.607 & $0,32 \%$ & 26 & 39,91 & $99,68 \%$ \\
fev/05 & 433,44 & 2.708 & $0,52 \%$ & 27 & 60,84 & $99,48 \%$ \\
mar/05 & 421,70 & 2.911 & $0,44 \%$ & 29 & 53,22 & $99,56 \%$ \\
abr/05 & 410,55 & 3.012 & $0,74 \%$ & 30 & 91,15 & $99,26 \%$ \\
mai/05 & 555,59 & 2.309 & $0,34 \%$ & 22 & 41,04 & $99,66 \%$ \\
jun/05 & 455,54 & 2.908 & $0,34 \%$ & 28 & 43,23 & $99,66 \%$ \\
& & & & & & \\
\hline MÉDIA & 494,39 & 2.562 & $0,53 \%$ & 25 & 63,46 & $99,47 \%$ \\
\hline
\end{tabular}

Tabela 6-11 - Valores dos Indicadores de Confiabilidade no Período. 


\begin{tabular}{|c|c|c|c|c|c|c|c|c|c|}
\hline Código & OS Mnt Corretiva & Cod Parada & Modalidade & Falha & Causa & Ocorrência & Gravidade & Detectabilidade & OGD \\
\hline 02203226 & 02T94020 & $02 \mathrm{C} 3297$ & ELÉTRICA & QUEIMA & FONTE DE ALIMENTAÇÃO & 1 & 10 & 10 & 100 \\
\hline 02203226 & 02T98400 & $02 \mathrm{C} 3441$ & MECÂNICA & DEFORMAÇÃO & DESGASTE & 1 & 10 & 10 & 100 \\
\hline 02203226 & 02U04302 & $02 \mathrm{C} 3621$ & MECÂNICA & MELHORIA & EIXO & 1 & 10 & 10 & 100 \\
\hline Subtotais & 3 & 3 & & & & 3 & & IRF & 300 \\
\hline 0220RP28 & 02 T98099 & $02 \mathrm{C} 3430$ & MECÂNICA & TRAVAMENTO & ROLAMENTO & 1 & 10 & 10 & 100 \\
\hline 0220RP28 & 02U06104 & 02C3700 & ELÉTRICA & INTERRUPÇÃO DE SINAL & PRESSOSTATO & 1 & 10 & 10 & 100 \\
\hline 0220RP28 & 02U05980 & 02С3690 & MECÂNICA & VAZAMENTO & HIDR.-CONEXÃO & 1 & 10 & 10 & 100 \\
\hline Subtotais & 3 & 3 & & & & 3 & & IRF & 300 \\
\hline 0220RP23 & 02U06328 & $02 \mathrm{C} 3717$ & MECÂNICA & DESGASTE & PARAFUSO & 1 & 10 & 10 & 100 \\
\hline 0220RP23 & 02U05016 & $02 \mathrm{C} 3646$ & ELÉTRICA & INTERRUPÇÃO DE SINAL & CHAVE FIM-DE-CURSO & 1 & 10 & 10 & 100 \\
\hline Subtotais & 2 & 2 & & & & 2 & & IRF & 200 \\
\hline 0220RP01 & 02U07871 & $02 \mathrm{C} 3779$ & MECÂNICA & QUEBRA & PARAFUSO & 1 & 10 & 10 & 100 \\
\hline 0220RP01 & 02 T95403 & & MECÂNICA & FOLGA & ROLAMENTO & 1 & 1 & 1 & 1 \\
\hline Subtotais & 2 & 1 & & & & 2 & & IRF & 101 \\
\hline 02202537 & $02 T 98419$ & $02 \mathrm{C} 3442$ & MECÂNICA & QUEBRA & PNEUM.-VÁLVULA & 1 & 10 & 10 & 100 \\
\hline Subtotais & 1 & 1 & & & & 1 & & IRF & 100 \\
\hline 0220RP04 & 02U05800 & $02 C 3679$ & ELÉTRICA & INTERRUPÇÃO DE SINAL & SENSOR & 1 & 10 & 10 & 100 \\
\hline Subtotais & 1 & 1 & & & & 1 & & IRF & 100 \\
\hline 0220RP15 & 02U07880 & 02C3780 & MECÂNICA & QUEBRA & LUBRIFIL & 1 & 10 & 10 & 100 \\
\hline Subtotais & 1 & 1 & & & & 1 & & IRF & 100 \\
\hline 0220RP18 & $02 \mathrm{~T} 97027$ & & MECÂNICA & SUJEIRA & BOMBA & 1 & 1 & 1 & 1 \\
\hline Subtotais & 1 & $\mathbf{0}$ & & & & 1 & & IRF & 1 \\
\hline 0220RP19 & 02U04115 & & MECÂNICA & QUEBRA & PROTEÇÃO/TAMPA & 1 & 1 & 1 & 1 \\
\hline Subtotais & 1 & 0 & & & & 1 & & IRF & 1 \\
\hline Totais & 15 & 12 & & & & 15 & & IRE & 1.203 \\
\hline
\end{tabular}

Tabela 6-12 - Apuração do Índice de Risco de Equipamento (IRE) da Célula para o mês 12/2004. 


\begin{tabular}{|c|c|c|c|c|c|c|c|c|c|c|c|c|c|c|}
\hline \multirow{2}{*}{ CÓDIGO } & \multicolumn{14}{|c|}{ ÍNDICE DE RISCO DA FALHA NO EQUIPAMENTO (IRF) } \\
\hline & jun/04 & jul/04 & ago/04 & set/04 & out/04 & nov/04 & dez/04 & jan/05 & fev/05 & mar/05 & abr/05 & mai/05 & jun/05 & $2004 / 2005$ \\
\hline 02200905 & & & & & & & & & & & & & & 0 \\
\hline 02200906 & & 2 & & & 2 & & & & & 100 & & 100 & 1 & 205 \\
\hline 02200907 & & & 100 & & 1 & 1 & & 100 & & 1 & 2 & & 102 & 307 \\
\hline 02202537 & & & & 100 & & 1 & 100 & & & & 1 & & & 202 \\
\hline 02202552 & & 100 & & & & & & & 200 & & 100 & & & 400 \\
\hline 02202560 & & & & 100 & & & & & & & & & & 100 \\
\hline 02203226 & 102 & 101 & 301 & 100 & 101 & 300 & 300 & 102 & 1 & 100 & 101 & & 100 & 1.709 \\
\hline 02205701 & & & & & & & & & & & & & & 0 \\
\hline 0220RP01 & 200 & 100 & 301 & 501 & 201 & 100 & 101 & 602 & 2 & 201 & & 101 & 502 & 2.912 \\
\hline 0220RP02 & 200 & 400 & 1 & 300 & 101 & 200 & & 100 & 400 & 202 & 101 & 101 & 100 & 2.206 \\
\hline 0220RP03 & 200 & 100 & 301 & 202 & 100 & 201 & & 500 & 301 & 801 & 100 & 301 & 200 & 3.307 \\
\hline 0220RP04 & 110 & 500 & 500 & 300 & 100 & 300 & 100 & 200 & 301 & 301 & 401 & 100 & & 3.213 \\
\hline 0220RP05 & 402 & 500 & 200 & 300 & 100 & 100 & & 200 & 1 & 102 & 301 & 200 & 400 & 2.806 \\
\hline 0220RP12 & & 100 & & & & 102 & & & 500 & & 102 & 201 & 1 & 1.006 \\
\hline 0220RP15 & & & & & & & 100 & & & 200 & & 400 & 1 & 701 \\
\hline 0220RP18 & 201 & 402 & 300 & 102 & 100 & 100 & 1 & 300 & 100 & 100 & 101 & & 100 & 1.907 \\
\hline 0220RP19 & & 102 & & 302 & 200 & 200 & 1 & 200 & & & 701 & 300 & 400 & 2.406 \\
\hline 0220RP21 & 200 & & 100 & & 100 & & & & 1 & & 100 & 100 & 200 & 801 \\
\hline 0220RP22 & 1 & & & 200 & 100 & & & & 100 & 300 & 200 & 101 & 301 & 1.303 \\
\hline 0220RP23 & 100 & 301 & 200 & 101 & 100 & & 200 & 101 & 201 & 1 & 400 & 101 & & 1.806 \\
\hline 0220RP24 & 201 & 1 & & 100 & & 100 & & & 200 & & & & & 602 \\
\hline 0220RP27 & 200 & 300 & 401 & 200 & 300 & 201 & & 201 & 400 & 401 & 300 & 102 & 300 & 3.306 \\
\hline 0220RP28 & & 300 & 401 & 400 & 200 & 100 & 300 & 1 & & & 1 & 1 & 200 & 1.904 \\
\hline 0220RP29 & & & & & & & & & & 101 & & 100 & & 201 \\
\hline IRE & 2.117 & 3.309 & 3.106 & 3.308 & 1.806 & 2.006 & 1.203 & 2.607 & 2.708 & 2.911 & 3.012 & 2.309 & 2.908 & 33.310 \\
\hline
\end{tabular}

Tabela 6-13 - Quadro Resumo de Apuração do Índice de Risco de Equipamento (IRE). 


\begin{tabular}{|c|c|c|c|c|c|c|c|}
\hline CÓDIGO & EQUIPAMENTO & TMEF & IRF & IFO & NF & HMC & DIF \\
\hline 02200905 & C.PM FILTRO OILMATC-GOETZE-BP 37760 & - & 0 & $0,00 \%$ & - & - & $100,00 \%$ \\
\hline 02200906 & C.RP FILTRO OBERLIN - BP 37711 & $6.557,89$ & 205 & $0,02 \%$ & 1 & 2 & $99,98 \%$ \\
\hline 02200907 & C.RP FILTRO OBERLIN - BP 37705 & $2.171,73$ & 307 & $0,09 \%$ & 3 & 6 & $99,91 \%$ \\
\hline 02202537 & C.RP PILAO (M) - BP 2138 & $3.270,07$ & 202 & $0,06 \%$ & 2 & 4 & $99,94 \%$ \\
\hline 02202552 & C.PM PILAO (E/M) - BP 9769 & $1.640,75$ & 400 & $0,11 \%$ & 4 & 7 & $99,89 \%$ \\
\hline 02202560 & C.PM PILAO (E/M) - BP 20013 & $6.567,43$ & 100 & $0,04 \%$ & 1 & 3 & $99,96 \%$ \\
\hline 02203226 & C.RP GRAVADORA CNC - BP 37741 & 380,38 & 1.709 & $1,37 \%$ & 17 & 89 & $98,63 \%$ \\
\hline 02205701 & C.RP DISPOSITIVO - BP 35485 & - & 0 & $0,00 \%$ & - & - & $100,00 \%$ \\
\hline 0220RP01 & C.RP RTF. PERFIL R4MG - BP 35014 & 223,70 & 2.912 & $0,77 \%$ & 29 & 50 & $99,23 \%$ \\
\hline 0220RP02 & C.RP RTF. PERFIL R7MG - BP 40058 & 293,49 & 2.206 & $1,17 \%$ & 22 & 75 & $98,83 \%$ \\
\hline 0220RP03 & C.RP RTF. PERFIL R7MG - BP 40057 & 194,21 & 3.307 & $1,25 \%$ & 33 & 80 & $98,75 \%$ \\
\hline 0220RP04 & C.RP RTF. PERFIL R7MG - BP 37703 & 197,46 & 3.213 & $0,93 \%$ & 32 & 59 & $99,07 \%$ \\
\hline 0220RP05 & C.RP RTF. PERFIL R7MG - BP 37704 & 232,79 & 2.806 & $1,00 \%$ & 27 & 63 & $99,00 \%$ \\
\hline 0220RP12 & C.RP RTF. KATAOKA PCG-1-NC-BP 36155 & 651,08 & 1.006 & $0,47 \%$ & 10 & 30 & $99,53 \%$ \\
\hline 0220RP15 & C.RP RTF. KATAOKA PCG - BP 36156 & 934,19 & 701 & $0,21 \%$ & 7 & 13 & $99,79 \%$ \\
\hline 0220RP18 & C.RP RTF. KATAOKA R7 - BP 900069 & 343,35 & 1.907 & $0,52 \%$ & 19 & 34 & $99,48 \%$ \\
\hline 0220RP19 & C.RP RTF. KATAOKA R7 - BP 900403 & 269,02 & 2.406 & $0,71 \%$ & 24 & 46 & $99,29 \%$ \\
\hline 0220RP21 & C.PM RTF. KATAOKA PCG - AF 0018 & 816,72 & 801 & $0,18 \%$ & 8 & 12 & $99,82 \%$ \\
\hline 0220RP22 & C.PM RTF. KATAOKA R4MG - BP 32606 & 501,69 & 1.303 & $0,32 \%$ & 13 & 21 & $99,68 \%$ \\
\hline $0220 \mathrm{RP} 23$ & C.PM RTF. KATAOKA R4MG - BP 28724 & 354,14 & 1.806 & $1,17 \%$ & 18 & 74 & $98,83 \%$ \\
\hline 0220RP24 & C.PM RTF. KATAOKA PCG - AF 0017 & $1.082,84$ & 602 & $0,81 \%$ & 6 & 52 & $99,19 \%$ \\
\hline 0220RP27 & C.RP RTF. KATAOKA R7 - BP 900573 & 195,94 & 3.306 & $0,98 \%$ & 33 & 63 & $99,02 \%$ \\
\hline 0220RP28 & C.RP RTF. KATAOKA R7 - BP 900113 & 338,65 & 1.904 & $0,57 \%$ & 19 & 37 & $99,43 \%$ \\
\hline 0220RP29 & C.RP RET. PERFIL PCG - BP 901518 & $3.268,22$ & 201 & $0,07 \%$ & 2 & 5 & $99,93 \%$ \\
\hline \multicolumn{2}{|r|}{ MÉDIA NA CÉLULA } & $1.385,72$ & 1.388 & $0,53 \%$ & 15 & 37,50 & $99,47 \%$ \\
\hline
\end{tabular}

Tabela 6-14 - Valores dos Indicadores de Confiabilidade pelos Equipamentos da Célula. 


\subsubsection{INDICADORES DE FLEXIBILIDADE}

A Tabela 6-15 resume a descrição dos indicadores desenvolvidos para a gestão da flexibilidade da função manutenção.

\begin{tabular}{|c|c|l|c|}
\hline Classificação & Sigla & \multicolumn{1}{|c|}{ Descrição } & Referência \\
\hline \multirow{3}{*}{ Principais } & TPE & Taxa de Polivalência das Equipes & Eq. [3-20] \\
\cline { 2 - 4 } & TRT & Taxa de Realização de Treinamentos & Eq. [3-21] \\
\cline { 2 - 4 } & TRSM & Taxa de Reatividade dos Svs de Manutenção & Eq. [3-22] \\
\hline
\end{tabular}

Tabela 6-15 - Indicadores de Flexibilidade para a Gestão da Manutenção.

A Tabela 6-16 permite visualizar o quadro geral das intervenções envolvendo equipamentos e funcionários e a apuração da TPE - Taxa de Polivalência das Equipes.

A Figura 6-2 complementa a apresentação deste indicador.

Já o Anexo 12 possibilita uma visão mais detalhada das intervenções realizadas e das horas previstas e realizadas dos treinamentos relativos à célula em questão.

O anexo em questão permite também observar os valores da TRSM - Taxa de Reatividade dos Serviços de Manutenção e da TRT - Taxa de Realização de Treinamentos ao longo dos meses do período considerado. 


\begin{tabular}{|c|c|c|c|c|c|c|c|c|c|c|c|c|c|c|c|c|c|c|c|c|c|c|c|c|c|c|}
\hline \multirow[b]{2}{*}{ FUNCIONÁRIOS } & \multicolumn{24}{|c|}{ NÚMERO DE INTERVENÇÕES } & \multirow[b]{2}{*}{$\sum_{\substack{0 \\
0}}^{\infty}$} & \multirow[b]{2}{*}{ TPE } \\
\hline & 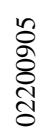 & 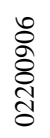 & 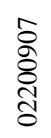 & 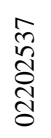 & 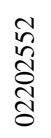 & 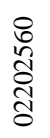 & 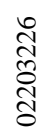 & 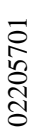 & 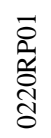 & 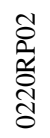 & 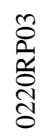 & 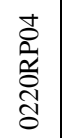 & 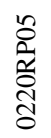 & 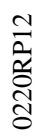 & 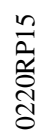 & 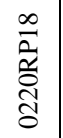 & 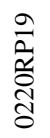 & 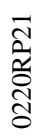 & 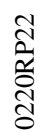 & 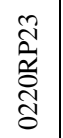 & 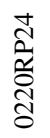 & 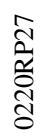 & 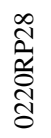 & 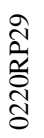 & & \\
\hline ADRIANO MACEDO & & 5 & 4 & & & & 5 & & 17 & 8 & 12 & 8 & 8 & 6 & 3 & 8 & 10 & & & 1 & & 8 & 8 & & 111 & $17 \%$ \\
\hline SILVIO JOSE LIMA & & & 1 & 1 & 2 & & & & 6 & 5 & 6 & 9 & 10 & 2 & 2 & 4 & 3 & 1 & 2 & 5 & & 7 & 2 & & 68 & $11 \%$ \\
\hline JOAO BATISTA DA SILVA & & & 2 & & & & 8 & & 7 & 2 & 6 & 3 & 4 & 4 & 1 & 1 & 4 & & 5 & 3 & 3 & 3 & 4 & 1 & 61 & $9 \%$ \\
\hline CLEZIO CARDOSO SILVA & & 1 & & & & & 4 & & 6 & 7 & 7 & 6 & 2 & 3 & & 7 & 3 & & & 1 & & 3 & 5 & & 55 & $9 \%$ \\
\hline EDSON HENRIQUE DA SILVA & & 1 & 1 & & & & 1 & & 3 & 1 & 3 & 1 & 1 & & 1 & 2 & 4 & 3 & 2 & 1 & 4 & 6 & 4 & & 39 & $6 \%$ \\
\hline GILBERTO CORREA DE CARVALHO & & & & & & & 2 & & 3 & 2 & 2 & 3 & 5 & 2 & 1 & 3 & 1 & 1 & 1 & 4 & 1 & 3 & 2 & 2 & 38 & $6 \%$ \\
\hline VALTEMIR FRANCISCO BARROS & & & 2 & & & & & & 5 & 4 & 4 & 4 & 2 & 3 & 1 & & 3 & & & & & 6 & 1 & & 35 & $5 \%$ \\
\hline NOEL TEIXEIRA DOS SANTOS & & & & & & & 1 & & & 3 & 1 & 3 & 4 & 2 & 1 & 3 & 3 & 1 & 2 & 1 & 1 & 2 & 2 & 1 & 31 & $5 \%$ \\
\hline LUCIANO JOSE CORTES & & & & & & & 2 & & 3 & 1 & 1 & 3 & 2 & & 1 & 5 & 4 & & & 1 & & 1 & & & 24 & $4 \%$ \\
\hline GERSON TADEU GONCALVES & & & 1 & & & & 2 & & 5 & 1 & 1 & 3 & 2 & 1 & 1 & & 1 & 1 & 1 & & & 3 & & & 23 & $4 \%$ \\
\hline CARLOS RENATO ALKMIM & & & & 2 & & & 1 & & & 1 & & 1 & & & & & & 1 & 2 & 10 & 2 & & & 1 & 21 & $3 \%$ \\
\hline SIDNEY GONCALVES FARIA MONTI & & & & & & & & & 1 & 2 & 6 & & 1 & 1 & & 1 & 1 & & & & 2 & 2 & 1 & & 18 & $3 \%$ \\
\hline JOSE ANDERSON DE PAULA & & & & & & & & & & & 1 & 1 & 1 & & 1 & 1 & 1 & 2 & 1 & 1 & 1 & 3 & 2 & 1 & 17 & $3 \%$ \\
\hline RICARDO MAGNO DO CARMO & & & 1 & & & & & & 1 & & 3 & 2 & 2 & 1 & & & 1 & & & 2 & & 1 & 2 & & 16 & $2 \%$ \\
\hline CLAUDIO RAIMUNDO DE ANDRADE & & 1 & & & & & & & 1 & & 4 & 1 & 1 & & & 1 & & & 1 & & & 3 & 3 & & 16 & $2 \%$ \\
\hline WAGNER KALAS PEREIRA & & & & 1 & 1 & 1 & & & & 2 & & & & & & & & 3 & 2 & 4 & & & 1 & & 15 & $2 \%$ \\
\hline JUNIOR MARCELO GONCALVES & & & 1 & & & & & & & 1 & 1 & 2 & 1 & 1 & & & & & & 1 & 1 & & 1 & 1 & 11 & $2 \%$ \\
\hline SIDINEI ALBERTO MENEZES & & 1 & & & & & 1 & & & & 1 & & & & & 1 & 2 & & & & 2 & & & & 8 & $1 \%$ \\
\hline SEBASTIAO DIVINO CARLOS & & & 1 & & & & & & & & 1 & 4 & & & & & & & 1 & & & & & & 7 & $1 \%$ \\
\hline NÃO IDENTIFICADO & & & & & & & 1 & & & 1 & & & & & 1 & 1 & & & & & & & 3 & & 7 & $1 \%$ \\
\hline JORGELINO BATISTA DE OLIVEIRA & & & 2 & & & & 1 & & & & & & 1 & 1 & & & & & & & & 1 & 1 & & 7 & $1 \%$ \\
\hline RENATO MARCEL CARVALHO & & 1 & & 1 & & & & & 1 & & & & & & & & & & & 2 & & & & & 5 & $1 \%$ \\
\hline WILLIAN DOS SANTOS FLAUZINO & & & & & & & 1 & & & 1 & & 1 & & & & 1 & & & & & & & & & 4 & $1 \%$ \\
\hline CLESIO TORRES GOMES & & & 1 & & & & & & & & & & & & & 1 & & & & & & & & & 2 & $0 \%$ \\
\hline MATHEUS MARQUES ANDRADE & & & & & & & & & & & & & & & & & & & & 1 & & & & & 1 & $0 \%$ \\
\hline LUIZ CARLOS NOGUEIRA & & & 1 & & & & & & & & & & & & & & & & & & & & & & 1 & $0 \%$ \\
\hline LUCAS GARCIA SIQUEIRA DA SILVA & & & & & & & & & & & & 1 & & & & & & & & & & & & & 1 & $0 \%$ \\
\hline EDMILSON CESAR FRANCISCO & & & & & 1 & & & & & & & & & & & & & & & & & & & & 1 & $0 \%$ \\
\hline DANIEL RIBEIRO & & & & & & & & & & & & & & & & & & & & & & & & 1 & 1 & $0 \%$ \\
\hline TOTAIS & 0 & 10 & 18 & 5 & 4 & 1 & 30 & 0 & 59 & 42 & 60 & 56 & 47 & 27 & 14 & 40 & 41 & 13 & 20 & 38 & 17 & 52 & 42 & 8 & 644 & \\
\hline
\end{tabular}

Tabela 6-16 - Quadro Geral das Intervenções: Equipamentos x Funcionários. 


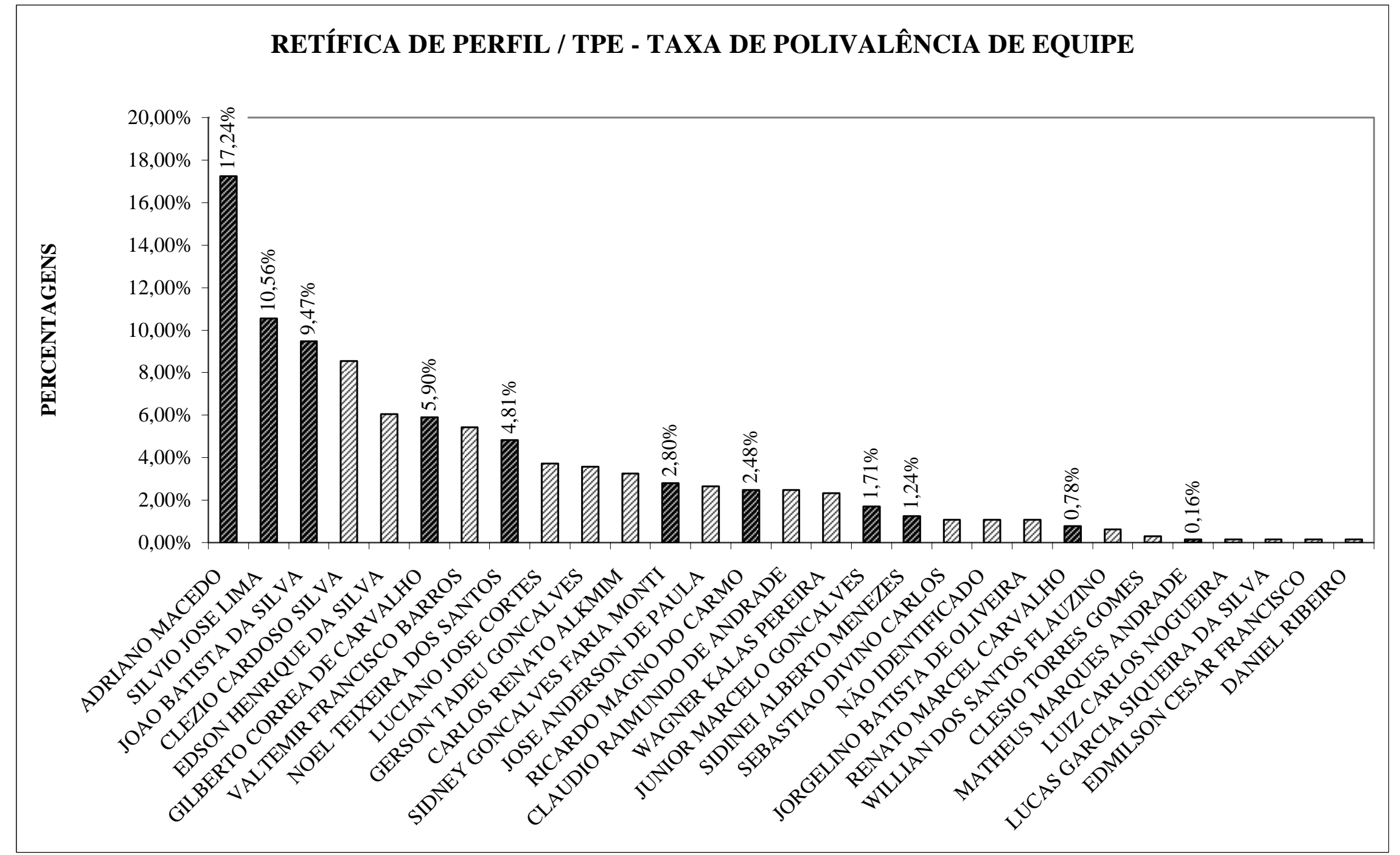

Figura 6-2 - Taxa de Polivalência das Equipes. 


\subsubsection{INDICADORES DE CUSTOS}

A Tabela 6-17 resume a descrição dos indicadores desenvolvidos para a gestão da qualidade dentro da função manutenção.

\begin{tabular}{|c|c|l|c|}
\hline Classificação & Sigla & \multicolumn{1}{|c|}{ Descrição } & Referência \\
\hline \multirow{5}{*}{ Principais } & CTM & Custo Total de Manutenção & Eq. [3-23] \\
\cline { 2 - 4 } & CTMUP & $\begin{array}{l}\text { Custo Total de Manutenção por Unidades } \\
\text { Produzidas }\end{array}$ & Eq. [3-35] \\
\cline { 2 - 4 } & CMUP & $\begin{array}{l}\text { Custo de Manutenção por Unidade de } \\
\text { Produto }\end{array}$ & Eq. [3-37] \\
\cline { 2 - 5 } & CPP & Custo da Paralisação da Produção & Eq. [3-33] \\
\hline \multirow{5}{*}{ Complementares } & CAA & Custo das Atividades de Apoio & Eq. [3-26] \\
\cline { 2 - 5 } & CMC & Custo da Manutenção Corretiva & Eq. [3-28] \\
\cline { 2 - 5 } & CMP & Custo da Manutenção Preventiva & $\begin{array}{l}\text { Custo Horário das Atividades de } \\
\text { Eanutenção }\end{array}$ \\
\cline { 2 - 5 } & EqS & $\begin{array}{l}\text { Custo da Hora em Serviço dos } \\
\text { Equipamentos }\end{array}$ \\
\cline { 2 - 5 } & Eq. [3-38] \\
\hline
\end{tabular}

Tabela 6-17 - Indicadores de Custos para a Gestão da Manutenção.

Assim, a partir dos dados organizados nos Anexos 3, 4 e 8 é possível compor a Tabela 6-18 para a apuração dos indicadores CHA, CAA, CMC E CMP, relativos à célula em estudo. As colunas da tabela em questão podem ser assim descritas:

- RECURSOS - Recursos consumidos pelo setor de manutenção no mês do período considerado em [R\$];

- H PER - Horas disponíveis do mês do período em [h];

- HAA - Horas das atividades de apoio no mês do período em [h], rateadas com base no número de equipamentos da célula (ver Tabela 6-1) e nas horas disponíveis dos meses do período considerado (ver Anexo 3). O número total de equipamentos da Célula Retífica de Perfil equivale a 1,3929\% do total da empresa. Assim, as horas das atividades de apoio distribuídas à célula podem também ser definidas na mesma proporção; 
- HMC - Horas de manutenção corretiva do mês do período em [h];

- HMP - Horas de manutenção preventiva do mês do período em [h];

- CHA - Custo horário das atividades de manutenção no mês do período em $[R \$ / h]$ :

$\checkmark \quad \mathrm{CHA}=\mathrm{RECURSOS} / \mathrm{H}$ PER ;

- CAA - Custo das atividades de apoio no mês do período em [R\$]:

$\checkmark \quad \mathrm{CAA}=\mathrm{CHA} \times \mathrm{HAA}$;

- CMC - Custo da manutenção corretiva no mês do período em [R \$]:

$\checkmark \mathrm{CMC}=\mathrm{CHA} \times \mathrm{HMC}$;

- CMP - Custo da manutenção preventiva no mês do período em [R\$]:

$\checkmark \mathrm{CMP}=\mathrm{CHA} \times \mathrm{HMP}$.

\begin{tabular}{|c|c|c|c|c|c|c|c|c|c|}
\hline MÊS & RECURSOS & H PER & HAA & HMC & HMP & CHA & CAA & CMC & CMP \\
\hline & & & & & & & & & \\
jun/04 & $422.603,00$ & 517,50 & 7,21 & 78,53 & 8,05 & 816,62 & $5.886,52$ & $64.129,49$ & $6.573,82$ \\
jul/04 & $474.797,00$ & 562,50 & 7,84 & 116,12 & 0,47 & 844,08 & $6.613,54$ & $98.014,98$ & 396,72 \\
ago/04 & $456.863,00$ & 540,00 & 7,52 & 53,04 & 130,85 & 846,04 & $6.363,73$ & $44.874,10$ & $110.704,67$ \\
set/04 & $389.813,00$ & 517,50 & 7,21 & 63,99 & 80,25 & 753,26 & $5.429,78$ & $48.201,22$ & $60.449,26$ \\
out/04 & $424.840,00$ & 495,00 & 6,89 & 39,53 & 208,46 & 858,26 & $5.917,68$ & $33.927,12$ & $178.913,43$ \\
nov/04 & $446.060,00$ & 495,00 & 6,89 & 95,49 & 12,35 & 901,13 & $6.213,26$ & $86.049,03$ & $11.128,97$ \\
dez/04 & $469.313,12$ & 337,50 & 4,70 & 59,50 & 75,24 & $1.390,56$ & $6.537,15$ & $82.738,16$ & $104.625,54$ \\
jan/05 & $439.339,00$ & 517,50 & 7,21 & 39,91 & 53,90 & 848,96 & $6.119,64$ & $33.882,16$ & $45.759,17$ \\
fev/05 & $457.740,00$ & 495,00 & 6,89 & 60,84 & 116,41 & 924,73 & $6.375,95$ & $56.260,41$ & $107.647,50$ \\
mar/05 & $491.395,00$ & 517,50 & 7,21 & 53,22 & 137,54 & 949,56 & $6.844,74$ & $50.535,35$ & $130.601,87$ \\
abr/05 & $551.087,00$ & 517,50 & 7,21 & 91,15 & 12,27 & $1.064,90$ & $7.676,20$ & $97.065,86$ & $13.066,35$ \\
mai/05 & $503.499,00$ & 517,50 & 7,21 & 41,04 & 155,88 & 972,94 & $7.013,33$ & $39.929,66$ & $151.662,66$ \\
jun/05 & $492.263,00$ & 540,00 & 7,52 & 43,23 & 161,78 & 911,60 & $6.856,83$ & $39.408,39$ & $147.478,35$ \\
& & & & & & & & & \\
\hline MÉDIA & $463.047,09$ & 505,38 & 7,04 & 64,28 & 88,73 & 929,44 & $6.449,87$ & $59.616,61$ & $82.231,41$ \\
\hline
\end{tabular}

Tabela 6-18 - Apuração dos Indicadores de Custos CHA, CAA, CMC e CMP.

A partir dos dados organizados nos Anexos 3, 4 e 6 pode-se compor a Tabela 6-19 para a apuração do Custo da Paralisação da Produção (CPP) relativo à célula em estudo. As colunas da tabela em questão são descritas como: 
- HP - Horas paralisadas no mês do período em [h];

- \% CRO - Percentagem de anéis cromados produzidos no mês do período;

- \% MET - Percentagem de anéis metalizados produzidos no mês do período;

- HP CRO - Horas paralisadas durante a produção de anéis cromados em [h]:

$$
\checkmark \quad \mathrm{HPCRO}=\% \mathrm{CRO} \times \mathrm{HP} \text {; }
$$

- HP MET - Horas paralisadas durante a produção de anéis metalizados em [h]:

$\checkmark \quad \mathrm{HP} \mathrm{MET}=\% \mathrm{MET} \times \mathrm{HP}$;

- TPU CRO - Tempo planejado da unidade de produção de anéis cromados em $[\mathrm{h} / \mathrm{u}]$;

- TPU MET - Tempo planejado da unidade de produção de anéis metalizados em $[\mathrm{h} / \mathrm{u}]$;

- QNP CRO - Quantidade não produzida de anéis cromados ou quantidade que deixou de ser produzida durante as HP CRO em [u]:

$\checkmark \mathrm{QNPCRO}=(\mathrm{HPCRO}) /(\mathrm{TPU} \mathrm{CRO})$;

- QNP MET - Quantidade não produzida de anéis metalizados ou quantidade que deixou de ser produzida durantes as HP MET em [u]:

$\checkmark \quad$ QNP MET $=($ HP MET $) /($ TPU MET $)$;

- LU CRO - Lucro unitário propiciado pelas vendas de anéis cromados em $[\mathrm{R} \$ / \mathrm{u}]$

- LU MET - Lucro unitário propiciado pelas vendas de anéis metalizados em $[R \$ / u]$

- CPP - Custo da paralisação da produção:

$\checkmark \mathrm{CPP}=\mathrm{QNP} \mathrm{CRO} \times \mathrm{LU} \mathrm{CRO}+\mathrm{QNP} \mathrm{MET} \times \mathrm{LU} \mathrm{MET}$. 


\begin{tabular}{|c|c|c|c|c|c|c|c|c|c|c|c|c|}
\hline MÊS & HP & $\begin{array}{c}\text { \% } \\
\text { CRO }\end{array}$ & $\begin{array}{c}\text { \% } \\
\text { MET }\end{array}$ & $\begin{array}{c}\text { HP } \\
\text { CRO }\end{array}$ & $\begin{array}{c}\text { HP } \\
\text { MET }\end{array}$ & $\begin{array}{c}\text { TPU } \\
\text { CRO }\end{array}$ & $\begin{array}{c}\text { TPU } \\
\text { MET }\end{array}$ & $\begin{array}{c}\text { QNP } \\
\text { CRO }\end{array}$ & $\begin{array}{c}\text { QNP } \\
\text { MET }\end{array}$ & $\begin{array}{c}\text { LU } \\
\text { CRO }\end{array}$ & $\begin{array}{c}\text { LU } \\
\text { MET }\end{array}$ & CPP \\
\hline jun/04 & 86,58 & $80 \%$ & $20 \%$ & 69,00 & 17,58 & 0,011 & 0,031 & $6.140,51$ & 565,95 & 5,00 & 1,50 & $31.551,47$ \\
jul/04 & 116,59 & $72 \%$ & $28 \%$ & 83,87 & 32,72 & 0,011 & 0,030 & $7.467,15$ & $1.084,82$ & 5,00 & 1,50 & $38.962,95$ \\
ago/04 & 183,89 & $76 \%$ & $24 \%$ & 139,43 & 44,46 & 0,011 & 0,029 & $12.991,39$ & $1.515,44$ & 5,00 & 1,50 & $67.230,14$ \\
set/04 & 144,24 & $77 \%$ & $23 \%$ & 110,38 & 33,86 & 0,010 & 0,024 & $10.812,67$ & $1.429,85$ & 5,00 & 1,50 & $56.208,13$ \\
out/04 & 247,99 & $78 \%$ & $22 \%$ & 194,10 & 53,89 & 0,011 & 0,022 & $17.421,19$ & $2.412,70$ & 5,00 & 1,50 & $90.725,01$ \\
nov/04 & 107,84 & $70 \%$ & $30 \%$ & 75,05 & 32,79 & 0,011 & 0,027 & $7.129,32$ & $1.202,47$ & 5,00 & 1,50 & $37.450,29$ \\
dez/04 & 134,74 & $72 \%$ & $28 \%$ & 96,39 & 38,35 & 0,011 & 0,029 & $9.144,26$ & $1.331,01$ & 5,00 & 1,50 & $47.717,79$ \\
jan/05 & 93,81 & $78 \%$ & $22 \%$ & 73,42 & 20,39 & 0,008 & 0,020 & $8.926,70$ & $1.010,53$ & 5,00 & 1,50 & $46.149,30$ \\
fev/05 & 177,25 & $76 \%$ & $24 \%$ & 134,42 & 42,83 & 0,008 & 0,020 & $16.046,68$ & $2.142,35$ & 5,00 & 1,50 & $83.446,91$ \\
mar/05 & 190,76 & $75 \%$ & $25 \%$ & 142,54 & 48,22 & 0,010 & 0,028 & $14.201,69$ & $1.748,25$ & 5,00 & 1,50 & $73.630,81$ \\
abr/05 & 103,42 & $67 \%$ & $33 \%$ & 69,06 & 34,36 & 0,013 & 0,021 & $5.416,48$ & $1.626,42$ & 5,00 & 1,50 & $29.522,02$ \\
mai/05 & 196,92 & $67 \%$ & $33 \%$ & 132,50 & 64,42 & 0,011 & 0,020 & $11.841,22$ & $3.197,34$ & 5,00 & 1,50 & $64.002,11$ \\
jun/05 & 205,01 & $66 \%$ & $34 \%$ & 134,30 & 70,71 & 0,011 & 0,020 & $12.747,71$ & $3.581,12$ & 5,00 & 1,50 & $69.110,22$ \\
& & & & & & & & & & & & \\
\hline MÉDIA & 153,00 & $73 \%$ & $27 \%$ & 111,88 & 41,12 & 0,011 & 0,025 & $12.747,71$ & $1.757,56$ & 5,00 & 1,50 & $56.592,86$ \\
\hline
\end{tabular}

Tabela 6-19 - Apuração do Custo de Paralisação da Produção (CPP).

As tabelas 6-18 e 6-19 permitem a construção da Tabela 6-20 para a apuração do Custo Total de Manutenção (CTM).

\begin{tabular}{|c|c|c|c|c|c|c|c|c|}
\hline MÊS & & CAA & & CMC & & CMP & CPP & CTM \\
\hline jun/04 & $\mathrm{R} \$$ & $5.886,52$ & $\mathrm{R} \$$ & $64.129,49$ & $\mathrm{R} \$$ & $6.573,82$ & R\$ $31.551,47$ & $\mathrm{R} \$ 108.141,31$ \\
\hline jul/04 & $\mathrm{R} \$$ & $6.613,54$ & $\mathrm{R} \$$ & $98.014,98$ & $\mathrm{R} \$$ & 396,72 & $\mathrm{R} \$ 38.962,95$ & $\mathrm{R} \$ 143.988,20$ \\
\hline ago/04 & $\mathrm{R} \$$ & $6.363,73$ & $\mathrm{R} \$$ & $44.874,10$ & $\mathrm{R} \$$ & $110.704,67$ & $\mathrm{R} \$ 67.230,14$ & R\$ 229.172,64 \\
\hline set/04 & $\mathrm{R} \$$ & $5.429,78$ & $\mathrm{R} \$$ & $48.201,22$ & $\mathrm{R} \$$ & $60.449,26$ & $\mathrm{R} \$ 56.208,13$ & $\mathrm{R} \$ 170.288,40$ \\
\hline out/04 & $\mathrm{R} \$$ & $5.917,68$ & $\mathrm{R} \$$ & $33.927,12$ & $\mathrm{R} \$$ & $178.913,43$ & $\mathrm{R} \$ 90.725,01$ & R\$ $309.483,24$ \\
\hline nov/04 & $\mathrm{R} \$$ & $6.213,26$ & $\mathrm{R} \$$ & $86.049,03$ & $\mathrm{R} \$$ & $11.128,97$ & $\mathrm{R} \$ 37.450,29$ & $\mathrm{R} \$ 140.841,55$ \\
\hline $\mathrm{dez} / 04$ & $\mathrm{R} \$$ & $6.537,15$ & $\mathrm{R} \$$ & $82.738,16$ & $\mathrm{R} \$$ & $104.625,54$ & $\mathrm{R} \$ 47.717,79$ & $\mathrm{R} \$ 241.618,65$ \\
\hline $\mathrm{jan} / 05$ & $\mathrm{R} \$$ & $6.119,64$ & $\mathrm{R} \$$ & $33.882,16$ & $\mathrm{R} \$$ & $45.759,17$ & $\mathrm{R} \$ 46.149,30$ & $\mathrm{R} \$ 131.910,27$ \\
\hline $\mathrm{fev} / 05$ & $\mathrm{R} \$$ & $6.375,95$ & $\mathrm{R} \$$ & $56.260,41$ & $\mathrm{R} \$$ & $107.647,50$ & $\mathrm{R} \$ 83.446,91$ & $\mathrm{R} \$ 253.730,77$ \\
\hline $\mathrm{mar} / 05$ & $\mathrm{R} \$$ & $6.844,74$ & $\mathrm{R} \$$ & $50.535,35$ & $\mathrm{R} \$$ & $130.601,87$ & $\mathrm{R} \$ 73.630,81$ & $\mathrm{R} \$ 261.612,77$ \\
\hline $\mathrm{abr} / 05$ & $\mathrm{R} \$$ & $7.676,20$ & $\mathrm{R} \$$ & $97.065,86$ & $\mathrm{R} \$$ & $13.066,35$ & R\$ 29.522,02 & $\mathrm{R} \$ 147.330,43$ \\
\hline mai/05 & $\mathrm{R} \$$ & 7.013,33 & $\mathrm{R} \$$ & $39.929,66$ & $\mathrm{R} \$$ & $151.662,66$ & $\mathrm{R} \$ 64.002,11$ & $\mathrm{R} \$ 262.607,76$ \\
\hline jun/05 & $\mathrm{R} \$$ & $6.856,83$ & $\mathrm{R} \$$ & $39.408,39$ & $\mathrm{R} \$$ & $147.478,35$ & R\$ $69.110,22$ & $\mathrm{R} \$ 262.853,79$ \\
\hline MÉDIA & $\mathrm{R} \$$ & $6.449,87$ & $\mathrm{R} \$$ & $59.616,61$ & $\mathrm{R} \$$ & $82.231,41$ & R\$ 56.592,86 & R\$ 204.890,75 \\
\hline
\end{tabular}

Tabela 6-20 - Apuração do Custo Total de Manutenção (CTM).

Com base na Tabela 6-20 e nos dados organizados nos Anexos 3, 4 e 5 podese construir a Tabela 6-21, onde: 
- CTM - Custo Total de Manutenção do mês do período em [R \$];

- Q TOTAL - Quantidade total de anéis cromados e metalizados produzidos no mês do período em [u];

- CHA - Custo horário das atividades de manutenção em [R $\$ / h]$;

- HS - Horas em serviço no mês do período em [h];

- \% CRO - Percentagem de anéis cromados produzidos no mês do período;

- \% MET - Percent. de anéis metalizados produzidos no mês do período;

- HS CRO - Horas em serviço necessárias para realizar a produção de anéis cromados no mês do período em [h]:

$\checkmark \mathrm{HSCRO}=\% \mathrm{CRO} \times \mathrm{HS}$;

- HS MET - Horas em serviço necessárias para realizar a produção de anéis metalizados no mês do período em [h]:

$\checkmark \quad \mathrm{HS} \mathrm{MET}=\% \mathrm{MET} \times \mathrm{HS}$;

- Q CRO - Qtde de anéis cromados produzidos no mês do período [u];

- Q MET - Qtde de anéis metalizados produzidos no mês do período [u];

- CTMUP - Custo total de manutenção por unidade produzida no mês do período em $[R \$ / u]$

$\checkmark$ CTMUP $=(\mathrm{CTM}) /(\mathrm{Q}$ TOTAL $)$;

- CMUP CRO - Custo de manutenção por unidade de produção de anéis cromados no mês do período em [R\$/u]:

$\checkmark$ CMUP CRO $=(\mathrm{CHA} \times \mathrm{HSC} \mathrm{CRO}) /(\mathrm{Q}$ CRO $)$;

- CMUP MET - Custo de manutenção por unidade de produção de anéis metalizados no mês do período em [R\$/u]:

$\checkmark \quad$ CMUP MET $=($ CHA $\times$ HSC MET $) /(\mathrm{Q}$ MET $) ;$

- CHS - Custo da hora em serviço dos equipamentos no mês do período em $[\mathrm{R} \$ / \mathrm{h}]$ :

$\checkmark \mathrm{CHS}=\mathrm{CTM} / \mathrm{HS}$. 


\begin{tabular}{|c|c|c|c|c|c|c|c|c|c|c|c|c|c|c|}
\hline MÊS & СТМ & $\begin{array}{c}\text { Q } \\
\text { TOTAL }\end{array}$ & CHA & HS & $\begin{array}{c}\% \\
\text { CRO }\end{array}$ & $\begin{array}{c}\% \\
\text { MET }\end{array}$ & $\begin{array}{c}\text { HS } \\
\text { CRO }\end{array}$ & $\begin{array}{c}\text { HS } \\
\text { MET }\end{array}$ & Q CRO & Q MET & CTMUP & $\begin{array}{c}\text { CMUP } \\
\text { CRO }\end{array}$ & $\begin{array}{c}\text { CMUP } \\
\text { MET }\end{array}$ & CHS \\
\hline jun/04 & 108.141,31 & 1.251 .039 & 816,62 & $12.333,42$ & $80 \%$ & $20 \%$ & 9.829 & 2.504 & 996.999 & 254.040 & 0,09 & 8,05 & 8,05 & 8,77 \\
\hline jul/04 & $143.988,20$ & 1.218 .930 & 844,08 & 13.383,41 & $72 \%$ & $28 \%$ & 9.627 & 3.756 & 876.820 & 342.110 & 0,12 & 9,27 & 9,27 & 10,76 \\
\hline ago/04 & $229.172,64$ & 1.286 .292 & 846,04 & $12.776,11$ & $76 \%$ & $24 \%$ & 9.687 & 3.089 & 975.291 & 311.001 & 0,18 & 8,40 & 8,40 & 17,94 \\
\hline set/04 & $170.288,40$ & 1.370 .639 & 753,26 & $12.275,76$ & $77 \%$ & $23 \%$ & 9.394 & 2.882 & 1.048 .838 & 321.801 & 0,12 & 6,75 & 6,75 & 13,87 \\
\hline out/04 & $309.483,24$ & 1.255 .947 & 858,26 & $11.632,01$ & $78 \%$ & $22 \%$ & 9.104 & 2.528 & 983.041 & 272.906 & 0,25 & 7,95 & 7,95 & 26,61 \\
\hline nov/04 & $140.841,55$ & 1.228 .387 & 901,13 & $11.772,16$ & $70 \%$ & $30 \%$ & 8.192 & 3.580 & 854.830 & 373.557 & 0,11 & 8,64 & 8,64 & 11,96 \\
\hline $\mathrm{dez} / 04$ & $241.618,65$ & 965.002 & $1.390,56$ & $7.965,26$ & $72 \%$ & $28 \%$ & 5.698 & 2.267 & 690.322 & 274.680 & 0,25 & 11,48 & 11,48 & 30,33 \\
\hline $\mathrm{jan} / 05$ & $131.910,27$ & 1.398 .749 & 848,96 & $11.786,19$ & $78 \%$ & $22 \%$ & 9.225 & 2.562 & 1.094 .739 & 304.010 & 0,09 & 7,15 & 7,15 & 11,19 \\
\hline fev/05 & 253.730,77 & 1.527 .412 & 924,73 & $11.702,75$ & $76 \%$ & $24 \%$ & 8.875 & 2.828 & 1.158 .310 & 369.102 & 0,17 & 7,09 & 7,09 & 21,68 \\
\hline mar/05 & $261.612,77$ & 1.542 .668 & 949,56 & $12.229,24$ & $75 \%$ & $25 \%$ & 9.138 & 3.091 & 1.152 .754 & 389.914 & 0,17 & 7,53 & 7,53 & 21,39 \\
\hline abr/05 & $147.330,43$ & 1.330 .921 & $1.064,90$ & $12.316,58$ & $67 \%$ & $33 \%$ & 8.225 & 4.092 & 888.760 & 442.161 & 0,11 & 9,85 & 9,85 & 11,96 \\
\hline mai/05 & $262.607,76$ & 1.336 .214 & 972,94 & $12.223,08$ & $67 \%$ & $33 \%$ & 8.224 & 3.999 & 899.061 & 437.153 & 0,20 & 8,90 & 8,90 & 21,48 \\
\hline jun/05 & $262.853,79$ & 1.548 .094 & 911,60 & $12.754,99$ & $66 \%$ & $34 \%$ & 8.356 & 4.399 & 1.014 .153 & 533.941 & 0,17 & 7,51 & 7,51 & 20,61 \\
\hline MÉDIA & $204.890,75$ & 1.327 .715 & 929,44 & $11.934,69$ & $73 \%$ & $27 \%$ & 8.736 & 3.198 & 971.840 & 355.875 & 0,16 & 8,35 & 8,35 & 17,58 \\
\hline
\end{tabular}

Tabela 6-21 - Apuração dos Indicadores de Custos (CTMUP, CMUP CRO, CMUP MET e CHS).

Nestas condições a Tabela 6-22 resume os valores dos indicadores de custos no período considerado. As figuras do Anexo 13 explicitam com maior nitidez as variações dos Indicadores de Custos ao longo do período considerado. 


\begin{tabular}{|c|c|c|c|c|c|c|c|c|c|c|c|c|c|c|c|c|}
\hline MÊS & CAA & CMC & & CMP & CPP & СТМ & CT & MUP & & $\begin{array}{l}\text { MUP } \\
\text { RO }\end{array}$ & & $\begin{array}{l}\text { IUP } \\
\text { ET }\end{array}$ & & СHA & \multicolumn{2}{|c|}{ CHS } \\
\hline jun/04 & $\mathrm{R} \$ 5.886,52$ & $\mathrm{R} \$ 64.129,49$ & $\mathrm{R} \$$ & $6.573,82$ & $\mathrm{R} \$ 31.551,47$ & $\mathrm{R} \$ 108.141,31$ & $\mathrm{R} \$$ & 0,08 & $\mathrm{R} \$$ & 8,05 & $\mathrm{R} \$$ & 8,05 & $\mathrm{R} \$$ & 816,62 & $\mathrm{R} \$$ & 8,59 \\
\hline jul/04 & $\mathrm{R} \$ 6.613,54$ & $\mathrm{R} \$ 98.014,98$ & $\mathrm{R} \$$ & 396,72 & $\mathrm{R} \$ 38.962,95$ & $\mathrm{R} \$ 143.988,20$ & $\mathrm{R} \$$ & 0,12 & $\mathrm{R} \$$ & 9,27 & $\mathrm{R} \$$ & 9,27 & $\mathrm{R} \$$ & 844,08 & $\mathrm{R} \$$ & 10,79 \\
\hline ago/04 & $\mathrm{R} \$ 6.363,73$ & $\mathrm{R} \$ 44.874,10$ & $\mathrm{R} \$$ & $110.704,67$ & $\mathrm{R} \$ 67.230,14$ & $\mathrm{R} \$ 229.172,64$ & $\mathrm{R} \$$ & 0,18 & $\mathrm{R} \$$ & 8,40 & $\mathrm{R} \$$ & 8,40 & $\mathrm{R} \$$ & 846,04 & $\mathrm{R} \$$ & 17,78 \\
\hline set/04 & $\mathrm{R} \$ 5.429,78$ & $\mathrm{R} \$ 48.201,22$ & $\mathrm{R} \$$ & $60.449,26$ & $\mathrm{R} \$ 56.208,13$ & $\mathrm{R} \$ 170.288,40$ & $\mathrm{R} \$$ & 0,12 & $\mathrm{R} \$$ & 6,75 & $\mathrm{R} \$$ & 6,75 & $\mathrm{R} \$$ & 753,26 & $\mathrm{R} \$$ & 13,54 \\
\hline out/04 & $\mathrm{R} \$ 5.91$ & $\mathrm{R} \$ 33.927,12$ & $\mathrm{R} \$$ & $178.913,43$ & $\mathrm{R} \$ 90.7$ & $\mathrm{R} \$ 309$ & $\mathrm{R} \$$ & & $\mathrm{R} \$$ & 7,95 & $\mathrm{R} \$$ & 7,95 & $\mathrm{R} \$$ & & $\mathrm{R} \$$ & 25,67 \\
\hline nov/04 & $\mathrm{R} \$ 6.213,26$ & $\mathrm{R} \$ 86.049,03$ & $\mathrm{R} \$$ & $11.128,97$ & $\mathrm{R} \$ 37.450,29$ & $\mathrm{R} \$ 140.841,55$ & $\mathrm{R} \$$ & 0,12 & $\mathrm{R} \$$ & 8,64 & $\mathrm{R} \$$ & 8,64 & $\mathrm{R} \$$ & 901,13 & $\mathrm{R} \$$ & 12,06 \\
\hline $\mathrm{dez} / 04$ & $\mathrm{R} \$ 6.537,15$ & $\mathrm{R} \$ 82.738,16$ & $\mathrm{R} \$$ & $104.625,54$ & $\mathrm{R} \$ 47.717,79$ & $\mathrm{R} \$ 241.618,65$ & $\mathrm{R} \$$ & 0,25 & $\mathrm{R} \$$ & 11,48 & $\mathrm{R} \$$ & 11,48 & $\mathrm{R} \$$ & $1.390,56$ & $\mathrm{R} \$$ & 30,45 \\
\hline jan/05 & $\mathrm{R} \$ 6.119,64$ & $\mathrm{R} \$ 33.882,16$ & $\mathrm{R} \$$ & $45.759,17$ & $\mathrm{R} \$ 46.149,30$ & $\mathrm{R} \$ 131.910,27$ & $\mathrm{R} \$$ & 0,09 & $\mathrm{R} \$$ & 7,15 & $\mathrm{R} \$$ & 7,15 & $\mathrm{R} \$$ & 848,96 & $\mathrm{R} \$$ & 10,89 \\
\hline fev/05 & $\mathrm{R} \$ 6.375,95$ & $\mathrm{R} \$ 56.260,41$ & $\mathrm{R} \$$ & $107.647,50$ & $\mathrm{R} \$ 83.446,91$ & $\mathrm{R} \$ 253.730,77$ & $\mathrm{R} \$$ & 0,16 & $\mathrm{R} \$$ & 7,09 & $\mathrm{R} \$$ & 7,09 & $\mathrm{R} \$$ & 924,73 & $\mathrm{R} \$$ & 21,26 \\
\hline mar/05 & $\mathrm{R} \$ 6.844,74$ & $\mathrm{R} \$ 50.535,35$ & $\mathrm{R} \$$ & $130.601,87$ & $\mathrm{R} \$ 73.630,81$ & $\mathrm{R} \$ 261.612,77$ & $\mathrm{R} \$$ & 0,17 & $\mathrm{R} \$$ & 7,53 & $\mathrm{R} \$$ & 7,53 & $\mathrm{R} \$$ & 949,56 & $\mathrm{R} \$$ & 21,29 \\
\hline $\mathrm{abr} / 05$ & $\mathrm{R} \$ 7.676,20$ & $\mathrm{R} \$ 97.065,86$ & $\mathrm{R} \$$ & 13.066,35 & $\mathrm{R} \$ 29.522,02$ & $\mathrm{R} \$ 147.330,43$ & $\mathrm{R} \$$ & 0,11 & $\mathrm{R} \$$ & 9,85 & $\mathrm{R} \$$ & 9,85 & $\mathrm{R} \$$ & $1.064,90$ & $\mathrm{R} \$$ & 11,84 \\
\hline mai/05 & $\mathrm{R} \$ 7.013,33$ & R\$39.929,66 & $\mathrm{R} \$$ & $151.662,66$ & $\mathrm{R} \$ 64.002,11$ & $\mathrm{R} \$ 262.607,76$ & $\mathrm{R} \$$ & 0,19 & $\mathrm{R} \$$ & 8,90 & $\mathrm{R} \$$ & 8,90 & $\mathrm{R} \$$ & 972,94 & $\mathrm{R} \$$ & 21,31 \\
\hline jun/05 & $\mathrm{R} \$ 6.856,83$ & R\$ 39.408,39 & $\mathrm{R} \$$ & $147.478,35$ & $\mathrm{R} \$ 69.110,22$ & $\mathrm{R} \$ 262.853,79$ & $\mathrm{R} \$$ & 0,17 & $\mathrm{R} \$$ & 7,51 & $\mathrm{R} \$$ & 7,51 & $\mathrm{R} \$$ & 911,60 & $\mathrm{R} \$$ & 20,59 \\
\hline MÉDIA & $\mathrm{R} \$ 6.449,87$ & R\$ 59.616,61 & $\mathrm{R} \$$ & $82.231,41$ & $\mathrm{R} \$ 56.592,86$ & R\$ 204.890,75 & $\mathrm{R} \$$ & 0,15 & $\mathrm{R} \$$ & 8,35 & $\mathrm{R} \$$ & 8,35 & $\mathrm{R} \$$ & 929,44 & $\mathrm{R} \$$ & 17,39 \\
\hline
\end{tabular}

Tabela 6-22 - Valores dos Indicadores de Custos. 


\subsection{ANÁLISE DE CORRELAÇÃo}

\subsubsection{CONSIDERAÇÕES INICIAIS}

Neste ponto do trabalho torna-se necessária uma análise mais profunda entre os diversos indicadores, para que a apresentação dos resultados se torne mais enriquecida. Já foi discutido, nas conclusões do Capítulo 3, que a lógica do interrelacionamento dos indicadores, através dos elementos de desempenho, dá a devida sustentação para a gestão do custeio e das atividades de manutenção. Assim, os indicadores, além de interligados, estão também subsidiando uns aos outros. Nesta direção, duas formas de análise são necessárias para ampliar um pouco mais as relações entre os diversos indicadores presentes no modelo de gestão.

Primeiramente, uma análise que permita observar as relações entre os indicadores representativos do mesmo elemento de desempenho do modelo (Análise Intra Indicadores). Em segundo lugar, há a necessidade de conhecer as relações entre os indicadores representativos dos diferentes elementos de desempenho (Análise Entre Indicadores). O que se pretende saber na Análise Intra Indicadores é se as relações entre os indicadores estão consistentes entre si, em termos de representar o mesmo elemento de desempenho. Já na Análise Entre Indicadores pretende-se observar a consistência das interligações dos indicadores que representam os diferentes elementos de desempenho no modelo de gestão.

Uma das formas de observar a consistência das relações entre variáveis é por meio da análise de correlação, conforme relata COSTA NETO (1990). O autor observa que o coeficiente de correlação $\mathbf{r}$ apresenta as propriedades de adimensionalidade e de variabilidade em um intervalo discreto de -1 a +1 . Nestas condições é possível estabelecer que a correlação negativa perfeita entre variáveis é definida pelo valor de $\mathbf{r}$ igual a -1 e a correlação positiva perfeita é caracterizada por $\mathbf{r}$ igual a +1 . Entretanto, os indicadores, qualificados com as variáveis em estudo, acabam por absorver variações advindas de fatores que afetam direta e indiretamente os processos desenvolvidos na função manutenção. Fatores tais como o estado de conservação das máquinas, métodos, mão-de-obra, materiais, medidas e ambiente 
seguramente interferem nos valores dos indicadores e podem não permitir uma correlação perfeita entre eles. Desta forma surge um questionamento sobre os valores intermediários do coeficiente de correlação $\mathbf{r}$ : a partir de qual valor de $\mathbf{r}$ é possível admitir uma forte correlação entre dois indicadores diferentes e a partir daí inferir que há uma consistência de relação entre eles? (PAMPLONA, 1997; COSTA NETO, 1990).

O coeficiente de correlação, a bem da verdade, não é suficiente para afirmar se existe ou não correlação linear entre duas variáveis. O grau e o sinal da correlação linear são indicados pelo coeficiente, porém seu cálculo se faz baseado em uma amostra de $\mathbf{n}$ elementos e apenas representa uma estimativa da correlação populacional, segundo COSTA NETO (1990). Nestas condições, o autor sugere efetuar um teste de hipóteses utilizando a distribuição $\mathbf{t}$ de Student com $\mathbf{n}-\mathbf{2}$ graus de liberdade, expressa pela Equação [6-17]. O teste é indicado quando se deseja saber se um valor do coeficiente de correlação $\mathbf{r}$, combinado com o tamanho $\mathbf{n}$ da amostra, permite concluir, para um dado nível de significância $\alpha$, a existência ou não de correlação entre as variáveis consideradas na amostra.

$$
t_{n-2}=r \sqrt{\frac{n-2}{1-r^{2}}}
$$

A sistemática sugerida pelo autor pretende testar a hipótese nula que não existe correlação linear entre dois indicadores diferentes, ou seja, que o coeficiente de correlação populacional $\rho$ é igual a zero. Assim, o valor $\mathbf{t}_{\mathbf{n}-2}$ calculado pela Equação [6-17] é comparado com o valor do $\mathbf{t}_{\mathbf{n}-2}$ crítico obtido da distribuição $\mathbf{t}$ de Student para um determinado nível de significância. A hipótese nula é rejeitada se o valor $\mathbf{t}_{\mathbf{n}-2}$ calculado for maior que o $\mathbf{t}_{\mathbf{n}-2}$ crítico máximo ou menor que o $\mathbf{t}_{\mathbf{n}-2}$ crítico mínimo. Nessa condição, pode-se concluir pela evidência de correlação linear dos indicadores. Caso contrário, não se pode concluir pela existência de correlação.

Convém observar que o valor do $\mathbf{t}_{\mathrm{n}-2}$ crítico é obtido a partir da distribuição bicaudal de Student, conforme consta no Apêndice I, para um nível de significância de $5 \%$ e n-2 graus de liberdade. O Apêndice I, por sua vez, foi construído a partir do Microsoft Office Excel 2003. O nível de significância de 5\% indica que são depositadas 95\% de confiança na estimativa da correlação, segundo COSTA NETO 
(1990). O teste de Student foi realizado a partir dos valores dos diferentes indicadores no período de avaliação. Eles foram organizados segundo o modelo do Quadro 6-1, conforme sugestão colocada por PAMPLONA (1997), onde $\mathbf{I}_{\mathbf{i k}}$ é o valor observado do indicador $\mathbf{I}_{\mathbf{i}}$ no período $\mathbf{k}$, e $\mathbf{I}_{\mathbf{j k}}$ o valor observado do indicador $\mathbf{I}_{\mathbf{j}}$ também no período k. Nestas condições, o coeficiente de correlação linear é calculado pela Equação [6-20] proposta por COSTA NETO (1990).

\begin{tabular}{|c|c|c|}
\hline PERÍODO & $\mathbf{I}_{\mathbf{i}}$ & $\mathbf{I}_{\mathbf{j}}$ \\
\hline 1 & $\mathrm{I}_{\mathrm{i} 1}$ & $\mathrm{I}_{\mathrm{j} 1}$ \\
2 & $\mathrm{I}_{\mathrm{i} 2}$ & $\mathrm{I}_{\mathrm{j} 2}$ \\
$\ldots$ & $\ldots$ & $\ldots$ \\
$\mathrm{k}$ & $\mathrm{I}_{\mathrm{ik}}$ & $\mathrm{I}_{\mathrm{jk}}$ \\
$\cdots$ & $\ldots$ & $\cdots$ \\
$\mathrm{n}$ & $\mathrm{I}_{\mathrm{in}}$ & $\mathrm{I}_{\mathrm{jn}}$ \\
\hline
\end{tabular}

Quadro 6-1 - Organização dos Indicadores.

Fonte: PAMPLONA (1997).

$$
r=\frac{n \sum_{k=1}^{n} I_{i k} I_{j k}-\sum_{k=1}^{n} I_{i k} \sum_{k=1}^{n} I_{j k}}{\sqrt{\left[n \sum_{k=1}^{n} I_{i k}^{2}-\left(\sum_{k=1}^{n} I_{i k}\right)^{2}\right] \times\left[n \sum_{k=1}^{n} I_{j k}^{2}-\left(\sum_{k=1}^{n} I_{j k}\right)^{2}\right]}}
$$

\subsubsection{RESULTADOS DAS ANÁLISES}

\section{A. ANÁLISE INTRA INDICADORES}

Na seqüência é apresentado o quadro resumo resultante das análises levadas a efeito. Os relatórios gerados pelo Microsoft Office Excel 2003 estão contidos nos anexos e indicados no decorrer do texto. A análise de correlação contempla apenas os indicadores principais do modelo de gestão, dado que os indicadores complementares são decorrentes dos principais. A análise de correlação entre estes e aqueles seria, portanto, redundante. 


\begin{tabular}{|c|c|c|c|c|c|c|c|}
\hline & Variáveis & $\mathbf{r}$ & tn-2 Calc & tn-2 Crit & Comparação & Conclusão & $\begin{array}{c}\text { Consistência } \\
\text { da Relação }\end{array}$ \\
\hline \multirow{4}{*}{ Qualidade } & IOP x EGE & 0,3033 & 1,0556 & 2,2010 & tn-2 Calc $<$ tn-2 Crit Max & Não Há Correlação Linear. & $\mathrm{V}$ \\
\hline & DOP x ROP & $-0,3544$ & $-1,2569$ & $-2,2010$ & tn-2 Calc > tn-2 Crit Min & Não Há Correlação Linear. & $\mathrm{V}$ \\
\hline & DOP x IAP & 0,2628 & 0,9034 & 2,2010 & tn-2 Calc $<$ tn-2 Crit Max & Não Há Correlação Linear. & $\mathrm{V}$ \\
\hline & ROP x IAP & $-0,1321$ & $-0,4420$ & $-2,2010$ & tn-2 Calc $>$ tn-2 Crit Min & Não Há Correlação Linear. & $\mathrm{V}$ \\
\hline \multirow{3}{*}{ Velocidade } & TMDR x VAT & $-0,3992$ & $-1,4442$ & $-2,2010$ & tn-2 Calc $>$ tn-2 Crit Min & Não Há Correlação Linear. & $\mathrm{V}$ \\
\hline & TMDR x IPR & 0,8036 & 4,4787 & 2,2010 & tn-2 Calc $>$ tn-2 Crit Max & Evidências de Correlação Linear Positiva. & $\mathrm{V}$ \\
\hline & VAT x IPR & $-0,7606$ & $-3,8861$ & $-2,2010$ & tn-2 Calc $<$ tn-2 Crit Min & Evidências de Correlação Linear Negativa. & $\mathrm{V}$ \\
\hline \multirow{6}{*}{ Confiabilidade } & TMEF x IRE & $-0,9696$ & $-13,1467$ & $-2,2010$ & tn-2 Calc $<$ tn-2 Crit Min & Evidências de Correlação Linear Negativa. & $\mathrm{V}$ \\
\hline & TMEF $x$ IFO & $-0,0004$ & $-0,0013$ & $-2,2010$ & tn-2 Calc $>$ tn-2 Crit Min & Não Há Correlação Linear. & $\mathrm{V}$ \\
\hline & TMEF x NF & $-0,9730$ & $-13,9888$ & $-2,2010$ & tn-2 Calc $<$ tn-2 Crit Min & Evidências de Correlação Linear Negativa. & $\mathrm{V}$ \\
\hline & IRE $x$ IFO & $-0,0420$ & $-0,1395$ & $-2,2010$ & tn-2 Calc $>$ tn-2 Crit Min & Não Há Correlação Linear. & $\mathrm{V}$ \\
\hline & IRE $x$ NF & 0,9982 & 55,8877 & 2,2010 & tn-2 Calc $>$ tn-2 Crit Max & Evidências de Correlação Linear Positiva. & $\mathrm{V}$ \\
\hline & IFO X NF & $-0,0180$ & $-0,0596$ & $-2,2010$ & tn-2 Calc $>$ tn-2 Crit Min & Não Há Correlação Linear. & $\mathrm{V}$ \\
\hline \multirow{6}{*}{ Custos } & СРР-СТМ & 0,8908 & 6,5029 & 2,2010 & tn-2 Calc $>$ tn-2 Crit Max & Evidências de Correlação Linear Positiva. & $\mathrm{V}$ \\
\hline & СРP-СTMUP & 0,6487 & 2,8272 & 2,2010 & tn-2 Calc $>$ tn-2 Crit Max & Evidências de Correlação Linear Positiva. & $\mathrm{V}$ \\
\hline & CPP-CMUP & $-0,4397$ & $-1,6238$ & $-2,2010$ & tn-2 Calc $>$ tn-2 Crit Min & Não Há Correlação Linear. & $\mathrm{V}$ \\
\hline & CTM-CTMUP & 0,8805 & 6,1603 & 2,2010 & tn-2 Calc $>$ tn-2 Crit Max & Evidências de Correlação Linear Positiva. & $\mathrm{V}$ \\
\hline & CTM-CMUP & $-0,0383$ & $-0,1272$ & $-2,2010$ & tn-2 Calc $>$ tn-2 Crit Min & Não Há Correlação Linear. & $\mathrm{V}$ \\
\hline & CTMUP-CMUP & 0,3580 & 1,2716 & 2,2010 & tn-2 Calc $<$ tn-2 Crit Max & Não Há Correlação Linear. & $\mathrm{V}$ \\
\hline
\end{tabular}

Quadro 6-2 - Resumo Análise Intra Indicadores.. 
Tendo em vista a peculiaridade dos Indicadores de Flexibilidade, a Análise Intra Indicadores dos mesmos foi descartada. Os indicadores TRT - Taxa de Realização de Treinamento e TRSM - Taxa de Reatividade dos Serviços de Manutenção apresentam um valor constante ao longo do período de observação. Não sendo possível, portanto, uma análise de suas variações ao longo do período considerado. De qualquer modo é possível inferir que as taxas em questão devem guardar uma correlação positiva entre si. A TPE - Taxa de Polivalência das Equipes, por sua vez, explicita a habilidade das equipes ou dos funcionários (como é o caso da empresa em estudo) em intervir nos ativos, observada no período considerado.

\section{1) INDICADORES DE QUALIDADE}

O Anexo 14 explicita os relatórios gerados pelo Microsoft Office Excel 2003 na análise de correlação linear dos Indicadores de Qualidade. As justificativas das consistências das relações entre os indicadores são:

- IOP x EGE - A Equação [3-2] caracteriza a dependência de EGE das variáveis DOP, ROP e IAP. IOP e DOP possuem relações inversas conforme pode ser observado na Equação [3-1]. Entretanto, a variação de IOP não afeta de forma explícita a variação de EGE, o que confirma a consistência da análise. Não havia qualquer tipo de expectativa de correlação linear entre tais indicadores. O resultado da análise apresenta-se como verdadeiro, portanto.

- DOP x ROP - DOP depende exclusivamente de HP. ROP é definido pela Equação [3-4] e depende da utilização do equipamento na produção de bens. Não há como estabelecer uma relação entre as horas planejadas para produzir uma dada quantidade de produção e as respectivas paralisações. Portanto, DOP e ROP não guardam uma relação entre si. Assim, o resultado da análise mostra-se como verdadeiro.

- DOP x IAP - Como já mencionado anteriormente, a dependência de DOP está tão somente relacionada com as HP. IAP, por sua vez, depende dos itens conformes produzidos pelos equipamentos. Logo 
não guardam relações entre si. Então, o resultado da análise apresentase como verdadeiro.

- ROP x IAP - ROP depende da utilização do equipamento e IAP está caracterizada pelos produtos conformes. Portanto, ROP e IAP não guardam relações entre si. O resultado da análise apresenta-se como verdadeiro.

\section{2) INDICADORES DE VELOCIDADE}

Os relatórios gerados pelo Microsoft Office Excel 2003 para a análise de correlação dos Indicadores de Velocidade podem ser vistos no Anexo 15. As consistências das relações entre os indicadores podem ser assim justificadas:

- TMDR x VAT - Os indicadores TMDR e VAT obedecem à formulação registrada respectivamente na Equação [3-12] e na Equação [3-15]. A variação positiva ou negativa do TMDR está condicionada à variação positiva ou negativa das $\mathrm{HCI}$, caso o NI permaneça invariável ao longo do tempo. Assim, se as HCI variarem de forma positiva ou negativa, nada se pode dizer do indicador VAT. O mesmo pode crescer, diminuir ou se manter estável porque depende das HPI. A previsão das horas necessárias para as intervenções reúne aspectos de natureza intangível de ordem administrativa, logística de suprimentos e de pessoal. Portanto, TMDR e VAT podem não guardar relações entre si. O TMDR, em última análise, explicita a velocidade de reparo enquanto que a VAT registra a eficiência da manutenção em realizar o reparo. O resultado da análise mostra-se como verdadeiro.

- TMDR x IPR - Trata-se de uma correlação clássica. À medida que o TMDR aumenta, necessariamente também cresce a IPR. TMDR é dependente das HCI ou HP, assim como também a IPR depende das HP conforme pode ser visto na Equação [3-13]. Portanto, o resultado da análise apresenta-se como verdadeiro. 
- VAT x IPR - Trata-se também de uma correlação clássica. Quanto maior for a eficiência da manutenção em efetuar o reparo, menor será a indisponibilidade observada. A VAT varia inversamente com as HCI (ou HP) enquanto que IPR tem uma variação direta com as HP. Nestas condições, o resultado da análise mostra-se como verdadeiro.

\section{3) INDICADORES DE CONFIABILIDADE}

O Anexo 16 explicita os relatórios gerados pelo Microsoft Office Excel 2003 na análise de correlação linear dos Indicadores de Confiabilidade. As justificativas das consistências das relações entre os indicadores são:

- TMEF x IRE - Mais uma correlação clássica. O risco diminui na medida em que a taxa de falhas decresce. Por outro lado, a taxa de falhas é refletida pelo TMEF. Quanto maior O TMEF menor será a taxa de falhas. Conseqüentemente, IRE e TMEF variam em sentidos opostos. Portanto, a análise apresenta-se como verdadeira.

- TMEF x IFO - Os indicadores TMEF e IFO obedecem à formulação registrada na Equação [3-16] e na Equação [3-18], respectivamente. O indicador IFO é dependente direto das HMC, enquanto que o TMEF tem uma relação inversa com o NF. Mas o NF e as HMC podem não guardar uma relação direta entre si. Se, de um mês para outro, o NF cresce, não significa necessariamente que as HMC tenham que crescer. Elas dependem exclusivamente da complexidade do reparo. Portanto, TMEF e IFO podem não guardar uma relação entre si e a análise mostra-se como verdadeira.

- TMEF x NF - É a mais clássica das correlações. Na medida em que o NF cresce, a freqüência de falhas aumenta e o TMEF diminui. Portanto, NF e TMEF variam em sentidos opostos, o que valida a análise efetuada e, por conseguinte, a consistência da relação.

- IRE x IFO - As variáveis presentes na formulação dos indicadores não guardam relações entre si, conforme pode ser observado 
respectivamente, na Equação [3-17] e na Equação [3-18]. Assim, a análise mostra-se como verdadeira.

- IRE x NF - Mais uma correlação clássica. Na medida em que a taxa de falhas aumenta por decorrência do crescimento do NF, maior é o risco envolvido. Portanto, a análise apresenta-se como verdadeira.

- IFO x NF - Conforme já exposto anteriormente, IFO é dependente direto das HMC que podem não guardar uma relação clara com o NF. As HMC estão condicionadas à complexidade do reparo. Em conseqüência disso, IFO e IRE podem não guardar uma relação clara entre si. Portanto, a análise mostra-se como verdadeira.

\section{4) INDICADORES DE CUSTOS}

Os relatórios gerados pelo Microsoft Office Excel 2003 para a análise de correlação dos Indicadores de Custos são apresentados no Anexo 17. As consistências das relações entre os indicadores podem ser assim justificadas:

- CPP x CTM - O CTM formulado pela Equação [3-23] tem relações diretas com o CPP que é uma de suas parcelas. Assim, as suas variações ocorrem no mesmo sentido e a análise apresenta-se como verdadeira.

- CPP x CTMUP - O CTMUP expresso pela Equação [3-35], tem dependência direta do CTM e por conseqüência também do CPP. Portanto, CPP e CTMUP variam no mesmo sentido e a análise mostra-se como verdadeira.

- CPP x CMUP - A formulação dos indicadores está devidamente registrada na Equação [3-33] e na Equação [3-37], respectivamente. As variáveis que compõem os indicadores não guardam relações entre si. Portanto, a análise apresenta-se como verdadeira.

- CTM x CTMUP - Conforme já mencionado anteriormente, a Equação [3-35] do CTMUP explicita a sua dependência direta do 
CTM. Assim, CTM e CTMUP variam no mesmo sentido e a análise mostra-se como verdadeira.

- CTM x CMUP - As variáveis que compõem a Equação [3-23] e Equação [3-37], que registram a formulação do CTM e CMUP, respectivamente, não guardam relações entre si. CMUP é dependente das horas em serviço para produzir um dado produto e da quantidade produzida e não guarda qualquer tipo de relação com os componentes do CTM. Portanto a análise mostra-se como verdadeira.

- CTMUP x CMUP - CTM e CMUP não guardam relações entre si, conforme já descrito anteriormente. CTMUP guarda uma dependência direta do CTM, conforme também descrito anteriormente. Assim, se CTM não guarda relações com CMUP, então, por transitividade, CTMUP e CMUP também não guardam relações entre si. Portanto, a análise apresenta-se como verdadeira.

\section{B. ANÁLISE ENTRE INDICADORES}

Da mesma maneira que no título anterior, será apresentado na seqüência um quadro resumo das análises efetuadas. Os relatórios gerados pelo Microsoft Office Excel 2003 estão descritos nos anexos e assinalados ao longo do texto. A análise contempla apenas os mais significativos dos indicadores que representam os diferentes elementos de desempenho. A finalidade é evitar análises redundantes.

Os indicadores representativos dos elementos de desempenho foram escolhidos com base na tradição de uso pelos diferentes profissionais de manutenção. Assim, os indicadores selecionados foram os seguintes:

- Qualidade: Disponibilidade Operacional (DOP);

- Velocidade: Tempo Médio de Reparo (TMDR);

- Confiabilidade: Tempo Médio Entre Falhas (TMEF);

- Custos: Custo de Paralisação da Produção (CPP), Custo Total de Manutenção (CTM), Custo Total de Manutenção por Unidade Produzida (CTMUP) e Custo de Manutenção por Unidade de Produto (CMUP). 


\begin{tabular}{|c|c|c|c|c|c|c|c|}
\hline & Variáveis & $\mathbf{r}$ & tn-2 Calc & tn-2 Crit & Comparação & Conclusão & $\begin{array}{l}\text { Consistência } \\
\text { da Relação }\end{array}$ \\
\hline \multirow{4}{*}{ Qualidade - Custos } & DOP-CPP & $-0,8538$ & $-5,4397$ & $-2,2010$ & tn-2 Calc $<$ tn-2 Crit Min & Evidências de Correlação Linear Negativa. & $\mathrm{V}$ \\
\hline & DOP-CTM & $-0,9818$ & $-17,1244$ & $-2,2010$ & tn-2 Calc $<$ tn-2 Crit Min & Evidências de Correlação Linear Negativa. & $\mathrm{V}$ \\
\hline & DOP-CTMUP & $-0,9414$ & $-9,2558$ & $-2,2010$ & tn-2 Calc $<$ tn-2 Crit Min & Evidências de Correlação Linear Negativa. & $\mathrm{V}$ \\
\hline & DOP-CMUP & $-0,0283$ & $-0,0939$ & $-2,2010$ & tn-2 Calc $>$ tn-2 Crit Min & Não Há Correlação Linear. & $\mathrm{V}$ \\
\hline Qualidade - Velocidade & DOP-TMDR & $-0,8619$ & $-5,6373$ & $-2,2010$ & tn-2 Calc $<$ tn-2 Crit Min & Evidências de Correlação Linear Negativa. & $\mathrm{V}$ \\
\hline Qualidade - Confiabilidade & DOP x TMEF & $-0,2962$ & $-1,0285$ & $-2,2010$ & tn-2 Calc $>$ tn-2 Crit Min & Não Há Correlação Linear. & $\mathrm{V}$ \\
\hline Velocidade - Confiabilidade & TMDR x TMEF & 0,6321 & 2,7053 & 2,2010 & tn-2 Calc $>$ tn-2 Crit Max & Evidências de Correlação Linear Positiva. & $\mathrm{V}$ \\
\hline \multirow{4}{*}{ Velocidade - Custos } & TMDR x CPP & 0,6427 & 2,7824 & 2,2010 & tn-2 Calc $>$ tn-2 Crit Max & Evidências de Correlação Linear Positiva. & $\mathrm{V}$ \\
\hline & TMDR x CTM & 0,8191 & 4,7358 & 2,2010 & tn-2 Calc $>$ tn-2 Crit Max & Evidências de Correlação Linear Positiva. & $\mathrm{V}$ \\
\hline & TMDR x CTMUP & 0,8698 & 5,8469 & 2,2010 & tn-2 Calc $>$ tn-2 Crit Max & Evidências de Correlação Linear Positiva. & $\mathrm{V}$ \\
\hline & TMDR x CMUP & 0,1837 & 0,6198 & 2,2010 & tn-2 Calc $<$ tn-2 Crit Max & Não Há Correlação Linear. & $\mathrm{V}$ \\
\hline \multirow{4}{*}{ Custos - Confiabilidade } & CPP x TMEF & $-0,0051$ & $-0,0168$ & $-2,2010$ & tn-2 Calc $>$ tn-2 Crit Min & Não Há Correlação Linear. & $\mathrm{V}$ \\
\hline & CTM x TMEF & 0,1924 & 0,6501 & 2,2010 & tn-2 Calc $<$ tn-2 Crit Max & Não Há Correlação Linear. & $\mathrm{V}$ \\
\hline & CTMUP x TMEF & 0,468 & 1,756253 & 2,200985 & tn-2 Calc $<$ tn-2 Crit Max & Não Há Correlação Linear. & $\mathrm{V}$ \\
\hline & CMUP x TMEF & 0,4317 & 1,58738 & 2,200985 & tn-2 Calc $<$ tn-2 Crit Max & Não Há correlação Linear. & $\mathrm{V}$ \\
\hline
\end{tabular}

Quadro 6-3 - Resumo Análise Entre Indicadores. 


\section{1) QUALIDADE - CUSTOS}

O Anexo 18 explicita os relatórios gerados pelo Microsoft Office Excel 2003 na análise de correlação linear entre os Indicadores de Qualidade e de Custos. As justificativas das consistências das relações entre os indicadores são:

- DOP x CPP - Trata-se de uma correlação clássica. A DOP diminui na medida em que as HP crescem e em decorrência aumenta também o CPP. Assim DOP e CPP variam em sentidos opostos. A análise apresenta-se como verdadeira, garantido a consistência da relação.

- DOP x CTM - A DOP guarda relação inversa com as HP e estas uma relação direta com o CTM. As HP afetam diretamente os componentes do CTM. Assim, a análise mostra-se como verdadeira uma vez que DOP e CTM variam em sentidos contrários.

- DOP x CTMUP - CTM e CTMUP guardam relações diretas entre si. Como DOP e CTM variam em sentidos inversos, então por transitividade direta DOP e CTMUP guardam também relações inversas entre si. A análise apresenta-se como verdadeira.

- DOP x CMUP - DOP e CTMUP guardam relações entre si. CTMUP e CMUP não guardam relações entre si, conforme já discutido anteriormente. Então, por transitividade direta, DOP e CMUP também não guardam relações entre si. Então, a consistência da relação está correta.

\section{2) QUALIDADE - VELOCIDADE}

Os relatórios gerados pelo Microsoft Office Excel 2003 para a análise de correlação dos Indicadores de Qualidade e de Velocidade podem ser vistos no Anexo 19. A consistência das relação entre os indicadores pode ser assim justificada:

- DOP x TMDR - DOP e TMDR guardam relações com as HP. DOP e HP variam em sentidos opostos. Como HP e TMDR variam no mesmo sentido, então DOP e TMDR guardam entre si relações inversas. Quando 
um cresce, o outro diminui. Portanto, a análise mostra-se como verdadeira.

\section{3) QUALIDADE - CONFIABILIDADE}

O Anexo 20 explicita os relatórios gerados pelo Microsoft Office Excel 2003 na análise de correlação linear entre os Indicadores de Qualidade e de Confiabilidade. A justificativa da consistência da relação entre os indicadores é a seguinte:

- DOP x TMEF - DOP guarda relações inversas com as HP. Por outro lado, TMEF guarda relações inversas com o NF. Entretanto, o NF e as HP não guardam relações entre si. Se o NF crescer de um período para o outro, não significa que poderá haver crescimento das HP. As HP dependem da complexidade do reparo. Nestas condições, DOP e TMEF também não guardam relações entre si. Então a consistência da relação está garantida pela análise.

\section{4) VELOCIDADE - CONFIABILIDADE}

Os relatórios gerados pelo Microsoft Office Excel 2003 para a análise de correlação dos Indicadores de Velocidade e de Confiabilidade podem ser vistos no Anexo 19. As consistências das relações entre os indicadores podem ser assim justificadas:

- TMDR x TMEF - O crescimento do TMDR depende da diminuição do NI, incluindo aí as intervenções de natureza corretiva e preventiva. Por outro lado, o crescimento do TMEF depende da diminuição do NF, incluindo aí somente as falhas de natureza corretiva. Obviamente, NI e NF guardam relações diretas. Se um cresce o outro também cresce. Então, TMDR e TMEF podem guardar relações diretas entre si. Portanto, a análise apresenta-se como verdadeira. 


\section{5) VELOCIDADE - CUSTOS}

O Anexo 20 explicita os relatórios gerados pelo Microsoft Office Excel 2003 na análise de correlação linear entre os Indicadores de Velocidade e de Custos. As justificativas das consistências das relações entre os indicadores são:

- TMDR x CPP - TMDR é dependente direto das HP. Na medida em que HP cresce, aumenta o TMDR. O crescimento nas HP significa também aumento nos CPP. Assim, TMDR e CPP variam no mesmo sentido. Portanto, a análise garante a consistência da relação.

- TMDR x CTM - O crescimento das HP, que implica no aumento do TMDR, promove crescimento nos componentes do CTM. Nestas condições, TMDR e CTM guardam relações diretas entre si. A análise mostra-se como verdadeira.

- TMDR x CTMUP - Conforme já visto anteriormente, CTM e CTMUP guardam relações diretas entre si. Assim, se CTM varia positivamente com a variação de TMDR, então, por transitividade direta, CTMUP e TMDR também guardam relações diretas entre si. Nestas condições, a consistência da relação está garantida pela análise.

- TMDR x CMUP - CTMUP e CMUP não guardam relações entre si, conforme já mencionado anteriormente. A relação de TMDR e CTMUP já acontece de forma direta como visto no parágrafo anterior, assim como também é a relação entre TMDR e CTM. Como CTM e CMUP também não guardam relações entre si, então, por transitividade direta, pode-se concluir que TMDR e CMUP também não guardam relações entre si. A análise apresenta-se como verdadeira.

\section{6) CUSTOS - CONFIABILIDADE}

Os relatórios gerados pelo Microsoft Office Excel 2003 para a análise de correlação dos Indicadores de Custos e de Confiabilidade podem ser vistos no Anexo 19. As consistências das relações entre os indicadores podem ser assim justificadas: 
- CPP x TMEF - A variação de CPP depende da variação das HP. A variação do TMEF, por sua vez, depende da do NF. Já foi discutido anteriormente que NF e HP não guardam relações entre si. Portanto, CPP e TMEF também não guardam relações entre si. Nestas condições a consistência da relação está garantida pela análise.

- CTM x TMEF - A variação do CTM pode ser afetada pela da HP. Então, pelas mesmas razões apresentadas anteriormente pode-se depreender que CTM e TMEF também não guardam relações entre si. A análise mostra-se como verdadeira.

- CTMUP x TMEF - A variação de CTMUP é afetada diretamente pela do CTM que, por sua vez, pode ser modificada pelas mudanças nas HP. Portanto, pelas mesmas razões apresentadas nos parágrafos anteriores infere-se que CMTUP e TMEF também não guardam relações entre si. Assim, a análise apresenta-se como verdadeira.

- CMUP x TMEF - TMEF não guarda relações com CTMUP e CTMUP também não possui relações com CMUP conforme já relatado anteriormente. Então, por transitividade direta, pode-se inferir que CMUP e TMEF também não guardam relações entre si. Portanto, a análise mostra-se como verdadeira.

\section{ANÁLISE DAS INTERLIGAÇõES DOS INDICADORES}

\section{1) MAIOR CUSTO TOTAL DE MANUTENÇÃO DO PERÍODO}

Neste ponto o trabalho pretende discutir as interligações existentes entre os diversos indicadores. A análise dos Indicadores de custos no Anexo 13 permite observar que, no mês de outubro de 2004, constatam-se os maiores valores do período para os seguintes indicadores, conforme apresentam-se nas figuras 6-3 a 6-5.

- CTM: R\$309.483,24;

- CMP: R\$178.913,43;

- CPP: R\$90.725,01. 


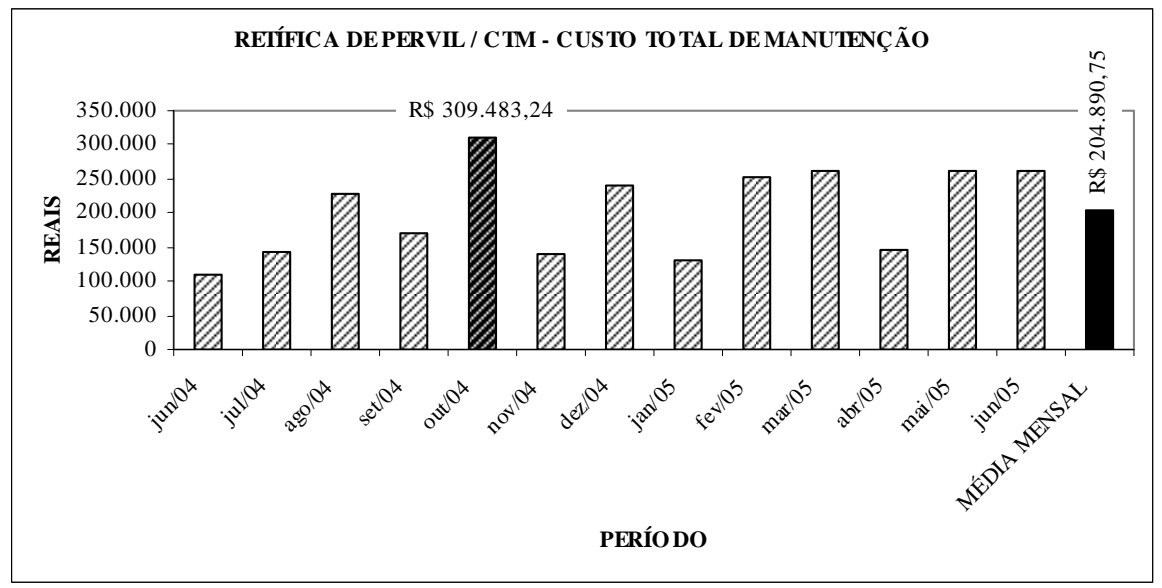

Figura 6-3 - Custo Total de Manutenção.

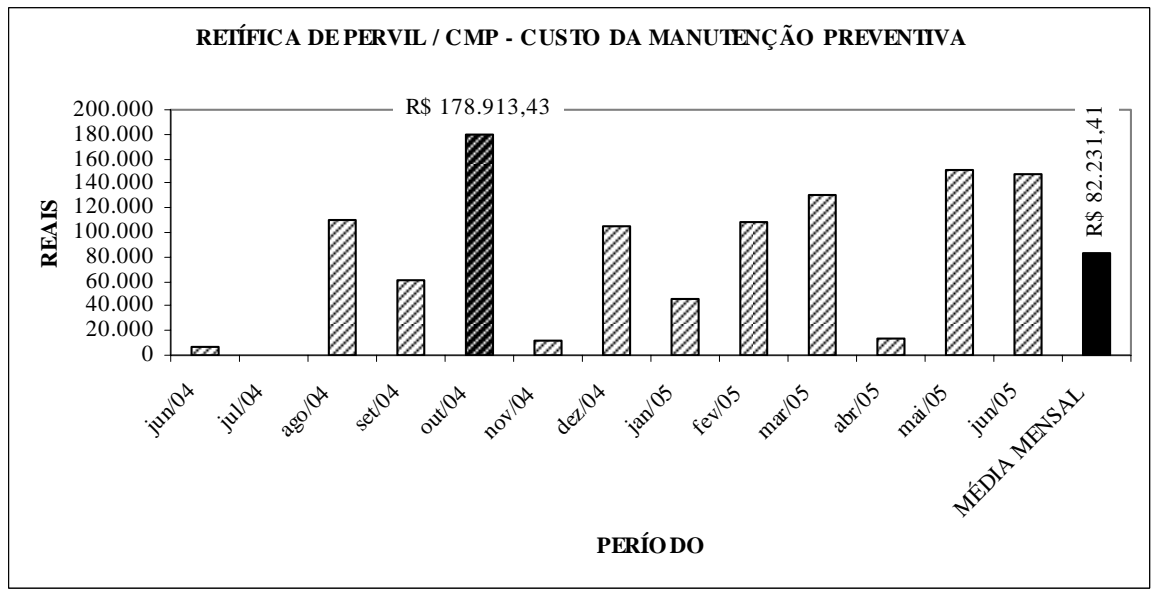

Figura 6-4 - Custo da Manutenção Preventiva.

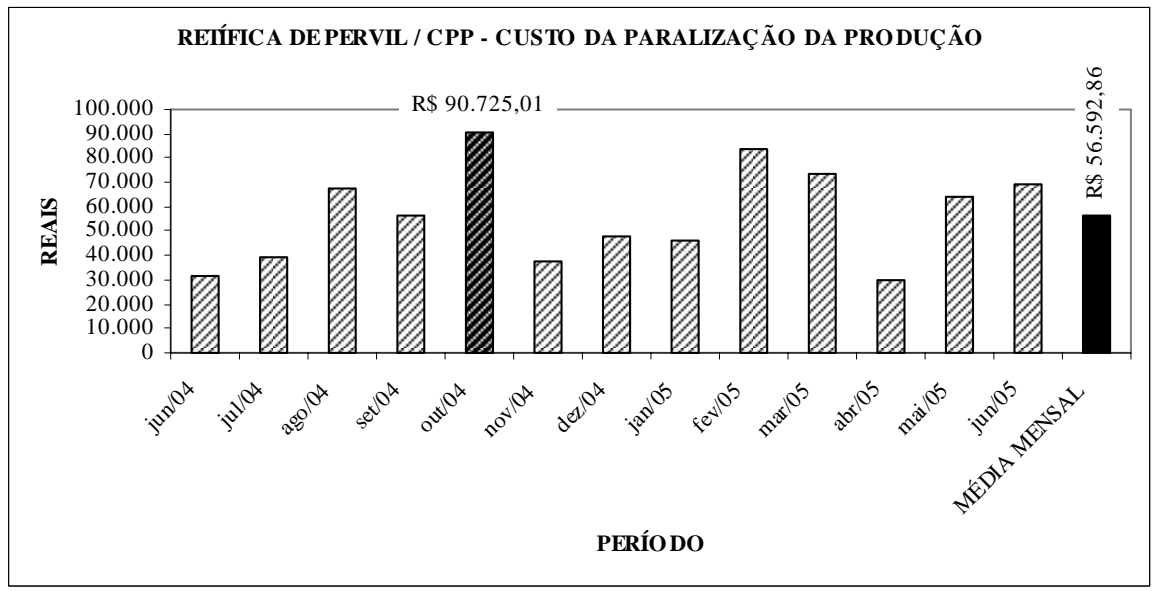

Figura 6-5 - Custo da Paralisação da Produção. 
Na seqüência, a análise dos Indicadores de Qualidade no Anexo 9, no mês de outubro de 2004, permite constatar os maiores valores do período para os seguintes indicadores:

- HP: 237,85 horas. O que justifica o valor do CPP como sendo também o maior do período

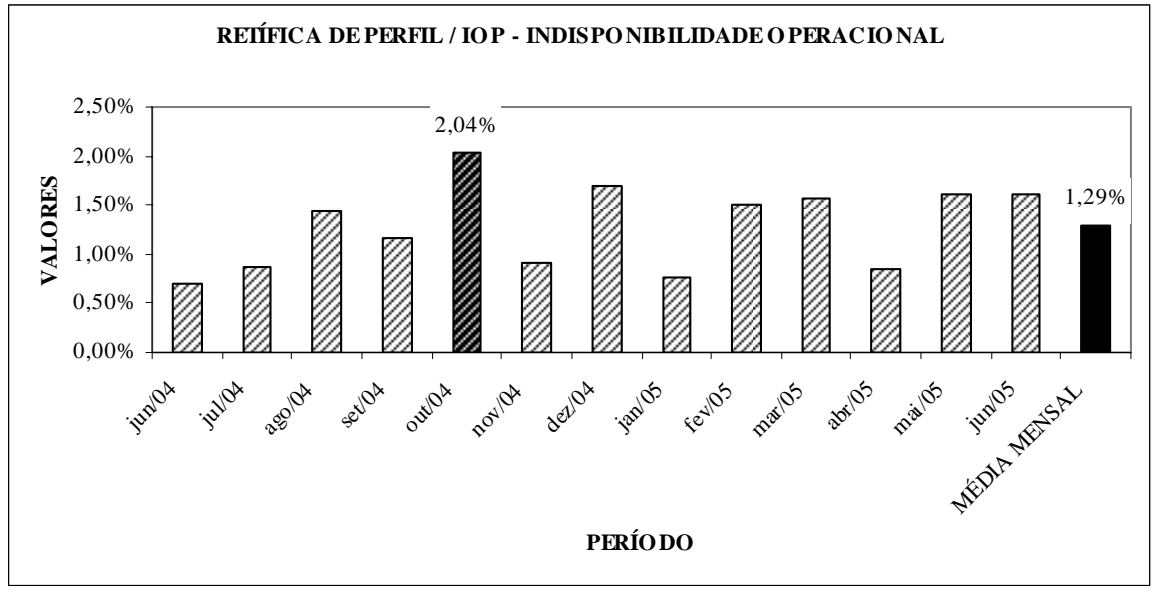

Figura 6-6 - Indisponibilidade Operacional.

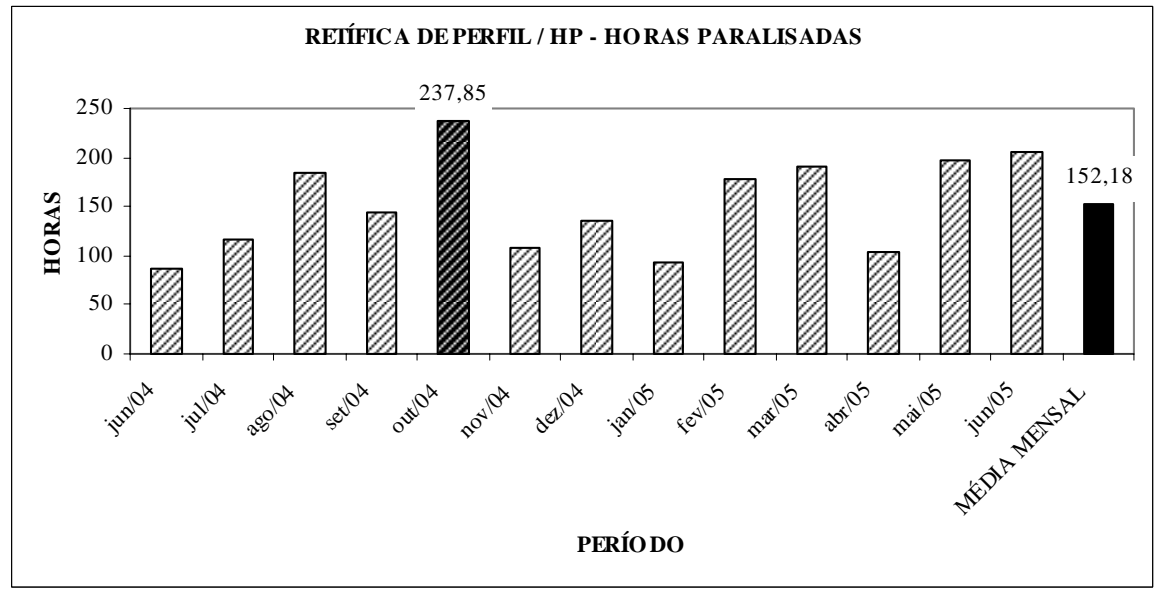

Figura 6-7 - Horas Paralisadas.

A análise dos Indicadores de Velocidade no Anexo 10, ainda no mês de outubro de 2004, apresenta as informações seguintes, apresentadas nas figuras 6-8 a 6-13: 
- Maiores valores do período para os seguintes indicadores:

$\checkmark$ HMP: 208,46 horas;

$\checkmark$ TMDR: 10,34 horas. Valor justificado pelas HP apresentadas na página anterior;

$\checkmark$ IPR: 1,79\%. Valor justificado pelas HMP observadas;

$\checkmark$ HCI: 237,85 horas. HCI e HP têm o mesmo significado;

- Menores valores do período para os seguintes indicadores:

DIP: 98,21\%. Justificado pelo valor da IPR apresentado;

VAT: 58,81\%. Justificado pelo valor das HCI ou HP.

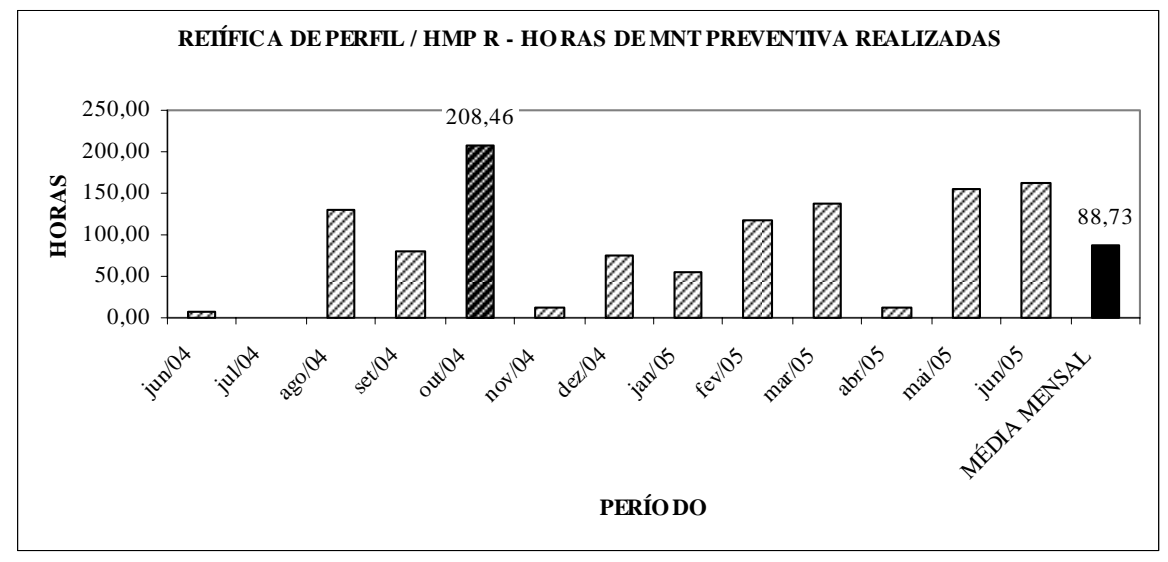

Figura 6-8 - Horas de Manutenção Preventiva Realizadas.

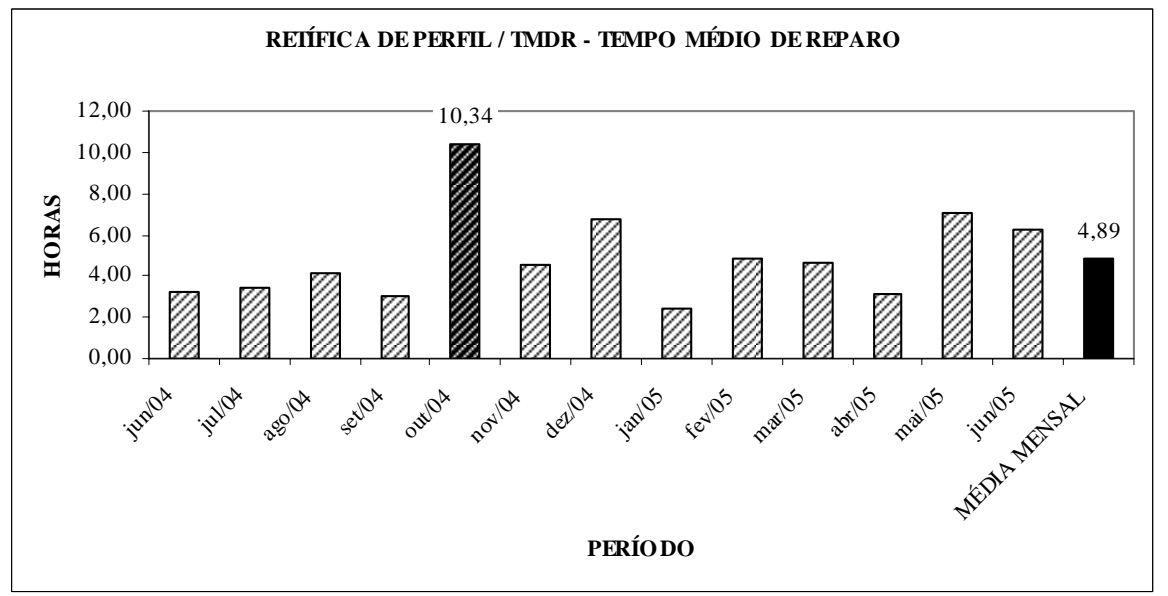

Figura 6-9 - Tempo Médio de Reparo. 


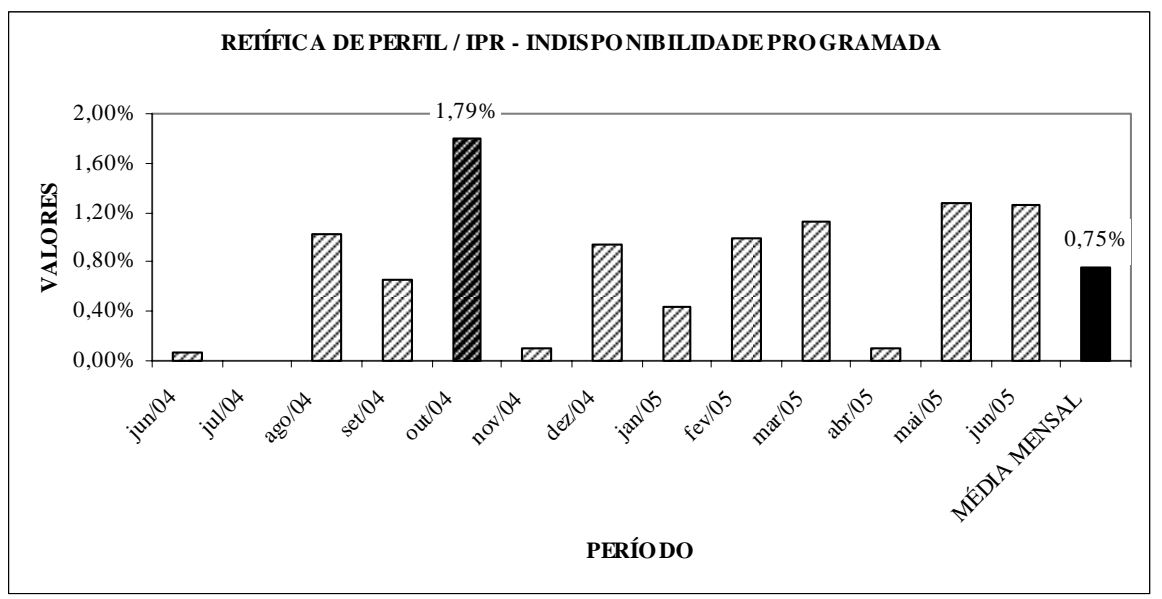

Figura 6-10 - Indisponibilidade Programada.

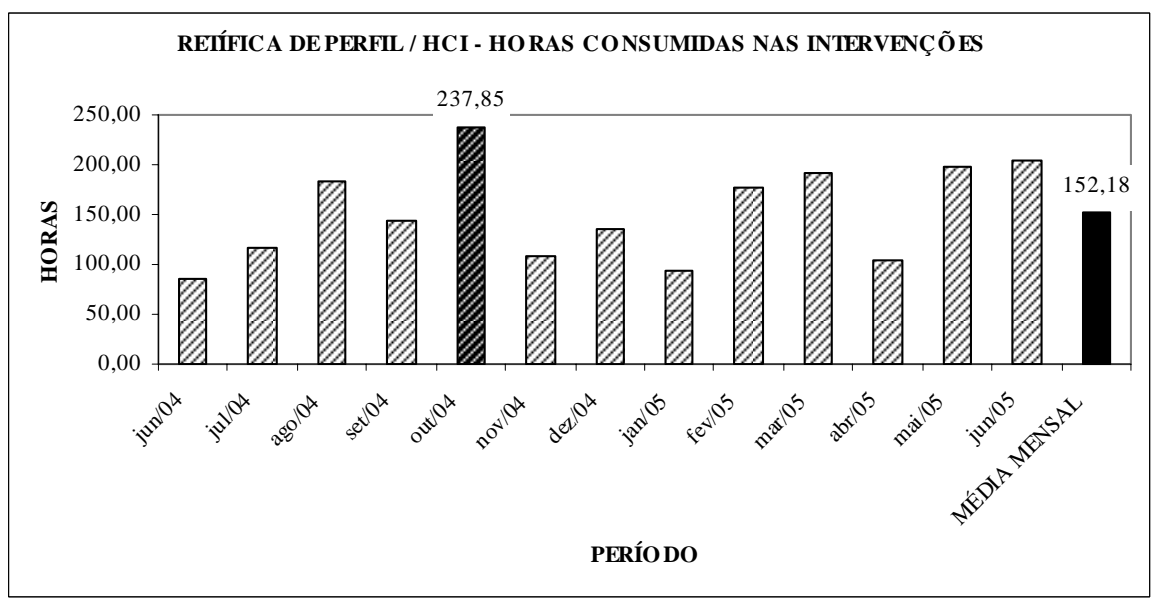

Figura 6-11 - Horas Consumidas nas Intervenções.

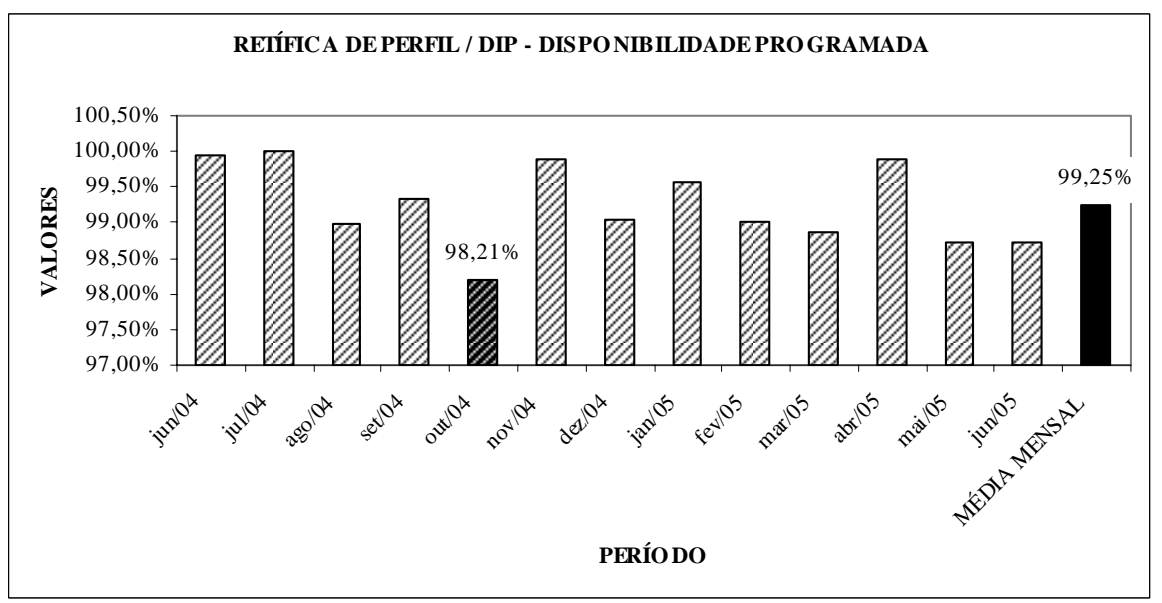

Figura 6-12 - Disponibilidade Programada. 


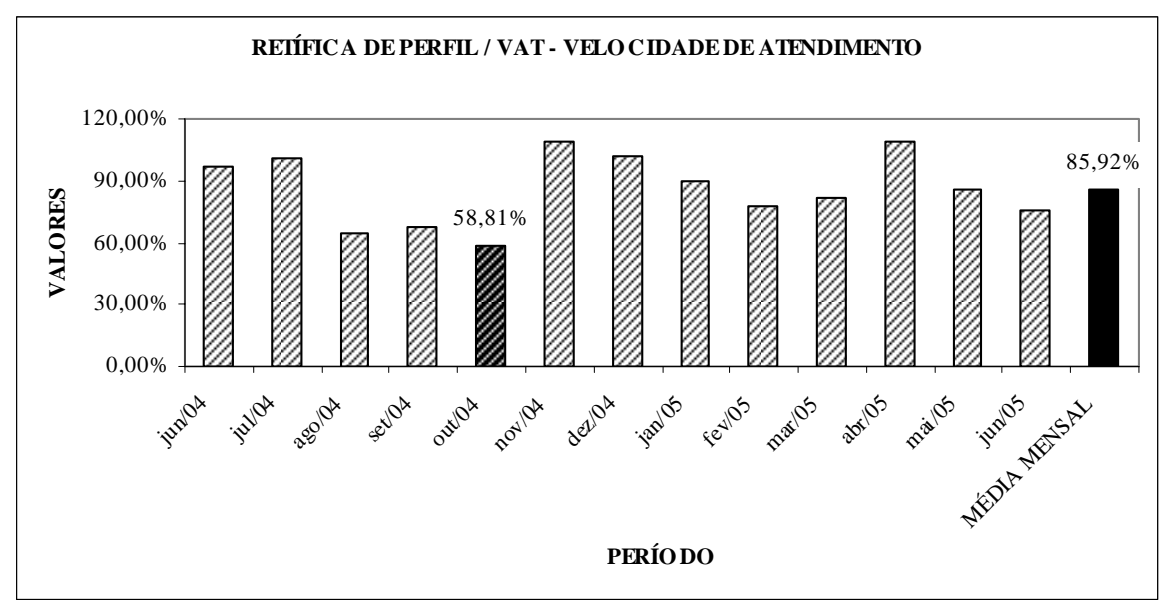

Figura 6-13 - Velocidade de Atendimento.

A análise do Anexo 11 evidencia que o mês de outubro de 2004 não apresentou dados relevantes para os Indicadores de Confiabilidade. Entretanto, o mês em apreço remete a atenção para o Anexo 3, onde se pode identificar o equipamento 0220RP23 como aquele que apresentou o maior impacto nas HMP R do período (ver Quadro 6-4).

A identificação do equipamento permite confirmar no Anexo 4 o número da ordem de serviço de manutenção preventiva que deu origem à intervenção propriamente dita. Tal confirmação está apresentada no Quadro 6-5. A OS de manutenção preventiva em apreço é a de número 02T40365, que descreve o seguinte serviço executado: Revisão no Cabeçote Porta Rebolo da Retífica Kataoka BP28724.

Já o Anexo 6 identifica, pelo do número da ordem de serviço em questão, os funcionários que participaram da intervenção, conforme consta no Quadro 6-6.

Assim, é possível construir a Tabela 6-23 que classifica os funcionários segundo a sua taxa de polivalência TPE, conforme consta na Tabela 6-16 e também da Figura 6-2, evidenciando a ação gerencial em escalar como responsáveis pela intervenção os funcionários melhores qualificados. Afinal, trata-se de um serviço de manutenção preventiva de alto custo e complexidade. 
RETÍFICA DE PERFIL - QUADRO GERAL DE DADOS

Período de Observação: 01/10/2004 a 31/10/2004

Dias Úteis:

22

Horas Dia: 22,5

Horas Disponíveis do Período: $\quad 495,00 \quad$ h/maq

\begin{tabular}{|c|c|c|c|c|c|c|c|c|c|c|c|c|}
\hline CÓDIGO & EQUIPAMENTO & HS & NF & HMC & NP & HMP R & HMP P & HP & NI & TI & HPI & HCI \\
\hline 02200905 & C.PM FILTRO OILMATC-GOETZE-BP 37760 & 495,00 & \multirow{8}{*}{1} & \multirow{8}{*}{1,32} & \multirow{18}{*}{1} & \multirow{18}{*}{83,67} & \multirow{18}{*}{21,00} & 0,00 & 0 & 0,00 & 0,00 & 0,00 \\
\hline 02200906 & C.RP FILTRO OBERLIN - BP 37711 & 495,00 & & & & & & 0,00 & 0 & 0,00 & 0,00 & 0,00 \\
\hline 02200907 & C.RP FILTRO OBERLIN - BP 37705 & 495,00 & & & & & & 0,00 & 0 & 0,00 & 0,00 & 0,00 \\
\hline 02202537 & C.RP PILAO (M) - BP 2138 & 495,00 & & & & & & 0,00 & 0 & 0,00 & 0,00 & 0,00 \\
\hline 02202552 & C.PM PILAO (E/M) - BP 9769 & 495,00 & & & & & & 0,00 & 0 & 0,00 & 0,00 & 0,00 \\
\hline 02202560 & C.PM PILAO (E/M) - BP 20013 & 495,00 & & & & & & 0,00 & 0 & 0,00 & 0,00 & 0,00 \\
\hline 02203226 & C.RP GRAVADORA CNC - BP 37741 & 493,68 & & & & & & 1,32 & 1 & 1,32 & 1,32 & 1,32 \\
\hline 02205701 & C.RP DISPOSITIVO - BP 35485 & 495,00 & & & & & & 0,00 & 0 & 0,00 & 0,00 & 0,00 \\
\hline 0220RP01 & C.RP RTF. PERFIL R4MG - BP 35014 & 491,71 & 2 & 1,41 & & & & 3,29 & 3 & 3,29 & 2,91 & 3,29 \\
\hline 0220RP02 & C.RP RTF. PERFIL R7MG - BP 40058 & 494,07 & 1 & 0,93 & & & & 0,93 & 1 & 0,93 & 0,93 & 0,93 \\
\hline 0220RP03 & C.RP RTF. PERFIL R7MG - BP 40057 & 494,45 & 1 & 0,55 & & & & 0,55 & 1 & 0,55 & 0,55 & 0,55 \\
\hline 0220RP04 & C.RP RTF. PERFIL R7MG - BP 37703 & 493,63 & 1 & 1,37 & & & & 1,37 & 1 & 1,37 & 1,37 & 1,37 \\
\hline 0220RP05 & C.RP RTF. PERFIL R7MG - BP 37704 & 409,70 & \multirow[t]{3}{*}{1} & \multirow[t]{3}{*}{1,63} & & & & 85,30 & 3 & 85,30 & 22,63 & 85,30 \\
\hline 0220RP12 & C.RP RTF. KATAOKA PCG-1-NC-BP 36155 & 495,00 & & & & & & 0,00 & 0 & 0,00 & 0,00 & 0,00 \\
\hline 0220RP15 & C.RP RTF. KATAOKA PCG - BP 36156 & 495,00 & & & & & & 0,00 & 0 & 0,00 & 0,00 & 0,00 \\
\hline 0220RP18 & C.RP RTF. KATAOKA R7 - BP 900069 & 493,95 & 1 & 1,05 & & & & 1,05 & 1 & 1,05 & 1,05 & 1,05 \\
\hline 0220RP19 & C.RP RTF. KATAOKA R7 - BP 900403 & 484,36 & 2 & 10,64 & & & & 10,64 & 2 & 10,64 & 10,64 & 10,64 \\
\hline 0220RP21 & C.PM RTF. KATAOKA PCG - AF 0018 & 494,50 & 1 & 0,50 & & & & 0,50 & 1 & 0,50 & 0,50 & 0,50 \\
\hline 0220RP23 & C.PM RTF. KATAOKA R4MG - BP 28724 & 397,23 & 1 & 2,03 & 1 & 95,74 & 64,00 & 97,77 & 2 & 97,77 & 66,03 & 97,77 \\
\hline 0220RP24 & C.PM RTF. KATAOKA PCG - AF 0017 & 495,00 & \multirow{4}{*}{$\begin{array}{l}3 \\
2\end{array}$} & \multirow{4}{*}{$\begin{array}{l}4,23 \\
2,00\end{array}$} & \multirow{4}{*}{1} & \multirow{4}{*}{27,17} & \multirow{4}{*}{24,00} & 0,00 & 0 & 0,00 & 0,00 & 0,00 \\
\hline 0220RP27 & C.RP RTF. KATAOKA R7 - BP 900573 & 490,77 & & & & & & 4,23 & 3 & 4,23 & 4,23 & 4,23 \\
\hline 0220RP28 & C.RP RTF. KATAOKA R7 - BP 900113 & 465,83 & & & & & & 29,17 & 3 & 29,17 & 26,00 & 29,17 \\
\hline 0220RP29 & C.RP RET. PERFIL PCG - BP 901518 & 495,00 & & & & & & 0,00 & 0 & 0,00 & 0,00 & 0,00 \\
\hline & TOTAIS & $11.642,15$ & 18 & 29,39 & 5 & 208,46 & 110,50 & 237,85 & 23 & 237,85 & 139,89 & 237,85 \\
\hline
\end{tabular}

Quadro 6-4 - Quadro Geral de Dados: Outubro de 2004. 


\begin{tabular}{|c|c|c|c|c|c|}
\hline CODIGO & OS MNT PREV & SERVIÇO EXECUTADO & DATA & H PREVISTAS & H REALISADAS \\
\hline 0220RP23 & 02U74432 & MP-0202E - ANUAL - RETIFICA KATAOKA R4 & 07/02/05 & 5,00 & 4,87 \\
\hline 0220RP23 & 02U74147 & MP-0202M - ANUAL - RETIFICA KATAOKA R4 & 07/02/05 & 16,00 & 15,4 \\
\hline 0220RP23 & 02R65937 & REPARO NO ALARME DO SISTEMA DE SEGURANCA DO REBOLO & $30 / 08 / 04$ & 1,00 & 4,52 \\
\hline 0220RP23 & $02 \mathrm{~T} 40365$ & REVISAO NO CABECOTE PORTA REBOLO DA RET.KATAOKA BP 28724 & $28 / 10 / 04$ & 64,00 & 95,74 \\
\hline 0220RP23 & $02 \mathrm{~T} 01479$ & TROCAR LAMPADA GIROFLEX DA RETIFICA R4 & $22 / 11 / 04$ & 0,50 & 0,5 \\
\hline Subtotais & 5 & & & 86,50 & 121,03 \\
\hline 0220RP24 & 02R09151 & SUBSTITUICAO DE BATERIA PARA SERVO DRIVE DA RET.PCG BP0017 & 20/07/04 & 1,00 & 0,47 \\
\hline 0220RP24 & 02R65946 & REPARO NO ALARME DO SISTEMA DE SEGURANCA DO REBOLO & 30/08/04 & 1,00 & 9,35 \\
\hline 0220RP24 & $02 \mathrm{~T} 82453$ & MP-0206E - ANUAL - RETIFICA KATAOKA PCG & 29/11/04 & 4,00 & 3,6 \\
\hline 0220RP24 & $02 \mathrm{~T} 82319$ & MP-0206M - ANUAL - RETIFICA KATAOKA PCG & 29/11/04 & 16,00 & 7,25 \\
\hline Subtotais & 4 & & & 22,00 & 20,67 \\
\hline 0220RP27 & $02 \mathrm{~T} 48713$ & TROCAR VISORES DO RESERVATORIO MANCAL HIDROSTATICO & 25/01/05 & 3,00 & 3,03 \\
\hline 0220RP27 & 02W29604 & TROCAR PROTECOES SANFONADAS DO MANGOTE FIXADOR & 24/05/05 & 2,00 & 5,53 \\
\hline 0220RP27 & 02R93434 & MP-0203M - ANUAL - RETIFICA KATAOKA R7 & 23/08/04 & 16,00 & 16,26 \\
\hline 0220RP27 & 02R93782 & MP-0203E - ANUAL - RETIFICA KATAOKA R7 & 23/08/04 & 5,00 & 7,77 \\
\hline 0220RP27 & 02R65973 & REPARO NO ALARME DO SISTEMA DE SEGURANCA DO REBOLO & 06/09/04 & 1,00 & 7,92 \\
\hline Subtotais & 5 & & & 27,00 & 40,51 \\
\hline 0220RP28 & 02V14194 & MP-0203M - TRIMESTRAL - RETIFICA KATAOKA R7 & 21/03/05 & 1,00 & 0 \\
\hline 0220RP28 & $02 \mathrm{~T} 48688$ & TROCAR VISORES DO RESERVATORIO MANCAL HIDROSTATICO & 25/01/05 & 3,00 & 3,02 \\
\hline 0220RP28 & 02V12757 & MP-0203M - ANUAL - RETIFICA KATAOKA R7 & 21/03/05 & 16,00 & 15,2 \\
\hline 0220RP28 & 02V13140 & MP-0203E - ANUAL - RETIFICA KATAOKA R7 & 21/03/05 & 5,00 & 4,78 \\
\hline 0220RP28 & 02W29622 & TROCAR PROTECOES SANFONADAS DO MANGOTE FIXADOR & 24/05/05 & 2,00 & 2,18 \\
\hline 0220RP28 & 02Q95745 & MP-0203M - TRIMESTRAL - RETIFICA KATAOKA R7 & 28/06/04 & 1,00 & 1 \\
\hline 0220RP28 & 02W78267 & MP-0203M - TRIMESTRAL - RETIFICA KATAOKA R7 & 27/06/05 & 1,00 & 1 \\
\hline 0220RP28 & $02 \mathrm{~S} 06037$ & REVISAO NO CABECOTE DO PONTO DA RET. KATAOKA R7 BP 900113 & $11 / 08 / 04$ & 16,00 & 34,55 \\
\hline 0220RP28 & 02R65982 & REPARO NO ALARME DO SISTEMA DE SEGURANCA DO REBOLO & 06/09/04 & 1,00 & 4,78 \\
\hline 0220RP28 & 02S41187 & MP-0203M - TRIMESTRAL - RETIFICA KATAOKA R7 & 27/09/04 & 1,00 & 3,5 \\
\hline 0220RP28 & $02 \mathrm{~T} 35460$ & TROCAR ROLAMENTO DA PLACA & 27/10/04 & 24,00 & 27,17 \\
\hline 0220RP28 & $02 \mathrm{~T} 84157$ & MP-0203M - TRIMESTRAL - RETIFICA KATAOKA R7 & 27/12/04 & 1,00 & 1,51 \\
\hline Subtotais & 12 & & & 72,00 & 98,69 \\
\hline
\end{tabular}

Quadro 6-5 - Anexo 4: Quadro Resumo de Dados (28/10/2004). 


\begin{tabular}{|c|c|c|c|c|c|}
\hline CÓDIGO & os MC & CP & OS MP & SERVIÇO EXECUTADO & FUNCIONÁRIOS \\
\hline 0220RP23 & 02W22601 & $02 \mathrm{C} 8960$ & & REG. VALV. DO DRESSADOR E CORRIGIDO PARTE ELETRICA & WAGNER KALAS PEREIRA \\
\hline $0220 \mathrm{RP} 23$ & 02W23316 & 02C8770 & & TROCADO MICRO DO ROBO & LUCIANO JOSE CORTES \\
\hline 0220RP23 & 02W50580 & $02 \mathrm{C} 9519$ & & RECUPERADO A CORRENTE DO EMPURRADOR & CARLOS RENATO ALKMIM \\
\hline 0220RP23 & 02W98227 & & & VERIFICADO A FOLGA DO ROBO & SILVIO JOSE LIMA \\
\hline 0220RP23 & & & $02 \mathrm{R} 65937$ & REPARO NO ALARME DO SISTEMA DE SEGURANCA DO REBOLO & GILBERTO CORREA DE CARVALHO \\
\hline 0220RP23 & & & 02R65937 & REPARO NO ALARME DO SISTEMA DE SEGURANCA DO REBOLO & JOSE ANDERSON DE PAULA \\
\hline $0220 \mathrm{RP} 23$ & & & 02T01479 & TROCAR LAMPADA GIROFLEX DA RETIFICA R4 & GILBERTO CORREA DE CARVALHO \\
\hline $0220 \mathrm{RP} 23$ & & & $02 \mathrm{~T} 40365$ & REVISAO NO CABECOTE PORTA REBOLO DA RET.KATAOKA BP 28724 & ADRIANO MACEDO \\
\hline 0220RP23 & & & $02 \mathrm{~T} 40365$ & REVISAO NO CABECOTE PORTA REBOLO DA RET.KATAOKA BP 28725 & GILBERTO CORREA DE CARVALHO \\
\hline 0220RP23 & & & $02 \mathrm{~T} 40365$ & REVISAO NO CABECOTE PORTA REBOLO DA RET.KATAOKA BP 28726 & JUNIOR MARCELO GONCALVES \\
\hline 0220RP23 & & & $02 \mathrm{~T} 40365$ & REVISAO NO CABECOTE PORTA REBOLO DA RET.KATAOKA BP 28727 & MATHEUS MARQUES ANDRADE \\
\hline 0220RP23 & & & $02 \mathrm{~T} 40365$ & REVISAO NO CABECOTE PORTA REBOLO DA RET.KATAOKA BP 28728 & NOEL TEIXEIRA DOS SANTOS \\
\hline 0220RP23 & & & $02 \mathrm{~T} 40365$ & REVISAO NO CABECOTE PORTA REBOLO DA RET.KATAOKA BP 28729 & RENATO MARCEL CARVALHO \\
\hline 0220RP23 & & & $02 \mathrm{~T} 40365$ & REVISAO NO CABECOTE PORTA REBOLO DA RET.KATAOKA BP 28730 & RICARDO MAGNO DO CARMO \\
\hline $0220 \mathrm{RP} 23$ & & & $02 \mathrm{~T} 40365$ & REVISAO NO CABECOTE PORTA REBOLO DA RET.KATAOKA BP 28731 & SILVIO JOSE LIMA \\
\hline 0220RP23 & & & $02 \mathrm{U} 74147$ & MP-0202M - ANUAL - RETIFICA KATAOKA R4 & RICARDO MAGNO DO CARMO \\
\hline 0220RP23 & & & $02 \mathrm{U} 74432$ & MP-0202E - ANUAL - RETIFICA KATAOKA R4 & JOAO BATISTA DA SILVA \\
\hline SUBTOTAIS & 24 & 18 & 5 & & 38 \\
\hline 0220RP24 & 02R07563 & 02B6482 & & REPARO NO CONJUNTO MOVEL DA PORTA DO REBOLO & EDSON HENRIQUE DA SILVA \\
\hline 0220RP24 & $02 \mathrm{R} 07563$ & 02B6482 & & REPARO NO CONJUNTO MOVEL DA PORTA DO REBOLO & SIDINEI ALBERTO MENEZES \\
\hline 0220RP24 & 02R12183 & & & TROCADO CORREIA DO ARRASTE & CARLOS RENATO ALKMIM \\
\hline 0220RP24 & $02 \mathrm{R} 43293$ & $02 \mathrm{~B} 7398$ & & REPARADO POTENCIOMETRO & SIDNEY GONCALVES FARIA MONTI \\
\hline 0220RP24 & $02 \mathrm{R} 65125$ & & & RECUPERADO OS SUPORTES DO VIBRADOR & CARLOS RENATO ALKMIM \\
\hline 0220RP24 & $02 S 62378$ & $02 \mathrm{C} 0442$ & & REPARADO COMANDO DO INVERSOR & EDSON HENRIQUE DA SILVA \\
\hline 0220RP24 & 02562378 & $02 \mathrm{C} 0442$ & & REPARADO COMANDO DO INVERSOR & SIDNEY GONCALVES FARIA MONTI \\
\hline 0220RP24 & $02 \mathrm{~T} 88466$ & $02 \mathrm{C} 3087$ & & PERDAS REFERENCIA DO EIXO DO ROLO & JOAO BATISTA DA SILVA \\
\hline 0220RP24 & $02 \mathrm{U} 96043$ & $02 \mathrm{C} 6037$ & & REFERENCIA NO EIXO X & JOAO BATISTA DA SILVA \\
\hline 0220RP24 & $02 \mathrm{~V} 36143$ & $02 \mathrm{C} 7022$ & & REPARO NOS PARAMETROS DE PROGRAMACAO & JOAO BATISTA DA SILVA \\
\hline 0220RP24 & & & 02R09151 & SUBSTITUICAO DE BATERIA PARA SERVO DRIVE DA RET.PCG BP0017 & SIDINEI ALBERTO MENEZES \\
\hline 0220RP24 & & & $02 \mathrm{R} 65946$ & REPARO NO ALARME DO SISTEMA DE SEGURANCA DO REBOLO & GILBERTO CORREA DE CARVALHO \\
\hline 0220RP24 & & & 02R65946 & REPARO NO ALARME DO SISTEMA DE SEGURANCA DO REBOLO & JOSE ANDERSON DE PAULA \\
\hline 0220RP24 & & & $02 \mathrm{~T} 82319$ & MP-0206M - ANUAL - RETIFICA KATAOKA PCG & JUNIOR MARCELO GONCALVES \\
\hline 0220RP24 & & & $02 \mathrm{~T} 82319$ & MP-0206M - ANUAL - RETIFICA KATAOKA PCG & NOEL TEIXEIRA DOS SANTOS \\
\hline 0220RP24 & & & $02 \mathrm{~T} 82453$ & MP-0206E - ANUAL - RETIFICA KATAOKA PCG & EDSON HENRIQUE DA SILVA \\
\hline 0220RP24 & & & $02 \mathrm{~T} 82453$ & MP-0206E - ANUAL - RETIFICA KATAOKA PCG & EDSON HENRIQUE DA SILVA \\
\hline SUBTOTAIS & 8 & 6 & 4 & & 17 \\
\hline 0220RP27 & 02R16982 & 02B6868 & & REPARADO BOTOEIRA DE MUDANCA DE POSICAO & GILBERTO CORREA DE CARVALHO \\
\hline
\end{tabular}

Quadro 6-6 - Quadro das Ordens de Serviço: OS MP 02 T40365. 


\begin{tabular}{|l|c|}
\hline \multicolumn{1}{|c|}{ Funcionários } & TPE \\
\hline Adriano Macedo & $17,24 \%$ \\
Silvio José Lima & $10,56 \%$ \\
Gilberto Correa de Carvalho & $5,90 \%$ \\
Noel Teixeira dos Santos & $4,81 \%$ \\
Ricardo Magno do Carmo & $2,48 \%$ \\
Junior Marcelo Gonçalves & $1,71 \%$ \\
Renato Marcel Carvalho & $0,78 \%$ \\
Matheus Marques Andrade & $0,16 \%$ \\
\hline
\end{tabular}

Tabela 6-23 - Funcionários Participantes da OS MP $02 T 40365$.

\section{2) MAIOR CUSTO DE MANUTENÇÃO CORRETIVA DO PERÍODO}

A análise dos Indicadores de Custos do Anexo 13 permite constatar que o mês de julho de 2004 foi o mês que apresentou o maior valor (R\$ 98.014,98) para o CMC, conforme mostra a Figura 6-14.

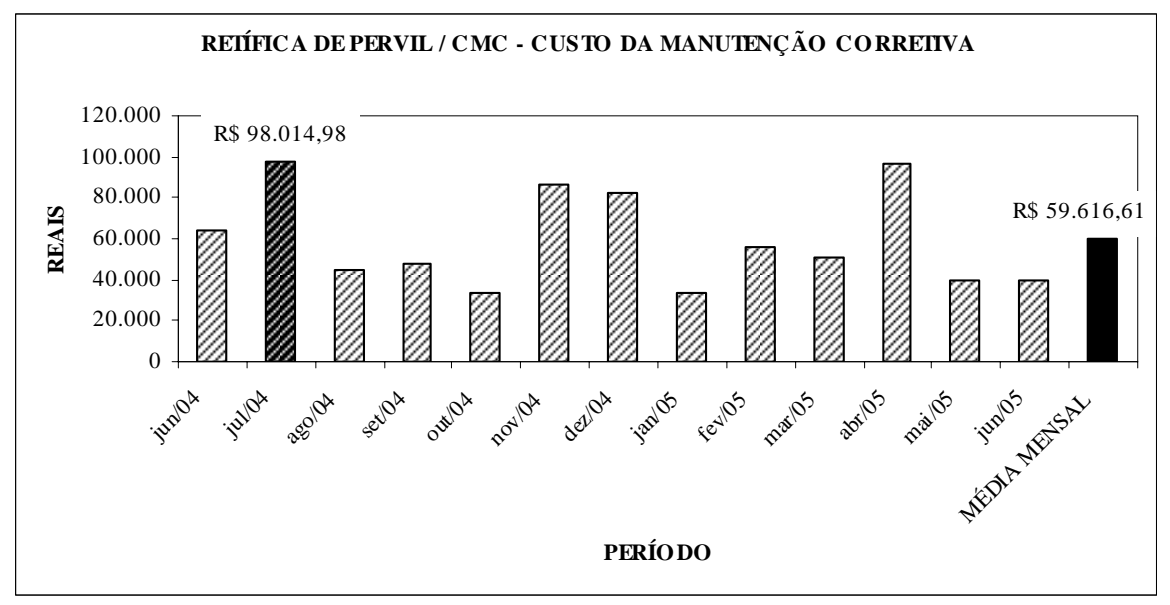

Figura 6-14 - Custo da Manutenção Corretiva.

Os Anexos 9 e 10 não apresentam resultados relevantes relacionados com os Indicadores de Qualidade e Velocidade, respectivamente, para o mês em pauta. O Anexo 11, entretanto, permite constatar as seguintes informações para os Indicadores de Confiabilidade, mostradas nas figuras 6-15 a 6-19: 
- Maiores valores do período:

$\checkmark$ HMC: 116,12 horas. O que justifica o CMC como sendo o maior valor do período;

$\checkmark$ IFO: 0,87\%. Decorrente do valor das HMC;

$\checkmark$ NF: 33 ocorrências;

$\checkmark$ IRE: 3.309. Justificado pelo maior NF do período;

- Menor valor do período:

DIF: 99,13\%. Justificada pelo valor da IFO.

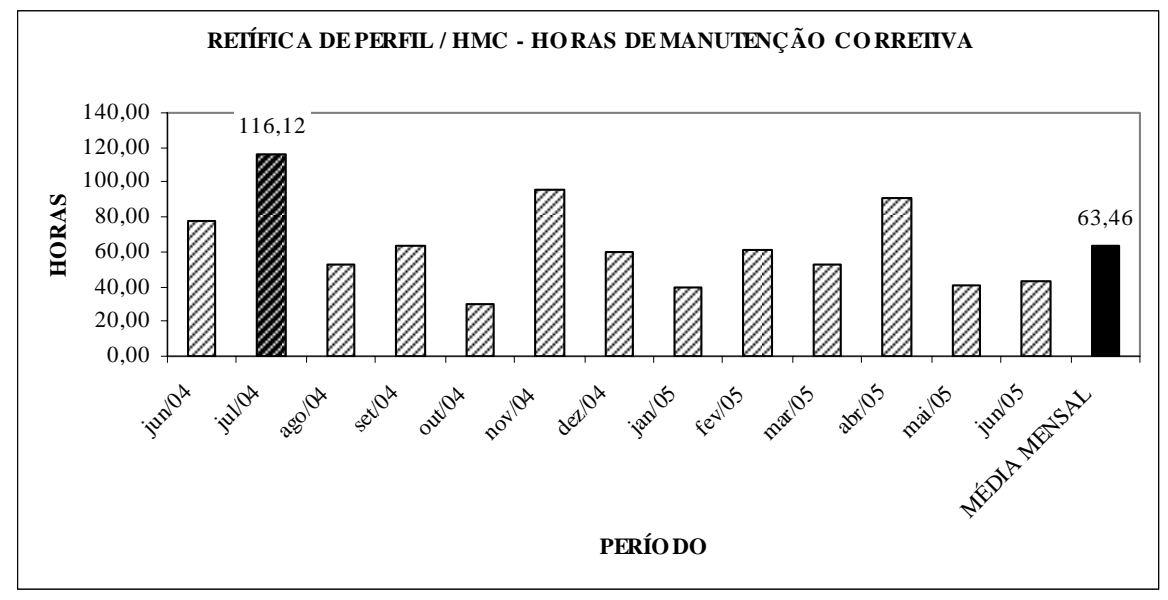

Figura 6-15 - Horas de Manutenção Corretiva.

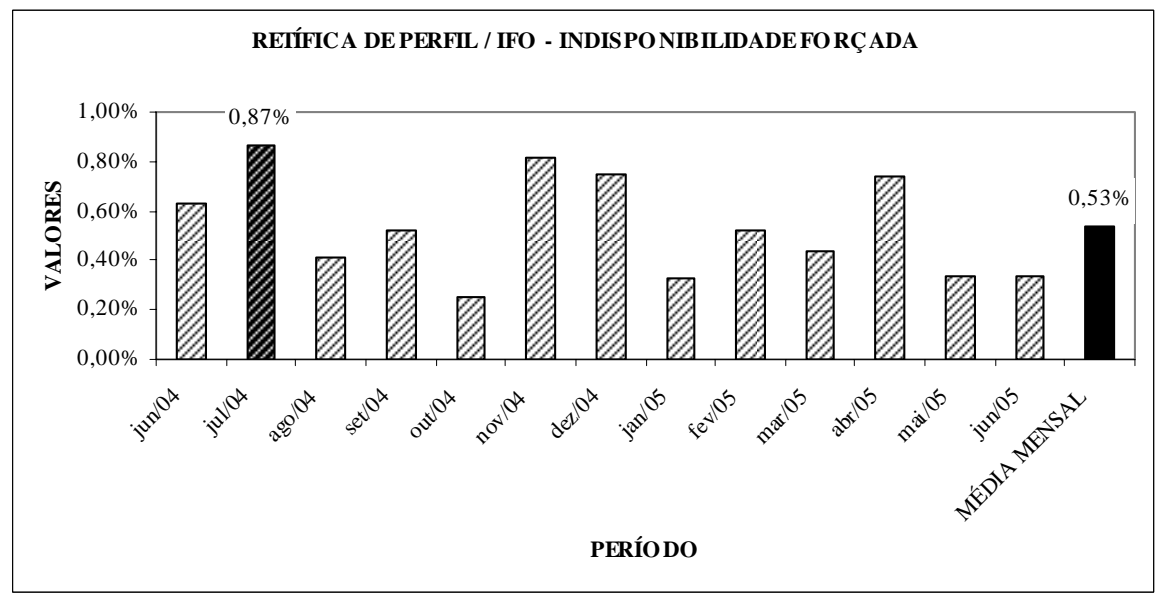

Figura 6-16 - Indisponibilidade Forçada. 


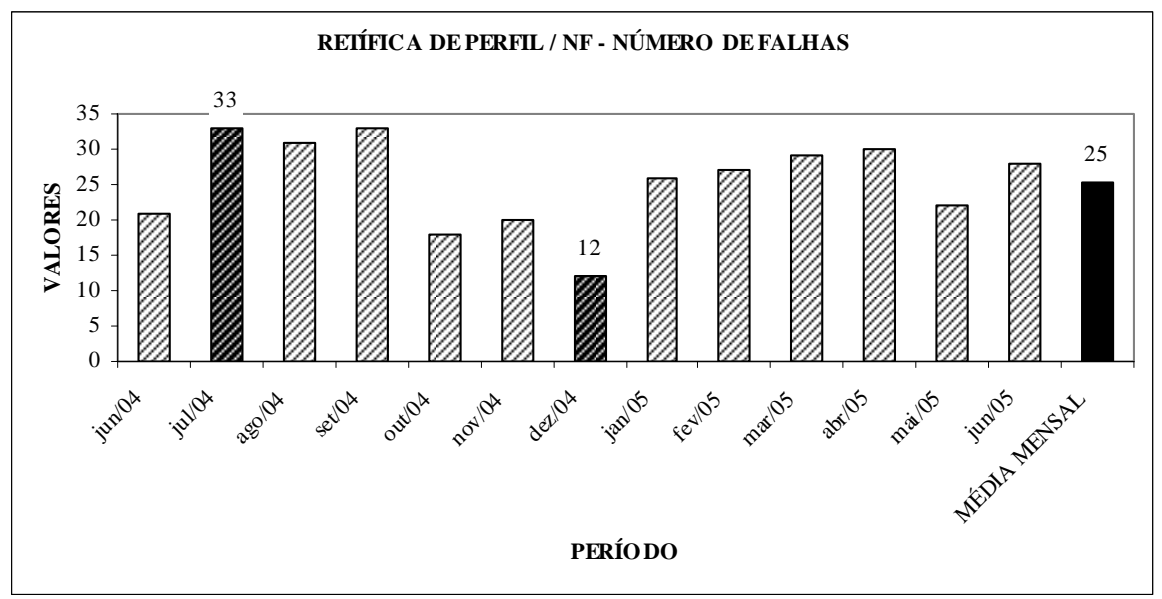

Figura 6-17 - Número de Falhas.

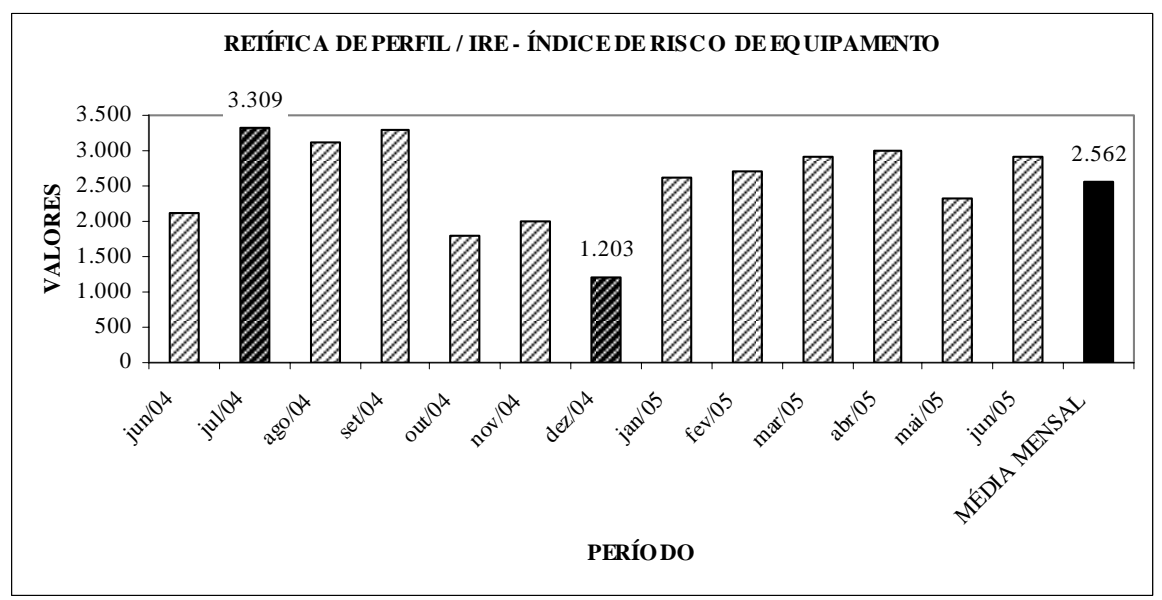

Figura 6-18 - Índice de Risco de Equipamento.

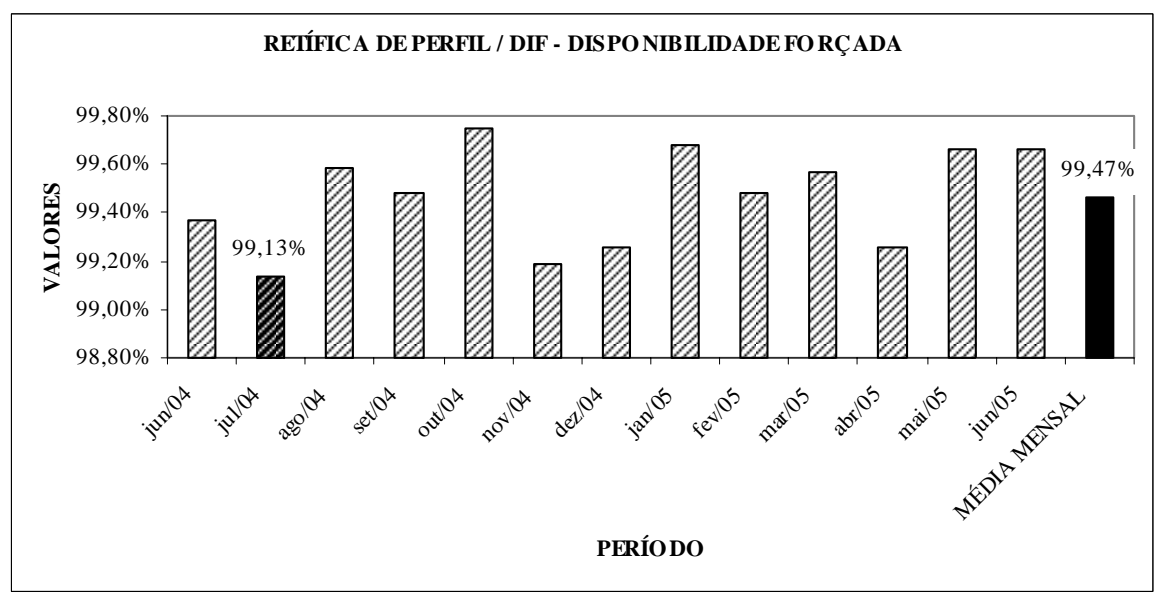

Figura 6-19 - Disponibilidade Forçada. 
O Quadro Geral de Dados do mês de julho de 2004 identifica o equipamento 0220RP03 como sendo aquele que maior impacto teve nas HMC do mês em questão, conforme apresenta o Quadro 6-7.

A Tabela 6-16 também identifica tal equipamento como aquele que recebeu o maior número de intervenções de funcionários no período considerado de 01/06/2004 a 30/06/2005.

O mês de julho de 2004 e o código do equipamento identificam, no Anexo 7, o número da ordem de manutenção corretiva como sendo a 02R85942, com código de parada número 02B8523, conforme mostra o Quadro 6-8.

Nestas condições, no Anexo 6 - Quadro das Ordens de Serviço pode-se identificar o serviço executado como sendo: Reparo no Drive do Eixo Central da Retífica, conforme está apresentado no Quadro 6-9.

Participaram dessa intervenção os funcionários relacionados na Tabela 6-24, classificados segundo sua taxa de polivalência, conforme consta da Tabela 6-16 e da Figura 6-2.

Fica novamente evidenciada a ação gerencial em escalar como responsável pela intervenção um dos mais qualificados funcionários em face de um serviço de manutenção corretiva de alto custo e complexidade.

\begin{tabular}{|l|c|}
\hline \multicolumn{1}{|c|}{ Funcionários } & TPE \\
\hline & \\
João Batista da Silva & $9,47 \%$ \\
Sidney Gonçalves Faria Monti & $2,80 \%$ \\
Sidinei Alberto Menezes & $1,24 \%$ \\
\hline
\end{tabular}

Tabela 6-24 - Funcionários Participantes da OS MC $02 R 85942$.

\section{3) ANÁLISE DOS EQUIPAMENTOS}

A observação dos Anexos 9, 10 e 11 permite listar os equipamentos sobre os quais a ação gerencial deverá estar presente através de ações corretivas e preventivas ou até mesmo para ações de destaque de desempenho (ver Quadro 6-10). 
RETÍFICA DE PERFIL - QUADRO GERAL DE DADOS

Período de Observação: 01/07/2004 a 31/07/2004

Dias Úteis: $\quad 25$

22,5

Horas Disponíveis do Período: $\quad 562,50 \quad$ h/maq

\begin{tabular}{|c|c|c|c|c|c|c|c|c|c|c|c|c|}
\hline CÓDIGO & EQUIPAMENTO & HS & NF & HMC & NP & HMP R & HMP P & HP & NI & TI & HPI & HCI \\
\hline 02200905 & C.PM FILTRO OILMATC-GOETZE-BP 37760 & 562,50 & \multirow{6}{*}{1} & \multirow{6}{*}{3,47} & & & & 0,00 & 0 & 0,00 & 0,00 & 0,00 \\
\hline 02200906 & C.RP FILTRO OBERLIN - BP 37711 & 562,50 & & & & & & 0,00 & 0 & 0,00 & 0,00 & 0,00 \\
\hline 02200907 & C.RP FILTRO OBERLIN - BP 37705 & 562,50 & & & & & & 0,00 & 0 & 0,00 & 0,00 & 0,00 \\
\hline 02202537 & C.RP PILAO (M) - BP 2138 & 562,50 & & & & & & 0,00 & 0 & 0,00 & 0,00 & 0,00 \\
\hline 02202552 & C.PM PILAO (E/M) - BP 9769 & 559,03 & & & & & & 3,47 & 1 & 3,47 & 3,47 & 3,47 \\
\hline 02202560 & C.PM PILAO (E/M) - BP 20013 & 562,50 & & & & & & 0,00 & 0 & 0,00 & 0,00 & 0,00 \\
\hline 02203226 & C.RP GRAVADORA CNC - BP 37741 & 561,43 & \multirow[t]{2}{*}{1} & \multirow[t]{2}{*}{1,07} & & & & 1,07 & 1 & 1,07 & 1,07 & 1,07 \\
\hline 02205701 & C.RP DISPOSITIVO - BP 35485 & 562,50 & & & & & & 0,00 & 0 & 0,00 & 0,00 & 0,00 \\
\hline 0220RP01 & C.RP RTF. PERFIL R4MG - BP 35014 & 561,55 & 1 & 0,95 & & & & 0,95 & 1 & 0,95 & 0,95 & 0,95 \\
\hline 0220RP02 & C.RP RTF. PERFIL R7MG - BP 40058 & 554,20 & 4 & 8,30 & & & & 8,30 & 4 & 8,30 & 8,30 & 8,30 \\
\hline 0220RP03 & C.RP RTF. PERFIL R7MG - BP 40057 & 530,63 & 1 & 31,87 & & & & 31,87 & 1 & 31,87 & 31,87 & 31,87 \\
\hline 0220RP04 & C.RP RTF. PERFIL R7MG - BP 37703 & 554,41 & 5 & 8,09 & \multirow{13}{*}{1} & \multirow{13}{*}{0,47} & \multirow{13}{*}{1,00} & 8,09 & 5 & 8,09 & 8,09 & 8,09 \\
\hline 0220RP05 & C.RP RTF. PERFIL R7MG - BP 37704 & 544,75 & 5 & 17,75 & & & & 17,75 & 5 & 17,75 & 17,75 & 17,75 \\
\hline 0220RP12 & C.RP RTF. KATAOKA PCG-1-NC-BP 36155 & 560,57 & 1 & 1,93 & & & & 1,93 & 1 & 1,93 & 1,93 & 1,93 \\
\hline 0220RP15 & C.RP RTF. KATAOKA PCG - BP 36156 & 562,50 & & & & & & 0,00 & 0 & 0,00 & 0,00 & 0,00 \\
\hline 0220RP18 & C.RP RTF. KATAOKA R7 - BP 900069 & 550,92 & 4 & 11,58 & & & & 11,58 & 4 & 11,58 & 11,58 & 11,58 \\
\hline 0220RP19 & C.RP RTF. KATAOKA R7 - BP 900403 & 561,37 & 1 & 1,13 & & & & 1,13 & 1 & 1,13 & 1,13 & 1,13 \\
\hline 0220RP21 & C.PM RTF. KATAOKA PCG - AF 0018 & 562,50 & & & & & & 0,00 & 0 & 0,00 & 0,00 & 0,00 \\
\hline 0220RP22 & C.PM RTF. KATAOKA R4MG - BP 32606 & 562,50 & \multirow{3}{*}{3} & \multirow{3}{*}{11,19} & & & & 0,00 & 0 & 0,00 & 0,00 & 0,00 \\
\hline 0220RP23 & C.PM RTF. KATAOKA R4MG - BP 28724 & 551,31 & & & & & & 11,19 & 3 & 11,19 & 11,19 & 11,19 \\
\hline 0220RP24 & C.PM RTF. KATAOKA PCG - AF 0017 & 562,03 & & & & & & 0,47 & 1 & 0,47 & 1,00 & 0,47 \\
\hline 0220RP27 & C.RP RTF. KATAOKA R7 - BP 900573 & 546,88 & \multirow{3}{*}{$\begin{array}{l}3 \\
3\end{array}$} & \multirow{3}{*}{$\begin{array}{c}15,62 \\
3,17\end{array}$} & & & & 15,62 & 3 & 15,62 & 15,62 & 15,62 \\
\hline 0220RP28 & C.RP RTF. KATAOKA R7 - BP 900113 & 559,33 & & & & & & 3,17 & 3 & 3,17 & 3,17 & 3,17 \\
\hline 0220RP29 & C.RP RET. PERFIL PCG - BP 901518 & 562,50 & & & & & & 0,00 & 0 & 0,00 & 0,00 & 0,00 \\
\hline & TOTAIS & $13.383,41$ & 33 & 116,12 & 1 & 0,47 & 1,00 & 116,59 & 34 & 116,59 & 117,12 & 116,59 \\
\hline
\end{tabular}

Quadro 6-7 - Quadro Geral de Dados: julho de 2004. 


\begin{tabular}{|c|c|c|c|c|c|c|c|c|c|}
\hline Código & OS Mnt Corretiva & Cod Parada & Modalidade & Falha & Causa & Ocorrência & Gravidade & Detectabilidade & OGD \\
\hline 0220RP23 & 02R61325 & 02B7920 & MECÂNICA & QUEBRA & GUIA & 1 & 10 & 10 & 100 \\
\hline 0220RP23 & 02R69130 & 02B8245 & MECÂNICA & QUEBRA & PARAFUSO & 1 & 10 & 10 & 100 \\
\hline 0220RP23 & $02 R 71895$ & 02B8374 & MECÂNICA & QUEBRA & HIDR.-TUBULACAO & 1 & 10 & 10 & 100 \\
\hline 0220RP23 & $02 \mathrm{R} 99875$ & & MECÂNICA & FOLGA & GUIA & 1 & 1 & 1 & 1 \\
\hline Subtotais & 4 & 3 & & & & 4 & & IRF & 301 \\
\hline 0220RP27 & 02R54627 & 02B7669 & ELÉTRICA & INTERRUPCAO DE SINAL & CLP & 1 & 10 & 10 & 100 \\
\hline 0220RP27 & $02 R 98634$ & 02B8689 & ELÉTRICA & CURTO-CIRCUITO & SENSOR & 1 & 10 & 10 & 100 \\
\hline 0220RP27 & 02R86512 & $02 B 8545$ & MECÂNICA & TRAVAMENTO & CONTRA-PONTO & 1 & 10 & 10 & 100 \\
\hline Subtotais & 3 & 3 & & & & 3 & & IRF & 300 \\
\hline 0220RP28 & 02R54529 & 02B7656 & ELÉTRICA & MAL-CONTATO & CABO ELETRICO & 1 & 10 & 10 & 100 \\
\hline 0220RP28 & 02R57401 & 02B7786 & ELÉTRICA & DESREGULAGEM & PRESSOSTATO & 1 & 10 & 10 & 100 \\
\hline 0220RP28 & 02R70501 & 02B8308 & ELÉTRICA & INTERRUPCAO DE SINAL & PRESSOSTATO & 1 & 10 & 10 & 100 \\
\hline Subtotais & 3 & 3 & & & & 3 & & IRF & 300 \\
\hline 0220RP19 & 02R86754 & 02B8560 & ELÉTRICA & INTERRUPCAO DE SINAL & CHAVE FIM-DE-CURSO & 1 & 10 & 10 & 100 \\
\hline 0220RP19 & 02R70299 & & ELÉTRICA & INTERRUPCAO DE SINAL & SENSOR & 1 & 1 & 1 & 1 \\
\hline 0220RP19 & $02 S 01675$ & & ELÉTRICA & INTERRUPCAO DE SINAL & SENSOR & 1 & 1 & 1 & 1 \\
\hline Subtotais & 3 & 1 & & & & 3 & & IRF & 102 \\
\hline 02203226 & 02R73688 & 02B8479 & ELÉTRICA & DESLOCAMENTO & CHAVE FIM-DE-CURSO & 1 & 10 & 10 & 100 \\
\hline 02203226 & 02R72527 & & ELÉTRICA & INTERRUPCAO DE SINAL & SENSOR & 1 & 1 & 1 & 1 \\
\hline Subtotais & 2 & 1 & & & & 2 & & IRF & 101 \\
\hline 02202552 & 02R73651 & 02B8476 & MECÂNICA & TRAVAMENTO & PNEUM.-VALVULA & 1 & 10 & 10 & 100 \\
\hline Subtotais & 1 & 1 & & & & 1 & & IRF & 100 \\
\hline 0220RP01 & $02 \mathrm{R} 70404$ & 02B8299 & MECÂNICA & QUEBRA & GUIA & 1 & 10 & 10 & 100 \\
\hline Subtotais & 1 & 1 & & & & 1 & & IRF & 100 \\
\hline 0220RP03 & 02R85942 & $02 \mathrm{~B} 8523$ & \begin{tabular}{|l|l|} 
ELÉTRICA \\
\end{tabular} & TRAVAMENTO & CONTROLADOR & 1 & 10 & 10 & 100 \\
\hline Subtotais & 1 & 1 & & & & 1 & & IRF & 100 \\
\hline
\end{tabular}

Quadro 6-8 - Quadro de Ocorrência de Falhas: 07/2004. 


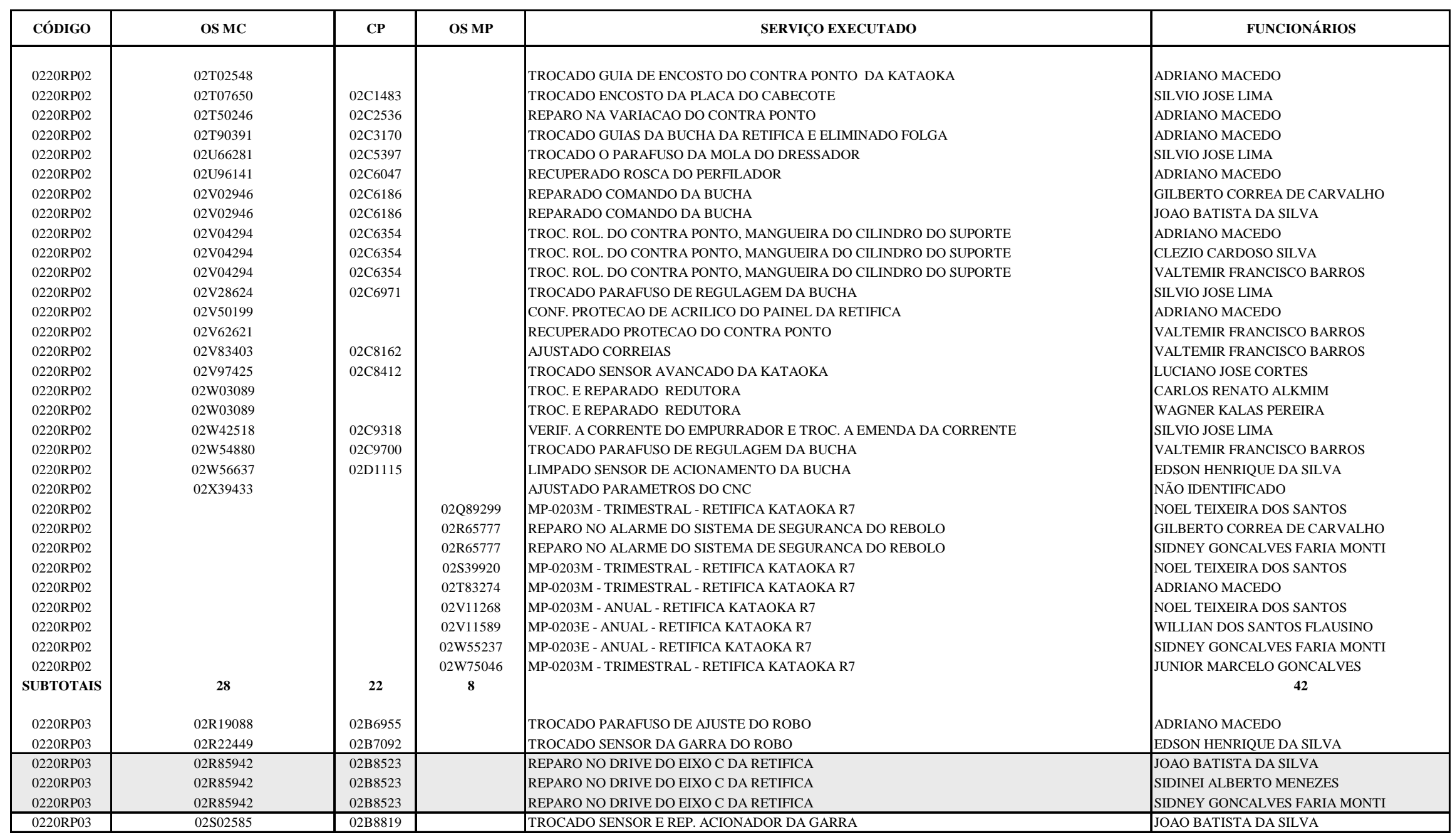

Quadro 6-9 - Quadro das Ordens de Serviço: OS MC $02 R 85942$. 


\begin{tabular}{|c|c|c|c|}
\hline Código do Equipamento & Indicadores de Qualidade & Indicadores de Velocidade & Indicadores de Confiabilidade \\
\hline 0220RP05 & $\begin{array}{l}\text { Maior HP do período - 284,73 h } \\
\text { Menor EGE do período - } 77,02 \% \\
\text { Menor DOP do período - 95,47\% } \\
\text { Maior IOP do período - 4,53\% }\end{array}$ & $\begin{array}{l}\text { Maior HCI do período - 284,73 h } \\
\text { NI do período - } 34 \text { intervenções } \\
\text { TMDR do período - 8,37 h } \\
\text { Maior IPR do período - 3,53\% } \\
\text { Menor DIP do período - 96,47\% } \\
\text { Maior HMP R do período - 222,03 h }\end{array}$ & \\
\hline 02202537 & & $\begin{array}{l}\text { Maior TMDR do período - 9,95 h } \\
\text { HCI do período - 29,86 h } \\
\text { NI do período - } 3 \text { intervenções }\end{array}$ & \\
\hline 0220RP03 & & Maior NI do período - 41 intervenções & $\begin{array}{l}\text { Menor TMEF do período - 194,21 h } \\
\text { Maior NF do período - } 33 \text { ocorrências } \\
\text { Maior IRF do período - } 3.307\end{array}$ \\
\hline 0220RP04 & & Maior NI do período - 41 intervenções & \\
\hline 02200906 & & Maior VAT do período - $144,51 \%^{2}$ & \\
\hline 02202560 & & & $\begin{array}{l}\text { Maior TMEF do período - } 6.567,43 \text { h } \\
\text { Menor NF do período - } 1 \text { ocorrência }\end{array}$ \\
\hline 02203226 & & & $\begin{array}{l}\text { Maior IFO do período - 1,37\% } \\
\text { Maior HMC do período - } 89 \text { horas } \\
\text { Menor DIF do período - 98,63\% }\end{array}$ \\
\hline
\end{tabular}

Quadro 6-10 - Análise dos Equipamentos.

${ }^{2}$ Significa que as Horas Previstas das Intervenções (HPI) são bem maiores que as Horas Consumidas nas Intervenções (HCI), o que permite inferir inconsistência nas previsões. 
O Anexo 12 também permite identificar os seguintes equipamentos e suas relações com as ordens de serviço emitidas. Tais equipamentos demandam uma atenção gerencial mais próxima:

- EQP 0220RP01 - Recebeu o maior número de ordens de serviço de manutenção corretiva durante o período considerado: 41 ordens. Para esse equipamento foram emitidas 29 ordens de serviço com código de parada de produção. Valor esse que também pode ser confirmado no Anexo 11, no gráfico que relaciona o NF dos equipamentos;

- EQP 0220RP03 - Para este equipamento foram emitidas 33 ordens de serviço com código de parada de produção. O maior valor do período. Tal número está consistente com o NF apresentado pelo equipamento e já declarado o Quadro 6-10 anterior;

- EQP 0220RP28 - Recebeu o maior número de ordens de serviço de manutenção preventiva do período. Foram 12 ordens emitidas. O Anexo 10 identifica para este equipamento um total de 98,69 horas de manutenção preventiva no ano. Em contrapartida, o equipamento 0220RP05 com o maior número de horas de manutenção preventiva do período, ou seja, 220,03 horas (já relatadas no Quadro 6-10) teve apenas 7 ordens de serviço emitidas. Tal diferença é explicada pela complexidade da intervenção realizada.

\subsection{CONCLUSÃO}

Pelo o que foi apresentado ao longo do texto pode-se concluir que o capítulo atingiu os propósitos estabelecidos em seu preâmbulo. Uma justificativa consistente foi apresentada para a escolha da Célula Retífica de Perfil como foco do objeto de estudo do trabalho. Além disso, também foi mostrado o seu posicionamento dentro do organograma da empresa.

Na seqüência, o texto recorda a descrição e a formulação dos indicadores desenvolvidos para o modelo de gestão. Quadros e tabelas foram construídos para facilitar a visualização das variações dos indicadores ao longo do período 
considerado. O texto também assinala a forma como tais quadros e tabelas foram compostos, identificando os dados organizados em seus respectivos anexos.

A apresentação dos resultados, em seguida, é enriquecida por intermédio de análises de correlação, propiciando uma observação minuciosa e detalhada das relações intra e entre indicadores.

Nestas condições, e em função dos resultados e análises apresentadas, pode se concluir pela validação dos indicadores no modelo de gestão. Em primeiro lugar, porque se pode constatar que o modelo e seus indicadores atendem de forma clara e precisa ao pressuposto do processo gerencial relatado na Figura 1-2. Os indicadores propiciam de fato o monitoramento do processo de manutenção. Em segundo, porque o modelo e os indicadores dão o devido suporte para o gerente desempenhar sua função de forma objetiva e direcionada na empresa. Os indicadores propiciam informações precisas e confiáveis para a interferência gerencial. 


\section{Capítulo 7}

\section{Conclusões}

As conclusões finais estão aqui alinhavadas como fechamento da Tese. Uma conclusão geral é considerada ressaltando o uso de indicadores na busca de melhores resultados competitivos. São apresentadas as contribuições acadêmicas e empíricas e a conclusão final do trabalho, evidenciando os objetivos atingidos. $O$ texto é finalizado pelas sugestões para trabalhos futuros.

\subsection{CONSIDERAÇÕES GERAIS}

Os níveis de competitividade na busca de resultados demonstram a realidade atual do mercado mundial e geram, em decorrência, para as empresas uma busca incessante de inovações criativas em todas as direções. As mudanças que se observam nos panoramas político, social e econômico são vetores representativos dessas necessidades. O comportamento dos consumidores diante de novos padrões de preço e qualidade de produtos e serviços, também aponta na direção de uma empresa mais integrada e flexível. Nestas condições, o desempenho das organizações passa a não depender tão somente de resultados individuais e evoluir para um conceito mais abrangente de resultados de processos.

Nesse contexto, o desempenho final da organização deve ser avaliado no sentido de tornar possível a percepção das melhorias isoladas contribuindo para a melhoria do todo. Assim, toda a geração de trabalho deve ser avaliada em função de sua necessidade maior de servir ao cliente. Satisfazer às necessidades dos clientes e ser muito melhor que os concorrentes devem ser as principais prioridades de qualquer empresa bem sucedida.

A relevância da função manutenção, nas organizações industriais, está explícita de forma clara e objetiva neste conceito sistêmico de resultados de 
processos. A sua importância está definida pelo bom desempenho do processo produtivo da organização que, por sua vez, depende da prontidão funcional de seus equipamentos. Falhas, quebras geram perdas, riscos de acidentes e danos ao meio ambiente além de impactarem fortemente nos custos da organização.

Assim, a relevância dos indicadores apresentados para a gestão do custeio e das atividades de manutenção pode ser sentida em vários aspectos. Em primeiro lugar porque a função manutenção representa um potencial considerável para a melhoria do desempenho da empresa. Em segundo porque a manutenção não é vista mais tão somente como uma fonte de custos. É um setor significativo dentro da organização e sobre o qual pesa a responsabilidade de minimizar perturbações, imprevistos e custos. Principalmente aqueles relacionados com a restauração do estado de funcionamento dos equipamentos, sistemas e instalações.

Nestas condições, o uso de indicadores, integrados em um modelo de gestão orientado para a função manutenção, esgota as políticas tradicionais, empíricas e, muitas vezes autoritárias, de planejamento de manutenção. Tais políticas já não acompanham a busca da maior produtividade. O uso de indicadores para a gestão do custeio e das atividades de manutenção promoverá ganhos significativos nas relações de cooperação das funções manutenção e produção. A cooperação interna é sem dúvida um catalisador do desempenho global.

\subsection{CONTRIBUIÇÃO DO TRABALHO}

\subsubsection{CONTRIBUIÇÃO ACADÊMICA}

Contribuições teóricas de relevante importância para a área de manutenção industrial foram propiciadas por autores tais como NAGAO (1998), ANHESINE (1999), RODRIGUES (2000), FURMANN (2002) e MENDES (2002), entre outros. Os autores são unânimes em afirmar que o fator determinante da competitividade de uma organização é o nível de integração dos processos de suas principais funções. Neste contexto, a função manutenção tem sua importância fundamentada no processo produtivo da empresa. Sua missão é garantir a disponibilidade dos equipamentos, 
sistemas e instalações de modo a viabilizar o processo produtivo, preservando o meio ambiente, em níveis adequados de segurança, confiabilidade e custos.

NAGAO (1988) relata que a função manutenção, em indústrias de processos contínuos, tem uma importância marcante na produção. Devido às suas características particulares, quebras ou falhas nos equipamentos, normalmente acarretam grandes perdas de produção e muitas vezes riscos de acidentes e danos ao meio ambiente. Nesta direção, o autor procurou identificar as melhores práticas na área de manutenção nessas indústrias, analisando a sua tendência e os riscos envolvidos. O autor discorre sobre as características de uma indústria de processo contínuo. Identifica os seus processos-chave e as práticas gerenciais que deveriam ser implementadas para o atendimento de suas necessidades.

Com base no modelo gerencial de avaliação de SINK \& TUTTLE (1993), o autor propõe alguns indicadores de desempenho para a área de manutenção industrial e utiliza, também, alguns indicadores divulgados por associações, principalmente pela ABRAMAN - Associação Brasileira de Manutenção. Tais indicadores são considerados pelos autores como uma base de referência para a análise do desempenho da manutenção (ver Título 2.1.3 - O Modelo de Avaliação, segundo Sink e Tuttle, do Capítulo 2, As Teorias de Base). A essência do trabalho dos autores, entretanto, prende-se no desenvolvimento de uma metodologia para análise, diagnóstico e propostas de melhorias de desempenho para a função manutenção em indústrias de processos contínuos. Tais melhorias irão constituir o planejamento estratégico para a função manutenção, neste tipo de indústria.

Já o trabalho de pesquisa de ANHESINE (1999) segue uma linha exploratória para investigar a realidade prática da gerência de manutenção na indústria nacional. Procura identificar quais as adequações, ou mesmo adaptações, que estão ocorrendo nas organizações industriais. Principalmente aquelas relacionadas com novos programas gerenciais de manutenção que possam ser introduzidos. Analisa também os riscos que os mesmos apresentam em face de rotina e cultura organizacional existentes. O foco de trabalho está centrado em uma metodologia, de enfoque sistêmico, que busca identificar as melhores práticas de gerenciamento para o setor de manutenção industrial. Através da metodologia, o autor procura analisar as 
necessidades de otimização para que novos métodos e procedimentos corporativos possam ser implementados.

O objeto de estudo da pesquisa é centrado nas atividades de gerenciamento, planejamento e controle da manutenção, verificando as interfaces com outras áreas tais como produção, qualidade e recursos humanos. Em síntese, trata-se de uma metodologia de enfoque holístico que propõe a solução de problemas de gestão de manutenção de modo padronizado. Para o autor, os subsistemas identificados como relevantes para a área de manutenção onde a situação problema é caracterizada são os seguintes:

- Gestão de recursos humanos;

- Estrutura organizacional da manutenção;

- Infra-estrutura, limpeza e organização;

- Sistema de gerenciamento da manutenção industrial;

- Políticas de intervenções de manutenção;

- Planejamento, programação e controle de serviços;

- Gestão de custos;

- Gestão de materiais;

- Gestão de contratação de serviços;

- Análise do estado físico da instalação;

- Cultura organizacional e novos modelos de gestão;

- Segurança industrial e meio ambiente;

- Indicadores de desempenho.

Enfim, a metodologia de diagnóstico, proposta por ANHESINE (1999), procura avaliar a forma como a organização lida com os subsistemas listados. Identifica os problemas existentes em cada um deles e nas implicações de uns com os outros, para propor soluções. Segundo o autor, a proposta da sistemática de diagnóstico tem como meta fornecer subsídios aos envolvidos, na situação problema, 
para que tomem decisões gradativas ou radicais, com o objetivo de resolver ou eliminar o problema identificado.

RODRIGUES (2000), por sua vez, conduz seus estudos no sentido de definir um modelo que permita a determinação da periodicidade da manutenção preventiva com base na tecnologia da confiabilidade. O modelo proposto é baseado nos conceitos mais atuais da MCC - Manutenção Centrada na Confiabilidade e tem como pressuposto básico uma visão integrada entre o planejamento da operação e o da manutenção. Conforme já discutido no Título 1.3.4 do Capítulo 1, o autor analisa a influência da periodicidade das atividades de preventiva nos custos globais de manutenção. É na verdade uma visão parcial do problema. A confiabilidade reflete a frequêencia das intervenções nos ativos e é apenas uma parte da disponibilidade e, por conseguinte, uma parcela também dos custos globais de manutenção. A manutenibilidade é outra variável que tem forte influência nos custos. Retrata a maior ou menor facilidade de executar as intervenções de prevenção (ou de reparo) e os custos decorrentes de tais facilidades. Assim, os custos de manutenção devem refletir os esforços do setor no sentido de propiciar uma disponibilidade tal que possa viabilizar o plano de produção.

A proposta de FURMANN (2002) é representada por um modelo para sistematizar a melhoria contínua do processo de manutenção com base na análise de desempenho de equipamentos. Nesta direção, o autor trabalha com indicadores de custos e de disponibilidade para equipamentos considerados críticos no processo produtivo. Leva em consideração o benchmark dos indicadores mencionados para definir metas de melhorias com vistas ao aprimoramento do processo de manutenção.

Já o trabalho de MENDES (2002) está direcionado para a gestão do valor das operações de manutenção para criar vantagem competitiva para os sistemas de manufatura. Para o autor, as operações de manutenção têm uma contribuição relevante no valor de transformação de um bem produzido. Assim, os gastos com manutenção devem ser transformados em vantagem competitiva mediante o gerenciamento do valor agregado dessas operações. Neste sentido propõe um modelo para a gestão do valor percebido no serviço de manutenção. 
Enfim, outros argumentos e sugestões dos autores mencionados assim como as de outros, também foram tratadas neste trabalho. Há um detalhamento abrangente no que diz respeito ao uso de indicadores para a gestão da função manutenção que pode ser visto no Título 2.3.8 do Capítulo 2.

O presente trabalho foi um pouco mais além das contribuições aqui mencionadas e discutidas nas Teorias de Base do Capítulo 2. A contribuição teórica do trabalho é um modelo que possibilita a gestão do custeio e das atividades de manutenção através de indicadores. O modelo explica como a função manutenção deve ser estruturada e gerida para efetivamente contribuir com o desempenho da organização como um todo. O modelo também identifica os fatores que interligam a utilização das políticas, da gestão dos custos e das atividades de manutenção.

Além disso, os indicadores desenvolvidos são capazes de efetuar um monitoramento seguro e objetivo das atividades. Os resultados apresentados demonstram as interligações existentes entre eles e ressaltam as possibilidades de uma gestão bastante eficaz das atividades e do custeio da manutenção.

\subsubsection{CONTRIBUIÇÃO EMPÍRICA}

A contribuição empírica deste trabalho está dirigida aos profissionais que atuam na área industrial e mais especificamente nas áreas de gestão de custos e atividades de manutenção industrial. O projeto fornece subsídios e técnicas que possibilitem o melhor aproveitamento dos recursos humanos e materiais na gestão das atividades corretivas e preventivas de manutenção. A acuracidade do custeio das atividades do departamento de manutenção industrial é também uma das contribuições relevantes do trabalho.

Em síntese, o mérito maior do tema do presente trabalho prende-se ao fato de que simplesmente estabelecer indicadores gerenciais não é suficiente para que os recursos do setor de manutenção de uma empresa sejam adequadamente gerenciados. É preciso considerá-los sob três aspectos que se interligam. O primeiro deve levar em conta a definição de indicadores que garantam um monitoramento correto da integração e flexibilidade do setor. O segundo aspecto deve admitir um sistema de indicadores inter-relacionáveis e de cunho sistêmico. Finalmente, o terceiro deve 
considerar um processo de gerenciamento de desempenho. Em outras palavras: acompanhamento sistemático e permanente dos procedimentos organizacionais e reavaliação constante dos dados fornecidos pelo sistema de medição para convertêlos em ações inteligentes.

\subsubsection{CONTRIBUIÇÃO IMEDIATA PARA A EMPRESA}

A empresa já possui um conjunto de indicadores que monitora as atividades e os custos de manutenção. De uma maneira bastante resumida, a lógica adotada para monitorar as atividades do setor é centrada em cima das horas paralisadas de produção, decorrentes das intervenções de natureza corretiva e preventiva.

Há um documento que organiza os indicadores de disponibilidade operacional das células, das mini-fábricas e dos setores. As decisões para a interferência gerencial são tomadas com base nas distorções detectadas por tais indicadores.

A gestão dos custos também é feita de forma simples e objetiva. A empresa apropria todos os recursos consumidos em um determinado período. Divide tal valor pelo número de horas apontadas decorrentes das intervenções de natureza corretiva e preventiva. Cria-se então um indicador que a empresa denomina de taxa de manutenção, que representa um custo por hora apontada de manutenção. Essa taxa de manutenção é global e reflete os gastos do setor de manutenção da fábrica por hora de intervenção nos equipamentos.

Nestas condições, o modelo de gestão considerado neste trabalho de pesquisa está sendo visto como uma contribuição importante no aprimoramento da gerência da função manutenção da fábrica. Entretanto alguns indicadores e valores encontrados a partir dos registros da própria organização chamaram a atenção dos gerentes para aspectos que ainda não tinham sido considerados pela organização.

Primeiramente o aspecto relacionado com o fato dos indicadores estarem grupados de acordo com objetivos de desempenho, dentro de um modelo gerencial específico, facilita o direcionamento da interferência gerencial.

Em segundo lugar, indicadores como o CPP - Custo da Paralisação da Produção fornece uma dimensão do lucro cessante da empresa em função das horas 
paralisadas decorrentes das intervenções de manutenção. O CHS - Custo da Hora de Serviço dos equipamentos fornece também uma visão do esforço do setor de manutenção para manter os equipamentos produzindo e gerando riquezas para a organização. Outro indicador importante que chamou a atenção da empresa foi o TPE - Taxa de Polivalência das Equipes. Este indicador apresenta uma visão precisa da capacitação dos funcionários para intervir nos equipamentos da célula. Além disso, vai direcionar o treinamento daqueles que apresentaram taxas menores. $\mathrm{O}$ CTMUP - Custo Total de Manutenção por Unidade Produzida e o CMUP - Custo de Manutenção por Unidade de Produto foram também muito bem recebidos pela gerência, pois tais indicadores revelam a participação do esforço do setor na produção de riquezas da empresa.

\subsection{CONCLUSÃO FINAL}

As funções manutenção e produção em uma organização industrial moderna estão inter-relacionadas. Não é possível e nem desejável considerar cada uma delas de forma isolada. Por esta razão, os indicadores propostos gerenciam os elementos de desempenho da função manutenção que produzem impactos na função produção da organização. Os indicadores também acrescentam vantagens competitivas para a empresa dentro do mercado.

Por outro lado, o custeio baseado em atividades proporciona vantagens qualitativas na análise apuradas das despesas dos serviços de manutenção. A primeira delas diz respeito ao direcionamento da atenção dos gerentes para aquelas atividades que mais impactam nos custos do setor. A segunda leva em conta a acuracidade das informações que possibilitam decisões estratégicas na empresa.

Nestas condições pode-se concluir que os objetivos gerais e específicos do trabalho, relatados no Título 1.2.1 do Capítulo 1 estão plenamente atendidos.

Em primeiro lugar os objetivos gerais, porque os elementos de desempenho considerados, no modelo, explicam como a função manutenção deve ser estruturada e gerida para contribuir efetivamente para o desempenho da organização como um todo. Tal estrutura e forma de gerenciamento acabam identificando os fatores que interligam a utilização das políticas de manutenção e a gestão dos custos de suas 
atividades. Assim, qualidade, confiabilidade, velocidade, flexibilidade e custos são os fatores que circunstanciam a gestão da função manutenção na empresa.

Em segundo lugar, porque o conjunto de indicadores apresentados atende ao objetivo específico do trabalho de pesquisa, relatado pela Figura 1-3. Os indicadores são interligados e capazes de gerenciar o custeio, as ocorrências de falhas dos ativos e as atividades de manutenção. Além disso, os indicadores desenvolvidos apresentam requisitos técnicos e culturais que os tornam eficientes para que os gerentes sejam providos de informações acuradas, relevantes e oportunas. Os indicadores não são ambíguos. São de fácil levantamento, compreensão e uso. Através deles o desempenho da função manutenção é facilmente avaliado. Eles ajudam a explicar como o sucesso da manutenção pode ser alcançado e mantido. A lógica do interrelacionamento dos indicadores através dos elementos de desempenho dá sustentação para a gestão do custeio e das atividades de manutenção. Neste sentido, os indicadores, além de interligados, estão também subsidiando uns aos outros. Além disso, as hipóteses formuladas do Título 1.2.2, do Capítulo 1 também são verificadas em sua plenitude. Os resultados apresentados demonstram que os indicadores desenvolvidos estão integrados entre si, dentro de um modelo específico para a função manutenção, possibilitando uma gestão eficaz de suas atividades e custeio.

\subsection{SUGESTÕES PARA TRABALHOS FUTUROS}

No sentido de contribuir de forma efetiva para o enriquecimento do tema discutido no presente trabalho, as seguintes sugestões para futuras pesquisas são apresentadas, nos parágrafos seguintes:

- A primeira sugestão para futuras pesquisas aponta para a direção de um modelo, com indicadores integrados, para a gestão do custeio e das atividades de manutenção empresas prestadoras de serviços tais como hospitais, hotéis, manutenção predial e empresas de entretenimento, como sistemas de rádio e de televisão. Desenvolver também indicadores que permitam quantificar o desempenho da função manutenção em sistemas organizacionais de resultados indiretos como universidades, organizações militares e defesa civil; 
- Analisar, discutir e propor novas formas de avaliação que permitam traçar o perfil da função manutenção de empresas industriais e prestadoras de serviços consideradas como de classe mundial;

- Comparar o estado de desempenho da função manutenção em empresas industriais com equipes de manutenção organizadas de forma centralizadas, descentralizadas e mistas. Estabelecer critérios que permitam direcionar a organização das equipes de manutenção nas formas mencionadas anteriormente;

- Analisar o impacto da tecnologia do TPM - Total Productive Maintenance na gestão dos custos e das atividades de manutenção;

- Desenvolver um conjunto de indicadores integrados com base no modelo gerencial de Sink \& Tuttle para a gestão do custeio e das atividades de manutenção para empresas industriais e prestadoras de serviço;

- Desenvolver estudos regionais para estabelecer padrões de desempenho para a função manutenção das empresas industriais. Efetuar estudos comparativos entre diferentes empresas da mesma região;

- Desenvolver estudos que permitam analisar e quantificar as influências do ritmo de trabalho e da fadiga no desempenho das atividades das equipes de manutenção em empresas industriais;

- Elaborar um modelo com indicadores integrados que possam sinalizar a criticidade dos ativos nos processos produção e permita o direcionamento das estratégias de manutenção para os diferentes ativos de uma organização industrial;

- Desenvolver estudos e pesquisa que permitam estabelecer as relações entre investimentos realizados no planejamento e controle de manutenção e os custos provenientes das falhas;

- Acredita-se que as sugestões apresentadas possam ser trabalhas e desdobradas de forma a contribuir para o aprofundamento do tema em discussão. 


\section{Referências}

AMATO, F. Estatal do Setor Bélico Vive sua Maior Crise. Folha de São Paulo. São Paulo: 11 de julho de 2005. Seção Dinheiro, p.B-6. Disponível em < http://www.defesa.ufjf.br/arq/FSP11072005.doc > Acesso em: 10/01/2006.

ANHESINE, M. W. Uma Abordagem Sistêmica para Diagnósticos em Manutenção Industrial. Escola de Engenharia de São Carlos, São Carlos, 1999, 204 p. (Tese de Doutorado).

ARIZA, C. F. Sistema de Administração para Manutenção Industrial. São Paulo: Editora McGraw Hill do Brasil Ltda., 1978.

BAZOVSKY, I. Reliability: Theory and Practice. New Jersey: Prentice Hall Inc., 1971.

BORNIA, A. C. Análise Gerencial de Custos: Aplicação em Empresas Modernas. Porto Alegre: Bookman, 2002.

BRUNSTEIN, I; MIORI, C. Avaliação da Normalidade da Estrutura de Custos Fixos da Empresa. Revista de Administração. São Paulo 23 (2): 21-28, abril/junho, 1988.

BUNGE, M. Epistemologia. Curso de Atualização. São Paulo: Editora EDUSP, 1980.

CAMPOS, V. F. Controle da Qualidade Total (No estilo Japonês). 2. ed. Rio de Janeiro: Bloch Editores S.A., 1992.

CERVO, A. L; BERVIAN, P. Metodologia Científica para Estudantes Universitários. São Paulo: Editora McGraw-Hill do Brasil, 1978.

CLIFTON, R. C, Principals of Planned Maintenance. Londres: Editora Edward Arnold Publishers ltd., 1974.

COKINS, G. Activity-Based Cost Management: Making it work. Chicago: Irwin Professional Publishing, 1996. 
CONTADOR, J. C. ET AL.Gestão de Operações:A Engenharia de Produção a Serviço da Modernização da Empresa. 2. ed. São Paulo: Edgard Blücher, 2004. COSTA NETO, P. L. Estatística. São Paulo: Editora Edgard Blücher, 1990.

DECARLI, M. S. ET AL. Sistema de Gerenciamento de Manutenção. $6^{o}$ Congresso Brasileiro de Manutenção. Trabalhos Técnicos, pp 172-186, ABRAMAN Associação Brasileira de Manutenção, Rio de Janeiro, 1991.

DEMING, W. E. Out of the crisis. Massachusetts: MIT Press, 1986.

DE ROCCHI, C. A. Sistema de Custeamento de Atividades (ABC Costing) versus Mapa de Localização de Custos: Um Estudo Comparativo.Revista do Conselho Regional de Contabilidade do Rio Grande do Sul. Porto Alegre: Conselho Regional de Contabilidade do Rio Grande do Sul, p. 9-23, v.23, n.77, abr./jun. 1994.

FURMANN, J. C. Desenvolvimento de um Modelo para a Melhoria do Processo de Manutenção Mediante a Análise de Desempenho de Equipamentos. Departamento de Engenharia de Produção da Universidade Federal de Santa Catarina, 2002, 147 p. (Dissertação de Mestrado)

GALLIMORE, K. F; PENLESKY, R. J. The Framework for Developing Maintenance Strategies. Production and Inventory Management Journal. Virginia, p. 16-21, 1988.

GOLD, B. Foundations of Strategic Planning for Productivity Improvement. Interfaces.Claremont Graduate School, Vol. 15, No. 3, pp. 15-30, May-june, 1985.

JOHNSON, H. T; KAPLAN, R. S. Relevance Lost: The Rise and Fall of Management Accounting. Boston: Harvard Business School Press, 1987.

JURAN, J. M; GRYNA, F. M. Controle da Qualidade: Conceitos, Políticas e Filosofia da Qualidade. São Paulo: Makron Books, 1991.

KAPLAN, R. S; NORTON, D. P. A Estratégia em Ação: Balanced Scorecard. Tradução Luiz Euclides Trindade Frazão Filho. Rio de Janeiro: Campus, 1997. 
KAPUR, K. C; LAMBERSON. L. R. Reliability in Engineering Design. New York: John Wiley \& Sons, 1977.

KAYDOS, W. Operational Performance Measurement: Increasing Total Productivity. New York: St Lucie Press, 1988.

KELLY, A; HARRIS, M. J. Administração da Manutenção Industrial. Rio de Janeiro: IBP, 1980.

KLETZ, T. A. O Que Houve de Errado? Casos de Desastres em Indústrias Químicas, Petroquímicas e Refinarias. São Paulo: Makron Books, 1993.

LAKATOS, E. M; MARCONI, M. A. Fundamentos da Metodologia Científica. 5. ed. São Paulo: Atlas, 2003.

Técnicas de Pesquisa. 5. ed. São Paulo: Atlas, 2002. Metodologia Científica. 3. ed. São Paulo: Atlas, 2000.

LAZZARINI, S. G. Estudos de Caso: Aplicabilidade e Limitaçoes do Método para Fins de Pesquisa. Revista Economia de Empresas. São Paulo, v.2, n.4, p.17-26, out./dez. 1995.

LORINO, P. Le Contrôle de Gestion Stratégique:La Gestion par les Activités. Paris, Dunod, 1991

MARTINA, S. Introdução à Manutenção Centrada na Confiabilidade. $1^{\circ}$ Seminário Brasileiro de Confiabilidade na Manutenção. ABRAMAN - Associação Brasileira de Manutenção. São Paulo: 1997.

MARTINS, E. Contabilidade e Custos.9. ed. São Paulo: Atlas, 2003.

MENDES, A. L. S. Gestão do Valor nas Operações de Manutenção. Departamento de Engenharia de Produção da Universidade Federal de Santa Catarina, 2002, 114 p. (Dissertação de Mestrado)

MIRSHAWKA, V; OLMEDO, N. L. Manutenção - Combate aos Custos da Não Eficácia: A Vez do Brasil. São Paulo: Makron Books, 1993. 
MONCHY, F. A Função Manutenção - Formação para a Gerência da Manutenção Industrial. São Paulo: Editora Durban, 1989.

MOUBRAY, J. Reliability Centred Maintenance. 2. ed. New York: Industrial Press Incorporation, 1997.

MUSCAT, A. R. N. Produtividade e Gestão da Produção. Apostila do NPGCT USP, São Paulo, 32 pg., 1987.

NAGAO, S. K. Manutenção industrial: Análise, Diagnóstico e Propostas de Melhorias de Performance em Indústrias de Processo. Departamento de Engenharia de Produção da Escola Politécnica da Universidade de São Paulo, São Paulo, 1998, 219 p. (Dissertação de Mestrado).

NAKAGAWA, M. ABC - Custeio Baseado em Atividades. São Paulo: Atlas, 1994.

NAKAGIMA, S. Introduction to TPM: Total Productive Maintenance. Portlando: Productivity Press, 1985.

NAKANO, D; FLEURY, A. Métodos de Pesquisa na Engenharia de Produção. Anais do XVI ENEGEPE, Piracicaba SP, 1996.

NEELY, A. The Performance Measurement Revolution: Why now and what next? International Journal of Operations \& Production Management. Vol. 19, No. 2, pp. 205-228, 1999.

NEPOMUCENO, L. X. Técnicas de Manutenção Preditiva. Volumes 1 e 2. São Paulo: Editora Edgard Blücher, 1989.

O’CONNOR, P. D. Practical Reliability Engineering. London: John Wiley \& Sons, 1989.

OHNO, T. O Sistema Toyota de Produção: Além da Produção em Larga Escala. Porto Alegre: Artes Médicas, 1997.

OSTREnGA, M. ET AL. Guia da Ernst \& Young para Gestão Total dos Custos. Radução de Nivaldo Montigelli Jr. Rio de Janeiro: Record, 1997. 
PAMPLONA, E. O. Contribuição para a análise crítica do sistema de custos ABC através da avaliação de direcionadores de custos. Faculdade de Administração de Empresas, Fundação Getúlio Vargas, São Paulo, 1997, 171p. (Tese de Doutorado).

A Obtenção de Direcionadores de Custos Adequados: O Ponto Crucial do Custeio Baseado em Atividades. $14^{\circ}$ Encontro Nacional de Engenharia de Produção. João Pessoa: 25 de outubro de 1994 (Publicado nos anais).

PINTO, A. K, XAVIER, J. A. N. Manutenção: Função Estratégica. Rio de Janeiro, Qualitymark Editora, 2001.

POPPER, K. A Lógica da Pesquisa Científica. 2. ed. São Paulo: Editora Cultrix, 1975.

PORTER, M. E. Vantagem Competitiva: Criando e Sustentando um Desempenho Superior. Rio de Janeiro: Editora Campus, 1992.

POZZI, F. A. Custo ABC em Pequenas e Médias Empresas. Departamento de Engenharia Industrial da Pontifícia Universidade Católica do Rio de Janeiro, 1995, 87 p. (Dissertação de Mestrado).

RIEGE, A. M. Validity and Reliability Tests in Case Study Research: literature review with "hands-on” applications for each research phase. Quality Market Research: An International Journal. Vol. 6, No. 2, pp. 75-86, 2003.

RODRIGUES, R. S. Manutenção Centrada na Confiabilidade - Aplicação do Método. Universidade Federal de Itajubá, Minas Gerais, 2000, 127 p. (Dissertação de Mestrado).

RODRIGUES, H. Indústria de Material Bélico do Brasil - IMBEL: Dois Séculos a Serviço da Soberania Nacional. Revista da ABEM - Associação Brasileira de Engenharia Militar. Rio de Janeiro: pp. 40-43, dez 2004. Disponível em < http://www.engmil.org.br >. Acesso em: 20/01/2006.

ROSA, E. B. Parâmetros de Desempenho: A Vantagem Competitiva das Empresas Estudo de Caso. Universidade Federal de Itajubá, Minas Gerais, 1996, 250 p. (Dissertação de Mestrado). 
ROSA, E. B. Desempenho de Sistemas Organizacionais - Uma Análise Sistematizada. X Simpósio de Engenharia de Produção. Bauru-SP: 10 a 12 de novembro de 2003.

ROSA, E. B. ET AL. Análise da Produtividade da Mão-de-Obra em uma Empresa Produtora de Bens de Consumo. X Simpósio de Engenharia de Produção. Bauru-SP: 10 a 12 de novembro de 2003.

RUMMLER, G. A; BRACHE, A. P. Melhores Desempenhos das Empresas: Ferramentas para a melhoria da Qualidade e da Competitividade. Trad. Katia Aparecida Roque. São Paulo: Makron Books, 1992.

SALERNO, M. S. Flexibilidade, organização e trabalho operatório: elementos para análise da produção na indústria. São Paulo. 1991. 232p. Tese (Doutorado)Departamento de Engenharia de Produção, Escola Politécnica. Universidade de São Paulo.

SALMON, W. C. Lógica. 4. ed. Rio de Janeiro: Editora Zahar, 1978.

SANTOS, I. E. Textos Selecionados de Métodos e Técnicas de Pesquisa Científica. 4. ed. Rio de Janeiro: Editora Impetus. 2003.

SILVEIRA, V. A IMBEL Exporta Armas Leves até para o FBI. Gazeta Mercantil. São Paulo: 20/04/2005. Disponível em < http://www.exercito.gov.br $>$. Acesso em: 19/01/2006.

SIMMMEI - Sindicato das Indústrias Metalúrgicas, Mecânicas e de Material Elétrico de Itajubá: MG, 2006. Disponível em: < http://www.simmmei.com.br >. Acesso em: 20/01/2006.

SINK, D. S, TUTTLE, T. C. Planejamento e medição para a performance. Trad. Elenice Mazzili e Lúcia Faria Silva. Rio de Janeiro: Qualitymark Editora, 1993.

SIQUEIRA, M. Indicadores de Desempenho: o Perfil Competitivo das Indústrias de Malhas do Pólo Industrial de Monte Sião. Universidade Federal de Itajubá, Minas Gerais, 1999, 216 p. (Dissertação de Mestrado). 
SLACK, N. Vantagem competitiva em manufatura: atingindo competitividade nas operações industriais. Trad. Sônia Maria Corrêa. São Paulo: Editora Atlas, 1993.

SLACK, N. ET AL. Administração da Produção. São Paulo: Editora Atlas, 1999.

SUMANTH, D. J. Productivity Engineering and Management. New York: MacGraw-Hill, 1984.

SUZAKI, K. The New Manufacturing Challenge: Techniques for Continuous Improvement. New York: Free Press, 1987.

VOSS, C; TSIRITSIS, N; FROHLICH, M. Case Research in Operations Management. International Journal of Operations \& Production Management. Vol. 22, No. 2, pp. 195-212, 2002.

XENOS, H. G. Gerenciando a Manutenção Produtiva. Belo Horizonte: Editora de Desenvolvimento Gerencial, 1998.

YIN, R. K. Case study research:design and methods. Sage, Newbury PARK, 166 p. 1994.

WESTWICK, C. A. How to use Manegement Ratios. Great Britain: Diddles Limited, 1989.

ZARIFIAN, P. La nouvelle productivité. Paris, L'Harmattan. 1990 
EURYCIBIADES BARRA ROSA

\section{INDICADORES DE DESEMPENHO E SISTEMA ABC O USO DE INDICADORES PARA UMA GESTÃO EFICAZ DO CUSTEIO E DAS ATIVIDADES DE MANUTENÇÃO.}

Tese apresentada à Escola Politécnica da Universidade de São Paulo para obtenção do título de Doutor em Engenharia

v.2 


\section{INDICADORES DE DESEMPENHO E SISTEMA ABC O USO DE INDICADORES PARA UMA GESTÃO EFICAZ DO CUSTEIO E DAS ATIVIDADES DE MANUTENÇÃO.}

Tese apresentada à Escola Politécnica da Universidade de São Paulo para obtenção do título de Doutor em Engenharia

Área de Concentração:

Engenharia de Produção

Orientador:

Prof. Dr. Israel Brunstein 
RETÍFICA DE PERFIL - COLETA DE DADOS PARA INDICADORES

Período de Observação: 01/06/2004 - 30/06/2004

Dias Úteis:

Horas Dia:

Horas Disponíveis do Período:

h/maq

\begin{tabular}{|c|c|c|c|c|c|c|c|c|c|c|c|}
\hline CÓDIGO & EQUIPAMENTO & HS & NF & HMC & NP & HMP R & HMP P & HP & NI & HPI & HCI \\
\hline & & & & & & & & & & & \\
\hline & & & & & & & & & & & \\
\hline & & & & & & & & & & & \\
\hline & & & & & & & & & & & \\
\hline & & & & & & & & & & & \\
\hline & & & & & & & & & & & \\
\hline & & & & & & & & & & & \\
\hline & & & & & & & & & & & \\
\hline & & & & & & & & & & & \\
\hline & & & & & & & & & & & \\
\hline & & & & & & & & & & & \\
\hline & & & & & & & & & & & \\
\hline & & & & & & & & & & & \\
\hline & & & & & & & & & & & \\
\hline & & & & & & & & & & & \\
\hline & & & & & & & & & & & \\
\hline & & & & & & & & & & & \\
\hline & & & & & & & & & & & \\
\hline & & & & & & & & & & & \\
\hline & & & & & & & & & & & \\
\hline & & & & & & & & & & & \\
\hline & TOTAIS & & & & & & & & & & \\
\hline
\end{tabular}

LEGENDA

$\begin{array}{ll}\text { HS } & \text { Horas em Serviço } \\ \text { NF } & \text { Número de Falhas } \\ \text { HMC } & \text { Horas de Manutenção Corretiva } \\ \text { NP } & \text { Número de Preventivas }\end{array}$


RETÍFICA DE PERFIL - HORAS PREVISTAS E REALISADAS (MNT PLANEJADA - PROGRAMADA)

(Período 01/06/2004 - 30/06/2005)

\begin{tabular}{|c|c|c|c|c|c|}
\hline CODIGO & OS MNT PREV & SERVIÇO EXECUTADO & DATA & H PREVISTAS & H REALISADAS \\
\hline & & & & & \\
\hline & & & & & \\
\hline & & & & & \\
\hline & & & & & \\
\hline & & & & & \\
\hline & & & & & \\
\hline & & & & & \\
\hline \multicolumn{6}{|l|}{ Subtotais } \\
\hline & & & & & \\
\hline & & & & & \\
\hline & & & & & \\
\hline & & & & & \\
\hline & & & & & \\
\hline & & & & & \\
\hline & & & & & \\
\hline & & & & & \\
\hline & & & & & \\
\hline \multicolumn{6}{|l|}{ Subtotais } \\
\hline & & & & & \\
\hline & & & & & \\
\hline & & & & & \\
\hline & & & & & \\
\hline & & & & & \\
\hline & & & & & \\
\hline & & & & & \\
\hline \multicolumn{6}{|l|}{ Subtotais } \\
\hline & & & & & \\
\hline Totais & & & & & \\
\hline
\end{tabular}

LEGENDA

$$
\begin{array}{ll}
\text { CÓDIGO } & \text { Código patrimonial do equipamento } \\
\text { OS MNT PREV } & \text { Ordem de Serviço de Manutenção Preventiva } \\
\text { H PREVISTAS } & \text { Horas de Manutenção Preventiva - Previstas } \\
\text { H REALIZADAS } & \text { Horas de Manutenção Preventiva - Realizadas }
\end{array}
$$


RETÍFICA DE PERFIL - HORAS DISPONÍVEIS

(Período de Observação: 01/06/2004 à 30/06/2005)

\begin{tabular}{|c|c|c|c|c|c|c|c|c|c|c|c|c|c|c|c|}
\hline CÓDIGO & EQUIPAMENTO & jun/04 & jul/04 & ago/04 & set/04 & out/04 & nov/04 & dez/04 & jan/05 & fev/05 & mar/05 & abr/05 & mai/05 & jun/05 & $2004 / 2005$ \\
\hline & & & & & & & & & & & & & & & \\
\hline & & & & & & & & & & & & & & & \\
\hline & & & & & & & & & & & & & & & \\
\hline & & & & & & & & & & & & & & & \\
\hline & & & & & & & & & & & & & & & \\
\hline & & & & & & & & & & & & & & & \\
\hline & & & & & & & & & & & & & & & \\
\hline & & & & & & & & & & & & & & & \\
\hline & & & & & & & & & & & & & & & \\
\hline & & & & & & & & & & & & & & & \\
\hline & & & & & & & & & & & & & & & \\
\hline & & & & & & & & & & & & & & & \\
\hline & & & & & & & & & & & & & & & \\
\hline & & & & & & & & & & & & & & & \\
\hline & & & & & & & & & & & & & & & \\
\hline & & & & & & & & & & & & & & & \\
\hline & & & & & & & & & & & & & & & \\
\hline & & & & & & & & & & & & & & & \\
\hline & & & & & & & & & & & & & & & \\
\hline & & & & & & & & & & & & & & & \\
\hline & & & & & & & & & & & & & & & \\
\hline & & & & & & & & & & & & & & & \\
\hline & & & & & & & & & & & & & & & \\
\hline & & & & & & & & & & & & & & & \\
\hline & & & & & & & & & & & & & & & \\
\hline & & & & & & & & & & & & & & & \\
\hline & & & & & & & & & & & & & & & \\
\hline & & & & & & & & & & & & & & & \\
\hline & & & & & & & & & & & & & & & \\
\hline & TOTAIS & & & & & & & & & & & & & & \\
\hline
\end{tabular}


RETÍFICA DE PERFIL - HORAS EM SERVIÇO

(Período de Observação: 01/06/2004 à 30/06/2005)

\begin{tabular}{|c|c|c|c|c|c|c|c|c|c|c|c|c|c|c|c|}
\hline CÓDIGO & EQUIPAMENTO & jun/04 & jul/04 & ago/04 & set/04 & out $/ 04$ & nov/04 & dez/04 & jan/05 & fev/05 & mar/05 & abr/05 & mai/05 & jun/05 & $2004 / 2005$ \\
\hline & & & & & & & & & & & & & & & \\
\hline & & & & & & & & & & & & & & & \\
\hline & & & & & & & & & & & & & & & \\
\hline & & & & & & & & & & & & & & & \\
\hline & & & & & & & & & & & & & & & \\
\hline & & & & & & & & & & & & & & & \\
\hline & & & & & & & & & & & & & & & \\
\hline & & & & & & & & & & & & & & & \\
\hline & & & & & & & & & & & & & & & \\
\hline & & & & & & & & & & & & & & & \\
\hline & & & & & & & & & & & & & & & \\
\hline & & & & & & & & & & & & & & & \\
\hline & & & & & & & & & & & & & & & \\
\hline & & & & & & & & & & & & & & & \\
\hline & & & & & & & & & & & & & & & \\
\hline & & & & & & & & & & & & & & & \\
\hline & & & & & & & & & & & & & & & \\
\hline & & & & & & & & & & & & & & & \\
\hline & & & & & & & & & & & & & & & \\
\hline & & & & & & & & & & & & & & & \\
\hline & & & & & & & & & & & & & & & \\
\hline & & & & & & & & & & & & & & & \\
\hline & & & & & & & & & & & & & & & \\
\hline & & & & & & & & & & & & & & & \\
\hline & & & & & & & & & & & & & & & \\
\hline & & & & & & & & & & & & & & & \\
\hline & TOTAIS & & & & & & & & & & & & & & \\
\hline
\end{tabular}


RETÍFICA DE PERFIL - HORAS DE MANUTENÇÃO CORRETIVA

(Período de Observação: 01/06/2004 à 30/06/2005)

\begin{tabular}{|c|c|c|c|c|c|c|c|c|c|c|c|c|c|c|c|}
\hline CÓDIGO & EQUIPAMENTO & jun/04 & jul/04 & ago/04 & set/04 & out/04 & nov/04 & dez/04 & jan/05 & fev/05 & mar/05 & abr/05 & mai/05 & jun/05 & $2004 / 2005$ \\
\hline & & & & & & & & & & & & & & & \\
\hline & & & & & & & & & & & & & & & \\
\hline & & & & & & & & & & & & & & & \\
\hline & & & & & & & & & & & & & & & \\
\hline & & & & & & & & & & & & & & & \\
\hline & & & & & & & & & & & & & & & \\
\hline & & & & & & & & & & & & & & & \\
\hline & & & & & & & & & & & & & & & \\
\hline & & & & & & & & & & & & & & & \\
\hline & & & & & & & & & & & & & & & \\
\hline & & & & & & & & & & & & & & & \\
\hline & & & & & & & & & & . & & & & & \\
\hline & & & & & & & & & & & & & & & \\
\hline & & & & & & & & & & & & & & & \\
\hline & & & & & & & & & & & & & & & \\
\hline & & & & & & & & & & & & & & & \\
\hline & & & & & & & & & & & & & & & \\
\hline & & & & & & & & & & & & & & & \\
\hline & & & & & & & & & & & & & & & \\
\hline & & & & & & & & & & & & & & & \\
\hline & & & & & & & & & & & & & & & \\
\hline & & & & & & & & & & & & & & & \\
\hline & & & & & & & & & & & & & & & \\
\hline & & & & & & & & & & & & & & & \\
\hline & & & & & & & & & & & & & & & \\
\hline & & & & & & & & & & & & & & & \\
\hline & TOTAIS & & & & & & & & & & & & & & \\
\hline
\end{tabular}


RETÍFICA DE PERFIL - HORAS DE MANUTENÇÃO PREVENTIVA - REALIZADAS

(Período de Observação: 01/06/2004 à 30/06/2005)

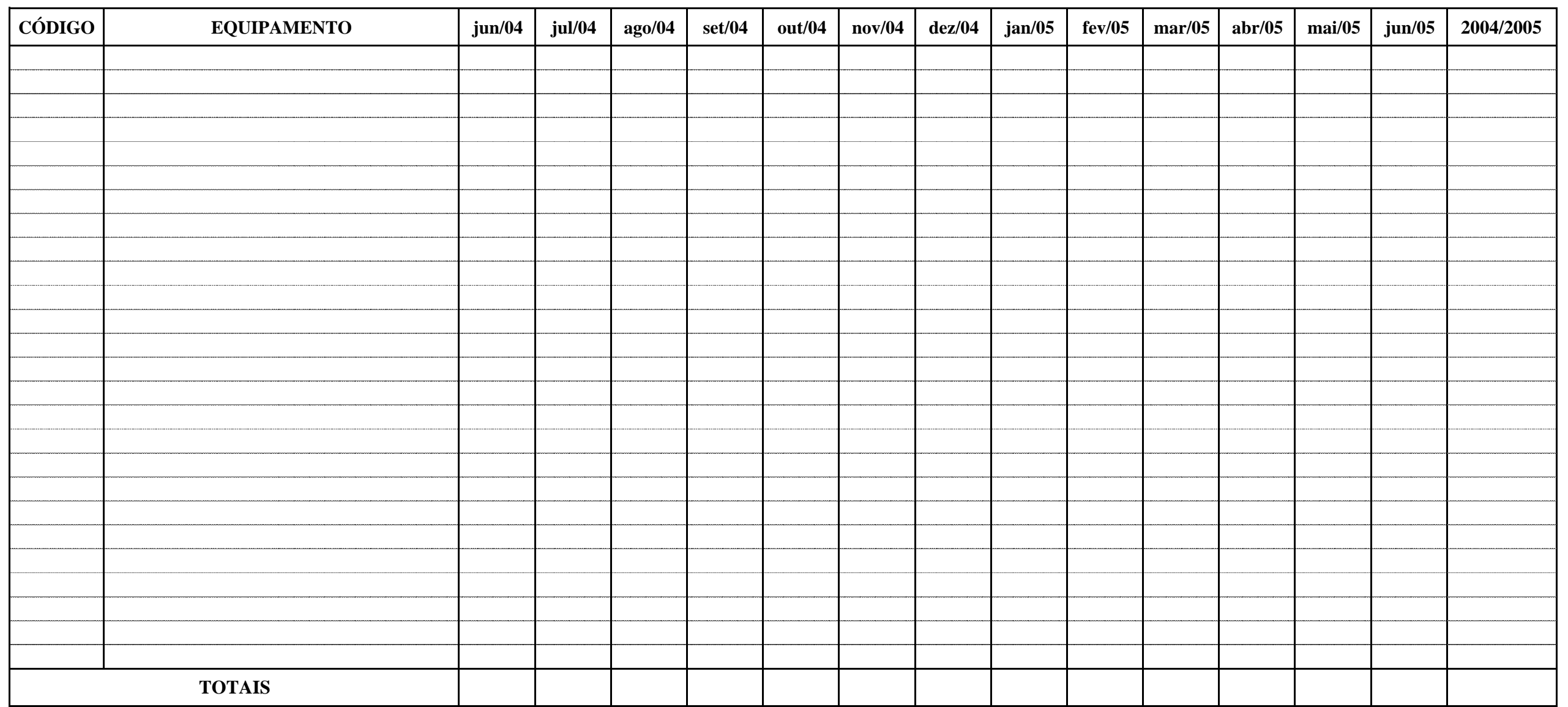


RETÍFICA DE PERFIL - HORAS DE MANUTENÇÃO PREVENTIVA - PREVISTAS

(Período de Observação: 01/06/2004 à 30/06/2005)

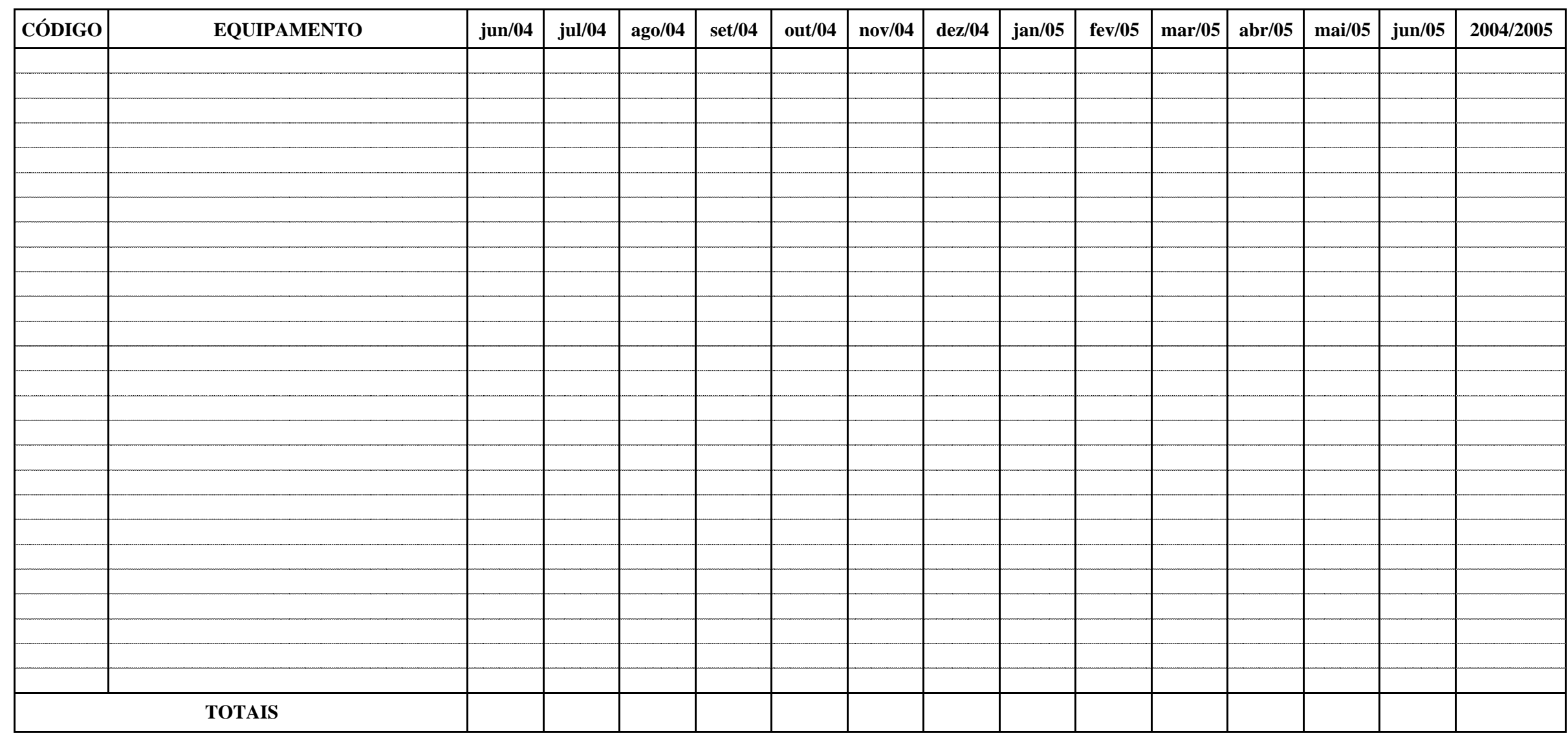


RETÍFICA DE PERFIL - HORAS PARALISADAS

(Período de Observação: 01/06/2004 à 30/06/2005)

\begin{tabular}{|c|c|c|c|c|c|c|c|c|c|c|c|c|c|c|c|}
\hline CÓDIGO & EQUIPAMENTO & jun/04 & jul/04 & ago/04 & set/04 & out/04 & nov/04 & dez/04 & jan/05 & fev/05 & mar/05 & abr/05 & mai/05 & jun/05 & $2004 / 2005$ \\
\hline & & & & & & & & & & & & & & & \\
\hline & & & & & & & & & & & & & & & \\
\hline & & & & & & & & & & & & & & & \\
\hline & & & & & & & & & & & & & & & \\
\hline & & & & & & & & & & & & & & & \\
\hline & & & & & & & & & & & & & & & \\
\hline & & & & & & & & & & & & & & & \\
\hline & & & & & & & & & & & & & & & \\
\hline & & & & & & & & & & & & & & & \\
\hline & & & & & & & & & & & & & & & \\
\hline & & & & & & & & & & & & & & & \\
\hline & & & & & & & & & & & & & & & \\
\hline & & & & & & & & & & & & & & & \\
\hline & & & & & & & & & & & & & & & \\
\hline & & & & & & & & & & & & & & & \\
\hline & & & & & & & & & & & & & & & \\
\hline & & & & & & & & & & & & & & & \\
\hline & & & & & & & & & & & & & & & \\
\hline & & & & & & & & & & & & & & & \\
\hline & & & & & & & & & & & & & & & \\
\hline & & & & & & & & & & & & & & & \\
\hline & & & & & & & & & & & & & & & \\
\hline & & & & & & & & & & & & & & & \\
\hline & & & & & & & & & & & & & & & \\
\hline & & & & & & & & & & & & & & & \\
\hline & & & & & & & & & & & & & & & \\
\hline & TOTAIS & & & & & & & & & & & & & & \\
\hline
\end{tabular}


RETÍFICA DE PERFIL - NÚMERO DE FALHAS

(Período de Observação: 01/06/2004 à 30/06/2005)

\begin{tabular}{|c|c|c|c|c|c|c|c|c|c|c|c|c|c|c|c|}
\hline CÓDIGO & EQUIPAMENTO & jun/04 & jul/04 & ago/04 & set/04 & out/04 & nov/04 & dez/04 & jan/05 & fev/05 & mar/05 & abr/05 & mai/05 & jun/05 & $2004 / 2005$ \\
\hline & & & & & & & & & & & & & & & \\
\hline & & & & & & & & & & & & & & & \\
\hline & & & & & & & & & & & & & & & \\
\hline & & & & & & & & & & & & & & & \\
\hline & & & & & & & & & & & & & & & \\
\hline & & & & & & & & & & & & & & & \\
\hline & & & & & & & & & & & & & & & \\
\hline & & & & & & & & & & & & & & & \\
\hline & & & & & & & & & & & & & & & \\
\hline & & & & & & & & & & & & & & & \\
\hline & & & & & & & & & & & & & & & \\
\hline & & & & & & & & & & & & & & & \\
\hline & & & & & & & & & & & & & & & \\
\hline & & & & & & & & & & & & & & & \\
\hline & & & & & & & & & & & & & & & \\
\hline & & & & & & & & & & & & & & & \\
\hline & & & & & & & & & & & & & & & \\
\hline & & & & & & & & & & & & & & & \\
\hline & & & & & & & & & & & & & & & \\
\hline & & & & & & & & & & & & & & & \\
\hline & & & & & & & & & & & & & & & \\
\hline & & & & & & & & & & & & & & & \\
\hline & & & & & & & & & & & & & & & \\
\hline & & & & & & & & & & & & & & & \\
\hline & & & & & & & & & & & & & & & \\
\hline & & & & & & & & & & & & & & & \\
\hline & TOTAIS & & & & & & & & & & & & & & \\
\hline
\end{tabular}


RETÍFICA DE PERFIL - NÚMERO DE PREVENTIVAS

(Período de Observação: 01/06/2004 à 30/06/2005)

\begin{tabular}{|c|c|c|c|c|c|c|c|c|c|c|c|c|c|c|c|}
\hline CÓDIGO & EQUIPAMENTO & jun/04 & jul/04 & ago/04 & set/04 & out/04 & nov/04 & dez/04 & jan/05 & fev/05 & mar/05 & abr/05 & mai/05 & jun/05 & $2004 / 2005$ \\
\hline & & & & & & & & & & & & & & & \\
\hline & & & & & & & & & & & & & & & \\
\hline & & & & & & & & & & & & & & & \\
\hline & & & & & & & & & & & & & & & \\
\hline & & & & & & & & & & & & & & & \\
\hline & & & & & & & & & & & & & & & \\
\hline & & & & & & & & & & & & & & & \\
\hline & & & & & & & & & & & & & & & \\
\hline & & & & & & & & & & & & & & & \\
\hline & & & & & & & & & & & & & & & \\
\hline & & & & & & & & & & & & & & & \\
\hline & & & & & & & & & & & & & & & \\
\hline & & & & & & & & & & & & & & & \\
\hline & & & & & & & & & & & & & & & \\
\hline & & & & & & & & & & & & & & & \\
\hline & & & & & & & & & & & & & & & \\
\hline & & & & & & & & & & & & & & & \\
\hline & & & & & & & & & & & & & & & \\
\hline & & & & & & & & & & & & & & & \\
\hline & & & & & & & & & & & & & & & \\
\hline & & & & & & & & & & & & & & & \\
\hline & & & & & & & & & & & & & & & \\
\hline & & & & & & & & & & & & & & & \\
\hline & & & & & & & & & & & & & & & \\
\hline & & & & & & & & & & & & & & & \\
\hline & & & & & & & & & & & & & & & \\
\hline & TOTAIS & & & & & & & & & & & & & & \\
\hline
\end{tabular}


RETÍFICA DE PERFIL - ÍNDICE DE RISCO DE EQUIPAMENTO - NÚMERO DE OCORRÊNCIAS

( Período: 01/06/04 a 30/06/04 )

\begin{tabular}{|c|c|c|c|c|c|c|c|c|c|}
\hline Código & OS Mnt Corretiva & Cod Parada & Modalidade & Falha & Causa & Ocorrência & Gravidade & Detectabilidade & OGD \\
\hline & & & & & & & & & \\
\hline & & & & & & & & & \\
\hline & & & & & & & & & \\
\hline & & & & & & & & & \\
\hline & & & & & & & & & \\
\hline & & & & & & & & & \\
\hline Subtotais & & & & & & & & IRF & \\
\hline & & & & & & & & & \\
\hline & & & & & & & & & \\
\hline & & & & & & & & & \\
\hline & & & & & & & & & \\
\hline & & & & & & & & & \\
\hline & & & & & & & & & \\
\hline & & & & & & & & & \\
\hline Subtotais & & & & & & & & IRF & \\
\hline & & & & & & & & & \\
\hline & & & & & & & & & \\
\hline & & & & & & & & & \\
\hline & & & & & & & & & \\
\hline & & & & & & & & & \\
\hline Subtotais & & & & & & & & IRF & \\
\hline & & & & & & & & & \\
\hline Totais & & & & & & & & & \\
\hline
\end{tabular}

LEGENDA

$\begin{array}{lll}\text { Código } & \text { Código patrimonial do equipamento } & \text { Ocono } \\ \text { OS Mnt Corretiva } & \text { Ordem de serviço de manutenção corretiva } & \text { Gr } \\ \text { Cod Parada } & \text { Código de parada de produção } & \text { De } \\ \text { Modalidade } & \text { Modalidade da falha (Mecânica, Elétrica ou Eletrônica) } & \text { OGD } \\ \text { Falha } & \text { Descrição da Falha } & \text { IR } \\ \text { Causa } & \text { Causa diagnosticada da falha } & \text { IRE }\end{array}$

Ocorrência

Gravidade

Detectabilidade

OGD

Falha

IRE
Número de vezes que a falha ocorreu no equipamento

Impacto que a falha causa no equipamento

Facilidade de detectar a falha antes que aconteça

Ocorrência x Gravidade x Detectabilidade

Índice de Risco da Falha no Equipamento

Índice de Risco de Equipamento 
RETÍFICA DE PERFIL - ÍNDICE DE RISCO DE EQUIPAMENTO

(Período de Observação: 01/06/2004 à 30/06/2005)

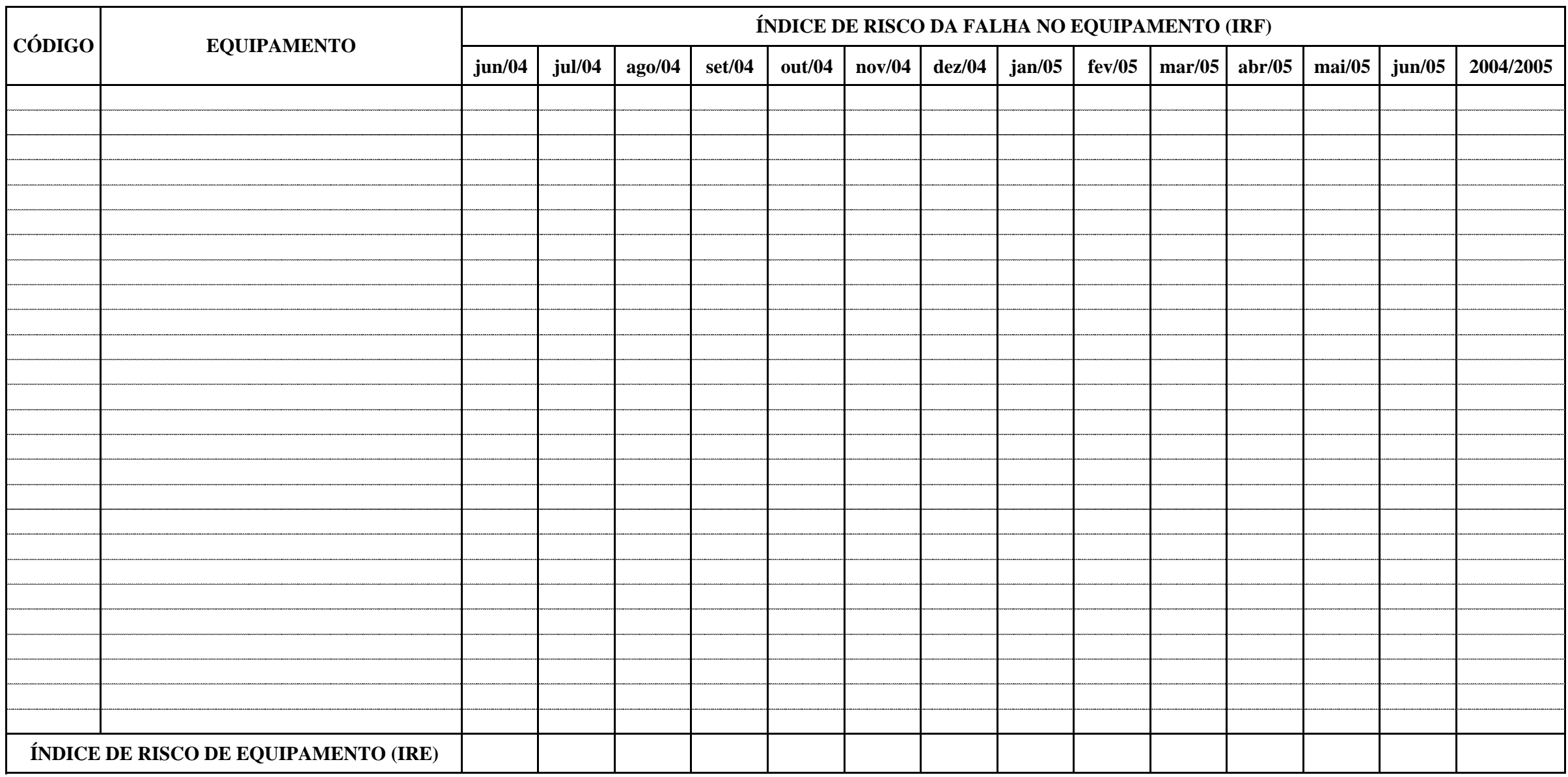


RETÍFICA DE PERFIL - DADOS PARA TAXA DE POLIVALÊNCIA

(Período de 01/06/2004 a 30/06/2005)

\begin{tabular}{|c|c|c|c|c|c|}
\hline Código & OS Mnt Corr & C Parada & OS Mnt Prev & Serviço Executado & Funcionários \\
\hline & & & & & \\
\hline & & & & & \\
\hline & & & & & \\
\hline & & & & & \\
\hline & & & & & \\
\hline & & & & & \\
\hline & & & & & \\
\hline & & & & & \\
\hline & & & & & \\
\hline Ocorrência & & & & & \\
\hline & & & & & \\
\hline & & & & & \\
\hline & & & & & \\
\hline & & & & & \\
\hline & & & & & \\
\hline & & & & & \\
\hline & & & & & \\
\hline & & & & & \\
\hline & & & & & \\
\hline & & & & & \\
\hline Ocorrência & & & & & \\
\hline & & & & & \\
\hline Totais & & & & & \\
\hline
\end{tabular}

LEGENDA

$\begin{array}{ll}\text { Código } & \text { Código patrimonial do equipamento } \\ \text { OS Mnt Corr } & \text { Ordem de Serviço de manutenção corretiva } \\ \text { C Parada } & \text { Código de parada de produção } \\ \text { OS Mnt Prev } & \text { Ordem de Serviço de manutenção preventiva } \\ \text { Serviço Executado } & \text { Descrição do serviço executado } \\ \text { Funcionário } & \text { Nome do funcionário que executou o serviço }\end{array}$


RETÍFICA DE PERFIL - DADOS PARA A TAXA DE POLIVALÊNCIA

(Período de 01/06/2004 a 30/06/2005)

\begin{tabular}{|c|c|c|c|c|}
\hline CÓDIGO & ORDEM SV MNT CORRETIVA & CÓDIGO PARADA & ORDEM SV MNT PREVENTIVA & FUNCIONÁRIOS \\
\hline & & & & \\
\hline & & & & \\
\hline & & & & \\
\hline & & & & \\
\hline & & & & \\
\hline & & & & \\
\hline & & & & \\
\hline & & & & \\
\hline & & & & \\
\hline & & & & \\
\hline & & & & \\
\hline & & & & \\
\hline & & & & \\
\hline & & & & \\
\hline & & & & \\
\hline & & & & \\
\hline & & & & \\
\hline & & & & \\
\hline & & & & \\
\hline & & & & \\
\hline & & & & \\
\hline & & & & \\
\hline & & & & \\
\hline & & & & \\
\hline TOTAIS & & & & \\
\hline
\end{tabular}


RETÍFICA DE PERFIL - TAXA DE POLIVALÊNCIA

(Período de Observação 01/06/2004 - 30/06/2005)

\begin{tabular}{|c|c|c|c|c|c|c|c|c|c|c|c|c|c|c|c|c|c|c|c|c|c|c|c|c|c|c|}
\hline \multirow[b]{2}{*}{ FUNCIONÁRIOS } & \multicolumn{24}{|c|}{ NÚMERO DE INTERVENÇÕES } & \multirow[b]{2}{*}{ 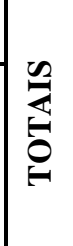 } & \multirow[b]{2}{*}{ TPE } \\
\hline & 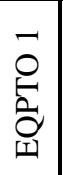 & 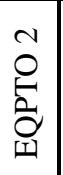 & 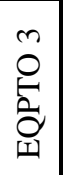 & 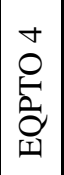 & $\begin{array}{l}10 \\
0 \\
0 \\
0 \\
0 \\
0 \\
01\end{array}$ & 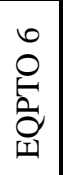 & 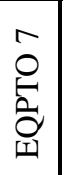 & 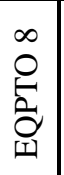 & 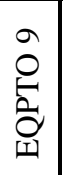 & 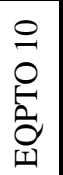 & 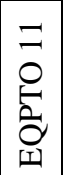 & 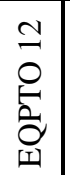 & 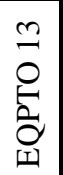 & 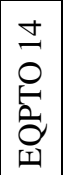 & $\begin{array}{l}10 \\
0 \\
0 \\
0 \\
0 \\
0 \\
0 \\
1\end{array}$ & $\begin{array}{c}0 \\
0 \\
0 \\
0 \\
0 \\
0 \\
01 \\
01\end{array}$ & 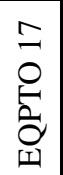 & 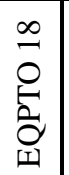 & 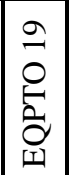 & 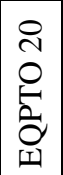 & 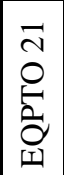 & 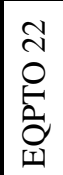 & 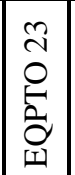 & 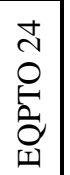 & & \\
\hline & & & & & & & & & & & & & & & & & & & & & & & & & & \\
\hline \multicolumn{27}{|l|}{ FUNCIONÁRIO 1} \\
\hline \multicolumn{27}{|l|}{ FUNCIONÁRIO 2} \\
\hline \multicolumn{27}{|l|}{ FUNCIONÁRIO 3} \\
\hline \multicolumn{27}{|l|}{ FUNCIONÁRIO 4} \\
\hline \multicolumn{27}{|l|}{ FUNCIONÁRIO 5} \\
\hline \multicolumn{27}{|l|}{ FUNCIONÁRIO 6} \\
\hline \multicolumn{27}{|l|}{ FUNCIONÁRIO 7} \\
\hline \multicolumn{27}{|l|}{ FUNCIONÁRIO 8} \\
\hline \multicolumn{27}{|l|}{ FUNCIONÁRIO 9} \\
\hline \multicolumn{27}{|l|}{ FUNCIONÁRIO 10} \\
\hline \multicolumn{27}{|l|}{ FUNCIONÁRIO 11} \\
\hline \multicolumn{27}{|l|}{ FUNCIONÁRIO 12} \\
\hline \multicolumn{27}{|l|}{ FUNCIONÁRIO 13} \\
\hline \multicolumn{27}{|l|}{ FUNCIONÁRIO 14} \\
\hline \multicolumn{27}{|l|}{ FUNCIONÁRIO 15} \\
\hline \multicolumn{27}{|l|}{ FUNCIONÁRIO 16} \\
\hline \multicolumn{27}{|l|}{ FUNCIONÁRIO 17} \\
\hline \multicolumn{27}{|l|}{ FUNCIONÁRIO 18} \\
\hline \multicolumn{27}{|l|}{ FUNCIONÁRIO 19} \\
\hline FUNCIONÁRIO 20 & & & & & & & & & & & & & & & & & & & & & & & & & & \\
\hline & & & & & & & & & & & & & & & & & & & & & & & & & & \\
\hline TOTAIS & & & & & & & & & & & & & & & & & & & & & & & & & & \\
\hline
\end{tabular}

LEGENDA: 
RETÍFICA DE PERFIL - TAXA DE REATIVIDADE DOS SERVIÇOS DE MANUTENÇÃo

(Número de Solicitações de Reparo Recebidas e Número de Ordens de Reparo Realizadas)

\begin{tabular}{|c|c|c|c|c|c|c|c|c|c|c|c|c|c|c|c|}
\hline CODIGO & EQUIPAMENTO & jun/04 & jul/04 & ago/04 & set/04 & out $/ 04$ & nov/04 & dez/04 & jan/05 & fev/05 & mar/05 & abr/05 & mai/05 & jun/05 & 2004-2005 \\
\hline & & & & & & & & & & & & & & & \\
\hline & & & & & & & & & & & & & & & \\
\hline & & & & & & & & & & & & & & & \\
\hline & & & & & & & & & & & & & & & \\
\hline & & & & & & & & & & & & & & & \\
\hline & & & & & & & & & & & & & & & \\
\hline & & & & & & & & & & & & & & & \\
\hline & & & & & & & & & & & & & & & \\
\hline & & & & & & & & & & & & & & & \\
\hline & & & & & & & & & & & & & & & \\
\hline & & & & & & & & & & & & & & & \\
\hline & & & & & & & & & & & & & & & \\
\hline & & & & & & & & & & & & & & & \\
\hline & & & & & & & & & & & & & & & \\
\hline & & & & & & & & & & & & & & & \\
\hline & & & & & & & & & & & & & & & \\
\hline & & & & & & & & & & & & & & & \\
\hline & & & & & & & & & & & & & & & \\
\hline & & & & & & & & & & & & & & & \\
\hline & & & & & & & & & & & & & & & \\
\hline & & & & & & & & & & & & & & & \\
\hline & & & & & & & & & & & & & & & \\
\hline & & & & & & & & & & & & & & & \\
\hline & & & & & & & & & & & & & & & \\
\hline & & & & & & & & & & & & & & & \\
\hline & & & & & & & & & & & & & & & \\
\hline & TOTAIS & & & & & & & & & & & & & & \\
\hline
\end{tabular}


MANUTENÇÃO GERAL

(Período de 01/06/2004 a 30/06/2005)

\begin{tabular}{|c|c|c|c|c|c|c|c|c|c|c|c|c|c|c|}
\hline \multirow{2}{*}{ RECURSOS CONSUMIDOS } & \multicolumn{14}{|c|}{ VALORES EM REAIS } \\
\hline & jun/04 & jul/04 & ago/04 & set/04 & out $/ 04$ & nov/04 & $\mathrm{dez} / 04$ & jan/05 & fev/05 & $\operatorname{mar} / 05$ & abr/05 & mai/05 & jun/05 & 2004-2005 \\
\hline & & & & & & & & & & & & & & \\
\hline & & & & & & & & & & & & & & \\
\hline & & & & & & & & & & & & & & \\
\hline & & & & & & & & & & & & & & \\
\hline & & & & & & & & & & & & & & \\
\hline & & & & & & & & & & & & & & \\
\hline & & & & & & & & & & & & & & \\
\hline & & & & & & & & & & & & & & \\
\hline & & & & & & & & & & & & & & \\
\hline & & & & & & & & & & & & & & \\
\hline & & & & & & & & & & & & & & \\
\hline & & & & & & & & & & & & & & \\
\hline & & & & & & & & & & & & & & \\
\hline & & & & & & & & & & & & & & \\
\hline & & & & & & & & & & & & & & \\
\hline & & & & & & & & & & & & & & \\
\hline TOTAIS & & & & & & & & & & & & & & \\
\hline
\end{tabular}


RETÍFICA DE PERFIL - APURAÇÃO DOS CUSTOS DE MANUTENÇÃO

\begin{tabular}{|c|c|c|c|c|c|c|c|c|c|c|c|c|c|c|c|}
\hline MÊS & H PER & HMC & HMP & HP & HAA & HP C & HP M & QNP C & QNP M & CHA & CAA & CMC & CMP & CPP & CTM \\
\hline jun/04 & & & & & & & & & & & & & & & \\
\hline jul/04 & & & & & & & & & & & & & & & \\
\hline ago/04 & & & & & & & & & & & & & & & \\
\hline set/04 & & & & & & & & & & & & & & & \\
\hline out/04 & & & & & & & & & & & & & & & \\
\hline nov/04 & & & & & & & & & & & & & & & \\
\hline dez/04 & & & & & & & & & & & & & & & \\
\hline jan/05 & & & & & & & & & & & & & & & \\
\hline fev/05 & & & & & & & & & & & & & & & \\
\hline mar/05 & & & & & & & & & & & & & & & \\
\hline$a b r / 05$ & & & & & & & & & & & & & & & \\
\hline mai/05 & & & & & & & & & & & & & & & \\
\hline jun/05 & & & & & & & & & & & & & & & \\
\hline & & & & & & & & & & & & & & & \\
\hline 2004-2005 & & & & & & & & & & & & & & & \\
\hline
\end{tabular}

\section{LEGENDA}

$\begin{array}{ll}\text { H PER } & \text { Horas do Período } \\ \text { HMC } & \text { Horas de Manutenção Corretiva } \\ \text { HMP } & \text { Horas de Manutenção Preventiva } \\ \text { HP } & \text { Horas Paralisadas } \\ \text { HS } & \text { Horas de Atividades de Apoio }\end{array}$

HP M Horas Paralisadas - Metalizados

QNP C Quantidade Não Produzida - Cromados

QNP M Quantidade Não Produzida - Metalizados

CHA
CAA Custo das Atividades de Apoio

CMC Custo da Manutenção Corretiva

CMP Custo da Manutenção Preventiva

CPP Custo da Paralisação da Produção

CTM Custo Total da Manutenção 
RETÍFICA DE PERFIL - DADOS DE PRODUÇÃO (Período de 01/06/2004 - 30/06/2004)

\begin{tabular}{|c|c|c|c|c|c|c|c|c|c|c|c|c|c|c|c|c|c|c|}
\hline \multirow{2}{*}{ MÊS } & \multirow{2}{*}{ H DISP } & \multirow{2}{*}{ HS } & \multicolumn{2}{|c|}{ CROMADOS } & \multicolumn{2}{|c|}{ METALIZADOS } & \multicolumn{2}{|c|}{ TOTAIS } & \multicolumn{2}{|c|}{ TPU } & \multicolumn{2}{|c|}{ \% PREV } & \multicolumn{2}{|c|}{$\%$ EXE } & \multicolumn{2}{|c|}{ HS } & \multicolumn{2}{|c|}{$\mathbf{L U}$} \\
\hline & & & PREV & EXE & PREV & EXE & PREV & EXE & CRO & MET & CRO & MET & CRO & MET & CRO & MET & CRO & MET \\
\hline & & & & & & & & & & & & & & & & & & \\
\hline jun-04 & & & & & & & & & & & & & & & & & & \\
\hline jul-04 & & & & & & & & & & & & & & & & & & \\
\hline ago-04 & & & & & & & & & & & & & & & & & & \\
\hline set-04 & & & & & & & & & & & & & & & & & & \\
\hline out-04 & & & & & & & & & & & & & & & & & & \\
\hline nov-04 & & & & & & & & & & & & & & & & & & \\
\hline dez-04 & & & & & & & & & & & & & & & & & & \\
\hline jan-05 & & & & & & & & & & & & & & & & & & \\
\hline fev-05 & & & & & & & & & & & & & & & & & & \\
\hline mar-05 & & & & & & & & & & & & & & & & & & \\
\hline abr-05 & & & & & & & & & & & & & & & & & & \\
\hline mai-05 & & & & & & & & & & & & & & & & & & \\
\hline jun-05 & & & & & & & & & & & & & & & & & & \\
\hline & & & & & & & & & & & & & & & & & & \\
\hline TOTAIS & & & & & & & & & & & & & & & & & & \\
\hline
\end{tabular}

LEGENDA

$\begin{array}{llllll}\text { H DISP } & \text { Horas Disponíveis } & \text { PREV } & \text { Previsto } & \text { TPU } & \text { Tempo de Planej da Unid de Produção } \\ \text { HS } & \text { Horas em Serviço } & \text { EXE } & \text { Executado } & \text { LU } & \text { Lucro Unitário }\end{array}$


RETÍFICA DE PERFIL - DADOS DE REFUGOS

(Período de 01/06/2004 - 30/06/2004)

\begin{tabular}{|c|l|l|l|}
\hline MÊS & ANÉIS CROMADOS & ANÉIS METALIZADOS & TOTAIS \\
\hline & & & \\
\hline jun-04 & & & \\
\hline jul-04 & & & \\
\hline ago-04 & & & \\
\hline set-04 & & & \\
\hline nut-04 & & & \\
\hline dez-04 04 & & & \\
\hline jan-05 & & & \\
\hline fev-05 & & & \\
\hline mar-05 & & & \\
\hline abr-05 & & & \\
\hline mai-05 & & & \\
\hline jun-05 & & & \\
\hline TOTAIS & & & \\
\hline
\end{tabular}


Aspectos Organizacionais da Manutenção

\begin{tabular}{|c|c|c|c|c|c|c|}
\hline \multirow{2}{*}{ Quesito 1} & \multicolumn{2}{|c|}{ MAHLE } & \multicolumn{2}{|c|}{ AREVA } & \multicolumn{2}{|c|}{ IMBEL } \\
\hline & Respostas & Pontos & Respostas & Pontos & Respostas & Pontos \\
\hline 1 & C & 2 & $\mathrm{~d}$ & 1 & $\mathrm{e}$ & 0 \\
\hline 2 & $\mathrm{a}$ & 4 & $\mathrm{~d}$ & 1 & $a$ & 4 \\
\hline 3 & $\mathrm{~d}$ & 1 & $\mathrm{a}$ & 4 & $\mathrm{~d}$ & 1 \\
\hline 4 & $\mathrm{a}$ & 4 & $\mathrm{e}$ & 0 & $\mathrm{e}$ & 0 \\
\hline 5 & $\mathrm{a}$ & 4 & C & 2 & C & 2 \\
\hline 6 & $\mathrm{a}$ & 4 & $\mathrm{~b}$ & 3 & $\mathrm{C}$ & 2 \\
\hline 7 & $\mathrm{a}$ & 4 & C & 2 & $\mathrm{a}$ & 4 \\
\hline 8 & $\mathrm{~b}$ & 3 & $\mathrm{~b}$ & 3 & $\mathrm{~b}$ & 3 \\
\hline 9 & $\mathrm{a}$ & 4 & $\mathrm{C}$ & 2 & $\mathrm{~d}$ & 1 \\
\hline 10 & $\mathrm{a}$ & 4 & $\mathrm{a}$ & 4 & $\mathrm{e}$ & 0 \\
\hline Subtotal & & 34 & & 22 & & 17 \\
\hline
\end{tabular}

Programas de Treinamento em Manutenção

\begin{tabular}{|c|c|c|c|c|c|c|}
\hline \multirow{2}{*}{ Quesito 2 } & \multicolumn{2}{|c|}{ MAHLE } & \multicolumn{2}{c|}{ AREVA } & \multicolumn{2}{c|}{ IMBEL } \\
\cline { 2 - 7 } & Respostas & Pontos & Respostas & Pontos & Respostas & Pontos \\
\hline 1 & b & 3 & b & 3 & e & 0 \\
\hline 2 & c & 2 & e & 0 & e & 0 \\
\hline 3 & a & 4 & e & 0 & a & 4 \\
\hline 4 & a & 4 & c & 2 & b & 3 \\
\hline 5 & a & 4 & c & 2 & d & 1 \\
\hline 6 & a & 4 & a & 4 & a & 4 \\
\hline 7 & d & 1 & a & 4 & c & 2 \\
\hline 8 & c & 2 & a & 4 & c & b \\
\hline 9 & b & 3 & c & 2 & & b \\
\hline 10 & c & 2 & b & 3 & & $\mathbf{1 9}$ \\
\hline Subtotal & & $\mathbf{2 9}$ & & $\mathbf{2 4}$ & & 3 \\
\hline
\end{tabular}


Ordens de Serviço da Manutenção

\begin{tabular}{|c|c|c|c|c|c|c|}
\hline \multirow{2}{*}{ Quesito 3} & \multicolumn{2}{|c|}{ MAHLE } & \multicolumn{2}{|c|}{ AREVA } & \multicolumn{2}{|c|}{ IMBEL } \\
\hline & Respostas & Pontos & Respostas & Pontos & Respostas & Pontos \\
\hline 1 & $\mathrm{a}$ & 4 & $a$ & 4 & $\mathrm{~b}$ & 3 \\
\hline 2 & C & 2 & $\mathrm{a}$ & 4 & $\mathrm{a}$ & 4 \\
\hline 3 & $\mathrm{a}$ & 4 & $\mathrm{~b}$ & 3 & $\mathrm{a}$ & 4 \\
\hline 4 & $\mathrm{a}$ & 4 & $\mathrm{~b}$ & 3 & $\mathrm{a}$ & 4 \\
\hline 5 & $\mathrm{a}$ & 4 & $\mathrm{a}$ & 4 & $\mathrm{a}$ & 4 \\
\hline 6 & $\mathrm{a}$ & 4 & $\mathrm{a}$ & 4 & $\mathrm{a}$ & 4 \\
\hline 7 & $\mathrm{~d}$ & 1 & $\mathrm{~b}$ & 3 & $\mathrm{e}$ & 0 \\
\hline 8 & $\mathrm{~b}$ & 3 & $\mathrm{~b}$ & 3 & $\mathrm{~b}$ & 3 \\
\hline 9 & $\mathrm{C}$ & 2 & $\mathrm{~b}$ & 3 & $\mathrm{e}$ & 0 \\
\hline 10 & $\mathrm{a}$ & 4 & C & 2 & $\mathrm{a}$ & 4 \\
\hline Subtotal & & 32 & & 33 & & 30 \\
\hline
\end{tabular}

Planejamento e Programação da Manutenção

\begin{tabular}{|c|c|c|c|c|c|c|}
\hline \multirow{2}{*}{ Quesito 4} & \multicolumn{2}{|c|}{ MAHLE } & \multicolumn{2}{|c|}{ AREVA } & \multicolumn{2}{|c|}{ IMBEL } \\
\hline & Respostas & Pontos & Respostas & Pontos & Respostas & Pontos \\
\hline 1 & $\mathrm{a}$ & 4 & $\mathrm{C}$ & 2 & $\mathrm{C}$ & 2 \\
\hline 2 & $\mathrm{a}$ & 4 & $\mathrm{~b}$ & 3 & $\mathrm{~d}$ & 1 \\
\hline 3 & $\mathrm{a}$ & 4 & $\mathrm{~b}$ & 3 & $\mathrm{a}$ & 4 \\
\hline 4 & $\mathrm{a}$ & 4 & $\mathrm{~b}$ & 3 & $\mathrm{a}$ & 4 \\
\hline 5 & $\mathrm{a}$ & 4 & $\mathrm{a}$ & 4 & $\mathrm{a}$ & 4 \\
\hline 6 & $\mathrm{~d}$ & 1 & $\mathrm{~b}$ & 3 & $\mathrm{e}$ & 0 \\
\hline 7 & $\mathrm{a}$ & 4 & $\mathrm{~b}$ & 3 & $\mathrm{~b}$ & 3 \\
\hline 8 & $\mathrm{a}$ & 4 & $\mathrm{a}$ & 4 & $\mathrm{a}$ & 4 \\
\hline 9 & $\mathrm{e}$ & 0 & $\mathrm{~b}$ & 3 & $\mathrm{e}$ & 0 \\
\hline 10 & $\mathrm{~b}$ & 3 & $\mathrm{a}$ & 4 & $\mathrm{a}$ & 4 \\
\hline Subtotal & & 32 & & 32 & & 26 \\
\hline
\end{tabular}


Manutenção Preventiva

\begin{tabular}{|c|c|c|c|c|c|c|}
\hline \multirow{2}{*}{ Quesito 5} & \multicolumn{2}{|c|}{ MAHLE } & \multicolumn{2}{|c|}{ AREVA } & \multicolumn{2}{|c|}{ IMBEL } \\
\hline & Respostas & Pontos & Respostas & Pontos & Respostas & Pontos \\
\hline 1 & $\mathrm{a}$ & 4 & $\mathrm{C}$ & 2 & $\mathrm{C}$ & 2 \\
\hline 2 & $\mathrm{~b}$ & 3 & $\mathrm{~b}$ & 3 & $\mathrm{a}$ & 4 \\
\hline 3 & $\mathrm{a}$ & 4 & C & 2 & C & 2 \\
\hline 4 & $\mathrm{e}$ & 0 & $\mathrm{C}$ & 2 & $\mathrm{e}$ & 0 \\
\hline 5 & $\mathrm{~b}$ & 3 & C & 2 & $a$ & 4 \\
\hline 6 & $\mathrm{C}$ & 2 & $\mathrm{~b}$ & 3 & $\mathrm{~d}$ & 1 \\
\hline 7 & $\mathrm{a}$ & 4 & C & 2 & $\mathrm{e}$ & 0 \\
\hline 8 & $\mathrm{~d}$ & 1 & $\mathrm{a}$ & 4 & $\mathrm{~b}$ & 3 \\
\hline 9 & $\mathrm{a}$ & 4 & $\mathrm{~d}$ & 1 & $\mathrm{e}$ & 0 \\
\hline 10 & $\mathrm{~b}$ & 3 & C & 2 & $\mathrm{~b}$ & 3 \\
\hline Subtotal & & 28 & & 23 & & 19 \\
\hline
\end{tabular}

Compras e Estoques de Manutenção

\begin{tabular}{|c|c|c|c|c|c|c|}
\hline \multirow{2}{*}{ Quesito 6} & \multicolumn{2}{|c|}{ MAHLE } & \multicolumn{2}{|c|}{ AREVA } & \multicolumn{2}{|c|}{ IMBEL } \\
\hline & Respostas & Pontos & Respostas & Pontos & Respostas & Pontos \\
\hline 1 & $a$ & 4 & $\mathrm{~d}$ & 1 & $\mathrm{e}$ & 0 \\
\hline 2 & $\mathrm{a}$ & 4 & $\mathrm{e}$ & 0 & $\mathrm{e}$ & 0 \\
\hline 3 & $\mathrm{C}$ & 2 & $\mathrm{~b}$ & 3 & $\mathrm{~b}$ & 3 \\
\hline 4 & $\mathrm{a}$ & 4 & $\mathrm{e}$ & 0 & $\mathrm{a}$ & 4 \\
\hline 5 & $\mathrm{a}$ & 4 & $\mathrm{e}$ & 0 & $\mathrm{e}$ & 0 \\
\hline 6 & $\mathrm{a}$ & 4 & $\bar{a}$ & 4 & $\bar{a}$ & 4 \\
\hline 7 & $\mathrm{a}$ & 4 & $\mathrm{e}$ & 0 & $\mathrm{a}$ & 4 \\
\hline 8 & $\mathrm{a}$ & 4 & $\mathrm{a}$ & 4 & $\mathrm{e}$ & 0 \\
\hline 9 & $a$ & 4 & $\mathrm{a}$ & 4 & $a$ & 4 \\
\hline 10 & $\mathrm{a}$ & 4 & $\mathrm{e}$ & 0 & $\mathrm{a}$ & 4 \\
\hline Subtotal & & 38 & & 16 & & 23 \\
\hline
\end{tabular}


Relatórios Gerenciais de Manutenção

\begin{tabular}{|c|c|c|c|c|c|c|}
\hline \multirow{2}{*}{ Quesito 7} & \multicolumn{2}{|c|}{ MAHLE } & \multicolumn{2}{|c|}{ AREVA } & \multicolumn{2}{|c|}{ IMBEL } \\
\hline & Respostas & Pontos & Respostas & Pontos & Respostas & Pontos \\
\hline 1 & $\mathrm{a}$ & 4 & $\mathrm{e}$ & 0 & $\mathrm{e}$ & 0 \\
\hline 2 & $\mathrm{a}$ & 4 & $\mathrm{e}$ & 0 & $\mathrm{e}$ & 0 \\
\hline 3 & C & 2 & $\mathrm{e}$ & 0 & $\mathrm{e}$ & 0 \\
\hline 4 & $\mathrm{a}$ & 4 & $\mathrm{~d}$ & 1 & $\mathrm{~d}$ & 1 \\
\hline 5 & $\mathrm{a}$ & 4 & $\mathrm{a}$ & 4 & C & 2 \\
\hline 6 & $\mathrm{C}$ & 2 & $\mathrm{~d}$ & 1 & $\mathrm{e}$ & 0 \\
\hline 7 & $\mathrm{~b}$ & 3 & $\mathrm{a}$ & 4 & $\mathrm{~d}$ & 1 \\
\hline 8 & $\mathrm{a}$ & 4 & $\mathrm{e}$ & 0 & $\mathrm{e}$ & 0 \\
\hline 9 & $\mathrm{C}$ & 2 & $\mathrm{e}$ & 0 & $\mathrm{e}$ & 0 \\
\hline 10 & $\mathrm{~b}$ & 3 & $\mathrm{~b}$ & 3 & $\mathrm{e}$ & 0 \\
\hline Subtotal & & 32 & & 13 & & 4 \\
\hline
\end{tabular}

Automação da Manutenção

\begin{tabular}{|c|c|c|c|c|c|c|}
\hline \multirow{2}{*}{ Quesito 8} & \multicolumn{2}{|c|}{ MAHLE } & \multicolumn{2}{|c|}{ AREVA } & \multicolumn{2}{|c|}{ IMBEL } \\
\hline & Respostas & Pontos & Respostas & Pontos & Respostas & Pontos \\
\hline 1 & $\mathrm{~b}$ & 3 & $\mathrm{e}$ & 0 & $\mathrm{a}$ & 4 \\
\hline 2 & $\mathrm{a}$ & 4 & $\mathrm{a}$ & 4 & $\mathrm{a}$ & 4 \\
\hline 3 & $\mathrm{a}$ & 4 & $\mathrm{e}$ & 0 & $\mathrm{a}$ & 4 \\
\hline 4 & $\mathrm{~b}$ & 3 & $\mathrm{~d}$ & 1 & $\mathrm{e}$ & 0 \\
\hline 5 & $\mathrm{a}$ & 4 & $\mathrm{e}$ & 0 & $\mathrm{e}$ & 0 \\
\hline 6 & e & 0 & $\mathrm{~d}$ & 1 & $\bar{e}$ & 0 \\
\hline 7 & $\mathrm{a}$ & 4 & $\mathrm{~d}$ & 1 & $\mathrm{a}$ & 4 \\
\hline 8 & $\mathrm{a}$ & 4 & $\mathrm{a}$ & 4 & $\mathrm{a}$ & 4 \\
\hline 9 & $a$ & 4 & $\mathrm{~b}$ & 3 & $\mathrm{~b}$ & 3 \\
\hline 10 & $\mathrm{~b}$ & 3 & $\mathrm{a}$ & 4 & $\mathrm{~d}$ & 1 \\
\hline Subtotal & & 33 & & 18 & & 24 \\
\hline
\end{tabular}


Pontuação Global

\begin{tabular}{|c|l|c|c|c|}
\hline Quesitos & \multicolumn{1}{|c|}{ Descrição } & MAHLE & AREVA & IMBEL \\
\hline 1 & Aspectos Organizacionais da Manutenção & 34 & 22 & 17 \\
\hline 2 & Programas de Treinamento em Manutenção & 29 & 24 & 19 \\
\hline 3 & Ordens de Serviço da Manutenção & 32 & 33 & 30 \\
\hline 4 & Planejamento e Programação da Manutenção & 32 & 32 & 26 \\
\hline 5 & Manutenção Preventiva & 28 & 23 & 19 \\
\hline 6 & Compras e Estoques de Manutenção & 38 & 16 & 23 \\
\hline 7 & Relatórios Gerenciais de Manutenção & 32 & 13 & 4 \\
\hline 8 & Automação da Manutenção & 33 & 18 & 24 \\
\hline & Totais & $\mathbf{2 5 8}$ & $\mathbf{1 8 1}$ & $\mathbf{1 6 2}$ \\
\hline
\end{tabular}




\section{RESPOSTAS DADAS PELAS EMPRESAS}

\section{M - MAHLE $\quad$ A - AREVA $\quad$ I - IMBEL FI}

\section{ASPECTOS ORGANIZACIONAIS DA MANUTENÇÃO}

1) O organograma de sua manutenção pode ser considerado:
a) Atualizado e completo; (M)
b) Atualizado, mas incompleto;
c) Completo, mas desatualizado;
d) Desatualizado e incompleto, porém existente; (A)
e) Não existe organograma. (I)

2) Cadernos de Encargos (job descriptions) estão disponíveis para:
a) Todas as posições de manutenção, incluindo os supervisores; (M) (I)
b) Todas as posições de manutenção, excluindo os supervisores;
c) Somente para os supervisores ou mais de $50 \%$ das posições;
d) Menos que $50 \%$ de todas as posições da manutenção; (A)
e) Não existem Cadernos de Encargos.

3) Relação supervisor/funcionários diretos da manutenção:
a) 1 para $8-12$; (A)
b) 1 para $13-16$;
c) 1 para menos de 8 ;
d) 1 para mais de 16; (M) (I)
e) Não existe supervisor.

4) Relação planejador de manutenção/funcionários diretos da manutenção:
a) 1 para $15-20$; $\mathbf{M})$
b) 1 para $10-14$;
c) 1 para 21-25;
d) 1 para 26-30;
e) Não existe planejador de manutenção ou qualquer relação diferente das citadas. (A) (I)

5) Mandato da gerência de manutenção:
a) Responsabilidades plenamente documentadas - completa autonomia; (M)
b) Responsabilidades claras - boa autonomia;
c) Supervisão e coordenação informais - autonomia restrita; (A) (I)
d) A manutenção reporta à produção/operação;
e) Linhas de autoridade e jurisdição indefinidas.

6) Esforços e atitudes do grupo de manutenção:

a) Excelente, orgulhosos de seu profissionalismo em todos os níveis, grupo motivado; (M) 
b) Executam seu trabalho de forma profissional, constante e sem comprometimento; (A)

c) Trabalham na média de aceitação mas com reclamações esporádicas; (I)

d) Freqüentes atrasos de serviços com muitas reclamações - raramente se esforçam;

e) Constantes atritos dentro do próprio grupo de manutenção e com outras áreas de operação.

7) Localização das áreas de escritórios/oficinas de manutenção:
a) Perfeita; (M) (I)
b) Boa (possível pequena melhoria);
c) Razoável (possível grande melhoria); (A)
d) Sofrível (necessária grande melhoria);
e) Inadequado ou inexistente.

8) Layouts dos escritórios/oficinas de manutenção:
a) Perfeito;
b) Bom (possível pequena melhoria); (M) (A) (I)
c) Razoável (possível grande melhoria);
d) Sofrível (necessária grande melhoria);
e) Inadequado ou inexistente.

9) Qualidade e quantidade das ferramentas e equipamentos de manutenção:
a) Perfeita; (M)
b) Boa (possível pequena melhoria);
c) Razoável (possível grande melhoria); (A)
d) Sofrível (necessária grande melhoria); (I)
e) Inadequada ou inexistente.

10) Qual a porcentagem do pessoal de manutenção que recebe bônus baseado no desempenho do grupo/empresa?
a) $100 \%$; (M) (A)
b) Acima de $90 \%$;
c) Entre $75 \%$ e $90 \%$;
d) Entre $50 \%$ e $75 \%$;
e) Menos que $50 \%$. (I)

\section{PROGRAMAS DE TREINAMENTO EM MANUTENÇÃO}

1) Treinamento para supervisores:
a) Todos são treinados de acordo com plano regular e, obrigatoriamente, se treinamento adicional for necessário;
b) Todos são treinados. Treinamento adicional é oferecido de forma opcional; (M) (A)
c) A maioria é treinada. Treinamento regular;
d) A maioria é treinada. Treinamento não regular;
e) Poucos são treinados ou o treinamento é inexistente. (I) 
2) Treinamento para planejadores:

a) Todos os planejadores/programadores atendem a um ou mais seminários externos referentes a sua especialidade;

b) Todos os planejadores/programadores dispõem de material escrito para treinamento sobre suas atividades;

c) Todos os planejadores/programadores recebem treinamento individual, assistidos no local de trabalho durante um mês, no mínimo; (M)

d) Planejadores/programadores aprendem trabalhando, parcialmente assistidos;

e) Não há programa de treinamento; (A) (I)

3) Quais dos quatro assuntos abaixo estão incluídos no conteúdo do treinamento dado aos planejadores de manutenção de sua empresa?

1 - Planejamento de materiais;

2 - Práticas de programação;

3 - Planejamento e execução - ordens de serviço;

4 - Planejamento de projetos.

a) Inclui todos os quatro assuntos acima; (M)

b) Inclui três dos assuntos acima;

c) Inclui dois dos assuntos acima;

d) Inclui um dos assuntos acima;

e) Não existe treinamento para planejadores. (A) (I)

4) Treinamento sobre produtividade e qualidade inclui:

a) Todos. Gerência, supervisores, horistas e pessoal de suporte; (M) (I)

b) Todos, menos pessoal de suporte;

c) Somente gerentes e supervisores; (A)

d) Somente gerência;

e) Não há programas nesta área ou existe somente para horistas.

5) Treinamento para especialistas em manutenção:

a) Está associado a incrementos salariais, conforme avanço no programa existente; (M)

b) Experiência anterior é necessária antes da contratação. É dado treinamento no trabalho; (I)

c) Basta experiência anterior antes de contratar. Já inicia produzindo; (A)

d) Treina no local após ter sido contratado. Não requer experiência;

e) Não existe treinamento formal nem pré-requisitos na contratação.

6) Intervalos de treinamento na manutenção. Treinamento formal é ministrado a todos especialistas com a seguinte freqüência:

a) Menos que 12 meses; (M) (A)

b) Entre 12 e 18 meses;

c) Entre 18 e 24 meses;

d) Treinamento apenas para alguns especialistas. Qualquer freqüência acima; (I)

e) Não há treinamento. 
7) Composição do treinamento de manutenção:
a) Treinamento é todo mesclado com teoria e prática reais; (A) (I)
b) Treinamento é todo teórico (sala de aula);
c) Treinamento é todo prático (em laboratório);
d) Todo treinamento é feito no serviço real; (M)
e) Não há programa de treinamento;

8) Instrutores do programa de treinamento:
a) Conduzido por especialistas externos; (A)
b) Conduzido pelo especialista do staff;
c) Conduzido pelos supervisores; (M) (I)
d) Conduzido pelos horistas;
e) Não existe programa de treinamento.

9) A qualidade, nível de conhecimento/habilidade do grupo de especialistas da manutenção é:
a) Perfeito;
b) Bom (possível pequena melhoria); (M)
c) Razoável (possível grande melhoria); (A) (I)
d) Sofrível (necessária grande melhoria);
e) Inaceitável.

10) A qualidade, nível de conhecimento/habilidade do grupo de supervisores é:
a) Perfeito;
b) Bom (possível pequena melhoria); (A) (I)
c) Razoável (possível grande melhoria); (M)
d) Sofrível (necessária grande melhoria);
e) Inaceitável.

\section{ORDENS DE SERVIÇO DA MANUTENÇÃO}

1) Que porcentagem aproximada dos homens.hora de manutenção é alocada em ordens de serviço?
a) $100 \%$; (M) (A)
b) $75 \%$; (I)
c) $50 \%$;
d) $25 \%$;
e) Menos que $25 \%$.

2) Que porcentagem aproximada de materiais de manutenção é alocada em ordens de serviço?
a) $100 \%$; (A) (I)
b) $75 \%$;
c) $50 \% ;(\mathbf{M})$ 
d) $25 \%$;

e) Menos que $25 \%$.

3) Que porcentagem dos serviços de manutenção é coberta por ordens de serviço?
a) $100 \%$; (M) (I)
b) $75 \%$; (A)
c) $50 \%$;
d) $25 \%$;
e) Menos que $25 \%$.

4) Que porcentagem de ordens de serviço, incompletas ou de backlog é mantida arquivada por número/código do equipamento?
a) $100 \%$; (M) (I)
b) $75 \%$; (A)
c) $50 \%$;
d) $25 \%$;
e) Menos que $25 \%$.

5) Que porcentagem de ordens de serviço é arquivada por número/código do equipamento depois de concluídas as intervenções?
a) $100 \%$; (M) (A) (I)
b) $75 \%$;
c) $50 \%$;
d) $25 \%$;
e) Menos que $25 \%$.

6) Que porcentagem das ordens de serviço está disponível para análise dos dados históricos dos equipamentos?
a) $100 \%$; (M) (A) (I)
b) $75 \%$;
c) $50 \%$;
d) $25 \%$;
e) Menos que $25 \%$.

7) Que porcentagem das ordens de serviço é conferida pelo supervisor nos aspectos de qualidade e efetiva a conclusão do serviço?
a) $100 \%$;
b) $75 \%$; (A)
c) $50 \%$;
d) $25 \%$; (M)
e) Menos que $25 \%$. (I)

8) Que porcentagem das ordens de serviço é encerrada dentro de oito semanas a contar da requisição dos serviços?
a) $100 \%$; 

b) 75\%; (M) (A) (I)
c) $50 \%$;
d) $25 \%$;
e) Menos que $25 \%$.

9) Que porcentagem das ordens de serviço é gerada por serviços de manutenção preventiva?
a) Entre $80 \%$ e $100 \%$;
b) Entre $60 \%$ e $80 \%$; (A)
c) Entre $40 \%$ e $60 \%$; (M)
d) Entre 20\% e 40\%;
e) Menos que $20 \%$. (I)

10) Considere as quatro informações abaixo e assinale quais as que estão contidas na ordem de serviço de sua manutenção?

1 - Tempo de desligamento;

2 - Homens.hora de especialistas necessários;

3 - Materiais necessários;

4 - Nome do requisitante/local.

a) A ordem de serviço contém as quatro informações acima; (M) (I)

b) Contém três das informações acima;

c) Contém duas das informações acima; (A)

d) Contém uma das informações acima;

e) Não registra essas informações.

\section{PLANEJAMENTO E PROGRAMAÇÃO DA MANUTENÇÃO}

1) Que porcentagem de ordens de serviço, não em emergência, é executada dentro de quatro semanas a contar da solicitação dos serviços?
a) Acima de 90\%; (M)
b) Entre $75 \%$ e $90 \%$;
c) Entre 60\% e 75\%; (A) (I)
d) Entre $40 \%$ e $60 \%$;
e) Menos que $40 \%$.

2) Considere o planejamento de uma ordem de serviço de sua manutenção e identifique quantos dos pontos abaixo ela inclui:

1 - Especialistas necessários;

2 - Materiais a serem utilizados;

3 - Ferramentas/equipamentos necessários;

4 - Instruções específicas/plano de trabalho.

a) Inclui todos os quatros itens acima mencionados; (M)

b) Inclui três dos itens acima mencionados; (A) 
c) Inclui dois dos itens acima mencionados;

d) Inclui um dos itens acima mencionados; (I)

e) Não há planejamento.

3) Qual a porcentagem de ordens de serviço planejadas que sofreram atrasos devido à deficiências no planejamento?

a) Menos que 10\%; (M) (I)

b) Entre $10 \%$ e $20 \%$; (A)

c) Entre $20 \%$ e $40 \%$;

d) Entre $40 \%$ e $50 \%$;

e) Mais que $50 \%$.

4) Quem é o responsável pelo planejamento das ordens de serviço?
a) Um planejador de manutenção 100\% dedicado a este trabalho; (M) (I)
b) Um supervisor de manutenção; (A)
c) O gerente de manutenção;
d) Cada especialista de manutenção;
e) Não há planejamento.

5) A programação dos trabalhos é emitida com a freqüência:
a) Semanal; (M) (A) (I)
b) Cada duas semanas;
c) Entre 3 e 7 dias
d) Diariamente;
e) Qualquer outra freqüência.

6) Reuniões de manutenção com o pessoal de produção são realizadas:
a) Semanalmente
b) Cada duas semanas; (A)
c) Entre 3 e 7 dias
d) Diariamente; (M)
e) Qualquer outra freqüência. (I)

7) O backlog de serviços de manutenção é possível de ser listado pelas categorias abaixo? Por quantas categorias é possível listar na sua empresa?

1 - Por especialista;

2 - Por área/departamento;

3 - Por requisitante;

4 - Por data a executar.

a) Disponível nas quatro categorias; (M)

b) Disponível em três categorias; (A) (I)

c) Disponível em duas categorias;

d) Disponível em uma categoria; 
e) Não controla backlog.

8) Quando o trabalho de manutenção é concluído, o tempo real gasto, o material, o tempo de desligamento e outras informações são anotados pelo:
a) Especialista que fez o serviço; (M) (A) (I)
b) Supervisor do grupo;
c) Qualquer um do grupo de trabalho;
d) Planejador
e) Informações não registradas.

9) Qual a porcentagem de acerto do planejamento comparando tempos reais com estimados?
a) Acima de $90 \%$;
b) Entre $75 \%$ e $90 \%$; (A)
c) Entre $60 \%$ e $75 \%$;
d) Entre 40 e 60\%;
e) Menos que $40 \%$. (M) (I)

10) Qual a relação de chefia entre os planejadores e supervisores de manutenção?
a) Ambos se reportam ao mesmo gerente de manutenção; (A) (I)
b) O planejador reporta ao supervisor; (M)
c) O supervisor reporta ao planejador;
d) O supervisor reporta à manutenção, o planejador à produção;
e) Ambos se reportam à produção.

\section{MANUTENÇÃO PREVENTIVA}

1) Um programa de manutenção preventiva inclui pontos, como:

1 - Checklist detalhado para equipamentos importantes;

2 - Lista de lubrificação dos equipamentos;

3 - Pessoal dedicado $100 \%$ a programas de manutenção preventiva;

4 - Programas dedicados de manutenção preventiva; análise de vibrações; análise de óleo; termovisão etc.

a) Todos os quatro itens acima estão no programa de manutenção preventiva; (M)

b) A manutenção preventiva inclui três dos itens acima;

c) A manutenção preventiva inclui dois dos itens acima; (A) (I)

d) A manutenção preventiva inclui um dos itens acima;

e) Não há programa de manutenção preventiva;

2) Que porcentagem das tarefas de programa de manutenção preventiva é efetivamente realizada?
a) Acima de $90 \%$; (I)
b) Entre $75 \%$ e $90 \%$; (M) (A)
c) Entre $60 \%$ e $75 \%$;
d) Entre $40 \%$ e $60 \%$; 
e) Menos que $40 \%$.

3) Que porcentagem dos equipamentos críticos da planta está coberta pelo programa de manutenção preventiva;
a) Acima de 90\%; (M)
b) Entre $75 \%$ e $90 \%$;
c) Entre $60 \%$ e $75 \%$;(A) (I)
d) Entre $40 \%$ e $60 \%$;
e) Menos que $40 \%$.

4) Que porcentagem dos programas de manutenção preventiva é avaliada anualmente contra dados históricos reais conseguidos para assegurar sua eficácia?
a) Acima de $90 \%$;
b) Entre $75 \%$ e $90 \%$;
c) Entre 60\% e 75\%; (A)
d) Entre $40 \%$ e $60 \%$;
e) Menos que $40 \%$. (M) (I)

5) Que porcentagem das manutenções preventivas é concluída dentro de até uma semana da data para a qual foi programada?
a) Acima de $90 \%$; (I)
b) Entre $75 \%$ e $90 \%$; (M)
c) Entre 60\% e 75\%; (A)
d) Entre $40 \%$ e $60 \%$;
e) Menos que $40 \%$.

6) O que determina a freqüência de inspeção de manutenção preventiva ou intervalos de serviços?
a) Programa baseado na condição do equipamento;
b) Programa baseado numa combinação de tempo de funcionamento do equipamento e intervalos de calendários pré-fixados; (A)
c) Programa baseado somente no tempo de funcionamento do equipamento; (M)
d) Programa baseado somente em intervalos de calendário; (I)
e) Programa dinâmico, baseado na última inspeção/serviço executado.

7) Que porcentagem das inspeções/tarefas de manutenção possui mais que cinco linhas escritas de detalhes ou instruções?
a) Acima de $90 \%$; (M)
b) Entre $75 \%$ e $90 \%$;
c) Entre 60\% e 75\%; (A)
d) Entre $40 \%$ e $60 \%$;
e) Menos que $40 \%$. (I)

8) O tempo médio para concluir uma inspeção completa de manutenção preventiva em um equipamento importante é:
a) 4 horas; (A) 
b) 4 a 8 horas; (I)

c) 2 a 4 horas;

d) Menos que 2 horas; (M)

e) Qualquer outro tempo.

9) Que porcentagem do programa de manutenção preventiva é checada anualmente, comparando resultados reais com as estimativas de tempo e material?
a) Acima de 90\%; (M)
b) Entre $75 \%$ e $90 \%$;
c) Entre 60\% e 75\%;
d) Entre 40\% e 60\%;(A)
e) Menos que $40 \%$. (I)

10) Quem é responsável pela execução das tarefas de manutenção preventiva?
a) Pessoal dedicado $100 \%$ a manutenção preventiva;
b) Pessoas específicas em cada grupo de trabalho; (M) (I)
c) Qualquer pessoa do grupo de manutenção; (A)
d) Os especialistas mais novos;
e) Pessoal de operação.

\section{COMPRAS E ESTOQUES DE MANUTENÇÃO}

1) Que porcentagem de vezes que o material requisitado é encontrado no estoque da manutenção?
a) Acima de 95\%;(M)
b) Entre $80 \%$ e $95 \%$;
c) Entre $70 \%$ e $80 \%$;
d) Entre 50\% e 70\%; (A)
e) Menos que $50 \%$. (I)

2) Que porcentagem dos itens em estoque dispõe de uma lista atualizada na manutenção?
a) Acima de 90\%; (M)
b) Entre $75 \%$ e $90 \%$;
c) Entre $60 \%$ e $75 \%$;
d) Entre $40 \%$ e $60 \%$;
e) Menos que $40 \%$. (A) (I)

3) Quem controla o que é estocado como estoque da manutenção?
a) A gerência de manutenção ouvindo seus subordinados;
b) Os supervisores de manutenção; (A) (I)
c) Os planejadores de manutenção; (M)
d) Manutenção conjuntamente com a produção;
e) Outros. 
4) A lista de materiais de manutenção em estoque é produzida:

a) Por computador on line com diversas opções de listagem; (M) (I)

b) Por ordem alfabética e códigos do item - listagem diária;

c) Por ordem alfabética - listagem periódica;

d) Por código do item - listagem periódica;

e) Não existe listagem impressa. (A)

5) A localização cartesiana (corredor - prateleira) é disponível para quais porcentagens de materiais em estoque?
a) Acima de 95\%; (M)
b) Entre $90 \%$ e $95 \%$;
c) Entre $80 \%$ e $90 \%$;
d) Entre $70 \%$ e $80 \%$;
e) Menos que $70 \%$. (A) (I)

6) Que porcentagem dos itens m estoque é retirada e debitada diretamente nas ordens de serviço específicas?
a) Acima de 95\%; (M) (A) (I)
b) Entre $90 \%$ e $95 \%$;
c) Entre $80 \%$ e $90 \%$;
d) Entre $70 \%$ e $80 \%$;
e) Menos que $70 \%$.

7) Qual a porcentagem de itens de estoque da manutenção é administrada através de níveis máximos e mínimos?
a) Acima de 95\%; (M) (I)
b) Entre $90 \%$ e $95 \%$;
c) Entre $80 \%$ e $90 \%$;
d) Entre $70 \%$ e $80 \%$;
e) Menos que $70 \%$. (A)

8) A lista para repor estoque é enviada para o departamento de compras:
a) Diariamente; (M) (A)
b) Cada 1 a 3 dias;
c) Semanalmente;
d) Quinzenalmente;
e) Outra freqüência. (I)

9) O recebimento de novos materiais no estoque requer uma atualização diária. A que porcentagem destes recebimentos é feita a atualização imediata?
a) Acima de 95\%; (M) (A) (I)
b) Entre $90 \%$ e $95 \%$;
c) Entre $80 \%$ e $90 \%$; 
d) Entre $70 \%$ e $80 \%$;

e) Menos que $70 \%$.

10) Que porcentagem dos itens de estoque é checada para verificar retiradas nos últimos seis meses?
a) Acima de $90 \%$; (M) (I)
b) Entre $80 \%$ e $90 \%$;
c) Entre $70 \%$ e $80 \%$;
d) Entre $50 \%$ e $70 \%$;
e) Menos que $50 \%$. (A)

\section{RELATÓRIOS GERENCIAIS DE MANUTENÇÃO}

1) Que porcentagem de vezes os relatórios gerenciais de manutenção chegam ao destinatário dentro de um dia da emissão?
a) Acima de 90\%; (M)
b) Entre $75 \%$ e $90 \%$;
c) Entre $60 \%$ e $75 \%$;
d) Entre 40\% e 60\%;
e) Menos que $40 \%$. (A) (I)

2) Do número de relatórios emitidos pela manutenção. Qual a porcentagem que você avalia como úteis, realmente atingindo as pessoas certas?
a) Acima de 90\%; (M)
b) Entre $75 \%$ e $90 \%$;
c) Entre $60 \%$ e $75 \%$;
d) Entre $40 \%$ e $60 \%$;
e) Menos que $40 \%$. (A) (I)

3) Considere os seguintes relatórios gerados por equipamentos importantes e verifique quais são disponíveis na sua manutenção:

1 - Indisponibilidade em número de horas por equipamento, preferencialmente da maior quantidade para a menor (semanal ou mensal);

2 - Perdas de produção em R\$ por indisponibilidade, listando em ordem decrescente os equipamentos responsáveis (semanal ou mensal);

3 - Custos de manutenção incorridos, preferencialmente por equipamento (semanal ou mensal) também em ordem decrescente;

4 - Número de horas aplicadas em Manutenção Preditiva (semanal ou mensal).

a) Todos os quatro relatórios acima são disponíveis;

b) Três dos relatórios acima são disponíveis;

c) Dois dos relatórios acima são disponíveis; (M)

d) Um dos relatórios acima são disponíveis;

e) Não existem relatórios com esses conteúdos. (A) (I)

4) Considere os relatórios de manutenção preventiva abaixo e indique quantos são disponíveis em sua 
manutenção?

1 - Lista de manutenções preventivas vencidas na data mais antiga para a mais recente;

2 - Custos em R\$ de manutenção preventiva por equipamento em ordem decrescente;

3 - Índice de horas de manutenção preventiva, comparado com as horas totais de manutenção (em $\%)$;

4 - Índice do custo de manutenção preventiva, comparado com os custos totais de manutenção (em $\%)$.

a) São disponíveis todos os quatro relatórios acima ou equivalentes; (M)

b) São disponíveis três dos relatórios acima;

c) São disponíveis dois dos relatórios acima;

d) É disponível um dos relatórios acima; (A) (I)

e) Não existem relatórios.

5) Observe os relatórios de pessoal de manutenção mostrados abaixo e indique quantos são disponíveis na sua manutenção:

1 - Horas trabalhadas por empregado em cada serviço/área/departamento;

2 - Horas empregadas em manutenção de emergência, corretiva e preventiva;

3 - Porcentagem de horas extras sobre as horas normais de manutenção;

4 - Porcentagem de funcionários de manutenção sobre o total de funcioários da empresa.

a) São disponíveis todos os quatro relatórios acima ou equivalentes; (M) (A)

b) São disponíveis três dos relatórios acima;

c) São disponíveis dois dos relatórios acima; (I)

d) É disponível um dos relatórios acima;

e) Não existem relatórios.

6) Relatórios de planejamento - Considere os quatro tipos de relatórios a seguir e assinale quantos são emitidos pela sua manutenção:

1 - Custos estimados versus custos reais ocorridos por ordem de serviço;

2 - Relatório de backlog - total de horas já identificadas versus a capacidade de horas disponível (por semana);

3 - Relatório de eficiência de planejamento, por planejador, mostrando todos os planejamentos concluídos com desvios superiores a 20\% para cima ou para baixo;

4 - Porcentagem de serviços concluídos até a data para a qual foram programados.

a) Emitidos todos os quatro relatórios acima ou equivalentes;

b) Emitidos três dos relatórios acima;

c) Emitidos dois dos relatórios acima; (M)

d) Emitido um dos relatórios acima; (A)

e) Não existem relatórios. (I)

7) Relatórios de programação - Considere os quatro tipos de relatórios de programação abaixo e assinale quantos são emitidos pela sua manutenção:

1 - Porcentagem de horas programadas referidas ao total de horas reais utilizadas na manutenção; 
2 - Capacidade em horas de trabalho da equipe de manutenção nos últimos quatro meses;

3 - Número de ordens de serviços planejadas comparadas com o número de ordens concluídas (periodicidade quinzenal);

4 - Número de horas programadas para manutenção preventiva e manutenção não planejada (corretiva e de emergência).

a) Emitidos todos os quatro relatórios acima ou equivalentes; (A)

b) Emitidos três dos relatórios acima; (M)

c) Emitidos dois dos relatórios acima;

d) Emitido um dos relatórios acima; (I)

e) Não existem relatórios.

8) Relatórios de estoque - Analise os quatro tipos de relatórios abaixo e assinale quantos são gerados por sua manutenção:

1 - Lista de valorização do estoque total;

2 - Lista para consulta por ordem alfabética ou produto;

3 - Lista de itens de estoque com datas de entrada, tempo de estoque e movimentação;

4 - Lista onde são usadas as peças - uso geral ou para equipamentos específicos.

a) Gerados todos os quatro relatórios acima ou equivalentes; (M)

b) Gerados três dos relatórios acima;

c) Gerados dois dos relatórios acima;

d) Gerado um dos relatórios acima;

e) Não existem relatórios de estoque. (A) (I)

9) Relatórios de compra - Considere os quatro tipos de relatórios abaixo e assinale quantos são disponíveis na sua manutenção:

1 - Desempenho de fornecedores com índice de pontualidade - data prometida e data de entregue;

2 - Valores totais adquiridos para estoque, investimentos e valores comprados direto para ordens de serviço (periodicidade mensal);

3 - Avaliação global dos fornecedores - analisando consistência de preços, documentação e presteza nas cotações;

4 - Lista de fornecedores qualificados por tipos de serviços.

a) Disponíveis todos os quatro relatórios acima ou equivalentes;

b) Disponíveis três dos relatórios acima;

c) Disponíveis dois dos relatórios acima; (M)

d) Disponível um dos relatórios acima;

e) Não existem relatórios de compra. (A) (I)

10) Relatórios administrativos - Analise os quatro relatórios apresentados abaixo e assinale quantos deles são disponíveis:

1 - Custos totais de manutenção por unidade de produção;

2 - Comparação dos custos de manutenção orçados versus custos reais acumulados até a data (periodicidade mensal);

3 - Porcentagem dos custos de mão-de-obra e de material, comparados com os custos totais de manu- 
tenção;

4 - Porcentagem dos custos totais de manutenção sobre o faturamento da empresa.

a) Disponíveis todos os quatro relatórios acima ou equivalentes;

b) Disponíveis três dos relatórios acima; (M) (A)

c) Disponíveis dois dos relatórios acima;

d) Disponível um dos relatórios acima;

e) Não existem relatórios administrativos. (I)

\section{AUTOMAÇÃO NA MANUTENÇÃO}

1) Que porcentagem das operações de manutenção é feita por computador?
a) Acima de $90 \%$; (I)
b) Entre $75 \%$ e $90 \%$; (M)
c) Entre $60 \%$ e $75 \%$;
d) Entre $40 \%$ e $60 \%$;
e) Menos que $40 \%$. (A)

2) Que porcentagem das atividades de planejamento e programação é feita por computador?
a) Acima de 90\%; (M) (A) (I)
b) Entre $75 \%$ e $90 \%$;
c) Entre $60 \%$ e $75 \%$;
d) Entre $40 \%$ e $60 \%$;
e) Menos que $40 \%$.

3) Que porcentagem das atividades de estoque e compras é feita por computador?
a) Acima de 90\%; (M) (I)
b) Entre $75 \%$ e $90 \%$;
c) Entre $60 \%$ e $75 \%$;
d) Entre 40\% e 60\%;
e) Menos que $40 \%$. (A)

4) Existe interligação entre as informações da manutenção e as do planejamento da produção?
a) Sim, automaticamente pelos sistemas automatizados on line;
b) Há reuniões conjuntas para decisões; (M)
c) A manutenção informa as necessidades de interferência à produção;
d) O planejamento da produção é que prioriza as tarefas de manutenção; (A)
e) Não existem interligações - constantes atritos (I)

5) Os sistemas mecanizados existentes na manutenção, principalmente as interligações com outros sistemas, apresentam precisão e confiabilidade:
a) Acima de 95\%; (M)
b) Entre $90 \%$ e $95 \%$; 
c) Entre 80 e $95 \%$

d) Entre $70 \%$ e $80 \%$

e) Menos que 70\% ou inexiste automação. (A) (I)

6) Qual o nível de interligação dos lançamentos de horas de manutenção e a folha de pagamentos no departamento de pessoal?

a) Sistemas on line completamente interligados;

b) A manutenção e o departamento de pessoal se informam por listas automatizadas;

c) Manutenção e departamento de pessoal usam o cartão de ponto como documento comum;

d) A manutenção gera lista especial só para atender o departamento de pessoal e vice-versa; (A)

e) A manutenção apropria as horas, independentemente das horas usadas para pagamento. (M) (I)

7) Como as informações de custos de manutenção chegam a contabilidade da empresa?
a) Sistema on line - manutenção e contabilidade; (M) (I)
b) As informações fluem por disquetes;
c) As ordens de serviço de manutenção são documentos que servem à manutenção e à contabilidade;
d) As informações migram por documentos manuais, só para atender ao sistema de custos; (A)
e) Cada área usa informações independentes.

8) Que porcentagem do pessoal de manutenção (planejadores, supervisores e gerentes) usa a informática no seu trabalho?
a) Acima de 90\%; (M) (A) (I)
b) Entre $75 \%$ e $90 \%$;
C) Entre $60 \%$ e $75 \%$;
d) Entre $40 \%$ e $60 \%$;
e) Menos que $40 \%$.

9) Qual o nível de cooperação existente dentro da empresa para que a manutenção contribua eficazmente no aumento da rentabilidade?
a) Cooperação irrestrita em todos os níveis; (M)
b) Na grande maioria dos casos; (A) (I)
c) Cooperação em todos os níveis de supervisão;
d) Poucos casos;
e) Não existe cooperação;

10) A manutenção é consultada quando uma decisão da alta gerência a afeta. Exemplo: compra de novos equipamentos etc?
a) Em todos os casos e antes de ocorrer; (A) (I)
b) Na maioria dos casos antes de ocorrer; (M)
c) Em poucos casos antes de ocorrer;
d) Informada a posteriori para tomar providências;
e) Não é consultada nem informada. 
RETÍFICA DE PERFIL - QUADRO GERAL DE DADOS

\section{DESCRIÇÃO DAS COLUNAS DO QUADRO}

\begin{tabular}{|c|c|c|}
\hline COLUNAS & DESCRIÇÃO & APURAÇÃO \\
\hline Dias Úteis [1] & Número de dias úteis do período [d]. & \\
\hline Horas Dia [2] & Horas disponíveis por dia do equipamento [h/d]. & \\
\hline $\begin{array}{l}\text { Horas Disponíveis do } \\
\text { Período [3] }\end{array}$ & Horas disponíveis por dia do equipamento no período considerado [h/d]. & {$[3]=[1] \times[2]$} \\
\hline Código & Código do registro patrimonial do equipamento. & \\
\hline HS [4] & Horas em serviço do equipamento no período considerado [h]. & {$[4]=[3]-[10]$} \\
\hline NF [5] & Número de falhas do equipamento no período considerado (tais falhas ensejam intervenções de natureza corretiva). & \\
\hline HMC [6] & Horas de manutenção corretiva realizadas no equipamento, no período [h]. & \\
\hline NP [7] & Número de intervenções de caráter preventivo executadas no equipamento, no período. & \\
\hline HMP R [8] & Horas de manutenção preventiva realizadas no equipamento no período considerado [h]. & \\
\hline HMP P [9] & Horas de manutenção preventiva previstas para o equipamento no período considerado [h]. & \\
\hline HP [10] & Horas paralisadas decorrentes das intervenções de correção e prevenção no equipamento, no período [h]. & {$[10]=[6]+[8]$} \\
\hline NI [11] & Número de intervenções de correção e de prevenção realizadas nos equipamentos no período considerado. & {$[11]=[5]+[7]$} \\
\hline TI [12] & Tempo das intervenções de correção e de prevenção realizadas nos equipamentos no período [h]. & {$[12]=[10]=[6]+[8]$} \\
\hline HPI [13] & Horas previstas para as intervenções de correção e de prevenção no equipamento, no período considerado [h]. & {$[13]=[6]+[9]$} \\
\hline HCI [14] & Horas consumidas pelas intervenções de correção e prevenção nos equipamentos, no período [h]. & {$[14]=[12]=[10]=[6]+[8]$} \\
\hline
\end{tabular}


RETÍFICA DE PERFIL - QUADRO GERAL DE DADOS

Período de Observação: 01/06/2004 a 30/06/2004

Dias Úteis: 23

Horas Dia: $\quad 22,5$

Horas Disponíveis do Período: $\quad 517,50 \quad$ h/maq

\begin{tabular}{|c|c|c|c|c|c|c|c|c|c|c|c|c|}
\hline CÓDIGO & EQUIPAMENTO & HS & NF & HMC & $\mathbf{N P}$ & HMP R & HMP P & HP & NI & TI & HPI & HCI \\
\hline 02200905 & C.PM FILTRO OILMATC-GOETZE-BP 37760 & 517,50 & \multirow{8}{*}{1} & \multirow{8}{*}{1,33} & \multirow[b]{10}{*}{1} & \multirow[b]{10}{*}{1,28} & \multirow[b]{10}{*}{1,00} & 0,00 & 0 & 0,00 & 0,00 & 0,00 \\
\hline 02200906 & C.RP FILTRO OBERLIN - BP 37711 & 517,50 & & & & & & 0,00 & 0 & 0,00 & 0,00 & 0,00 \\
\hline 02200907 & C.RP FILTRO OBERLIN - BP 37705 & 517,50 & & & & & & 0,00 & 0 & 0,00 & 0,00 & 0,00 \\
\hline 02202537 & C.RP PILAO (M) - BP 2138 & 517,50 & & & & & & 0,00 & 0 & 0,00 & 0,00 & 0,00 \\
\hline 02202552 & C.PM PILAO (E/M) - BP 9769 & 517,50 & & & & & & 0,00 & 0 & 0,00 & 0,00 & 0,00 \\
\hline 02202560 & C.PM PILAO (E/M) - BP 20013 & 517,50 & & & & & & 0,00 & 0 & 0,00 & 0,00 & 0,00 \\
\hline 02203226 & C.RP GRAVADORA CNC - BP 37741 & 516,17 & & & & & & 1,33 & 1 & 1,33 & 1,33 & 1,33 \\
\hline 02205701 & C.RP DISPOSITIVO - BP 35485 & 517,50 & & & & & & 0,00 & 0 & 0,00 & 0,00 & 0,00 \\
\hline 0220RP01 & C.RP RTF. PERFIL R4MG - BP 35014 & 514,43 & 2 & 3,07 & & & & 3,07 & 2 & 3,07 & 3,07 & 3,07 \\
\hline 0220RP02 & C.RP RTF. PERFIL R7MG - BP 40058 & 514,09 & 2 & 2,13 & & & & 3,41 & 3 & 3,41 & 3,13 & 3,41 \\
\hline 0220RP03 & C.RP RTF. PERFIL R7MG - BP 40057 & 514,60 & 2 & 1,78 & 1 & \multirow{2}{*}{$\begin{array}{l}1,12 \\
4,13\end{array}$} & \multirow{2}{*}{$\begin{array}{l}1,00 \\
1,50\end{array}$} & 2,90 & 3 & 2,90 & 2,78 & 2,90 \\
\hline 0220RP04 & C.RP RTF. PERFIL R7MG - BP 37703 & 511,99 & 1 & 1,38 & 2 & & & 5,51 & 3 & 5,51 & 2,88 & 5,51 \\
\hline 0220RP05 & C.RP RTF. PERFIL R7MG - BP 37704 & 508,28 & 4 & 8,70 & 1 & 0,52 & 0,50 & 9,22 & 5 & 9,22 & 9,20 & 9,22 \\
\hline 0220RP12 & C.RP RTF. KATAOKA PCG-1-NC-BP 36155 & 517,50 & & & & & & 0,00 & 0 & 0,00 & 0,00 & 0,00 \\
\hline 0220RP15 & C.RP RTF. KATAOKA PCG - BP 36156 & 517,50 & & & & & & 0,00 & 0 & 0,00 & 0,00 & 0,00 \\
\hline 0220RP18 & C.RP RTF. KATAOKA R7 - BP 900069 & 513,73 & 2 & 3,77 & & & & 3,77 & 2 & 3,77 & 3,77 & 3,77 \\
\hline 0220RP19 & C.RP RTF. KATAOKA R7 - BP 900403 & 517,50 & & & & & & 0,00 & 0 & 0,00 & 0,00 & 0,00 \\
\hline 0220RP21 & C.PM RTF. KATAOKA PCG - AF 0018 & 514,45 & 2 & 3,05 & & & & 3,05 & 2 & 3,05 & 3,05 & 3,05 \\
\hline 0220RP22 & C.PM RTF. KATAOKA R4MG - BP 32606 & 517,50 & & & & & & 0,00 & 0 & 0,00 & 0,00 & 0,00 \\
\hline 0220RP23 & C.PM RTF. KATAOKA R4MG - BP 28724 & 515,60 & 1 & 1,90 & & & & 1,90 & 1 & 1,90 & 1,90 & 1,90 \\
\hline 0220RP24 & C.PM RTF. KATAOKA PCG - AF 0017 & 474,53 & 2 & 42,97 & & & & 42,97 & 2 & 42,97 & 42,97 & 42,97 \\
\hline 0220RP27 & C.RP RTF. KATAOKA R7 - BP 900573 & 509,55 & 2 & 7,95 & & & & 7,95 & 2 & 7,95 & 7,95 & 7,95 \\
\hline 0220RP28 & C.RP RTF. KATAOKA R7 - BP 900113 & 516,50 & & & 1 & 1,00 & 1,00 & 1,00 & 1 & 1,00 & 1,00 & 1,00 \\
\hline 0220RP29 & C.RP RET. PERFIL PCG - BP 901518 & 517,50 & & & & & & 0,00 & 0 & 0,00 & 0,00 & 0,00 \\
\hline & TOTAIS & $12.333,92$ & 21 & 78,03 & 6 & 8,05 & 5,00 & 86,08 & 27 & 86,08 & 83,03 & 86,08 \\
\hline
\end{tabular}


RETÍFICA DE PERFIL - QUADRO GERAL DE DADOS

Período de Observação: 01/07/2004 a 31/07/2004

Dias Úteis: 25

Horas Dia: $\quad 22,5$

Horas Disponíveis do Período: $\quad 562,50 \quad$ h/maq

\begin{tabular}{|c|c|c|c|c|c|c|c|c|c|c|c|c|}
\hline CÓDIGO & EQUIPAMENTO & HS & NF & HMC & NP & HMP R & HMP P & HP & NI & TI & HPI & HCI \\
\hline $\begin{array}{l}02200905 \\
02200906 \\
02200907 \\
02202537 \\
02202552 \\
02202560 \\
02203226 \\
02205701 \\
0220 \text { RP01 } \\
\text { 0220RP02 } \\
\text { 0220RP03 } \\
\text { 0220RP04 } \\
\text { 0220RP05 } \\
\text { 0220RP12 } \\
\text { 0220RP15 } \\
\text { 0220RP18 } \\
\text { 0220RP19 } \\
\text { 0220RP21 } \\
\text { 0220RP22 } \\
\text { 0220RP23 } \\
\text { 0220RP24 } \\
\text { 0220RP27 } \\
\text { 0220RP28 } \\
\text { 0220RP29 }\end{array}$ & $\begin{array}{l}\text { C.PM FILTRO OILMATC-GOETZE-BP } 37760 \\
\text { C.RP FILTRO OBERLIN - BP } 37711 \\
\text { C.RP FILTRO OBERLIN - BP } 37705 \\
\text { C.RP PILAO (M) - BP } 2138 \\
\text { C.PM PILAO (E/M) - BP } 9769 \\
\text { C.PM PILAO (E/M) - BP } 20013 \\
\text { C.RP GRAVADORA CNC - BP } 37741 \\
\text { C.RP DISPOSITIVO - BP } 35485 \\
\text { C.RP RTF. PERFIL R4MG - BP } 35014 \\
\text { C.RP RTF. PERFIL R7MG - BP } 40058 \\
\text { C.RP RTF. PERFIL R7MG - BP } 40057 \\
\text { C.RP RTF. PERFIL R7MG - BP } 37703 \\
\text { C.RP RTF. PERFIL R7MG - BP } 37704 \\
\text { C.RP RTF. KATAOKA PCG-1-NC-BP } 36155 \\
\text { C.RP RTF. KATAOKA PCG - BP } 36156 \\
\text { C.RP RTF. KATAOKA R7 - BP } 900069 \\
\text { C.RP RTF. KATAOKA R7 - BP } 900403 \\
\text { C.PM RTF. KATAOKA PCG - AF } 0018 \\
\text { C.PM RTF. KATAOKA R4MG - BP } 32606 \\
\text { C.PM RTF. KATAOKA R4MG - BP } 28724 \\
\text { C.PM RTF. KATAOKA PCG - AF } 0017 \\
\text { C.RP RTF. KATAOKA R7 - BP } 900573 \\
\text { C.RP RTF. KATAOKA R7 - BP } 900113 \\
\text { C.RP RET. PERFIL PCG - BP 901518 }\end{array}$ & $\begin{array}{l}562,50 \\
562,50 \\
562,50 \\
562,50 \\
559,03 \\
562,50 \\
561,43 \\
562,50 \\
561,55 \\
554,20 \\
530,63 \\
554,41 \\
544,75 \\
560,57 \\
562,50 \\
550,92 \\
561,37 \\
562,50 \\
562,50 \\
551,31 \\
562,03 \\
546,88 \\
559,33 \\
562,50\end{array}$ & $\begin{array}{l}1 \\
4 \\
1 \\
5 \\
5 \\
1 \\
4 \\
1\end{array}$ & $\begin{array}{c}1,07 \\
\\
0,95 \\
8,30 \\
31,87 \\
8,09 \\
17,75 \\
1,93 \\
11,58 \\
1,13 \\
\\
11,19 \\
15,62 \\
3,17\end{array}$ & 1 & 0,47 & 1,00 & $\begin{array}{c}0,00 \\
0,00 \\
0,00 \\
0,00 \\
3,47 \\
0,00 \\
1,07 \\
0,00 \\
0,95 \\
8,30 \\
31,87 \\
8,09 \\
17,75 \\
1,93 \\
0,00 \\
11,58 \\
1,13 \\
0,00 \\
0,00 \\
11,19 \\
0,47 \\
15,62 \\
3,17 \\
0,00\end{array}$ & $\begin{array}{l}0 \\
0 \\
0 \\
0 \\
1 \\
0 \\
1 \\
0 \\
1 \\
4 \\
1 \\
5 \\
5 \\
1 \\
0 \\
4 \\
1 \\
0 \\
0 \\
3 \\
1 \\
3 \\
3 \\
0\end{array}$ & $\begin{array}{c}0,00 \\
0,00 \\
0,00 \\
0,00 \\
3,47 \\
0,00 \\
1,07 \\
0,00 \\
0,95 \\
8,30 \\
31,87 \\
8,09 \\
17,75 \\
1,93 \\
0,00 \\
11,58 \\
1,13 \\
0,00 \\
0,00 \\
11,19 \\
0,47 \\
15,62 \\
3,17 \\
0,00\end{array}$ & $\begin{array}{c}0,00 \\
0,00 \\
0,00 \\
0,00 \\
3,47 \\
0,00 \\
1,07 \\
0,00 \\
0,95 \\
8,30 \\
31,87 \\
8,09 \\
17,75 \\
1,93 \\
0,00 \\
11,58 \\
1,13 \\
0,00 \\
0,00 \\
11,19 \\
1,00 \\
15,62 \\
3,17 \\
0,00\end{array}$ & $\begin{array}{c}0,00 \\
0,00 \\
0,00 \\
0,00 \\
3,47 \\
0,00 \\
1,07 \\
0,00 \\
0,95 \\
8,30 \\
31,87 \\
8,09 \\
17,75 \\
1,93 \\
0,00 \\
11,58 \\
1,13 \\
0,00 \\
0,00 \\
11,19 \\
0,47 \\
15,62 \\
3,17 \\
0,00\end{array}$ \\
\hline & TOTAIS & $13.383,41$ & 33 & 116,12 & 1 & 0,47 & 1,00 & 116,59 & 34 & 116,59 & 117,12 & 116,59 \\
\hline
\end{tabular}


RETÍFICA DE PERFIL - QUADRO GERAL DE DADOS

Período de Observação: 01/08/2004 a 31/08/2004

Dias Úteis: 24

Horas Dia: $\quad 22,5$

Horas Disponíveis do Período: $\quad 540,00 \quad$ h/maq

\begin{tabular}{|c|c|c|c|c|c|c|c|c|c|c|c|c|}
\hline CÓDIGO & EQUIPAMENTO & HS & NF & HMC & $\mathbf{N P}$ & HMP R & HMP P & HP & NI & TI & HPI & HCI \\
\hline 02200905 & C.PM FILTRO OILMATC-GOETZE-BP 37760 & 540,00 & \multirow{6}{*}{1} & \multirow{6}{*}{0,95} & \multirow{14}{*}{1} & \multirow{14}{*}{1,28} & \multirow{14}{*}{0,00} & 0,00 & 0 & 0,00 & 0,00 & 0,00 \\
\hline 02200906 & C.RP FILTRO OBERLIN - BP 37711 & 540,00 & & & & & & 0,00 & 0 & 0,00 & 0,00 & 0,00 \\
\hline 02200907 & C.RP FILTRO OBERLIN - BP 37705 & 537,77 & & & & & & 2,23 & 2 & 2,23 & 0,95 & 2,23 \\
\hline 02202537 & C.RP PILAO (M) - BP 2138 & 540,00 & & & & & & 0,00 & 0 & 0,00 & 0,00 & 0,00 \\
\hline 02202552 & C.PM PILAO (E/M) - BP 9769 & 540,00 & & & & & & 0,00 & 0 & 0,00 & 0,00 & 0,00 \\
\hline 02202560 & C.PM PILAO (E/M) - BP 20013 & 540,00 & & & & & & 0,00 & 0 & 0,00 & 0,00 & 0,00 \\
\hline 02203226 & C.RP GRAVADORA CNC - BP 37741 & 535,09 & \multirow[t]{2}{*}{3} & \multirow[t]{2}{*}{4,91} & & & & 4,91 & 3 & 4,91 & 4,91 & 4,91 \\
\hline 02205701 & C.RP DISPOSITIVO - BP 35485 & 540,00 & & & & & & 0,00 & 0 & 0,00 & 0,00 & 0,00 \\
\hline 0220RP01 & C.RP RTF. PERFIL R4MG - BP 35014 & 534,89 & \multirow[t]{2}{*}{3} & \multirow[t]{2}{*}{5,11} & & & & 5,11 & 3 & 5,11 & 5,11 & 5,11 \\
\hline 0220RP02 & C.RP RTF. PERFIL R7MG - BP 40058 & 540,00 & & & & & & 0,00 & 0 & 0,00 & 0,00 & 0,00 \\
\hline 0220RP03 & C.RP RTF. PERFIL R7MG - BP 40057 & 531,18 & 3 & 8,82 & & & & 8,82 & 3 & 8,82 & 8,82 & 8,82 \\
\hline 0220RP04 & C.RP RTF. PERFIL R7MG - BP 37703 & 529,00 & 5 & 11,00 & & & & 11,00 & 5 & 11,00 & 11,00 & 11,00 \\
\hline 0220RP05 & C.RP RTF. PERFIL R7MG - BP 37704 & 537,53 & \multirow[t]{3}{*}{2} & \multirow[t]{3}{*}{2,47} & & & & 2,47 & 2 & 2,47 & 2,47 & 2,47 \\
\hline 0220RP12 & C.RP RTF. KATAOKA PCG-1-NC-BP 36155 & 540,00 & & & & & & 0,00 & 0 & 0,00 & 0,00 & 0,00 \\
\hline 0220RP15 & C.RP RTF. KATAOKA PCG - BP 36156 & 536,95 & & & 1 & 3,05 & 1,00 & 3,05 & 1 & 3,05 & 1,00 & 3,05 \\
\hline 0220RP18 & C.RP RTF. KATAOKA R7 - BP 900069 & 528,67 & \multirow[t]{2}{*}{3} & \multirow[t]{2}{*}{3,08} & 2 & 8,25 & 2,00 & 11,33 & 5 & 11,33 & 5,08 & 11,33 \\
\hline 0220RP19 & C.RP RTF. KATAOKA R7 - BP 900403 & 506,15 & & & 3 & 33,85 & 22,00 & 33,85 & 3 & 33,85 & 22,00 & 33,85 \\
\hline 0220RP21 & C.PM RTF. KATAOKA PCG - AF 0018 & 534,46 & \multirow[t]{2}{*}{1} & \multirow[t]{2}{*}{0,57} & 1 & 4,97 & 1,00 & 5,54 & 2 & 5,54 & 1,57 & 5,54 \\
\hline 0220RP22 & C.PM RTF. KATAOKA R4MG - BP 32606 & 533,00 & & & 1 & 7,00 & 1,00 & 7,00 & 1 & 7,00 & 1,00 & 7,00 \\
\hline 0220RP23 & C.PM RTF. KATAOKA R4MG - BP 28724 & 532,50 & \multirow[t]{2}{*}{2} & \multirow[t]{2}{*}{2,98} & 1 & 4,52 & 1,00 & 7,50 & 3 & 7,50 & 3,98 & 7,50 \\
\hline 0220RP24 & C.PM RTF. KATAOKA PCG - AF 0017 & 530,65 & & & 1 & 9,35 & 1,00 & 9,35 & 1 & 9,35 & 1,00 & 9,35 \\
\hline 0220RP27 & C.RP RTF. KATAOKA R7 - BP 900573 & 511,62 & 4 & 4,35 & 2 & 24,03 & 21,00 & 28,38 & 6 & 28,38 & 25,35 & 28,38 \\
\hline 0220RP28 & C.RP RTF. KATAOKA R7 - BP 900113 & 496,65 & \multirow[t]{2}{*}{4} & \multirow[t]{2}{*}{8,80} & \multirow[t]{2}{*}{1} & \multirow[t]{2}{*}{34,55} & \multirow[t]{2}{*}{16,00} & 43,35 & 5 & 43,35 & 24,80 & 43,35 \\
\hline 0220RP29 & C.RP RET. PERFIL PCG - BP 901518 & 540,00 & & & & & & 0,00 & 0 & 0,00 & 0,00 & 0,00 \\
\hline & TOTAIS & $12.776,11$ & 31 & 53,04 & 14 & 130,85 & 66,00 & 183,89 & 45 & 183,89 & 119,04 & 183,89 \\
\hline
\end{tabular}


RETÍFICA DE PERFIL - QUADRO GERAL DE DADOS

Período de Observação: 01/09/2004 a 30/09/2004

Dias Úteis: 23

Horas Dia: $\quad 22,5$

Horas Disponíveis do Período: $\quad 517,50 \quad$ h/maq

\begin{tabular}{|c|c|c|c|c|c|c|c|c|c|c|c|c|}
\hline CÓDIGO & EQUIPAMENTO & HS & NF & HMC & NP & HMP R & HMP P & HP & NI & TI & HPI & HCI \\
\hline 02200905 & C.PM FILTRO OILMATC-GOETZE-BP 37760 & 517,50 & \multirow{5}{*}{1} & \multirow{5}{*}{2,88} & & & \multirow[b]{9}{*}{22,00} & 0,00 & 0 & 0,00 & 0,00 & 0,00 \\
\hline 02200906 & C.RP FILTRO OBERLIN - BP 37711 & 517,50 & & & & & & 0,00 & 0 & 0,00 & 0,00 & 0,00 \\
\hline 02200907 & C.RP FILTRO OBERLIN - BP 37705 & 517,50 & & & & & & 0,00 & 0 & 0,00 & 0,00 & 0,00 \\
\hline 02202537 & C.RP PILAO (M) - BP 2138 & 514,62 & & & & & & 2,88 & 1 & 2,88 & 2,88 & 2,88 \\
\hline 02202552 & C.PM PILAO (E/M) - BP 9769 & 517,50 & & & & & & 0,00 & 0 & 0,00 & 0,00 & 0,00 \\
\hline 02202560 & C.PM PILAO (E/M) - BP 20013 & 514,93 & 1 & 2,57 & & & & 2,57 & 1 & 2,57 & 2,57 & 2,57 \\
\hline 02203226 & C.RP GRAVADORA CNC - BP 37741 & 516,50 & \multirow[t]{2}{*}{1} & \multirow[t]{2}{*}{1,00} & & & & 1,00 & 1 & 1,00 & 1,00 & 1,00 \\
\hline 02205701 & C.RP DISPOSITIVO - BP 35485 & 517,50 & & & & & & 0,00 & 0 & 0,00 & 0,00 & 0,00 \\
\hline 0220RP01 & C.RP RTF. PERFIL R4MG - BP 35014 & 488,61 & 5 & 7,55 & 3 & 21,34 & & 28,89 & 8 & 28,89 & 29,55 & 28,89 \\
\hline 0220RP02 & C.RP RTF. PERFIL R7MG - BP 40058 & 499,79 & 3 & 7,71 & 2 & 10,00 & 2,00 & 17,71 & 5 & 17,71 & 9,71 & 17,71 \\
\hline 0220RP03 & C.RP RTF. PERFIL R7MG - BP 40057 & 505,29 & 2 & 1,35 & 2 & 10,86 & 2,00 & 12,21 & 4 & 12,21 & 3,35 & 12,21 \\
\hline 0220RP04 & C.RP RTF. PERFIL R7MG - BP 37703 & 503,77 & 3 & 3,10 & 2 & 10,63 & 2,00 & 13,73 & 5 & 13,73 & 5,10 & 13,73 \\
\hline 0220RP05 & C.RP RTF. PERFIL R7MG - BP 37704 & 504,17 & \multirow[t]{3}{*}{3} & \multirow[t]{3}{*}{10,83} & 1 & 2,50 & 1,00 & 13,33 & 4 & 13,33 & 11,83 & 13,33 \\
\hline 0220RP12 & C.RP RTF. KATAOKA PCG-1-NC-BP 36155 & 515,50 & & & \multirow[t]{8}{*}{1} & \multirow[t]{8}{*}{2,00} & \multirow[t]{8}{*}{1,00} & 2,00 & 1 & 2,00 & 1,00 & 2,00 \\
\hline 0220RP15 & C.RP RTF. KATAOKA PCG - BP 36156 & 517,50 & & & & & & 0,00 & 0 & 0,00 & 0,00 & 0,00 \\
\hline 0220RP18 & C.RP RTF. KATAOKA R7 - BP 900069 & 515,92 & 1 & 1,58 & & & & 1,58 & 1 & 1,58 & 1,58 & 1,58 \\
\hline 0220RP19 & C.RP RTF. KATAOKA R7 - BP 900403 & 508,14 & \multirow[t]{2}{*}{3} & \multirow[t]{2}{*}{9,36} & & & & 9,36 & 3 & 9,36 & 9,36 & 9,36 \\
\hline 0220RP21 & C.PM RTF. KATAOKA PCG - AF 0018 & 517,50 & & & & & & 0,00 & 0 & 0,00 & 0,00 & 0,00 \\
\hline 0220RP22 & C.PM RTF. KATAOKA R4MG - BP 32606 & 515,61 & 2 & 1,89 & & & & 1,89 & 2 & 1,89 & 1,89 & 1,89 \\
\hline $0220 \mathrm{RP} 23$ & C.PM RTF. KATAOKA R4MG - BP 28724 & 513,57 & 1 & 3,93 & & & & 3,93 & 1 & 3,93 & 3,93 & 3,93 \\
\hline 0220RP24 & C.PM RTF. KATAOKA PCG - AF 0017 & 513,83 & 1 & 3,67 & & & & 3,67 & 1 & 3,67 & 3,67 & 3,67 \\
\hline 0220RP27 & C.RP RTF. KATAOKA R7 - BP 900573 & 508,38 & 2 & 1,20 & 1 & 7,92 & 1,00 & 9,12 & 3 & 9,12 & 2,20 & 9,12 \\
\hline 0220RP28 & C.RP RTF. KATAOKA R7 - BP 900113 & 503,85 & 4 & 5,37 & 2 & 8,28 & 2,00 & 13,65 & 6 & 13,65 & 7,37 & 13,65 \\
\hline 0220RP29 & C.RP RET. PERFIL PCG - BP 901518 & 510,78 & & & 1 & 6,72 & 1,00 & 6,72 & 1 & 6,72 & 1,00 & 6,72 \\
\hline \multicolumn{2}{|r|}{ TOTAIS } & $12.275,76$ & 33 & 63,99 & 15 & 80,25 & 34,00 & 144,24 & 48 & 144,24 & 97,99 & 144,24 \\
\hline
\end{tabular}


RETÍFICA DE PERFIL - QUADRO GERAL DE DADOS

Período de Observação: 01/10/2004 a 31/10/2004

Dias Úteis: $\quad 22$

Horas Dia: $\quad 22,5$

Horas Disponíveis do Período: $\quad 495,00 \quad$ h/maq

\begin{tabular}{|c|c|c|c|c|c|c|c|c|c|c|c|c|}
\hline CÓDIGO & EQUIPAMENTO & HS & NF & HMC & $\mathbf{N P}$ & HMP R & HMP P & HP & NI & TI & HPI & HCI \\
\hline 02200905 & C.PM FILTRO OILMATC-GOETZE-BP 37760 & 495,00 & \multirow{8}{*}{1} & \multirow{8}{*}{1,32} & \multirow{19}{*}{1} & \multirow{19}{*}{83,67} & \multirow{19}{*}{21,00} & 0,00 & 0 & 0,00 & 0,00 & 0,00 \\
\hline 02200906 & C.RP FILTRO OBERLIN - BP 37711 & 495,00 & & & & & & 0,00 & 0 & 0,00 & 0,00 & 0,00 \\
\hline 02200907 & C.RP FILTRO OBERLIN - BP 37705 & 495,00 & & & & & & 0,00 & 0 & 0,00 & 0,00 & 0,00 \\
\hline 02202537 & C.RP PILAO (M) - BP 2138 & 495,00 & & & & & & 0,00 & 0 & 0,00 & 0,00 & 0,00 \\
\hline 02202552 & C.PM PILAO (E/M) - BP 9769 & 495,00 & & & & & & 0,00 & 0 & 0,00 & 0,00 & 0,00 \\
\hline 02202560 & C.PM PILAO (E/M) - BP 20013 & 495,00 & & & & & & 0,00 & 0 & 0,00 & 0,00 & 0,00 \\
\hline 02203226 & C.RP GRAVADORA CNC - BP 37741 & 493,68 & & & & & & 1,32 & 1 & 1,32 & 1,32 & 1,32 \\
\hline 02205701 & C.RP DISPOSITIVO - BP 35485 & 495,00 & & & & & & 0,00 & 0 & 0,00 & 0,00 & 0,00 \\
\hline 0220RP01 & C.RP RTF. PERFIL R4MG - BP 35014 & 491,71 & 2 & 1,41 & & & & 3,29 & 3 & 3,29 & 2,91 & 3,29 \\
\hline 0220RP02 & C.RP RTF. PERFIL R7MG - BP 40058 & 494,07 & 1 & 0,93 & & & & 0,93 & 1 & 0,93 & 0,93 & 0,93 \\
\hline 0220RP03 & C.RP RTF. PERFIL R7MG - BP 40057 & 494,45 & 1 & 0,55 & & & & 0,55 & 1 & 0,55 & 0,55 & 0,55 \\
\hline 0220RP04 & C.RP RTF. PERFIL R7MG - BP 37703 & 493,63 & 1 & 1,37 & & & & 1,37 & 1 & 1,37 & 1,37 & 1,37 \\
\hline 0220RP05 & C.RP RTF. PERFIL R7MG - BP 37704 & 409,70 & \multirow[t]{3}{*}{1} & \multirow[t]{3}{*}{1,63} & & & & 85,30 & 3 & 85,30 & 22,63 & 85,30 \\
\hline 0220RP12 & C.RP RTF. KATAOKA PCG-1-NC-BP 36155 & 495,00 & & & & & & 0,00 & 0 & 0,00 & 0,00 & 0,00 \\
\hline 0220RP15 & C.RP RTF. KATAOKA PCG - BP 36156 & 495,00 & & & & & & 0,00 & 0 & 0,00 & 0,00 & 0,00 \\
\hline 0220RP18 & C.RP RTF. KATAOKA R7 - BP 900069 & 493,95 & 1 & 1,05 & & & & 1,05 & 1 & 1,05 & 1,05 & 1,05 \\
\hline 0220RP19 & C.RP RTF. KATAOKA R7 - BP 900403 & 484,36 & 2 & 10,64 & & & & 10,64 & 2 & 10,64 & 10,64 & 10,64 \\
\hline 0220RP21 & C.PM RTF. KATAOKA PCG - AF 0018 & 494,50 & 1 & 0,50 & & & & 0,50 & 1 & 0,50 & 0,50 & 0,50 \\
\hline 0220RP22 & C.PM RTF. KATAOKA R4MG - BP 32606 & 493,27 & 1 & 1,73 & & & & 1,73 & 1 & 1,73 & 1,73 & 1,73 \\
\hline 0220RP23 & C.PM RTF. KATAOKA R4MG - BP 28724 & 397,23 & 1 & 2,03 & 1 & 95,74 & 64,00 & 97,77 & 2 & 97,77 & 66,03 & 97,77 \\
\hline 0220RP24 & C.PM RTF. KATAOKA PCG - AF 0017 & 495,00 & \multirow{4}{*}{$\begin{array}{l}3 \\
2\end{array}$} & \multirow{4}{*}{$\begin{array}{l}4,23 \\
2,00\end{array}$} & \multirow{4}{*}{1} & \multirow{4}{*}{27,17} & \multirow{4}{*}{24,00} & 0,00 & 0 & 0,00 & 0,00 & 0,00 \\
\hline 0220RP27 & C.RP RTF. KATAOKA R7 - BP 900573 & 490,77 & & & & & & 4,23 & 3 & 4,23 & 4,23 & 4,23 \\
\hline 0220RP28 & C.RP RTF. KATAOKA R7 - BP 900113 & 465,83 & & & & & & 29,17 & 3 & 29,17 & 26,00 & 29,17 \\
\hline 0220RP29 & C.RP RET. PERFIL PCG - BP 901518 & 495,00 & & & & & & 0,00 & 0 & 0,00 & 0,00 & 0,00 \\
\hline & TOTAIS & $11.642,15$ & 18 & 29,39 & 5 & 208,46 & 110,50 & 237,85 & 23 & 237,85 & 139,89 & 237,85 \\
\hline
\end{tabular}


RETÍFICA DE PERFIL - QUADRO GERAL DE DADOS

Período de Observação: 01/11/2004 a 30/11/2004

Dias Úteis: 22

Horas Dia: $\quad 22,5$

Horas Disponíveis do Período: $\quad 495,00 \quad$ h/maq

\begin{tabular}{|c|c|c|c|c|c|c|c|c|c|c|c|c|}
\hline CÓDIGO & EQUIPAMENTO & HS & NF & HMC & NP & HMP R & HMP P & HP & NI & TI & HPI & HCI \\
\hline 02200905 & C.PM FILTRO OILMATC-GOETZE-BP 37760 & 495,00 & \multirow{8}{*}{3} & \multirow{8}{*}{34,13} & \multirow{24}{*}{$\begin{array}{l}1 \\
2\end{array}$} & \multirow{24}{*}{$\begin{array}{c}0,50 \\
10,85\end{array}$} & \multirow{24}{*}{$\begin{array}{c}0,50 \\
20,00\end{array}$} & 0,00 & 0 & 0,00 & 0,00 & 0,00 \\
\hline 02200906 & C.RP FILTRO OBERLIN - BP 37711 & 495,00 & & & & & & 0,00 & 0 & 0,00 & 0,00 & 0,00 \\
\hline 02200907 & C.RP FILTRO OBERLIN - BP 37705 & 495,00 & & & & & & 0,00 & 0 & 0,00 & 0,00 & 0,00 \\
\hline 02202537 & C.RP PILAO (M) - BP 2138 & 495,00 & & & & & & 0,00 & 0 & 0,00 & 0,00 & 0,00 \\
\hline 02202552 & C.PM PILAO (E/M) - BP 9769 & 495,00 & & & & & & 0,00 & 0 & 0,00 & 0,00 & 0,00 \\
\hline 02202560 & C.PM PILAO (E/M) - BP 20013 & 495,00 & & & & & & 0,00 & 0 & 0,00 & 0,00 & 0,00 \\
\hline 02203226 & C.RP GRAVADORA CNC - BP 37741 & 460,87 & & & & & & 34,13 & 3 & 34,13 & 34,13 & 34,13 \\
\hline 02205701 & C.RP DISPOSITIVO - BP 35485 & 495,00 & & & & & & 0,00 & 0 & 0,00 & 0,00 & 0,00 \\
\hline 0220RP01 & C.RP RTF. PERFIL R4MG - BP 35014 & 493,88 & 1 & 1,12 & & & & 1,12 & 1 & 1,12 & 1,12 & 1,12 \\
\hline 0220RP02 & C.RP RTF. PERFIL R7MG - BP 40058 & 462,32 & 2 & 32,68 & & & & 32,68 & 2 & 32,68 & 32,68 & 32,68 \\
\hline 0220RP03 & C.RP RTF. PERFIL R7MG - BP 40057 & 493,53 & 2 & 1,47 & & & & 1,47 & 2 & 1,47 & 1,47 & 1,47 \\
\hline 0220RP04 & C.RP RTF. PERFIL R7MG - BP 37703 & 482,63 & 3 & 12,37 & & & & 12,37 & 3 & 12,37 & 12,37 & 12,37 \\
\hline 0220RP05 & C.RP RTF. PERFIL R7MG - BP 37704 & 493,03 & 1 & 1,97 & & & & 1,97 & 1 & 1,97 & 1,97 & 1,97 \\
\hline 0220RP12 & C.RP RTF. KATAOKA PCG-1-NC-BP 36155 & 493,03 & 1 & 1,97 & & & & 1,97 & 1 & 1,97 & 1,97 & 1,97 \\
\hline 0220RP15 & C.RP RTF. KATAOKA PCG - BP 36156 & 495,00 & & & & & & 0,00 & 0 & 0,00 & 0,00 & 0,00 \\
\hline 0220RP18 & C.RP RTF. KATAOKA R7 - BP 900069 & 492,07 & 1 & 1,93 & & & & 2,93 & 2 & 2,93 & 2,93 & 2,93 \\
\hline 0220RP19 & C.RP RTF. KATAOKA R7 - BP 900403 & 492,85 & \multirow[t]{4}{*}{2} & \multirow[t]{4}{*}{2,15} & & & & 2,15 & 2 & 2,15 & 2,15 & 2,15 \\
\hline 0220RP21 & C.PM RTF. KATAOKA PCG - AF 0018 & 495,00 & & & & & & 0,00 & 0 & 0,00 & 0,00 & 0,00 \\
\hline 0220RP22 & C.PM RTF. KATAOKA R4MG - BP 32606 & 495,00 & & & & & & 0,00 & 0 & 0,00 & 0,00 & 0,00 \\
\hline 0220RP23 & C.PM RTF. KATAOKA R4MG - BP 28724 & 494,50 & & & & & & 0,50 & 1 & 0,50 & 0,50 & 0,50 \\
\hline 0220RP24 & C.PM RTF. KATAOKA PCG - AF 0017 & 482,02 & 1 & 2,13 & & & & 12,98 & 3 & 12,98 & 22,13 & 12,98 \\
\hline 0220RP27 & C.RP RTF. KATAOKA R7 - BP 900573 & 492,25 & 2 & 2,75 & & & & 2,75 & 2 & 2,75 & 2,75 & 2,75 \\
\hline 0220RP28 & C.RP RTF. KATAOKA R7 - BP 900113 & 494,18 & 1 & 0,82 & & & & 0,82 & 1 & 0,82 & 0,82 & 0,82 \\
\hline 0220RP29 & C.RP RET. PERFIL PCG - BP 901518 & 495,00 & & & & & & 0,00 & 0 & 0,00 & 0,00 & 0,00 \\
\hline \multicolumn{2}{|r|}{ TOTAIS } & $11.772,16$ & 20 & 95,49 & 4 & 12,35 & 21,50 & 107,84 & 24 & 107,84 & 116,99 & 107,84 \\
\hline
\end{tabular}


RETÍFICA DE PERFIL - QUADRO GERAL DE DADOS

Período de Observação: 01/12/2004 a 31/12/2004

Dias Úteis: $\quad 15$

Horas Dia: $\quad 22,5$

Horas Disponíveis do Período: $\quad 337,50 \quad$ h/maq

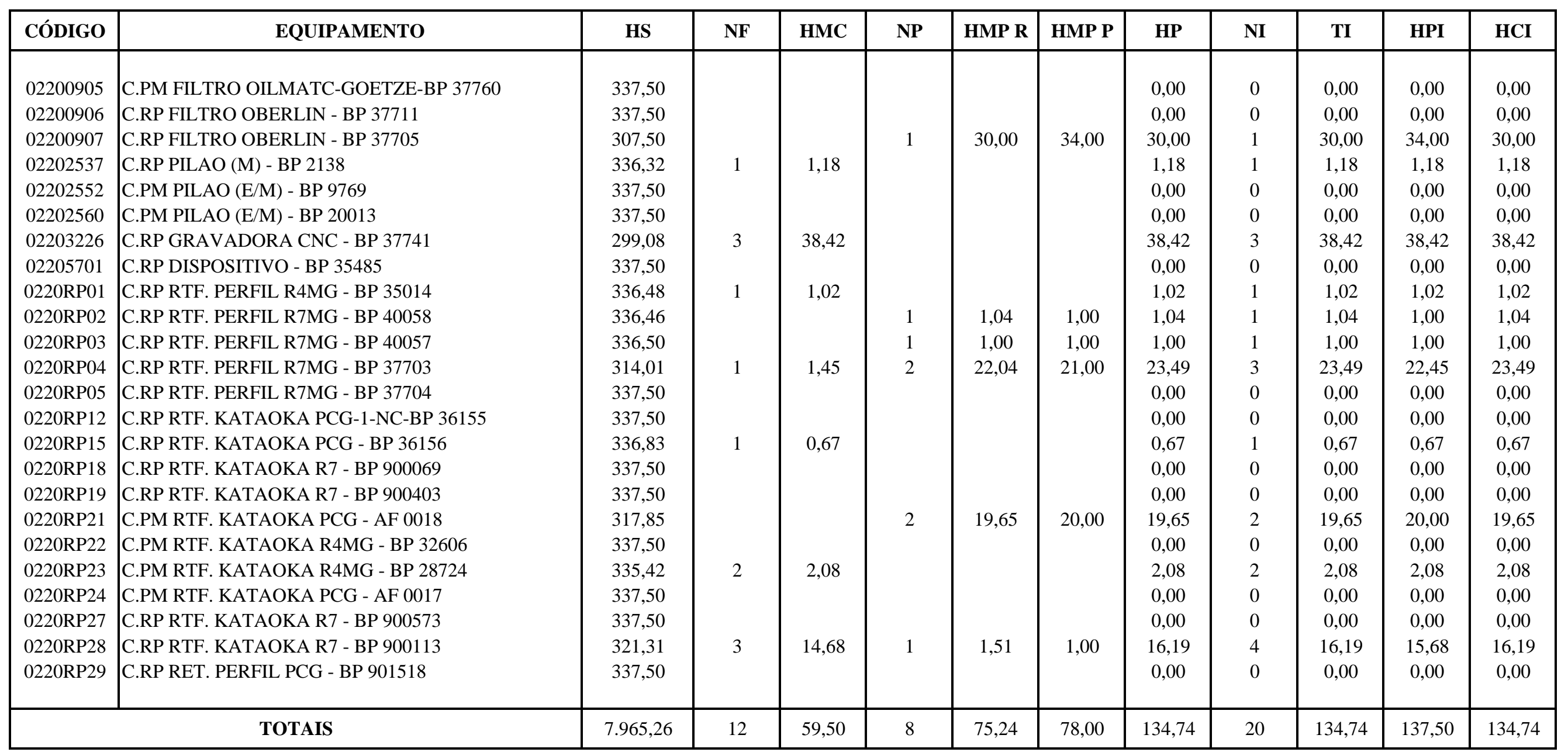


RETÍFICA DE PERFIL - QUADRO GERAL DE DADOS

Período de Observação: 01/01/2005 a 31/01/2005

Dias Úteis: $\quad 23$

Horas Dia: $\quad 22,5$

Horas Disponíveis do Período: $\quad$ 517,50 h/maq

\begin{tabular}{|c|c|c|c|c|c|c|c|c|c|c|c|c|}
\hline CÓDIGO & EQUIPAMENTO & HS & NF & HMC & NP & HMP R & HMP P & HP & NI & TI & HPI & HCI \\
\hline 02200905 & C.PM FILTRO OILMATC-GOETZE-BP 37760 & 517,50 & \multirow{6}{*}{1} & \multirow{6}{*}{0,53} & \multirow{8}{*}{2} & \multirow{8}{*}{14,85} & \multirow{8}{*}{16,00} & 0,00 & 0 & 0,00 & 0,00 & 0,00 \\
\hline 02200906 & C.RP FILTRO OBERLIN - BP 37711 & 517,50 & & & & & & 0,00 & 0 & 0,00 & 0,00 & 0,00 \\
\hline 02200907 & C.RP FILTRO OBERLIN - BP 37705 & 516,97 & & & & & & 0,53 & 1 & 0,53 & 0,53 & 0,53 \\
\hline 02202537 & C.RP PILAO (M) - BP 2138 & 517,50 & & & & & & 0,00 & 0 & 0,00 & 0,00 & 0,00 \\
\hline 02202552 & C.PM PILAO (E/M) - BP 9769 & 517,50 & & & & & & 0,00 & 0 & 0,00 & 0,00 & 0,00 \\
\hline 02202560 & C.PM PILAO (E/M) - BP 20013 & 517,50 & & & & & & 0,00 & 0 & 0,00 & 0,00 & 0,00 \\
\hline 02203226 & C.RP GRAVADORA CNC - BP 37741 & 500,58 & 1 & 2,07 & & & & 16,92 & 3 & 16,92 & 18,07 & 16,92 \\
\hline 02205701 & C.RP DISPOSITIVO - BP 35485 & 517,50 & & & & & & 0,00 & 0 & 0,00 & 0,00 & 0,00 \\
\hline 0220RP01 & C.RP RTF. PERFIL R4MG - BP 35014 & 501,68 & 6 & 6,57 & \multirow[t]{3}{*}{1} & \multirow[t]{3}{*}{9,25} & \multirow[t]{3}{*}{2,00} & 15,82 & 7 & 15,82 & 8,57 & 15,82 \\
\hline 0220RP02 & C.RP RTF. PERFIL R7MG - BP 40058 & 516,47 & 1 & 1,03 & & & & 1,03 & 1 & 1,03 & 1,03 & 1,03 \\
\hline 0220RP03 & C.RP RTF. PERFIL R7MG - BP 40057 & 504,95 & 5 & 12,55 & & & & 12,55 & 5 & 12,55 & 12,55 & 12,55 \\
\hline 0220RP04 & C.RP RTF. PERFIL R7MG - BP 37703 & 511,89 & 2 & 2,61 & 1 & 3,00 & 3,00 & 5,61 & 3 & 5,61 & 5,61 & 5,61 \\
\hline 0220RP05 & C.RP RTF. PERFIL R7MG - BP 37704 & 512,04 & \multirow[t]{3}{*}{2} & \multirow[t]{3}{*}{1,46} & 1 & 4,00 & 3,00 & 5,46 & 3 & 5,46 & 4,46 & 5,46 \\
\hline 0220RP12 & C.RP RTF. KATAOKA PCG-1-NC-BP 36155 & 510,00 & & & 1 & 7,50 & 2,00 & 7,50 & 1 & 7,50 & 2,00 & 7,50 \\
\hline 0220RP15 & C.RP RTF. KATAOKA PCG - BP 36156 & 514,50 & & & 1 & 3,00 & 2,00 & 3,00 & 1 & 3,00 & 2,00 & 3,00 \\
\hline 0220RP18 & C.RP RTF. KATAOKA R7 - BP 900069 & 509,89 & 3 & 5,61 & 2 & 2,00 & 4,00 & 7,61 & 5 & 7,61 & 9,61 & 7,61 \\
\hline 0220RP19 & C.RP RTF. KATAOKA R7 - BP 900403 & 514,37 & \multirow[t]{3}{*}{2} & \multirow[t]{3}{*}{2,13} & \multirow[t]{5}{*}{1} & \multirow[t]{5}{*}{1,00} & \multirow[t]{5}{*}{3,00} & 3,13 & 3 & 3,13 & 5,13 & 3,13 \\
\hline 0220RP21 & C.PM RTF. KATAOKA PCG - AF 0018 & 517,50 & & & & & & 0,00 & 0 & 0,00 & 0,00 & 0,00 \\
\hline 0220RP22 & C.PM RTF. KATAOKA R4MG - BP 32606 & 517,50 & & & & & & 0,00 & 0 & 0,00 & 0,00 & 0,00 \\
\hline 0220RP23 & C.PM RTF. KATAOKA R4MG - BP 28724 & 515,63 & \multirow[t]{2}{*}{1} & \multirow[t]{2}{*}{1,87} & & & & 1,87 & 1 & 1,87 & 1,87 & 1,87 \\
\hline 0220RP24 & C.PM RTF. KATAOKA PCG - AF 0017 & 517,50 & & & & & & 0,00 & 0 & 0,00 & 0,00 & 0,00 \\
\hline 0220RP27 & C.RP RTF. KATAOKA R7 - BP 900573 & 510,99 & \multirow[t]{3}{*}{2} & \multirow[t]{3}{*}{3,48} & 1 & 3,03 & 3,00 & 6,51 & 3 & 6,51 & 6,48 & 6,51 \\
\hline 0220RP28 & C.RP RTF. KATAOKA R7 - BP 900113 & 514,48 & & & 1 & 3,02 & 3,00 & 3,02 & 1 & 3,02 & 3,00 & 3,02 \\
\hline 0220RP29 & C.RP RET. PERFIL PCG - BP 901518 & 514,25 & & & 1 & 3,25 & 3,00 & 3,25 & 1 & 3,25 & 3,00 & 3,25 \\
\hline & TOTAIS & $12.326,19$ & 26 & 39,91 & 13 & 53,90 & 44,00 & 93,81 & 39 & 93,81 & 83,91 & 93,81 \\
\hline
\end{tabular}


RETÍFICA DE PERFIL - QUADRO GERAL DE DADOS

Período de Observação: 01/02/2005 a 28/02/2005

Dias Úteis: 22

Horas Dia: $\quad 22,5$

Horas Disponíveis do Período: $\quad 495,00 \quad$ h/maq

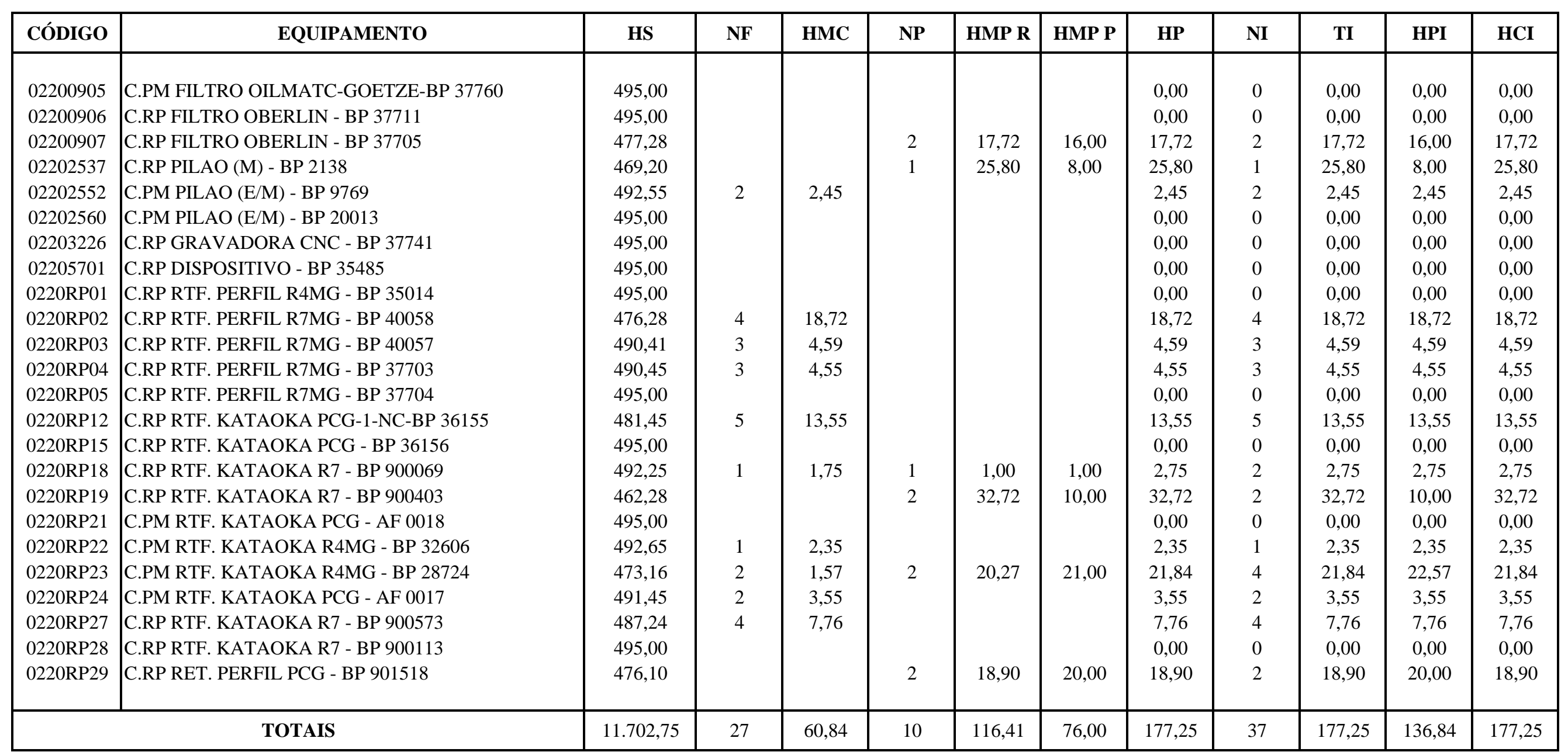


RETÍFICA DE PERFIL - QUADRO GERAL DE DADOS

Período de Observação: 01/03/2005 a 31/03/2005

Dias Úteis: 23

Horas Dia: $\quad 22,5$

Horas Disponíveis do Período: $\quad 517,50 \quad$ h/maq

\begin{tabular}{|c|c|c|c|c|c|c|c|c|c|c|c|c|}
\hline CÓDIGO & EQUIPAMENTO & HS & NF & HMC & $\mathbf{N P}$ & HMP R & HMP P & HP & NI & TI & HPI & HCI \\
\hline 02200905 & C.PM FILTRO OILMATC-GOETZE-BP 37760 & 517,50 & \multirow{6}{*}{1} & \multirow{5}{*}{0,83} & \multirow{9}{*}{2} & \multirow{9}{*}{10,61} & \multirow{9}{*}{16,00} & 0,00 & 0 & 0,00 & 0,00 & 0,00 \\
\hline 02200906 & C.RP FILTRO OBERLIN - BP 37711 & 506,06 & & & & & & 11,44 & 3 & 11,44 & 16,83 & 11,44 \\
\hline 02200907 & C.RP FILTRO OBERLIN - BP 37705 & 517,50 & & & & & & 0,00 & 0 & 0,00 & 0,00 & 0,00 \\
\hline 02202537 & C.RP PILAO (M) - BP 2138 & 517,50 & & & & & & 0,00 & 0 & 0,00 & 0,00 & 0,00 \\
\hline 02202552 & C.PM PILAO (E/M) - BP 9769 & 517,50 & & & & & & 0,00 & 0 & 0,00 & 0,00 & 0,00 \\
\hline 02202560 & C.PM PILAO (E/M) - BP 20013 & 517,50 & & \multirow{3}{*}{1,40} & & & & 0,00 & 0 & 0,00 & 0,00 & 0,00 \\
\hline 02203226 & C.RP GRAVADORA CNC - BP 37741 & 516,10 & \multirow[t]{2}{*}{1} & & & & & 1,40 & 1 & 1,40 & 1,40 & 1,40 \\
\hline 02205701 & C.RP DISPOSITIVO - BP 35485 & 517,50 & & & & & & 0,00 & 0 & 0,00 & 0,00 & 0,00 \\
\hline 0220RP01 & C.RP RTF. PERFIL R4MG - BP 35014 & 507,63 & 2 & 9,87 & & & & 9,87 & 2 & 9,87 & 9,87 & 9,87 \\
\hline 0220RP02 & C.RP RTF. PERFIL R7MG - BP 40058 & 496,23 & 2 & 1,23 & 2 & \multirow{3}{*}{$\begin{array}{c}20,04 \\
65,76 \\
1,00\end{array}$} & \multirow{4}{*}{$\begin{array}{c}21,00 \\
21,00 \\
1,00\end{array}$} & 21,27 & 4 & 21,27 & 22,23 & 21,27 \\
\hline 0220RP03 & C.RP RTF. PERFIL R7MG - BP 40057 & 441,83 & 8 & 9,91 & 2 & & & 75,67 & 10 & 75,67 & 30,91 & 75,67 \\
\hline 0220RP04 & C.RP RTF. PERFIL R7MG - BP 37703 & 508,61 & 3 & 7,89 & 1 & & & 8,89 & 4 & 8,89 & 8,89 & 8,89 \\
\hline 0220RP05 & C.RP RTF. PERFIL R7MG - BP 37704 & 513,05 & 1 & 4,45 & & & & 4,45 & 1 & 4,45 & 4,45 & 4,45 \\
\hline 0220RP12 & C.RP RTF. KATAOKA PCG-1-NC-BP 36155 & 517,50 & & & & & & 0,00 & 0 & 0,00 & 0,00 & 0,00 \\
\hline 0220RP15 & C.RP RTF. KATAOKA PCG - BP 36156 & 515,48 & 2 & 2,02 & & & & 2,02 & 2 & 2,02 & 2,02 & 2,02 \\
\hline 0220RP18 & C.RP RTF. KATAOKA R7 - BP 900069 & 515,33 & 1 & 2,17 & & & & 2,17 & 1 & 2,17 & 2,17 & 2,17 \\
\hline 0220RP19 & C.RP RTF. KATAOKA R7 - BP 900403 & 517,50 & & & & & & 0,00 & 0 & 0,00 & 0,00 & 0,00 \\
\hline 0220RP21 & C.PM RTF. KATAOKA PCG - AF 0018 & 517,50 & & & & & & 0,00 & 0 & 0,00 & 0,00 & 0,00 \\
\hline 0220RP22 & C.PM RTF. KATAOKA R4MG - BP 32606 & 490,37 & 3 & 6,98 & 2 & 20,15 & 21,00 & 27,13 & 5 & 27,13 & 27,98 & 27,13 \\
\hline 0220RP23 & C.PM RTF. KATAOKA R4MG - BP 28724 & 517,50 & & & & & & 0,00 & 0 & 0,00 & 0,00 & 0,00 \\
\hline 0220RP24 & C.PM RTF. KATAOKA PCG - AF 0017 & 517,50 & & & & & & 0,00 & 0 & 0,00 & 0,00 & 0,00 \\
\hline 0220RP27 & C.RP RTF. KATAOKA R7 - BP 900573 & 513,23 & 4 & 4,27 & & & & 4,27 & 4 & 4,27 & 4,27 & 4,27 \\
\hline 0220RP28 & C.RP RTF. KATAOKA R7 - BP 900113 & 497,52 & & & 3 & 19,98 & 22,00 & 19,98 & 3 & 19,98 & 22,00 & 19,98 \\
\hline 0220RP29 & C.RP RET. PERFIL PCG - BP 901518 & 515,30 & 1 & 2,20 & & & & 2,20 & 1 & 2,20 & 2,20 & 2,20 \\
\hline & TOTAIS & $12.229,24$ & 29 & 53,22 & 12 & 137,54 & 102,00 & 190,76 & 41 & 190,76 & 155,22 & 190,76 \\
\hline
\end{tabular}


RETÍFICA DE PERFIL - QUADRO GERAL DE DADOS

Período de Observação: 01/04/2005 a 30/04/2005

Dias Úteis: 23

Horas Dia: $\quad 22,5$

Horas Disponíveis do Período: $\quad 517,50 \quad$ h/maq

\begin{tabular}{|c|c|c|c|c|c|c|c|c|c|c|c|c|}
\hline CÓDIGO & EQUIPAMENTO & HS & NF & HMC & NP & HMP R & HMP P & HP & NI & TI & HPI & HCI \\
\hline $\begin{array}{l}02200905 \\
02200906 \\
02200907 \\
02202537 \\
02202552 \\
02202560 \\
02203226 \\
02205701 \\
0220 \text { RP01 } \\
\text { 0220RP02 } \\
\text { 0220RP03 } \\
\text { 0220RP04 } \\
\text { 0220RP05 } \\
\text { 0220RP12 } \\
\text { 0220RP15 } \\
\text { 0220RP18 } \\
\text { 0220RP19 } \\
\text { 0220RP21 } \\
\text { 0220RP22 } \\
\text { 0220RP23 } \\
\text { 0220RP24 } \\
\text { 0220RP27 } \\
\text { 0220RP28 } \\
\text { 0220RP29 }\end{array}$ & $\begin{array}{l}\text { C.PM FILTRO OILMATC-GOETZE-BP } 37760 \\
\text { C.RP FILTRO OBERLIN - BP } 37711 \\
\text { C.RP FILTRO OBERLIN - BP } 37705 \\
\text { C.RP PILAO (M) - BP } 2138 \\
\text { C.PM PILAO (E/M) - BP } 9769 \\
\text { C.PM PILAO (E/M) - BP } 20013 \\
\text { C.RP GRAVADORA CNC - BP } 37741 \\
\text { C.RP DISPOSITIVO - BP } 35485 \\
\text { C.RP RTF. PERFIL R4MG - BP } 35014 \\
\text { C.RP RTF. PERFIL R7MG - BP } 40058 \\
\text { C.RP RTF. PERFIL R7MG - BP } 40057 \\
\text { C.RP RTF. PERFIL R7MG - BP } 37703 \\
\text { C.RP RTF. PERFIL R7MG - BP } 37704 \\
\text { C.RP RTF. KATAOKA PCG-1-NC-BP } 36155 \\
\text { C.RP RTF. KATAOKA PCG - BP } 36156 \\
\text { C.RP RTF. KATAOKA R7 - BP } 900069 \\
\text { C.RP RTF. KATAOKA R7 - BP } 900403 \\
\text { C.PM RTF. KATAOKA PCG - AF } 0018 \\
\text { C.PM RTF. KATAOKA R4MG - BP } 32606 \\
\text { C.PM RTF. KATAOKA R4MG - BP } 28724 \\
\text { C.PM RTF. KATAOKA PCG - AF } 0017 \\
\text { C.RP RTF. KATAOKA R7 - BP } 900573 \\
\text { C.RP RTF. KATAOKA R7 - BP } 900113 \\
\text { C.RP RET. PERFIL PCG - BP 901518 }\end{array}$ & $\begin{array}{l}517,50 \\
517,50 \\
517,50 \\
517,50 \\
516,43 \\
517,50 \\
516,15 \\
517,50 \\
517,50 \\
516,48 \\
515,63 \\
513,70 \\
511,45 \\
507,00 \\
506,38 \\
516,62 \\
507,18 \\
515,63 \\
514,63 \\
473,04 \\
517,50 \\
511,26 \\
517,50 \\
517,50\end{array}$ & $\begin{array}{l}1 \\
1 \\
4 \\
3 \\
1 \\
\\
1 \\
7 \\
1 \\
2 \\
4\end{array}$ & $\begin{array}{c} \\
1,02 \\
0,72 \\
3,80 \\
6,05 \\
10,50 \\
\\
0,88 \\
10,32 \\
1,87 \\
2,87 \\
44,46 \\
\\
6,24\end{array}$ & 1 & 1,15 & 1,00 & $\begin{array}{c}0,00 \\
0,00 \\
0,00 \\
0,00 \\
1,07 \\
0,00 \\
1,35 \\
0,00 \\
0,00 \\
1,02 \\
1,87 \\
3,80 \\
6,05 \\
10,50 \\
11,12 \\
0,88 \\
10,32 \\
1,87 \\
2,87 \\
44,46 \\
0,00 \\
6,24 \\
0,00 \\
0,00\end{array}$ & $\begin{array}{l}0 \\
0 \\
0 \\
0 \\
1 \\
0 \\
1 \\
0 \\
0 \\
1 \\
2 \\
4 \\
3 \\
1 \\
2 \\
1 \\
7 \\
1 \\
2 \\
4 \\
0 \\
3 \\
0 \\
0\end{array}$ & $\begin{array}{c}0,00 \\
0,00 \\
0,00 \\
0,00 \\
1,07 \\
0,00 \\
1,35 \\
0,00 \\
0,00 \\
1,02 \\
1,87 \\
3,80 \\
6,05 \\
10,50 \\
11,12 \\
0,88 \\
10,32 \\
1,87 \\
2,87 \\
44,46 \\
0,00 \\
6,24 \\
0,00 \\
0,00\end{array}$ & $\begin{array}{c}0,00 \\
0,00 \\
0,00 \\
0,00 \\
1,07 \\
0,00 \\
1,35 \\
0,00 \\
0,00 \\
1,02 \\
1,72 \\
3,80 \\
6,05 \\
10,50 \\
20,00 \\
0,88 \\
10,32 \\
1,87 \\
2,87 \\
44,46 \\
0,00 \\
6,24 \\
0,00 \\
0,00\end{array}$ & $\begin{array}{c}0,00 \\
0,00 \\
0,00 \\
0,00 \\
1,07 \\
0,00 \\
1,35 \\
0,00 \\
0,00 \\
1,02 \\
1,87 \\
3,80 \\
6,05 \\
10,50 \\
11,12 \\
0,88 \\
10,32 \\
1,87 \\
2,87 \\
44,46 \\
0,00 \\
6,24 \\
0,00 \\
0,00\end{array}$ \\
\hline & TOTAIS & $12.316,58$ & 30 & 91,15 & 3 & 12,27 & 21,00 & 103,42 & 33 & 103,42 & 112,15 & 103,42 \\
\hline
\end{tabular}


RETÍFICA DE PERFIL - QUADRO GERAL DE DADOS

Período de Observação: 01/05/2005 a 31/05/2005

Dias Úteis: $\quad 23$

Horas Dia: $\quad 22,5$

Horas Disponíveis do Período: $\quad 517,50 \quad$ h/maq

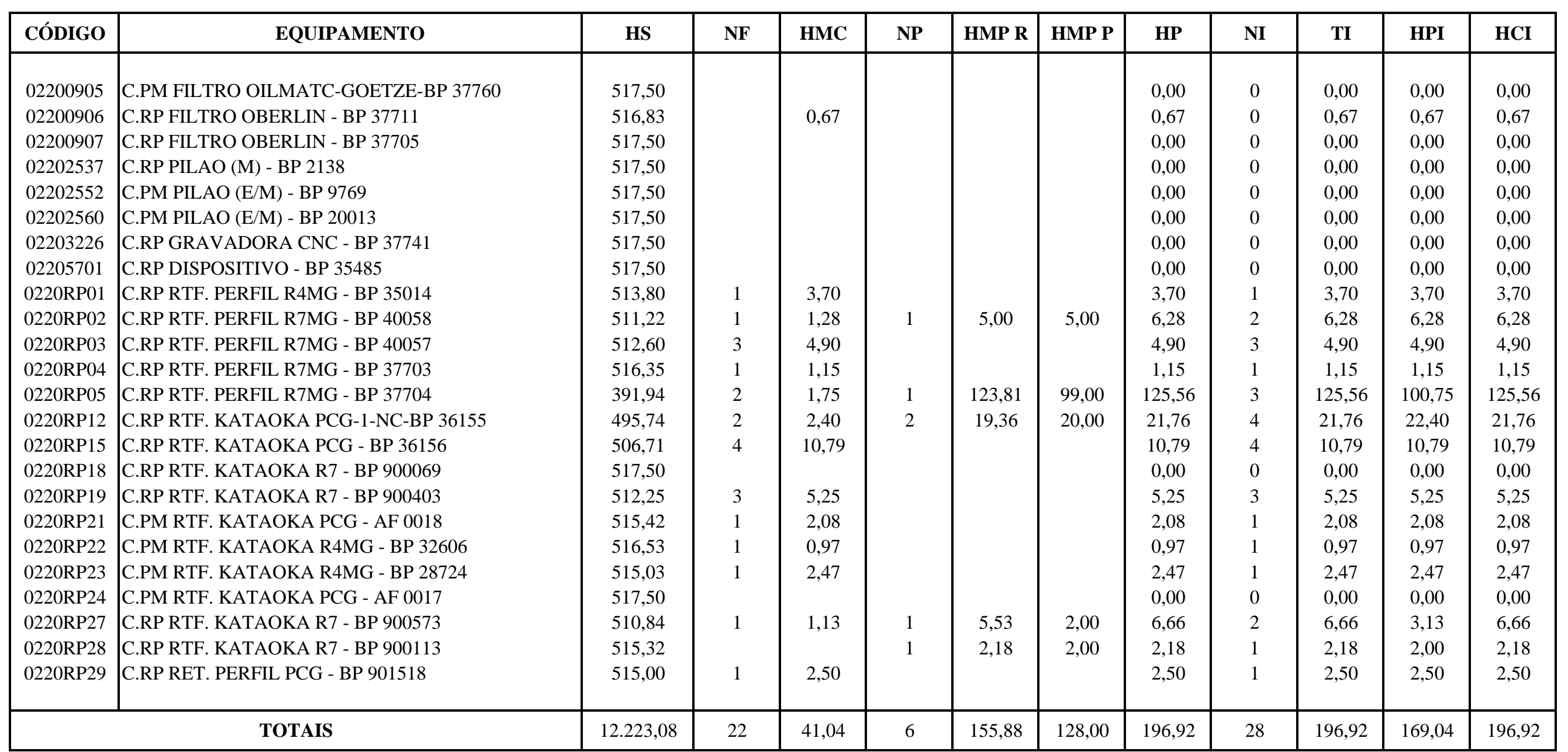


RETÍFICA DE PERFIL - QUADRO GERAL DE DADOS

Período de Observação: 01/06/2005 a 30/06/2005

Dias Úteis: $\quad 24$

Horas Dia: $\quad 22,5$

Horas Disponíveis do Período: $\quad 540,00 \quad$ h/maq

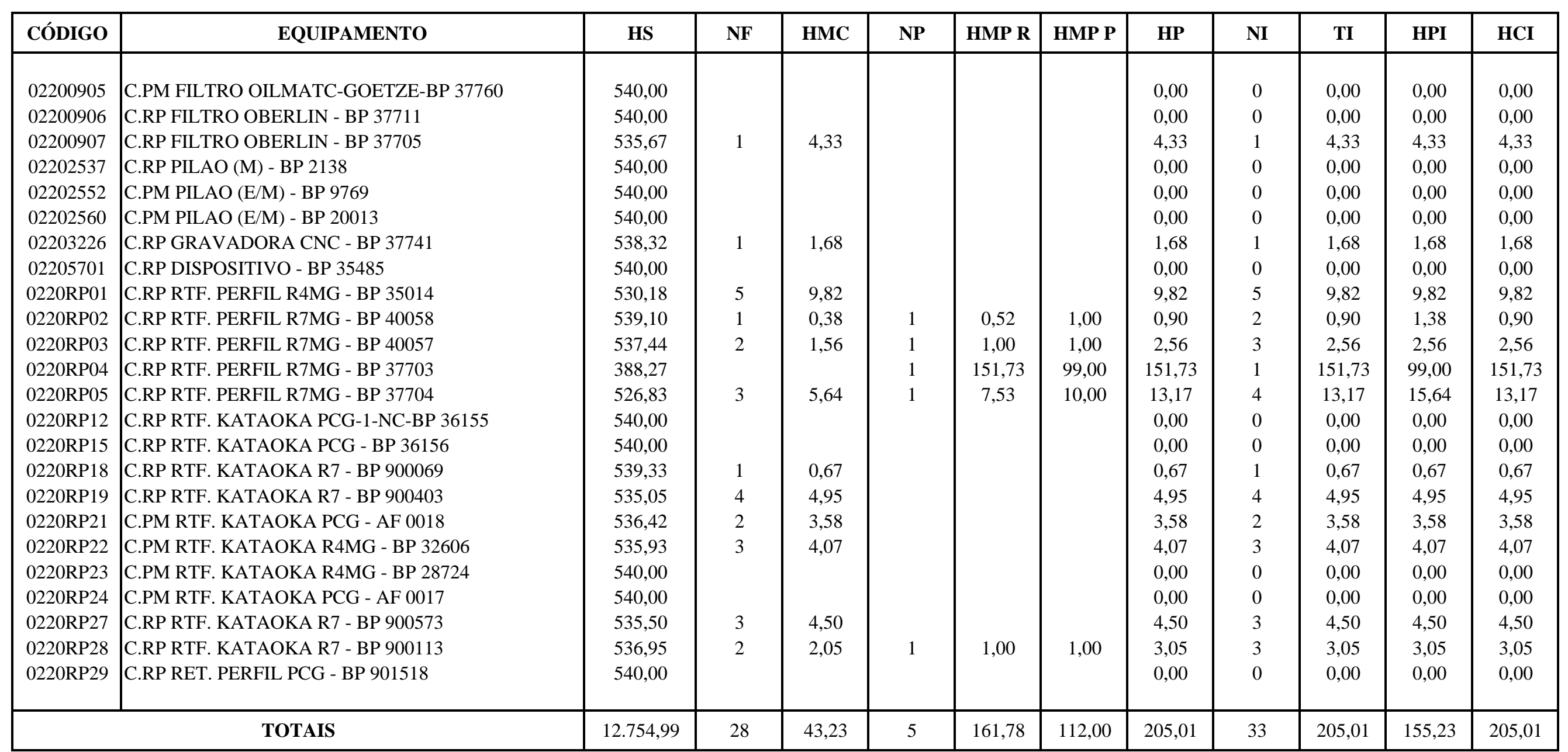


RETÍFICA DE PERFIL - QUADRO GERAL DE DADOS

Período de Observação: 01/06/2004 a 30/06/2005

Dias Úteis: 292

Horas Dia: $\quad 22,5$

Horas Disponíveis do Período: $\quad 6.570,00 \quad$ h/maq

\begin{tabular}{|c|c|c|c|c|c|c|c|c|c|c|c|c|}
\hline CÓDIGO & EQUIPAMENTO & HS & NF & HMC & NP & HMP R & HMP P & HP & NI & TI & HPI & HCI \\
\hline 02200905 & C.PM FILTRO OILMATC-GOETZE-BP 37760 & $6.570,00$ & & & & & & 0,00 & 0 & 0,00 & 0,00 & 0,00 \\
\hline 02200906 & C.RP FILTRO OBERLIN - BP 37711 & $6.557,89$ & 1 & 1,50 & 2 & 10,61 & 16,00 & 12,11 & 3 & 12,11 & 17,50 & 12,11 \\
\hline 02200907 & C.RP FILTRO OBERLIN - BP 37705 & $6.515,19$ & 3 & 5,81 & 4 & 49,00 & 50,00 & 54,81 & 7 & 54,81 & 55,81 & 54,81 \\
\hline 02202537 & C.RP PILAO (M) - BP 2138 & $6.540,14$ & 2 & 4,06 & 1 & 25,80 & 8,00 & 29,86 & 3 & 29,86 & 12,06 & 29,86 \\
\hline 02202552 & C.PM PILAO (E/M) - BP 9769 & $6.563,01$ & 4 & 6,99 & & & & 6,99 & 4 & 6,99 & 6,99 & 6,99 \\
\hline 02202560 & C.PM PILAO (E/M) - BP 20013 & $6.567,43$ & 1 & 2,57 & & & & 2,57 & 1 & 2,57 & 2,57 & 2,57 \\
\hline 02203226 & C.RP GRAVADORA CNC - BP 37741 & $6.466,47$ & 17 & 88,68 & 2 & 14,85 & 16,00 & 103,53 & 19 & 103,53 & 104,68 & 103,53 \\
\hline 02205701 & C.RP DISPOSITIVO - BP 35485 & $6.570,00$ & & & & & & 0,00 & 0 & 0,00 & 0,00 & 0,00 \\
\hline 0220RP01 & C.RP RTF. PERFIL R4MG - BP 35014 & $6.487,34$ & 29 & 50,19 & 5 & 32,47 & 25,50 & 82,66 & 34 & 82,66 & 75,69 & 82,66 \\
\hline 0220RP02 & C.RP RTF. PERFIL R7MG - BP 40058 & $6.456,71$ & 22 & 75,41 & 8 & 37,88 & 31,00 & 113,29 & 30 & 113,29 & 106,41 & 113,29 \\
\hline 0220RP03 & C.RP RTF. PERFIL R7MG - BP 40057 & $6.409,04$ & 33 & 80,07 & 8 & 80,89 & 27,00 & 160,96 & 41 & 160,96 & 107,07 & 160,96 \\
\hline 0220RP04 & C.RP RTF. PERFIL R7MG - BP 37703 & $6.318,71$ & 32 & 58,76 & 9 & 192,53 & 127,50 & 251,29 & 41 & 251,29 & 186,26 & 251,29 \\
\hline 0220RP05 & C.RP RTF. PERFIL R7MG - BP 37704 & $6.285,27$ & 27 & 62,70 & 7 & 222,03 & 134,50 & 284,73 & 34 & 284,73 & 197,20 & 284,73 \\
\hline 0220RP12 & C.RP RTF. KATAOKA PCG-1-NC-BP 36155 & $6.510,79$ & 10 & 30,35 & 4 & 28,86 & 23,00 & 59,21 & 14 & 59,21 & 53,35 & 59,21 \\
\hline 0220RP15 & C.RP RTF. KATAOKA PCG - BP 36156 & $6.539,35$ & 7 & 13,48 & 4 & 17,17 & 23,00 & 30,65 & 11 & 30,65 & 36,48 & 30,65 \\
\hline 0220RP18 & C.RP RTF. KATAOKA R7 - BP 900069 & $6.523,68$ & 19 & 34,07 & 6 & 12,25 & 8,00 & 46,32 & 25 & 46,32 & 42,07 & 46,32 \\
\hline 0220RP19 & C.RP RTF. KATAOKA R7 - BP 900403 & $6.456,50$ & 24 & 45,93 & 6 & 67,57 & 35,00 & 113,50 & 30 & 113,50 & 80,93 & 113,50 \\
\hline 0220RP21 & C.PM RTF. KATAOKA PCG - AF 0018 & $6.533,73$ & 8 & 11,65 & 3 & 24,62 & 21,00 & 36,27 & 11 & 36,27 & 32,65 & 36,27 \\
\hline 0220RP22 & C.PM RTF. KATAOKA R4MG - BP 32606 & $6.521,99$ & 13 & 20,86 & 3 & 27,15 & 22,00 & 48,01 & 16 & 48,01 & 42,86 & 48,01 \\
\hline $0220 \mathrm{RP} 23$ & C.PM RTF. KATAOKA R4MG - BP 28724 & $6.374,49$ & 18 & 74,48 & 5 & 121,03 & 86,50 & 195,51 & 23 & 195,51 & 160,98 & 195,51 \\
\hline 0220RP24 & C.PM RTF. KATAOKA PCG - AF 0017 & $6.497,01$ & 6 & 52,32 & 4 & 20,67 & 22,00 & 72,99 & 10 & 72,99 & 74,32 & 72,99 \\
\hline 0220RP27 & C.RP RTF. KATAOKA R7 - BP 900573 & $6.466,01$ & 33 & 63,48 & 5 & 40,51 & 27,00 & 103,99 & 38 & 103,99 & 90,48 & 103,99 \\
\hline 0220RP28 & C.RP RTF. KATAOKA R7 - BP 900113 & $6.434,42$ & 19 & 36,89 & 12 & 98,69 & 72,00 & 135,58 & 31 & 135,58 & 108,89 & 135,58 \\
\hline 0220RP29 & C.RP RET. PERFIL PCG - BP 901518 & $6.536,43$ & 2 & 4,70 & 4 & 28,87 & 24,00 & 33,57 & 6 & 33,57 & 28,70 & 33,57 \\
\hline & TOTAIS & $155.701,60$ & 330 & 824,95 & 102 & $1.153,45$ & 799,00 & $1.978,40$ & 432 & $1.978,40$ & $1.623,95$ & $1.978,40$ \\
\hline
\end{tabular}


RETÍFICA DE PERFIL - QUADRO RESUMO DE DADOS

HORAS DISPONÍVEIS

(Período de Observação: 01/06/2004 à 30/06/2005)

\begin{tabular}{|c|c|c|c|c|c|c|c|c|c|c|c|c|c|c|c|}
\hline CÓDIGO & EQUIPAMENTO & jun/04 & jul/04 & ago/04 & set/04 & out/04 & nov/04 & dez/04 & jan/05 & fev/05 & mar/05 & abr/05 & mai/05 & jun/05 & $2004 / 2005$ \\
\hline 0220RP23 & C.PM RTF. KATAOKA R4MG - BP 28724 & 517,50 & 562,50 & 540,00 & 517,50 & 495,00 & 495,00 & 337,50 & 517,50 & 495,00 & 517,50 & 517,50 & 517,50 & 540,00 & $6.570,00$ \\
\hline 0220RP29 & C.RP RET. PERFIL PCG - BP 901518 & 517,50 & 562,50 & 540,00 & 517,50 & 495,00 & 495,00 & 337,50 & 517,50 & 495,00 & 517,50 & 517,50 & 517,50 & 540,00 & $6.570,00$ \\
\hline 0220RP28 & C.RP RTF. KATAOKA R7 - BP 900113 & 517,50 & 562,50 & 540,00 & 517,50 & 495,00 & 495,00 & 337,50 & 517,50 & 495,00 & 517,50 & 517,50 & 517,50 & 540,00 & $6.570,00$ \\
\hline 0220RP19 & C.RP RTF. KATAOKA R7 - BP 900403 & 517,50 & 562,50 & 540,00 & 517,50 & 495,00 & 495,00 & 337,50 & 517,50 & 495,00 & 517,50 & 517,50 & 517,50 & 540,00 & $6.570,00$ \\
\hline 0220RP01 & C.RP RTF. PERFIL R4MG - BP 35014 & 517,50 & 562,50 & 540,00 & 517,50 & 495,00 & 495,00 & 337,50 & 517,50 & 495,00 & 517,50 & 517,50 & 517,50 & 540,00 & $6.570,00$ \\
\hline 0220RP04 & C.RP RTF. PERFIL R7MG - BP 37703 & 517,50 & 562,50 & 540,00 & 517,50 & 495,00 & 495,00 & 337,50 & 517,50 & 495,00 & 517,50 & 517,50 & 517,50 & 540,00 & $6.570,00$ \\
\hline 0220RP05 & C.RP RTF. PERFIL R7MG - BP 37704 & 517,50 & 562,50 & 540,00 & 517,50 & 495,00 & 495,00 & 337,50 & 517,50 & 495,00 & 517,50 & 517,50 & 517,50 & 540,00 & $6.570,00$ \\
\hline 0220RP03 & C.RP RTF. PERFIL R7MG - BP 40057 & 517,50 & 562,50 & 540,00 & 517,50 & 495,00 & 495,00 & 337,50 & 517,50 & 495,00 & 517,50 & 517,50 & 517,50 & 540,00 & $6.570,00$ \\
\hline 0220RP02 & C.RP RTF. PERFIL R7MG - BP 40058 & 517,50 & 562,50 & 540,00 & 517,50 & 495,00 & 495,00 & 337,50 & 517,50 & 495,00 & 517,50 & 517,50 & 517,50 & 540,00 & $6.570,00$ \\
\hline 0220RP24 & C.PM RTF. KATAOKA PCG - AF 0017 & 517,50 & 562,50 & 540,00 & 517,50 & 495,00 & 495,00 & 337,50 & 517,50 & 495,00 & 517,50 & 517,50 & 517,50 & 540,00 & $6.570,00$ \\
\hline 0220RP21 & C.PM RTF. KATAOKA PCG - AF 0018 & 517,50 & 562,50 & 540,00 & 517,50 & 495,00 & 495,00 & 337,50 & 517,50 & 495,00 & 517,50 & 517,50 & 517,50 & 540,00 & $6.570,00$ \\
\hline 0220RP22 & C.PM RTF. KATAOKA R4MG - BP 32606 & 517,50 & 562,50 & 540,00 & 517,50 & 495,00 & 495,00 & 337,50 & 517,50 & 495,00 & 517,50 & 517,50 & 517,50 & 540,00 & $6.570,00$ \\
\hline 02200907 & C.RP FILTRO OBERLIN - BP 37705 & 517,50 & 562,50 & 540,00 & 517,50 & 495,00 & 495,00 & 337,50 & 517,50 & 495,00 & 517,50 & 517,50 & 517,50 & 540,00 & $6.570,00$ \\
\hline 02200906 & C.RP FILTRO OBERLIN - BP 37711 & 517,50 & 562,50 & 540,00 & 517,50 & 495,00 & 495,00 & 337,50 & 517,50 & 495,00 & 517,50 & 517,50 & 517,50 & 540,00 & $6.570,00$ \\
\hline 02203226 & C.RP GRAVADORA CNC - BP 37741 & 517,50 & 562,50 & 540,00 & 517,50 & 495,00 & 495,00 & 337,50 & 517,50 & 495,00 & 517,50 & 517,50 & 517,50 & 540,00 & $6.570,00$ \\
\hline 0220RP15 & C.RP RTF. KATAOKA PCG - BP 36156 & 517,50 & 562,50 & 540,00 & 517,50 & 495,00 & 495,00 & 337,50 & 517,50 & 495,00 & 517,50 & 517,50 & 517,50 & 540,00 & $6.570,00$ \\
\hline 0220RP12 & C.RP RTF. KATAOKA PCG-1-NC-BP 36155 & 517,50 & 562,50 & 540,00 & 517,50 & 495,00 & 495,00 & 337,50 & 517,50 & 495,00 & 517,50 & 517,50 & 517,50 & 540,00 & $6.570,00$ \\
\hline 0220RP18 & C.RP RTF. KATAOKA R7 - BP 900069 & 517,50 & 562,50 & 540,00 & 517,50 & 495,00 & 495,00 & 337,50 & 517,50 & 495,00 & 517,50 & 517,50 & 517,50 & 540,00 & $6.570,00$ \\
\hline 02200905 & C.PM FILTRO OILMATC-GOETZE-BP 37760 & 517,50 & 562,50 & 540,00 & 517,50 & 495,00 & 495,00 & 337,50 & 517,50 & 495,00 & 517,50 & 517,50 & 517,50 & 540,00 & $6.570,00$ \\
\hline 02202560 & C.PM PILAO (E/M) - BP 20013 & 517,50 & 562,50 & 540,00 & 517,50 & 495,00 & 495,00 & 337,50 & 517,50 & 495,00 & 517,50 & 517,50 & 517,50 & 540,00 & $6.570,00$ \\
\hline 02202552 & C.PM PILAO (E/M) - BP 9769 & 517,50 & 562,50 & 540,00 & 517,50 & 495,00 & 495,00 & 337,50 & 517,50 & 495,00 & 517,50 & 517,50 & 517,50 & 540,00 & $6.570,00$ \\
\hline 02205701 & C.RP DISPOSITIVO - BP 35485 & 517,50 & 562,50 & 540,00 & 517,50 & 495,00 & 495,00 & 337,50 & 517,50 & 495,00 & 517,50 & 517,50 & 517,50 & 540,00 & $6.570,00$ \\
\hline 02202537 & C.RP PILAO (M) - BP 2138 & 517,50 & 562,50 & 540,00 & 517,50 & 495,00 & 495,00 & 337,50 & 517,50 & 495,00 & 517,50 & 517,50 & 517,50 & 540,00 & $6.570,00$ \\
\hline 0220RP27 & C.RP RTF. KATAOKA R7 - BP 900573 & 517,50 & 562,50 & 540,00 & 517,50 & 495,00 & 495,00 & 337,50 & 517,50 & 495,00 & 517,50 & 517,50 & 517,50 & 540,00 & $6.570,00$ \\
\hline & TOTAIS & $12.420,00$ & $13.500,00$ & $12.960,00$ & $12.420,00$ & $11.880,00$ & $11.880,00$ & $8.100,00$ & $12.420,00$ & $11.880,00$ & $12.420,00$ & $12.420,00$ & $12.420,00$ & $12.960,00$ & $157.680,00$ \\
\hline
\end{tabular}


RETÍFICA DE PERFIL - QUADRO RESUMO DE DADOS

HORAS PARALISADAS / HORAS CONSUMIDAS NAS INTERVENÇÕES / TEMPO DAS INTERVENÇÕES

(Período de Observação: 01/06/2004 à 30/06/2005)

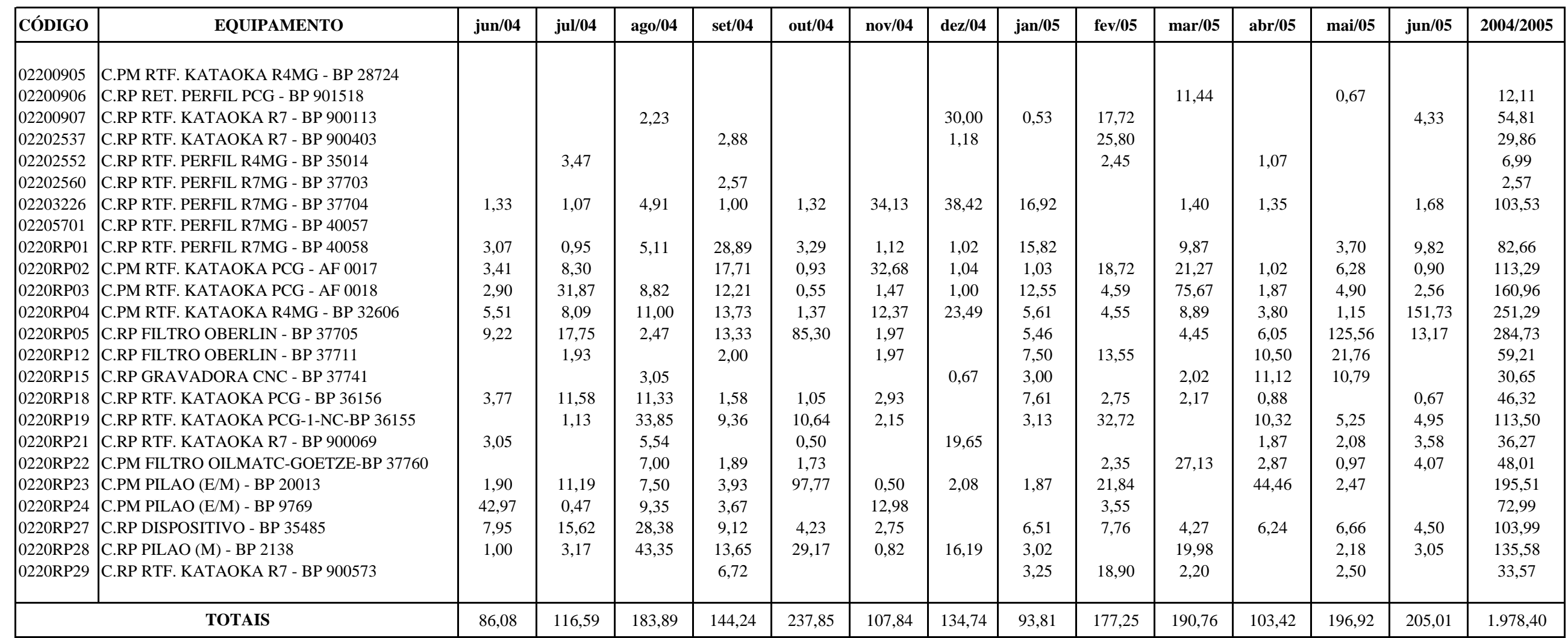


RETÍFICA DE PERFIL - QUADRO RESUMO DE DADOS

HORAS PARALISADAS / HORAS CONSUMIDAS NAS INTERVENÇÕES / TEMPO DAS INTERVENÇÕES

(Período de Observação: 01/06/2004 à 30/06/2005)

\begin{tabular}{|c|c|c|c|c|c|c|c|c|c|c|c|c|c|c|c|}
\hline CÓDIGO & EQUIPAMENTO & jun/04 & jul/04 & ago/04 & set/04 & out/04 & nov/04 & dez/04 & jan/05 & fev/05 & $\operatorname{mar} / 05$ & abr/05 & mai/05 & jun/05 & $2004 / 2005$ \\
\hline 02200905 & C.PM RTF. KATAOKA R4MG - BP 28724 & 0,00 & 0,00 & 0,00 & 0,00 & 0,00 & 0,00 & 0,00 & 0,00 & 0,00 & 0,00 & 0,00 & 0,00 & 0,00 & 0,00 \\
\hline 02200906 & C.RP RET. PERFIL PCG - BP 901518 & 0,00 & 0,00 & 0,00 & 0,00 & 0,00 & 0,00 & 0,00 & 0,00 & 0,00 & 16,83 & 0,00 & 0,67 & 0,00 & 17,50 \\
\hline 02200907 & C.RP RTF. KATAOKA R7 - BP 900113 & 0,00 & 0,00 & 0,95 & 0,00 & 0,00 & 0,00 & 34,00 & 0,53 & 16,00 & 0,00 & 0,00 & 0,00 & 4,33 & 55,81 \\
\hline 02202537 & C.RP RTF. KATAOKA R7 - BP 900403 & 0,00 & 0,00 & 0,00 & 2,88 & 0,00 & 0,00 & 1,18 & 0,00 & 8,00 & 0,00 & 0,00 & 0,00 & 0,00 & 12,06 \\
\hline 02202552 & C.RP RTF. PERFIL R4MG - BP 35014 & 0,00 & 3,47 & 0,00 & 0,00 & 0,00 & 0,00 & 0,00 & 0,00 & 2,45 & 0,00 & 1,07 & 0,00 & 0,00 & 6,99 \\
\hline 02202560 & C.RP RTF. PERFIL R7MG - BP 37703 & 0,00 & 0,00 & 0,00 & 2,57 & 0,00 & 0,00 & 0,00 & 0,00 & 0,00 & 0,00 & 0,00 & 0,00 & 0,00 & 2,57 \\
\hline 02203226 & C.RP RTF. PERFIL R7MG - BP 37704 & 1,33 & 1,07 & 4,91 & 1,00 & 1,32 & 34,13 & 38,42 & 18,07 & 0,00 & 1,40 & 1,35 & 0,00 & 1,68 & 104,68 \\
\hline 02205701 & C.RP RTF. PERFIL R7MG - BP 40057 & 0,00 & 0,00 & 0,00 & 0,00 & 0,00 & 0,00 & 0,00 & 0,00 & 0,00 & 0,00 & 0,00 & 0,00 & 0,00 & 0,00 \\
\hline 0220RP01 & C.RP RTF. PERFIL R7MG - BP 40058 & 3,07 & 0,95 & 5,11 & 29,55 & 2,91 & 1,12 & 1,02 & 8,57 & 0,00 & 9,87 & 0,00 & 3,70 & 9,82 & 75,69 \\
\hline 0220RP02 & C.PM RTF. KATAOKA PCG - AF 0017 & 3,13 & 8,30 & 0,00 & 9,71 & 0,93 & 32,68 & 1,00 & 1,03 & 18,72 & 22,23 & 1,02 & 6,28 & 1,38 & 106,41 \\
\hline 0220RP03 & C.PM RTF. KATAOKA PCG - AF 0018 & 2,78 & 31,87 & 8,82 & 3,35 & 0,55 & 1,47 & 1,00 & 12,55 & 4,59 & 30,91 & 1,72 & 4,90 & 2,56 & 107,07 \\
\hline 0220RP04 & C.PM RTF. KATAOKA R4MG - BP 32606 & 2,88 & 8,09 & 11,00 & 5,10 & 1,37 & 12,37 & 22,45 & 5,61 & 4,55 & 8,89 & 3,80 & 1,15 & 99,00 & 186,26 \\
\hline 0220RP05 & C.RP FILTRO OBERLIN - BP 37705 & 9,20 & 17,75 & 2,47 & 11,83 & 22,63 & 1,97 & 0,00 & 4,46 & 0,00 & 4,45 & 6,05 & 100,75 & 15,64 & 197,20 \\
\hline 0220RP12 & C.RP FILTRO OBERLIN - BP 37711 & 0,00 & 1,93 & 0,00 & 1,00 & 0,00 & 1,97 & 0,00 & 2,00 & 13,55 & 0,00 & 10,50 & 22,40 & 0,00 & 53,35 \\
\hline 0220RP15 & C.RP GRAVADORA CNC - BP 37741 & 0,00 & 0,00 & 1,00 & 0,00 & 0,00 & 0,00 & 0,67 & 2,00 & 0,00 & 2,02 & 20,00 & 10,79 & 0,00 & 36,48 \\
\hline 0220RP18 & C.RP RTF. KATAOKA PCG - BP 36156 & 3,77 & 11,58 & 5,08 & 1,58 & 1,05 & 2,93 & 0,00 & 9,61 & 2,75 & 2,17 & 0,88 & 0,00 & 0,67 & 42,07 \\
\hline 0220RP19 & C.RP RTF. KATAOKA PCG-1-NC-BP 36155 & 0,00 & 1,13 & 22,00 & 9,36 & 10,64 & 2,15 & 0,00 & 5,13 & 10,00 & 0,00 & 10,32 & 5,25 & 4,95 & 80,93 \\
\hline 0220RP21 & C.RP RTF. KATAOKA R7 - BP 900069 & 3,05 & 0,00 & 1,57 & 0,00 & 0,50 & 0,00 & 20,00 & 0,00 & 0,00 & 0,00 & 1,87 & 2,08 & 3,58 & 32,65 \\
\hline 0220RP22 & C.PM FILTRO OILMATC-GOETZE-BP 37760 & 0,00 & 0,00 & 1,00 & 1,89 & 1,73 & 0,00 & 0,00 & 0,00 & 2,35 & 27,98 & 2,87 & 0,97 & 4,07 & 42,86 \\
\hline 0220RP23 & C.PM PILAO (E/M) - BP 20013 & 1,90 & 11,19 & 3,98 & 3,93 & 66,03 & 0,50 & 2,08 & 1,87 & 22,57 & 0,00 & 44,46 & 2,47 & 0,00 & 160,98 \\
\hline 0220RP24 & C.PM PILAO (E/M) - BP 9769 & 42,97 & 1,00 & 1,00 & 3,67 & 0,00 & 22,13 & 0,00 & 0,00 & 3,55 & 0,00 & 0,00 & 0,00 & 0,00 & 74,32 \\
\hline 0220RP27 & C.RP DISPOSITIVO - BP 35485 & 7,95 & 15,62 & 25,35 & 2,20 & 4,23 & 2,75 & 0,00 & 6,48 & 7,76 & 4,27 & 6,24 & 3,13 & 4,50 & 90,48 \\
\hline 0220RP28 & C.RP PILAO (M) - BP 2138 & 1,00 & 3,17 & 24,80 & 7,37 & 26,00 & 0,82 & 15,68 & 3,00 & 0,00 & 22,00 & 0,00 & 2,00 & 3,05 & 108,89 \\
\hline 0220RP29 & C.RP RTF. KATAOKA R7 - BP 900573 & 0,00 & 0,00 & 0,00 & 1,00 & 0,00 & 0,00 & 0,00 & 3,00 & 20,00 & 2,20 & 0,00 & 2,50 & 0,00 & 28,70 \\
\hline & TOTAIS & 83,03 & 117,12 & 119,04 & 97,99 & 139,89 & 116,99 & 137,50 & 83,91 & 136,84 & 155,22 & 112,15 & 169,04 & 155,23 & $1.623,95$ \\
\hline
\end{tabular}


RETÍFICA DE PERFIL - QUADRO RESUMO DE DADOS

HORAS EM SERVICYO

(Período de Obserão: 01/06/2004 à 30/06/2005)

\begin{tabular}{|c|c|c|c|c|c|c|c|c|c|c|c|c|c|c|c|}
\hline CÓDIGO & EQUIPAMENTO & jun/04 & jul/04 & ago/04 & set/04 & out/04 & nov/04 & dez/04 & jan/05 & fev/05 & $\operatorname{mar} / 05$ & abr/05 & mai/05 & jun/05 & 2004/2005 \\
\hline 02200905 & C.PM RTF. KATAOKA R4MG - BP 28724 & 517,50 & 562,50 & 540,00 & 517,50 & 495,00 & 495,00 & 337,50 & 517,50 & 495,00 & 517,50 & 517,50 & 517,50 & 540,00 & $6.570,00$ \\
\hline 02200906 & C.RP RET. PERFIL PCG - BP 901518 & 517,50 & 562,50 & 540,00 & 517,50 & 495,00 & 495,00 & 337,50 & 517,50 & 495,00 & 506,06 & 517,50 & 516,83 & 540,00 & $6.557,89$ \\
\hline 02200907 & C.RP RTF. KATAOKA R7 - BP 900113 & 517,50 & 562,50 & 537,77 & 517,50 & 495,00 & 495,00 & 307,50 & 516,97 & 477,28 & 517,50 & 517,50 & 517,50 & 535,67 & $6.515,19$ \\
\hline 02202537 & C.RP RTF. KATAOKA R7 - BP 900403 & 517,50 & 562,50 & 540,00 & 514,62 & 495,00 & 495,00 & 336,32 & 517,50 & 469,20 & 517,50 & 517,50 & 517,50 & 540,00 & $6.540,14$ \\
\hline 02202552 & C.RP RTF. PERFIL R4MG - BP 35014 & 517,50 & 559,03 & 540,00 & 517,50 & 495,00 & 495,00 & 337,50 & 517,50 & 492,55 & 517,50 & 516,43 & 517,50 & 540,00 & $6.563,01$ \\
\hline 02202560 & C.RP RTF. PERFIL R7MG - BP 37703 & 517,50 & 562,50 & 540,00 & 514,93 & 495,00 & 495,00 & 337,50 & 517,50 & 495,00 & 517,50 & 517,50 & 517,50 & 540,00 & $6.567,43$ \\
\hline 02203226 & C.RP RTF. PERFIL R7MG - BP 37704 & 516,17 & 561,43 & 535,09 & 516,50 & 493,68 & 460,87 & 299,08 & 500,58 & 495,00 & 516,10 & 516,15 & 517,50 & 538,32 & $6.466,47$ \\
\hline 02205701 & C.RP RTF. PERFIL R7MG - BP 40057 & 517,50 & 562,50 & 540,00 & 517,50 & 495,00 & 495,00 & 337,50 & 517,50 & 495,00 & 517,50 & 517,50 & 517,50 & 540,00 & $6.570,00$ \\
\hline 0220RP01 & C.RP RTF. PERFIL R7MG - BP 40058 & 514,43 & 561,55 & 534,89 & 488,61 & 491,71 & 493,88 & 336,48 & 501,68 & 495,00 & 507,63 & 517,50 & 513,80 & 530,18 & $6.487,34$ \\
\hline 0220RP02 & C.PM RTF. KATAOKA PCG - AF 0017 & 514,09 & 554,20 & 540,00 & 499,79 & 494,07 & 462,32 & 336,46 & 516,47 & 476,28 & 496,23 & 516,48 & 511,22 & 539,10 & $6.456,71$ \\
\hline 0220RP03 & C.PM RTF. KATAOKA PCG - AF 0018 & 514,60 & 530,63 & 531,18 & 505,29 & 494,45 & 493,53 & 336,50 & 504,95 & 490,41 & 441,83 & 515,63 & 512,60 & 537,44 & $6.409,04$ \\
\hline 0220RP04 & C.PM RTF. KATAOKA R4MG - BP 32606 & 511,99 & 554,41 & 529,00 & 503,77 & 493,63 & 482,63 & 314,01 & 511,89 & 490,45 & 508,61 & 513,70 & 516,35 & 388,27 & $6.318,71$ \\
\hline 0220RP05 & C.RP FILTRO OBERLIN - BP 37705 & 508,28 & 544,75 & 537,53 & 504,17 & 409,70 & 493,03 & 337,50 & 512,04 & 495,00 & 513,05 & 511,45 & 391,94 & 526,83 & $6.285,27$ \\
\hline 0220RP12 & C.RP FILTRO OBERLIN - BP 37711 & 517,50 & 560,57 & 540,00 & 515,50 & 495,00 & 493,03 & 337,50 & 510,00 & 481,45 & 517,50 & 507,00 & 495,74 & 540,00 & $6.510,79$ \\
\hline 0220RP15 & C.RP GRAVADORA CNC - BP 37741 & 517,50 & 562,50 & 536,95 & 517,50 & 495,00 & 495,00 & 336,83 & 514,50 & 495,00 & 515,48 & 506,38 & 506,71 & 540,00 & $6.539,35$ \\
\hline 0220RP18 & C.RP RTF. KATAOKA PCG - BP 36156 & 513,73 & 550,92 & 528,67 & 515,92 & 493,95 & 492,07 & 337,50 & 509,89 & 492,25 & 515,33 & 516,62 & 517,50 & 539,33 & $6.523,68$ \\
\hline 0220RP19 & C.RP RTF. KATAOKA PCG-1-NC-BP 36155 & 517,50 & 561,37 & 506,15 & 508,14 & 484,36 & 492,85 & 337,50 & 514,37 & 462,28 & 517,50 & 507,18 & 512,25 & 535,05 & $6.456,50$ \\
\hline 0220RP21 & C.RP RTF. KATAOKA R7 - BP 900069 & 514,45 & 562,50 & 534,46 & 517,50 & 494,50 & 495,00 & 317,85 & 517,50 & 495,00 & 517,50 & 515,63 & 515,42 & 536,42 & $6.533,73$ \\
\hline 0220RP22 & C.PM FILTRO OILMATC-GOETZE-BP 37760 & 517,50 & 562,50 & 533,00 & 515,61 & 493,27 & 495,00 & 337,50 & 517,50 & 492,65 & 490,37 & 514,63 & 516,53 & 535,93 & $6.521,99$ \\
\hline 0220RP23 & C.PM PILAO (E/M) - BP 20013 & 515,60 & 551,31 & 532,50 & 513,57 & 397,23 & 494,50 & 335,42 & 515,63 & 473,16 & 517,50 & 473,04 & 515,03 & 540,00 & $6.374,49$ \\
\hline 0220RP24 & C.PM PILAO (E/M) - BP 9769 & 474,53 & 562,03 & 530,65 & 513,83 & 495,00 & 482,02 & 337,50 & 517,50 & 491,45 & 517,50 & 517,50 & 517,50 & 540,00 & $6.497,01$ \\
\hline 0220RP27 & C.RP DISPOSITIVO - BP 35485 & 509,55 & 546,88 & 511,62 & 508,38 & 490,77 & 492,25 & 337,50 & 510,99 & 487,24 & 513,23 & 511,26 & 510,84 & 535,50 & $6.466,01$ \\
\hline 0220RP28 & C.RP PILAO (M) - BP 2138 & 516,50 & 559,33 & 496,65 & 503,85 & 465,83 & 494,18 & 321,31 & 514,48 & 495,00 & 497,52 & 517,50 & 515,32 & 536,95 & $6.434,42$ \\
\hline 0220RP29 & C.RP RTF. KATAOKA R7 - BP 900573 & 517,50 & 562,50 & 540,00 & 510,78 & 495,00 & 495,00 & 337,50 & 514,25 & 476,10 & 515,30 & 517,50 & 515,00 & 540,00 & $6.536,43$ \\
\hline & TOTAIS & $12.333,92$ & $13.383,41$ & $12.776,11$ & $12.275,76$ & $11.642,15$ & $11.772,16$ & $7.965,26$ & $12.326,19$ & $11.702,75$ & $12.229,24$ & $12.316,58$ & $12.223,08$ & $12.754,99$ & $155.701,60$ \\
\hline
\end{tabular}


RETÍFICA DE PERFIL - QUADRO RESUMO DE DADOS

HORAS DE MANUTENÇÃO CORRETIVA

(Período de Observação: 01/06/2004 à 30/06/2005)

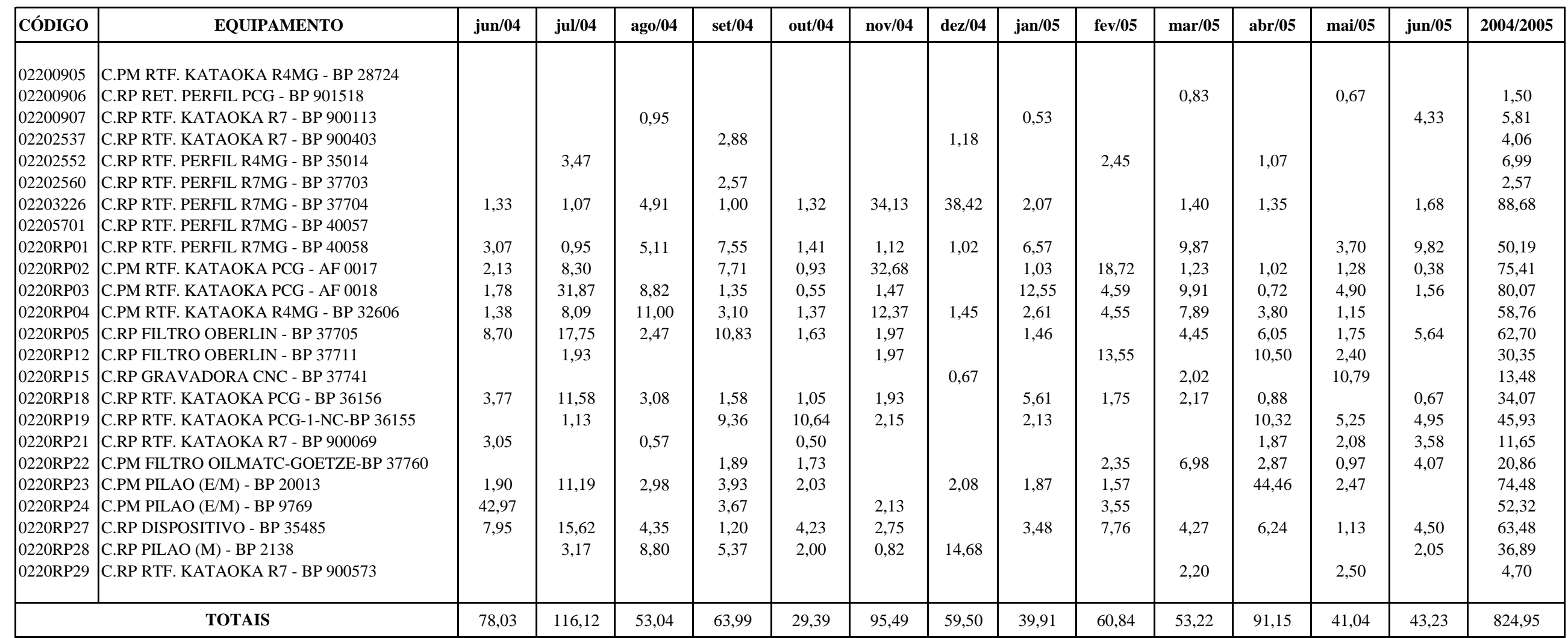


RETÍFICA DE PERFIL - QUADRO RESUMO DE DADOS

HORAS DE MANUTENÇÃO PREVENTIVA (REALIZADAS)

(Período de Observação: 01/06/2004 à 30/06/2005)

\begin{tabular}{|c|c|c|c|c|c|c|c|c|c|c|c|c|c|c|c|}
\hline CÓDIGO & EQUIPAMENTO & jun/04 & jul/04 & ago/04 & set/04 & out/04 & nov/04 & dez/04 & jan/05 & fev/05 & mar/05 & abr/05 & mai/05 & jun/05 & $2004 / 2005$ \\
\hline $\begin{array}{l}02200905 \\
02200906 \\
02200907 \\
02202537 \\
02202552 \\
02202560 \\
02203226 \\
02205701 \\
0220 \mathrm{RP} 01 \\
0220 \mathrm{RP} 02 \\
0220 \mathrm{RP} 03 \\
0220 \mathrm{RP} 04 \\
0220 \mathrm{RP} 05 \\
0220 \mathrm{RP} 12 \\
0220 \mathrm{RP} 15 \\
\text { 0220RP18 } \\
\text { 0220RP19 } \\
\text { 0220RP21 } \\
\text { 0220RP22 } \\
\text { 0220RP23 } \\
\text { 0220RP24 } \\
\text { 0220RP27 } \\
\text { 0220RP28 } \\
\text { 0220RP29 }\end{array}$ & $\begin{array}{l}\text { C.PM RTF. KATAOKA R4MG - BP } 28724 \\
\text { C.RP RET. PERFIL PCG - BP } 901518 \\
\text { C.RP RTF. KATAOKA R7 - BP } 900113 \\
\text { C.RP RTF. KATAOKA R7 - BP } 900403 \\
\text { C.RP RTF. PERFIL R4MG - BP } 35014 \\
\text { C.RP RTF. PERFIL R7MG - BP } 37703 \\
\text { C.RP RTF. PERFIL R7MG - BP } 37704 \\
\text { C.RP RTF. PERFIL R7MG - BP } 40057 \\
\text { C.RP RTF. PERFIL R7MG - BP } 40058 \\
\text { C.PM RTF. KATAOKA PCG - AF } 0017 \\
\text { C.PM RTF. KATAOKA PCG - AF } 0018 \\
\text { C.PM RTF. KATAOKA R4MG - BP } 32606 \\
\text { C.RP FILTRO OBERLIN - BP } 37705 \\
\text { C.RP FILTRO OBERLIN - BP } 37711 \\
\text { C.RP GRAVADORA CNC - BP } 37741 \\
\text { C.RP RTF. KATAOKA PCG - BP } 36156 \\
\text { C.RP RTF. KATAOKA PCG-1-NC-BP } 36155 \\
\text { C.RP RTF. KATAOKA R7 - BP 900069 } \\
\text { C.PM FILTRO OILMATC-GOETZE-BP } 37760 \\
\text { C.PM PILAO (E/M) - BP 20013 } \\
\text { C.PM PILAO (E/M) - BP 9769 } \\
\text { C.RP DISPOSITIVO - BP } 35485 \\
\text { C.RP PILAO (M) - BP 2138 } \\
\text { C.RP RTF. KATAOKA R7 - BP 900573 }\end{array}$ & $\begin{array}{l}1,28 \\
1,12 \\
4,13 \\
0,52\end{array}$ & 0,47 & $\begin{array}{c}3,05 \\
8,25 \\
33,85 \\
4,97 \\
7,00 \\
4,52 \\
9,35 \\
24,03 \\
34,55\end{array}$ & $\begin{array}{c}21,34 \\
10,00 \\
10,86 \\
10,63 \\
2,50 \\
2,00 \\
\end{array}$ & $\begin{array}{l}1,88 \\
83,67 \\
\\
95,74 \\
27,17\end{array}$ & 1,00 & $\begin{array}{c}1,04 \\
1,00 \\
22,04 \\
\\
\\
19,65\end{array}$ & $\begin{array}{l}14,85 \\
9,25 \\
\\
3,00 \\
4,00 \\
7,50 \\
3,00 \\
2,00 \\
1,00\end{array}$ & $\begin{array}{l}17,72 \\
25,80\end{array}$ & $\begin{array}{c}20,04 \\
65,76 \\
1,00 \\
20,15 \\
19,98\end{array}$ & 11,12 & $\begin{array}{c}123,81 \\
19,36\end{array}$ & $\begin{array}{c}0,52 \\
1,00 \\
151,73 \\
7,53\end{array}$ & $\begin{array}{c}10,61 \\
49,00 \\
25,80 \\
\\
14,85 \\
\\
32,47 \\
37,88 \\
80,89 \\
192,53 \\
222,03 \\
28,86 \\
17,17 \\
12,25 \\
67,57 \\
24,62 \\
27,15 \\
121,03 \\
20,67 \\
40,51 \\
98,69 \\
28,87\end{array}$ \\
\hline & TOTAIS & 8,05 & 0,47 & 130,85 & 80,25 & 208,46 & 12,35 & 75,24 & 53,90 & 116,41 & 137,54 & 12,27 & 155,88 & 161,78 & $1.153,45$ \\
\hline
\end{tabular}


RETÍFICA DE PERFIL - QUADRO RESUMO DE DADOS

HORAS DE MANUTENÇÃO PREVENTIVA (PREVISTAS)

(Período de Observação: 01/06/2004 à 30/06/2005)

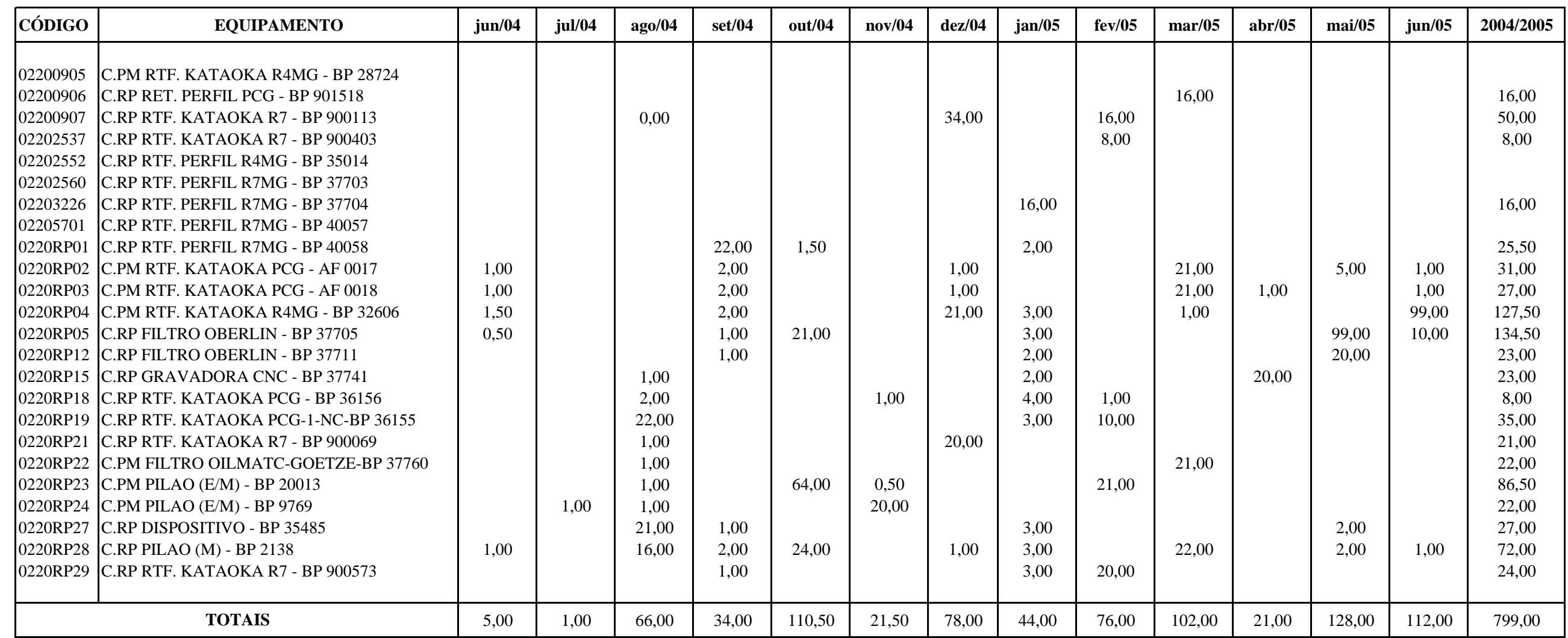




\section{RETÍFICA DE PERFIL}

\section{MANUTENÇÃO PREVENTIVA - HORAS PREVISTAS E REALIZADAS}

\begin{tabular}{|c|c|c|c|c|c|}
\hline CODIGO & OS MNT PREV & SERVIÇO EXECUTADO & DATA & H PREVISTAS & H REALISADAS \\
\hline 02200906 & 02V09814 & MP-0200M - ANUAL - FILTRO OBERLIN & 07/03/05 & 8,00 & 4,78 \\
\hline 02200906 & $02 \mathrm{~V} 10045$ & MP-0200E - ANUAL - FILTRO OBERLIN & 07/03/05 & 8,00 & 5,83 \\
\hline Subtotais & 2 & & & 16,00 & 10,61 \\
\hline 02200907 & 02U75164 & MP-0200M - ANUAL - FILTRO OBERLIN & $14 / 02 / 05$ & 8,00 & 10,27 \\
\hline 02200907 & 02U75501 & MP-0200E - ANUAL - FILTRO OBERLIN & $14 / 02 / 05$ & 8,00 & 7,45 \\
\hline 02200907 & 02R72313 & SUBSTITUICAO DO LUBRIFIL DO FILTRO OBERLIN BP 37705 & 23/08/04 & 0,00 & 1,28 \\
\hline 02200907 & $02 \mathrm{~T} 55606$ & MANUTENCAO NO FILTRO OBERLIN BP 37705 & 20/12/04 & 34,00 & 30 \\
\hline Subtotais & 4 & & & 50,00 & 49 \\
\hline 02202537 & 02U76430 & MP-0133M - ANUAL - PILAO & $21 / 02 / 05$ & 8,00 & 25,8 \\
\hline Subtotais & 1 & & & 8,00 & 25,8 \\
\hline 02203226 & 02U27314 & MP-0146M - ANUAL - GRAVADORA CNC & $24 / 01 / 05$ & 8,00 & 7,35 \\
\hline 02203226 & $02 \mathrm{U} 27653$ & MP-0146E - ANUAL - GRAVADORA CNC & $24 / 01 / 05$ & 8,00 & 7,5 \\
\hline Subtotais & 2 & & & 16,00 & 14,85 \\
\hline 0220RP01 & 02U04909 & ADAPTACAO DE CHAVE DE SEGURANCA NA RETIFICA DE PERFIL & $31 / 01 / 05$ & 2,00 & 9,25 \\
\hline 0220RP01 & 02R65731 & REPARO NO ALARME DO SISTEMA DE SEGURANCA DO REBOLO & $13 / 09 / 04$ & 1,00 & 1,92 \\
\hline 0220RP01 & 02S40614 & MP-0202E - ANUAL - RETIFICA KATAOKA R4 & $20 / 09 / 04$ & 5,00 & 3,9 \\
\hline 0220RP01 & 02S40357 & MP-0202M - ANUAL - RETIFICA KATAOKA R4 & $20 / 09 / 04$ & 16,00 & 15,52 \\
\hline 0220RP01 & 02S13608 & REPARO EM VAZAMENTO DE VALVULA NA KATAOKA & $25 / 10 / 04$ & 1,50 & 1,88 \\
\hline Subtotais & 5 & & & 25,50 & 32,47 \\
\hline 0220RP02 & $02 \mathrm{~V} 11268$ & MP-0203M - ANUAL - RETIFICA KATAOKA R7 & $14 / 03 / 05$ & 16,00 & 15,54 \\
\hline 0220RP02 & 02V11589 & MP-0203E - ANUAL - RETIFICA KATAOKA R7 & $14 / 03 / 05$ & 5,00 & 4,5 \\
\hline 0220RP02 & 02W55237 & MP-0203E - ANUAL - RETIFICA KATAOKA R7 & 19/05/05 & 5,00 & 5 \\
\hline 0220RP02 & 02Q89299 & MP-0203M - TRIMESTRAL - RETIFICA KATAOKA R7 & $14 / 06 / 04$ & 1,00 & 1,28 \\
\hline 0220RP02 & $02 \mathrm{~W} 75046$ & MP-0203M - TRIMESTRAL - RETIFICA KATAOKA R7 & $13 / 06 / 05$ & 1,00 & 0,52 \\
\hline 0220RP02 & 02S39920 & MP-0203M - TRIMESTRAL - RETIFICA KATAOKA R7 & $13 / 09 / 04$ & 1,00 & 8,28 \\
\hline 0220RP02 & 02R65777 & REPARO NO ALARME DO SISTEMA DE SEGURANCA DO REBOLO & $13 / 09 / 04$ & 1,00 & 1,72 \\
\hline 0220RP02 & $02 \mathrm{~T} 83274$ & MP-0203M - TRIMESTRAL - RETIFICA KATAOKA R7 & $13 / 12 / 04$ & 1,00 & 1,04 \\
\hline Subtotais & 8 & & & 31,00 & 37,88 \\
\hline
\end{tabular}




\begin{tabular}{|c|c|c|c|c|c|}
\hline CODIGO & OS MNT PREV & SERVIÇO EXECUTADO & DATA & H PREVISTAS & H REALISADAS \\
\hline 0220RP03 & 02V14087 & MP-0203M - ANUAL - RETIFICA KATAOKA R7 & 28/03/05 & 16,00 & 61,26 \\
\hline 0220RP03 & $02 \mathrm{~V} 14274$ & MP-0203E - ANUAL - RETIFICA KATAOKA R7 & 28/03/05 & 5,00 & 4,5 \\
\hline 0220RP03 & $02 \mathrm{~V} 62391$ & TROCAR CORREIA VB 35 DO ARRASTE DA PLACA & $25 / 04 / 05$ & 1,00 & 1,15 \\
\hline 0220RP03 & 02Q95674 & MP-0203M - TRIMESTRAL - RETIFICA KATAOKA R7 & $28 / 06 / 04$ & 1,00 & 1,12 \\
\hline 0220RP03 & $02 W 78203$ & MP-0203M - TRIMESTRAL - RETIFICA KATAOKA R7 & $27 / 06 / 05$ & 1,00 & 1 \\
\hline 0220RP03 & 02R65786 & REPARO NO ALARME DO SISTEMA DE SEGURANCA DO REBOLO & 06/09/04 & 1,00 & 6,18 \\
\hline 0220RP03 & 02S41114 & MP-0203M - TRIMESTRAL - RETIFICA KATAOKA R7 & $27 / 09 / 04$ & 1,00 & 4,68 \\
\hline 0220RP03 & $02 \mathrm{~T} 84095$ & MP-0203M - TRIMESTRAL - RETIFICA KATAOKA R7 & $27 / 12 / 04$ & 1,00 & 1 \\
\hline Subtotais & 8 & & & 27,00 & 80,89 \\
\hline 0220RP04 & 02V09912 & MP-0203M - TRIMESTRAL - RETIFICA KATAOKA R7 & 07/03/05 & 1,00 & 1 \\
\hline 0220RP04 & $02 \mathrm{~T} 48722$ & TROCAR VISORES DO RESERVATORIO MANCAL HIDROSTATICO & $25 / 01 / 05$ & 3,00 & 3 \\
\hline 0220RP04 & 02W93632 & REVISAO MECANICA GERAL NA RETIFICA & 02/06/05 & 99,00 & 151,73 \\
\hline 0220RP04 & 02Q88762 & MP-0203M - TRIMESTRAL - RETIFICA KATAOKA R7 & 07/06/04 & 1,00 & 1,63 \\
\hline 0220RP04 & 02Q52256 & TROCA DE MEMBRANA SOFT-KEY PARA TECLADO DE DADOS & $14 / 06 / 04$ & 0,50 & 2,5 \\
\hline 0220RP04 & 02S39289 & MP-0203M - TRIMESTRAL - RETIFICA KATAOKA R7 & 06/09/04 & 1,00 & 1,55 \\
\hline 0220RP04 & 02R65795 & REPARO NO ALARME DO SISTEMA DE SEGURANCA DO REBOLO & 06/09/04 & 1,00 & 9,08 \\
\hline 0220RP04 & $02 \mathrm{~T} 82854$ & MP-0203M - ANUAL - RETIFICA KATAOKA R7 & $06 / 12 / 04$ & 16,00 & 16,87 \\
\hline 0220RP04 & $02 \mathrm{~T} 83103$ & MP-0203E - ANUAL - RETIFICA KATAOKA R7 & $06 / 12 / 04$ & 5,00 & 5,17 \\
\hline Subtotais & 9 & & & 127,50 & 192,53 \\
\hline 0220RP05 & $02 \mathrm{~T} 48740$ & TROCAR VISORES DO RESERVATORIO MANCAL HIDROSTATICO & $25 / 01 / 05$ & 3,00 & 4 \\
\hline 0220RP05 & $02 \mathrm{~W} 41724$ & REVISAO GERAL MECANICA DA RETIFICA DE PERFIL R7 BP 37704 & $04 / 05 / 05$ & 99,00 & 123,81 \\
\hline 0220RP05 & 02W29436 & TROCAR PROTECOES SANFONADAS DO MANGOTE FIXADOR & 06/06/05 & 10,00 & 7,53 \\
\hline 0220RP05 & 02Q52274 & TROCA DE MEMBRANA SOFT-KEY PARA TECLADO DE DADOS & $14 / 06 / 04$ & 0,50 & 0,52 \\
\hline 0220RP05 & 02R65811 & REPARO NO ALARME DO SISTEMA DE SEGURANCA DO REBOLO & $13 / 09 / 04$ & 1,00 & 2,5 \\
\hline 0220RP05 & $02 \mathrm{~T} 04216$ & MP-0203M - ANUAL - RETIFICA KATAOKA R7 & $13 / 10 / 04$ & 16,00 & 79,4 \\
\hline 0220RP05 & $02 \mathrm{~T} 04412$ & MP-0203E - ANUAL - RETIFICA KATAOKA R7 & $13 / 10 / 04$ & 5,00 & 4,27 \\
\hline Subtotais & 7 & & & 134,50 & 222,03 \\
\hline 0220RP12 & 02U04892 & ADAPTACAO DE CHAVE DE SEGURANCA NA RETIFICA DE PERFIL & $31 / 01 / 05$ & 2,00 & 7,5 \\
\hline 0220RP12 & 02W31600 & MP-0206M - ANUAL - RETIFICA KATAOKA PCG & 02/05/05 & 16,00 & 15,36 \\
\hline 0220RP12 & $02 \mathrm{~W} 31913$ & MP-0206E - ANUAL - RETIFICA KATAOKA PCG & 02/05/05 & 4,00 & 4 \\
\hline 0220RP12 & 02R65848 & REPARO NO ALARME DO SISTEMA DE SEGURANCA DO REBOLO & $13 / 09 / 04$ & 1,00 & 2 \\
\hline Subtotais & 4 & & & 23,00 & 28,86 \\
\hline
\end{tabular}




\begin{tabular}{|c|c|c|c|c|c|}
\hline CODIGO & OS MNT PREV & SERVIÇO EXECUTADO & DATA & H PREVISTAS & H REALISADAS \\
\hline 0220RP15 & 02U04918 & ADAPTACAO DE CHAVE DE SEGURANCA NA RETIFICA DE PERFIL & 31/01/05 & 2,00 & 3 \\
\hline 0220RP15 & $02 \mathrm{~V} 85269$ & MP-0206E - ANUAL - RETIFICA KATAOKA PCG & 04/04/05 & 4,00 & 3,5 \\
\hline 0220RP15 & $02 \mathrm{~V} 85018$ & MP-0206M - ANUAL - RETIFICA KATAOKA PCG & 04/04/05 & 16,00 & 7,62 \\
\hline 0220RP15 & 02R65857 & REPARO NO ALARME DO SISTEMA DE SEGURANCA DO REBOLO & $30 / 08 / 04$ & 1,00 & 3,05 \\
\hline Subtotais & 4 & & & 23,00 & 17,17 \\
\hline 0220RP18 & 02G74430 & TROCAR DISJUNTOR C/ DETECCAO DE FULGA P/ TERRA NA KATAOKA & $10 / 01 / 05$ & 1,00 & 1 \\
\hline 0220RP18 & $02 \mathrm{~V} 08076$ & MP-0203M - TRIMESTRAL - RETIFICA KATAOKA R7 & 28/02/05 & 1,00 & 1 \\
\hline 0220RP18 & $02 \mathrm{~T} 48660$ & TROCAR VISORES DO RESERVATORIO MANCAL HIDROSTATICO & 25/01/05 & 3,00 & 1 \\
\hline 0220RP18 & 02R65820 & REPARO NO ALARME DO SISTEMA DE SEGURANCA DO REBOLO & 30/08/04 & 1,00 & 6,9 \\
\hline 0220RP18 & $02 S 38627$ & MP-0203M - TRIMESTRAL - RETIFICA KATAOKA R7 & $30 / 08 / 04$ & 1,00 & 1,35 \\
\hline 0220RP18 & $02 \mathrm{~T} 82328$ & MP-0203M - TRIMESTRAL - RETIFICA KATAOKA R7 & 29/11/04 & 1,00 & 1 \\
\hline Subtotais & 6 & & & 8,00 & 12,25 \\
\hline 0220RP19 & 02U99638 & REALIZAR ALINHAMENTO E GEOMETRIA & $10 / 02 / 05$ & 8,00 & 30,72 \\
\hline 0220RP19 & 02S62840 & TROCAR VALVULA DA GARRA DO ROBO & 28/02/05 & 2,00 & 2 \\
\hline 0220RP19 & $02 \mathrm{~T} 48697$ & TROCAR VISORES DO RESERVATORIO MANCAL HIDROSTATICO & 25/01/05 & 3,00 & 1 \\
\hline 0220RP19 & 02R90552 & MP-0203M - ANUAL - RETIFICA KATAOKA R7 & 02/08/04 & 16,00 & 20,49 \\
\hline 0220RP19 & $02 \mathrm{R} 91891$ & MP-0203E - ANUAL - RETIFICA KATAOKA R7 & 02/08/04 & 5,00 & 8,83 \\
\hline 0220RP19 & 02R65875 & REPARO NO ALARME DO SISTEMA DE SEGURANCA DO REBOLO & $30 / 08 / 04$ & 1,00 & 4,53 \\
\hline Subtotais & 6 & & & 35,00 & 67,57 \\
\hline 0220RP21 & 02R65900 & REPARO NO ALARME DO SISTEMA DE SEGURANCA DO REBOLO & $30 / 08 / 04$ & 1,00 & 4,97 \\
\hline 0220RP21 & $02 \mathrm{~T} 83247$ & MP-0206M - ANUAL - RETIFICA KATAOKA PCG & $13 / 12 / 04$ & 16,00 & 16,06 \\
\hline 0220RP21 & $02 \mathrm{~T} 83407$ & MP-0206E - ANUAL - RETIFICA KATAOKA PCG & $13 / 12 / 04$ & 4,00 & 3,59 \\
\hline Subtotais & 3 & & & 21,00 & 24,62 \\
\hline 0220RP22 & 02V10072 & MP-0202E - ANUAL - RETIFICA KATAOKA R4 & 07/03/05 & 5,00 & 4,68 \\
\hline 0220RP22 & 02V09850 & MP-0202M - ANUAL - RETIFICA KATAOKA R4 & 07/03/05 & 16,00 & 15,47 \\
\hline 0220RP22 & 02R65919 & REPARO NO ALARME DO SISTEMA DE SEGURANCA DO REBOLO & $30 / 08 / 04$ & 1,00 & 7 \\
\hline Subtotais & 3 & & & 22,00 & 27,15 \\
\hline
\end{tabular}




\begin{tabular}{|c|c|c|c|c|c|}
\hline CODIGO & OS MNT PREV & SERVIÇO EXECUTADO & DATA & H PREVISTAS & H REALISADAS \\
\hline 0220RP23 & 02U74432 & MP-0202E - ANUAL - RETIFICA KATAOKA R4 & 07/02/05 & 5,00 & 4,87 \\
\hline 0220RP23 & $02 \mathrm{U} 74147$ & MP-0202M - ANUAL - RETIFICA KATAOKA R4 & 07/02/05 & 16,00 & 15,4 \\
\hline 0220RP23 & 02R65937 & REPARO NO ALARME DO SISTEMA DE SEGURANCA DO REBOLO & $30 / 08 / 04$ & 1,00 & 4,52 \\
\hline 0220RP23 & $02 T 40365$ & REVISAO NO CABECOTE PORTA REBOLO DA RET.KATAOKA BP 28724 & $28 / 10 / 04$ & 64,00 & 95,74 \\
\hline 0220RP23 & $02 \mathrm{~T} 01479$ & TROCAR LAMPADA GIROFLEX DA RETIFICA R4 & $22 / 11 / 04$ & 0,50 & 0,5 \\
\hline Subtotais & 5 & & & 86,50 & 121,03 \\
\hline 0220RP24 & 02R09151 & SUBSTITUICAO DE BATERIA PARA SERVO DRIVE DA RET.PCG BP0017 & 20/07/04 & 1,00 & 0,47 \\
\hline 0220RP24 & 02R65946 & REPARO NO ALARME DO SISTEMA DE SEGURANCA DO REBOLO & $30 / 08 / 04$ & 1,00 & 9,35 \\
\hline 0220RP24 & $02 \mathrm{~T} 82453$ & MP-0206E - ANUAL - RETIFICA KATAOKA PCG & 29/11/04 & 4,00 & 3,6 \\
\hline 0220RP24 & $02 \mathrm{~T} 82319$ & MP-0206M - ANUAL - RETIFICA KATAOKA PCG & 29/11/04 & 16,00 & 7,25 \\
\hline Subtotais & 4 & & & 22,00 & 20,67 \\
\hline 0220RP27 & $02 \mathrm{~T} 48713$ & TROCAR VISORES DO RESERVATORIO MANCAL HIDROSTATICO & 25/01/05 & 3,00 & 3,03 \\
\hline 0220RP27 & $02 \mathrm{~W} 29604$ & TROCAR PROTECOES SANFONADAS DO MANGOTE FIXADOR & 24/05/05 & 2,00 & 5,53 \\
\hline 0220RP27 & $02 \mathrm{R} 93434$ & MP-0203M - ANUAL - RETIFICA KATAOKA R7 & 23/08/04 & 16,00 & 16,26 \\
\hline 0220RP27 & 02R93782 & MP-0203E - ANUAL - RETIFICA KATAOKA R7 & 23/08/04 & 5,00 & 7,77 \\
\hline 0220RP27 & $02 \mathrm{R} 65973$ & REPARO NO ALARME DO SISTEMA DE SEGURANCA DO REBOLO & 06/09/04 & 1,00 & 7,92 \\
\hline Subtotais & 5 & & & 27,00 & 40,51 \\
\hline 0220RP28 & $02 \mathrm{~V} 14194$ & MP-0203M - TRIMESTRAL - RETIFICA KATAOKA R7 & $21 / 03 / 05$ & 1,00 & 0 \\
\hline 0220RP28 & $02 \mathrm{~T} 48688$ & TROCAR VISORES DO RESERVATORIO MANCAL HIDROSTATICO & $25 / 01 / 05$ & 3,00 & 3,02 \\
\hline 0220RP28 & 02V12757 & MP-0203M - ANUAL - RETIFICA KATAOKA R7 & 21/03/05 & 16,00 & 15,2 \\
\hline 0220RP28 & $02 \mathrm{~V} 13140$ & MP-0203E - ANUAL - RETIFICA KATAOKA R7 & 21/03/05 & 5,00 & 4,78 \\
\hline 0220RP28 & 02W29622 & TROCAR PROTECOES SANFONADAS DO MANGOTE FIXADOR & 24/05/05 & 2,00 & 2,18 \\
\hline 0220RP28 & 02Q95745 & MP-0203M - TRIMESTRAL - RETIFICA KATAOKA R7 & $28 / 06 / 04$ & 1,00 & 1 \\
\hline 0220RP28 & $02 \mathrm{~W} 78267$ & MP-0203M - TRIMESTRAL - RETIFICA KATAOKA R7 & $27 / 06 / 05$ & 1,00 & 1 \\
\hline 0220RP28 & 02S06037 & REVISAO NO CABECOTE DO PONTO DA RET. KATAOKA R7 BP 900113 & $11 / 08 / 04$ & 16,00 & 34,55 \\
\hline 0220RP28 & 02R65982 & REPARO NO ALARME DO SISTEMA DE SEGURANCA DO REBOLO & 06/09/04 & 1,00 & 4,78 \\
\hline 0220RP28 & 02S41187 & MP-0203M - TRIMESTRAL - RETIFICA KATAOKA R7 & 27/09/04 & 1,00 & 3,5 \\
\hline 0220RP28 & $02 \mathrm{~T} 35460$ & TROCAR ROLAMENTO DA PLACA & $27 / 10 / 04$ & 24,00 & 27,17 \\
\hline 0220RP28 & $02 \mathrm{~T} 84157$ & MP-0203M - TRIMESTRAL - RETIFICA KATAOKA R7 & $27 / 12 / 04$ & 1,00 & 1,51 \\
\hline Subtotais & 12 & & & 72,00 & 98,69 \\
\hline
\end{tabular}




\begin{tabular}{|c|c|c|c|c|c|}
\hline CODIGO & OS MNT PREV & SERVIÇO EXECUTADO & DATA & H PREVISTAS & H REALISADAS \\
\hline 0220RP29 & $02 \mathrm{U} 74414$ & MP-0206E - ANUAL - RETIFICA KATAOKA PCG & 07/02/05 & 4,00 & 3,98 \\
\hline 0220RP29 & $02 \mathrm{U} 74003$ & MP-0206M - ANUAL - RETIFICA KATAOKA PCG & 07/02/05 & 16,00 & 14,92 \\
\hline 0220RP29 & $02 \mathrm{~T} 48820$ & TROCAR VISORES DO RESERVATORIO MANCAL HIDROSTATICO & 25/01/05 & 3,00 & 3,25 \\
\hline 0220RP29 & 02R65991 & REPARO NO ALARME DO SISTEMA DE SEGURANCA DO REBOLO & 06/09/04 & 1,00 & 6,72 \\
\hline Subtotais & 4 & & & 24,00 & 28,87 \\
\hline Totais & 102 & & & 799,00 & $1.153,45$ \\
\hline
\end{tabular}


RETÍFICA DE PERFIL DESCRIÇÃO DAS COLUNAS

\begin{tabular}{|c|c|c|}
\hline COLUNAS & DESCRIÇÃO & APURAÇÃO \\
\hline MÊS & MÊS DO PERÍODO CONSIDERADO & \\
\hline H DISP [1] & HORAS DISPONÍVEIS DOS EQPTOS NO MÊS DO PERÍODO [h]. & \\
\hline HS [2] & HORAS EM SERVIÇO DOS EQPTOS NO MÊS DO PERÍODO [h]. & \\
\hline $\begin{array}{l}\text { CROMADOS } \\
\text { PREV [3] } \\
\text { EXE [4] }\end{array}$ & $\begin{array}{l}\text { ANÉIS CROMADOS } \\
\text { QUANTIDADES PREVISTAS DE ANÉIS CROMADAS PARA O MÊS DO PERÍODO [u]. } \\
\text { QUANTIDADES EXECUTADAS DE ANÉIS CROMADOS NO MÊS DO PERÍODO [u]. }\end{array}$ & \\
\hline $\begin{array}{l}\text { METALIZADOS } \\
\text { PREV [5] } \\
\text { EXE [6] }\end{array}$ & $\begin{array}{l}\text { ANÉIS METALIZADOS } \\
\text { QUANTIDADES PREVISTAS DE ANÉIS METALIZADOS PARA O MÊS DO PERÍODO [u]. } \\
\text { QUANTIDADES EXECUTADAS DE ANÉIS METALIZADOS NO MÊS DO PERÍODO [u]. }\end{array}$ & \\
\hline $\begin{array}{l}\text { TOTAIS } \\
\text { PREV [7] } \\
\text { EXE [8] }\end{array}$ & $\begin{array}{l}\text { QTDES TOTAIS. } \\
\text { QTDES TOTAIS PREVISTAS DE ANÉIS CROMADOS E METALIZADOS PARA O MÊS DO PERÍODO [u]. } \\
\text { QTDES TOTAIS EXECUTADAS DE ANÉIS CROMADOS E METALIZADOS NO MÊS DO PERÍODO [u]. }\end{array}$ & \\
\hline $\begin{array}{l}\text { TPU } \\
\text { CRO [9] } \\
\text { MET [10] }\end{array}$ & $\begin{array}{l}\text { TEMPO PREVISTO DA UNIDADE DE PRODUÇÃO [h]. } \\
\text { TPU DE ANÉIS CROMADOS OCORRIDO NO MÊS DO PERÍODO [h]. } \\
\text { TPU DE ANÉIS METALIZADOS OCORRIDO NO MÊS DO PERÍODO [h]. } \\
\text { Obs.: na totalização dos valores está declarado o valor médio do TPU no período. }\end{array}$ & $\begin{aligned} {[9] } & =[1] /[3] \\
{[10] } & =[1] /[5]\end{aligned}$ \\
\hline $\begin{array}{l}\text { \%PREV } \\
\text { CRO [11] } \\
\text { MET [12] }\end{array}$ & $\begin{array}{l}\text { PERCENTAGENS PREVISTAS } \\
\text { \% PREV DE ANÉIS CROMADOS PARA O MÊS DO PERÍODO. } \\
\text { \% PREV DE ANÉIS METALIZADOS PARA O MÊS DO PERÍODO. } \\
\text { Obs.: na totalização dos valores está declarado o valor médio das \%PREV no período. }\end{array}$ & $\begin{array}{l}{[11]=[3] /[7]} \\
{[12]=[5] /[7]}\end{array}$ \\
\hline $\begin{array}{l}\text { \%EXE } \\
\text { CRO [13] } \\
\text { MET [14] }\end{array}$ & $\begin{array}{l}\text { PERCENTAGENS EXECUTADAS } \\
\text { \% EXE DE ANÉIS CROMADOS PARA O MÊS DO PERÍODO. } \\
\text { \% EXE DE ANÉIS METALIZADOS PARA O MÊS DO PERÍODO. } \\
\text { Obs.: na totalização dos valores está declarado o valor médio das \%EXE no período. } \\
\end{array}$ & $\begin{array}{l}{[13]=[4] /[8]} \\
{[14]=[6] /[8]}\end{array}$ \\
\hline $\begin{array}{l}\text { HS } \\
\qquad \begin{array}{l}\text { CRO [15] } \\
\text { MET [16] }\end{array}\end{array}$ & $\begin{array}{l}\text { HORAS EM SERVIÇO NECESSÁRIAS PARA A EXECUÇÃO DAS QUANTIDADES DE ANÉIS CROMADOS E } \\
\text { METALIZADOS NO MÊS DO PERÍODO [h]. } \\
\text { HS PARA A EXECUÇÃO DAS QTDES TOTAIS DE ANÉIS CROMADOS NO MÊS DO PERÍODO [h]. } \\
\text { HS PARA A EXECUÇÃO DAS QTDES TOTAIS DE ANÉIS CROMADOS NO MÊS DO PERÍODO [h]. }\end{array}$ & $\begin{array}{l}{[15]=[13] \times[2]} \\
{[16]=[14] \times[2]}\end{array}$ \\
\hline $\begin{array}{l}\text { LU } \\
\text { CRO [17] } \\
\text { MET [18] }\end{array}$ & $\begin{array}{l}\text { LUCRO UNITÁRIO } \\
\text { LU DE ANÉIS CROMADOS NO MÊS DO PERÍODO [R\$/u] } \\
\text { LU DE ANÉIS METALIZADOS NO MÊS DO PERÍODO [R\$/u] } \\
\text { Obs.: na totalização dos valores está declarado o valor médio do LU no período. } \\
\end{array}$ & \\
\hline
\end{tabular}


RETÍFICA DE PERFIL - DADOS DE PRODUÇÃO

PRODUÇÃO PREVISTA E REALIZADA

(Período de 01/06/2004 - 30/06/2005)

\begin{tabular}{|c|c|c|c|c|c|c|c|c|c|c|c|c|c|c|c|c|c|c|}
\hline \multirow{2}{*}{ MÊS } & \multirow{2}{*}{ H DISP } & \multirow{2}{*}{ HS } & \multicolumn{2}{|c|}{ CROMADOS } & \multicolumn{2}{|c|}{ METALIZADOS } & \multicolumn{2}{|c|}{ TOTAIS } & \multicolumn{2}{|c|}{ TPU } & \multicolumn{2}{|c|}{ \% PREV } & \multicolumn{2}{|c|}{$\%$ EXE } & \multicolumn{2}{|c|}{ HS } & \multicolumn{2}{|c|}{$\mathbf{L U}$} \\
\hline & & & PREV & EXE & PREV & EXE & PREV & EXE & CRO & MET & CRO & MET & CRO & MET & CRO & MET & CRO & MET \\
\hline jul-04 & 13.500 & 13.383 & 1.201 .975 & 876.820 & 447.550 & 342.110 & 1.649 .525 & 1.218 .930 & 0,0112 & 0,0302 & $73 \%$ & $27 \%$ & $72 \%$ & $28 \%$ & 9.627 & 3.756 & 5,00 & 1,50 \\
\hline ago-04 & 12.960 & 12.776 & 1.207 .558 & 975.291 & 441.738 & 311.001 & 1.649 .296 & 1.286 .292 & 0,0107 & 0,0293 & $73 \%$ & $27 \%$ & $76 \%$ & $24 \%$ & 9.687 & 3.089 & 5,00 & 1,50 \\
\hline set-04 & 12.420 & 12.276 & 1.216 .700 & 1.048 .838 & 524.400 & 321.801 & 1.741 .100 & 1.370 .639 & 0,0102 & 0,0237 & $70 \%$ & $30 \%$ & $77 \%$ & $23 \%$ & 9.394 & 2.882 & 5,00 & 1,50 \\
\hline out-04 & 11.880 & 11.632 & 1.066 .252 & 983.041 & 531.916 & 272.906 & 1.598 .168 & 1.255 .947 & 0,0111 & 0,0223 & $67 \%$ & $33 \%$ & $78 \%$ & $22 \%$ & 9.104 & 2.528 & 5,00 & 1,50 \\
\hline nov-04 & 11.880 & 11.772 & 1.128 .600 & 854.830 & 435.600 & 373.557 & 1.564 .200 & 1.228 .387 & 0,0105 & 0,0273 & $72 \%$ & $28 \%$ & $70 \%$ & $30 \%$ & 8.192 & 3.580 & 5,00 & 1,50 \\
\hline dez-04 & 8.100 & 7.965 & 768.446 & 690.322 & 281.106 & 274.680 & 1.049 .552 & 965.002 & 0,0105 & 0,0288 & $73 \%$ & $27 \%$ & $72 \%$ & $28 \%$ & 5.698 & 2.267 & 5,00 & 1,50 \\
\hline jan-05 & 11.880 & 11.786 & 1.444 .400 & 1.094 .739 & 588.800 & 304.010 & 2.033.200 & 1.398 .749 & 0,0082 & 0,0202 & $71 \%$ & $29 \%$ & $78 \%$ & $22 \%$ & 9.225 & 2.562 & 5,00 & 1,50 \\
\hline fev-05 & 11.880 & 11.703 & 1.418 .230 & 1.158.310 & 594.198 & 369.102 & 2.012 .428 & 1.527 .412 & 0,0084 & 0,0200 & $70 \%$ & $30 \%$ & $76 \%$ & $24 \%$ & 8.875 & 2.828 & 5,00 & 1,50 \\
\hline mar-05 & 12.420 & 12.229 & 1.237 .400 & 1.152 .754 & 450.340 & 389.914 & 1.687 .740 & 1.542 .668 & 0,0100 & 0,0276 & $73 \%$ & $27 \%$ & $75 \%$ & $25 \%$ & 9.138 & 3.091 & 5,00 & 1,50 \\
\hline abr-05 & 12.420 & 12.317 & 974.096 & 888.760 & 587.926 & 442.161 & 1.562 .022 & 1.330 .921 & 0,0128 & 0,0211 & $62 \%$ & $38 \%$ & $67 \%$ & $33 \%$ & 8.225 & 4.092 & 5,00 & 1,50 \\
\hline mai-05 & 12.420 & 12.223 & 1.109 .980 & 899.061 & 616.400 & 437.153 & 1.726 .380 & 1.336 .214 & 0,0112 & 0,0201 & $64 \%$ & $36 \%$ & $67 \%$ & $33 \%$ & 8.224 & 3.999 & 5,00 & 1,50 \\
\hline jun-05 & 12.960 & 12.755 & 1.230 .144 & 1.014 .153 & 656.376 & 533.941 & 1.886 .520 & 1.548 .094 & 0,0105 & 0,0197 & $65 \%$ & $35 \%$ & $66 \%$ & $34 \%$ & 8.356 & 4.399 & 5,00 & 1,50 \\
\hline TOTAIS & 157.140 & 155.151 & 15.109 .092 & 12.633.918 & 6.556 .159 & 4.626.376 & 21.665.251 & 17.260.294 & 0,0105 & 0,0247 & $70 \%$ & $30 \%$ & $73 \%$ & $27 \%$ & 113.574 & 41.577 & 5,00 & 1,50 \\
\hline
\end{tabular}


RETÍFICA DE PERFIL - DADOS DE PRODUÇÃO

REFUGOS

(Período de 01/06/2004 - 30/06/2005)

\begin{tabular}{|c|c|c|c|}
\hline MÊS & ANÉIS CROMADOS & ANÉIS METALIZADOS & TOTAIS \\
\hline & & & \\
jun-04 & 8.519 & & 8.519 \\
jul-04 & 6.891 & & 6.891 \\
ago-04 & 7.400 & & 7.400 \\
set-04 & 9.718 & & 9.718 \\
out-04 & 9.311 & & 9.311 \\
nov-04 & 9.371 & 14 & 9.371 \\
dez-04 & 8.271 & 239 & 8.285 \\
jan-05 & 12.468 & 3.087 & 12.707 \\
fev-05 & 12.749 & 2.235 & 15.836 \\
mar-05 & 11.199 & 1.266 & 13.434 \\
abr-05 & 9.226 & 1.979 & 10.492 \\
mai-05 & 8.712 & 1.669 & 10.691 \\
jun-05 & 11.772 & & 13.441 \\
& & & \\
\hline TOTAIS & 125.607 & 10.489 & 136.096 \\
\hline
\end{tabular}


RETÍFICA DE PERFIL

MANUTENÇÃO CORRETIVA

(Período: 01/06/2004 a 30/06/2005)

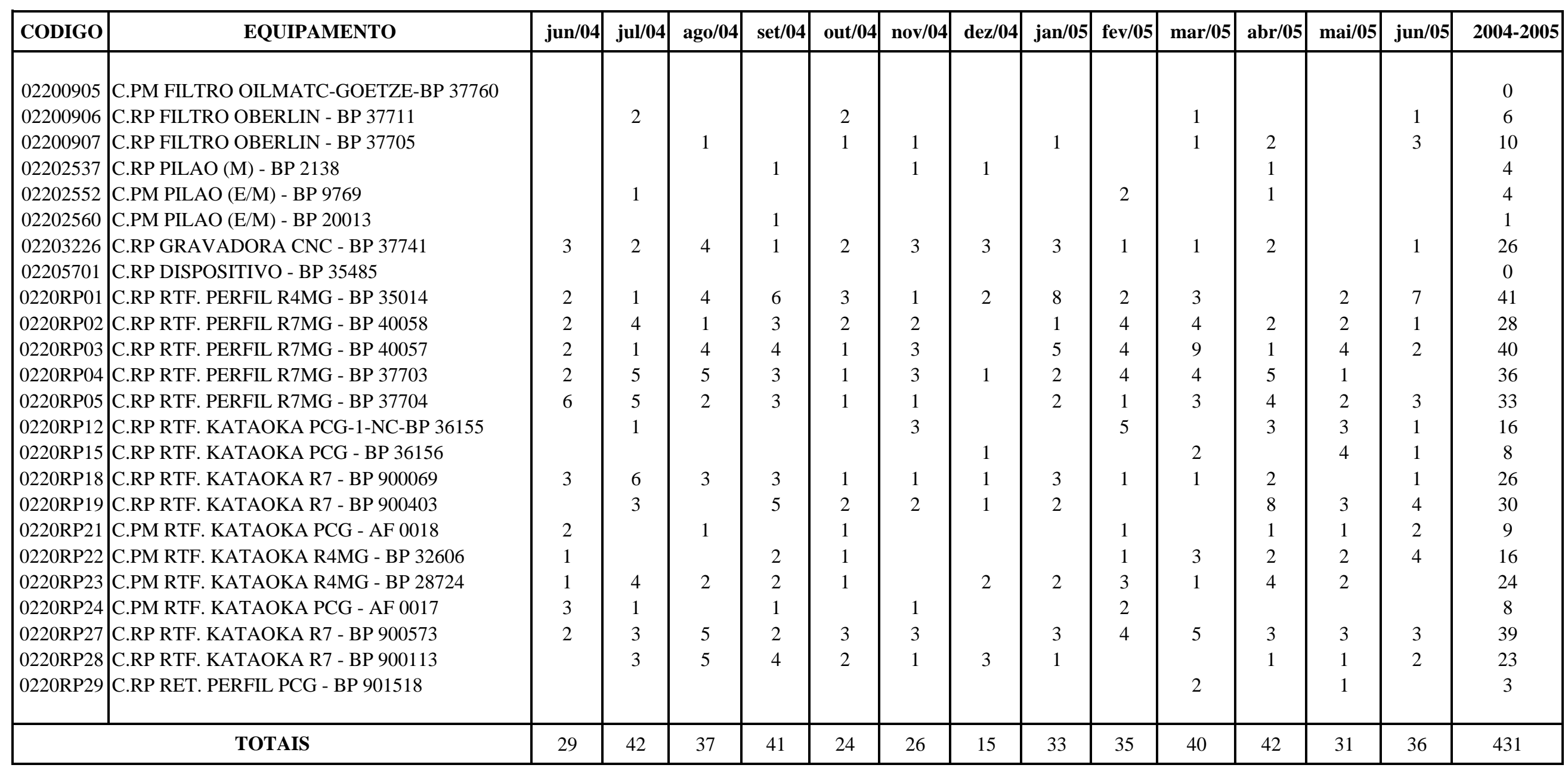


RETÍFICA DE PERFIL

MANUTENÇÃO PREVENTIVA (NÚMERO DE PREVENTIVAS)

(Período: 01/06/2004 a 30/06/2005)

\begin{tabular}{|c|c|c|c|c|c|c|c|c|c|c|c|c|c|c|c|}
\hline CÓDIGO & EQUIPAMENTO & jun/04 & jul/04 & ago/04 & set/04 & out $/ 04$ & nov/04 & dez/04 & jan/05 & fev/05 & $\operatorname{mar} / 05$ & abr/05 & mai/05 & jun/05 & $2004 / 2005$ \\
\hline $\begin{array}{l}02200905 \\
02200906 \\
02200907 \\
02202537 \\
02202552 \\
02202560 \\
02203226 \\
02205701 \\
0220 \mathrm{RP} 01 \\
0220 \mathrm{RP} 02 \\
0220 \mathrm{RP} 03 \\
0220 \mathrm{RP} 04 \\
0220 \mathrm{RP} 05 \\
0220 \mathrm{RP} 12 \\
0220 \mathrm{RP} 15 \\
0220 \mathrm{RP} 18 \\
0220 \mathrm{RP} 19 \\
0220 \mathrm{RP} 21 \\
0220 \mathrm{RP} 22 \\
0220 \mathrm{RP} 23 \\
0220 \mathrm{RP} 24 \\
\text { 0220RP27 } \\
\text { 0220RP28 } \\
\text { 0220RP29 }\end{array}$ & $\begin{array}{l}\text { C.PM RTF. KATAOKA R4MG - BP } 28724 \\
\text { C.RP RET. PERFIL PCG - BP } 901518 \\
\text { C.RP RTF. KATAOKA R7 - BP } 900113 \\
\text { C.RP RTF. KATAOKA R7 - BP } 900403 \\
\text { C.RP RTF. PERFIL R4MG - BP } 35014 \\
\text { C.RP RTF. PERFIL R7MG - BP } 37703 \\
\text { C.RP RTF. PERFIL R7MG - BP } 37704 \\
\text { C.RP RTF. PERFIL R7MG - BP } 40057 \\
\text { C.RP RTF. PERFIL R7MG - BP } 40058 \\
\text { C.PM RTF. KATAOKA PCG - AF } 0017 \\
\text { C.PM RTF. KATAOKA PCG - AF } 0018 \\
\text { C.PM RTF. KATAOKA R4MG - BP } 32606 \\
\text { C.RP FILTRO OBERLIN - BP } 37705 \\
\text { C.RP FILTRO OBERLIN - BP } 37711 \\
\text { C.RP GRAVADORA CNC - BP } 37741 \\
\text { C.RP RTF. KATAOKA PCG - BP } 36156 \\
\text { C.RP RTF. KATAOKA PCG-1-NC-BP } 36155 \\
\text { C.RP RTF. KATAOKA R7 - BP 900069 } \\
\text { C.PM FILTRO OILMATC-GOETZE-BP } 37760 \\
\text { C.PM PILAO (E/M) - BP } 20013 \\
\text { C.PM PILAO (E/M) - BP 9769 } \\
\text { C.RP DISPOSITIVO - BP } 35485 \\
\text { C.RP PILAO (M) - BP 2138 } \\
\text { C.RP RTF. KATAOKA R7 - BP 900573 }\end{array}$ & $\begin{array}{l}1 \\
1 \\
2 \\
1\end{array}$ & 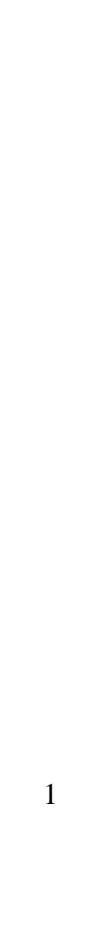 & 1 & $\begin{array}{l}3 \\
2 \\
2 \\
2 \\
1 \\
1 \\
\\
\\
\\
\\
1 \\
2 \\
1\end{array}$ & 2 & $\begin{array}{l}1 \\
2\end{array}$ & $\begin{array}{l}1 \\
1 \\
2\end{array}$ & $\begin{array}{l}1 \\
1 \\
1 \\
1 \\
2 \\
1\end{array}$ & $\begin{array}{l}2 \\
1\end{array}$ & $\begin{array}{l}2 \\
2 \\
1\end{array}$ & 1 & 1 & $\begin{array}{l}1 \\
1 \\
1 \\
1\end{array}$ & $\begin{array}{c}2 \\
4 \\
1 \\
\\
\\
2 \\
\\
5 \\
8 \\
8 \\
9 \\
7 \\
4 \\
4 \\
6 \\
6 \\
3 \\
3 \\
5 \\
4 \\
5 \\
12 \\
4\end{array}$ \\
\hline & TOTAIS & 6 & 1 & 14 & 15 & 5 & 4 & 8 & 13 & 10 & 12 & 3 & 6 & 5 & 102 \\
\hline
\end{tabular}


RETÍFICA DE PERFIL

CÓDIGO DE PARADAS (NÚMERO DE FALHAS)

(Período: 01/06/2004 a 30/06/2005)

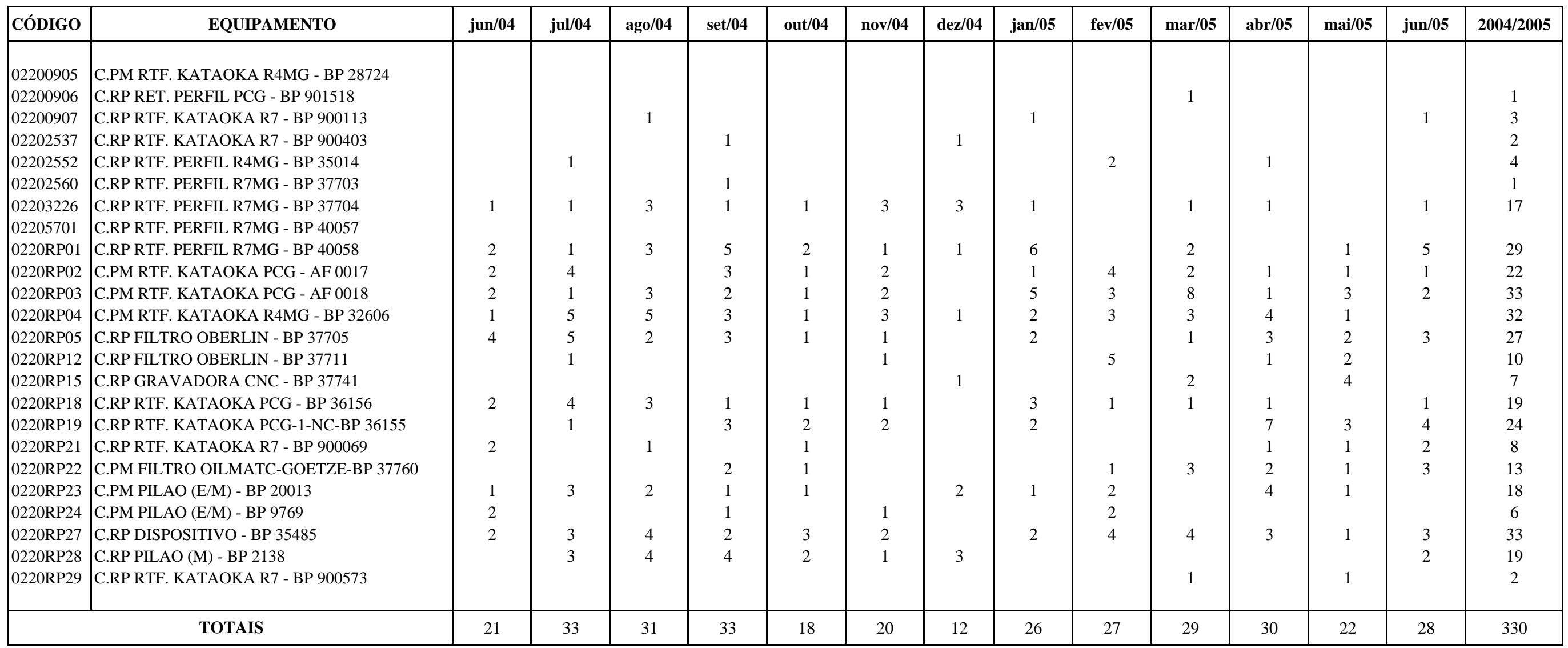


RETÍFICA DE PERFIL

QUADRO RESUMO DAS ORDENS DE SERVIÇO

(Período: 01/06/2004 a 30/06/2005)

\begin{tabular}{|c|c|c|c|c|c|}
\hline CÓDIGO & EQUIPAMENTO & $\begin{array}{l}\mathbf{N}^{0} \text { DE ORDENS DE SV } \\
\text { DE MNT CORRETIVA }\end{array}$ & $\begin{array}{c}\text { No DE CÓD. DE PARADA } \\
\text { DE PRODUÇÃO }\end{array}$ & $\begin{array}{l}\text { No DE ORDENS DE SV } \\
\text { DE MNT PREVENTIVA }\end{array}$ & No DE FUNCIONÁRIOS \\
\hline 02200905 & C.PM FILTRO OILMATC-GOETZE-BP 37760 & 0 & 0 & 0 & 0 \\
\hline 02200906 & C.RP FILTRO OBERLIN - BP 37711 & 6 & 1 & 2 & 10 \\
\hline 02200907 & C.RP FILTRO OBERLIN - BP 37705 & 10 & 3 & 4 & 18 \\
\hline 02202537 & C.RP PILAO (M) - BP 2138 & 4 & 2 & 1 & 5 \\
\hline 02202552 & C.PM PILAO (E/M) - BP 9769 & 4 & 4 & 0 & 4 \\
\hline 02202560 & C.PM PILAO (E/M) - BP 20013 & 1 & 1 & 0 & 1 \\
\hline 02203226 & C.RP GRAVADORA CNC - BP 37741 & 26 & 17 & 2 & 30 \\
\hline 02205701 & C.RP DISPOSITIVO - BP 35485 & 0 & 0 & 0 & 0 \\
\hline 0220RP01 & C.RP RTF. PERFIL R4MG - BP 35014 & 41 & 29 & 5 & 59 \\
\hline 0220RP02 & C.RP RTF. PERFIL R7MG - BP 40058 & 28 & 22 & 8 & 42 \\
\hline 0220RP03 & C.RP RTF. PERFIL R7MG - BP 40057 & 40 & 33 & 8 & 60 \\
\hline 0220RP04 & C.RP RTF. PERFIL R7MG - BP 37703 & 36 & 32 & 9 & 56 \\
\hline 0220RP05 & C.RP RTF. PERFIL R7MG - BP 37704 & 33 & 27 & 7 & 47 \\
\hline 0220RP12 & C.RP RTF. KATAOKA PCG-1-NC-BP 36155 & 16 & 10 & 4 & 27 \\
\hline 0220RP15 & C.RP RTF. KATAOKA PCG - BP 36156 & 8 & 7 & 4 & 14 \\
\hline 0220RP18 & C.RP RTF. KATAOKA R7 - BP 900069 & 26 & 19 & 6 & 40 \\
\hline 0220RP19 & C.RP RTF. KATAOKA R7 - BP 900403 & 30 & 24 & 6 & 41 \\
\hline 0220RP21 & C.PM RTF. KATAOKA PCG - AF 0018 & 9 & 8 & 3 & 13 \\
\hline 0220RP22 & C.PM RTF. KATAOKA R4MG - BP 32606 & 16 & 13 & 3 & 20 \\
\hline 0220RP23 & C.PM RTF. KATAOKA R4MG - BP 28724 & 24 & 18 & 5 & 38 \\
\hline 0220RP24 & C.PM RTF. KATAOKA PCG - AF 0017 & 8 & 6 & 4 & 17 \\
\hline 0220RP27 & C.RP RTF. KATAOKA R7 - BP 900573 & 39 & 33 & 5 & 52 \\
\hline 0220RP28 & C.RP RTF. KATAOKA R7 - BP 900113 & 23 & 19 & 12 & 42 \\
\hline 0220RP29 & C.RP RET. PERFIL PCG - BP 901518 & 3 & 2 & 4 & 8 \\
\hline TOTAIS & & 431 & 330 & 102 & 644 \\
\hline
\end{tabular}


RETÍFICA DE PERFIL

\section{QUADRO COMPLETO}

(Período: 01/06/2004 a 30/06/2005)

\begin{tabular}{|c|c|c|c|c|c|}
\hline CÓDIGO & OS MC & $\mathbf{C P}$ & OS MP & SERVIÇO EXECUTADO & FUNCIONÁRIOS \\
\hline 02200906 & 02R63822 & & & TROCADO ANEL ORING E CONFEC. CHAPA DE OLEO & ADRIANO MACEDO \\
\hline 02200906 & 02R68266 & & & REP. CHAPA DE ACO E AJUST. PRESSAO E LIMP. HASTE DO SENSOR & ADRIANO MACEDO \\
\hline 02200906 & $02 \mathrm{R} 68266$ & & & REP. CHAPA DE ACO E AJUST. PRESSAO E LIMP. HASTE DO SENSOR & CLEZIO CARDOSO SILVA \\
\hline 02200906 & 02R68266 & & & REP. CHAPA DE ACO E AJUST. PRESSAO E LIMP. HASTE DO SENSOR & EDSON HENRIQUE DA SILVA \\
\hline 02200906 & $02 \mathrm{~T} 11850$ & & & TROCADO CONJUNTO DE LUBRIFIL & ADRIANO MACEDO \\
\hline 02200906 & $02 \mathrm{~T} 12699$ & & & TROCADO MANGUEIRA & CLAUDIO RAIMUNDO DE ANDRADE \\
\hline 02200906 & $02 \mathrm{~V} 61365$ & 02C7937 & & TROCADO CONEXAO DE AR E ELIMINADO VAZAMENTO & ADRIANO MACEDO \\
\hline 02200906 & $02 X 08056$ & & & CONFECCIONADO PROTECAO PARA O PAINLEL DO FILTRO OBERLIN CONF & ADRIANO MACEDO \\
\hline 02200906 & & & 02V09814 & MP-0200M - ANUAL - FILTRO OBERLIN & RENATO MARCEL CARVALHO \\
\hline 02200906 & & & 02V10045 & MP-0200E - ANUAL - FILTRO OBERLIN & SIDINEI ALBERTO MENEZES \\
\hline SUBTOTAIS & 6 & 1 & 2 & & 10 \\
\hline 02200907 & 02S13341 & 02B9317 & & REPARO E LIMP. SENSORES DE NIVEL & JOAO BATISTA DA SILVA \\
\hline 02200907 & $02 \mathrm{~T} 29896$ & & & TROCADO MANGUEIRA PNEUMATICA & JORGELINO BATISTA DE OLIVEIRA \\
\hline 02200907 & $02 \mathrm{~T} 47894$ & & & TROCADO PARAFUSOS FIXADOS TAMPA DO MOTOR & ADRIANO MACEDO \\
\hline 02200907 & 02U37811 & 02C4788 & & TROCADO FUSIVEIS DA CHAVE GERAL & EDSON HENRIQUE DA SILVA \\
\hline 02200907 & 02 V53533 & & & REGULADO PRESSOES DO SISTEMA & JOAO BATISTA DA SILVA \\
\hline 02200907 & 02W04220 & & & LIMPADO E LUBRIF. VALVULA & ADRIANO MACEDO \\
\hline 02200907 & 02W05639 & & & ALINHADO CATRACA DA CORRENTE & ADRIANO MACEDO \\
\hline 02200907 & $02 X 00731$ & & & FOI REVISADO VALVULA E FEITOAJUSTE DO CONJUNTO DE ARRASTE DA & VALTEMIR FRANCISCO BARROS \\
\hline 02200907 & $02 X 07743$ & & & FOI SUBSTITUIDO VALVULA DO CONJUNTO DE ARRASTE DO FILTRO & VALTEMIR FRANCISCO BARROS \\
\hline 02200907 & 02X07832 & 02D0724 & & REPARO NA ESTERIA DO FILTRO OBERLIM & ADRIANO MACEDO \\
\hline 02200907 & & & 02R72313 & SUBSTITUICAO DO LUBRIFIL DO FILTRO OBERLIN BP 37705 & JORGELINO BATISTA DE OLIVEIRA \\
\hline 02200907 & & & $02 \mathrm{~T} 55606$ & MANUTENCAO NO FILTRO OBERLIN BP 37705 & CLESIO TORRES GOMES \\
\hline 02200907 & & & $02 T 55606$ & MANUTENCAO NO FILTRO OBERLIN BP 37705 & JUNIOR MARCELO GONCALVES \\
\hline 02200907 & & & $02 T 55606$ & MANUTENCAO NO FILTRO OBERLIN BP 37705 & LUIZ CARLOS NOGUEIRA \\
\hline 02200907 & & & $02 \mathrm{~T} 55606$ & MANUTENCAO NO FILTRO OBERLIN BP 37705 & SEBASTIAO DIVINO CARLOS \\
\hline 02200907 & & & $02 \mathrm{~T} 55606$ & MANUTENCAO NO FILTRO OBERLIN BP 37706 & SILVIO JOSE LIMA \\
\hline 02200907 & & & 02U75164 & MP-0200M - ANUAL - FILTRO OBERLIN & RICARDO MAGNO DO CARMO \\
\hline 02200907 & & & $02 U 75501$ & MP-0200E - ANUAL - FILTRO OBERLIN & GERSON TADEU GONCALVES \\
\hline SUBTOTAIS & 10 & 3 & 4 & & 18 \\
\hline 02202537 & 02S84700 & $02 \mathrm{C} 0873$ & & REPARADO SAPATA DA HASTE DO PILAO E TROCADO PARAFUSO DO VIBR & WAGNER KALAS PEREIRA \\
\hline 02202537 & $02 \mathrm{~T} 90836$ & & & RECUP. E TROCADO O SUPORTE DO VIBRADOR & CARLOS RENATO ALKMIM \\
\hline 02202537 & $02 \mathrm{~T} 98419$ & $02 \mathrm{C} 3442$ & & TROCADO VALVULA DO PILAO & SILVIO JOSE LIMA \\
\hline
\end{tabular}




\begin{tabular}{|c|c|c|c|c|c|}
\hline CÓDIGO & OS MC & $\mathbf{C P}$ & OS MP & SERVIÇO EXECUTADO & FUNCIONÁRIOS \\
\hline 02202537 & 02W38364 & & & FIXADO A CAIXA DO BOTAO DE ACIONAMENTO DO PILAO & CARLOS RENATO ALKMIM \\
\hline 02202537 & & & 02U76430 & MP-0133M - ANUAL - PILAO & RENATO MARCEL CARVALHO \\
\hline SUBTOTAIS & 4 & 2 & 1 & & 5 \\
\hline 02202552 & $02 \mathrm{R} 73651$ & $02 \mathrm{~B} 8476$ & & LIMPADO VALVULA DE ACIONAMENTO DA HASTE & SILVIO JOSE LIMA \\
\hline 02202552 & 02V02241 & 02C6179 & & TROCADO SILENCIADOR DE ESCAPE DO PILAO & WAGNER KALAS PEREIRA \\
\hline 02202552 & 02V07415 & 02C6578 & & TROCADO PEDAL E MANGUEIRAS & EDMILSON CESAR FRANCISCO \\
\hline 02202552 & 02W03310 & 02C8612 & & TROCADO A MANGUEIRA DA APERTADEIRA & SILVIO JOSE LIMA \\
\hline SUBTOTAIS & 4 & 4 & $\mathbf{0}$ & & 4 \\
\hline 02202560 & 02S63803 & $02 \mathrm{C} 0475$ & & LUBRIF. E DESTRAV. HASTE E COLOCADO OLEO NA UNID. DE CONSERV & WAGNER KALAS PEREIRA \\
\hline SUBTOTAIS & 1 & 1 & $\mathbf{0}$ & & 1 \\
\hline 02203226 & 02R10862 & 02B6576 & & ADAPTADO OUTRO TIPO DE SENSOR NO ROBO AVANCO & JOAO BATISTA DA SILVA \\
\hline 02203226 & 02R21486 & & & TROCADO SENSOR DE FALTA DE ANEIS E REP. FIXADOR & JOAO BATISTA DA SILVA \\
\hline 02203226 & 02R25197 & & & TROCADO CONJUNTO DO LUBRIFIL & ADRIANO MACEDO \\
\hline 02203226 & 02R72527 & & & TROCADO SENSOS QUE INDICA FAÇTA DE ANIL GRAVADORA CNC & GILBERTO CORREA DE CARVALHO \\
\hline 02203226 & 02R73688 & 02B8479 & & AJUSTADO ACIONADOR DOS MICROS E REFERENCIADOS EIXOS & GILBERTO CORREA DE CARVALHO \\
\hline 02203226 & $02 \mathrm{~S} 03218$ & 02B8862 & & REPARO NA ENTRADA DO CLP & JOAO BATISTA DA SILVA \\
\hline 02203226 & 02S14144 & & & TROCADO AMORTECEDOR DO ROBO DA RETIFICA & ADRIANO MACEDO \\
\hline 02203226 & 02S22331 & $02 \mathrm{~B} 9522$ & & REPARO NO CLP DE ENTRADA & JOAO BATISTA DA SILVA \\
\hline 02203226 & 02S31535 & $02 B 9546$ & & ATERRADO BANCADA DO FERRAMENTAL E ALINHADOR & JOAO BATISTA DA SILVA \\
\hline 02203226 & 02S58739 & $02 \mathrm{C} 0248$ & & TROCADO SENSOR DO ROBO RETORNADO & JOAO BATISTA DA SILVA \\
\hline 02203226 & $02 \mathrm{~T} 11878$ & 02C1589 & & TROCADO PARAFUSOS E RECUPERADO ROSCAS & ADRIANO MACEDO \\
\hline 02203226 & $02 \mathrm{~T} 17667$ & & & TROCADO SENSOR DO SUPORTE DE MAGAZINE DA GRAVADORA & EDSON HENRIQUE DA SILVA \\
\hline 02203226 & $02 \mathrm{~T} 57445$ & 02C2820 & & TROCADO SENSOR DA GRAVADORA & GERSON TADEU GONCALVES \\
\hline 02203226 & $02 \mathrm{~T} 81515$ & $02 C 3038$ & & FIXADO ACIONADOR DO SENSOR & CLEZIO CARDOSO SILVA \\
\hline 02203226 & $02 \mathrm{~T} 89919$ & 02C3156 & & REPARO NA FONTE - CNC EM ALARME & JOAO BATISTA DA SILVA \\
\hline 02203226 & $02 \mathrm{~T} 89919$ & $02 \mathrm{C} 3156$ & & REPARO NA FONTE - CNC EM ALARME & LUCIANO JOSE CORTES \\
\hline 02203226 & $02 \mathrm{~T} 89919$ & 02C3156 & & REPARO NA FONTE - CNC EM ALARME & SIDINEI ALBERTO MENEZES \\
\hline 02203226 & $02 \mathrm{~T} 94020$ & $02 \mathrm{C} 3297$ & & REPARO NA FONTE DO DRIVE DOS EIXOS & NÃO IDENTIFICADO \\
\hline 02203226 & $02 \mathrm{~T} 98400$ & 02C3441 & & TROCADO ROTOR DA GRAVADORA & CLEZIO CARDOSO SILVA \\
\hline 02203226 & 02U04302 & 02C3621 & & TROCADO EIXO DE 3 PALETAS POR UM DE 4 PALETAS & CLEZIO CARDOSO SILVA \\
\hline 02203226 & 02U47668 & & & INSTALADO UMA TOMADA DTECK P/ ALIMENTACAO DO EXAUSTOR & LUCIANO JOSE CORTES \\
\hline 02203226 & 02U47944 & & & FEITO FURACAO E ABERTO ROSCAS DE 6MM NA GRAVADORA & JORGELINO BATISTA DE OLIVEIRA \\
\hline 02203226 & 02U69769 & 02C5493 & & LIMP. E LUBRIFICADO CILINDRO DA GRAVADORA & CLEZIO CARDOSO SILVA \\
\hline 02203226 & 02V04089 & & & TROC. MEMBRANA DO TECLADO E LIMPEZA GERAL & GERSON TADEU GONCALVES \\
\hline 02203226 & $02 \mathrm{~V} 61347$ & $02 \mathrm{C} 7936$ & & TROCADO REGULADORA DE FLUXO DO CILINDRO & CARLOS RENATO ALKMIM \\
\hline 02203226 & 02W00233 & & & TROCADFO MANGUEIRA DE AR E ELIMINADO VAZAMENTO & ADRIANO MACEDO \\
\hline
\end{tabular}




\begin{tabular}{|c|c|c|c|c|c|}
\hline CÓDIGO & OS MC & $\mathbf{C P}$ & OS MP & SERVIÇO EXECUTADO & FUNCIONÁRIOS \\
\hline 02203226 & 02W05979 & 02C8670 & & TROC. ROLAMENTOS E ELIMINADO VARIACAO & ADRIANO MACEDO \\
\hline 02203226 & 02X00777 & 02D0457 & & TROCA DO SENSOR DO ESTRATOR DESTRAVADA VALVULA & JOAO BATISTA DA SILVA \\
\hline 02203226 & & & 02U27314 & MP-0146M - ANUAL - GRAVADORA CNC & NOEL TEIXEIRA DOS SANTOS \\
\hline 02203226 & & & 02U27653 & MP-0146E - ANUAL - GRAVADORA CNC & WILLIAN DOS SANTOS FLAUSINO \\
\hline SUBTOTAIS & 26 & 17 & 2 & & 30 \\
\hline 0220RP01 & 02R07581 & 02B6480 & & REPARADO REFRIGERACAO DA KATAOKA & ADRIANO MACEDO \\
\hline 0220RP01 & 02R10746 & 02B6587 & & EMENDADO CORRENTE DO CARREGADOR DE ANEIS & ADRIANO MACEDO \\
\hline 0220RP01 & 02R70404 & 02B8299 & & DESEMPENADO GUIA DO SUPORTE DO ROBO & ADRIANO MACEDO \\
\hline 0220RP01 & $02 \mathrm{~S} 13635$ & & & REPARAR VALVULA GEMU DA RETIFICA & ADRIANO MACEDO \\
\hline 0220RP01 & 02S13635 & & & REPARAR VALVULA GEMU DA RETIFICA & CLEZIO CARDOSO SILVA \\
\hline 0220RP01 & 02S15241 & $02 \mathrm{~B} 9475$ & & REPARADO CILINDRO DO ROBO & CLEZIO CARDOSO SILVA \\
\hline 0220RP01 & $02 S 15857$ & 02B9490 & & REPASSADO ROSCA NO PARAFUSO DA CORRENTE DO EMPURRADOR & CLEZIO CARDOSO SILVA \\
\hline 0220RP01 & 02S31839 & $02 B 9554$ & & TROCADO MOLA DO ROBO & SILVIO JOSE LIMA \\
\hline 0220RP01 & 02S55377 & 02C0080 & & REPARO DO DRESSADOR INTERROMPIDO & JOAO BATISTA DA SILVA \\
\hline 0220RP01 & 02S58301 & 02C0215 & & REPARADO O CABO DO SENSOR DE ROBO & EDSON HENRIQUE DA SILVA \\
\hline 0220RP01 & 02S58668 & $02 \mathrm{C} 0242$ & & REPARADO PARAFUSO E RECUPERADO ROSCA & ADRIANO MACEDO \\
\hline 0220RP01 & $02 S 58695$ & 02C0245 & & REPARO NO SENSOR DO ROBO & JOAO BATISTA DA SILVA \\
\hline 0220RP01 & 02S63377 & & & REPARADO COMANDO DE DRESSAGEM & EDSON HENRIQUE DA SILVA \\
\hline 0220RP01 & 02S63377 & & & REPARADO COMANDO DE DRESSAGEM & GERSON TADEU GONCALVES \\
\hline 0220RP01 & 02S63377 & & & REPARADO COMANDO DE DRESSAGEM & JOAO BATISTA DA SILVA \\
\hline 0220RP01 & $02 S 74169$ & $02 \mathrm{C} 0737$ & & TROCADO CORRENTE DO EMPURRADOR DE ANEIS & CLEZIO CARDOSO SILVA \\
\hline 0220RP01 & $02 \mathrm{~T} 12350$ & 02C1692 & & REPARO NA ALIMENTACAO DO EMPURRADOR DE ANEL & JOAO BATISTA DA SILVA \\
\hline 0220RP01 & $02 \mathrm{~T} 17845$ & & & LIMPADO E LUBRIFIFCADO REGUAS E GUIAS DA RETIFICA & ADRIANO MACEDO \\
\hline 0220RP01 & $02 \mathrm{~T} 30152$ & 02C2033 & & REARMADO, RESETADO TERMICOS E VERIFIFCADO MICROS & GERSON TADEU GONCALVES \\
\hline 0220RP01 & $02 \mathrm{~T} 94164$ & $02 \mathrm{C} 3305$ & & REPARADO PARAFUSOS DE SUSTENTACAO DA BUCHA & ADRIANO MACEDO \\
\hline 0220RP01 & $02 \mathrm{~T} 95403$ & & & TROCADO ROLAMENTO DO EMPURRADOR POR BUCHA DE LATAO & ADRIANO MACEDO \\
\hline 0220RP01 & 02U07871 & $02 \mathrm{C} 3779$ & & TROCADO PARAFUSO DA BUCHA & SILVIO JOSE LIMA \\
\hline 0220RP01 & 02U38455 & 02C4837 & & RECUPERADO ROSCA DO PARAFUSO DA BUCHA & GILBERTO CORREA DE CARVALHO \\
\hline 0220RP01 & $02 \mathrm{U} 38455$ & 02C4837 & & RECUPERADO ROSCA DO PARAFUSO DA BUCHA & SILVIO JOSE LIMA \\
\hline 0220RP01 & 02U65451 & $02 \mathrm{C} 5359$ & & VERIFICADO DO CABO DE ALIUMENTACAO DO MOTOR DO EMPURRADOR & GILBERTO CORREA DE CARVALHO \\
\hline 0220RP01 & 02U65914 & & & TROCADO REBOLO - ERRO OPERACIONAL & LUCIANO JOSE CORTES \\
\hline 0220RP01 & 02U69064 & $02 \mathrm{C} 5484$ & & LIMPADO SENSORES DA GARRA & GERSON TADEU GONCALVES \\
\hline 0220RP01 & $02 \mathrm{U} 72309$ & 02C5544 & & LIMPADO E LUBRIFICADO VALVULA DE REFRIGERACAO & ADRIANO MACEDO \\
\hline 0220RP01 & 02U72309 & 02C5544 & & LIMPADO E LUBRIFICADO VALVULA DE REFRIGERACAO & LUCIANO JOSE CORTES \\
\hline 0220RP01 & 02U81255 & $02 \mathrm{C} 5634$ & & REPARADO CABO DO SENSOR & EDSON HENRIQUE DA SILVA \\
\hline 0220RP01 & $02 \mathrm{U} 82753$ & 02C5836 & & LIMPADO CONEXAO HIDRAULICA & CLEZIO CARDOSO SILVA \\
\hline 0220RP01 & 02U94660 & & & TROC. DO BARRAMENTO E RECUPERADO E SOLDADO & ADRIANO MACEDO \\
\hline 0220RP01 & 02U94660 & & & TROC. DO BARRAMENTO E RECUPERADO E SOLDADO & CLEZIO CARDOSO SILVA \\
\hline
\end{tabular}




\begin{tabular}{|c|c|c|c|c|c|}
\hline CÓDIGO & OS MC & $\mathbf{C P}$ & OS MP & SERVIÇO EXECUTADO & FUNCIONÁRIOS \\
\hline 0220RP01 & $02 \mathrm{~V} 22559$ & & & TROCADO PROTECAO DE ACRILICO & ADRIANO MACEDO \\
\hline 0220RP01 & $02 \mathrm{~V} 40771$ & & & TROC. CARREGADOR DE ANEIS E CONFECCIONADO PECA & ADRIANO MACEDO \\
\hline 0220RP01 & 02V41495 & $02 \mathrm{C} 7134$ & & LIMP. LIMPEZA, TROC. CONEXOES E ELIMINADO VAZAMENTO & ADRIANO MACEDO \\
\hline 0220RP01 & $02 \mathrm{~V} 44349$ & $02 C 7257$ & & VERIFICAR SISTEMA DE ARRASTE DA RETIFICA & GERSON TADEU GONCALVES \\
\hline 0220RP01 & $02 \mathrm{~V} 44349$ & 02C7257 & & VERIFICAR SISTEMA DE ARRASTE DA RETIFICA & SIDNEY GONCALVES FARIA MONTI \\
\hline 0220RP01 & $02 \mathrm{~V} 44349$ & 02C7257 & & VERIFICAR SISTEMA DE ARRASTE DA RETIFICA & SILVIO JOSE LIMA \\
\hline 0220RP01 & $02 \mathrm{~V} 44349$ & 02C7257 & & VERIFICAR SISTEMA DE ARRASTE DA RETIFICA & VALTEMIR FRANCISCO BARROS \\
\hline 0220RP01 & $02 \mathrm{~V} 60366$ & & & AJUSTADO CONEXOES E LIMPADO E ELIMINADO VAZAMENTO & ADRIANO MACEDO \\
\hline 0220RP01 & $02 W 54185$ & & & LIMP. UNIDADE HIDRAULICA E AJUST. CONEXOES E MANGUEIRAS & ADRIANO MACEDO \\
\hline 0220RP01 & $02 \mathrm{~W} 54185$ & & & LIMP. UNIDADE HIDRAULICA E AJUST. CONEXOES E MANGUEIRAS & VALTEMIR FRANCISCO BARROS \\
\hline 0220RP01 & 02W88470 & 02C9958 & & TROCADO REPARO ELIMINADO VAZAMENTO & ADRIANO MACEDO \\
\hline 0220RP01 & 02X00786 & $02 \mathrm{D} 0458$ & & RREPARO NO CONTATO LIGA HIDRAULICA & JOAO BATISTA DA SILVA \\
\hline 0220RP01 & $02 X 05317$ & $02 D 0619$ & & RECUPERADO CORRENTE DO CARREGADOR DE ANEIS & VALTEMIR FRANCISCO BARROS \\
\hline 0220RP01 & $02 X 08519$ & & & REPARO NA PRESAO DO CABECOTE E TEMPOS DE PRESSAGEM & JOAO BATISTA DA SILVA \\
\hline 0220RP01 & $02 X 26624$ & & & LIMPEZA NA VALVULA DE REFRIGERACAO DO REBOLO & SILVIO JOSE LIMA \\
\hline 0220RP01 & 02X34054 & 02D0896 & & REPOSICIONADO CABECOTE DO REBOLO & JOAO BATISTA DA SILVA \\
\hline 0220RP01 & $02 X 34054$ & $02 \mathrm{D} 0896$ & & REPOSICIONADO CABECOTE DO REBOLO & VALTEMIR FRANCISCO BARROS \\
\hline 0220RP01 & $02 X 35712$ & $02 \mathrm{D} 0944$ & & RECUPERADO SUPORTE DO ALINHADOR DE ANEL & SILVIO JOSE LIMA \\
\hline 0220RP01 & $02 X 37248$ & 02D0991 & & TROCADO PARAFUSO E RECUP. ROSCA DO SUPORTE DRESSADOR & VALTEMIR FRANCISCO BARROS \\
\hline 0220RP01 & & & 02R65731 & REPARO NO ALARME DO SISTEMA DE SEGURANCA DO REBOLO & GILBERTO CORREA DE CARVALHO \\
\hline 0220RP01 & & & $02 S 13608$ & REPARO EM VAZAMENTO DE VALVULA NA KATAOKA & ADRIANO MACEDO \\
\hline 0220RP01 & & & 02S40357 & MP-0202M - ANUAL - RETIFICA KATAOKA R4 & CLAUDIO RAIMUNDO DE ANDRADE \\
\hline 0220RP01 & & & 02S40357 & MP-0202M - ANUAL - RETIFICA KATAOKA R5 & RICARDO MAGNO DO CARMO \\
\hline 0220RP01 & & & 02S40614 & MP-0202E - ANUAL - RETIFICA KATAOKA R4 & LUCIANO JOSE CORTES \\
\hline 0220RP01 & & & 02U04909 & ADAPTACAO DE CHAVE DE SEGURANCA NA RETIFICA DE PERFIL & GERSON TADEU GONCALVES \\
\hline 0220RP01 & & & 02U04909 & ADAPTACAO DE CHAVE DE SEGURANCA NA RETIFICA DE PERFIL & RENATO MARCEL CARVALHO \\
\hline SUBTOTAIS & 41 & 29 & 5 & & 59 \\
\hline 0220RP02 & 02R17115 & 02B6875 & & RECUPERADO CORRENTRE DO EMPURRADOR DE ANEIS & CLEZIO CARDOSO SILVA \\
\hline 0220RP02 & $02 \mathrm{R} 21663$ & 02B7050 & & REPARADO ACIONADOR DA BARRA DO ROBO & JOAO BATISTA DA SILVA \\
\hline 0220RP02 & $02 \mathrm{R} 54333$ & 02B7639 & & REPARO NO SUPORTE DO CONTRA PONTO DA RETIFICA & CLEZIO CARDOSO SILVA \\
\hline 0220RP02 & $02 \mathrm{R} 54333$ & 02B7639 & & REPARO NO SUPORTE DO CONTRA PONTO DA RETIFICA & WAGNER KALAS PEREIRA \\
\hline 0220RP02 & 02R64705 & 02B8060 & & RECUP. E SOLDADO SUPORTE DE APOIO DO CONTRA PONTO & CLEZIO CARDOSO SILVA \\
\hline 0220RP02 & $02 \mathrm{R} 72554$ & 02B8424 & & TROCADO PARAFUSO DE APERTO DA BUCHA & CLEZIO CARDOSO SILVA \\
\hline 0220RP02 & 02R73624 & 02B8475 & & LIMPADO TUBULACOES E VALVULA DA REFRIGERACAO DA RETIFICA & SILVIO JOSE LIMA \\
\hline 0220RP02 & 02S48386 & & & LIMPADO E LUBRIFICADO GUIAS DA REGUA & ADRIANO MACEDO \\
\hline 0220RP02 & $02 S 81115$ & 02C0795 & & AJUST. DISP. DE FOLGA E APROX. CAME DE ACIONAMENTO DO SENSOR & GERSON TADEU GONCALVES \\
\hline 0220RP02 & 02S81614 & $02 \mathrm{C} 0825$ & & AJUSTADO FOLGA DO SUPORTE DA BUCHA & CLEZIO CARDOSO SILVA \\
\hline 0220RP02 & 02S81623 & $02 \mathrm{C} 0826$ & & RECUPERADO HASTE DO CILINDRO DO ROBO & CLEZIO CARDOSO SILVA \\
\hline
\end{tabular}




\begin{tabular}{|c|c|c|c|c|c|}
\hline CÓDIGO & OS MC & $\mathbf{C P}$ & OS MP & SERVIÇO EXECUTADO & FUNCIONÁRIOS \\
\hline 0220RP02 & $02 \mathrm{~T} 02548$ & & & TROCADO GUIA DE ENCOSTO DO CONTRA PONTO DA KATAOKA & ADRIANO MACEDO \\
\hline 0220RP02 & 02T07650 & $02 \mathrm{C} 1483$ & & TROCADO ENCOSTO DA PLACA DO CABECOTE & SILVIO JOSE LIMA \\
\hline 0220RP02 & $02 \mathrm{~T} 50246$ & $02 \mathrm{C} 2536$ & & REPARO NA VARIACAO DO CONTRA PONTO & ADRIANO MACEDO \\
\hline 0220RP02 & $02 \mathrm{~T} 90391$ & 02C3170 & & TROCADO GUIAS DA BUCHA DA RETIFICA E ELIMINADO FOLGA & ADRIANO MACEDO \\
\hline 0220RP02 & 02U66281 & 02C5397 & & TROCADO O PARAFUSO DA MOLA DO DRESSADOR & SILVIO JOSE LIMA \\
\hline 0220RP02 & 02U96141 & 02C6047 & & RECUPERADO ROSCA DO PERFILADOR & ADRIANO MACEDO \\
\hline 0220RP02 & 02V02946 & 02C6186 & & REPARADO COMANDO DA BUCHA & GILBERTO CORREA DE CARVALHO \\
\hline 0220RP02 & 02V02946 & 02C6186 & & REPARADO COMANDO DA BUCHA & JOAO BATISTA DA SILVA \\
\hline 0220RP02 & 02V04294 & 02C6354 & & TROC. ROL. DO CONTRA PONTO, MANGUEIRA DO CILINDRO DO SUPORTE & ADRIANO MACEDO \\
\hline 0220RP02 & 02V04294 & 02C6354 & & TROC. ROL. DO CONTRA PONTO, MANGUEIRA DO CILINDRO DO SUPORTE & CLEZIO CARDOSO SILVA \\
\hline 0220RP02 & 02V04294 & 02C6354 & & TROC. ROL. DO CONTRA PONTO, MANGUEIRA DO CILINDRO DO SUPORTE & VALTEMIR FRANCISCO BARROS \\
\hline 0220RP02 & $02 \mathrm{~V} 28624$ & 02C6971 & & TROCADO PARAFUSO DE REGULAGEM DA BUCHA & SILVIO JOSE LIMA \\
\hline 0220RP02 & 02V50199 & & & CONF. PROTECAO DE ACRILICO DO PAINEL DA RETIFICA & ADRIANO MACEDO \\
\hline 0220RP02 & $02 \mathrm{~V} 62621$ & & & RECUPERADO PROTECAO DO CONTRA PONTO & VALTEMIR FRANCISCO BARROS \\
\hline 0220RP02 & $02 \mathrm{~V} 83403$ & 02C8162 & & AJUSTADO CORREIAS & VALTEMIR FRANCISCO BARROS \\
\hline 0220RP02 & 02 V97425 & $02 \mathrm{C} 8412$ & & TROCADO SENSOR AVANCADO DA KATAOKA & LUCIANO JOSE CORTES \\
\hline 0220RP02 & 02W03089 & & & TROC. E REPARADO REDUTORA & CARLOS RENATO ALKMIM \\
\hline 0220RP02 & 02W03089 & & & TROC. E REPARADO REDUTORA & WAGNER KALAS PEREIRA \\
\hline 0220RP02 & 02W42518 & $02 \mathrm{C} 9318$ & & VERIF. A CORRENTE DO EMPURRADOR E TROC. A EMENDA DA CORRENTE & SILVIO JOSE LIMA \\
\hline 0220RP02 & 02W54880 & 02C9700 & & TROCADO PARAFUSO DE REGULAGEM DA BUCHA & VALTEMIR FRANCISCO BARROS \\
\hline 0220RP02 & 02W56637 & $02 \mathrm{D} 1115$ & & LIMPADO SENSOR DE ACIONAMENTO DA BUCHA & EDSON HENRIQUE DA SILVA \\
\hline 0220RP02 & $02 X 39433$ & & & AJUSTADO PARAMETROS DO CNC & NÃO IDENTIFICADO \\
\hline 0220RP02 & & & 02Q89299 & MP-0203M - TRIMESTRAL - RETIFICA KATAOKA R7 & NOEL TEIXEIRA DOS SANTOS \\
\hline 0220RP02 & & & 02R65777 & REPARO NO ALARME DO SISTEMA DE SEGURANCA DO REBOLO & GILBERTO CORREA DE CARVALHO \\
\hline 0220RP02 & & & 02R65777 & REPARO NO ALARME DO SISTEMA DE SEGURANCA DO REBOLO & SIDNEY GONCALVES FARIA MONTI \\
\hline 0220RP02 & & & 02S39920 & MP-0203M - TRIMESTRAL - RETIFICA KATAOKA R7 & NOEL TEIXEIRA DOS SANTOS \\
\hline 0220RP02 & & & $02 \mathrm{~T} 83274$ & MP-0203M - TRIMESTRAL - RETIFICA KATAOKA R7 & ADRIANO MACEDO \\
\hline 0220RP02 & & & $02 \mathrm{~V} 11268$ & MP-0203M - ANUAL - RETIFICA KATAOKA R7 & NOEL TEIXEIRA DOS SANTOS \\
\hline 0220RP02 & & & 02V11589 & MP-0203E - ANUAL - RETIFICA KATAOKA R7 & WILLIAN DOS SANTOS FLAUSINO \\
\hline 0220RP02 & & & 02W55237 & MP-0203E - ANUAL - RETIFICA KATAOKA R7 & SIDNEY GONCALVES FARIA MONTI \\
\hline 0220RP02 & & & 02W75046 & MP-0203M - TRIMESTRAL - RETIFICA KATAOKA R7 & JUNIOR MARCELO GONCALVES \\
\hline SUBTOTAIS & 28 & 22 & 8 & & 42 \\
\hline 0220RP03 & 02R19088 & 02B6955 & & TROCADO PARAFUSO DE AJUSTE DO ROBO & ADRIANO MACEDO \\
\hline 0220RP03 & 02R22449 & 02B7092 & & TROCADO SENSOR DA GARRA DO ROBO & EDSON HENRIQUE DA SILVA \\
\hline 0220RP03 & 02R85942 & $02 B 8523$ & & REPARO NO DRIVE DO EIXO C DA RETIFICA & JOAO BATISTA DA SILVA \\
\hline 0220RP03 & 02R85942 & 02B8523 & & REPARO NO DRIVE DO EIXO C DA RETIFICA & SIDINEI ALBERTO MENEZES \\
\hline 0220RP03 & $02 R 85942$ & $02 \mathrm{~B} 8523$ & & REPARO NO DRIVE DO EIXO C DA RETIFICA & SIDNEY GONCALVES FARIA MONTI \\
\hline 0220RP03 & 02S02585 & 02B8819 & & TROCADO SENSOR E REP. ACIONADOR DA GARRA & JOAO BATISTA DA SILVA \\
\hline
\end{tabular}




\begin{tabular}{|c|c|c|c|c|c|}
\hline CÓDIGO & OS MC & $\mathbf{C P}$ & OS MP & SERVIÇO EXECUTADO & FUNCIONÁRIOS \\
\hline 0220RP03 & 02S25123 & 02B9528 & & TROCADO SENSOR DA PINCA DO ROBO DA RETIFICA & GERSON TADEU GONCALVES \\
\hline 0220RP03 & 02S31811 & 02B9552 & & TROC. VALV. DO CILINDRO DO ROBO E AJUST. SENSOR DO CILINDRO & SILVIO JOSE LIMA \\
\hline 0220RP03 & 02S47537 & & & AJUSTADO CORREIA, POLIA SUPERIOR E INFERIOR, E TROC. MANCAL & ADRIANO MACEDO \\
\hline 0220RP03 & 02S60691 & & & CONFECCIONADO PROTECAO DE ACRILICO DO PAINEL & ADRIANO MACEDO \\
\hline 0220RP03 & 02S60860 & $02 \mathrm{C} 0376$ & & TROCADO PARAFUSO DE AJUSTE DE ABERTURA DO ROBO & ADRIANO MACEDO \\
\hline 0220RP03 & $02 S 63331$ & & & CONFECCIONADO EIXO, POLIA E TROCADO ROLAMENTO & ADRIANO MACEDO \\
\hline 0220RP03 & $02 S 63331$ & & & CONFECCIONADO EIXO, POLIA E TROCADO ROLAMENTO & CLEZIO CARDOSO SILVA \\
\hline 0220RP03 & 02S63331 & & & CONFECCIONADO EIXO, POLIA E TROCADO ROLAMENTO & SILVIO JOSE LIMA \\
\hline 0220RP03 & $02 S 93175$ & 02C0954 & & TROCADO CORREIA DO CONTRA PONTO & CLAUDIO RAIMUNDO DE ANDRADE \\
\hline 0220RP03 & $02 \mathrm{~T} 42808$ & $02 \mathrm{C} 2270$ & & EMENDADO CORRENTE DO EMPURRADOR & CLEZIO CARDOSO SILVA \\
\hline 0220RP03 & $02 \mathrm{~T} 53868$ & $02 \mathrm{C} 2697$ & & RETIRADA MAU CONTATO DO SENSOR DO ROBO & LUCIANO JOSE CORTES \\
\hline 0220RP03 & $02 \mathrm{~T} 57114$ & & & TROCADO UNIDADE & CLAUDIO RAIMUNDO DE ANDRADE \\
\hline 0220RP03 & $02 \mathrm{~T} 88643$ & $02 \mathrm{C} 3104$ & & RECUPERADO ROSCA DA BUCHA & SILVIO JOSE LIMA \\
\hline 0220RP03 & 02U31595 & $02 \mathrm{C} 4500$ & & EMENDADO CORRENTE DO EMPURRADOR & CLEZIO CARDOSO SILVA \\
\hline 0220RP03 & 02U38222 & $02 \mathrm{C} 4816$ & & TROCADO SUPORTE DE ENCOSTO DOS ANEIS & SEBASTIAO DIVINO CARLOS \\
\hline 0220RP03 & 02U49096 & $02 \mathrm{C} 5161$ & & RETIRADO PARAFUSO QUEBRADO DO CILINDRO DE AQUECIMENTO & ADRIANO MACEDO \\
\hline 0220RP03 & 02U61990 & $02 \mathrm{C} 5322$ & & REPARADO VALVULA E TROCADO SENSOR & CLEZIO CARDOSO SILVA \\
\hline 0220RP03 & 02U61990 & $02 \mathrm{C} 5322$ & & REPARADO VALVULA E TROCADO SENSOR & EDSON HENRIQUE DA SILVA \\
\hline 0220RP03 & 02U61990 & $02 \mathrm{C} 5322$ & & REPARADO VALVULA E TROCADO SENSOR & GILBERTO CORREA DE CARVALHO \\
\hline 0220RP03 & 02U83841 & $02 C 5911$ & & RECUPERADO PARAFUSO DE REGULAGEM DA BUCHA & CLEZIO CARDOSO SILVA \\
\hline 0220RP03 & 02U96276 & $02 C 6059$ & & TROCADO CORRENTE DO EMPURRADOR DE ANEIS & ADRIANO MACEDO \\
\hline 0220RP03 & $02 \mathrm{~V} 03794$ & 02C6291 & & REPARO EM VALVULA DA GARRA & JOAO BATISTA DA SILVA \\
\hline 0220RP03 & 02V07950 & & & TROCADO COPO DO LUBRIFIL E ELIMINADO VAZAMENTO DA CONEXAO & ADRIANO MACEDO \\
\hline 0220RP03 & 02 V21989 & $02 C 6778$ & & TROCADO MANGUEIRA DO CILINDRO DA BUCHA & CLEZIO CARDOSO SILVA \\
\hline 0220RP03 & $02 \mathrm{~V} 45053$ & $02 \mathrm{C} 7286$ & & REFERENCIADO CIADO MAQUINA & SIDNEY GONCALVES FARIA MONTI \\
\hline 0220RP03 & $02 \mathrm{~V} 45277$ & $02 \mathrm{C} 7297$ & & AJUSTADO SENSOR DO ROBO & SIDNEY GONCALVES FARIA MONTI \\
\hline 0220RP03 & 02V48041 & $02 \mathrm{C} 7389$ & & TROCADO CONJUNTO DO LUBRIFIL & ADRIANO MACEDO \\
\hline 0220RP03 & $02 \mathrm{~V} 53365$ & & & CONF. PROTECAO DE PVC PARA RETIF. DE PERFIL & ADRIANO MACEDO \\
\hline 0220RP03 & 02V53766 & $02 \mathrm{C} 7616$ & & AJUSTADO INVERSOR DE FREQUENCIA DA RETIFICA & SIDNEY GONCALVES FARIA MONTI \\
\hline 0220RP03 & 02V59225 & $02 \mathrm{C} 7822$ & & REGULADO SENSOR DO ROBO & SIDNEY GONCALVES FARIA MONTI \\
\hline 0220RP03 & $02 \mathrm{~V} 60071$ & $02 \mathrm{C} 7881$ & & VERIFICADO CORREIA DO ARRASTE DA PLACA & SILVIO JOSE LIMA \\
\hline 0220RP03 & 02V60981 & $02 \mathrm{C} 7912$ & & RECUP. ROSCA DE APERTO E FIXADO BUCHA DA RETIF. & ADRIANO MACEDO \\
\hline 0220RP03 & 02 V76974 & $02 \mathrm{C} 7977$ & & RETIRADA VALVULA ACIONAMENTO ROBO FITA LIMPEZA LUBRIFICACAO & VALTEMIR FRANCISCO BARROS \\
\hline 0220RP03 & $02 \mathrm{~V} 94525$ & 02C8297 & & TROCADO A HASTE DO CILINDRO DO ROBO & SILVIO JOSE LIMA \\
\hline 0220RP03 & 02W44071 & & & REPARO NO COMANDO MARPOSS & JOAO BATISTA DA SILVA \\
\hline 0220RP03 & 02W90234 & 02D0052 & & REPARO NO COMANDO DE DRESSAGEM & JOAO BATISTA DA SILVA \\
\hline 0220RP03 & 02W91563 & 02D0102 & & EMENDADO CORRENTE DO CARREGADOR & ADRIANO MACEDO \\
\hline 0220RP03 & 02W93099 & 02D0174 & & RECUPERADO A PONTA DA HASTE DO CILINDRO DO ROBO & SILVIO JOSE LIMA \\
\hline 0220RP03 & 02X05442 & 02D0629 & & AJUSTADO PRESSOSTATO DE LUBRIFICACAO DO REBOLO & EDSON HENRIQUE DA SILVA \\
\hline
\end{tabular}




\begin{tabular}{|c|c|c|c|c|c|}
\hline CÓDIGO & OS MC & $\mathbf{C P}$ & OS MP & SERVIÇO EXECUTADO & FUNCIONÁRIOS \\
\hline 0220RP03 & 02X34063 & 02D0895 & & TROCADO AS CORREIAS DO DRESSADOR & VALTEMIR FRANCISCO BARROS \\
\hline 0220RP03 & & & 02Q95674 & MP-0203M - TRIMESTRAL - RETIFICA KATAOKA R7 & RICARDO MAGNO DO CARMO \\
\hline 0220RP03 & & & 02R65786 & REPARO NO ALARME DO SISTEMA DE SEGURANCA DO REBOLO & GILBERTO CORREA DE CARVALHO \\
\hline 0220RP03 & & & 02R65786 & REPARO NO ALARME DO SISTEMA DE SEGURANCA DO REBOLO & JOSE ANDERSON DE PAULA \\
\hline 0220RP03 & & & 02R65786 & REPARO NO ALARME DO SISTEMA DE SEGURANCA DO REBOLO & SIDNEY GONCALVES FARIA MONTI \\
\hline 0220RP03 & & & $02 \mathrm{~S} 41114$ & MP-0203M - TRIMESTRAL - RETIFICA KATAOKA R7 & CLEZIO CARDOSO SILVA \\
\hline 0220RP03 & & & $02 \mathrm{~T} 84095$ & MP-0203M - TRIMESTRAL - RETIFICA KATAOKA R7 & RICARDO MAGNO DO CARMO \\
\hline 0220RP03 & & & 02V14087 & MP-0203M - ANUAL - RETIFICA KATAOKA R7 & CLAUDIO RAIMUNDO DE ANDRADE \\
\hline 0220RP03 & & & 02V14087 & MP-0203M - ANUAL - RETIFICA KATAOKA R7 & JUNIOR MARCELO GONCALVES \\
\hline 0220RP03 & & & 02V14087 & MP-0203M - ANUAL - RETIFICA KATAOKA R7 & NOEL TEIXEIRA DOS SANTOS \\
\hline 0220RP03 & & & 02V14087 & MP-0203M - ANUAL - RETIFICA KATAOKA R7 & RICARDO MAGNO DO CARMO \\
\hline 0220RP03 & & & 02V14087 & MP-0203M - ANUAL - RETIFICA KATAOKA R7 & VALTEMIR FRANCISCO BARROS \\
\hline 0220RP03 & & & $02 \mathrm{~V} 14274$ & MP-0203E - ANUAL - RETIFICA KATAOKA R7 & JOAO BATISTA DA SILVA \\
\hline 0220RP03 & & & 02V62391 & TROCAR CORREIA VB 35 DO ARRASTE DA PLACA & VALTEMIR FRANCISCO BARROS \\
\hline 0220RP03 & & & $02 W 78203$ & MP-0203M - TRIMESTRAL - RETIFICA KATAOKA R7 & CLAUDIO RAIMUNDO DE ANDRADE \\
\hline SUBTOTAIS & 40 & 33 & 8 & & $\begin{array}{r}60 \\
\end{array}$ \\
\hline 0220RP04 & 02R05850 & & & AJUST. BUCHA E CONFEC. FLANGE & ADRIANO MACEDO \\
\hline 0220RP04 & 02R05850 & & & AJUST. BUCHA E CONFEC. FLANGE & GERSON TADEU GONCALVES \\
\hline 0220RP04 & 02R11594 & 02B6644 & & TROCADO CORRENTE DO EMPURRADOR DE ANEIS & SILVIO JOSE LIMA \\
\hline 0220RP04 & 02R54495 & 02B7653 & & VERIFICADO CONTATO DA BOTOEIRA DO COMANDO & GILBERTO CORREA DE CARVALHO \\
\hline 0220RP04 & $02 \mathrm{R} 55902$ & 02B7736 & & RECUPERADO CORRENTE DO EMPURRADOR DE ANEIS & CLEZIO CARDOSO SILVA \\
\hline 0220RP04 & 02R98279 & 02B8646 & & REAJUSTADO MICRO DE INDICACAO DO RETORNO DA BUCHA & GILBERTO CORREA DE CARVALHO \\
\hline 0220RP04 & $02 \mathrm{R} 98313$ & 02B8650 & & REPARO NO CABECOTE DO REBOLO & ADRIANO MACEDO \\
\hline 0220RP04 & 02R99063 & 02B8728 & & AJUST. E TROC. SENSOR DO ROBO E CORREIAS DO MOTOR DO REBOLO & CLEZIO CARDOSO SILVA \\
\hline 0220RP04 & 02S02709 & 02B8830 & & TROCADO TUBULACAO HIDRAULICA DA GUILHOTINA POR MANGUEIRA & CLEZIO CARDOSO SILVA \\
\hline 0220RP04 & $02 S 03584$ & 02B8893 & & ADAPTADO PONTO DO CILINDRO DO ROBO & SILVIO JOSE LIMA \\
\hline 0220RP04 & 02S03619 & 02B8900 & & COMPLETADO NIVEL DE OLEO DO TQ DO REBOLO & SILVIO JOSE LIMA \\
\hline 0220RP04 & $02 S 10601$ & 02B9259 & & EMENDADA CORRENTE DO CARREGADOR DA RETIFICA & ADRIANO MACEDO \\
\hline 0220RP04 & 02S53093 & 02B9963 & & RECUOERADO CORRENTE DO EMPURRADOR DE ANEIS & CLEZIO CARDOSO SILVA \\
\hline 0220RP04 & 02S57981 & 02C0191 & & TROCADO A CORRENTE DO ALIMENTADOR DE ANEL & SILVIO JOSE LIMA \\
\hline 0220RP04 & 02S66196 & 02C0612 & & TROCADO MANOMETRO DA KATAOKA & CLEZIO CARDOSO SILVA \\
\hline 0220RP04 & 02S66221 & 02C0614 & & VERIFIFCADO PRESSOES DP MANOMETRO E AJUSTE NA PRESSAO MOLA & SILVIO JOSE LIMA \\
\hline 0220RP04 & $02 \mathrm{~T} 18112$ & 02C1960 & & REPARO NA REFERENCIA DO EIXO X & JOAO BATISTA DA SILVA \\
\hline 0220RP04 & $02 \mathrm{~T} 49632$ & 02C2499 & & RETIRADO PARAFUSO DE FIXACAO A BUCHA DA RETIFICA & ADRIANO MACEDO \\
\hline 0220RP04 & $02 \mathrm{~T} 49641$ & $02 \mathrm{C} 2500$ & & RECUP. MROSCA DA BASE DE APOIO DA BUCHA DA RETIFICA & ADRIANO MACEDO \\
\hline 0220RP04 & $02 \mathrm{~T} 57409$ & 02C2818 & & TROCADO ROLAMENTO DE COMANDO DE GUIA DO CILINDRO & CLAUDIO RAIMUNDO DE ANDRADE \\
\hline 0220RP04 & 02U05800 & 02C3679 & & REPARADO CIRCUITO DE SEGURANCA DA KATAOKA & JOAO BATISTA DA SILVA \\
\hline 0220RP04 & 02U32120 & $02 \mathrm{C} 4305$ & & TROCADO SUPORTE DA KATAOKA & SEBASTIAO DIVINO CARLOS \\
\hline
\end{tabular}




\begin{tabular}{|c|c|c|c|c|c|}
\hline CÓDIGO & OS MC & $\mathbf{C P}$ & OS MP & SERVIÇO EXECUTADO & FUNCIONÁRIOS \\
\hline 0220RP04 & 02U39347 & 02C4968 & & REAPRO CORRENTE DO ALIMENTADOR & SEBASTIAO DIVINO CARLOS \\
\hline 0220RP04 & 02V02553 & & & CONFECCIONADO PROTECAO DE ACRILICO PARA PAINEL & ADRIANO MACEDO \\
\hline 0220RP04 & 02V06602 & $02 \mathrm{C} 6536$ & & AJUSTADO SISTEMA FERRAMENTAL & NOEL TEIXEIRA DOS SANTOS \\
\hline 0220RP04 & 02V06639 & 02C6539 & & AJUST. GUIAS DO EMPURRADOR DE ANEL E TROC. CORRENTE & SILVIO JOSE LIMA \\
\hline 0220RP04 & $02 \mathrm{~V} 41351$ & 02C7121 & & TROCADO SENSORES DO ROBO AVANCADO E FECHADO & LUCIANO JOSE CORTES \\
\hline 0220RP04 & $02 \mathrm{~V} 53999$ & 02C7636 & & TROCADO A CORREIA DO REBOLO & ADRIANO MACEDO \\
\hline 0220RP04 & 02V55522 & & & ELIMINADO VAZAMENTO DO CABECOTE HIDROSTATICO & VALTEMIR FRANCISCO BARROS \\
\hline 0220RP04 & $02 \mathrm{~V} 61310$ & 02C7934 & & TROCADO CORRENTE DO EMPURRADOR DE ANEIS & CARLOS RENATO ALKMIM \\
\hline 0220RP04 & $02 \mathrm{~V} 77054$ & $02 \mathrm{C} 8033$ & & SACADO PARAFUSO QUEBRADO DA BUCHA & SILVIO JOSE LIMA \\
\hline 0220RP04 & $02 \mathrm{~V} 94712$ & $02 \mathrm{C} 8312$ & & TIRADO ALARME DO CNC & LUCIANO JOSE CORTES \\
\hline 0220RP04 & 02V98718 & 02C8474 & & TROCA DO MICRO DA LUVA DA RETIFICA & LUCIANO JOSE CORTES \\
\hline 0220RP04 & 02W00368 & & & RECUPERADO ROSCA DA BUCHA DE FIXACAO DE ANEIS & VALTEMIR FRANCISCO BARROS \\
\hline 0220RP04 & 02W06353 & 02C8698 & & REPARO NA PERDA DE REFERENCIA DOS EIXOS & JOAO BATISTA DA SILVA \\
\hline 0220RP04 & 02W09289 & 02C8801 & & SOLDADO TUBULACOES DO HIDRAULICO & VALTEMIR FRANCISCO BARROS \\
\hline 0220RP04 & 02W50198 & 02C9491 & & TROCADO REGUA DO ALIMENTADOR DE ANEL & SILVIO JOSE LIMA \\
\hline 0220RP04 & & & 02Q52256 & TROCA DE MEMBRANA SOFT-KEY PARA TECLADO DE DADOS & GERSON TADEU GONCALVES \\
\hline 0220RP04 & & & 02Q88762 & MP-0203M - TRIMESTRAL - RETIFICA KATAOKA R7 & ADRIANO MACEDO \\
\hline 0220RP04 & & & 02R65795 & REPARO NO ALARME DO SISTEMA DE SEGURANCA DO REBOLO & GILBERTO CORREA DE CARVALHO \\
\hline 0220RP04 & & & 02R65795 & REPARO NO ALARME DO SISTEMA DE SEGURANCA DO REBOLO & JOSE ANDERSON DE PAULA \\
\hline 0220RP04 & & & 02S39289 & MP-0203M - TRIMESTRAL - RETIFICA KATAOKA R7 & CLEZIO CARDOSO SILVA \\
\hline 0220RP04 & & & 02S39289 & MP-0203M - TRIMESTRAL - RETIFICA KATAOKA R7 & JUNIOR MARCELO GONCALVES \\
\hline 0220RP04 & & & $02 S 39289$ & MP-0203M - TRIMESTRAL - RETIFICA KATAOKA R7 & RICARDO MAGNO DO CARMO \\
\hline 0220RP04 & & & $02 \mathrm{~T} 48722$ & TROCAR VISORES DO RESERVATORIO MANCAL HIDROSTATICO & WILLIAN DOS SANTOS FLAUSINO \\
\hline 0220RP04 & & & $02 T 82854$ & MP-0203M - ANUAL - RETIFICA KATAOKA R7 & NOEL TEIXEIRA DOS SANTOS \\
\hline 0220RP04 & & & $02 \mathrm{~T} 82854$ & MP-0203M - ANUAL - RETIFICA KATAOKA R7 & RICARDO MAGNO DO CARMO \\
\hline 0220RP04 & & & $02 T 83103$ & MP-0203E - ANUAL - RETIFICA KATAOKA R7 & GERSON TADEU GONCALVES \\
\hline 0220RP04 & & & 02V09912 & MP-0203M - TRIMESTRAL - RETIFICA KATAOKA R7 & SEBASTIAO DIVINO CARLOS \\
\hline 0220RP04 & & & 02W93632 & REVISAO MECANICA GERAL NA RETIFICA & EDSON HENRIQUE DA SILVA \\
\hline 0220RP04 & & & 02W93632 & REVISAO MECANICA GERAL NA RETIFICA & JUNIOR MARCELO GONCALVES \\
\hline 0220RP04 & & & 02W93632 & REVISAO MECANICA GERAL NA RETIFICA & LUCAS GARCIA SIQUEIRA DA SILVA \\
\hline 0220RP04 & & & 02W93632 & REVISAO MECANICA GERAL NA RETIFICA & NOEL TEIXEIRA DOS SANTOS \\
\hline 0220RP04 & & & $02 W 93632$ & REVISAO MECANICA GERAL NA RETIFICA & SEBASTIAO DIVINO CARLOS \\
\hline 0220RP04 & & & 02W93632 & REVISAO MECANICA GERAL NA RETIFICA & SILVIO JOSE LIMA \\
\hline 0220RP04 & & & 02W93632 & REVISAO MECANICA GERAL NA RETIFICA & VALTEMIR FRANCISCO BARROS \\
\hline SUBTOTAIS & 36 & 32 & 9 & & 56 \\
\hline 0220RP05 & 02R21468 & & & REPARADO ALIMENTACAO DA LUMINARIA DA KATAOKA & JOAO BATISTA DA SILVA \\
\hline 0220RP05 & 02R22323 & 02B7078 & & CONFECCIONADO BUCHA E EMBUCHADO BASE DO SUPORTE & CLEZIO CARDOSO SILVA \\
\hline 0220RP05 & 02R37727 & $02 \mathrm{~B} 7301$ & & TROCADO A CORRENTE DO EMPURRADOR DE ANEIS & SILVIO JOSE LIMA \\
\hline
\end{tabular}




\begin{tabular}{|c|c|c|c|c|c|}
\hline CÓDIGO & OS MC & $\mathbf{C P}$ & OS MP & SERVIÇO EXECUTADO & FUNCIONÁRIOS \\
\hline 0220RP05 & 02R38156 & 02B6818 & & REPARADA CORRENTE E EFETUADO LIMPEZA NAS GUIAS & NOEL TEIXEIRA DOS SANTOS \\
\hline 0220RP05 & 02R43328 & 02B7404 & & TROCADO SENSOR DO REBOLO E AJUSTADAS OUTROS SENSORES & GILBERTO CORREA DE CARVALHO \\
\hline 0220RP05 & $02 \mathrm{R} 47315$ & & & LIMPEZA NA VALVULA REFRIGERAÇÃO R 7 & SILVIO JOSE LIMA \\
\hline 0220RP05 & 02R57884 & 02B7805 & & REPARADO PERDA DE REFERENCIA DOS EIXOS & JOAO BATISTA DA SILVA \\
\hline 0220RP05 & 02R58311 & 02B7813 & & REPARADO CORRENTE DE CARREGADOR & ADRIANO MACEDO \\
\hline 0220RP05 & 02R61959 & 02B7937 & & LIMPADO, LUBRIFICADO E AJUSTADO GUIAS TROC. PARAFUSO E MOLA & ADRIANO MACEDO \\
\hline 0220RP05 & $02 \mathrm{R} 65143$ & 02B8099 & & REPARADO REFERENCIA DO EIXO X & JOAO BATISTA DA SILVA \\
\hline 0220RP05 & $02 \mathrm{R} 70574$ & 02B8315 & & TROCADO O RELE DE COMANDO DO MOVIMENTO DA GARRA & GILBERTO CORREA DE CARVALHO \\
\hline 0220RP05 & 02S09971 & 02B9227 & & REPARO NOS ACIONADORES DO SENSOR & JOAO BATISTA DA SILVA \\
\hline 0220RP05 & 02S10228 & 02B9237 & & TROCADO SENSOR DO ROBO QUE INDICA GARRA FECHADA & GILBERTO CORREA DE CARVALHO \\
\hline 0220RP05 & 02S59337 & 02C0297 & & AJUST. ROLAMENTO DO CONTRA PONTO E TROCAOD SUPORTE DO COLAR & JORGELINO BATISTA DE OLIVEIRA \\
\hline 0220RP05 & $02 \mathrm{~S} 62207$ & $02 \mathrm{C} 0436$ & & TROCADO OS PARAFUSOS DO SUPORTE DO CILINDRO & SILVIO JOSE LIMA \\
\hline 0220RP05 & $02 S 66249$ & $02 \mathrm{C} 0616$ & & TROCADO CORRENTE DO EMPURRADOR DE ANEIS & SILVIO JOSE LIMA \\
\hline 0220RP05 & 02 Т30679 & 02C2079 & & AJUSTADO CORREIA E ARRASTE DA RETIFICA & ADRIANO MACEDO \\
\hline 0220RP05 & $02 \mathrm{~T} 46154$ & $02 \mathrm{C} 2343$ & & TROCADO POTENCIOMETRO DA ENTRADA ANALOGICA & LUCIANO JOSE CORTES \\
\hline 0220RP05 & 02U71710 & $02 \mathrm{C} 5514$ & & VERIFICADO ARRASTE DA PLACA & SILVIO JOSE LIMA \\
\hline 0220RP05 & 02U92975 & $02 C 5975$ & & AJUSTADO MICRO DO AVANCO DA BUCHA & GILBERTO CORREA DE CARVALHO \\
\hline 0220RP05 & 02V36241 & & & TROCADO UNIDADE DE VENTILACAO DO PAINEL & GERSON TADEU GONCALVES \\
\hline 0220RP05 & 02V50055 & & & CONFECCIONADA -PROTECAO DE ACRILICO DO PAINEL DA RETIFICA & ADRIANO MACEDO \\
\hline 0220RP05 & 02V51651 & & & LIMP. UNIDADE E AJUST. CONEXOES, MANGUEIRA E ELIM. VAZAMENTO & ADRIANO MACEDO \\
\hline 0220RP05 & 02V55238 & $02 \mathrm{C} 7678$ & & TROC. ANEIS ORING E FIXADO EIXO DO CILINDRO E ELIMIN. FOLGA & ADRIANO MACEDO \\
\hline 0220RP05 & $02 \mathrm{~V} 94561$ & 02C8299 & & REPARO EM MANGUEIRA DO CILINDRO DO ROBO & SILVIO JOSE LIMA \\
\hline 0220RP05 & 02V97461 & $02 \mathrm{C} 8416$ & & TROCADO VALVULAS E SOLENOIDES DE ALIMENTACAO DO ROBO & LUCIANO JOSE CORTES \\
\hline 0220RP05 & 02V99209 & $02 C 8505$ & & TROCADO CABO E SENSOR DA GARRA DO ROBO & EDSON HENRIQUE DA SILVA \\
\hline 0220RP05 & 02W00395 & & & AJUSTADO CONEXAO E MANGUEIRA & VALTEMIR FRANCISCO BARROS \\
\hline 0220RP05 & 02W90341 & 02D0059 & & LIMPADO NA TUBULACAO D O REBOLO & SILVIO JOSE LIMA \\
\hline 0220RP05 & 02W91554 & 02D0101 & & REP. E LIMPADO CILINDRO E TROCADO REPAROS & ADRIANO MACEDO \\
\hline 0220RP05 & $02 X 03694$ & 02D0531 & & FOI VERIFICADO O CABECOTE DO REBOLO DA KATAOKA & SILVIO JOSE LIMA \\
\hline 0220RP05 & 02X03774 & 02D0536 & & FOI AJUSTADO PRESSAO DA MOLA DO PERFILADOR E SUBSTITUIDO DEP & VALTEMIR FRANCISCO BARROS \\
\hline 0220RP05 & $02 X 35758$ & 02D0947 & & AJUSTADO PARAFUSO DO SUPORTE DO CILINDRO DA BUCHA & SILVIO JOSE LIMA \\
\hline 0220RP05 & & & 02Q52274 & TROCA DE MEMBRANA SOFT-KEY PARA TECLADO DE DADOS & GERSON TADEU GONCALVES \\
\hline 0220RP05 & & & 02R65811 & REPARO NO ALARME DO SISTEMA DE SEGURANCA DO REBOLO & GILBERTO CORREA DE CARVALHO \\
\hline 0220RP05 & & & 02R65811 & MP-0203M - ANUAL - RETIFICA KATAOKA R7 & SIDNEY GONCALVES FARIA MONTI \\
\hline 0220RP05 & & & $02 \mathrm{~T} 04216$ & MP-0203E - ANUAL - RETIFICA KATAOKA R7 & ADRIANO MACEDO \\
\hline 0220RP05 & & & $02 \mathrm{~T} 04216$ & MP-0203E - ANUAL - RETIFICA KATAOKA R7 & CLEZIO CARDOSO SILVA \\
\hline 0220RP05 & & & $02 \mathrm{~T} 04216$ & MP-0203E - ANUAL - RETIFICA KATAOKA R7 & NOEL TEIXEIRA DOS SANTOS \\
\hline 0220RP05 & & & $02 \mathrm{~T} 04216$ & MP-0203E - ANUAL - RETIFICA KATAOKA R7 & RICARDO MAGNO DO CARMO \\
\hline 0220RP05 & & & $02 \mathrm{~T} 04216$ & MP-0203E - ANUAL - RETIFICA KATAOKA R7 & SILVIO JOSE LIMA \\
\hline 0220RP05 & & & $02 \mathrm{~T} 04412$ & MP-0203E - ANUAL - RETIFICA KATAOKA R7 & JOSE ANDERSON DE PAULA \\
\hline
\end{tabular}




\begin{tabular}{|c|c|c|c|c|c|}
\hline CÓDIGO & OS MC & $\mathbf{C P}$ & OS MP & SERVIÇO EXECUTADO & FUNCIONÁRIOS \\
\hline 0220RP05 & & & $02 \mathrm{~T} 48740$ & TROCAR VISORES DO RESERVATORIO MANCAL HIDROSTATICO & JUNIOR MARCELO GONCALVES \\
\hline 0220RP05 & & & 02W29436 & TROCAR PROTECOES SANFONADAS DO MANGOTE FIXADOR & NOEL TEIXEIRA DOS SANTOS \\
\hline 0220RP05 & & & $02 \mathrm{~W} 41724$ & REVISAO GERAL MECANICA DA RETIFICA DE PERFIL R7 BP 37704 & CLAUDIO RAIMUNDO DE ANDRADE \\
\hline 0220RP05 & & & 02W41724 & REVISAO GERAL MECANICA DA RETIFICA DE PERFIL R7 BP 37704 & NOEL TEIXEIRA DOS SANTOS \\
\hline 0220RP05 & & & $02 \mathrm{~W} 41724$ & REVISAO GERAL MECANICA DA RETIFICA DE PERFIL R7 BP 37704 & RICARDO MAGNO DO CARMO \\
\hline SUBTOTAIS & 33 & 27 & 7 & & 47 \\
\hline 0220RP12 & 02R55724 & 02B7720 & & REPARADO REFERENCIA DO EIXO X & JOAO BATISTA DA SILVA \\
\hline 0220RP12 & $02 \mathrm{~T} 47867$ & & & TROCADO PARAFUSO DO ROLO DA RETIFICA & ADRIANO MACEDO \\
\hline 0220RP12 & $02 \mathrm{~T} 58177$ & 02C2861 & & TROCADO MANGUEIRA DE AR & JORGELINO BATISTA DE OLIVEIRA \\
\hline 0220RP12 & $02 \mathrm{~T} 94912$ & & & CONFECCIONADO PROTECAO PARA VEDACAO DE OLEO DE REFRIGERACAO & ADRIANO MACEDO \\
\hline 0220RP12 & 02U96212 & $02 \mathrm{C} 6053$ & & TROC. CORREIAS DA PLACA DA RETIFICA & ADRIANO MACEDO \\
\hline 0220RP12 & $02 \mathrm{~V} 04276$ & $02 \mathrm{C} 6353$ & & LIMPADO POLIAS E ALINHADO E ESTICADO CORREIAS & CLEZIO CARDOSO SILVA \\
\hline 0220RP12 & 02V07255 & $02 \mathrm{C} 6568$ & & REPARO EM PAINEL DE OPERAÇÃO MONITOR & GILBERTO CORREA DE CARVALHO \\
\hline 0220RP12 & 02V07255 & 02C6568 & & REPARO EM PAINEL DE OPERAÇÃO MONITOR & JOAO BATISTA DA SILVA \\
\hline 0220RP12 & 02V21257 & $02 \mathrm{C} 6730$ & & TROCADO MANGUEIRA DA REFRIGERACAO DO REBOLO & SILVIO JOSE LIMA \\
\hline 0220RP12 & $02 \mathrm{~V} 25431$ & $02 \mathrm{C} 6955$ & & TROCADO CORREIAS DO MOTOR DA PLACA & ADRIANO MACEDO \\
\hline 0220RP12 & $02 \mathrm{~V} 25431$ & $02 \mathrm{C} 6955$ & & TROCADO CORREIAS DO MOTOR DA PLACA & CLEZIO CARDOSO SILVA \\
\hline 0220RP12 & 02V92064 & $02 \mathrm{C} 8225$ & & TROCADO GAXETA DE VEDACAO DO CILINDRO DE EXPANSAO DO MANDRIL & ADRIANO MACEDO \\
\hline 0220RP12 & 02 V92064 & $02 \mathrm{C} 8225$ & & TROCADO GAXETA DE VEDACAO DO CILINDRO DE EXPANSAO DO MANDRIL & NOEL TEIXEIRA DOS SANTOS \\
\hline 0220RP12 & 02V92064 & $02 \mathrm{C} 8225$ & & TROCADO GAXETA DE VEDACAO DO CILINDRO DE EXPANSAO DO MANDRIL & SILVIO JOSE LIMA \\
\hline 0220RP12 & $02 \mathrm{~V} 92778$ & & & REPARO NOS FINS DE CURSO DA COMUTACAO & JOAO BATISTA DA SILVA \\
\hline 0220RP12 & 02W17751 & & & COMPLETADO GRAXA DA BUCHA EXPANSIVA & CLEZIO CARDOSO SILVA \\
\hline 0220RP12 & $02 \mathrm{~W} 17751$ & & & COMPLETADO GRAXA DA BUCHA EXPANSIVA & VALTEMIR FRANCISCO BARROS \\
\hline 0220RP12 & 02W46337 & & & REPARADO VALVULA, LIMPADO E LUBRIFICAO & ADRIANO MACEDO \\
\hline 0220RP12 & $02 \mathrm{~W} 51222$ & 02C9558 & & REPARO NA REFERENCIA DOS EIXOS & JOAO BATISTA DA SILVA \\
\hline 0220RP12 & $02 \mathrm{~W} 51892$ & $02 C 9592$ & & LIMPADO VALVULA DE REFRIGERACAO & VALTEMIR FRANCISCO BARROS \\
\hline 0220RP12 & $02 X 33475$ & & & FOI FEITO LIMPEZA DAS CONEXOES EVALVULA DO SISTEMA DE REFRIG & VALTEMIR FRANCISCO BARROS \\
\hline 0220RP12 & & & 02R65848 & REPARO NO ALARME DO SISTEMA DE SEGURANCA DO REBOLO & GILBERTO CORREA DE CARVALHO \\
\hline 0220RP12 & & & 02U04892 & ADAPTACAO DE CHAVE DE SEGURANCA NA RETIFICA DE PERFIL & GERSON TADEU GONCALVES \\
\hline 0220RP12 & & & 02U04892 & ADAPTACAO DE CHAVE DE SEGURANCA NA RETIFICA DE PERFIL & JUNIOR MARCELO GONCALVES \\
\hline 0220RP12 & & & 02W31600 & MP-0206M - ANUAL - RETIFICA KATAOKA PCG & NOEL TEIXEIRA DOS SANTOS \\
\hline 0220RP12 & & & 02W31600 & MP-0206M - ANUAL - RETIFICA KATAOKA PCG & RICARDO MAGNO DO CARMO \\
\hline 0220RP12 & & & $02 W 31913$ & MP-0206E - ANUAL - RETIFICA KATAOKA PCG & SIDNEY GONCALVES FARIA MONTI \\
\hline SUBTOTAIS & 16 & 10 & 4 & & 27 \\
\hline 0220RP15 & 02U07880 & 02C3780 & & TROCADO COPO DO LUBRIFIL & SILVIO JOSE LIMA \\
\hline 0220RP15 & $02 \mathrm{~V} 52384$ & $02 \mathrm{C} 7575$ & & TROCADO BOTAO DO COMANDO MANUAL & EDSON HENRIQUE DA SILVA \\
\hline 0220RP15 & 02V55434 & $02 \mathrm{C} 7692$ & & TROCADO CORREIA DO MOTOR DO ARRASTE & SILVIO JOSE LIMA \\
\hline
\end{tabular}




\begin{tabular}{|c|c|c|c|c|c|}
\hline CÓDIGO & OS MC & $\mathbf{C P}$ & OS MP & SERVIÇO EXECUTADO & FUNCIONÁRIOS \\
\hline 0220RP15 & 02W51133 & 02C9551 & & LIMPADO E LUBRIFICADO ARRASTE & ADRIANO MACEDO \\
\hline 0220RP15 & 02W51302 & 02C9564 & & VERIFICADO VAZAMENTO DA PCG & ADRIANO MACEDO \\
\hline 0220RP15 & 02W51302 & 02C9564 & & VERIFICADO VAZAMENTO DA PCG & LUCIANO JOSE CORTES \\
\hline 0220RP15 & 02W88425 & $02 C 9955$ & & TROCADA CONEXAO HIDRAULICA MANGUEIRA & ADRIANO MACEDO \\
\hline 0220RP15 & 02W91929 & 02D0128 & & TROCADO CONEXOES E MANGUEIRA DO CILINDRO PERFILADOR & VALTEMIR FRANCISCO BARROS \\
\hline 0220RP15 & $02 X 38452$ & & & AJUSTADO CORREIA DO MANCAL INTERMEDIARIO & NÃO IDENTIFICADO \\
\hline 0220RP15 & & & 02R65857 & REPARO NO ALARME DO SISTEMA DE SEGURANCA DO REBOLO & GILBERTO CORREA DE CARVALHO \\
\hline 0220RP15 & & & 02R65857 & REPARO NO ALARME DO SISTEMA DE SEGURANCA DO REBOLO & JOSE ANDERSON DE PAULA \\
\hline 0220RP15 & & & 02U04918 & ADAPTACAO DE CHAVE DE SEGURANCA NA RETIFICA DE PERFIL & GERSON TADEU GONCALVES \\
\hline 0220RP15 & & & 02V85018 & MP-0206M - ANUAL - RETIFICA KATAOKA PCG & NOEL TEIXEIRA DOS SANTOS \\
\hline 0220RP15 & & & $02 V 85269$ & MP-0206E - ANUAL - RETIFICA KATAOKA PCG & JOAO BATISTA DA SILVA \\
\hline SUBTOTAIS & 8 & 7 & 4 & & 14 \\
\hline 0220RP18 & 02R18659 & & & MODIFICADO DISPOSITIVO DE ASSENTAMENTO & NÃO IDENTIFICADO \\
\hline 0220RP18 & 02R22895 & 02B7247 & & TROCADO RETENTOR DA BOMBA HIDRAULICA DA RETIFICA & CLEZIO CARDOSO SILVA \\
\hline 0220RP18 & 02R22895 & 02B7247 & & TROCADO RETENTOR DA BOMBA HIDRAULICA DA RETIFICA & SILVIO JOSE LIMA \\
\hline 0220RP18 & 02R38012 & 02B7315 & & TROCADO CORREIA DO ROLO DRESSADOR & ADRIANO MACEDO \\
\hline 0220RP18 & 02R53049 & & & TROCADO SENSOR DO MARPOSS & JOAO BATISTA DA SILVA \\
\hline 0220RP18 & $02 \mathrm{R} 57312$ & 02B7783 & & TROCADO SENSOR DO MARPOSS & EDSON HENRIQUE DA SILVA \\
\hline 0220RP18 & 02R57900 & & & LIMPADO TUBULACAO DE REFRIGERACAO DO REBOLO & ADRIANO MACEDO \\
\hline 0220RP18 & 02R69238 & 02B8261 & & TROCADO RETENTOR DA BOMBA DE OLEO HIDRAULICO & ADRIANO MACEDO \\
\hline 0220RP18 & $02 \mathrm{R} 86683$ & 02B8553 & & SOLDADO SUPORTE DE APOIO DO CONTRA PONTO & SILVIO JOSE LIMA \\
\hline 0220RP18 & $02 \mathrm{R} 99125$ & 02B8731 & & REPARADO SUPORTE DE APOIO DO CONTRA PONTO & SILVIO JOSE LIMA \\
\hline 0220RP18 & $02 \mathrm{~S} 02727$ & 02B8831 & & LIMPADO VALVULA E CONEXOES DE REFRIGERACAO & CLEZIO CARDOSO SILVA \\
\hline 0220RP18 & 02S10362 & 02B9247 & & REPARADO FIO DANIFICADO DO SENSOR & EDSON HENRIQUE DA SILVA \\
\hline 0220RP18 & 02S50826 & 02B9881 & & USINADO E REPARADO GUIA DA BUCHA & ADRIANO MACEDO \\
\hline 0220RP18 & $02 S 50826$ & 02B9881 & & USINADO E REPARADO GUIA DA BUCHA & CLEZIO CARDOSO SILVA \\
\hline 0220RP18 & 02S53841 & & & CONFECCIONADO PROTECAO DE ACRILICO DO PAINEL & ADRIANO MACEDO \\
\hline 0220RP18 & 02S55420 & 02C0084 & & AJUSTADO PRESSAO, VAZAO E AVANCO DO CONTRA PONTO & CLEZIO CARDOSO SILVA \\
\hline 0220RP18 & 02S97402 & & & AJUSTADO SISTEMA HIDRAULICO & CLEZIO CARDOSO SILVA \\
\hline 0220RP18 & $02 S 97402$ & & & AJUSTADO SISTEMA HIDRAULICO & NOEL TEIXEIRA DOS SANTOS \\
\hline 0220RP18 & $02 S 97402$ & & & AJUSTADO SISTEMA HIDRAULICO & SILVIO JOSE LIMA \\
\hline 0220RP18 & $02 \mathrm{~T} 23240$ & 02C1976 & & TROCADO MANGUEIRA PNEUMATICA DE ALIMENTACAO DO ROBO & CLESIO TORRES GOMES \\
\hline 0220RP18 & $02 \mathrm{~T} 89036$ & 02C3139 & & RECUPERADO ADAPTADOR DO CONTRA PONTO & CLAUDIO RAIMUNDO DE ANDRADE \\
\hline 0220RP18 & $02 \mathrm{~T} 97027$ & & & REPARO NA BOMBA DO HIDRAULICO & ADRIANO MACEDO \\
\hline 0220RP18 & $02 \mathrm{~T} 97027$ & & & REPARO NA BOMBA DO HIDRAULICO & CLEZIO CARDOSO SILVA \\
\hline 0220RP18 & 02U31577 & 02C4499 & & TROC. PARAFUSO DE REGULAGEM DA BUCHA & CLEZIO CARDOSO SILVA \\
\hline 0220RP18 & 02U47828 & $02 \mathrm{C} 5127$ & & TROC. SENSOR DO ROBO DE INDICACAO DA GARRA & GILBERTO CORREA DE CARVALHO \\
\hline 0220RP18 & & & & TROC. SENSOR DO ROBO DE INDICACAO DA GARRA & LUCIANO JOSE CORTES \\
\hline
\end{tabular}




\begin{tabular}{|c|c|c|c|c|c|}
\hline CÓDIGO & OS MC & $\mathbf{C P}$ & OS MP & SERVIÇO EXECUTADO & FUNCIONÁRIOS \\
\hline 0220RP18 & 02U51377 & $02 \mathrm{C} 5244$ & & TROCADO SENSORES DO MARPOSS - 04 SENSORES & LUCIANO JOSE CORTES \\
\hline 0220RP18 & 02V05202 & $02 \mathrm{C} 6483$ & & TROCADO SENSOR DE INDICA A GARRA & GILBERTO CORREA DE CARVALHO \\
\hline 0220RP18 & $02 \mathrm{~V} 42546$ & 02C7200 & & TROC. ANILIA E ELIMINADO VAZAM. PARCIAL & ADRIANO MACEDO \\
\hline 0220RP18 & 02 V97112 & & & TROCADO MARPOSS E AJUSTADO DOS SENSORES & LUCIANO JOSE CORTES \\
\hline 0220RP18 & 02W22674 & 02C8965 & & RETIRADO ALARME DO CNC & LUCIANO JOSE CORTES \\
\hline 0220RP18 & 02X09509 & 02D0769 & & TROCADO SENSOR DA GARRA DO ROBO & LUCIANO JOSE CORTES \\
\hline 0220RP18 & & & 02G74430 & TROCAR DISJUNTOR C/ DETECCAO DE FULGA P/ TERRA NA KATAOKA & WILLIAN DOS SANTOS FLAUSINO \\
\hline 0220RP18 & & & 02R65820 & REPARO NO ALARME DO SISTEMA DE SEGURANCA DO REBOLO & GILBERTO CORREA DE CARVALHO \\
\hline 0220RP18 & & & 02R65820 & REPARO NO ALARME DO SISTEMA DE SEGURANCA DO REBOLO & JOSE ANDERSON DE PAULA \\
\hline 0220RP18 & & & 02R65820 & REPARO NO ALARME DO SISTEMA DE SEGURANCA DO REBOLO & SIDNEY GONCALVES FARIA MONTI \\
\hline 0220RP18 & & & 02S38627 & MP-0203M - TRIMESTRAL - RETIFICA KATAOKA R7 & ADRIANO MACEDO \\
\hline 0220RP18 & & & $02 \mathrm{~T} 48660$ & TROCAR VISORES DO RESERVATORIO MANCAL HIDROSTATICO & SIDINEI ALBERTO MENEZES \\
\hline 0220RP18 & & & $02 \mathrm{~T} 82328$ & MP-0203M - TRIMESTRAL - RETIFICA KATAOKA R7 & NOEL TEIXEIRA DOS SANTOS \\
\hline 0220RP18 & & & 02V08076 & MP-0203M - TRIMESTRAL - RETIFICA KATAOKA R7 & NOEL TEIXEIRA DOS SANTOS \\
\hline SUBTOTAIS & 26 & 19 & 6 & & 40 \\
\hline 0220RP19 & 02R70299 & & & REPARO NOS SENSORES DOS CILINDROS DO ROBO & JOAO BATISTA DA SILVA \\
\hline 0220RP19 & 02R86754 & 02B8560 & & TROCADO SENSOR DE INDICACAO DO CARRO & GILBERTO CORREA DE CARVALHO \\
\hline 0220RP19 & 02S01675 & & & REPARADO DO ACIONADOR DO CONTRA PONTO & JOAO BATISTA DA SILVA \\
\hline 0220RP19 & 02S54706 & 02C0051 & & LIMPADO VALV. DE ACIONAMENTO E LUBRIFICADO & ADRIANO MACEDO \\
\hline 0220RP19 & 02S57062 & & & VERIFICADO A VALVULA DO AVANCO DO CILINDRO DO ROBO & SILVIO JOSE LIMA \\
\hline 0220RP19 & 02S58659 & & & LIMPADO E LUBRIFICADO VALVULA DA KATAOKA & ADRIANO MACEDO \\
\hline 0220RP19 & $02 S 60879$ & 02C0377 & & RETIRADO PARAFUSO E TROCADO COLAR & ADRIANO MACEDO \\
\hline 0220RP19 & 02S66169 & 02C0609 & & RECUPERADO HASTE DO CILINDRO DO ROBO & CLEZIO CARDOSO SILVA \\
\hline 0220RP19 & $02 \mathrm{~T} 10325$ & 02C1544 & & TROCADO ROLAMENTOS DO CONTRA PONTO & ADRIANO MACEDO \\
\hline 0220RP19 & $02 \mathrm{~T} 10325$ & 02C1544 & & TROCADO ROLAMENTOS DO CONTRA PONTO & CLEZIO CARDOSO SILVA \\
\hline 0220RP19 & $02 \mathrm{~T} 30571$ & 02C2071 & & TROCADO SENSOR DA GARRA DO ROBO & EDSON HENRIQUE DA SILVA \\
\hline 0220RP19 & $02 \mathrm{~T} 88689$ & 02C3108 & & LIMPADO E AJUSTADO SENSORES DO ROBO & LUCIANO JOSE CORTES \\
\hline 0220RP19 & $02 \mathrm{~T} 89045$ & 02C3140 & & TROCADO ROLAMENTO DO CONTRA PONTO E CORREIA DA PLACA & ADRIANO MACEDO \\
\hline 0220RP19 & $02 \mathrm{~T} 89045$ & 02C3140 & & TROCADO ROLAMENTO DO CONTRA PONTO E CORREIA DA PLACA & CLEZIO CARDOSO SILVA \\
\hline 0220RP19 & 02U04115 & & & CONFECCIONADO PROTRECAO DE ACRILICO DO PAINEL DE CONTROLE & ADRIANO MACEDO \\
\hline 0220RP19 & 02U69046 & 02C5483 & & AJUSTADO SENSORES DO CARRO DE MEDICAO & GERSON TADEU GONCALVES \\
\hline 0220RP19 & $02 \mathrm{~V} 02125$ & 02C6172 & & REPARADO PRESSOSTATO E COMPLETADO NIVEL DE OLEO & EDSON HENRIQUE DA SILVA \\
\hline 0220RP19 & 02 V94749 & 02C8314 & & TROCADO SENSOR DO ROBO E MICRO NA BUCHA RECUADA & LUCIANO JOSE CORTES \\
\hline 0220RP19 & 02W00518 & 02C8541 & & TROCADO PARAFUSO ATUADOR DO SENSOR DO ROBO & ADRIANO MACEDO \\
\hline 0220RP19 & $02 \mathrm{~W} 05103$ & 02C8649 & & RETIRADO VALVULA, LIMPADO E LUBRIFICADO & ADRIANO MACEDO \\
\hline 0220RP19 & 02W07762 & & & TROCADO MANGUEIRA PNEUMATICA DAS VALVULAS DE REFRIGERACAO & VALTEMIR FRANCISCO BARROS \\
\hline 0220RP19 & 02W09430 & 02C8818 & & CORRECAO DOS PARAMETROS DE TRABALHO DO CNC & LUCIANO JOSE CORTES \\
\hline 0220RP19 & 02W22692 & 02C8966 & & TROCADO CABO DO MOTOR DA ARVORE & LUCIANO JOSE CORTES \\
\hline
\end{tabular}




\begin{tabular}{|c|c|c|c|c|c|}
\hline CÓDIGO & OS MC & $\mathbf{C P}$ & OS MP & SERVIÇO EXECUTADO & FUNCIONÁRIOS \\
\hline 0220RP19 & 02W23165 & 02C8989 & & VERIFICADO A REGULAGEM DO AVANCO DO CILINDRO DO ROBO & SILVIO JOSE LIMA \\
\hline 0220RP19 & 02W23557 & 02C9011 & & PERDA DE REFERENCIA DOS EIXOS & JOAO BATISTA DA SILVA \\
\hline 0220RP19 & 02W51259 & 02C9561 & & RECUPERADO ROSCA DA BUCHA DE FIXACAO DA GUIA & ADRIANO MACEDO \\
\hline 0220RP19 & $02 W 57093$ & 02C9727 & & REFERENCIAMENTO E TROC. BATERIAS DE MEMORIA & EDSON HENRIQUE DA SILVA \\
\hline 0220RP19 & 02W91607 & 02D0105 & & RECUPERADO ROSCA DA HASTE DO CILINDRO DO ROBO & VALTEMIR FRANCISCO BARROS \\
\hline 0220RP19 & 02W95471 & 02D0270 & & TROCADO PORTA FERRAMENTA & VALTEMIR FRANCISCO BARROS \\
\hline 0220RP19 & $02 X 03523$ & $02 \mathrm{D} 0521$ & & FOI TROCADO A MANGUEIRA HIDRAULICA DA MAQUINA & SILVIO JOSE LIMA \\
\hline 0220RP19 & 02X05424 & 02D0628 & & REFERENCIADO OS EIXOS E ACERTADO POSICAO INICIAL & EDSON HENRIQUE DA SILVA \\
\hline 0220RP19 & 02X07681 & $02 \mathrm{D} 0721$ & & REPARO NA PERDA DE REFERENCIA DOS EIXOS DO REBOLO & JOAO BATISTA DA SILVA \\
\hline 0220RP19 & & & 02R65875 & REPARO NO ALARME DO SISTEMA DE SEGURANCA DO REBOLO & JOSE ANDERSON DE PAULA \\
\hline 0220RP19 & & & 02R65875 & REPARO NO ALARME DO SISTEMA DE SEGURANCA DO REBOLO & SIDNEY GONCALVES FARIA MONTI \\
\hline 0220RP19 & & & 02R90552 & MP-0203M - ANUAL - RETIFICA KATAOKA R7 & NOEL TEIXEIRA DOS SANTOS \\
\hline 0220RP19 & & & 02R90552 & MP-0203M - ANUAL - RETIFICA KATAOKA R7 & NOEL TEIXEIRA DOS SANTOS \\
\hline 0220RP19 & & & 02R90552 & MP-0203M - ANUAL - RETIFICA KATAOKA R7 & RICARDO MAGNO DO CARMO \\
\hline 0220RP19 & & & 02R91891 & MP-0203E - ANUAL - RETIFICA KATAOKA R7 & SIDINEI ALBERTO MENEZES \\
\hline 0220RP19 & & & 02S62840 & TROCAR VALVULA DA GARRA DO ROBO & NOEL TEIXEIRA DOS SANTOS \\
\hline 0220RP19 & & & $02 \mathrm{~T} 48697$ & TROCAR VISORES DO RESERVATORIO MANCAL HIDROSTATICO & SIDINEI ALBERTO MENEZES \\
\hline 0220RP19 & & & 02U99638 & REALIZAR ALINHAMENTO E GEOMETRIA & ADRIANO MACEDO \\
\hline SUBTOTAIS & 30 & 24 & 6 & & 41 \\
\hline 0220RP21 & 02R10684 & 02B6592 & & REPARADO HASTE DO CONTRA PONTO & WAGNER KALAS PEREIRA \\
\hline 0220RP21 & 02R11601 & $02 B 6645$ & & TROCADO CAIXA DE ARRASTE PARA TROCAR CORREIA & SILVIO JOSE LIMA \\
\hline 0220RP21 & 02S16142 & $02 B 9507$ & & REPARO NO INVERSOR COM FALHA SOBRECORRENTE & JOSE ANDERSON DE PAULA \\
\hline 0220RP21 & $02 \mathrm{~T} 13732$ & $02 \mathrm{C} 1783$ & & ACERTADO OS PARAMETROS DO INVERSOR DE FREQUENCIA & EDSON HENRIQUE DA SILVA \\
\hline 0220RP21 & $02 \mathrm{~V} 40753$ & & & TROCADO A APERTADEIRA DO PILAO & CARLOS RENATO ALKMIM \\
\hline 0220RP21 & 02 V97862 & $02 \mathrm{C} 8445$ & & REPARO CORRENTE DO PILAO & WAGNER KALAS PEREIRA \\
\hline 0220RP21 & $02 \mathrm{~W} 92116$ & $02 \mathrm{D} 0144$ & & RETIRADO ALARME DA MAQ. E REPOSICIONADO EIXOS & EDSON HENRIQUE DA SILVA \\
\hline 0220RP21 & $02 X 05353$ & $02 \mathrm{D} 0623$ & & TROCADO APERTADEIRA DO PILAO & WAGNER KALAS PEREIRA \\
\hline 0220RP21 & 02X05380 & 02D0625 & & AJUSTADO POSICAO INICIAL E REFERENCIADO EIXOS & EDSON HENRIQUE DA SILVA \\
\hline 0220RP21 & & & 02R65900 & REPARO NO ALARME DO SISTEMA DE SEGURANCA DO REBOLO & GILBERTO CORREA DE CARVALHO \\
\hline 0220RP21 & & & 02R65900 & REPARO NO ALARME DO SISTEMA DE SEGURANCA DO REBOLO & JOSE ANDERSON DE PAULA \\
\hline 0220RP21 & & & $02 \mathrm{~T} 83247$ & MP-0206M - ANUAL - RETIFICA KATAOKA PCG & NOEL TEIXEIRA DOS SANTOS \\
\hline 0220RP21 & & & $02 \mathrm{~T} 83407$ & MP-0206E - ANUAL - RETIFICA KATAOKA PCG & GERSON TADEU GONCALVES \\
\hline SUBTOTAIS & 9 & 8 & 3 & & 13 \\
\hline 0220RP22 & 02R12209 & & & RECUPERADO A ROSCA DE FIXACAO DA GARRA DO ROBO & CARLOS RENATO ALKMIM \\
\hline 0220RP22 & 02S58230 & 02C0209 & & AJUSTADO ACIONAMENTO DO SENSOR DA PINCA & GERSON TADEU GONCALVES \\
\hline 0220RP22 & 02S81231 & 02C0802 & & REPARAO NO POSICIONAMENTO DOS SENSORES DO ROBO & JOAO BATISTA DA SILVA \\
\hline 0220RP22 & $02 \mathrm{~T} 30349$ & $02 \mathrm{C} 2053$ & & RECUPERADO PARAFUSO DA KATAOKA & SEBASTIAO DIVINO CARLOS \\
\hline
\end{tabular}




\begin{tabular}{|c|c|c|c|c|c|}
\hline CÓDIGO & OS MC & $\mathbf{C P}$ & OS MP & SERVIÇO EXECUTADO & FUNCIONÁRIOS \\
\hline 0220RP22 & 02V06915 & 02C6562 & & TROCADO MOLA DA POLIA VARIADORA DE VELOCIADES & WAGNER KALAS PEREIRA \\
\hline 0220RP22 & $02 \mathrm{~V} 48372$ & 02C7422 & & TROCA DE MANGUEIRA HIDRAULICA & CARLOS RENATO ALKMIM \\
\hline 0220RP22 & $02 \mathrm{~V} 77090$ & 02C8039 & & AJUSTADA PRESSAO HIDRAULICO ACOMPANHADO FUNCIONAMENTO & EDSON HENRIQUE DA SILVA \\
\hline 0220RP22 & $02 \mathrm{~V} 83305$ & 02C8153 & & TROCADO SENOSR DA GARRA DO ROBO & EDSON HENRIQUE DA SILVA \\
\hline 0220RP22 & 02V95702 & $02 \mathrm{C} 8353$ & & REPARO NO COMANDO DO DRESSADOR & |JOAO BATISTA DA SILVA \\
\hline 0220RP22 & $02 \mathrm{~V} 97880$ & 02C8447 & & TROCADO CORREIA DE TRANSMISSAO DE VELOCIDADE DO CONJUNTO & WAGNER KALAS PEREIRA \\
\hline 0220RP22 & 02W44035 & & & REPARO NA FIXACAO DO FIM DE CURSO & JOAO BATISTA DA SILVA \\
\hline 0220RP22 & 02W91732 & 02D0116 & & AJUSTADO COLAR DO DRESSADOR & NOEL TEIXEIRA DOS SANTOS \\
\hline 0220RP22 & 02W96746 & 02D0311 & & REPARO NO COMANDO DA DRESSAGEM & JOAO BATISTA DA SILVA \\
\hline 0220RP22 & 02X01525 & & & RETIRADO BLOCO HIDRAULICO E VALVULAS E ELIMINADO VAZAMENTO & CLAUDIO RAIMUNDO DE ANDRADE \\
\hline 0220RP22 & 02X35669 & 02D0942 & & TROCADO A MOLA DO ROBO & SILVIO JOSE LIMA \\
\hline 0220RP22 & $02 X 37346$ & $02 D 0994$ & & TROCADO A CONEXAO DO CILINDRO DO ROBO & SILVIO JOSE LIMA \\
\hline 0220RP22 & & & 02R65919 & REPARO NO ALARME DO SISTEMA DE SEGURANCA DO REBOLO & GILBERTO CORREA DE CARVALHO \\
\hline 0220RP22 & & & 02R65919 & REPARO NO ALARME DO SISTEMA DE SEGURANCA DO REBOLO & JOSE ANDERSON DE PAULA \\
\hline 0220RP22 & & & 02V09850 & MP-0202M - ANUAL - RETIFICA KATAOKA R4 & NOEL TEIXEIRA DOS SANTOS \\
\hline 0220RP22 & & & 02V10072 & MP-0202E - ANUAL - RETIFICA KATAOKA R4 & JOAO BATISTA DA SILVA \\
\hline SUBTOTAIS & 16 & 13 & 3 & & 20 \\
\hline 0220RP23 & 02R21681 & $02 B 7053$ & & REPARADO FIACAO DO COMANDO DO ROBO & JOAO BATISTA DA SILVA \\
\hline $0220 \mathrm{RP} 23$ & 02R61325 & 02B7920 & & REPARO NO SENSOR DO ROBO & WAGNER KALAS PEREIRA \\
\hline 0220RP23 & 02R69130 & $02 B 8245$ & & TROC. O SUPORTE DE CENTRAGEM DA BUCHA & CARLOS RENATO ALKMIM \\
\hline $0220 \mathrm{RP} 23$ & 02R71895 & 02B8374 & & TROCADO O TUBO DA REFRIGERACAO & SILVIO JOSE LIMA \\
\hline 0220RP23 & 02R99875 & & & AJUSTADO FOLGA DO ROBO E MUD. FURACAO DA GARRA & CARLOS RENATO ALKMIM \\
\hline $0220 \mathrm{RP} 23$ & 02S05396 & 02B9014 & & TROCA DE FIM DE CURSO DO ROBO QUE PRENDE A GARRA & JOAO BATISTA DA SILVA \\
\hline $0220 \mathrm{RP} 23$ & 02S43452 & $02 B 9679$ & & TROCADO MOLA DO ROBO & CLEZIO CARDOSO SILVA \\
\hline 0220RP23 & 02S54519 & 02C0039 & & EMBUCHADO SUPORTE DA REGUA DA KATAOKA & CARLOS RENATO ALKMIM \\
\hline $0220 \mathrm{RP} 23$ & $02 S 97466$ & & & REPARADO VALVULA DA REFRIGERACAO DO REBOLO & CARLOS RENATO ALKMIM \\
\hline $0220 \mathrm{RP} 23$ & $02 \mathrm{~T} 06483$ & 02C1424 & & TROCADO A VALVULA DE ACIONAMENTO DA VALVULA DE REFRIGERACAO & CARLOS RENATO ALKMIM \\
\hline 0220RP23 & 02U05016 & $02 \mathrm{C} 3646$ & & TROCADO BLOCO DE CONTATO DO FIM DE CURSO DO ROBO & EDSON HENRIQUE DA SILVA \\
\hline 0220RP23 & 02U06328 & 02C3717 & & RECUPERADO ROSCA DE FIXACAO DO DIAMANTE & CARLOS RENATO ALKMIM \\
\hline $0220 \mathrm{RP} 23$ & 02U66129 & & & TROCADO PROTECAO DE ACRILICO DA KATAOKA & CARLOS RENATO ALKMIM \\
\hline 0220RP23 & 02U82824 & $02 \mathrm{C} 5841$ & & TROCADO ACRILICO E AJUSTADO FIXACAO DA PORTA & RENATO MARCEL CARVALHO \\
\hline $0220 \mathrm{RP} 23$ & 02U96025 & $02 \mathrm{C} 6035$ & & RECUPERADO A ROSCA DDO SUPORTE DA BUCHA & SILVIO JOSE LIMA \\
\hline $0220 \mathrm{RP} 23$ & $02 \mathrm{~V} 23004$ & & & TROCADO ROLAMENTOS, BRACO E GARRA DO ROBO & WAGNER KALAS PEREIRA \\
\hline $0220 \mathrm{RP} 23$ & 02 V31111 & $02 C 6983$ & & AJUSTADO ACIONADOR DO MICRO DO RETORNO DA REGUA & GILBERTO CORREA DE CARVALHO \\
\hline $0220 \mathrm{RP} 23$ & 02V62701 & & & LIMPADO VALVULA DE REFRIGERACAO & SILVIO JOSE LIMA \\
\hline $0220 \mathrm{RP} 23$ & 02 V97693 & $02 \mathrm{C} 8434$ & & REPARO ROSCA DO SUPORTE DA BUCHA & WAGNER KALAS PEREIRA \\
\hline $0220 \mathrm{RP} 23$ & 02W09047 & 02C8770 & & RECUPERADO A ROSCA DO SUPORTE DA BUCHA & CARLOS RENATO ALKMIM \\
\hline $0220 R P 23$ & 02W22601 & 02C8960 & & REG. VALV. DO DRESSADOR E CORRIGIDO PARTE ELETRICA & CARLOS RENATO ALKMIM \\
\hline
\end{tabular}




\begin{tabular}{|c|c|c|c|c|c|}
\hline CÓDIGO & OS MC & $\mathbf{C P}$ & OS MP & SERVIÇO EXECUTADO & FUNCIONÁRIOS \\
\hline $0220 \mathrm{RP} 23$ & 02W22601 & 02C8960 & & REG. VALV. DO DRESSADOR E CORRIGIDO PARTE ELETRICA & WAGNER KALAS PEREIRA \\
\hline $0220 \mathrm{RP} 23$ & $02 \mathrm{~W} 23316$ & $02 \mathrm{C} 8770$ & & TROCADO MICRO DO ROBO & LUCIANO JOSE CORTES \\
\hline $0220 \mathrm{RP} 23$ & 02W50580 & $02 C 9519$ & & RECUPERADO A CORRENTE DO EMPURRADOR & CARLOS RENATO ALKMIM \\
\hline 0220RP23 & 02W98227 & & & VERIFICADO A FOLGA DO ROBO & SILVIO JOSE LIMA \\
\hline $0220 \mathrm{RP} 23$ & & & 02R65937 & REPARO NO ALARME DO SISTEMA DE SEGURANCA DO REBOLO & GILBERTO CORREA DE CARVALHO \\
\hline 0220RP23 & & & 02R65937 & REPARO NO ALARME DO SISTEMA DE SEGURANCA DO REBOLO & JOSE ANDERSON DE PAULA \\
\hline 0220RP23 & & & $02 \mathrm{~T} 01479$ & TROCAR LAMPADA GIROFLEX DA RETIFICA R4 & GILBERTO CORREA DE CARVALHO \\
\hline 0220RP23 & & & $02 \mathrm{~T} 40365$ & REVISAO NO CABECOTE PORTA REBOLO DA RET.KATAOKA BP 28724 & ADRIANO MACEDO \\
\hline 0220RP23 & & & $02 \mathrm{~T} 40365$ & REVISAO NO CABECOTE PORTA REBOLO DA RET.KATAOKA BP 28725 & GILBERTO CORREA DE CARVALHO \\
\hline 0220RP23 & & & $02 \mathrm{~T} 40365$ & REVISAO NO CABECOTE PORTA REBOLO DA RET.KATAOKA BP 28726 & JUNIOR MARCELO GONCALVES \\
\hline $0220 \mathrm{RP} 23$ & & & $02 \mathrm{~T} 40365$ & REVISAO NO CABECOTE PORTA REBOLO DA RET.KATAOKA BP 28727 & MATHEUS MARQUES ANDRADE \\
\hline $0220 \mathrm{RP} 23$ & & & $02 \mathrm{~T} 40365$ & REVISAO NO CABECOTE PORTA REBOLO DA RET.KATAOKA BP 28728 & NOEL TEIXEIRA DOS SANTOS \\
\hline 0220RP23 & & & $02 \mathrm{~T} 40365$ & REVISAO NO CABECOTE PORTA REBOLO DA RET.KATAOKA BP 28729 & RENATO MARCEL CARVALHO \\
\hline 0220RP23 & & & $02 \mathrm{~T} 40365$ & REVISAO NO CABECOTE PORTA REBOLO DA RET.KATAOKA BP 28730 & RICARDO MAGNO DO CARMO \\
\hline $0220 \mathrm{RP} 23$ & & & $02 \mathrm{~T} 40365$ & REVISAO NO CABECOTE PORTA REBOLO DA RET.KATAOKA BP 28731 & SILVIO JOSE LIMA \\
\hline $0220 \mathrm{RP} 23$ & & & $02 \mathrm{U} 74147$ & MP-0202M - ANUAL - RETIFICA KATAOKA R4 & RICARDO MAGNO DO CARMO \\
\hline 0220RP23 & & & 02U74432 & MP-0202E - ANUAL - RETIFICA KATAOKA R4 & JOAO BATISTA DA SILVA \\
\hline SUBTOTAIS & 24 & 18 & 5 & & 38 \\
\hline 0220RP24 & 02R07563 & 02B6482 & & REPARO NO CONJUNTO MOVEL DA PORTA DO REBOLO & EDSON HENRIQUE DA SILVA \\
\hline 0220RP24 & 02R07563 & 02B6482 & & REPARO NO CONJUNTO MOVEL DA PORTA DO REBOLO & SIDINEI ALBERTO MENEZES \\
\hline 0220RP24 & 02R12183 & & & TROCADO CORREIA DO ARRASTE & CARLOS RENATO ALKMIM \\
\hline 0220RP24 & $02 \mathrm{R} 43293$ & 02B7398 & & REPARADO POTENCIOMETRO & SIDNEY GONCALVES FARIA MONTI \\
\hline 0220RP24 & $02 \mathrm{R} 65125$ & & & RECUPERADO OS SUPORTES DO VIBRADOR & CARLOS RENATO ALKMIM \\
\hline 0220RP24 & 02S62378 & $02 \mathrm{C} 0442$ & & REPARADO COMANDO DO INVERSOR & EDSON HENRIQUE DA SILVA \\
\hline 0220RP24 & 02S62378 & $02 \mathrm{C} 0442$ & & REPARADO COMANDO DO INVERSOR & SIDNEY GONCALVES FARIA MONTI \\
\hline 0220RP24 & $02 \mathrm{~T} 88466$ & 02C3087 & & PERDAS REFERENCIA DO EIXO DO ROLO & JOAO BATISTA DA SILVA \\
\hline 0220RP24 & 02U96043 & $02 C 6037$ & & REFERENCIA NO EIXO X & JOAO BATISTA DA SILVA \\
\hline 0220RP24 & $02 \mathrm{~V} 36143$ & $02 \mathrm{C} 7022$ & & REPARO NOS PARAMETROS DE PROGRAMACAO & JOAO BATISTA DA SILVA \\
\hline 0220RP24 & & & 02R09151 & SUBSTITUICAO DE BATERIA PARA SERVO DRIVE DA RET.PCG BP0017 & SIDINEI ALBERTO MENEZES \\
\hline 0220RP24 & & & $02 \mathrm{R} 65946$ & REPARO NO ALARME DO SISTEMA DE SEGURANCA DO REBOLO & GILBERTO CORREA DE CARVALHO \\
\hline 0220RP24 & & & 02R65946 & REPARO NO ALARME DO SISTEMA DE SEGURANCA DO REBOLO & JOSE ANDERSON DE PAULA \\
\hline 0220RP24 & & & $02 \mathrm{~T} 82319$ & MP-0206M - ANUAL - RETIFICA KATAOKA PCG & JUNIOR MARCELO GONCALVES \\
\hline 0220RP24 & & & $02 T 82319$ & MP-0206M - ANUAL - RETIFICA KATAOKA PCG & NOEL TEIXEIRA DOS SANTOS \\
\hline 0220RP24 & & & $02 \mathrm{~T} 82453$ & MP-0206E - ANUAL - RETIFICA KATAOKA PCG & EDSON HENRIQUE DA SILVA \\
\hline 0220RP24 & & & $02 \mathrm{~T} 82453$ & MP-0206E - ANUAL - RETIFICA KATAOKA PCG & EDSON HENRIQUE DA SILVA \\
\hline SUBTOTAIS & 8 & 6 & 4 & & 17 \\
\hline 0220RP27 & 02R16982 & 02B6868 & & REPARADO BOTOEIRA DE MUDANCA DE POSICAO & GILBERTO CORREA DE CARVALHO \\
\hline
\end{tabular}




\begin{tabular}{|c|c|c|c|c|c|}
\hline CÓDIGO & OS MC & $\mathbf{C P}$ & OS MP & SERVIÇO EXECUTADO & FUNCIONÁRIOS \\
\hline 0220RP27 & 02R22332 & 02B7079 & & REPARADO CILINDRO E TROCADO VALVULA CONTROLADORA DE FLUXO & ADRIANO MACEDO \\
\hline 0220RP27 & 02R22332 & 02B7079 & & REPARADO CILINDRO E TROCADO VALVULA CONTROLADORA DE FLUXO & CLEZIO CARDOSO SILVA \\
\hline 0220RP27 & 02R54627 & 02B7669 & & RESETADO MAQUINA E VERIFICADO FUNCIONAMENTO DO REBOLO & EDSON HENRIQUE DA SILVA \\
\hline 0220RP27 & 02R86512 & 02B8545 & & TROCAR ROLAMENTO DO CONTRA PONTO & CLEZIO CARDOSO SILVA \\
\hline 0220RP27 & 02R86512 & 02B8545 & & TROCAR ROLAMENTO DO CONTRA PONTO & SILVIO JOSE LIMA \\
\hline 0220RP27 & 02R98634 & 02B8689 & & TROCADO O SENSOR DE ROBO & EDSON HENRIQUE DA SILVA \\
\hline 0220RP27 & 02S06910 & 02B9055 & & AJUSTADO MICRO DO RETORNO DO EMPURRADOR DE ANEL & GILBERTO CORREA DE CARVALHO \\
\hline 0220RP27 & $02 S 06974$ & 02B9061 & & REPARO NO CILINDRO DA GARRA DA RETIFICA & JOAO BATISTA DA SILVA \\
\hline 0220RP27 & 02S15679 & & & REPARADO ROSCA DE 1/4 E AJUSTADO DISPOSITIVO DE ANGULO & ADRIANO MACEDO \\
\hline 0220RP27 & $02 \mathrm{~S} 48616$ & 02B9790 & & REPARO NA VALVULA DO ROBO & JOAO BATISTA DA SILVA \\
\hline 0220RP27 & 02S50728 & $02 B 9873$ & & REPARO NA FALHA DO SENSOR REPOSICIONADO & GERSON TADEU GONCALVES \\
\hline 0220RP27 & $02 S 64072$ & $02 \mathrm{C} 0491$ & & COLOCADO MAQUINA NA POSICAO INICIAL DE TRABALHO & SIDNEY GONCALVES FARIA MONTI \\
\hline 0220RP27 & $02 S 81044$ & 02C0790 & & AJUSTADO O SENSOR DE GARRA ABERTA & EDSON HENRIQUE DA SILVA \\
\hline 0220RP27 & $02 \mathrm{~T} 01969$ & 02C1298 & & REPARO NA GARRA DO ROBO DE ACIONAMENTO DO SENSOR & JOSE ANDERSON DE PAULA \\
\hline 0220RP27 & $02 \mathrm{~T} 02307$ & 02C1316 & & AJUSTADO PARAMETROS DA KATAOKA & GERSON TADEU GONCALVES \\
\hline 0220RP27 & $02 \mathrm{~T} 30615$ & 02C2075 & & VERIFICADO AS PRESSOES DA MAQUINA & SILVIO JOSE LIMA \\
\hline 0220RP27 & $02 \mathrm{~T} 57150$ & & & TROCADO CONEXOES DE LUBRIFICACAO & CLAUDIO RAIMUNDO DE ANDRADE \\
\hline 0220RP27 & $02 \mathrm{~T} 88803$ & 02C3120 & & TROCADO TUBO DE ALIMENTACAO DA VALVULA & ADRIANO MACEDO \\
\hline 0220RP27 & $02 \mathrm{~T} 88803$ & $02 \mathrm{C} 3120$ & & TROCADO TUBO DE ALIMENTACAO DA VALVULA & CLAUDIO RAIMUNDO DE ANDRADE \\
\hline 0220RP27 & $02 \mathrm{~T} 94182$ & $02 \mathrm{C} 3307$ & & TROCADO ADAPTADOR DO COLAR & CLAUDIO RAIMUNDO DE ANDRADE \\
\hline 0220RP27 & 02U69028 & 02C5482 & & TROCADO RELE DO FIM DE CURSO E RESETADO CNC & GERSON TADEU GONCALVES \\
\hline 0220RP27 & $02 \mathrm{U} 83645$ & 02C5898 & & TROCADO ANILHA E TUBULACAO DE OLEO & ADRIANO MACEDO \\
\hline 0220RP27 & 02U94759 & & & DESMONTADO A VALVULA DE REFRIGERACAO & SILVIO JOSE LIMA \\
\hline 0220RP27 & 02U96132 & 02C6046 & & RETIRADA VALCULA FEITA LIMPEZA E LUBRIFICACAO E DESTRAVADA & ADRIANO MACEDO \\
\hline 0220RP27 & 02U96132 & $02 \mathrm{C} 6046$ & & RETIRADA VALCULA FEITA LIMPEZA E LUBRIFICACAO E DESTRAVADA & LUCIANO JOSE CORTES \\
\hline 0220RP27 & $02 \mathrm{~V} 02116$ & $02 \mathrm{C} 6171$ & & DESENTUPIDO CONEXAO HIDRAULICA & CLEZIO CARDOSO SILVA \\
\hline 0220RP27 & 02V03099 & $02 \mathrm{C} 6195$ & & LIMP. E LUBRIF. CONJ. DE VALVULAS E ELIMINADO TRAVAMENTO & ADRIANO MACEDO \\
\hline 0220RP27 & 02V03838 & 02C6296 & & REL. LIMPADO E LUBRIFICADO O CONJUNTO DE VAL. DE REFRIG. & ADRIANO MACEDO \\
\hline 0220RP27 & $02 \mathrm{~V} 47505$ & 02C7361 & & RECUPERADO HASTE DO CILINDRO DA GARRA & VALTEMIR FRANCISCO BARROS \\
\hline 0220RP27 & 02V49344 & 02C7449 & & AJUSTADO CONEXAO DO CILINDRO & VALTEMIR FRANCISCO BARROS \\
\hline 0220RP27 & 02V49709 & 02C7504 & & TROCADO SENSOR DA BARRA DO ROBO & EDSON HENRIQUE DA SILVA \\
\hline 0220RP27 & 02V60357 & & & LIMPADO VALVULA DE REFRIGERACAO DO REBOLO & SILVIO JOSE LIMA \\
\hline 0220RP27 & $02 \mathrm{~V} 83378$ & 02C8160 & & TROCADO PORTA COLAR CONTRA PONTO & VALTEMIR FRANCISCO BARROS \\
\hline 0220RP27 & 02 V94552 & 02C8298 & & LIMPADO VALVULAS DE REFRIGERACAO & SILVIO JOSE LIMA \\
\hline 0220RP27 & 02W21568 & 02C8902 & & REPARADO O ROBO E REC. A PONTA DA HASTE DO CILINDRO & EDSON HENRIQUE DA SILVA \\
\hline 0220RP27 & 02W21568 & 02C8902 & & REPARADO O ROBO E REC. A PONTA DA HASTE DO CILINDRO & SILVIO JOSE LIMA \\
\hline 0220RP27 & 02W39577 & $02 \mathrm{C} 9155$ & & TROCADO PORTA COLAR E PARAFUSOS & VALTEMIR FRANCISCO BARROS \\
\hline 0220RP27 & 02W54194 & & & AJUST. CONEXOES E MANGUEIRAS E ELIMINADO VAZAMENTOS & ADRIANO MACEDO \\
\hline 0220RP27 & $02 W 89503$ & & & RECUPERADO ROSCA DA HASTE DO CILINDRO DA REGUA E TROC. PORCA & VALTEMIR FRANCISCO BARROS \\
\hline
\end{tabular}




\begin{tabular}{|c|c|c|c|c|c|}
\hline CÓDIGO & OS MC & $\mathbf{C P}$ & OS MP & SERVIÇO EXECUTADO & FUNCIONÁRIOS \\
\hline 0220RP27 & 02W92232 & $02 \mathrm{D} 0153$ & & REGULADO PRESSOE E COLOCADO OLEO NO TANQUE & SILVIO JOSE LIMA \\
\hline 0220RP27 & 02X05264 & 02D0615 & & TROCADO GRAXETA DO CILINDRO DO DRESSADOR E AJUSTADO SENSORES & VALTEMIR FRANCISCO BARROS \\
\hline 0220RP27 & $02 X 34571$ & 02D0916 & & AJUSTADO SENSOR DA GARRA DO ROBO & EDSON HENRIQUE DA SILVA \\
\hline 0220RP27 & 02X37621 & 02D1010 & & REPARO DO LIGA DESLIGA DO EMPURRADOR & JOAO BATISTA DA SILVA \\
\hline 0220RP27 & & & $02 \mathrm{R} 65973$ & REPARO NO ALARME DO SISTEMA DE SEGURANCA DO REBOLO & GILBERTO CORREA DE CARVALHO \\
\hline 0220RP27 & & & $02 \mathrm{R} 65973$ & REPARO NO ALARME DO SISTEMA DE SEGURANCA DO REBOLO & JOSE ANDERSON DE PAULA \\
\hline 0220RP27 & & & $02 \mathrm{R} 65973$ & REPARO NO ALARME DO SISTEMA DE SEGURANCA DO REBOLO & SIDNEY GONCALVES FARIA MONTI \\
\hline 0220RP27 & & & 02R93434 & MP-0203M - ANUAL - RETIFICA KATAOKA R7 & JORGELINO BATISTA DE OLIVEIRA \\
\hline 0220RP27 & & & 02R93434 & MP-0203M - ANUAL - RETIFICA KATAOKA R8 & RICARDO MAGNO DO CARMO \\
\hline 0220RP27 & & & 02R93782 & MP-0203E - ANUAL - RETIFICA KATAOKA R7 & JOSE ANDERSON DE PAULA \\
\hline 0220RP27 & & & $02 \mathrm{~T} 48713$ & TROCAR VISORES DO RESERVATORIO MANCAL HIDROSTATICO & NOEL TEIXEIRA DOS SANTOS \\
\hline 0220RP27 & & & $02 W 29604$ & TROCAR PROTECOES SANFONADAS DO MANGOTE FIXADOR & NOEL TEIXEIRA DOS SANTOS \\
\hline SUBTOTAIS & 39 & 33 & 5 & & 52 \\
\hline 0220RP28 & 02R54529 & 02B7656 & & VERIFICADO CONTATO DO PLUG DA VALVULA DO AVANCO DO ROBO & GILBERTO CORREA DE CARVALHO \\
\hline 0220RP28 & 02R57401 & 02B7786 & & AJUSTADO PRESSOSTATO DA BOMBA DE LUBRIFICACAO & EDSON HENRIQUE DA SILVA \\
\hline 0220RP28 & 02R70501 & 02B8308 & & COMPLETADO NIVEL DE OLEO E LUBRIFICADO CABECOTE & NÃO IDENTIFICADO \\
\hline 0220RP28 & 02S02567 & 02B8818 & & REPARO NO MOTOR DO ALINHADOR & JOAO BATISTA DA SILVA \\
\hline 0220RP28 & 02S03931 & 02B8909 & & REPARO NO CILINDRO E ROLAMENTOS & NÃO IDENTIFICADO \\
\hline 0220RP28 & 02S13412 & $02 B 9321$ & & COMPLETADO NIVEL DE OLEO E RESETADO FALHA & EDSON HENRIQUE DA SILVA \\
\hline 0220RP28 & $02 S 47617$ & & & LIMPADO UNID. HIDRAULICA DA RETIFICA & ADRIANO MACEDO \\
\hline 0220RP28 & 02S48796 & $02 B 9803$ & & TROCADO SUPORTE DE APOIO DO CONTRA PONTO & CLEZIO CARDOSO SILVA \\
\hline 0220RP28 & $02 S 54662$ & 02C0049 & & RECUP. SUPORTE DO CONTRA PONTO E TROC. SENSOR DO RETORNO & CLEZIO CARDOSO SILVA \\
\hline 0220RP28 & $02 S 61244$ & 02C0401 & & REPARADO SENSOR DA GARRA DE ROBO & EDSON HENRIQUE DA SILVA \\
\hline 0220RP28 & 02S64928 & $02 \mathrm{C} 0526$ & & TROCADO SUPORTE DO CONTRA PONTO & JORGELINO BATISTA DE OLIVEIRA \\
\hline 0220RP28 & $02 S 97723$ & 02C1019 & & TROC. MOTOR DO ALINHADOR DE ANEIS & SILVIO JOSE LIMA \\
\hline 0220RP28 & $02 \mathrm{~T} 01978$ & 02C1300 & & AJUSTADO CHAVE DE COMUTACAO DO PAINEL AUXILIAR & JOSE ANDERSON DE PAULA \\
\hline 0220RP28 & $02 \mathrm{~T} 07669$ & $02 \mathrm{C} 1484$ & & TROCADO PARAFUSO DO FLANGE DO CABECOTE & SILVIO JOSE LIMA \\
\hline 0220RP28 & $02 \mathrm{~T} 90658$ & 02C3184 & & TROCADO SENSOR DA GUILHOTINA & EDSON HENRIQUE DA SILVA \\
\hline 0220RP28 & 02 T98099 & 02C3430 & & REPARO EM CONTRA PONTO & ADRIANO MACEDO \\
\hline 0220RP28 & $02 T 98099$ & $02 \mathrm{C} 3430$ & & REPARO EM CONTRA PONTO & CLAUDIO RAIMUNDO DE ANDRADE \\
\hline 0220RP28 & 02U05980 & 02C3690 & & TROCADO CONEXAO HIDRAULICA DA RETIFICA & CLEZIO CARDOSO SILVA \\
\hline 0220RP28 & 02U06104 & 02C3700 & & REPARADO PRESSOSTATO LUBRIFICACAO DO CABECOTE DO REBOLO & JOAO BATISTA DA SILVA \\
\hline 0220RP28 & 02U66227 & & & ENGRAX. ROLAMENTOS E ELIMINADO FOLGA NO SUPORTE DA BUCHA & ADRIANO MACEDO \\
\hline 0220RP28 & 02W42885 & & & CONF. GARRAS DO ROBO DO COLETOR DE ANEIS & ADRIANO MACEDO \\
\hline 0220RP28 & 02W87024 & & & REALIZADO REAPERTO EM MANGUEIRAS E CONEXOES HIDRAULICA & ADRIANO MACEDO \\
\hline 0220RP28 & 02X00795 & 02D0459 & & PERDA DE REFERERNCIA DOS FIXOS & JOAO BATISTA DA SILVA \\
\hline 0220RP28 & $02 X 09377$ & 02D0759 & & TROCADO PORTA COLAR & VALTEMIR FRANCISCO BARROS \\
\hline 0220RP28 & & & 02Q95745 & MP-0203M - TRIMESTRAL - RETIFICA KATAOKA R7 & RICARDO MAGNO DO CARMO \\
\hline
\end{tabular}




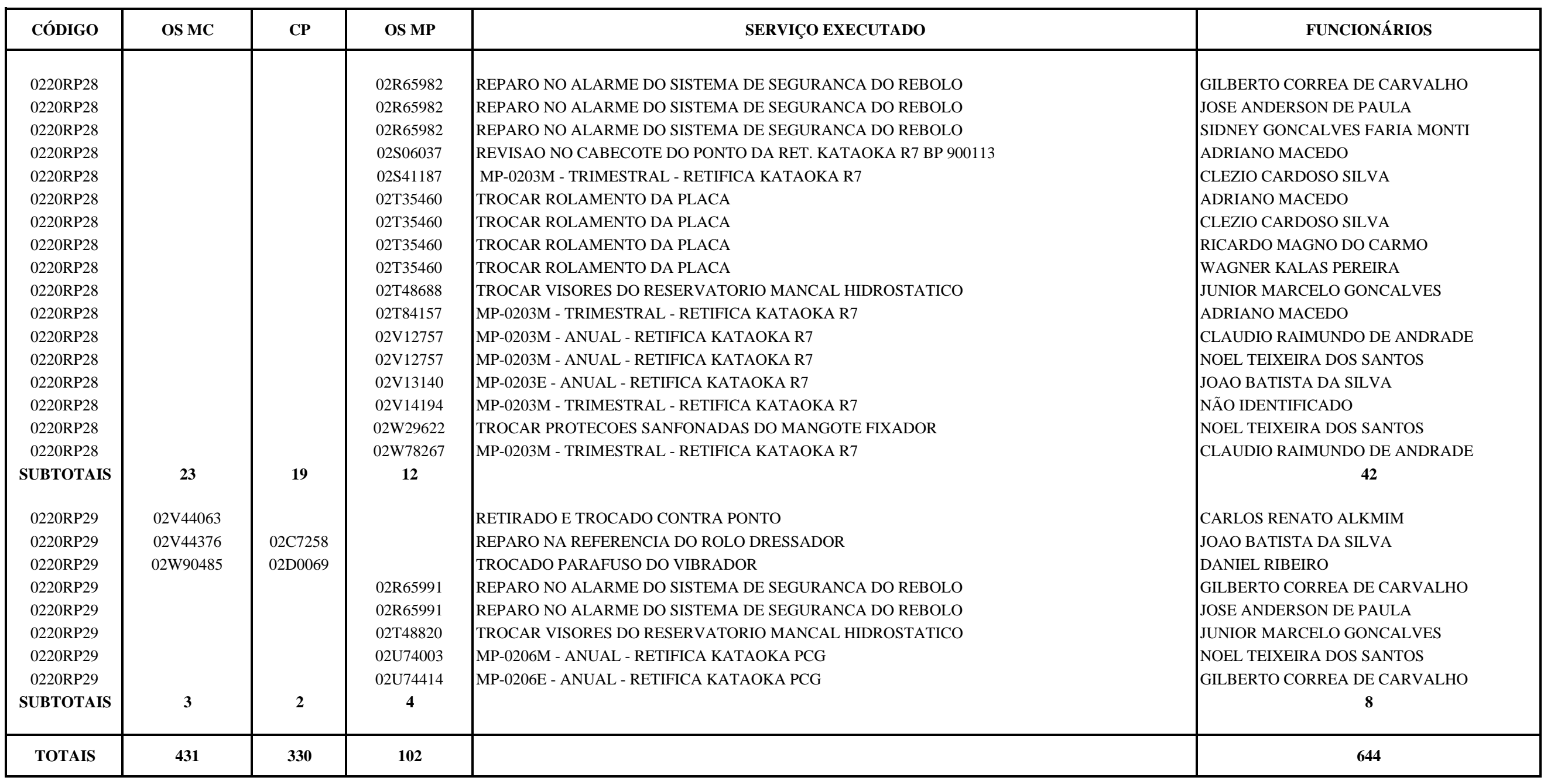


RETÍFICA DE PERFIL - ÍNDICE DE RISCO DE EQUIPAMENTO - NÚMERO DE OCORRÊNCIAS

( Período: 01/06/04 a 30/06/04 )

DESCRIÇÃO DAS COLUNAS

\begin{tabular}{|l|l|}
\hline \multicolumn{1}{|c|}{ COLUNA } & \multicolumn{1}{c|}{ DESCRIÇÃO } \\
\hline Código & Código patrimonial do equipamento \\
\hline OS Mnt Corretiva & Ordem de serviço de manutenção corretiva \\
\hline Cod Parada & Código de parada de produção \\
\hline Modalidade & Modalidade da falha (Mecânica, Elétrica ou Eletrônica) \\
\hline Falha & Descrição da Falha \\
\hline Causa & Causa diagnosticada da falha \\
\hline Ocorrência & Número de vezes que a falha ocorreu no equipamento \\
\hline Gravidade & Impacto que a falha causa no equipamento \\
\hline Detectabilidade & Facilidade de detectar a falha antes que aconteça \\
\hline OGD & Ocorrência x Gravidade x Detectabilidade \\
\hline IRF & Índice de Risco da Falha no Equipamento \\
\hline IRE & Índice de Risco de Equipamento \\
\hline
\end{tabular}


RETÍFICA DE PERFIL - ÍNDICE DE RISCO DE EQUIPAMENTO - NÚMERO DE OCORRÊNCIAS

( Período: 01/06/04 a 30/06/04 )

\begin{tabular}{|c|c|c|c|c|c|c|c|c|c|}
\hline Código & OS Mnt Corretiva & Cod Parada & Modalidade & Falha & Causa & Ocorrência & Gravidade & Detectabilidade & OGD \\
\hline 0220RP05 & 02R38156 & 02B6818 & MECÂNICA & DESLOCAMENTO & QUEBRA & 1 & 10 & 10 & 100 \\
\hline 0220RP05 & $02 \mathrm{R} 22323$ & 02B7078 & MECÂNICA & DESGASTE & ROSCA ESPANADA & 1 & 10 & 10 & 100 \\
\hline 0220RP05 & 02R43328 & 02B7404 & ELÉTRICA & INTERRUPCAO DE SINAL & SENSOR & 1 & 10 & 10 & 100 \\
\hline 0220RP05 & 02R37727 & 02B7301 & MECÂNICA & QUEBRA & CORRENTE & 1 & 10 & 10 & 100 \\
\hline 0220RP05 & 02R21468 & & ELÉTRICA & CURTO-CIRCUITO & ILUMINACAO & 1 & 1 & 1 & 1 \\
\hline 0220RP05 & 02R47315 & & ELÉTRICA & SUJEIRA & PNEUM.-VALVULA & 1 & 1 & 1 & 1 \\
\hline Subtotais & 6 & 4 & & & & 6 & & IRF & 402 \\
\hline 0220RP18 & 02R38012 & 02B7315 & MECÂNICA & FOLGA & CORREIA & 1 & 10 & 10 & 100 \\
\hline 0220RP18 & 02R22895 & 02B7247 & MECÂNICA & VAZAMENTO & BOMBA & 1 & 10 & 10 & 100 \\
\hline 0220RP18 & 02R18659 & & MECÂNICA & MELHORIA & EIXO & 1 & 1 & 1 & 1 \\
\hline Subtotais & 3 & 2 & & & & 3 & & IRF & 201 \\
\hline 0220RP24 & 02R07563 & 02B6482 & ELÉTRICA & DEFEITO INTERMITENTE & CLP & 1 & 10 & 10 & 100 \\
\hline 0220RP24 & $02 \mathrm{R} 43293$ & 02B7398 & ELÉTRICA & MAL-CONTATO & POTENCIOMETRO & 1 & 10 & 10 & 100 \\
\hline 0220RP24 & 02R12183 & & MECÂNICA & ROMPIMENTO & CORREIA & 1 & 1 & 1 & 1 \\
\hline Subtotais & 3 & 2 & & & & 3 & & IRF & 201 \\
\hline 0220RP01 & 02R07581 & 02B6480 & MECÂNICA & TRAVAMENTO & PNEUM.-VALVULA & 1 & 10 & 10 & 100 \\
\hline 0220RP01 & 02R10746 & 02B6587 & MECÂNICA & QUEBRA & CORRENTE & 1 & 10 & 10 & 100 \\
\hline Subtotais & 2 & 2 & & & & 2 & & IRF & 200 \\
\hline 0220RP02 & 02R17115 & 02B6875 & MECÂNICA & QUEBRA & CORRENTE & 1 & 10 & 10 & 100 \\
\hline 0220RP02 & $02 R 21663$ & 02B7050 & ELÉTRICA & INTERRUPCAO DE SINAL & SENSOR & 1 & 10 & 10 & 100 \\
\hline Subtotais & 2 & 2 & & & & 2 & & IRF & 200 \\
\hline 0220RP03 & 02R19088 & 02B6955 & MECÂNICA & QUEBRA & PARAFUSO & 1 & 10 & 10 & 100 \\
\hline 0220RP03 & 02R22449 & 02B7092 & ELÉTRICA & QUEBRA & SENSOR & 1 & 10 & 10 & 100 \\
\hline Subtotais & 2 & 2 & & & & 2 & & IRF & 200 \\
\hline
\end{tabular}




\begin{tabular}{|c|c|c|c|c|c|c|c|c|c|}
\hline Código & OS Mnt Corretiva & Cod Parada & Modalidade & Falha & Causa & Ocorrência & Gravidade & Detectabilidade & OGD \\
\hline 0220RP21 & 02R10684 & 02B6592 & MECÂNICA & DESLOCAMENTO & PNEUM.-CILINDRO & 1 & 10 & 10 & 100 \\
\hline 0220RP21 & 02R11601 & 02B6645 & MECÂNICA & QUEBRA & CORREIA & 1 & 10 & 10 & 100 \\
\hline Subtotais & 2 & 2 & & & & 2 & & IRF & 200 \\
\hline 0220RP27 & 02R16982 & 02B6868 & ELÉTRICA & DESGASTE & CHAVE/BOTOEIRA & 1 & 10 & 10 & 100 \\
\hline 0220RP27 & 02R22332 & 02B7079 & MECÂNICA & VAZAMENTO INTERNO & HIDR.-CILINDRO & 1 & 10 & 10 & 100 \\
\hline Subtotais & 2 & 2 & & & & 2 & & IRF & 200 \\
\hline 0220RP04 & 02R05850 & & MECÂNICA & VAZAMENTO & BUCHA & 1 & 1 & 10 & 10 \\
\hline 0220RP04 & 02R11594 & 02B6644 & MECÂNICA & QUEBRA & CORRENTE & 1 & 10 & 10 & 100 \\
\hline Subtotais & 2 & 1 & & & & 2 & & IRF & 110 \\
\hline 02203226 & 02R10862 & 02B6576 & ELÉTRICA & INTERRUPCAO DE SINAL & SENSOR & 1 & 10 & 10 & 100 \\
\hline 02203226 & 02R21486 & & ELÉTRICA & QUEBRA & SENSOR & 1 & 1 & 1 & 1 \\
\hline 02203226 & 02R25197 & & MECÂNICA & VAZAMENTO & LUBRIFIL & 1 & 1 & 1 & 1 \\
\hline Subtotais & 3 & 1 & & & & 3 & & IRF & 102 \\
\hline 0220RP23 & 02R21681 & 02B7053 & ELÉTRICA & FALTA ENERGIA ELET. & ELETRODUTO & 1 & 10 & 10 & 100 \\
\hline Subtotais & 1 & 1 & & & & 1 & & IRF & 100 \\
\hline 0220RP22 & 02R12209 & & MECÂNICA & DEFORMACAO & ROSCA ESPANADA & 1 & 1 & 1 & 1 \\
\hline Subtotais & 1 & $\mathbf{0}$ & & & & 1 & & IRF & 1 \\
\hline Totais & 29 & 21 & & & & 29 & & IRE & 2.117 \\
\hline
\end{tabular}


RETÍFICA DE PERFIL - ÍNDICE DE RISCO DE EQUIPAMENTO - NÚMERO DE OCORRÊNCIAS

( Período: 01/07/04 a 31/07/04 )

\begin{tabular}{|c|c|c|c|c|c|c|c|c|c|}
\hline Código & OS Mnt Corretiva & Cod Parada & Modalidade & Falha & Causa & Ocorrência & Gravidade & Detectabilidade & OGD \\
\hline 0220RP04 & 02R54495 & $02 B 7653$ & ELÉTRICA & MAL-CONTATO & CHAVE/BOTOEIRA & 1 & 10 & 10 & 100 \\
\hline 0220RP04 & 02R55902 & 02B7736 & MECÂNICA & QUEBRA & CORRENTE & 1 & 10 & 10 & 100 \\
\hline 0220RP04 & 02R98279 & $02 B 8646$ & ELÉTRICA & DESREGULAGEM & CHAVE FIM-DE-CURSO & 1 & 10 & 10 & 100 \\
\hline 0220RP04 & 02S03584 & $02 B 8893$ & MECÂNICA & QUEBRA & PNEUM.-CILINDRO & 1 & 10 & 10 & 100 \\
\hline 0220RP04 & 02R99063 & 02B8728 & MECÂNICA & FOLGA & CORREIA & 1 & 10 & 10 & 100 \\
\hline Subtotais & 5 & 5 & & & & 5 & & IRF & 500 \\
\hline 0220RP05 & 02R58311 & $02 B 7813$ & MECÂNICA & ROMPIMENTO & CORRENTE & 1 & 10 & 10 & 100 \\
\hline 0220RP05 & 02R57884 & 02B7805 & ELÉTRICA & INTERRUPCAO DE SINAL & CONTROLADOR & 1 & 10 & 10 & 100 \\
\hline 0220RP05 & 02R61959 & 02B7937 & MECÂNICA & DESREGULAGEM & GUIA & 1 & 10 & 10 & 100 \\
\hline 0220RP05 & $02 \mathrm{R} 65143$ & 02B8099 & ELÉTRICA & INTERRUPCAO DE SINAL & MOTOR & 1 & 10 & 10 & 100 \\
\hline 0220RP05 & 02R70574 & 02B8315 & ELÉTRICA & INTERRUPCAO DE SINAL & RELE & 1 & 10 & 10 & 100 \\
\hline Subtotais & 5 & 5 & & & & 5 & & IRF & 500 \\
\hline 0220RP18 & 02R57312 & 02B7783 & ELÉTRICA & QUEBRA & SENSOR & 1 & 10 & 10 & 100 \\
\hline 0220RP18 & 02R69238 & 02B8261 & MECÂNICA & VAZAMENTO & BOMBA & 1 & 10 & 10 & 100 \\
\hline 0220RP18 & 02R86683 & 02B8553 & MECÂNICA & QUEBRA & GUIA & 1 & 10 & 10 & 100 \\
\hline 0220RP18 & 02R99125 & 02B8731 & MECÂNICA & QUEBRA & GUIA & 1 & 10 & 10 & 100 \\
\hline 0220RP18 & 02R53049 & & ELÉTRICA & CURTO-CIRCUITO & SENSOR & 1 & 1 & 1 & 1 \\
\hline 0220RP18 & 02R57900 & & MECÂNICA & SUJEIRA & SIST. REFRIGERACAO & 1 & 1 & 1 & 1 \\
\hline Subtotais & 6 & 4 & & & & 6 & & IRF & 402 \\
\hline 0220RP02 & 02R54333 & 02B7639 & MECÂNICA & QUEBRA & QUEBRA & 1 & 10 & 10 & 100 \\
\hline 0220RP02 & 02R64705 & 02B8060 & MECÂNICA & QUEBRA & CONTRA-PONTO & 1 & 10 & 10 & 100 \\
\hline 0220RP02 & 02R72554 & 02B8424 & MECÂNICA & QUEBRA & PARAFUSO & 1 & 10 & 10 & 100 \\
\hline 0220RP02 & 02R73624 & 02B8475 & MECÂNICA & SUJEIRA & HIDR.-TUBULACAO & 1 & 10 & 10 & 100 \\
\hline Subtotais & 4 & 4 & & & & 4 & & IRF & 400 \\
\hline
\end{tabular}




\begin{tabular}{|c|c|c|c|c|c|c|c|c|c|}
\hline Código & OS Mnt Corretiva & Cod Parada & Modalidade & Falha & Causa & Ocorrência & Gravidade & Detectabilidade & OGD \\
\hline $0220 \mathrm{RP} 23$ & $02 R 61325$ & 02B7920 & MECÂNICA & QUEBRA & GUIA & 1 & 10 & 10 & 100 \\
\hline $0220 R P 23$ & 02R69130 & 02B8245 & MECÂNICA & QUEBRA & PARAFUSO & 1 & 10 & 10 & 100 \\
\hline $0220 \mathrm{RP} 23$ & 02R71895 & 02B8374 & MECÂNICA & QUEBRA & HIDR.-TUBULACAO & 1 & 10 & 10 & 100 \\
\hline $0220 \mathrm{RP} 23$ & 02 R99875 & & MECÂNICA & FOLGA & GUIA & 1 & 1 & 1 & 1 \\
\hline Subtotais & 4 & 3 & & & & 4 & & IRF & 301 \\
\hline 0220RP27 & 02R54627 & 02B7669 & ELÉTRICA & INTERRUPCAO DE SINAL & CLP & 1 & 10 & 10 & 100 \\
\hline 0220RP27 & $02 \mathrm{R} 98634$ & 02B8689 & ELÉTRICA & CURTO-CIRCUITO & SENSOR & 1 & 10 & 10 & 100 \\
\hline 0220RP27 & $02 \mathrm{R} 86512$ & $02 \mathrm{~B} 8545$ & MECÂNICA & TRAVAMENTO & CONTRA-PONTO & 1 & 10 & 10 & 100 \\
\hline Subtotais & 3 & 3 & & & & 3 & & IRF & 300 \\
\hline 0220RP28 & 02R54529 & $02 B 7656$ & ELÉTRICA & MAL-CONTATO & CABO ELETRICO & 1 & 10 & 10 & 100 \\
\hline 0220RP28 & 02R57401 & 02B7786 & ELÉTRICA & DESREGULAGEM & PRESSOSTATO & 1 & 10 & 10 & 100 \\
\hline 0220RP28 & 02R70501 & 02B8308 & ELÉTRICA & INTERRUPCAO DE SINAL & PRESSOSTATO & 1 & 10 & 10 & 100 \\
\hline Subtotais & 3 & 3 & & & & 3 & & IRF & 300 \\
\hline 0220RP19 & 02R86754 & 02B8560 & ELÉTRICA & INTERRUPCAO DE SINAL & CHAVE FIM-DE-CURSO & 1 & 10 & 10 & 100 \\
\hline 0220RP19 & 02R70299 & & ELÉTRICA & INTERRUPCAO DE SINAL & SENSOR & 1 & 1 & 1 & 1 \\
\hline 0220RP19 & $02 \mathrm{~S} 01675$ & & ELÉTRICA & INTERRUPCAO DE SINAL & SENSOR & 1 & 1 & 1 & 1 \\
\hline Subtotais & 3 & 1 & & & & 3 & & IRF & 102 \\
\hline 02203226 & 02R73688 & $02 B 8479$ & ELÉTRICA & DESLOCAMENTO & CHAVE FIM-DE-CURSO & 1 & 10 & 10 & 100 \\
\hline 02203226 & 02R72527 & & ELÉTRICA & INTERRUPCAO DE SINAL & SENSOR & 1 & 1 & 1 & 1 \\
\hline Subtotais & 2 & 1 & & & & 2 & & IRF & 101 \\
\hline 02202552 & 02R73651 & $02 B 8476$ & MECÂNICA & TRAVAMENTO & PNEUM.-VALVULA & 1 & 10 & 10 & 100 \\
\hline Subtotais & 1 & 1 & & & & 1 & & IRF & 100 \\
\hline 0220RP01 & 02R70404 & 02B8299 & MECÂNICA & QUEBRA & GUIA & 1 & 10 & 10 & 100 \\
\hline Subtotais & 1 & 1 & & & & 1 & & IRF & 100 \\
\hline 0220RP03 & 02R85942 & $02 B 8523$ & ELÉTRICA & TRAVAMENTO & CONTROLADOR & 1 & 10 & 10 & 100 \\
\hline Subtotais & 1 & 1 & & & & 1 & & IRF & 100 \\
\hline
\end{tabular}




\begin{tabular}{|c|c|c|c|c|c|c|c|c|c|}
\hline Código & OS Mnt Corretiva & Cod Parada & Modalidade & Falha & Causa & Ocorrência & Gravidade & Detectabilidade & OGD \\
\hline $\begin{array}{l}0220 R P 12 \\
\text { Subtotais }\end{array}$ & $\begin{array}{c}\text { 02R55724 } \\
\mathbf{1}\end{array}$ & $\begin{array}{c}\text { 02B } 7720 \\
\mathbf{1}\end{array}$ & ELÉTRICA & INTERRUPCAO DE SINAL & MOTOR & $\begin{array}{l}1 \\
1\end{array}$ & 10 & $\begin{array}{c}10 \\
\text { IRF }\end{array}$ & $\begin{array}{l}100 \\
100\end{array}$ \\
\hline 02200906 & 02R63822 & & MECÂNICA & VAZAMENTO & LUBRIFIL & 1 & 1 & 1 & 1 \\
\hline 02200906 & 02R68266 & & MECÂNICA & MELHORIA & FILTRO & 1 & 1 & 1 & 1 \\
\hline Subtotais & 2 & $\mathbf{0}$ & & & & 2 & & IRF & 2 \\
\hline $\begin{array}{l}0220 R P 24 \\
\text { Subtotais }\end{array}$ & $\begin{array}{c}\text { 02R65125 } \\
\mathbf{1}\end{array}$ & $\mathbf{0}$ & MECÂNICA & QUEBRA & ROSCA ESPANADA & $\begin{array}{l}1 \\
1\end{array}$ & 1 & $\begin{array}{c}1 \\
\text { IRF }\end{array}$ & $\begin{array}{l}1 \\
1\end{array}$ \\
\hline Totais & 42 & 33 & & & & 42 & & IRE & 3.309 \\
\hline
\end{tabular}


RETÍFICA DE PERFIL - ÍNDICE DE RISCO DE EQUIPAMENTO - NÚMERO DE OCORRÊNCIAS

( Período: 01/08/04 a 30/08/04 )

\begin{tabular}{|c|c|c|c|c|c|c|c|c|c|}
\hline Código & OS Mnt Corretiva & Cod Parada & Modalidade & Falha & Causa & Ocorrência & Gravidade & Detectabilidade & OGD \\
\hline 0220RP04 & 02R98313 & 02B8650 & MECÂNICA & MELHORIA & OPERACAO & 1 & 10 & 10 & 100 \\
\hline 0220RP04 & 02S02709 & 02B8830 & MECÂNICA & VAZAMENTO & HIDR.-TUBULACAO & 1 & 10 & 10 & 100 \\
\hline 0220RP04 & 02S03619 & 02B8900 & MECÂNICA & TRAVAMENTO & OLEO & 1 & 10 & 10 & 100 \\
\hline 0220RP04 & 02S10601 & 02B9259 & MECÂNICA & ROMPIMENTO & CORRENTE & 1 & 10 & 10 & 100 \\
\hline 0220RP04 & 02S53093 & 02B9963 & MECÂNICA & QUEBRA & CORRENTE & 1 & 10 & 10 & 100 \\
\hline Subtotais & 5 & 5 & & & Subtotais & 5 & & IRF & 500 \\
\hline 0220RP27 & 02S06974 & 02B9061 & ELÉTRICA & TRAVAMENTO & PNEUM.-CILINDRO & 1 & 10 & 10 & 100 \\
\hline 0220RP27 & 02S06910 & 02B9055 & ELÉTRICA & DESREGULAGEM & CHAVE FIM-DE-CURSO & 1 & 10 & 10 & 100 \\
\hline 0220RP27 & 02S48616 & 02B9790 & ELÉTRICA & TRAVAMENTO & PNEUM.-VALVULA & 1 & 10 & 10 & 100 \\
\hline 0220RP27 & 02S50728 & 02B9873 & ELÉTRICA & INTERRUPCAO DE SIN & SENSOR & 1 & 10 & 10 & 100 \\
\hline 0220RP27 & 02S15679 & & MECÂNICA & FOLGA & PARAFUSO & 1 & 1 & 1 & 1 \\
\hline Subtotais & 5 & 4 & & & Subtotais & 5 & & IRF & 401 \\
\hline 0220RP28 & 02S02567 & 02B8818 & MECÂNICA & TRAVAMENTO & MOTOR & 1 & 10 & 10 & 100 \\
\hline 0220RP28 & 02S03931 & 02B8909 & MECÂNICA & DESGASTE & VIDA UTIL & 1 & 10 & 10 & 100 \\
\hline 0220RP28 & 02S13412 & 02B9321 & ELÉTRICA & BAIXA VAZAO & SIST. LUBRIFICACAO & 1 & 10 & 10 & 100 \\
\hline 0220RP28 & 02S48796 & 02B9803 & MECÂNICA & QUEBRA & QUEBRA & 1 & 10 & 10 & 100 \\
\hline 0220RP28 & 02S47617 & & MECÂNICA & MELHORIA & SIST. LUBRIFICACAO & 1 & 1 & 1 & 1 \\
\hline Subtotais & 5 & 4 & & & Subtotais & 5 & & IRF & 401 \\
\hline 02203226 & 02S03218 & 02B8862 & ELÉTRICA & INTERRUPCAO DE SINAL & CLP & 1 & 10 & 10 & 100 \\
\hline 02203226 & 02S31535 & 02B9546 & ELÉTRICA & BAIXA ISOLACAO & CAIXA DE LIGACAO & 1 & 10 & 10 & 100 \\
\hline 02203226 & 02S22331 & 02B9522 & ELÉTRICA & INTERRUPCAO DE SINAL & CLP & 1 & 10 & 10 & 100 \\
\hline 02203226 & 02S14144 & & MECÂNICA & VAZAMENTO & PNEUM.-CILINDRO & 1 & 1 & 1 & 1 \\
\hline Subtotais & 4 & 3 & & & Subtotais & 4 & & IRF & 301 \\
\hline
\end{tabular}




\begin{tabular}{|c|c|c|c|c|c|c|c|c|c|}
\hline Código & OS Mnt Corretiva & Cod Parada & Modalidade & Falha & Causa & Ocorrência & Gravidade & Detectabilidade & OGD \\
\hline 0220RP01 & $02 S 15241$ & 02B9475 & MECÂNICA & VAZAMENTO & PNEUM.-CILINDRO & 1 & 10 & 10 & 100 \\
\hline 0220RP01 & 02S15857 & 02B9490 & MECÂNICA & QUEBRA & PARAFUSO & 1 & 10 & 10 & 100 \\
\hline 0220RP01 & 02S13635 & 02B9554 & MECÂNICA & QUEBRA & GUIA & 1 & 10 & 10 & 100 \\
\hline 0220RP01 & 02S31839 & & MECÂNICA & VAZAMENTO & PNEUM.-CILINDRO & 1 & 1 & 1 & 1 \\
\hline Subtotais & 4 & 3 & & & & 4 & & IRF & 301 \\
\hline 0220RP03 & 02S02585 & 02B8819 & ELÉTRICA & INTERRUPCAO DE SINAL & SENSOR & 1 & 10 & 10 & 100 \\
\hline 0220RP03 & 02S25123 & 02B9528 & ELÉTRICA & INTERRUPCAO DE SINAL & SENSOR & 1 & 10 & 10 & 100 \\
\hline 0220RP03 & 02S31811 & 02B9552 & MECÂNICA & TRAVAMENTO & PNEUM.-VALVULA & 1 & 10 & 10 & 100 \\
\hline 0220RP03 & 02S47537 & & MECÂNICA & RUIDO & CORREIA & 1 & 1 & 1 & 1 \\
\hline Subtotais & 4 & 3 & & & & 4 & & IRF & 301 \\
\hline 0220RP18 & 02S02727 & 02B8831 & MECÂNICA & SUJEIRA & PNEUM.-VALVULA & 1 & 10 & 10 & 100 \\
\hline 0220RP18 & 02S10362 & 02B9247 & ELÉTRICA & CABO ELE. DANIFICADO & SENSOR & 1 & 10 & 10 & 100 \\
\hline 0220RP18 & 02S50826 & 02B9881 & MECÂNICA & FOLGA & BUCHA & 1 & 10 & 10 & 100 \\
\hline Subtotais & 3 & 3 & & & & 3 & & IRF & 300 \\
\hline 0220RP05 & 02S09971 & 02B9227 & ELÉTRICA & INTERRUPCAO DE SINAL & SENSOR & 1 & 10 & 10 & 100 \\
\hline 0220RP05 & 02S10228 & 02B9237 & ELÉTRICA & INTERRUPCAO DE SINAL & SENSOR & 1 & 10 & 10 & 100 \\
\hline Subtotais & 2 & 2 & & & & 2 & & IRF & 200 \\
\hline 0220RP23 & 02S05396 & 02B9014 & ELÉTRICA & INTERRUPCAO DE SINAL & CHAVE FIM-DE-CURSO & 1 & 10 & 10 & 100 \\
\hline 0220RP23 & 02S43452 & 02B9679 & MECÂNICA & QUEBRA & QUEBRA & 1 & 10 & 10 & 100 \\
\hline Subtotais & 2 & 2 & & & & 2 & & IRF & 200 \\
\hline 02200907 & 02S13341 & 02B9317 & ELÉTRICA & INTERRUPCAO DE SINAL & SENSOR & 1 & 10 & 10 & 100 \\
\hline Subtotais & 1 & 1 & & & & 1 & & IRF & 100 \\
\hline 0220RP21 & 02S16142 & 02B9507 & ELÉTRICA & SOBRECARGA & CONVERSOR & 1 & 10 & 10 & 100 \\
\hline Subtotais & 1 & 1 & & & & 1 & & IRF & 100 \\
\hline 0220RP02 & 02S48386 & & MECÂNICA & SUJEIRA & GUIA & 1 & 1 & 1 & 1 \\
\hline Subtotais & 1 & $\mathbf{0}$ & & & & 1 & & IRF & 1 \\
\hline Totais & 37 & 31 & & & & 37 & & IRE & 3.106 \\
\hline
\end{tabular}


RETÍFICA DE PERFIL - ÍNDICE DE RISCO DE EQUIPAMENTO - NÚMERO DE OCORRÊNCIAS

( Período: 01/09/04 a 30/09/04 )

\begin{tabular}{|c|c|c|c|c|c|c|c|c|c|}
\hline Código & OS Mnt Corretiva & Cod Parada & Modalidade & Falha & Causa & Ocorrência & Gravidade & Detectabilidade & OGD \\
\hline 0220RP01 & 02S58668 & $02 \mathrm{C} 0242$ & MECÂNICA & QUEBRA & PARAFUSO & 1 & 10 & 10 & 100 \\
\hline 0220RP01 & 02S55377 & 02C0080 & ELÉTRICA & INTERRUPCAO DE SINAL & CHAVE FIM-DE-CURSO & 1 & 10 & 10 & 100 \\
\hline 0220RP01 & 02S58301 & $02 \mathrm{C} 0215$ & ELÉTRICA & INTERRUPCAO DE SINAL & SENSOR & 1 & 10 & 10 & 100 \\
\hline 0220RP01 & 02S58695 & $02 \mathrm{C} 0245$ & ELÉTRICA & CURTO-CIRCUITO & SENSOR & 1 & 10 & 10 & 100 \\
\hline 0220RP01 & 02S74169 & $02 \mathrm{C} 0737$ & MECÂNICA & QUEBRA & CORRENTE & 1 & 10 & 10 & 100 \\
\hline 0220RP01 & 02S63377 & & ELÉTRICA & DESLOCAMENTO & HIDR.-CILINDRO & 1 & 1 & 1 & 1 \\
\hline Subtotais & 6 & 5 & & & & 6 & & IRF & 501 \\
\hline 0220RP28 & 02S54662 & $02 \mathrm{C} 0049$ & MECÂNICA & QUEBRA & QUEBRA & 1 & 10 & 10 & 100 \\
\hline 0220RP28 & 02S61244 & $02 \mathrm{C} 0401$ & ELÉTRICA & DESREGULAGEM & SENSOR & 1 & 10 & 10 & 100 \\
\hline 0220RP28 & 02S64928 & $02 \mathrm{C} 0526$ & MECÂNICA & QUEBRA & CONTRA-PONTO & 1 & 10 & 10 & 100 \\
\hline 0220RP28 & 02S97723 & 02C1019 & MECÂNICA & TRAVAMENTO & MOTOR & 1 & 10 & 10 & 100 \\
\hline Subtotais & 4 & 4 & & & & 4 & & IRF & 400 \\
\hline 0220RP19 & 02S54706 & 02C0051 & MECÂNICA & SUJEIRA & PNEUM.-VALVULA & 1 & 10 & 10 & 100 \\
\hline 0220RP19 & 02S60879 & $02 \mathrm{C} 0377$ & MECÂNICA & QUEBRA & PARAFUSO & 1 & 10 & 10 & 100 \\
\hline 0220RP19 & 02S66169 & 02C0609 & MECÂNICA & QUEBRA & PNEUM.-CILINDRO & 1 & 10 & 10 & 100 \\
\hline 0220RP19 & 02S57062 & & MECÂNICA & DESREGULAGEM & PNEUM.-VALVULA & 1 & 1 & 1 & 1 \\
\hline 0220RP19 & 02S58659 & & MECÂNICA & SUJEIRA & SUJEIRA & 1 & 1 & 1 & 1 \\
\hline Subtotais & 5 & 3 & & & & 5 & & IRF & 302 \\
\hline 0220RP02 & 02S81614 & $02 \mathrm{C} 0825$ & MECÂNICA & FOLGA & FOLGA & 1 & 10 & 10 & 100 \\
\hline 0220RP02 & $02 S 81623$ & $02 \mathrm{C} 0826$ & MECÂNICA & QUEBRA & EIXO & 1 & 10 & 10 & 100 \\
\hline 0220RP02 & 02S81115 & $02 C 0795$ & ELÉTRICA & INTERRUPCAO DE SINAL & FOLGA & 1 & 10 & 10 & 100 \\
\hline Subtotais & 3 & 3 & & & & 3 & & IRF & 300 \\
\hline 0220RP04 & 02S57981 & $02 \mathrm{C} 0191$ & MECÂNICA & QUEBRA & CORRENTE & 1 & 10 & 10 & 100 \\
\hline 0220RP04 & 02S66196 & $02 \mathrm{C} 0612$ & MECÂNICA & QUEBRA & MANOMETRO & 1 & 10 & 10 & 100 \\
\hline 0220RP04 & 02S66221 & $02 \mathrm{C} 0614$ & MECÂNICA & DESREGULAGEM & HIDR.-VALVULA & 1 & 10 & 10 & 100 \\
\hline Subtotais & 3 & 3 & & & & 3 & & IRF & 300 \\
\hline 0220RP05 & 02S59337 & $02 \mathrm{C} 0297$ & MECÂNICA & FOLGA & ROLAMENTO & 1 & 10 & 10 & 100 \\
\hline 0220RP05 & 02S62207 & $02 \mathrm{C} 0436$ & MECÂNICA & QUEBRA & PARAFUSO & 1 & 10 & 10 & 100 \\
\hline 0220RP05 & 02S66249 & $02 \mathrm{C} 0616$ & MECÂNICA & QUEBRA & CORRENTE & 1 & 10 & 10 & 100 \\
\hline Subtotais & 3 & 3 & & & & 3 & & IRF & 300 \\
\hline
\end{tabular}




\begin{tabular}{|c|c|c|c|c|c|c|c|c|c|}
\hline Código & OS Mnt Corretiva & Cod Parada & Modalidade & Falha & Causa & Ocorrência & Gravidade & Detectabilidade & OGD \\
\hline 0220RP03 & 02S63331 & & MECÂNICA & QUEBRA & POLIA & 1 & 1 & 1 & 1 \\
\hline 0220RP03 & 02S60860 & $02 \mathrm{C} 0376$ & MECÂNICA & QUEBRA & PARAFUSO & 1 & 10 & 10 & 100 \\
\hline 0220RP03 & 02S93175 & $02 C 0954$ & MECÂNICA & QUEBRA & POLIA & 1 & 10 & 10 & 100 \\
\hline 0220RP03 & 02S60691 & & MECÂNICA & QUEBRA & PROTECAO/TAMPA & 1 & 1 & 1 & 1 \\
\hline Subtotais & 4 & 2 & & & & 4 & & IRF & 202 \\
\hline 0220RP22 & 02S58230 & $02 \mathrm{C} 0209$ & ELÉTRICA & INTERRUPCAO DE SINAL & DESREGULAGEM & 1 & 10 & 10 & 100 \\
\hline 0220RP22 & 02S81231 & 02C0802 & ELÉTRICA & INTERRUPCAO DE SINAL & SENSOR & 1 & 10 & 10 & 100 \\
\hline Subtotais & 2 & 2 & & & & 2 & & IRF & 200 \\
\hline 0220RP27 & 02S64072 & $02 \mathrm{C} 0491$ & MECÂNICA & DESLOCAMENTO & SENSOR & 1 & 10 & 10 & 100 \\
\hline 0220RP27 & 02S81044 & 02C0790 & ELÉTRICA & INTERRUPCAO DE SINAL & SENSOR & 1 & 10 & 10 & 100 \\
\hline Subtotais & 2 & 2 & & & & 2 & & IRF & 200 \\
\hline 0220RP18 & 02S55420 & $02 \mathrm{C} 0084$ & MECÂNICA & BAIXA PRESSAO & BOMBA & 1 & 10 & 10 & 100 \\
\hline 0220RP18 & 02S53841 & & MECÂNICA & QUEBRA & PROTECAO/TAMPA & 1 & 1 & 1 & 1 \\
\hline 0220RP18 & 02S97402 & & MECÂNICA & VAZAMENTO INTERNO & HIDR.-VALVULA & 1 & 1 & 1 & 1 \\
\hline Subtotais & 3 & 1 & & & & 3 & & IRF & 102 \\
\hline 0220RP23 & 02S54519 & $02 C 0039$ & MECÂNICA & DEFORMACAO & ROSCA ESPANADA & 1 & 10 & 10 & 100 \\
\hline 0220RP23 & 02S97466 & & MECÂNICA & TRAVAMENTO & PNEUM.-VALVULA & 1 & 1 & 1 & 1 \\
\hline Subtotais & 2 & 1 & & & & 2 & & IRF & 101 \\
\hline 02202537 & 02S84700 & $02 \mathrm{C} 0873$ & MECÂNICA & TRAVAMENTO & GUIA & 1 & 10 & 10 & 100 \\
\hline Subtotais & 1 & 1 & & & & 1 & & IRF & 100 \\
\hline 02202560 & $02 S 63803$ & $02 \mathrm{C} 0475$ & MECÂNICA & TRAVAMENTO & GUIA & 1 & 10 & 10 & 100 \\
\hline Subtotais & 1 & 1 & & & & 1 & & IRF & 100 \\
\hline 02203226 & 02S58739 & $02 \mathrm{C} 0248$ & ELÉTRICA & CURTO-CIRCUITO & SENSOR & 1 & 10 & 10 & 100 \\
\hline Subtotais & 1 & 1 & & & & 1 & & IRF & 100 \\
\hline 0220RP24 & 02S62378 & $02 \mathrm{C} 0442$ & ELÉTRICA & INTERRUPCAO DE SINAL & CONVERSOR & 1 & 10 & 10 & 100 \\
\hline Subtotais & 1 & 1 & & & & 1 & & IRF & 100 \\
\hline Totais & 41 & 33 & & & & 41 & & IRE & 3.308 \\
\hline
\end{tabular}


RETÍFICA DE PERFIL - ÍNDICE DE RISCO DE EQUIPAMENTO - NÚMERO DE OCORRÊNCIAS

( Período: 01/10/04 a 31/10/04)

\begin{tabular}{|c|c|c|c|c|c|c|c|c|c|}
\hline Código & OS Mnt Corretiva & Cod Parada & Modalidade & Falha & Causa & Ocorrência & Gravidade & Detectabilidade & OGD \\
\hline 0220RP27 & $02 \mathrm{~T} 01969$ & 02C1298 & ELÉTRICA & TRAVAMENTO & SENSOR & 1 & 10 & 10 & 100 \\
\hline 0220RP27 & 02T02307 & $02 \mathrm{C} 1316$ & MECÂNICA & DESREGULAGEM & OPERACAO & 1 & 10 & 10 & 100 \\
\hline 0220RP27 & $02 \mathrm{~T} 30615$ & $02 \mathrm{C} 2075$ & MECÂNICA & DESREGULAGEM & HIDR.-VALVULA & 1 & 10 & 10 & 100 \\
\hline Subtotais & 3 & 3 & & & & 3 & & IRF & 300 \\
\hline 0220RP01 & $02 \mathrm{~T} 12350$ & $02 \mathrm{C} 1692$ & ELÉTRICA & FALTA ENERGIA ELET. & MOTOR & 1 & 10 & 10 & 100 \\
\hline 0220RP01 & 02Т30152 & $02 C 2033$ & ELÉTRICA & INTERRUPCAO DE SINAL & CHAVE FIM-DE-CURSO & 1 & 10 & 10 & 100 \\
\hline 0220RP01 & $02 \mathrm{~T} 17845$ & & MECÂNICA & SUJEIRA & GUIA & 1 & 1 & 1 & 1 \\
\hline Subtotais & 3 & 2 & & & & 3 & & IRF & 201 \\
\hline 0220RP19 & $02 \mathrm{~T} 10325$ & 02C1544 & MECÂNICA & TRAVAMENTO & ROLAMENTO & 1 & 10 & 10 & 100 \\
\hline 0220RP19 & 02 Т30571 & 02C2071 & ELÉTRICA & QUEBRA & SENSOR & 1 & 10 & 10 & 100 \\
\hline Subtotais & 2 & 2 & & & & 2 & & IRF & 200 \\
\hline 0220RP28 & 02T01978 & $02 \mathrm{C} 1300$ & ELÉTRICA & MAL-CONTATO & SECCIONADORA & 1 & 10 & 10 & 100 \\
\hline 0220RP28 & $02 \mathrm{~T} 07669$ & 02C1484 & MECÂNICA & QUEBRA & PARAFUSO & 1 & 10 & 10 & 100 \\
\hline Subtotais & 2 & 2 & & & & 2 & & IRF & 200 \\
\hline 02203226 & $02 \mathrm{~T} 11878$ & 02C1589 & MECÂNICA & QUEBRA & PARAFUSO & 1 & 10 & 10 & 100 \\
\hline 02203226 & $02 \mathrm{~T} 17667$ & & ELÉTRICA & QUEBRA & SENSOR & 1 & 1 & 1 & 1 \\
\hline Subtotais & 2 & 1 & & & & 2 & & IRF & 101 \\
\hline 0220RP02 & $02 \mathrm{~T} 07650$ & $02 \mathrm{C} 1483$ & MECÂNICA & QUEBRA & GUIA & 1 & 10 & 10 & 100 \\
\hline 0220RP02 & $02 T 02548$ & & MECÂNICA & QUEBRA & GUIA & 1 & 1 & 1 & 1 \\
\hline Subtotais & 2 & 1 & & & & 2 & & IRF & 101 \\
\hline 0220RP03 & $02 \mathrm{~T} 42808$ & $02 \mathrm{C} 2270$ & MECÂNICA & QUEBRA & CORRENTE & 1 & 10 & 10 & 100 \\
\hline Subtotais & 1 & 1 & & & & 1 & & IRF & 100 \\
\hline 0220RP04 & $02 \mathrm{~T} 18112$ & 02C1960 & ELÉTRICA & INTERRUPCAO DE SINAL & MOTOR & 1 & 10 & 10 & 100 \\
\hline Subtotais & 1 & 1 & & & & 1 & & IRF & 100 \\
\hline
\end{tabular}




\begin{tabular}{|c|c|c|c|c|c|c|c|c|c|}
\hline Código & OS Mnt Corretiva & Cod Parada & Modalidade & Falha & Causa & Ocorrência & Gravidade & Detectabilidade & OGD \\
\hline 0220RP05 & 02 Т30679 & 02C2079 & MECÂNICA & TRAVAMENTO & CORREIA & 1 & 10 & 10 & 100 \\
\hline 0220RP05 & 1 & 1 & & & Subtotais & 1 & & IRF & 100 \\
\hline 0220RP18 & $02 \mathrm{~T} 23240$ & 02C1976 & MECÂNICA & ROMPIMENTO & PNEUM.-MANGUEIRA & 1 & 10 & 10 & 100 \\
\hline 0220RP18 & 1 & 1 & & & Subtotais & 1 & & IRF & 100 \\
\hline 0220RP21 & 02T13732 & $02 \mathrm{C} 1783$ & ELÉTRICA & PROCESSO & CONVERSOR & 1 & 10 & 10 & 100 \\
\hline 0220RP21 & 1 & 1 & & & Subtotais & 1 & & IRF & 100 \\
\hline 0220RP22 & 02 Т30349 & $02 C 2053$ & MECÂNICA & QUEBRA & PARAFUSO & 1 & 10 & 10 & 100 \\
\hline 0220RP22 & 1 & 1 & & & Subtotais & 1 & & IRF & 100 \\
\hline 0220RP23 & $02 \mathrm{~T} 06483$ & $02 \mathrm{C} 1424$ & MECÂNICA & ENTUPIMENTO & PNEUM.-VALVULA & 1 & 10 & 10 & 100 \\
\hline 0220RP23 & 1 & 1 & & & Subtotais & 1 & & IRF & 100 \\
\hline 02200906 & $02 \mathrm{~T} 12699$ & & MECÂNICA & ROMPIMENTO & PNEUM.-MANGUEIRA & 1 & 1 & 1 & 1 \\
\hline 02200906 & $02 \mathrm{~T} 11850$ & & MECÂNICA & QUEBRA & LUBRIFIL & 1 & 1 & 1 & 1 \\
\hline 02200906 & 2 & $\mathbf{0}$ & & & Subtotais & 2 & & IRF & 2 \\
\hline \multirow{3}{*}{$\begin{array}{l}02200907 \\
02200907\end{array}$} & $02 T 29896$ & & MECÂNICA & VAZAMENTO & PNEUM.-MANGUEIRA & 1 & 1 & 1 & 1 \\
\hline & 1 & $\mathbf{0}$ & & & Subtotais & 1 & & IRF & 1 \\
\hline & 24 & 18 & & & Totais & 24 & & IRE & 1.806 \\
\hline
\end{tabular}


RETÍFICA DE PERFIL - ÍNDICE DE RISCO DE EQUIPAMENTO - NÚMERO DE OCORRÊNCIAS

( Período: 01/11/04 a 30/11/04 )

\begin{tabular}{|c|c|c|c|c|c|c|c|c|c|}
\hline Código & OS Mnt Corretiva & Cod Parada & Modalidade & Falha & Causa & Ocorrência & Gravidade & Detectabilidade & OGD \\
\hline 02203226 & $02 \mathrm{~T} 57445$ & 02C2820 & ELÉTRICA & RETRABALHO DO ANEL & SENSOR & 1 & 10 & 10 & 100 \\
\hline 02203226 & $02 T 81515$ & 02C3038 & MECÂNICA & FIXACAO & GUIA & 1 & 10 & 10 & 100 \\
\hline 02203226 & $02 T 89919$ & 02C3156 & ELÉTRICA & QUEIMA & FONTE DE ALIMENTACAO & 1 & 10 & 10 & 100 \\
\hline Subtotais & 3 & 3 & & & Subtotais & 3 & & IRF & 300 \\
\hline 0220RP04 & $02 \mathrm{~T} 49632$ & 02C2499 & MECÂNICA & QUEBRA & PARAFUSO & 1 & 10 & 10 & 100 \\
\hline 0220RP04 & $02 T 49641$ & 02C2500 & MECÂNICA & DESGASTE & PARAFUSO & 1 & 10 & 10 & 100 \\
\hline 0220RP04 & $02 T 57409$ & 02C2818 & MECÂNICA & TRAVAMENTO & ROLAMENTO & 1 & 10 & 10 & 100 \\
\hline Subtotais & 3 & 3 & & & Subtotais & 3 & & IRF & 300 \\
\hline 0220RP03 & $02 T 53868$ & 02C2697 & ELÉTRICA & MAL-CONTATO & CABO ELETRICO & 1 & 10 & 10 & 100 \\
\hline 0220RP03 & $02 \mathrm{~T} 88643$ & 02C3104 & MECÂNICA & DESGASTE & GUIA & 1 & 10 & 10 & 100 \\
\hline 0220RP03 & $02 \mathrm{~T} 57114$ & & MECÂNICA & QUEBRA & SIST. LUBRIFICACAO & 1 & 1 & 1 & 1 \\
\hline Subtotais & 3 & 2 & & & Subtotais & 3 & & IRF & 201 \\
\hline 0220RP27 & $02 T 88803$ & 02C3120 & MECÂNICA & VAZAMENTO & HIDR.-TUBULACAO & 1 & 10 & 10 & 100 \\
\hline 0220RP27 & $02 T 94182$ & 02C3307 & MECÂNICA & QUEBRA & PARAFUSO & 1 & 10 & 10 & 100 \\
\hline 0220RP27 & $02 T 57150$ & & MECÂNICA & QUEBRA & HIDR.-CONEXAO & 1 & 1 & 1 & 1 \\
\hline Subtotais & 3 & 2 & & & Subtotais & 3 & & IRF & 201 \\
\hline 0220RP02 & $02 \mathrm{~T} 50246$ & $02 C 2536$ & MECÂNICA & TREPIDACAO & GUIA & 1 & 10 & 10 & 100 \\
\hline 0220RP02 & 02 T90391 & 02С3170 & MECÂNICA & FOLGA & GUIA & 1 & 10 & 10 & 100 \\
\hline Subtotais & 2 & 2 & & & Subtotais & 2 & & IRF & 200 \\
\hline 0220RP19 & $02 T 88689$ & 02C3108 & ELÉTRICA & MAL-CONTATO & SENSOR & 1 & 10 & 10 & 100 \\
\hline 0220RP19 & $02 T 89045$ & $02 C 3140$ & MECÂNICA & DESGASTE & ROLAMENTO & 1 & 10 & 10 & 100 \\
\hline Subtotais & 2 & 2 & & & Subtotais & 2 & & IRF & 200 \\
\hline
\end{tabular}




\begin{tabular}{|c|c|c|c|c|c|c|c|c|c|}
\hline Código & OS Mnt Corretiva & Cod Parada & Modalidade & Falha & Causa & Ocorrência & Gravidade & Detectabilidade & OGD \\
\hline 0220RP12 & $02 \mathrm{~T} 58177$ & $02 \mathrm{C} 2861$ & MECÂNICA & VAZAMENTO & PNEUM.-MANGUEIRA & 1 & 10 & 10 & 100 \\
\hline 0220RP12 & $02 \mathrm{~T} 47867$ & & MECÂNICA & QUEBRA & PARAFUSO & 1 & 1 & 1 & 1 \\
\hline 0220RP12 & $02 \mathrm{~T} 94912$ & & MECÂNICA & VAZAMENTO & PROTECAO/TAMPA & 1 & 1 & 1 & 1 \\
\hline Subtotais & 3 & 1 & & & & 3 & & IRF & 102 \\
\hline 0220RP01 & $02 \mathrm{~T} 94164$ & 02C3305 & MECÂNICA & QUEBRA & PARAFUSO & 1 & 10 & 10 & 100 \\
\hline Subtotais & 1 & 1 & & & & 1 & & IRF & 100 \\
\hline 0220RP05 & $02 \mathrm{~T} 46154$ & $02 C 2343$ & ELÉTRICA & INTERRUPCAO DE SINAL & POTENCIOMETRO & 1 & 10 & 10 & 100 \\
\hline Subtotais & 1 & 1 & & & & 1 & & IRF & 100 \\
\hline 0220RP18 & $02 T 89036$ & 02C3139 & MECÂNICA & QUEBRA & PARAFUSO & 1 & 10 & 10 & 100 \\
\hline Subtotais & 1 & 1 & & & & 1 & & IRF & 100 \\
\hline 0220RP24 & $02 T 88466$ & 02C3087 & ELÉTRICA & INTERRUPCAO DE SINAL & MOTOR & 1 & 10 & 10 & 100 \\
\hline Subtotais & 1 & 1 & & & & 1 & & IRF & 100 \\
\hline 0220RP28 & 02T90658 & $02 C 3184$ & ELÉTRICA & QUEBRA & SENSOR & 1 & 10 & 10 & 100 \\
\hline Subtotais & 1 & 1 & & & & 1 & & IRF & 100 \\
\hline 02200907 & $02 \mathrm{~T} 47894$ & & MECÂNICA & FIXACAO & PARAFUSO & 1 & 1 & 1 & 1 \\
\hline Subtotais & 1 & $\mathbf{0}$ & & & & 1 & & IRF & 1 \\
\hline 02202537 & $02 \mathrm{~T} 90836$ & & MECÂNICA & QUEBRA & GUIA & 1 & 1 & 1 & 1 \\
\hline Subtotais & 1 & $\mathbf{0}$ & & & & 1 & & IRF & 1 \\
\hline Totais & 26 & 20 & & & & 26 & & IRE & 2.006 \\
\hline
\end{tabular}


RETÍFICA DE PERFIL - ÍNDICE DE RISCO DE EQUIPAMENTO - NÚMERO DE OCORRÊNCIAS

( Período: 01/12/04 a 31/12/04 )

\begin{tabular}{|c|c|c|c|c|c|c|c|c|c|}
\hline Código & OS Mnt Corretiva & Cod Parada & Modalidade & Falha & Causa & Ocorrência & Gravidade & Detectabilidade & OGD \\
\hline 02203226 & 02T94020 & 02C3297 & ELÉTRICA & QUEIMA & FONTE DE ALIMENTACAO & 1 & 10 & 10 & 100 \\
\hline 02203226 & $02 \mathrm{~T} 98400$ & $02 C 3441$ & MECÂNICA & DEFORMACAO & DESGASTE & 1 & 10 & 10 & 100 \\
\hline 02203226 & 02U04302 & 02C3621 & MECÂNICA & MELHORIA & EIXO & 1 & 10 & 10 & 100 \\
\hline Subtotais & 3 & 3 & & & & 3 & & IRF & 300 \\
\hline 0220RP28 & 02 T98099 & 02C3430 & MECÂNICA & TRAVAMENTO & ROLAMENTO & 1 & 10 & 10 & 100 \\
\hline 0220RP28 & 02U06104 & 02C3700 & ELÉTRICA & INTERRUPCAO DE SINAL & PRESSOSTATO & 1 & 10 & 10 & 100 \\
\hline 0220RP28 & 02U05980 & 02C3690 & MECÂNICA & VAZAMENTO & HIDR.-CONEXAO & 1 & 10 & 10 & 100 \\
\hline Subtotais & 3 & 3 & & & & 3 & & IRF & 300 \\
\hline 0220RP23 & 02U06328 & $02 \mathrm{C} 3717$ & MECÂNICA & DESGASTE & PARAFUSO & 1 & 10 & 10 & 100 \\
\hline 0220RP23 & 02U05016 & $02 C 3646$ & ELÉTRICA & INTERRUPCAO DE SINAL & CHAVE FIM-DE-CURSO & 1 & 10 & 10 & 100 \\
\hline Subtotais & 2 & 2 & & & & 2 & & IRF & 200 \\
\hline 0220RP01 & 02U07871 & $02 C 3779$ & MECÂNICA & QUEBRA & PARAFUSO & 1 & 10 & 10 & 100 \\
\hline 0220RP01 & 02 T95403 & & MECÂNICA & FOLGA & ROLAMENTO & 1 & 1 & 1 & 1 \\
\hline Subtotais & 2 & 1 & & & & 2 & & IRF & 101 \\
\hline 02202537 & $02 T 98419$ & 02C3442 & MECÂNICA & QUEBRA & PNEUM.-VALVULA & 1 & 10 & 10 & 100 \\
\hline Subtotais & 1 & 1 & & & & 1 & & IRF & 100 \\
\hline 0220RP04 & 02U05800 & 02C3679 & ELÉTRICA & INTERRUPCAO DE SINAL & SENSOR & 1 & 10 & 10 & 100 \\
\hline Subtotais & 1 & 1 & & & & 1 & & IRF & 100 \\
\hline 0220RP15 & 02U07880 & 02C3780 & MECÂNICA & QUEBRA & LUBRIFIL & 1 & 10 & 10 & 100 \\
\hline Subtotais & 1 & 1 & & & & 1 & & IRF & 100 \\
\hline 0220RP18 & $02 \mathrm{~T} 97027$ & & MECÂNICA & SUJEIRA & BOMBA & 1 & 1 & 1 & 1 \\
\hline Subtotais & 1 & $\mathbf{0}$ & & & & 1 & & IRF & 1 \\
\hline 0220RP19 & 02U04115 & & MECÂNICA & QUEBRA & PROTECAO/TAMPA & 1 & 1 & 1 & 1 \\
\hline Subtotais & 1 & $\mathbf{0}$ & & & & 1 & & IRF & 1 \\
\hline Totais & 15 & 12 & & & & 15 & & IRE & 1.203 \\
\hline
\end{tabular}


RETÍFICA DE PERFIL - ÍNDICE DE RISCO DE EQUIPAMENTO - NÚMERO DE OCORRÊNCIAS

( Período: 01/01/05 a 31/01/05 )

\begin{tabular}{|c|c|c|c|c|c|c|c|c|c|}
\hline Código & OS Mnt Corretiva & Cod Parada & Modalidade & Falha & Causa & Ocorrência & Gravidade & Detectabilidade & OGD \\
\hline 0220RP01 & 02U38455 & $02 C 4837$ & MECÂNICA & QUEBRA & BUCHA & 1 & 10 & 10 & 100 \\
\hline 0220RP01 & 02U65451 & 02C5359 & ELÉTRICA & MAL-CONTATO & CABO ELETRICO & 1 & 10 & 10 & 100 \\
\hline 0220RP01 & 02U69064 & $02 \mathrm{C} 5484$ & ELÉTRICA & INTERRUPCAO DE SINAL & SENSOR & 1 & 10 & 10 & 100 \\
\hline 0220RP01 & 02U81255 & $02 \mathrm{C} 5634$ & ELÉTRICA & CABO ELE. DANIFICADO & SENSOR & 1 & 10 & 10 & 100 \\
\hline 0220RP01 & 02U72309 & $02 \mathrm{C} 5544$ & MECÂNICA & TRAVAMENTO & PNEUM.-VALVULA & 1 & 10 & 10 & 100 \\
\hline 0220RP01 & $02 U 82753$ & $02 C 5836$ & MECÂNICA & ENTUPIMENTO & HIDR.-CONEXAO & 1 & 10 & 10 & 100 \\
\hline 0220RP01 & 02U65914 & & ELÉTRICA & OPERACAO & MATERIAL & 1 & 1 & 1 & 1 \\
\hline 0220RP01 & 02U94660 & & MECÂNICA & QUEBRA & PROTECAO/TAMPA & 1 & 1 & 1 & 1 \\
\hline Subtotais & 8 & 6 & & & & 8 & & IRF & 602 \\
\hline 0220RP03 & 02U38222 & $02 C 4816$ & MECÂNICA & QUEBRA & BARRAMENTO MECANICO & 1 & 10 & 10 & 100 \\
\hline 0220RP03 & 02U31595 & 02C4500 & MECÂNICA & QUEBRA & CORRENTE & 1 & 10 & 10 & 100 \\
\hline 0220RP03 & 02U49096 & $02 \mathrm{C} 5161$ & MECÂNICA & QUEBRA & PARAFUSO & 1 & 10 & 10 & 100 \\
\hline 0220RP03 & 02U61990 & $02 \mathrm{C} 5322$ & ELÉTRICA & DESREGULAGEM & SENSOR & 1 & 10 & 10 & 100 \\
\hline 0220RP03 & $02 U 83841$ & 02C5911 & MECÂNICA & QUEBRA & PARAFUSO & 1 & 10 & 10 & 100 \\
\hline Subtotais & 5 & 5 & & & & 5 & & IRF & 500 \\
\hline 0220RP18 & 02U31577 & 02C4499 & MECÂNICA & QUEBRA & PARAFUSO & 1 & 10 & 10 & 100 \\
\hline 0220RP18 & 02U51377 & 02C5244 & ELÉTRICA & CURTO-CIRCUITO & SENSOR & 1 & 10 & 10 & 100 \\
\hline Subtotais & 2 & 2 & & & & 2 & & IRF & 200 \\
\hline 0220RP27 & 02U69028 & $02 C 5482$ & ELÉTRICA & DEFEITO INTERMITENTE & RELE & 1 & 10 & 10 & 100 \\
\hline 0220RP27 & 02U83645 & 02C5898 & MECÂNICA & VAZAMENTO & HIDR.-CONEXAO & 1 & 10 & 10 & 100 \\
\hline 0220RP27 & 02U94759 & & MECÂNICA & SUJEIRA & BUCHA & 1 & 1 & 1 & 1 \\
\hline Subtotais & 3 & 2 & & & & 3 & & IRF & 201 \\
\hline 0220RP04 & 02U32120 & $02 \mathrm{C} 4305$ & MECÂNICA & QUEBRA & BARRAMENTO MECANICO & 1 & 10 & 10 & 100 \\
\hline 0220RP04 & 02U39347 & 02C4968 & MECÂNICA & QUEBRA & CORRENTE & 1 & 10 & 10 & 100 \\
\hline Subtotais & 2 & 2 & & & & 2 & & IRF & 200 \\
\hline
\end{tabular}




\begin{tabular}{|c|c|c|c|c|c|c|c|c|c|}
\hline Código & OS Mnt Corretiva & Cod Parada & Modalidade & Falha & Causa & Ocorrência & Gravidade & Detectabilidade & OGD \\
\hline 0220RP05 & 02U71710 & $02 \mathrm{C} 5514$ & MECÂNICA & FOLGA & CORREIA & 1 & 10 & 10 & 100 \\
\hline 0220RP05 & 02U92975 & $02 \mathrm{C} 5975$ & ELÉTRICA & DESREGULAGEM & CHAVE FIM-DE-CURSO & 1 & 10 & 10 & 100 \\
\hline Subtotais & 2 & 2 & & & & 2 & & IRF & 200 \\
\hline 0220RP19 & 02U69046 & $02 \mathrm{C} 5483$ & MECÂNICA & INTERRUPCAO DE SINAL & SENSOR & 1 & 10 & 10 & 100 \\
\hline 0220RP19 & $02 \mathrm{~V} 02125$ & $02 \mathrm{C} 6172$ & MECÂNICA & BAIXA VAZAO & PRESSOSTATO & 1 & 10 & 10 & 100 \\
\hline Subtotais & 2 & 2 & & & & 2 & & IRF & 200 \\
\hline 02203226 & 02U69769 & $02 \mathrm{C} 5493$ & MECÂNICA & TRAVAMENTO & PNEUM.-CILINDRO & 1 & 10 & 10 & 100 \\
\hline 02203226 & 02U47668 & & ELÉTRICA & CURTO-CIRCUITO & CONECTOR/BORNE & 1 & 1 & 1 & 1 \\
\hline 02203226 & 02U47944 & & MECÂNICA & DESGASTE & ROSCA ESPANADA & 1 & 1 & 1 & 1 \\
\hline Subtotais & 3 & 1 & & & & 3 & & IRF & 102 \\
\hline 0220RP23 & 02U82824 & 02C5841 & MECÂNICA & QUEBRA & PROTECAO/TAMPA & 1 & 10 & 10 & 100 \\
\hline 0220RP23 & 02U66129 & & MECÂNICA & QUEBRA & PROTECAO/TAMPA & 1 & 1 & 1 & 1 \\
\hline Subtotais & 2 & 1 & & & & 2 & & IRF & 101 \\
\hline 02200907 & 02U37811 & 02C4788 & ELÉTRICA & QUEIMA & FUSIVEL & 1 & 10 & 10 & 100 \\
\hline Subtotais & 1 & 1 & & & & 1 & & IRF & 100 \\
\hline 0220RP02 & 02U66281 & $02 C 5397$ & MECÂNICA & QUEBRA & GUIA & 1 & 10 & 10 & 100 \\
\hline Subtotais & 1 & 1 & & & & 1 & & IRF & 100 \\
\hline 0220RP28 & 02U66227 & & MECÂNICA & QUEBRA & ROLAMENTO & 1 & 1 & 1 & 1 \\
\hline Subtotais & 1 & $\mathbf{0}$ & & & & 1 & & IRF & 1 \\
\hline Totais & 32 & 25 & & & & 32 & & IRE & 2507 \\
\hline
\end{tabular}


RETÍFICA DE PERFIL - ÍNDICE DE RISCO DE EQUIPAMENTO - NÚMERO DE OCORRÊNCIAS

( Período: 01/02/05 a 28/02/05 )

\begin{tabular}{|c|c|c|c|c|c|c|c|c|c|}
\hline Código & OS Mnt Corretiva & Cod Parada & Modalidade & Falha & Causa & Ocorrência & Gravidade & Detectabilidade & OGD \\
\hline 0220RP12 & 02U96212 & $02 \mathrm{C} 6053$ & MECÂNICA & DESGASTE & CORREIA & 1 & 10 & 10 & 100 \\
\hline 0220RP12 & $02 \mathrm{~V} 07255$ & $02 C 6568$ & ELÉTRICA & INTERRUPCAO DE SINAL & CLP & 1 & 10 & 10 & 100 \\
\hline 0220RP12 & $02 \mathrm{~V} 04276$ & $02 \mathrm{C} 6353$ & MECÂNICA & FOLGA & CORREIA & 1 & 10 & 10 & 100 \\
\hline 0220RP12 & $02 \mathrm{~V} 25431$ & 02C6955 & MECÂNICA & DESGASTE & CORREIA & 1 & 10 & 10 & 100 \\
\hline 0220RP12 & $02 \mathrm{~V} 21257$ & $02 \mathrm{C} 6730$ & MECÂNICA & TRAVAMENTO & PNEUM.-MANGUEIRA & 1 & 10 & 10 & 100 \\
\hline Subtotais & 5 & 5 & & & & 5 & & IRF & 500 \\
\hline 0220RP02 & 02U96141 & $02 \mathrm{C} 6047$ & MECÂNICA & DESGASTE & PARAFUSO & 1 & 10 & 10 & 100 \\
\hline 0220RP02 & $02 \mathrm{~V} 02946$ & $02 \mathrm{C} 6186$ & ELÉTRICA & INTERRUPCAO DE SINAL & CLP & 1 & 10 & 10 & 100 \\
\hline 0220RP02 & $02 \mathrm{~V} 04294$ & $02 C 6354$ & MECÂNICA & QUEBRA & ROLAMENTO & 1 & 10 & 10 & 100 \\
\hline 0220RP02 & $02 \mathrm{~V} 28624$ & $02 C 6971$ & MECÂNICA & QUEBRA & PARAFUSO & 1 & 10 & 10 & 100 \\
\hline Subtotais & 4 & 4 & & & & 4 & & IRF & 400 \\
\hline 0220RP27 & 02U96132 & $02 C 6046$ & MECÂNICA & TRAVAMENTO & PNEUM.-VALVULA & 1 & 10 & 10 & 100 \\
\hline 0220RP27 & 02V02116 & $02 \mathrm{C} 6171$ & MECÂNICA & ENTUPIMENTO & HIDR.-CONEXAO & 1 & 10 & 10 & 100 \\
\hline 0220RP27 & 02V03099 & $02 \mathrm{C} 6195$ & MECÂNICA & SUJEIRA & PNEUM.-VALVULA & 1 & 10 & 10 & 100 \\
\hline 0220RP27 & 02V03838 & $02 C 6296$ & MECÂNICA & SUJEIRA & PNEUM.-VALVULA & 1 & 10 & 10 & 100 \\
\hline Subtotais & 4 & 4 & & & & 4 & & IRF & 400 \\
\hline 0220RP03 & 02U96276 & 02C6059 & MECÂNICA & QUEBRA & CORRENTE & 1 & 10 & 10 & 100 \\
\hline 0220RP03 & 02V03794 & $02 C 6291$ & ELÉTRICA & TRAVAMENTO & PNEUM.-VALVULA & 1 & 10 & 10 & 100 \\
\hline 0220RP03 & 02V21989 & $02 C 6778$ & MECÂNICA & ROMPIMENTO & HIDR.-MANGUEIRA & 1 & 10 & 10 & 100 \\
\hline 0220RP03 & 02V07950 & & MECÂNICA & VAZAMENTO & LUBRIFIL & 1 & 1 & 1 & 1 \\
\hline Subtotais & 4 & 3 & & & & 4 & & IRF & 301 \\
\hline 0220RP04 & 02V06639 & $02 C 6539$ & MECÂNICA & TRAVAMENTO & GUIA & 1 & 10 & 10 & 100 \\
\hline 0220RP04 & 02V06602 & $02 \mathrm{C} 6536$ & MECÂNICA & DESREGULAGEM & PNEUM.-VALVULA & 1 & 10 & 10 & 100 \\
\hline 0220RP04 & 02V41351 & $02 C 7121$ & ELÉTRICA & CURTO-CIRCUITO & SENSOR & 1 & 10 & 10 & 100 \\
\hline 0220RP04 & $02 \mathrm{~V} 02553$ & & MECÂNICA & QUEBRA & PROTECAO/TAMPA & 1 & 1 & 1 & 1 \\
\hline Subtotais & 4 & 3 & & & & 4 & & IRF & 301 \\
\hline
\end{tabular}




\begin{tabular}{|c|c|c|c|c|c|c|c|c|c|}
\hline Código & OS Mnt Corretiva & Cod Parada & Modalidade & Falha & Causa & Ocorrência & Gravidade & Detectabilidade & OGD \\
\hline $0220 \mathrm{RP} 23$ & 02U96025 & $02 C 6035$ & MECÂNICA & DESGASTE & GUIA & 1 & 10 & 10 & 100 \\
\hline 0220RP23 & $02 \mathrm{~V} 31111$ & $02 C 6983$ & ELÉTRICA & DESLOCAMENTO & CHAVE FIM-DE-CURSO & 1 & 10 & 10 & 100 \\
\hline $0220 \mathrm{RP} 23$ & $02 \mathrm{~V} 23004$ & & MECÂNICA & QUEBRA & GUIA & 1 & 1 & 1 & 1 \\
\hline Subtotais & 3 & 2 & & & & 3 & & IRF & 201 \\
\hline 02202552 & $02 \mathrm{~V} 07415$ & $02 C 6578$ & MECÂNICA & VAZAMENTO & PNEUM.-VALVULA & 1 & 10 & 10 & 100 \\
\hline 02202552 & 02V02241 & $02 C 6179$ & MECÂNICA & VAZAMENTO & PNEUM.-MANGUEIRA & 1 & 10 & 10 & 100 \\
\hline Subtotais & 2 & 2 & & & & 2 & & IRF & 200 \\
\hline 0220RP24 & 02U96043 & $02 \mathrm{C} 6037$ & ELÉTRICA & INTERRUPCAO DE SINAL & MOTOR & 1 & 10 & 10 & 100 \\
\hline 0220RP24 & $02 \mathrm{~V} 36143$ & 02C7022 & ELÉTRICA & INTERRUPCAO DE SINAL & CLP & 1 & 10 & 10 & 100 \\
\hline Subtotais & 2 & 2 & & & & 2 & & IRF & 200 \\
\hline 0220RP18 & 02V05202 & $02 \mathrm{C} 6483$ & ELÉTRICA & QUEIMA & SENSOR & 1 & 10 & 10 & 100 \\
\hline Subtotais & 1 & 1 & & & & 1 & & IRF & 100 \\
\hline 0220RP22 & 02V06915 & $02 C 6562$ & MECÂNICA & QUEBRA & POLIA & 1 & 10 & 10 & 100 \\
\hline Subtotais & 1 & 1 & & & & 1 & & IRF & 100 \\
\hline 0220RP01 & $02 \mathrm{~V} 22559$ & & MECÂNICA & QUEBRA & PROTECAO/TAMPA & 1 & 1 & 1 & 1 \\
\hline 0220RP01 & $02 \mathrm{~V} 40771$ & & MECÂNICA & QUEBRA & GUIA & 1 & 1 & 1 & 1 \\
\hline Subtotais & 2 & $\mathbf{0}$ & & & & 2 & & IRF & 2 \\
\hline 02203226 & 02V04089 & & ELÉTRICA & MAL-CONTATO & CONTROLADOR & 1 & 1 & 1 & 1 \\
\hline Subtotais & 1 & $\mathbf{0}$ & & & & 1 & & IRF & 1 \\
\hline 0220RP05 & 02V36241 & & ELÉTRICA & RETRABALHO DO ANEL & SIST. REFRIGERACAO & 1 & 1 & 1 & 1 \\
\hline Subtotais & 1 & $\mathbf{0}$ & & & & 1 & & IRF & 1 \\
\hline 0220RP21 & $02 \mathrm{~V} 40753$ & & MECÂNICA & TRAVAMENTO & APERTADEIRA & 1 & 1 & 1 & 1 \\
\hline Subtotais & 1 & $\mathbf{0}$ & & & & 1 & & IRF & 1 \\
\hline Totais & 35 & 27 & & & & 35 & & IRE & 2.708 \\
\hline
\end{tabular}


RETÍFICA DE PERFIL - ÍNDICE DE RISCO DE EQUIPAMENTO - NÚMERO DE OCORRÊNCIAS

( Período: 01/03/05 a 31/03/05 )

\begin{tabular}{|c|c|c|c|c|c|c|c|c|c|}
\hline Código & OS Mnt Corretiva & Cod Parada & Modalidade & Falha & Causa & Ocorrência & Gravidade & Detectabilidade & OGD \\
\hline 0220RP03 & 02V45277 & $02 C 7297$ & ELÉTRICA & MAL-CONTATO & PLACA ELETRONICA & 1 & 10 & 10 & 100 \\
\hline 0220RP03 & $02 \mathrm{~V} 48041$ & 02C7389 & MECÂNICA & QUEBRA & LUBRIFIL & 1 & 10 & 10 & 100 \\
\hline 0220RP03 & $02 \mathrm{~V} 45053$ & $02 C 7286$ & ELÉTRICA & OPERACAO & CONTROLADOR & 1 & 10 & 10 & 100 \\
\hline 0220RP03 & 02V60071 & $02 C 7881$ & MECÂNICA & DESGASTE & CORREIA & 1 & 10 & 10 & 100 \\
\hline 0220RP03 & 02 V53766 & $02 C 7616$ & ELÉTRICA & DESREGULAGEM & CONVERSOR & 1 & 10 & 10 & 100 \\
\hline 0220RP03 & 02V60981 & $02 C 7912$ & MECÂNICA & DESGASTE & PARAFUSO & 1 & 10 & 10 & 100 \\
\hline 0220RP03 & 02 V59225 & 02C7822 & ELÉTRICA & DESREGULAGEM & SENSOR & 1 & 10 & 10 & 100 \\
\hline 0220RP03 & 02 V76974 & $02 C 7977$ & MECÂNICA & TRAVAMENTO & PNEUM.-VALVULA & 1 & 10 & 10 & 100 \\
\hline 0220RP03 & $02 \mathrm{~V} 53365$ & & MECÂNICA & MELHORIA & PROTECAO/TAMPA & 1 & 1 & 1 & 1 \\
\hline Subtotais & 9 & 8 & & & & 9 & & IRF & 801 \\
\hline 0220RP27 & $02 \mathrm{~V} 47505$ & $02 C 7361$ & MECÂNICA & QUEBRA & PNEUM.-CILINDRO & 1 & 10 & 10 & 100 \\
\hline 0220RP27 & 02V49709 & $02 C 7504$ & ELÉTRICA & MAL-CONTATO & SENSOR & 1 & 10 & 10 & 100 \\
\hline 0220RP27 & 02V49344 & $02 C 7449$ & MECÂNICA & VAZAMENTO & HIDR.-CILINDRO & 1 & 10 & 10 & 100 \\
\hline 0220RP27 & 02V83378 & $02 C 8160$ & MECÂNICA & DESGASTE & GUIA & 1 & 10 & 10 & 100 \\
\hline 0220RP27 & 02V60357 & & MECÂNICA & SUJEIRA & PNEUM.-VALVULA & 1 & 1 & 1 & 1 \\
\hline Subtotais & 5 & 4 & & & & 5 & & IRF & 401 \\
\hline 0220RP04 & 02V53999 & $02 C 7636$ & MECÂNICA & QUEBRA & CORREIA & 1 & 10 & 10 & 100 \\
\hline 0220RP04 & 02V61310 & $02 C 7934$ & MECÂNICA & QUEBRA & CORRENTE & 1 & 10 & 10 & 100 \\
\hline 0220RP04 & 02V77054 & $02 C 8033$ & MECÂNICA & QUEBRA & PARAFUSO & 1 & 10 & 10 & 100 \\
\hline 0220RP04 & 02V55522 & & MECÂNICA & VAZAMENTO & HIDR.-MANGUEIRA & 1 & 1 & 1 & 1 \\
\hline Subtotais & 4 & 3 & & & & 4 & & IRF & 301 \\
\hline 0220RP22 & 02V48372 & $02 C 7422$ & MECÂNICA & VAZAMENTO & HIDR.-MANGUEIRA & 1 & 10 & 10 & 100 \\
\hline 0220RP22 & 02V77090 & $02 C 8039$ & ELÉTRICA & BAIXA PRESSAO & HIDR.-VALVULA & 1 & 10 & 10 & 100 \\
\hline 0220RP22 & 02 V83305 & $02 C 8153$ & MECÂNICA & DEFEITO INTERMITENTE & SENSOR & 1 & 10 & 10 & 100 \\
\hline Subtotais & 3 & 3 & & & & 3 & & IRF & 300 \\
\hline 0220RP02 & 02 V83403 & $02 C 8162$ & MECÂNICA & FOLGA & CORREIA & 1 & 10 & 10 & 100 \\
\hline 0220RP02 & 02V97425 & $02 C 8412$ & ELÉTRICA & CURTO-CIRCUITO & SENSOR & 1 & 10 & 10 & 100 \\
\hline 0220RP02 & 02V50199 & & MECÂNICA & QUEBRA & PROTECAO/TAMPA & 1 & 1 & 1 & 1 \\
\hline 0220RP02 & 02V62621 & & MECÂNICA & QUEBRA & PROTECAO/TAMPA & 1 & 1 & 1 & 1 \\
\hline Subtotais & 4 & 2 & & & & 4 & & IRF & 202 \\
\hline
\end{tabular}




\begin{tabular}{|c|c|c|c|c|c|c|c|c|c|}
\hline Código & OS Mnt Corretiva & Cod Parada & Modalidade & Falha & Causa & Ocorrência & Gravidade & Detectabilidade & OGD \\
\hline 0220RP01 & 02V41495 & $02 C 7134$ & MECÂNICA & VAZAMENTO & PNEUM.-CONEXAO & 1 & 10 & 10 & 100 \\
\hline 0220RP01 & $02 \mathrm{~V} 44349$ & $02 C 7257$ & ELÉTRICA & DESGASTE & CORREIA & 1 & 10 & 10 & 100 \\
\hline 0220RP01 & 02V60366 & & MECÂNICA & VAZAMENTO & HIDR.-CONEXAO & 1 & 1 & 1 & 1 \\
\hline Subtotais & 3 & 2 & & & & 3 & & IRF & 201 \\
\hline 0220RP15 & 02V55434 & $02 C 7692$ & MECÂNICA & DESGASTE & CORREIA & 1 & 10 & 10 & 100 \\
\hline 0220RP15 & 02V52384 & $02 C 7575$ & ELÉTRICA & DESGASTE & CHAVE/BOTOEIRA & 1 & 10 & 10 & 100 \\
\hline Subtotais & 2 & 2 & & & & 2 & & IRF & 200 \\
\hline 0220RP05 & 02V55238 & $02 C 7678$ & MECÂNICA & FOLGA & EIXO & 1 & 10 & 10 & 100 \\
\hline 0220RP05 & 02V50055 & & MECÂNICA & QUEBRA & PROTECAO/TAMPA & 1 & 1 & 1 & 1 \\
\hline 0220RP05 & $02 \mathrm{~V} 51651$ & & MECÂNICA & VAZAMENTO & RESERVATORIO & 1 & 1 & 1 & 1 \\
\hline Subtotais & 3 & 1 & & & & 3 & & IRF & 102 \\
\hline 0220RP29 & 02V44376 & 02C7258 & ELÉTRICA & INTERRUPCAO DE SINAL & MOTOR & 1 & 10 & 10 & 100 \\
\hline 0220RP29 & $02 \mathrm{~V} 44063$ & & MECÂNICA & QUEBRA & CONTRA-PONTO & 1 & 1 & 1 & 1 \\
\hline Subtotais & 2 & 1 & & & & 2 & & IRF & 101 \\
\hline 02200906 & 02V61365 & $02 C 7937$ & MECÂNICA & VAZAMENTO & PNEUM.-CONEXAO & 1 & 10 & 10 & 100 \\
\hline Subtotais & 1 & 1 & & & & 1 & & IRF & 100 \\
\hline 02203226 & 02V61347 & $02 C 7936$ & MECÂNICA & QUEBRA & PNEUM.-VALVULA & 1 & 10 & 10 & 100 \\
\hline Subtotais & 1 & 1 & & & & 1 & & IRF & 100 \\
\hline 0220RP18 & $02 \mathrm{~V} 42546$ & 02C7200 & MECÂNICA & VAZAMENTO & HIDR.-CONEXAO & 1 & 10 & 10 & 100 \\
\hline Subtotais & 1 & 1 & & & & 1 & & IRF & 100 \\
\hline 02200907 & $02 \mathrm{~V} 53533$ & & MECÂNICA & DESREGULAGEM & CONTROLADOR & 1 & 1 & 1 & 1 \\
\hline Subtotais & 1 & $\mathbf{0}$ & & & & 1 & & IRF & 1 \\
\hline 0220RP23 & 02V62701 & & MECÂNICA & SUJEIRA & PNEUM.-VALVULA & 1 & 1 & 1 & 1 \\
\hline Subtotais & 1 & $\mathbf{0}$ & & & & 1 & & IRF & 1 \\
\hline Totais & 40 & 29 & & & & 40 & & IRE & 2.911 \\
\hline
\end{tabular}


RETÍFICA DE PERFIL - ÍNDICE DE RISCO DE EQUIPAMENTO - NÚMERO DE OCORRÊNCIAS

( Período: 01/04/05 a 30/04/05 )

\begin{tabular}{|c|c|c|c|c|c|c|c|c|c|}
\hline Código & OS Mnt Corretiva & Cod Parada & Modalidade & Falha & Causa & Ocorrência & Gravidade & Detectabilidade & OGD \\
\hline 0220RP19 & 02V94749 & $02 C 8314$ & ELÉTRICA & DESREGULAGEM & CHAVE FIM-DE-CURSO & 1 & 10 & 10 & 100 \\
\hline 0220RP19 & 02W00518 & $02 C 8541$ & MECÂNICA & QUEBRA & PARAFUSO & 1 & 10 & 10 & 100 \\
\hline 0220RP19 & 02W22692 & $02 C 8966$ & ELÉTRICA & CURTO-CIRCUITO & CABO ELETRICO & 1 & 10 & 10 & 100 \\
\hline 0220RP19 & $02 \mathrm{~W} 05103$ & $02 C 8649$ & MECÂNICA & TRAVAMENTO & PNEUM.-VALVULA & 1 & 10 & 10 & 100 \\
\hline 0220RP19 & 02W09430 & $02 C 8818$ & ELÉTRICA & TRAVAMENTO & CLP & 1 & 10 & 10 & 100 \\
\hline 0220RP19 & $02 \mathrm{~W} 23165$ & 02C8989 & MECÂNICA & BAIXA PRESSAO & PNEUM.-VALVULA & 1 & 10 & 10 & 100 \\
\hline 0220RP19 & 02W23557 & $02 C 9011$ & ELÉTRICA & INTERRUPCAO DE SINAL & MOTOR & 1 & 10 & 10 & 100 \\
\hline 0220RP19 & 02W07762 & & MECÂNICA & VAZAMENTO & PNEUM.-MANGUEIRA & 1 & 1 & 1 & 1 \\
\hline Subtotais & 8 & 7 & & & & 8 & & IRF & 701 \\
\hline 0220RP04 & 02 V94712 & $02 C 8312$ & ELÉTRICA & TRAVAMENTO & CLP & 1 & 10 & 10 & 100 \\
\hline 0220RP04 & 02V98718 & $02 C 8474$ & ELÉTRICA & INTERRUPCAO DE SINAL & CHAVE FIM-DE-CURSO & 1 & 10 & 10 & 100 \\
\hline 0220RP04 & 02W06353 & $02 C 8698$ & ELÉTRICA & INTERRUPCAO DE SINAL & MOTOR & 1 & 10 & 10 & 100 \\
\hline 0220RP04 & 02W09289 & $02 C 8801$ & MECÂNICA & VAZAMENTO & HIDR.-TUBULACAO & 1 & 10 & 10 & 100 \\
\hline 0220RP04 & 02W00368 & & MECÂNICA & FIXACAO & BUCHA & 1 & 1 & 1 & 1 \\
\hline Subtotais & 5 & 4 & & & & 5 & & IRF & 401 \\
\hline 0220RP23 & $02 \mathrm{~V} 97693$ & $02 C 8434$ & MECÂNICA & QUEBRA & PARAFUSO & 1 & 10 & 10 & 100 \\
\hline 0220RP23 & 02W09047 & $02 C 8770$ & MECÂNICA & DESGASTE & PARAFUSO & 1 & 10 & 10 & 100 \\
\hline 0220RP23 & $02 \mathrm{~W} 23316$ & $02 C 8770$ & ELÉTRICA & INTERRUPCAO DE SINAL & CHAVE FIM-DE-CURSO & 1 & 10 & 10 & 100 \\
\hline 0220RP23 & 02W22601 & $02 C 8960$ & MECÂNICA & MEDICAO INCORRETA & HIDR.-VALVULA & 1 & 10 & 10 & 100 \\
\hline Subtotais & 4 & 4 & & & & 4 & & IRF & 400 \\
\hline 0220RP05 & 02V94561 & 02C8299 & MECÂNICA & VAZAMENTO & PNEUM.-MANGUEIRA & 1 & 10 & 10 & 100 \\
\hline 0220RP05 & 02 V97461 & $02 C 8416$ & ELÉTRICA & QUEIMA & SOLENOIDE & 1 & 10 & 10 & 100 \\
\hline 0220RP05 & 02V99209 & $02 C 8505$ & MECÂNICA & QUEBRA & SENSOR & 1 & 10 & 10 & 100 \\
\hline 0220RP05 & 02W00395 & & MECÂNICA & VAZAMENTO & HIDR.-CONEXAO & 1 & 1 & 1 & 1 \\
\hline Subtotais & 4 & 3 & & & & 4 & & IRF & 301 \\
\hline 0220RP27 & 02V94552 & $02 C 8298$ & MECÂNICA & TRAVAMENTO & PNEUM.-VALVULA & 1 & 10 & 10 & 100 \\
\hline 0220RP27 & 02W21568 & $02 C 8902$ & MECÂNICA & QUEBRA & PNEUM.-CILINDRO & 1 & 10 & 10 & 100 \\
\hline 0220RP27 & 02W39577 & 02C9155 & MECÂNICA & QUEBRA & GUIA & 1 & 10 & 10 & 100 \\
\hline Subtotais & 3 & 3 & & & & 3 & & IRF & 300 \\
\hline
\end{tabular}




\begin{tabular}{|c|c|c|c|c|c|c|c|c|c|}
\hline Código & OS Mnt Corretiva & Cod Parada & Modalidade & Falha & Causa & Ocorrência & Gravidade & Detectabilidade & OGD \\
\hline 0220RP22 & 02V97880 & $02 \mathrm{C} 8447$ & MECÂNICA & QUEBRA & CORREIA & 1 & 10 & 10 & 100 \\
\hline 0220RP22 & 02V95702 & $02 C 8353$ & MECÂNICA & INTERRUPCAO DE SINAL & CLP & 1 & 10 & 10 & 100 \\
\hline Subtotais & 2 & 2 & & & & 2 & & IRF & 200 \\
\hline 0220RP12 & 02V92064 & $02 C 8225$ & MECÂNICA & DESGASTE & DESGASTE & 1 & 10 & 10 & 100 \\
\hline 0220RP12 & $02 \mathrm{~V} 92778$ & & ELÉTRICA & INTERRUPCAO DE SINAL & SENSOR & 1 & 1 & 1 & 1 \\
\hline 0220RP12 & 02W17751 & & MECÂNICA & FOLGA & BUCHA & 1 & 1 & 1 & 1 \\
\hline Subtotais & 3 & 1 & & & & 3 & & IRF & 102 \\
\hline 02203226 & 02W05979 & $02 C 8670$ & MECÂNICA & TRAVAMENTO & PNEUM.-CILINDRO & 1 & 10 & 10 & 100 \\
\hline 02203226 & 02W00233 & & MECÂNICA & VAZAMENTO & PNEUM.-MANGUEIRA & 1 & 1 & 1 & 1 \\
\hline Subtotais & 2 & 1 & & & & 2 & & IRF & 101 \\
\hline 0220RP02 & 02W42518 & 02C9318 & MECÂNICA & QUEBRA & CORRENTE & 1 & 10 & 10 & 100 \\
\hline 0220RP02 & 02W03089 & & MECÂNICA & DESREGULAGEM & REDUTOR & 1 & 1 & 1 & 1 \\
\hline Subtotais & 2 & 1 & & & & 2 & & IRF & 101 \\
\hline 0220RP18 & 02W22674 & $02 C 8965$ & ELÉTRICA & TRAVAMENTO & CLP & 1 & 10 & 10 & 100 \\
\hline 0220RP18 & 02V97112 & & ELÉTRICA & MEDICAO INCORRETA & CONTROLADOR & 1 & 1 & 1 & 1 \\
\hline Subtotais & 2 & 1 & & & & 2 & & IRF & 101 \\
\hline 02202552 & 02W03310 & $02 C 8612$ & MECÂNICA & VAZAMENTO & PNEUM.-MANGUEIRA & 1 & 10 & 10 & 100 \\
\hline Subtotais & 1 & 1 & & & & 1 & & IRF & 100 \\
\hline 0220RP03 & 02 V94525 & $02 \mathrm{C} 8297$ & MECÂNICA & QUEBRA & PNEUM.-CILINDRO & 1 & 10 & 10 & 100 \\
\hline Subtotais & 1 & 1 & & & & 1 & & IRF & 100 \\
\hline 0220RP21 & 02V97862 & $02 C 8445$ & MECÂNICA & QUEBRA & CORRENTE & 1 & 10 & 10 & 100 \\
\hline Subtotais & 1 & 1 & & & & 1 & & IRF & 100 \\
\hline 02200907 & 02W04220 & & MECÂNICA & TRAVAMENTO & PNEUM.-VALVULA & 1 & 1 & 1 & 1 \\
\hline 02200907 & 02W05639 & & MECÂNICA & DESLOCAMENTO & CORRENTE & 1 & 1 & 1 & 1 \\
\hline Subtotais & 2 & $\mathbf{0}$ & & & & 2 & & IRF & 2 \\
\hline 02202537 & 02W38364 & & MECÂNICA & VIBRACAO & PARAFUSO & 1 & 1 & 1 & 1 \\
\hline Subtotais & 1 & $\mathbf{0}$ & & & & 1 & & IRF & 1 \\
\hline
\end{tabular}




\begin{tabular}{|c|c|c|c|c|c|c|c|c|c|}
\hline Código & OS Mnt Corretiva & Cod Parada & Modalidade & Falha & Causa & Ocorrência & Gravidade & Detectabilidade & OGD \\
\hline $\begin{array}{l}\text { 0220RP28 } \\
\text { Subtotais }\end{array}$ & $\begin{array}{c}\text { 02W42885 } \\
\mathbf{1}\end{array}$ & $\mathbf{0}$ & MECÂNICA & MELHORIA & PROTECAO/TAMPA & $\begin{array}{l}1 \\
\mathbf{1}\end{array}$ & 1 & $\begin{array}{c}1 \\
\text { IRF }\end{array}$ & $\begin{array}{l}1 \\
1\end{array}$ \\
\hline Totais & 42 & 30 & & & & 42 & & IRE & 3.012 \\
\hline
\end{tabular}


RETÍFICA DE PERFIL - ÍNDICE DE RISCO DE EQUIPAMENTO - NÚMERO DE OCORRÊNCIAS

( Período: 01/05/05 a 31/05/05 )

\begin{tabular}{|c|c|c|c|c|c|c|c|c|c|}
\hline Código & OS Mnt Corretiva & Cod Parada & Modalidade & Falha & Causa & Ocorrência & Gravidade & Detectabilidade & OGD \\
\hline 0220RP15 & 02W51302 & $02 C 9564$ & MECÂNICA & VAZAMENTO & HIDR.-CILINDRO & 1 & 10 & 10 & 100 \\
\hline 0220RP15 & 02W51133 & $02 C 9551$ & MECÂNICA & TRAVAMENTO & MANCAL & 1 & 10 & 10 & 100 \\
\hline 0220RP15 & $02 W 88425$ & $02 C 9955$ & MECÂNICA & VAZAMENTO & HIDR.-MANGUEIRA & 1 & 10 & 10 & 100 \\
\hline 0220RP15 & $02 W 91929$ & 02D0128 & MECÂNICA & VAZAMENTO & HIDR.-MANGUEIRA & 1 & 10 & 10 & 100 \\
\hline Subtotais & 4 & 4 & & & & 4 & & IRF & 400 \\
\hline 0220RP03 & 02W90234 & $02 \mathrm{D} 0052$ & ELÉTRICA & INTERRUPCAO DE SINAL & SENSOR & 1 & 10 & 10 & 100 \\
\hline 0220RP03 & $02 \mathrm{~W} 91563$ & 02D0102 & MECÂNICA & ROMPIMENTO & CORRENTE & 1 & 10 & 10 & 100 \\
\hline 0220RP03 & 02W93099 & $02 \mathrm{D} 0174$ & MECÂNICA & QUEBRA & PNEUM.-CILINDRO & 1 & 10 & 10 & 100 \\
\hline 0220RP03 & 02W44071 & & ELÉTRICA & CURTO-CIRCUITO & SENSOR & 1 & 1 & 1 & 1 \\
\hline Subtotais & 4 & 3 & & & & 4 & & IRF & 301 \\
\hline 0220RP19 & 02W51259 & $02 C 9561$ & MECÂNICA & DESGASTE & PARAFUSO & 1 & 10 & 10 & 100 \\
\hline 0220RP19 & $02 W 57093$ & $02 C 9727$ & ELÉTRICA & PERDA DE MEMORIA & CLP & 1 & 10 & 10 & 100 \\
\hline 0220RP19 & 02W91607 & 02D0105 & MECÂNICA & QUEBRA & HIDR.-CILINDRO & 1 & 10 & 10 & 100 \\
\hline Subtotais & 3 & 3 & & & & 3 & & IRF & 300 \\
\hline 0220RP12 & 02W51222 & $02 C 9558$ & ELÉTRICA & INTERRUPCAO DE SINAL & MOTOR & 1 & 10 & 10 & 100 \\
\hline 0220RP12 & 02W51892 & $02 C 9592$ & MECÂNICA & SUJEIRA & PNEUM.-VALVULA & 1 & 10 & 10 & 100 \\
\hline 0220RP12 & 02W46337 & & MECÂNICA & TRAVAMENTO & PNEUM.-VALVULA & 1 & 1 & 1 & 1 \\
\hline Subtotais & 3 & 2 & & & & 3 & & IRF & 201 \\
\hline 0220RP05 & 02W90341 & 02D0059 & MECÂNICA & SUJEIRA & SIST. REFRIGERACAO & 1 & 10 & 10 & 100 \\
\hline 0220RP05 & 02W91554 & 02D0101 & MECÂNICA & TRAVAMENTO & HIDR.-CILINDRO & 1 & 10 & 10 & 100 \\
\hline Subtotais & 2 & 2 & & & & 2 & & IRF & 200 \\
\hline 0220RP27 & 02W92232 & $02 \mathrm{D} 0153$ & MECÂNICA & DESREGULAGEM & HIDR.-VALVULA & 1 & 10 & 10 & 100 \\
\hline 0220RP27 & 02W54194 & & MECÂNICA & VAZAMENTO & HIDR.-CONEXAO & 1 & 1 & 1 & 1 \\
\hline 0220RP27 & $02 \mathrm{~W} 89503$ & & MECÂNICA & TRAVAMENTO & HIDR.-CILINDRO & 1 & 1 & 1 & 1 \\
\hline Subtotais & 3 & 1 & & & & 3 & & IRF & 102 \\
\hline
\end{tabular}




\begin{tabular}{|c|c|c|c|c|c|c|c|c|c|}
\hline Código & OS Mnt Corretiva & Cod Parada & Modalidade & Falha & Causa & Ocorrência & Gravidade & Detectabilidade & OGD \\
\hline 0220RP01 & 02W88470 & 02C9958 & MECÂNICA & VAZAMENTO & HIDR.-CILINDRO & 1 & 10 & 10 & 100 \\
\hline 0220RP01 & $02 W 54185$ & & MECÂNICA & VAZAMENTO & HIDR.-CONEXAO & 1 & 1 & 1 & 1 \\
\hline Subtotais & 2 & 1 & & & & 2 & & IRF & 101 \\
\hline 0220RP02 & 02W54880 & 02C9700 & MECÂNICA & QUEBRA & PARAFUSO & 1 & 10 & 10 & 100 \\
\hline 0220RP02 & 02W56637 & & ELÉTRICA & DEFEITO INTERMITENTE & SENSOR & 1 & 1 & 1 & 1 \\
\hline Subtotais & 2 & 1 & & & & 2 & & IRF & 101 \\
\hline 0220RP22 & 02W91732 & $02 \mathrm{D} 0116$ & MECÂNICA & DESGASTE & DESGASTE & 1 & 10 & 10 & 100 \\
\hline 0220RP22 & 02W44035 & & ELÉTRICA & INTERRUPCAO DE SINAL & SENSOR & 1 & 1 & 1 & 1 \\
\hline Subtotais & 2 & 1 & & & & 2 & & IRF & 101 \\
\hline 0220RP23 & 02W50580 & $02 C 9519$ & MECÂNICA & ROMPIMENTO & CORRENTE & 1 & 10 & 10 & 100 \\
\hline 0220RP23 & 02W98227 & & MECÂNICA & FOLGA & GUIA & 1 & 1 & 1 & 1 \\
\hline Subtotais & 2 & 1 & & & & 2 & & IRF & 101 \\
\hline 0220RP04 & 02W50198 & 02C9491 & MECÂNICA & TRAVAMENTO & GUIA & 1 & 10 & 10 & 100 \\
\hline Subtotais & 1 & 1 & & & & 1 & & IRF & 100 \\
\hline 0220RP21 & 02W92116 & 02D0144 & ELÉTRICA & PERDA DE MEMORIA & CLP & 1 & 10 & 10 & 100 \\
\hline Subtotais & 1 & 1 & & & & 1 & & IRF & 100 \\
\hline 02200906 & 02W92358 & $02 \mathrm{D} 0092$ & LIMPEZA & ENTUPIMENTO & SUJEIRA & 1 & 10 & 10 & 100 \\
\hline Subtotais & 1 & 1 & & & & 1 & & IRF & 100 \\
\hline 0220RP29 & 02W90485 & 02D0069 & MECÂNICA & DESGASTE & PARAFUSO & 1 & 10 & 10 & 100 \\
\hline Subtotais & 1 & 1 & & & & 1 & & IRF & 100 \\
\hline 0220RP28 & $02 W 87024$ & & MECÂNICA & VAZAMENTO & HIDR.-CONEXAO & 1 & 1 & 1 & 1 \\
\hline Subtotais & 1 & $\mathbf{0}$ & & & & 1 & & IRF & 1 \\
\hline Totais & 32 & 23 & & & & 32 & & IRE & 2.309 \\
\hline
\end{tabular}


RETÍFICA DE PERFIL - ÍNDICE DE RISCO DE EQUIPAMENTO - NÚMERO DE OCORRÊNCIAS

( Período: 01/06/05 a 30/06/05 )

\begin{tabular}{|c|c|c|c|c|c|c|c|c|c|}
\hline Código & OS Mnt Corretiva & Cod Parada & Modalidade & Falha & Causa & Ocorrência & Gravidade & Detectabilidade & OGD \\
\hline 0220RP01 & 02X00786 & 02D0458 & ELÉTRICA & INTERRUPCAO DE SINAL & CHAVE/BOTOEIRA & 1 & 10 & 10 & 100 \\
\hline 0220RP01 & 02X05317 & $02 \mathrm{D} 0619$ & MECÂNICA & QUEBRA & CORRENTE & 1 & 10 & 10 & 100 \\
\hline 0220RP01 & $02 X 35712$ & 02D0944 & MECÂNICA & QUEBRA & GUIA & 1 & 10 & 10 & 100 \\
\hline 0220RP01 & 02X34054 & $02 \mathrm{D} 0896$ & MECÂNICA & TRAVAMENTO & BARRAMENTO MECANICO & 1 & 10 & 10 & 100 \\
\hline 0220RP01 & 02X37248 & 02D0991 & MECÂNICA & QUEBRA & PARAFUSO & 1 & 10 & 10 & 100 \\
\hline 0220RP01 & 02X08519 & & ELÉTRICA & INTERRUPCAO DE SINAL & CLP & 1 & 1 & 1 & 1 \\
\hline 0220RP01 & 02X26624 & & MECÂNICA & TRAVAMENTO & PNEUM.-VALVULA & 1 & 1 & 1 & 1 \\
\hline Subtotais & 7 & 5 & & & & 7 & & IRF & 502 \\
\hline 0220RP19 & $02 W 95471$ & $02 \mathrm{D} 0270$ & MECÂNICA & QUEBRA & GUIA & 1 & 10 & 10 & 100 \\
\hline 0220RP19 & $02 X 05424$ & 02D0628 & ELÉTRICA & PERDA DE MEMORIA & CLP & 1 & 10 & 10 & 100 \\
\hline 0220RP19 & $02 X 03523$ & 02D0521 & MECÂNICA & VAZAMENTO & HIDR.-MANGUEIRA & 1 & 10 & 10 & 100 \\
\hline 0220RP19 & 02X07681 & $02 \mathrm{D} 0721$ & ELÉTRICA & INTERRUPCAO DE SINAL & CLP & 1 & 10 & 10 & 100 \\
\hline Subtotais & 4 & 4 & & & & 4 & & IRF & 400 \\
\hline 0220RP22 & 02W96746 & $02 \mathrm{D} 0311$ & ELÉTRICA & INTERRUPCAO DE SINAL & CLP & 1 & 10 & 10 & 100 \\
\hline 0220RP22 & 02X35669 & 02D0942 & MECÂNICA & QUEBRA & GUIA & 1 & 10 & 10 & 100 \\
\hline 0220RP22 & 02X37346 & 02D0994 & MECÂNICA & QUEBRA & PNEUM.-CONEXAO & 1 & 10 & 10 & 100 \\
\hline 0220RP22 & $02 X 01525$ & & MECÂNICA & VAZAMENTO & HIDR.-VALVULA & 1 & 1 & 1 & 1 \\
\hline Subtotais & 4 & 3 & & & & 4 & & IRF & 301 \\
\hline 0220RP05 & $02 X 03774$ & $02 \mathrm{D} 0536$ & MECÂNICA & FOLGA & GUIA & 1 & 10 & 10 & 100 \\
\hline 0220RP05 & $02 X 03694$ & $02 \mathrm{D} 0531$ & MECÂNICA & TRAVAMENTO & MANCAL & 1 & 10 & 10 & 100 \\
\hline 0220RP05 & 02X35758 & $02 \mathrm{D} 0947$ & MECÂNICA & DESREGULAGEM & PARAFUSO & 1 & 10 & 10 & 100 \\
\hline 0220RP05 & 02W97219 & 02D0331 & LIMPEZA & CONTAMINACAO & SUJEIRA & 1 & 10 & 10 & 100 \\
\hline Subtotais & 4 & 4 & & & & 4 & & IRF & 400 \\
\hline 0220RP27 & 02X05264 & 02D0615 & MECÂNICA & VAZAMENTO INTERNO & HIDR.-CILINDRO & 1 & 10 & 10 & 100 \\
\hline 0220RP27 & $02 X 34571$ & 02D0916 & ELÉTRICA & DESREGULAGEM & SENSOR & 1 & 10 & 10 & 100 \\
\hline 0220RP27 & $02 \times 37621$ & 02D1010 & ELÉTRICA & INTERRUPCAO DE SINAL & CLP & 1 & 10 & 10 & 100 \\
\hline Subtotais & 3 & 3 & & & & 3 & & IRF & 300 \\
\hline
\end{tabular}




\begin{tabular}{|c|c|c|c|c|c|c|c|c|c|}
\hline Código & OS Mnt Corretiva & Cod Parada & Modalidade & Falha & Causa & Ocorrência & Gravidade & Detectabilidade & OGD \\
\hline 0220RP03 & 02X05442 & $02 \mathrm{D} 0629$ & ELÉTRICA & BAIXA PRESSAO & PRESSOSTATO & 1 & 10 & 10 & 100 \\
\hline 0220RP03 & $02 X 34063$ & 02D0895 & MECÂNICA & DESGASTE & CORREIA & 1 & 10 & 10 & 100 \\
\hline Subtotais & 2 & 2 & & & & 2 & & IRF & 200 \\
\hline 0220RP21 & 02X05380 & $02 \mathrm{D} 0625$ & ELÉTRICA & PERDA DE MEMORIA & CLP & 1 & 10 & 10 & 100 \\
\hline 0220RP21 & $02 X 05353$ & $02 \mathrm{D} 0623$ & MECÂNICA & CAPABILIDADE & PNEUM.-VALVULA & 1 & 10 & 10 & 100 \\
\hline Subtotais & 2 & 2 & & & & 2 & & IRF & 200 \\
\hline 0220RP28 & 02X00795 & $02 \mathrm{D} 0459$ & ELÉTRICA & INTERRUPCAO DE SINAL & CONTROLADOR & 1 & 10 & 10 & 100 \\
\hline 0220RP28 & 02X09377 & $02 D 0759$ & MECÂNICA & QUEBRA & GUIA & 1 & 10 & 10 & 100 \\
\hline Subtotais & 2 & 2 & & & & 2 & & IRF & 200 \\
\hline 02200907 & 02X07832 & 02D0724 & MECÂNICA & TRAVAMENTO & CORREIA & 1 & 10 & 10 & 100 \\
\hline 02200907 & $02 X 00731$ & & MECÂNICA & TRAVAMENTO & PNEUM.-VALVULA & 1 & 1 & 1 & 1 \\
\hline 02200907 & $02 X 07743$ & & MECÂNICA & MELHORIA & PNEUM.-VALVULA & 1 & 1 & 1 & 1 \\
\hline Subtotais & 3 & 1 & & & & 3 & & IRF & 102 \\
\hline 02203226 & 02X00777 & $02 \mathrm{D} 0457$ & ELÉTRICA & INTERRUPCAO DE SINAL & SENSOR & 1 & 10 & 10 & 100 \\
\hline Subtotais & 1 & 1 & & & & 1 & & IRF & 100 \\
\hline 0220RP02 & $02 X 39433$ & $02 \mathrm{D} 1115$ & ELÉTRICA & TRAVAMENTO & CLP & 1 & 10 & 10 & 100 \\
\hline Subtotais & 1 & 1 & & & & 1 & & IRF & 100 \\
\hline 0220RP18 & 02X09509 & 02D0769 & ELÉTRICA & QUEBRA & SENSOR & 1 & 10 & 10 & 100 \\
\hline Subtotais & 1 & 1 & & & & 1 & & IRF & 100 \\
\hline 02200906 & 02X08056 & & MECÂNICA & MELHORIA & FILTRO & 1 & 1 & 1 & 1 \\
\hline Subtotais & 1 & $\mathbf{0}$ & & & & 1 & & IRF & 1 \\
\hline 0220RP12 & $02 X 33475$ & & MECÂNICA & BAIXA VAZAO & HIDR.-CONEXAO & 1 & 1 & 1 & 1 \\
\hline Subtotais & 1 & $\mathbf{0}$ & & & & 1 & & IRF & 1 \\
\hline 0220RP15 & 02X38452 & & MECÂNICA & FOLGA & CORREIA & 1 & 1 & 1 & 1 \\
\hline Subtotais & 1 & $\mathbf{0}$ & & & & 1 & & IRF & 1 \\
\hline Totais & 37 & 29 & & & & 37 & & IRE & 2.908 \\
\hline
\end{tabular}


RETÍFICA DE PERFIL - ÍNDICE DE RISCO DE EQUIPAMENTO - NÚMERO DE OCORRÊNCIAS

( Período: 01/06/04 a 30/06/05 )

\begin{tabular}{|c|c|c|c|c|c|c|c|c|c|}
\hline Código & OS Mnt Corretiva & Cod Parada & Modalidade & Falha & Causa & Ocorrência & Gravidade & Detectabilidade & OGD \\
\hline 0220RP03 & 02R19088 & 02B6955 & MECÂNICA & QUEBRA & PARAFUSO & 1 & 10 & 10 & 100 \\
\hline 0220RP03 & 02R22449 & 02B7092 & ELÉTRICA & QUEBRA & SENSOR & 1 & 10 & 10 & 100 \\
\hline 0220RP03 & 02R85942 & $02 \mathrm{~B} 8523$ & ELÉTRICA & TRAVAMENTO & CONTROLADOR & 1 & 10 & 10 & 100 \\
\hline 0220RP03 & $02 \mathrm{~S} 02585$ & $02 B 8819$ & ELÉTRICA & INTERRUPCAO DE SINAL & SENSOR & 1 & 10 & 10 & 100 \\
\hline 0220RP03 & $02 \mathrm{~S} 25123$ & 02B9528 & ELÉTRICA & INTERRUPCAO DE SINAL & SENSOR & 1 & 10 & 10 & 100 \\
\hline 0220RP03 & 02S31811 & 02B9552 & MECÂNICA & TRAVAMENTO & PNEUM.-VALVULA & 1 & 10 & 10 & 100 \\
\hline 0220RP03 & $02 S 60860$ & $02 \mathrm{C} 0376$ & MECÂNICA & QUEBRA & PARAFUSO & 1 & 10 & 10 & 100 \\
\hline 0220RP03 & 02S93175 & $02 C 0954$ & MECÂNICA & QUEBRA & POLIA & 1 & 10 & 10 & 100 \\
\hline 0220RP03 & $02 T 42808$ & 02C2270 & MECÂNICA & QUEBRA & CORRENTE & 1 & 10 & 10 & 100 \\
\hline 0220RP03 & $02 T 53868$ & 02C2697 & ELÉTRICA & MAL-CONTATO & CABO ELETRICO & 1 & 10 & 10 & 100 \\
\hline 0220RP03 & $02 \mathrm{~T} 88643$ & 02C3104 & MECÂNICA & DESGASTE & GUIA & 1 & 10 & 10 & 100 \\
\hline 0220RP03 & 02U38222 & $02 \mathrm{C} 4816$ & MECÂNICA & QUEBRA & BARRAMENTO MECANICO & 1 & 10 & 10 & 100 \\
\hline 0220RP03 & 02U31595 & $02 C 4500$ & MECÂNICA & QUEBRA & CORRENTE & 1 & 10 & 10 & 100 \\
\hline 0220RP03 & 02U49096 & $02 \mathrm{C} 5161$ & MECÂNICA & QUEBRA & PARAFUSO & 1 & 10 & 10 & 100 \\
\hline 0220RP03 & 02U61990 & $02 \mathrm{C} 5322$ & ELÉTRICA & DESREGULAGEM & SENSOR & 1 & 10 & 10 & 100 \\
\hline 0220RP03 & 02U83841 & $02 \mathrm{C} 5911$ & MECÂNICA & QUEBRA & PARAFUSO & 1 & 10 & 10 & 100 \\
\hline 0220RP03 & 02U96276 & $02 C 6059$ & MECÂNICA & QUEBRA & CORRENTE & 1 & 10 & 10 & 100 \\
\hline 0220RP03 & 02V03794 & $02 C 6291$ & ELÉTRICA & TRAVAMENTO & PNEUM.-VALVULA & 1 & 10 & 10 & 100 \\
\hline 0220RP03 & $02 \mathrm{~V} 21989$ & $02 C 6778$ & MECÂNICA & ROMPIMENTO & HIDR.-MANGUEIRA & 1 & 10 & 10 & 100 \\
\hline 0220RP03 & 02V45277 & $02 C 7297$ & ELÉTRICA & MAL-CONTATO & PLACA ELETRONICA & 1 & 10 & 10 & 100 \\
\hline 0220RP03 & 02V48041 & 02C7389 & MECÂNICA & QUEBRA & LUBRIFIL & 1 & 10 & 10 & 100 \\
\hline 0220RP03 & $02 \mathrm{~V} 45053$ & $02 C 7286$ & ELÉTRICA & OPERACAO & CONTROLADOR & 1 & 10 & 10 & 100 \\
\hline 0220RP03 & $02 \mathrm{~V} 60071$ & 02C7881 & MECÂNICA & DESGASTE & CORREIA & 1 & 10 & 10 & 100 \\
\hline 0220RP03 & 02V53766 & $02 C 7616$ & ELÉTRICA & DESREGULAGEM & CONVERSOR & 1 & 10 & 10 & 100 \\
\hline 0220RP03 & 02V60981 & $02 C 7912$ & MECÂNICA & DESGASTE & PARAFUSO & 1 & 10 & 10 & 100 \\
\hline 0220RP03 & $02 \mathrm{~V} 59225$ & $02 C 7822$ & ELÉTRICA & DESREGULAGEM & SENSOR & 1 & 10 & 10 & 100 \\
\hline 0220RP03 & 02 V76974 & $02 C 7977$ & MECÂNICA & TRAVAMENTO & PNEUM.-VALVULA & 1 & 10 & 10 & 100 \\
\hline 0220RP03 & $02 \mathrm{~V} 94525$ & $02 C 8297$ & MECÂNICA & QUEBRA & PNEUM.-CILINDRO & 1 & 10 & 10 & 100 \\
\hline 0220RP03 & 02W90234 & 02D0052 & ELÉTRICA & INTERRUPCAO DE SINAL & SENSOR & 1 & 10 & 10 & 100 \\
\hline 0220RP03 & 02W91563 & 02D0102 & MECÂNICA & ROMPIMENTO & CORRENTE & 1 & 10 & 10 & 100 \\
\hline 0220RP03 & 02W93099 & $02 \mathrm{D} 0174$ & MECÂNICA & QUEBRA & PNEUM.-CILINDRO & 1 & 10 & 10 & 100 \\
\hline
\end{tabular}




\begin{tabular}{|c|c|c|c|c|c|c|c|c|c|}
\hline Código & OS Mnt Corretiva & Cod Parada & Modalidade & Falha & Causa & Ocorrência & Gravidade & Detectabilidade & OGD \\
\hline 0220RP03 & 02X05442 & $02 D 0629$ & ELÉTRICA & BAIXA PRESSAO & PRESSOSTATO & 1 & 10 & 10 & 100 \\
\hline 0220RP03 & $02 \times 34063$ & 02D0895 & MECÂNICA & DESGASTE & CORREIA & 1 & 10 & 10 & 100 \\
\hline 0220RP03 & 02S47537 & & MECÂNICA & RUIDO & CORREIA & 1 & 1 & 1 & 1 \\
\hline 0220RP03 & 02S63331 & & MECÂNICA & QUEBRA & POLIA & 1 & 1 & 1 & 1 \\
\hline 0220RP03 & 02S60691 & & MECÂNICA & QUEBRA & PROTECAO/TAMPA & 1 & 1 & 1 & 1 \\
\hline 0220RP03 & $02 \mathrm{~T} 57114$ & & MECÂNICA & QUEBRA & SIST. LUBRIFICACAO & 1 & 1 & 1 & 1 \\
\hline 0220RP03 & 02V07950 & & MECÂNICA & VAZAMENTO & LUBRIFIL & 1 & 1 & 1 & 1 \\
\hline 0220RP03 & $02 \mathrm{~V} 53365$ & & MECÂNICA & MELHORIA & PROTECAO/TAMPA & 1 & 1 & 1 & 1 \\
\hline 0220RP03 & 02W44071 & & ELÉTRICA & CURTO-CIRCUITO & SENSOR & 1 & 1 & 1 & 1 \\
\hline Subtotais & 41 & 34 & & & & 40 & & IRF & 3.307 \\
\hline 0220RP27 & 02R16982 & 02B6868 & ELÉTRICA & DESGASTE & CHAVE/BOTOEIRA & 1 & 10 & 10 & 100 \\
\hline 0220RP27 & 02R22332 & 02B7079 & MECÂNICA & VAZAMENTO INTERNO & HIDR.-CILINDRO & 1 & 10 & 10 & 100 \\
\hline 0220RP27 & 02R54627 & 02B7669 & ELÉTRICA & INTERRUPCAO DE SINAL & CLP & 1 & 10 & 10 & 100 \\
\hline 0220RP27 & 02R98634 & 02B8689 & ELÉTRICA & CURTO-CIRCUITO & SENSOR & 1 & 10 & 10 & 100 \\
\hline 0220RP27 & 02R86512 & 02B8545 & MECÂNICA & TRAVAMENTO & CONTRA-PONTO & 1 & 10 & 10 & 100 \\
\hline 0220RP27 & 02S06974 & 02B9061 & ELÉTRICA & TRAVAMENTO & PNEUM.-CILINDRO & 1 & 10 & 10 & 100 \\
\hline 0220RP27 & 02S06910 & 02B9055 & ELÉTRICA & DESREGULAGEM & CHAVE FIM-DE-CURSO & 1 & 10 & 10 & 100 \\
\hline 0220RP27 & 02S48616 & 02B9790 & ELÉTRICA & TRAVAMENTO & PNEUM.-VALVULA & 1 & 10 & 10 & 100 \\
\hline 0220RP27 & 02S50728 & $02 B 9873$ & ELÉTRICA & INTERRUPCAO DE SINAL & SENSOR & 1 & 10 & 10 & 100 \\
\hline 0220RP27 & 02S64072 & $02 \mathrm{C} 0491$ & MECÂNICA & DESLOCAMENTO & SENSOR & 1 & 10 & 10 & 100 \\
\hline 0220RP27 & 02S81044 & 02C0790 & ELÉTRICA & INTERRUPCAO DE SINAL & SENSOR & 1 & 10 & 10 & 100 \\
\hline 0220RP27 & $02 \mathrm{~T} 01969$ & 02C1298 & ELÉTRICA & TRAVAMENTO & SENSOR & 1 & 10 & 10 & 100 \\
\hline 0220RP27 & $02 \mathrm{~T} 02307$ & $02 \mathrm{C} 1316$ & MECÂNICA & DESREGULAGEM & OPERACAO & 1 & 10 & 10 & 100 \\
\hline 0220RP27 & $02 \mathrm{~T} 30615$ & 02C2075 & MECÂNICA & DESREGULAGEM & HIDR.-VALVULA & 1 & 10 & 10 & 100 \\
\hline 0220RP27 & $02 \mathrm{~T} 88803$ & 02C3120 & MECÂNICA & VAZAMENTO & HIDR.-TUBULACAO & 1 & 10 & 10 & 100 \\
\hline 0220RP27 & $02 \mathrm{~T} 94182$ & 02C3307 & MECÂNICA & QUEBRA & PARAFUSO & 1 & 10 & 10 & 100 \\
\hline 0220RP27 & 02U69028 & $02 \mathrm{C} 5482$ & ELÉTRICA & DEFEITO INTERMITENTE & RELE & 1 & 10 & 10 & 100 \\
\hline 0220RP27 & 02U83645 & 02C5898 & MECÂNICA & VAZAMENTO & HIDR.-CONEXAO & 1 & 10 & 10 & 100 \\
\hline 0220RP27 & 02U96132 & $02 \mathrm{C} 6046$ & MECÂNICA & TRAVAMENTO & PNEUM.-VALVULA & 1 & 10 & 10 & 100 \\
\hline 0220RP27 & 02V02116 & $02 \mathrm{C} 6171$ & MECÂNICA & ENTUPIMENTO & HIDR.-CONEXAO & 1 & 10 & 10 & 100 \\
\hline 0220RP27 & 02V03099 & $02 C 6195$ & MECÂNICA & SUJEIRA & PNEUM.-VALVULA & 1 & 10 & 10 & 100 \\
\hline 0220RP27 & 02V03838 & $02 C 6296$ & MECÂNICA & SUJEIRA & PNEUM.-VALVULA & 1 & 10 & 10 & 100 \\
\hline 0220RP27 & $02 \mathrm{~V} 47505$ & $02 C 7361$ & MECÂNICA & QUEBRA & PNEUM.-CILINDRO & 1 & 10 & 10 & 100 \\
\hline 0220RP27 & 02V49709 & 02C7504 & ELÉTRICA & MAL-CONTATO & SENSOR & 1 & 10 & 10 & 100 \\
\hline
\end{tabular}




\begin{tabular}{|c|c|c|c|c|c|c|c|c|c|}
\hline Código & OS Mnt Corretiva & Cod Parada & Modalidade & Falha & Causa & Ocorrência & Gravidade & Detectabilidade & OGD \\
\hline 0220RP27 & 02V49344 & $02 C 7449$ & MECÂNICA & VAZAMENTO & HIDR.-CILINDRO & 1 & 10 & 10 & 100 \\
\hline 0220RP27 & 02V83378 & $02 C 8160$ & MECÂNICA & DESGASTE & GUIA & 1 & 10 & 10 & 100 \\
\hline 0220RP27 & 02V94552 & 02C8298 & MECÂNICA & TRAVAMENTO & PNEUM.-VALVULA & 1 & 10 & 10 & 100 \\
\hline 0220RP27 & 02W21568 & 02C8902 & MECÂNICA & QUEBRA & PNEUM.-CILINDRO & 1 & 10 & 10 & 100 \\
\hline 0220RP27 & 02W39577 & 02C9155 & MECÂNICA & QUEBRA & GUIA & 1 & 10 & 10 & 100 \\
\hline 0220RP27 & 02W92232 & $02 \mathrm{D} 0153$ & MECÂNICA & DESREGULAGEM & HIDR.-VALVULA & 1 & 10 & 10 & 100 \\
\hline 0220RP27 & 02X05264 & $02 \mathrm{D} 0615$ & MECÂNICA & VAZAMENTO INTERNO & HIDR.-CILINDRO & 1 & 10 & 10 & 100 \\
\hline 0220RP27 & $02 X 34571$ & $02 \mathrm{D} 0916$ & ELÉTRICA & DESREGULAGEM & SENSOR & 1 & 10 & 10 & 100 \\
\hline 0220RP27 & $02 X 37621$ & 02D1010 & ELÉTRICA & INTERRUPCAO DE SINAL & CLP & 1 & 10 & 10 & 100 \\
\hline 0220RP27 & 02S15679 & & MECÂNICA & FOLGA & PARAFUSO & 1 & 1 & 1 & 1 \\
\hline 0220RP27 & $02 \mathrm{~T} 57150$ & & MECÂNICA & QUEBRA & HIDR.-CONEXAO & 1 & 1 & 1 & 1 \\
\hline 0220RP27 & 02U94759 & & MECÂNICA & SUJEIRA & BUCHA & 1 & 1 & 1 & 1 \\
\hline 0220RP27 & 02V60357 & & MECÂNICA & SUJEIRA & PNEUM.-VALVULA & 1 & 1 & 1 & 1 \\
\hline 0220RP27 & $02 W 54194$ & & MECÂNICA & VAZAMENTO & HIDR.-CONEXAO & 1 & 1 & 1 & 1 \\
\hline 0220RP27 & $02 W 89503$ & & MECÂNICA & TRAVAMENTO & HIDR.-CILINDRO & 1 & 1 & 1 & 1 \\
\hline Subtotais & 40 & 34 & & & & 39 & & IRF & 3.306 \\
\hline 0220RP04 & 02R11594 & 02B6644 & MECÂNICA & QUEBRA & CORRENTE & 1 & 10 & 10 & 100 \\
\hline 0220RP04 & 02R54495 & 02B7653 & ELÉTRICA & MAL-CONTATO & CHAVE/BOTOEIRA & 1 & 10 & 10 & 100 \\
\hline 0220RP04 & 02R55902 & 02B7736 & MECÂNICA & QUEBRA & CORRENTE & 1 & 10 & 10 & 100 \\
\hline 0220RP04 & 02R98279 & 02B8646 & ELÉTRICA & DESREGULAGEM & CHAVE FIM-DE-CURSO & 1 & 10 & 10 & 100 \\
\hline 0220RP04 & 02S03584 & 02B8893 & MECÂNICA & QUEBRA & PNEUM.-CILINDRO & 1 & 10 & 10 & 100 \\
\hline 0220RP04 & 02R99063 & 02B8728 & MECÂNICA & FOLGA & CORREIA & 1 & 10 & 10 & 100 \\
\hline 0220RP04 & 02R98313 & 02B8650 & MECÂNICA & MELHORIA & OPERACAO & 1 & 10 & 10 & 100 \\
\hline 0220RP04 & 02S02709 & 02B8830 & MECÂNICA & VAZAMENTO & HIDR.-TUBULACAO & 1 & 10 & 10 & 100 \\
\hline 0220RP04 & 02S03619 & 02B8900 & MECÂNICA & TRAVAMENTO & OLEO & 1 & 10 & 10 & 100 \\
\hline 0220RP04 & 02S10601 & 02B9259 & MECÂNICA & ROMPIMENTO & CORRENTE & 1 & 10 & 10 & 100 \\
\hline 0220RP04 & 02S53093 & 02B9963 & MECÂNICA & QUEBRA & CORRENTE & 1 & 10 & 10 & 100 \\
\hline 0220RP04 & 02S57981 & 02C0191 & MECÂNICA & QUEBRA & CORRENTE & 1 & 10 & 10 & 100 \\
\hline 0220RP04 & 02S66196 & 02C0612 & MECÂNICA & QUEBRA & MANOMETRO & 1 & 10 & 10 & 100 \\
\hline 0220RP04 & 02S66221 & $02 \mathrm{C} 0614$ & MECÂNICA & DESREGULAGEM & HIDR.-VALVULA & 1 & 10 & 10 & 100 \\
\hline 0220RP04 & $02 \mathrm{~T} 18112$ & 02C1960 & ELÉTRICA & INTERRUPCAO DE SINAL & MOTOR & 1 & 10 & 10 & 100 \\
\hline 0220RP04 & $02 \mathrm{~T} 49632$ & 02C2499 & MECÂNICA & QUEBRA & PARAFUSO & 1 & 10 & 10 & 100 \\
\hline 0220RP04 & $02 \mathrm{~T} 49641$ & 02C2500 & MECÂNICA & DESGASTE & PARAFUSO & 1 & 10 & 10 & 100 \\
\hline 0220RP04 & $02 T 57409$ & 02C2818 & MECÂNICA & TRAVAMENTO & ROLAMENTO & 1 & 10 & 10 & 100 \\
\hline
\end{tabular}




\begin{tabular}{|c|c|c|c|c|c|c|c|c|c|}
\hline Código & OS Mnt Corretiva & Cod Parada & Modalidade & Falha & Causa & Ocorrência & Gravidade & Detectabilidade & OGD \\
\hline 0220RP04 & 02U05800 & 02C3679 & ELÉTRICA & INTERRUPCAO DE SINAL & SENSOR & 1 & 10 & 10 & 100 \\
\hline 0220RP04 & 02U32120 & $02 C 4305$ & MECÂNICA & QUEBRA & BARRAMENTO MECANICO & 1 & 10 & 10 & 100 \\
\hline 0220RP04 & 02U39347 & 02C4968 & MECÂNICA & QUEBRA & CORRENTE & 1 & 10 & 10 & 100 \\
\hline 0220RP04 & 02V06639 & 02C6539 & MECÂNICA & TRAVAMENTO & GUIA & 1 & 10 & 10 & 100 \\
\hline 0220RP04 & 02V06602 & $02 C 6536$ & MECÂNICA & DESREGULAGEM & PNEUM.-VALVULA & 1 & 10 & 10 & 100 \\
\hline 0220RP04 & 02V41351 & $02 \mathrm{C} 7121$ & ELÉTRICA & CURTO-CIRCUITO & SENSOR & 1 & 10 & 10 & 100 \\
\hline 0220RP04 & 02V53999 & $02 C 7636$ & MECÂNICA & QUEBRA & CORREIA & 1 & 10 & 10 & 100 \\
\hline 0220RP04 & 02V61310 & 02C7934 & MECÂNICA & QUEBRA & CORRENTE & 1 & 10 & 10 & 100 \\
\hline 0220RP04 & 02V77054 & $02 C 8033$ & MECÂNICA & QUEBRA & PARAFUSO & 1 & 10 & 10 & 100 \\
\hline 0220RP04 & 02 V94712 & $02 C 8312$ & ELÉTRICA & TRAVAMENTO & CLP & 1 & 10 & 10 & 100 \\
\hline 0220RP04 & 02V98718 & $02 \mathrm{C} 8474$ & ELÉTRICA & INTERRUPCAO DE SINAL & CHAVE FIM-DE-CURSO & 1 & 10 & 10 & 100 \\
\hline 0220RP04 & $02 \mathrm{~W} 06353$ & $02 C 8698$ & ELÉTRICA & INTERRUPCAO DE SINAL & MOTOR & 1 & 10 & 10 & 100 \\
\hline 0220RP04 & 02W09289 & 02C8801 & MECÂNICA & VAZAMENTO & HIDR.-TUBULACAO & 1 & 10 & 10 & 100 \\
\hline 0220RP04 & 02W50198 & $02 \mathrm{C} 9491$ & MECÂNICA & TRAVAMENTO & GUIA & 1 & 10 & 10 & 100 \\
\hline 0220RP04 & 02R05850 & & MECÂNICA & VAZAMENTO & BUCHA & 1 & 1 & 10 & 10 \\
\hline 0220RP04 & 02V02553 & & MECÂNICA & QUEBRA & PROTECAO/TAMPA & 1 & 1 & 1 & 1 \\
\hline 0220RP04 & 02 V55522 & & MECÂNICA & VAZAMENTO & HIDR.-MANGUEIRA & 1 & 1 & 1 & 1 \\
\hline 0220RP04 & 02W00368 & & MECÂNICA & FIXACAO & BUCHA & 1 & 1 & 1 & 1 \\
\hline Subtotais & 37 & 33 & & & & 36 & & IRF & 3.213 \\
\hline 0220RP01 & 02R07581 & 02B6480 & MECÂNICA & TRAVAMENTO & PNEUM.-VALVULA & 1 & 10 & 10 & 100 \\
\hline 0220RP01 & 02R10746 & 02B6587 & MECÂNICA & QUEBRA & CORRENTE & 1 & 10 & 10 & 100 \\
\hline 0220RP01 & 02R70404 & 02B8299 & MECÂNICA & QUEBRA & GUIA & 1 & 10 & 10 & 100 \\
\hline 0220RP01 & 02S15241 & $02 B 9475$ & MECÂNICA & VAZAMENTO & PNEUM.-CILINDRO & 1 & 10 & 10 & 100 \\
\hline 0220RP01 & 02S15857 & 02B9490 & MECÂNICA & QUEBRA & PARAFUSO & 1 & 10 & 10 & 100 \\
\hline 0220RP01 & 02S31839 & 02B9554 & MECÂNICA & QUEBRA & GUIA & 1 & 10 & 10 & 100 \\
\hline 0220RP01 & 02S58668 & $02 \mathrm{C} 0242$ & MECÂNICA & QUEBRA & PARAFUSO & 1 & 10 & 10 & 100 \\
\hline 0220RP01 & 02S55377 & 02C0080 & ELÉTRICA & INTERRUPCAO DE SINAL & CHAVE FIM-DE-CURSO & 1 & 10 & 10 & 100 \\
\hline 0220RP01 & 02S58301 & $02 \mathrm{C} 0215$ & ELÉTRICA & INTERRUPCAO DE SINAL & SENSOR & 1 & 10 & 10 & 100 \\
\hline 0220RP01 & 02S58695 & $02 \mathrm{C} 0245$ & ELÉTRICA & CURTO-CIRCUITO & SENSOR & 1 & 10 & 10 & 100 \\
\hline 0220RP01 & 02S74169 & $02 \mathrm{C} 0737$ & MECÂNICA & QUEBRA & CORRENTE & 1 & 10 & 10 & 100 \\
\hline 0220RP01 & $02 \mathrm{~T} 12350$ & $02 \mathrm{C} 1692$ & ELÉTRICA & FALTA ENERGIA ELET. & MOTOR & 1 & 10 & 10 & 100 \\
\hline 0220RP01 & $02 \mathrm{~T} 30152$ & $02 C 2033$ & ELÉTRICA & INTERRUPCAO DE SINAL & CHAVE FIM-DE-CURSO & 1 & 10 & 10 & 100 \\
\hline 0220RP01 & $02 \mathrm{~T} 94164$ & $02 C 3305$ & MECÂNICA & QUEBRA & PARAFUSO & 1 & 10 & 10 & 100 \\
\hline 0220RP01 & 02U07871 & 02C3779 & MECÂNICA & QUEBRA & PARAFUSO & 1 & 10 & 10 & 100 \\
\hline
\end{tabular}




\begin{tabular}{|c|c|c|c|c|c|c|c|c|c|}
\hline Código & OS Mnt Corretiva & Cod Parada & Modalidade & Falha & Causa & Ocorrência & Gravidade & Detectabilidade & OGD \\
\hline 0220RP01 & 02U38455 & 02C4837 & MECÂNICA & QUEBRA & BUCHA & 1 & 10 & 10 & 100 \\
\hline 0220RP01 & 02U65451 & $02 C 5359$ & ELÉTRICA & MAL-CONTATO & CABO ELETRICO & 1 & 10 & 10 & 100 \\
\hline 0220RP01 & 02U69064 & $02 C 5484$ & ELÉTRICA & INTERRUPCAO DE SINAL & SENSOR & 1 & 10 & 10 & 100 \\
\hline 0220RP01 & 02U81255 & 02C5634 & ELÉTRICA & CABO ELE. DANIFICADO & SENSOR & 1 & 10 & 10 & 100 \\
\hline 0220RP01 & 02U72309 & $02 C 5544$ & MECÂNICA & TRAVAMENTO & PNEUM.-VALVULA & 1 & 10 & 10 & 100 \\
\hline 0220RP01 & 02U82753 & $02 C 5836$ & MECÂNICA & ENTUPIMENTO & HIDR.-CONEXAO & 1 & 10 & 10 & 100 \\
\hline 0220RP01 & $02 \mathrm{~V} 41495$ & $02 C 7134$ & MECÂNICA & VAZAMENTO & PNEUM.-CONEXAO & 1 & 10 & 10 & 100 \\
\hline 0220RP01 & $02 \mathrm{~V} 44349$ & $02 C 7257$ & ELÉTRICA & DESGASTE & CORREIA & 1 & 10 & 10 & 100 \\
\hline 0220RP01 & 02W88470 & 02C9958 & MECÂNICA & VAZAMENTO & HIDR.-CILINDRO & 1 & 10 & 10 & 100 \\
\hline 0220RP01 & 02X00786 & 02D0458 & ELÉTRICA & INTERRUPCAO DE SINAL & CHAVE/BOTOEIRA & 1 & 10 & 10 & 100 \\
\hline 0220RP01 & $02 \times 05317$ & 02D0619 & MECÂNICA & QUEBRA & CORRENTE & 1 & 10 & 10 & 100 \\
\hline 0220RP01 & $02 X 35712$ & 02D0944 & MECÂNICA & QUEBRA & GUIA & 1 & 10 & 10 & 100 \\
\hline 0220RP01 & 02X34054 & 02D0896 & MECÂNICA & TRAVAMENTO & BARRAMENTO MECANICO & 1 & 10 & 10 & 100 \\
\hline 0220RP01 & $02 X 37248$ & 02D0991 & MECÂNICA & QUEBRA & PARAFUSO & 1 & 10 & 10 & 100 \\
\hline 0220RP01 & 02S13635 & & MECÂNICA & VAZAMENTO & PNEUM.-CILINDRO & 1 & 1 & 1 & 1 \\
\hline 0220RP01 & 02S63377 & & ELÉTRICA & DESLOCAMENTO & HIDR.-CILINDRO & 1 & 1 & 1 & 1 \\
\hline 0220RP01 & $02 \mathrm{~T} 17845$ & & MECÂNICA & SUJEIRA & GUIA & 1 & 1 & 1 & 1 \\
\hline 0220RP01 & $02 \mathrm{~T} 95403$ & & MECÂNICA & FOLGA & ROLAMENTO & 1 & 1 & 1 & 1 \\
\hline 0220RP01 & 02U65914 & & ELÉTRICA & OPERACAO & MATERIAL & 1 & 1 & 1 & 1 \\
\hline 0220RP01 & 02U94660 & & MECÂNICA & QUEBRA & PROTECAO/TAMPA & 1 & 1 & 1 & 1 \\
\hline 0220RP01 & 02V22559 & & MECÂNICA & QUEBRA & PROTECAO/TAMPA & 1 & 1 & 1 & 1 \\
\hline 0220RP01 & $02 \mathrm{~V} 40771$ & & MECÂNICA & QUEBRA & GUIA & 1 & 1 & 1 & 1 \\
\hline 0220RP01 & $02 \mathrm{~V} 60366$ & & MECÂNICA & VAZAMENTO & HIDR.-CONEXAO & 1 & 1 & 1 & 1 \\
\hline 0220RP01 & $02 W 54185$ & & MECÂNICA & VAZAMENTO & HIDR.-CONEXAO & 1 & 1 & 1 & 1 \\
\hline 0220RP01 & 02X08519 & & ELÉTRICA & INTERRUPCAO DE SINAL & CLP & 1 & 1 & 1 & 1 \\
\hline 0220RP01 & $02 X 26624$ & & MECÂNICA & TRAVAMENTO & PNEUM.-VALVULA & 1 & 1 & 1 & 1 \\
\hline Subtotais & 42 & 30 & & & & 41 & & IRF & 2.912 \\
\hline 0220RP05 & 02R38156 & 02B6818 & MECÂNICA & DESLOCAMENTO & QUEBRA & 1 & 10 & 10 & 100 \\
\hline 0220RP05 & $02 \mathrm{R} 22323$ & 02B7078 & MECÂNICA & DESGASTE & ROSCA ESPANADA & 1 & 10 & 10 & 100 \\
\hline 0220RP05 & 02R43328 & 02B7404 & ELÉTRICA & INTERRUPCAO DE SINAL & SENSOR & 1 & 10 & 10 & 100 \\
\hline 0220RP05 & 02R37727 & 02B7301 & MECÂNICA & QUEBRA & CORRENTE & 1 & 10 & 10 & 100 \\
\hline 0220RP05 & 02R58311 & $02 B 7813$ & MECÂNICA & ROMPIMENTO & CORRENTE & 1 & 10 & 10 & 100 \\
\hline 0220RP05 & 02R57884 & 02B7805 & ELÉTRICA & INTERRUPCAO DE SINAL & CONTROLADOR & 1 & 10 & 10 & 100 \\
\hline 0220RP05 & 02R61959 & 02B7937 & MECÂNICA & DESREGULAGEM & GUIA & 1 & 10 & 10 & 100 \\
\hline
\end{tabular}




\begin{tabular}{|c|c|c|c|c|c|c|c|c|c|}
\hline Código & OS Mnt Corretiva & Cod Parada & Modalidade & Falha & Causa & Ocorrência & Gravidade & Detectabilidade & OGD \\
\hline 0220RP05 & 02R65143 & 02B8099 & ELÉTRICA & INTERRUPCAO DE SINAL & MOTOR & 1 & 10 & 10 & 100 \\
\hline 0220RP05 & 02R70574 & 02B8315 & ELÉTRICA & INTERRUPCAO DE SINAL & RELE & 1 & 10 & 10 & 100 \\
\hline 0220RP05 & 02S09971 & 02B9227 & ELÉTRICA & INTERRUPCAO DE SINAL & SENSOR & 1 & 10 & 10 & 100 \\
\hline 0220RP05 & 02S10228 & 02B9237 & ELÉTRICA & INTERRUPCAO DE SINAL & SENSOR & 1 & 10 & 10 & 100 \\
\hline 0220RP05 & 02S59337 & $02 \mathrm{C} 0297$ & MECÂNICA & FOLGA & ROLAMENTO & 1 & 10 & 10 & 100 \\
\hline 0220RP05 & 02S62207 & $02 \mathrm{C} 0436$ & MECÂNICA & QUEBRA & PARAFUSO & 1 & 10 & 10 & 100 \\
\hline 0220RP05 & 02S66249 & $02 C 0616$ & MECÂNICA & QUEBRA & CORRENTE & 1 & 10 & 10 & 100 \\
\hline 0220RP05 & $02 \mathrm{~T} 30679$ & 02C2079 & MECÂNICA & TRAVAMENTO & CORREIA & 1 & 10 & 10 & 100 \\
\hline 0220RP05 & $02 \mathrm{~T} 46154$ & $02 C 2343$ & ELÉTRICA & INTERRUPCAO DE SINAL & POTENCIOMETRO & 1 & 10 & 10 & 100 \\
\hline 0220RP05 & 02U71710 & $02 C 5514$ & MECÂNICA & FOLGA & CORREIA & 1 & 10 & 10 & 100 \\
\hline 0220RP05 & 02U92975 & $02 C 5975$ & ELÉTRICA & DESREGULAGEM & CHAVE FIM-DE-CURSO & 1 & 10 & 10 & 100 \\
\hline 0220RP05 & 02V55238 & $02 C 7678$ & MECÂNICA & FOLGA & EIXO & 1 & 10 & 10 & 100 \\
\hline 0220RP05 & 02V94561 & 02C8299 & MECÂNICA & VAZAMENTO & PNEUM.-MANGUEIRA & 1 & 10 & 10 & 100 \\
\hline 0220RP05 & 02V97461 & $02 \mathrm{C} 8416$ & ELÉTRICA & QUEIMA & SOLENOIDE & 1 & 10 & 10 & 100 \\
\hline 0220RP05 & 02V99209 & 02C8505 & MECÂNICA & QUEBRA & SENSOR & 1 & 10 & 10 & 100 \\
\hline 0220RP05 & 02W90341 & 02D0059 & MECÂNICA & SUJEIRA & SIST. REFRIGERACAO & 1 & 10 & 10 & 100 \\
\hline 0220RP05 & 02W91554 & 02D0101 & MECÂNICA & TRAVAMENTO & HIDR.-CILINDRO & 1 & 10 & 10 & 100 \\
\hline 0220RP05 & 02X03774 & $02 \mathrm{D} 0536$ & MECÂNICA & FOLGA & GUIA & 1 & 10 & 10 & 100 \\
\hline 0220RP05 & 02X03694 & 02D0531 & MECÂNICA & TRAVAMENTO & MANCAL & 1 & 10 & 10 & 100 \\
\hline 0220RP05 & 02X35758 & $02 \mathrm{D} 0947$ & MECÂNICA & DESREGULAGEM & PARAFUSO & 1 & 10 & 10 & 100 \\
\hline 0220RP05 & 02W97219 & $02 \mathrm{D} 0331$ & LIMPEZA & CONTAMINACAO & SUJEIRA & 1 & 10 & 10 & 100 \\
\hline 0220RP05 & 02R21468 & & ELÉTRICA & CURTO-CIRCUITO & ILUMINACAO & 1 & 1 & 1 & 1 \\
\hline 0220RP05 & 02R47315 & & ELÉTRICA & SUJEIRA & PNEUM.-VALVULA & 1 & 1 & 1 & 1 \\
\hline 0220RP05 & 02V36241 & & ELÉTRICA & RETRABALHO DO ANEL & SIST. REFRIGERACAO & 1 & 1 & 1 & 1 \\
\hline 0220RP05 & $02 \mathrm{~V} 50055$ & & MECÂNICA & QUEBRA & PROTECAO/TAMPA & 1 & 1 & 1 & 1 \\
\hline 0220RP05 & 02V51651 & & MECÂNICA & VAZAMENTO & RESERVATORIO & 1 & 1 & 1 & 1 \\
\hline 0220RP05 & 02W00395 & & MECÂNICA & VAZAMENTO & HIDR.-CONEXAO & 1 & 1 & 1 & 1 \\
\hline Subtotais & 35 & 29 & & & & 34 & & IRF & 2.806 \\
\hline 0220RP19 & 02R86754 & 02B8560 & ELÉTRICA & INTERRUPCAO DE SINAL & CHAVE FIM-DE-CURSO & 1 & 10 & 10 & 100 \\
\hline 0220RP19 & 02S54706 & $02 \mathrm{C} 0051$ & MECÂNICA & SUJEIRA & PNEUM.-VALVULA & 1 & 10 & 10 & 100 \\
\hline 0220RP19 & 02S60879 & $02 \mathrm{C} 0377$ & MECÂNICA & QUEBRA & PARAFUSO & 1 & 10 & 10 & 100 \\
\hline 0220RP19 & 02S66169 & 02C0609 & MECÂNICA & QUEBRA & PNEUM.-CILINDRO & 1 & 10 & 10 & 100 \\
\hline 0220RP19 & $02 \mathrm{~T} 10325$ & $02 \mathrm{C} 1544$ & MECÂNICA & TRAVAMENTO & ROLAMENTO & 1 & 10 & 10 & 100 \\
\hline 0220RP19 & $02 \mathrm{~T} 30571$ & 02C2071 & ELÉTRICA & QUEBRA & SENSOR & 1 & 10 & 10 & 100 \\
\hline
\end{tabular}




\begin{tabular}{|c|c|c|c|c|c|c|c|c|c|}
\hline Código & OS Mnt Corretiva & Cod Parada & Modalidade & Falha & Causa & Ocorrência & Gravidade & Detectabilidade & OGD \\
\hline 0220RP19 & $02 T 88689$ & 02C3108 & ELÉTRICA & MAL-CONTATO & SENSOR & 1 & 10 & 10 & 100 \\
\hline 0220RP19 & $02 \mathrm{~T} 89045$ & 02C3140 & MECÂNICA & DESGASTE & ROLAMENTO & 1 & 10 & 10 & 100 \\
\hline 0220RP19 & 02U69046 & $02 C 5483$ & MECÂNICA & INTERRUPCAO DE SINAL & SENSOR & 1 & 10 & 10 & 100 \\
\hline 0220RP19 & $02 \mathrm{~V} 02125$ & $02 \mathrm{C} 6172$ & MECÂNICA & BAIXA VAZAO & PRESSOSTATO & 1 & 10 & 10 & 100 \\
\hline 0220RP19 & 02V94749 & $02 \mathrm{C} 8314$ & ELÉTRICA & DESREGULAGEM & CHAVE FIM-DE-CURSO & 1 & 10 & 10 & 100 \\
\hline 0220RP19 & 02W00518 & $02 \mathrm{C} 8541$ & MECÂNICA & QUEBRA & PARAFUSO & 1 & 10 & 10 & 100 \\
\hline 0220RP19 & 02W22692 & $02 C 8966$ & ELÉTRICA & CURTO-CIRCUITO & CABO ELETRICO & 1 & 10 & 10 & 100 \\
\hline 0220RP19 & 02W05103 & $02 C 8649$ & MECÂNICA & TRAVAMENTO & PNEUM.-VALVULA & 1 & 10 & 10 & 100 \\
\hline 0220RP19 & 02W09430 & $02 C 8818$ & ELÉTRICA & TRAVAMENTO & CLP & 1 & 10 & 10 & 100 \\
\hline 0220RP19 & $02 \mathrm{~W} 23165$ & 02C8989 & MECÂNICA & BAIXA PRESSAO & PNEUM.-VALVULA & 1 & 10 & 10 & 100 \\
\hline 0220RP19 & 02W23557 & 02C9011 & ELÉTRICA & INTERRUPCAO DE SINAL & MOTOR & 1 & 10 & 10 & 100 \\
\hline 0220RP19 & 02W51259 & $02 C 9561$ & MECÂNICA & DESGASTE & PARAFUSO & 1 & 10 & 10 & 100 \\
\hline 0220RP19 & $02 W 57093$ & $02 C 9727$ & ELÉTRICA & PERDA DE MEMORIA & CLP & 1 & 10 & 10 & 100 \\
\hline 0220RP19 & 02W91607 & 02D0105 & MECÂNICA & QUEBRA & HIDR.-CILINDRO & 1 & 10 & 10 & 100 \\
\hline 0220RP19 & 02W95471 & 02D0270 & MECÂNICA & QUEBRA & GUIA & 1 & 10 & 10 & 100 \\
\hline 0220RP19 & 02X05424 & 02D0628 & ELÉTRICA & PERDA DE MEMORIA & CLP & 1 & 10 & 10 & 100 \\
\hline 0220RP19 & $02 X 03523$ & $02 \mathrm{D} 0521$ & MECÂNICA & VAZAMENTO & HIDR.-MANGUEIRA & 1 & 10 & 10 & 100 \\
\hline 0220RP19 & $02 X 07681$ & $02 \mathrm{D} 0721$ & ELÉTRICA & INTERRUPCAO DE SINAL & CLP & 1 & 10 & 10 & 100 \\
\hline 0220RP19 & 02R70299 & & ELÉTRICA & INTERRUPCAO DE SINAL & SENSOR & 1 & 1 & 1 & 1 \\
\hline 0220RP19 & 02S01675 & & ELÉTRICA & INTERRUPCAO DE SINAL & SENSOR & 1 & 1 & 1 & 1 \\
\hline 0220RP19 & 02S57062 & & MECÂNICA & DESREGULAGEM & PNEUM.-VALVULA & 1 & 1 & 1 & 1 \\
\hline 0220RP19 & 02S58659 & & MECÂNICA & SUJEIRA & SUJEIRA & 1 & 1 & 1 & 1 \\
\hline 0220RP19 & 02U04115 & & MECÂNICA & QUEBRA & PROTECAO/TAMPA & 1 & 1 & 1 & 1 \\
\hline 0220RP19 & 02W07762 & & MECÂNICA & VAZAMENTO & PNEUM.-MANGUEIRA & 1 & 1 & 1 & 1 \\
\hline Subtotais & 31 & 25 & & & & 30 & & IRF & 2.406 \\
\hline 0220RP02 & 02R17115 & 02B6875 & MECÂNICA & QUEBRA & CORRENTE & 1 & 10 & 10 & 100 \\
\hline 0220RP02 & 02R21663 & 02B7050 & ELÉTRICA & INTERRUPCAO DE SINAL & SENSOR & 1 & 10 & 10 & 100 \\
\hline 0220RP02 & 02R54333 & 02B7639 & MECÂNICA & QUEBRA & QUEBRA & 1 & 10 & 10 & 100 \\
\hline 0220RP02 & 02R64705 & 02B8060 & MECÂNICA & QUEBRA & CONTRA-PONTO & 1 & 10 & 10 & 100 \\
\hline 0220RP02 & 02R72554 & 02B8424 & MECÂNICA & QUEBRA & PARAFUSO & 1 & 10 & 10 & 100 \\
\hline 0220RP02 & 02R73624 & 02B8475 & MECÂNICA & SUJEIRA & HIDR.-TUBULACAO & 1 & 10 & 10 & 100 \\
\hline 0220RP02 & 02S81614 & $02 \mathrm{C} 0825$ & MECÂNICA & FOLGA & FOLGA & 1 & 10 & 10 & 100 \\
\hline 0220RP02 & $02 S 81623$ & $02 \mathrm{C} 0826$ & MECÂNICA & QUEBRA & EIXO & 1 & 10 & 10 & 100 \\
\hline 0220RP02 & 02S81115 & 02C0795 & ELÉTRICA & INTERRUPCAO DE SINAL & FOLGA & 1 & 10 & 10 & 100 \\
\hline
\end{tabular}




\begin{tabular}{|c|c|c|c|c|c|c|c|c|c|}
\hline Código & OS Mnt Corretiva & Cod Parada & Modalidade & Falha & Causa & Ocorrência & Gravidade & Detectabilidade & OGD \\
\hline 0220RP02 & 02Т07650 & $02 \mathrm{C} 1483$ & MECÂNICA & QUEBRA & GUIA & 1 & 10 & 10 & 100 \\
\hline 0220RP02 & $02 \mathrm{~T} 50246$ & $02 C 2536$ & MECÂNICA & TREPIDACAO & GUIA & 1 & 10 & 10 & 100 \\
\hline 0220RP02 & 02 T90391 & 02C3170 & MECÂNICA & FOLGA & GUIA & 1 & 10 & 10 & 100 \\
\hline 0220RP02 & 02U66281 & 02C5397 & MECÂNICA & QUEBRA & GUIA & 1 & 10 & 10 & 100 \\
\hline 0220RP02 & 02U96141 & $02 \mathrm{C} 6047$ & MECÂNICA & DESGASTE & PARAFUSO & 1 & 10 & 10 & 100 \\
\hline 0220RP02 & 02V02946 & $02 C 6186$ & ELÉTRICA & INTERRUPCAO DE SINAL & CLP & 1 & 10 & 10 & 100 \\
\hline 0220RP02 & $02 \mathrm{~V} 04294$ & $02 C 6354$ & MECÂNICA & QUEBRA & ROLAMENTO & 1 & 10 & 10 & 100 \\
\hline 0220RP02 & 02 V28624 & $02 \mathrm{C} 6971$ & MECÂNICA & QUEBRA & PARAFUSO & 1 & 10 & 10 & 100 \\
\hline 0220RP02 & 02 V83403 & $02 C 8162$ & MECÂNICA & FOLGA & CORREIA & 1 & 10 & 10 & 100 \\
\hline 0220RP02 & 02 V97425 & $02 C 8412$ & ELÉTRICA & CURTO-CIRCUITO & SENSOR & 1 & 10 & 10 & 100 \\
\hline 0220RP02 & 02W42518 & 02C9318 & MECÂNICA & QUEBRA & CORRENTE & 1 & 10 & 10 & 100 \\
\hline 0220RP02 & 02W54880 & 02C9700 & MECÂNICA & QUEBRA & PARAFUSO & 1 & 10 & 10 & 100 \\
\hline 0220RP02 & $02 \times 39433$ & $02 \mathrm{D} 1115$ & ELÉTRICA & TRAVAMENTO & CLP & 1 & 10 & 10 & 100 \\
\hline 0220RP02 & 02S48386 & & MECÂNICA & SUJEIRA & GUIA & 1 & 1 & 1 & 1 \\
\hline 0220RP02 & $02 \mathrm{~T} 02548$ & & MECÂNICA & QUEBRA & GUIA & 1 & 1 & 1 & 1 \\
\hline 0220RP02 & 02V50199 & & MECÂNICA & QUEBRA & PROTECAO/TAMPA & 1 & 1 & 1 & 1 \\
\hline 0220RP02 & 02V62621 & & MECÂNICA & QUEBRA & PROTECAO/TAMPA & 1 & 1 & 1 & 1 \\
\hline 0220RP02 & 02W03089 & & MECÂNICA & DESREGULAGEM & REDUTOR & 1 & 1 & 1 & 1 \\
\hline 0220RP02 & 02W56637 & & ELÉTRICA & DEFEITO INTERMITENTE & SENSOR & 1 & 1 & 1 & 1 \\
\hline Subtotais & 29 & 23 & & & & 28 & & IRF & 2.206 \\
\hline 0220RP18 & 02R38012 & 02B7315 & MECÂNICA & FOLGA & CORREIA & 1 & 10 & 10 & 100 \\
\hline 0220RP18 & 02R22895 & 02B7247 & MECÂNICA & VAZAMENTO & BOMBA & 1 & 10 & 10 & 100 \\
\hline 0220RP18 & 02R57312 & 02B7783 & ELÉTRICA & QUEBRA & SENSOR & 1 & 10 & 10 & 100 \\
\hline 0220RP18 & 02R69238 & 02B8261 & MECÂNICA & VAZAMENTO & BOMBA & 1 & 10 & 10 & 100 \\
\hline 0220RP18 & 02R86683 & 02B8553 & MECÂNICA & QUEBRA & GUIA & 1 & 10 & 10 & 100 \\
\hline 0220RP18 & 02R99125 & 02B8731 & MECÂNICA & QUEBRA & GUIA & 1 & 10 & 10 & 100 \\
\hline 0220RP18 & 02S02727 & 02B8831 & MECÂNICA & SUJEIRA & PNEUM.-VALVULA & 1 & 10 & 10 & 100 \\
\hline 0220RP18 & 02S10362 & 02B9247 & ELÉTRICA & CABO ELE. DANIFICADO & SENSOR & 1 & 10 & 10 & 100 \\
\hline 0220RP18 & 02S50826 & 02B9881 & MECÂNICA & FOLGA & BUCHA & 1 & 10 & 10 & 100 \\
\hline 0220RP18 & 02S55420 & $02 \mathrm{C} 0084$ & MECÂNICA & BAIXA PRESSAO & BOMBA & 1 & 10 & 10 & 100 \\
\hline 0220RP18 & $02 \mathrm{~T} 23240$ & $02 C 1976$ & MECÂNICA & ROMPIMENTO & PNEUM.-MANGUEIRA & 1 & 10 & 10 & 100 \\
\hline 0220RP18 & $02 \mathrm{~T} 89036$ & 02C3139 & MECÂNICA & QUEBRA & PARAFUSO & 1 & 10 & 10 & 100 \\
\hline 0220RP18 & 02U31577 & 02C4499 & MECÂNICA & QUEBRA & PARAFUSO & 1 & 10 & 10 & 100 \\
\hline 0220RP18 & 02U51377 & 02C5244 & ELÉTRICA & CURTO-CIRCUITO & SENSOR & 1 & 10 & 10 & 100 \\
\hline
\end{tabular}




\begin{tabular}{|c|c|c|c|c|c|c|c|c|c|}
\hline Código & OS Mnt Corretiva & Cod Parada & Modalidade & Falha & Causa & Ocorrência & Gravidade & Detectabilidade & OGD \\
\hline 0220RP18 & 02V05202 & $02 \mathrm{C} 6483$ & ELÉTRICA & QUEIMA & SENSOR & 1 & 10 & 10 & 100 \\
\hline 0220RP18 & 02V42546 & 02C7200 & MECÂNICA & VAZAMENTO & HIDR.-CONEXAO & 1 & 10 & 10 & 100 \\
\hline 0220RP18 & 02W22674 & 02C8965 & ELÉTRICA & TRAVAMENTO & CLP & 1 & 10 & 10 & 100 \\
\hline 0220RP18 & 02X09509 & 02D0769 & ELÉTRICA & QUEBRA & SENSOR & 1 & 10 & 10 & 100 \\
\hline 0220RP18 & 02R18659 & & MECÂNICA & MELHORIA & EIXO & 1 & 1 & 1 & 1 \\
\hline 0220RP18 & 02R53049 & & ELÉTRICA & CURTO-CIRCUITO & SENSOR & 1 & 1 & 1 & 1 \\
\hline 0220RP18 & 02R57900 & & MECÂNICA & SUJEIRA & SIST. REFRIGERACAO & 1 & 1 & 1 & 1 \\
\hline 0220RP18 & 02S53841 & & MECÂNICA & QUEBRA & PROTECAO/TAMPA & 1 & 1 & 1 & 1 \\
\hline 0220RP18 & 02S97402 & & MECÂNICA & VAZAMENTO INTERNO & HIDR.-VALVULA & 1 & 1 & 1 & 1 \\
\hline 0220RP18 & 02 Т97027 & & MECÂNICA & SUJEIRA & BOMBA & 1 & 1 & 1 & 1 \\
\hline 0220RP18 & 02 V97112 & & ELÉTRICA & MEDICAO INCORRETA & CONTROLADOR & 1 & 1 & 1 & 1 \\
\hline Subtotais & 26 & 19 & & & & 25 & & IRF & 1.807 \\
\hline 0220RP28 & 02R54529 & $02 \mathrm{~B} 7656$ & ELÉTRICA & MAL-CONTATO & CABO ELETRICO & 1 & 10 & 10 & 100 \\
\hline 0220RP28 & 02R57401 & 02B7786 & ELÉTRICA & DESREGULAGEM & PRESSOSTATO & 1 & 10 & 10 & 100 \\
\hline 0220RP28 & 02R70501 & 02B8308 & ELÉTRICA & INTERRUPCAO DE SINAL & PRESSOSTATO & 1 & 10 & 10 & 100 \\
\hline 0220RP28 & 02S02567 & 02B8818 & MECÂNICA & TRAVAMENTO & MOTOR & 1 & 10 & 10 & 100 \\
\hline 0220RP28 & 02S03931 & 02B8909 & MECÂNICA & DESGASTE & VIDA UTIL & 1 & 10 & 10 & 100 \\
\hline 0220RP28 & 02S13412 & 02B9321 & ELÉTRICA & BAIXA VAZAO & SIST. LUBRIFICACAO & 1 & 10 & 10 & 100 \\
\hline 0220RP28 & 02S48796 & 02B9803 & MECÂNICA & QUEBRA & QUEBRA & 1 & 10 & 10 & 100 \\
\hline 0220RP28 & 02S54662 & $02 C 0049$ & MECÂNICA & QUEBRA & QUEBRA & 1 & 10 & 10 & 100 \\
\hline 0220RP28 & 02S61244 & 02C0401 & ELÉTRICA & DESREGULAGEM & SENSOR & 1 & 10 & 10 & 100 \\
\hline 0220RP28 & 02S64928 & $02 \mathrm{C} 0526$ & MECÂNICA & QUEBRA & CONTRA-PONTO & 1 & 10 & 10 & 100 \\
\hline 0220RP28 & $02 S 97723$ & 02C1019 & MECÂNICA & TRAVAMENTO & MOTOR & 1 & 10 & 10 & 100 \\
\hline 0220RP28 & 02 Т01978 & 02C1300 & ELÉTRICA & MAL-CONTATO & SECCIONADORA & 1 & 10 & 10 & 100 \\
\hline 0220RP28 & 02Т07669 & 02C1484 & MECÂNICA & QUEBRA & PARAFUSO & 1 & 10 & 10 & 100 \\
\hline 0220RP28 & 02Т90658 & 02C3184 & ELÉTRICA & QUEBRA & SENSOR & 1 & 10 & 10 & 100 \\
\hline 0220RP28 & 02Т98099 & 02C3430 & MECÂNICA & TRAVAMENTO & ROLAMENTO & 1 & 10 & 10 & 100 \\
\hline 0220RP28 & 02U06104 & 02C3700 & ELÉTRICA & INTERRUPCAO DE SINAL & PRESSOSTATO & 1 & 10 & 10 & 100 \\
\hline 0220RP28 & 02U05980 & 02C3690 & MECÂNICA & VAZAMENTO & HIDR.-CONEXAO & 1 & 10 & 10 & 100 \\
\hline 0220RP28 & $02 X 00795$ & $02 \mathrm{D} 0459$ & ELÉTRICA & INTERRUPCAO DE SINAL & CONTROLADOR & 1 & 10 & 10 & 100 \\
\hline 0220RP28 & $02 X 09377$ & 02D0759 & MECÂNICA & QUEBRA & GUIA & 1 & 10 & 10 & 100 \\
\hline 0220RP28 & 02S47617 & & MECÂNICA & MELHORIA & SIST. LUBRIFICACAO & 1 & 1 & 1 & 1 \\
\hline 0220RP28 & 02U66227 & & MECÂNICA & QUEBRA & ROLAMENTO & 1 & 1 & 1 & 1 \\
\hline 0220RP28 & $02 \mathrm{~W} 42885$ & & MECÂNICA & MELHORIA & PROTECAO/TAMPA & 1 & 1 & 1 & 1 \\
\hline
\end{tabular}




\begin{tabular}{|c|c|c|c|c|c|c|c|c|c|}
\hline Código & OS Mnt Corretiva & Cod Parada & Modalidade & Falha & Causa & Ocorrência & Gravidade & Detectabilidade & OGD \\
\hline $\begin{array}{c}\text { 0220RP28 } \\
\text { Subtotais }\end{array}$ & $\begin{array}{c}\text { 02W87024 } \\
24\end{array}$ & 20 & MECÂNICA & VAZAMENTO & HIDR.-CONEXAO & $\begin{array}{c}1 \\
23\end{array}$ & 1 & $\begin{array}{c}1 \\
\text { IRF }\end{array}$ & $\begin{array}{c}1 \\
\mathbf{1 . 9 0 4}\end{array}$ \\
\hline $0220 \mathrm{RP} 23$ & 02R21681 & $02 \mathrm{~B} 7053$ & ELÉTRICA & FALTA ENERGIA ELET. & ELETRODUTO & 1 & 10 & 10 & 100 \\
\hline 0220RP23 & 02R61325 & 02B7920 & MECÂNICA & QUEBRA & GUIA & 1 & 10 & 10 & 100 \\
\hline 0220RP23 & 02R69130 & 02B8245 & MECÂNICA & QUEBRA & PARAFUSO & 1 & 10 & 10 & 100 \\
\hline $0220 \mathrm{RP} 23$ & 02R71895 & 02B8374 & MECÂNICA & QUEBRA & HIDR.-TUBULACAO & 1 & 10 & 10 & 100 \\
\hline 0220RP23 & 02S05396 & 02B9014 & ELÉTRICA & INTERRUPCAO DE SINAL & CHAVE FIM-DE-CURSO & 1 & 10 & 10 & 100 \\
\hline 0220RP23 & 02S43452 & 02B9679 & MECÂNICA & QUEBRA & QUEBRA & 1 & 10 & 10 & 100 \\
\hline 0220RP23 & 02S54519 & $02 C 0039$ & MECÂNICA & DEFORMACAO & ROSCA ESPANADA & 1 & 10 & 10 & 100 \\
\hline 0220RP23 & $02 \mathrm{~T} 06483$ & $02 \mathrm{C} 1424$ & MECÂNICA & ENTUPIMENTO & PNEUM.-VALVULA & 1 & 10 & 10 & 100 \\
\hline 0220RP23 & 02U06328 & $02 \mathrm{C} 3717$ & MECÂNICA & DESGASTE & PARAFUSO & 1 & 10 & 10 & 100 \\
\hline 0220RP23 & 02U05016 & $02 \mathrm{C} 3646$ & ELÉTRICA & INTERRUPCAO DE SINAL & CHAVE FIM-DE-CURSO & 1 & 10 & 10 & 100 \\
\hline 0220RP23 & 02U82824 & $02 \mathrm{C} 5841$ & MECÂNICA & QUEBRA & PROTECAO/TAMPA & 1 & 10 & 10 & 100 \\
\hline 0220RP23 & 02U96025 & $02 \mathrm{C} 6035$ & MECÂNICA & DESGASTE & GUIA & 1 & 10 & 10 & 100 \\
\hline 0220RP23 & 02 V31111 & $02 C 6983$ & ELÉTRICA & DESLOCAMENTO & CHAVE FIM-DE-CURSO & 1 & 10 & 10 & 100 \\
\hline 0220RP23 & $02 \mathrm{~V} 97693$ & $02 \mathrm{C} 8434$ & MECÂNICA & QUEBRA & PARAFUSO & 1 & 10 & 10 & 100 \\
\hline 0220RP23 & 02W09047 & $02 \mathrm{C} 8770$ & MECÂNICA & DESGASTE & PARAFUSO & 1 & 10 & 10 & 100 \\
\hline 0220RP23 & $02 \mathrm{~W} 23316$ & 02C8770 & ELÉTRICA & INTERRUPCAO DE SINAL & CHAVE FIM-DE-CURSO & 1 & 10 & 10 & 100 \\
\hline 0220RP23 & $02 \mathrm{~W} 22601$ & 02C8960 & MECÂNICA & MEDICAO INCORRETA & HIDR.-VALVULA & 1 & 10 & 10 & 100 \\
\hline 0220RP23 & 02W50580 & $02 C 9519$ & MECÂNICA & ROMPIMENTO & CORRENTE & 1 & 10 & 10 & 100 \\
\hline 0220RP23 & $02 \mathrm{R} 99875$ & & MECÂNICA & FOLGA & GUIA & 1 & 1 & 1 & 1 \\
\hline 0220RP23 & 02S97466 & & MECÂNICA & TRAVAMENTO & PNEUM.-VALVULA & 1 & 1 & 1 & 1 \\
\hline 0220RP23 & 02U66129 & & MECÂNICA & QUEBRA & PROTECAO/TAMPA & 1 & 1 & 1 & 1 \\
\hline 0220RP23 & 02V23004 & & MECÂNICA & QUEBRA & GUIA & 1 & 1 & 1 & 1 \\
\hline 0220RP23 & $02 \mathrm{~V} 62701$ & & MECÂNICA & SUJEIRA & PNEUM.-VALVULA & 1 & 1 & 1 & 1 \\
\hline 0220RP23 & 02W98227 & & MECÂNICA & FOLGA & GUIA & 1 & 1 & 1 & 1 \\
\hline Subtotais & 24 & 18 & & & & 24 & & IRF & 1.806 \\
\hline 02203226 & 02R10862 & 02B6576 & ELÉTRICA & INTERRUPCAO DE SINAL & SENSOR & 1 & 10 & 10 & 100 \\
\hline 02203226 & 02R73688 & 02B8479 & ELÉTRICA & DESLOCAMENTO & CHAVE FIM-DE-CURSO & 1 & 10 & 10 & 100 \\
\hline 02203226 & 02S03218 & 02B8862 & ELÉTRICA & INTERRUPCAO DE SINAL & CLP & 1 & 10 & 10 & 100 \\
\hline 02203226 & 02S31535 & 02B9546 & ELÉTRICA & BAIXA ISOLACAO & CAIXA DE LIGACAO & 1 & 10 & 10 & 100 \\
\hline 02203226 & 02S22331 & 02B9522 & ELÉTRICA & INTERRUPCAO DE SINAL & CLP & 1 & 10 & 10 & 100 \\
\hline 02203226 & 02S58739 & 02C0248 & ELÉTRICA & CURTO-CIRCUITO & SENSOR & 1 & 10 & 10 & 100 \\
\hline
\end{tabular}




\begin{tabular}{|c|c|c|c|c|c|c|c|c|c|}
\hline Código & OS Mnt Corretiva & Cod Parada & Modalidade & Falha & Causa & Ocorrência & Gravidade & Detectabilidade & OGD \\
\hline 02203226 & $02 \mathrm{~T} 11878$ & 02C1589 & MECÂNICA & QUEBRA & PARAFUSO & 1 & 10 & 10 & 100 \\
\hline 02203226 & $02 \mathrm{~T} 57445$ & 02C2820 & ELÉTRICA & RETRABALHO DO ANEL & SENSOR & 1 & 10 & 10 & 100 \\
\hline 02203226 & $02 \mathrm{~T} 81515$ & 02C3038 & MECÂNICA & FIXACAO & GUIA & 1 & 10 & 10 & 100 \\
\hline 02203226 & $02 T 89919$ & 02C3156 & ELÉTRICA & QUEIMA & FONTE DE ALIMENTACAO & 1 & 10 & 10 & 100 \\
\hline 02203226 & 02Т94020 & 02C3297 & ELÉTRICA & QUEIMA & FONTE DE ALIMENTACAO & 1 & 10 & 10 & 100 \\
\hline 02203226 & $02 \mathrm{~T} 98400$ & $02 C 3441$ & MECÂNICA & DEFORMACAO & DESGASTE & 1 & 10 & 10 & 100 \\
\hline 02203226 & 02U04302 & 02C3621 & MECÂNICA & MELHORIA & EIXO & 1 & 10 & 10 & 100 \\
\hline 02203226 & 02U69769 & $02 \mathrm{C} 5493$ & MECÂNICA & TRAVAMENTO & PNEUM.-CILINDRO & 1 & 10 & 10 & 100 \\
\hline 02203226 & 02V61347 & 02C7936 & MECÂNICA & QUEBRA & PNEUM.-VALVULA & 1 & 10 & 10 & 100 \\
\hline 02203226 & 02W05979 & $02 C 8670$ & MECÂNICA & TRAVAMENTO & PNEUM.-CILINDRO & 1 & 10 & 10 & 100 \\
\hline 02203226 & 02X00777 & $02 \mathrm{D} 0457$ & ELÉTRICA & INTERRUPCAO DE SINAL & SENSOR & 1 & 10 & 10 & 100 \\
\hline 02203226 & 02R21486 & & ELÉTRICA & QUEBRA & SENSOR & 1 & 1 & 1 & 1 \\
\hline 02203226 & 02R25197 & & MECÂNICA & VAZAMENTO & LUBRIFIL & 1 & 1 & 1 & 1 \\
\hline 02203226 & 02R72527 & & ELÉTRICA & INTERRUPCAO DE SINAL & SENSOR & 1 & 1 & 1 & 1 \\
\hline 02203226 & 02S14144 & & MECÂNICA & VAZAMENTO & PNEUM.-CILINDRO & 1 & 1 & 1 & 1 \\
\hline 02203226 & $02 \mathrm{~T} 17667$ & & ELÉTRICA & QUEBRA & SENSOR & 1 & 1 & 1 & 1 \\
\hline 02203226 & 02U47668 & & ELÉTRICA & CURTO-CIRCUITO & CONECTOR/BORNE & 1 & 1 & 1 & 1 \\
\hline 02203226 & 02U47944 & & MECÂNICA & DESGASTE & ROSCA ESPANADA & 1 & 1 & 1 & 1 \\
\hline 02203226 & 02V04089 & & ELÉTRICA & MAL-CONTATO & CONTROLADOR & 1 & 1 & 1 & 1 \\
\hline 02203226 & $02 \mathrm{~W} 00233$ & & MECÂNICA & VAZAMENTO & PNEUM.-MANGUEIRA & 1 & 1 & 1 & 1 \\
\hline Subtotais & 27 & 18 & & & & 26 & & IRF & 1.709 \\
\hline 0220RP22 & 02S58230 & 02C0209 & ELÉTRICA & INTERRUPCAO DE SINAL & DESREGULAGEM & 1 & 10 & 10 & 100 \\
\hline 0220RP22 & 02S81231 & $02 \mathrm{C} 0802$ & ELÉTRICA & INTERRUPCAO DE SINAL & SENSOR & 1 & 10 & 10 & 100 \\
\hline 0220RP22 & 02 T30349 & 02C2053 & MECÂNICA & QUEBRA & PARAFUSO & 1 & 10 & 10 & 100 \\
\hline 0220RP22 & 02V06915 & $02 C 6562$ & MECÂNICA & QUEBRA & POLIA & 1 & 10 & 10 & 100 \\
\hline 0220RP22 & $02 \mathrm{~V} 48372$ & $02 \mathrm{C} 7422$ & MECÂNICA & VAZAMENTO & HIDR.-MANGUEIRA & 1 & 10 & 10 & 100 \\
\hline 0220RP22 & 02V77090 & 02C8039 & ELÉTRICA & BAIXA PRESSAO & HIDR.-VALVULA & 1 & 10 & 10 & 100 \\
\hline 0220RP22 & 02 V83305 & $02 C 8153$ & MECÂNICA & DEFEITO INTERMITENTE & SENSOR & 1 & 10 & 10 & 100 \\
\hline 0220RP22 & 02V97880 & $02 C 8447$ & MECÂNICA & QUEBRA & CORREIA & 1 & 10 & 10 & 100 \\
\hline 0220RP22 & 02V95702 & $02 C 8353$ & MECÂNICA & INTERRUPCAO DE SINAL & CLP & 1 & 10 & 10 & 100 \\
\hline 0220RP22 & 02W91732 & $02 \mathrm{D} 0116$ & MECÂNICA & DESGASTE & DESGASTE & 1 & 10 & 10 & 100 \\
\hline 0220RP22 & 02W96746 & $02 \mathrm{D} 0311$ & ELÉTRICA & INTERRUPCAO DE SINAL & CLP & 1 & 10 & 10 & 100 \\
\hline 0220RP22 & 02X35669 & $02 \mathrm{D} 0942$ & MECÂNICA & QUEBRA & GUIA & 1 & 10 & 10 & 100 \\
\hline 0220RP22 & $02 \times 37346$ & 02D0994 & MECÂNICA & QUEBRA & PNEUM.-CONEXAO & 1 & 10 & 10 & 100 \\
\hline
\end{tabular}




\begin{tabular}{|c|c|c|c|c|c|c|c|c|c|}
\hline Código & OS Mnt Corretiva & Cod Parada & Modalidade & Falha & Causa & Ocorrência & Gravidade & Detectabilidade & OGD \\
\hline 0220RP22 & 02R12209 & & MECÂNICA & DEFORMACAO & ROSCA ESPANADA & 1 & 1 & 1 & 1 \\
\hline 0220RP22 & $02 \mathrm{~W} 44035$ & & ELÉTRICA & INTERRUPCAO DE SINAL & SENSOR & 1 & 1 & 1 & 1 \\
\hline 0220RP22 & $02 X 01525$ & & MECÂNICA & VAZAMENTO & HIDR.-VALVULA & 1 & 1 & 1 & 1 \\
\hline Subtotais & 17 & 14 & & & & 16 & & IRF & 1.303 \\
\hline 0220RP12 & 02R55724 & 02B7720 & ELÉTRICA & INTERRUPCAO DE SINAL & MOTOR & 1 & 10 & 10 & 100 \\
\hline 0220RP12 & $02 \mathrm{~T} 58177$ & 02C2861 & MECÂNICA & VAZAMENTO & PNEUM.-MANGUEIRA & 1 & 10 & 10 & 100 \\
\hline 0220RP12 & 02U96212 & $02 \mathrm{C} 6053$ & MECÂNICA & DESGASTE & CORREIA & 1 & 10 & 10 & 100 \\
\hline 0220RP12 & 02V07255 & 02C6568 & ELÉTRICA & INTERRUPCAO DE SINAL & CLP & 1 & 10 & 10 & 100 \\
\hline 0220RP12 & $02 \mathrm{~V} 04276$ & $02 \mathrm{C} 6353$ & MECÂNICA & FOLGA & CORREIA & 1 & 10 & 10 & 100 \\
\hline 0220RP12 & $02 \mathrm{~V} 25431$ & $02 C 6955$ & MECÂNICA & DESGASTE & CORREIA & 1 & 10 & 10 & 100 \\
\hline 0220RP12 & $02 \mathrm{~V} 21257$ & $02 \mathrm{C} 6730$ & MECÂNICA & TRAVAMENTO & PNEUM.-MANGUEIRA & 1 & 10 & 10 & 100 \\
\hline 0220RP12 & 02V92064 & $02 \mathrm{C} 8225$ & MECÂNICA & DESGASTE & DESGASTE & 1 & 10 & 10 & 100 \\
\hline 0220RP12 & 02W51222 & 02C9558 & ELÉTRICA & INTERRUPCAO DE SINAL & MOTOR & 1 & 10 & 10 & 100 \\
\hline 0220RP12 & 02W51892 & 02C9592 & MECÂNICA & SUJEIRA & PNEUM.-VALVULA & 1 & 10 & 10 & 100 \\
\hline 0220RP12 & $02 \mathrm{~T} 47867$ & & MECÂNICA & QUEBRA & PARAFUSO & 1 & 1 & 1 & 1 \\
\hline 0220RP12 & 02 Т94912 & & MECÂNICA & VAZAMENTO & PROTECAO/TAMPA & 1 & 1 & 1 & 1 \\
\hline 0220RP12 & 02 V92778 & & ELÉTRICA & INTERRUPCAO DE SINAL & SENSOR & 1 & 1 & 1 & 1 \\
\hline 0220RP12 & 02W17751 & & MECÂNICA & FOLGA & BUCHA & 1 & 1 & 1 & 1 \\
\hline 0220RP12 & 02W46337 & & MECÂNICA & TRAVAMENTO & PNEUM.-VALVULA & 1 & 1 & 1 & 1 \\
\hline 0220RP12 & $02 X 33475$ & & MECÂNICA & BAIXA VAZAO & HIDR.-CONEXAO & 1 & 1 & 1 & 1 \\
\hline Subtotais & 16 & 10 & & & & 16 & & IRF & 1.006 \\
\hline 0220RP21 & 02R10684 & 02B6592 & MECÂNICA & DESLOCAMENTO & PNEUM.-CILINDRO & 1 & 10 & 10 & 100 \\
\hline 0220RP21 & 02R11601 & 02B6645 & MECÂNICA & QUEBRA & CORREIA & 1 & 10 & 10 & 100 \\
\hline 0220RP21 & 02S16142 & 02B9507 & ELÉTRICA & SOBRECARGA & CONVERSOR & 1 & 10 & 10 & 100 \\
\hline 0220RP21 & $02 \mathrm{~T} 13732$ & $02 \mathrm{C} 1783$ & ELÉTRICA & PROCESSO & CONVERSOR & 1 & 10 & 10 & 100 \\
\hline 0220RP21 & 02 V97862 & $02 \mathrm{C} 8445$ & MECÂNICA & QUEBRA & CORRENTE & 1 & 10 & 10 & 100 \\
\hline 0220RP21 & 02W92116 & 02D0144 & ELÉTRICA & PERDA DE MEMORIA & CLP & 1 & 10 & 10 & 100 \\
\hline 0220RP21 & 02X05380 & 02D0625 & ELÉTRICA & PERDA DE MEMORIA & CLP & 1 & 10 & 10 & 100 \\
\hline 0220RP21 & $02 X 05353$ & $02 \mathrm{D} 0623$ & MECÂNICA & CAPABILIDADE & PNEUM.-VALVULA & 1 & 10 & 10 & 100 \\
\hline 0220RP21 & $02 \mathrm{~V} 40753$ & & MECÂNICA & TRAVAMENTO & APERTADEIRA & 1 & 1 & 1 & 1 \\
\hline Subtotais & 9 & 8 & & & & 9 & & IRF & 801 \\
\hline
\end{tabular}




\begin{tabular}{|c|c|c|c|c|c|c|c|c|c|}
\hline Código & OS Mnt Corretiva & Cod Parada & Modalidade & Falha & Causa & Ocorrência & Gravidade & Detectabilidade & OGD \\
\hline 0220RP15 & 02U07880 & 02C3780 & MECÂNICA & QUEBRA & LUBRIFIL & 1 & 10 & 10 & 100 \\
\hline 0220RP15 & 02V55434 & $02 C 7692$ & MECÂNICA & DESGASTE & CORREIA & 1 & 10 & 10 & 100 \\
\hline 0220RP15 & 02V52384 & $02 C 7575$ & ELÉTRICA & DESGASTE & CHAVE/BOTOEIRA & 1 & 10 & 10 & 100 \\
\hline 0220RP15 & 02W51302 & 02C9564 & MECÂNICA & VAZAMENTO & HIDR.-CILINDRO & 1 & 10 & 10 & 100 \\
\hline 0220RP15 & 02W51133 & 02C9551 & MECÂNICA & TRAVAMENTO & MANCAL & 1 & 10 & 10 & 100 \\
\hline 0220RP15 & 02W88425 & $02 C 9955$ & MECÂNICA & VAZAMENTO & HIDR.-MANGUEIRA & 1 & 10 & 10 & 100 \\
\hline 0220RP15 & 02W91929 & 02D0128 & MECÂNICA & VAZAMENTO & HIDR.-MANGUEIRA & 1 & 10 & 10 & 100 \\
\hline 0220RP15 & 02X38452 & & MECÂNICA & FOLGA & CORREIA & 1 & 1 & 1 & 1 \\
\hline Subtotais & 8 & 7 & & & & 8 & & IRF & 701 \\
\hline 0220RP24 & 02R07563 & 02B6482 & ELÉTRICA & DEFEITO INTERMITENTE & CLP & 1 & 10 & 10 & 100 \\
\hline 0220RP24 & $02 \mathrm{R} 43293$ & 02B7398 & ELÉTRICA & MAL-CONTATO & POTENCIOMETRO & 1 & 10 & 10 & 100 \\
\hline 0220RP24 & 02S62378 & $02 \mathrm{C} 0442$ & ELÉTRICA & INTERRUPCAO DE SINAL & CONVERSOR & 1 & 10 & 10 & 100 \\
\hline 0220RP24 & $02 \mathrm{~T} 88466$ & 02C3087 & ELÉTRICA & INTERRUPCAO DE SINAL & MOTOR & 1 & 10 & 10 & 100 \\
\hline 0220RP24 & 02U96043 & 02C6037 & ELÉTRICA & INTERRUPCAO DE SINAL & MOTOR & 1 & 10 & 10 & 100 \\
\hline 0220RP24 & 02 V36143 & 02C7022 & ELÉTRICA & INTERRUPCAO DE SINAL & CLP & 1 & 10 & 10 & 100 \\
\hline 0220RP24 & 02R12183 & & MECÂNICA & ROMPIMENTO & CORREIA & 1 & 1 & 1 & 1 \\
\hline 0220RP24 & 02R65125 & & MECÂNICA & QUEBRA & ROSCA ESPANADA & 1 & 1 & 1 & 1 \\
\hline Subtotais & 8 & 6 & & & & 8 & & IRF & 602 \\
\hline 02202552 & 02R73651 & 02B8476 & MECÂNICA & TRAVAMENTO & PNEUM.-VALVULA & 1 & 10 & 10 & 100 \\
\hline 02202552 & $02 \mathrm{~V} 07415$ & 02C6578 & MECÂNICA & VAZAMENTO & PNEUM.-VALVULA & 1 & 10 & 10 & 100 \\
\hline 02202552 & 02V02241 & $02 \mathrm{C} 6179$ & MECÂNICA & VAZAMENTO & PNEUM.-MANGUEIRA & 1 & 10 & 10 & 100 \\
\hline 02202552 & 02W03310 & $02 C 8612$ & MECÂNICA & VAZAMENTO & PNEUM.-MANGUEIRA & 1 & 10 & 10 & 100 \\
\hline Subtotais & 4 & 4 & & & & 4 & & IRF & 400 \\
\hline 02200907 & 02S13341 & 02B9317 & ELÉTRICA & INTERRUPCAO DE SINAL & SENSOR & 1 & 10 & 10 & 100 \\
\hline 02200907 & 02U37811 & 02C4788 & ELÉTRICA & QUEIMA & FUSIVEL & 1 & 10 & 10 & 100 \\
\hline 02200907 & 02X07832 & $02 \mathrm{D} 0724$ & MECÂNICA & TRAVAMENTO & CORREIA & 1 & 10 & 10 & 100 \\
\hline 02200907 & $02 \mathrm{~T} 29896$ & & MECÂNICA & VAZAMENTO & PNEUM.-MANGUEIRA & 1 & 1 & 1 & 1 \\
\hline 02200907 & $02 \mathrm{~T} 47894$ & & MECÂNICA & FIXACAO & PARAFUSO & 1 & 1 & 1 & 1 \\
\hline 02200907 & $02 V 53533$ & & MECÂNICA & DESREGULAGEM & CONTROLADOR & 1 & 1 & 1 & 1 \\
\hline 02200907 & 02W04220 & & MECÂNICA & TRAVAMENTO & PNEUM.-VALVULA & 1 & 1 & 1 & 1 \\
\hline 02200907 & 02W05639 & & MECÂNICA & DESLOCAMENTO & CORRENTE & 1 & 1 & 1 & 1 \\
\hline 02200907 & 02X00731 & & MECÂNICA & TRAVAMENTO & PNEUM.-VALVULA & 1 & 1 & 1 & 1 \\
\hline
\end{tabular}




\begin{tabular}{|c|c|c|c|c|c|c|c|c|c|}
\hline Código & OS Mnt Corretiva & Cod Parada & Modalidade & Falha & Causa & Ocorrência & Gravidade & Detectabilidade & OGD \\
\hline $\begin{array}{l}02200907 \\
\text { Subtotais }\end{array}$ & $\begin{array}{c}\text { 02X07743 } \\
\mathbf{1 1}\end{array}$ & 4 & MECÂNICA & MELHORIA & PNEUM.-VALVULA & $\begin{array}{c}1 \\
10\end{array}$ & 1 & $\begin{array}{c}1 \\
\text { IRF }\end{array}$ & $\begin{array}{c}1 \\
307\end{array}$ \\
\hline 02202537 & 02S84700 & $02 \mathrm{C} 0873$ & MECÂNICA & TRAVAMENTO & GUIA & 1 & 10 & 10 & 100 \\
\hline 02202537 & 02 T98419 & $02 \mathrm{C} 3442$ & MECÂNICA & QUEBRA & PNEUM.-VALVULA & 1 & 10 & 10 & 100 \\
\hline 02202537 & 02 T90836 & & MECÂNICA & QUEBRA & GUIA & 1 & 1 & 1 & 1 \\
\hline 02202537 & 02W38364 & & MECÂNICA & VIBRACAO & PARAFUSO & 1 & 1 & 1 & 1 \\
\hline Subtotais & 4 & 2 & & & & 4 & & IRF & 202 \\
\hline 0220RP29 & $02 \mathrm{~V} 44376$ & $02 C 7258$ & ELÉTRICA & INTERRUPCAO DE SINAL & MOTOR & 1 & 10 & 10 & 100 \\
\hline 0220RP29 & 02W90485 & 02D0069 & MECÂNICA & DESGASTE & PARAFUSO & 1 & 10 & 10 & 100 \\
\hline 0220RP29 & $02 \mathrm{~V} 44063$ & & MECÂNICA & QUEBRA & CONTRA-PONTO & 1 & 1 & 1 & 1 \\
\hline Subtotais & 3 & 2 & & & & 3 & & IRF & 201 \\
\hline 02200906 & 02V61365 & $02 C 7937$ & MECÂNICA & VAZAMENTO & PNEUM.-CONEXAO & 1 & 10 & 10 & 100 \\
\hline 02200906 & 02W92358 & 02D0092 & LIMPEZA & ENTUPIMENTO & SUJEIRA & 1 & 10 & 10 & 100 \\
\hline 02200906 & 02R63822 & & MECÂNICA & VAZAMENTO & LUBRIFIL & 1 & 1 & 1 & 1 \\
\hline 02200906 & 02R68266 & & MECÂNICA & MELHORIA & FILTRO & 1 & 1 & 1 & 1 \\
\hline 02200906 & $02 \mathrm{~T} 12699$ & & MECÂNICA & ROMPIMENTO & PNEUM.-MANGUEIRA & 1 & 1 & 1 & 1 \\
\hline 02200906 & $02 \mathrm{~T} 11850$ & & MECÂNICA & QUEBRA & LUBRIFIL & 1 & 1 & 1 & 1 \\
\hline 02200906 & 02X08056 & & MECÂNICA & MELHORIA & FILTRO & 1 & 1 & 1 & 1 \\
\hline Subtotais & 7 & 2 & & & & 7 & & IRF & 205 \\
\hline 02202560 & 6 & $02 C 0475$ & MECÂNICA & TRAVAMENTO & GUIA & 1 & 10 & 10 & 100 \\
\hline Subtotais & 1 & 1 & & & & 1 & & IRF & 100 \\
\hline Totais & 444 & 343 & & & & 432 & & IRE & 33.210 \\
\hline
\end{tabular}


MANUTENÇÃO GERAL

(Período de 01/06/2004 a 30/06/2005)

\begin{tabular}{|c|c|c|c|c|c|c|c|c|c|c|c|c|c|c|}
\hline \multirow{2}{*}{ RECURSOS CONSUMIDOS } & \multicolumn{14}{|c|}{ VALORES EM REAIS } \\
\hline & jun/04 & jul/04 & ago/04 & set/04 & out/04 & nov/04 & dez/04 & jan/05 & fev/05 & mar/05 & abr/05 & mai/05 & jun/05 & 2004-2005 \\
\hline Pessoal Próprio (Horas Extras com 72\% de Encargos & 266.458 & 234.108 & 243.088 & 237.119 & 287.025 & 285.047 & 282.122 & 265.392 & 255.331 & 242.972 & 249.497 & 224.699 & 232.062 & 3.304 .920 \\
\hline Mão-de-Obra Colaboradores (Terceiros) & 6.209 & 4.842 & 24.715 & 8.809 & 7.419 & 7.243 & 12.463 & 36.693 & 50.294 & 86.161 & 107.338 & 101.975 & 94.917 & 549.078 \\
\hline Benefícios & 46.299 & 53.831 & 49.197 & 43.480 & 38.345 & 39.580 & 46.746 & 32.983 & 34.368 & 32.731 & 41.511 & 29.848 & 38.033 & 526.952 \\
\hline Depreciação & 3.529 & 3.811 & 4.256 & 4.515 & 4.551 & 4.584 & 4.589 & 5.692 & 4.581 & 4.598 & 4.598 & 4.598 & 4.655 & 58.557 \\
\hline Serviços Profissionais & 796 & 1.179 & 859 & 1.718 & 1.955 & 1.586 & 780 & 729 & 11.105 & 14.188 & 13.756 & 15.030 & 13.632 & 77.313 \\
\hline Materiais de Suprimentos & 12.617 & 32.582 & 16.287 & 16.424 & 15.566 & 10.547 & 20.889 & 6.861 & 12.066 & 16.585 & 26.691 & 16.293 & 11.606 & 215.014 \\
\hline Despesas Gerais de Viagens & 11.666 & 7.851 & 7.447 & 4.093 & 3.160 & 2.942 & 4.497 & 9.378 & 7.512 & 5.674 & 6.870 & 10.242 & 7.361 & 88.693 \\
\hline Manutenção de Máquinas & 0 & 57.381 & 26.707 & 0 & 0 & 711 & 18.420 & 601 & 53 & 0 & 0 & 8.090 & 0 & 111.963 \\
\hline Manutenção de Utilidades & 0 & 0 & 0 & 0 & 0 & 0 & 0 & 0 & 0 & 0 & 0 & 0 & 0 & 0 \\
\hline Manutenção de Ferramental & 3.158 & 1.378 & 1.572 & 3.521 & 4.848 & 3.378 & 2.976 & 4.854 & 6.248 & 5.208 & 7.521 & 7.262 & 4.766 & 56.690 \\
\hline Estação de Tratamento de Efluentes, Energia Elétrica e Água & 12.285 & 13.538 & 15.993 & 12.486 & 14.705 & 17.507 & 14.419 & 11.854 & 14.738 & 18.757 & 17.625 & 19.483 & 18.636 & 202.026 \\
\hline Auxílio à Produção (Qual. / Proc. / Eng.) & 11.998 & 13.839 & 11.119 & 10.527 & 15.090 & 19.669 & 13.707 & 10.380 & 11.659 & 15.658 & 22.846 & 14.028 & 8.745 & 179.265 \\
\hline logística & 25.900 & 27.296 & 29.602 & 24.409 & 27.311 & 32.727 & 27.874 & 29.389 & 29.860 & 31.445 & 32.563 & 31.863 & 36.858 & 387.097 \\
\hline Treinamentos & 21.688 & 23.161 & 26.021 & 22.712 & 4.865 & 20.539 & 19.831 & 24.533 & 19.925 & 17.418 & 20.271 & 20.088 & 20.992 & 262.044 \\
\hline TOTAIS & 422.603 & 474.797 & 456.863 & 389.813 & 424.840 & 446.060 & 469.313 & 439.339 & 457.740 & 491.395 & 551.087 & 503.499 & 492.263 & 6.019.612 \\
\hline
\end{tabular}



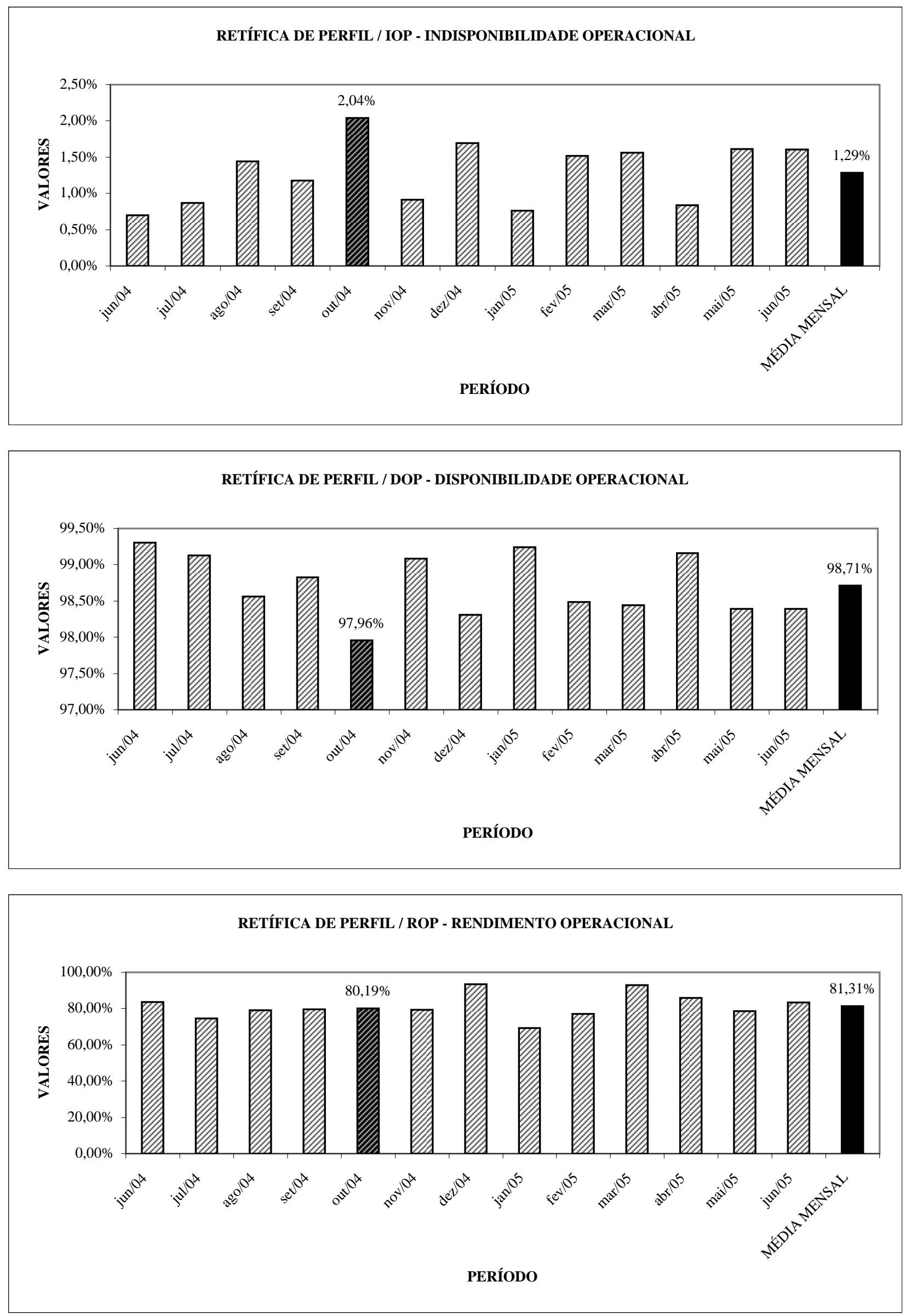

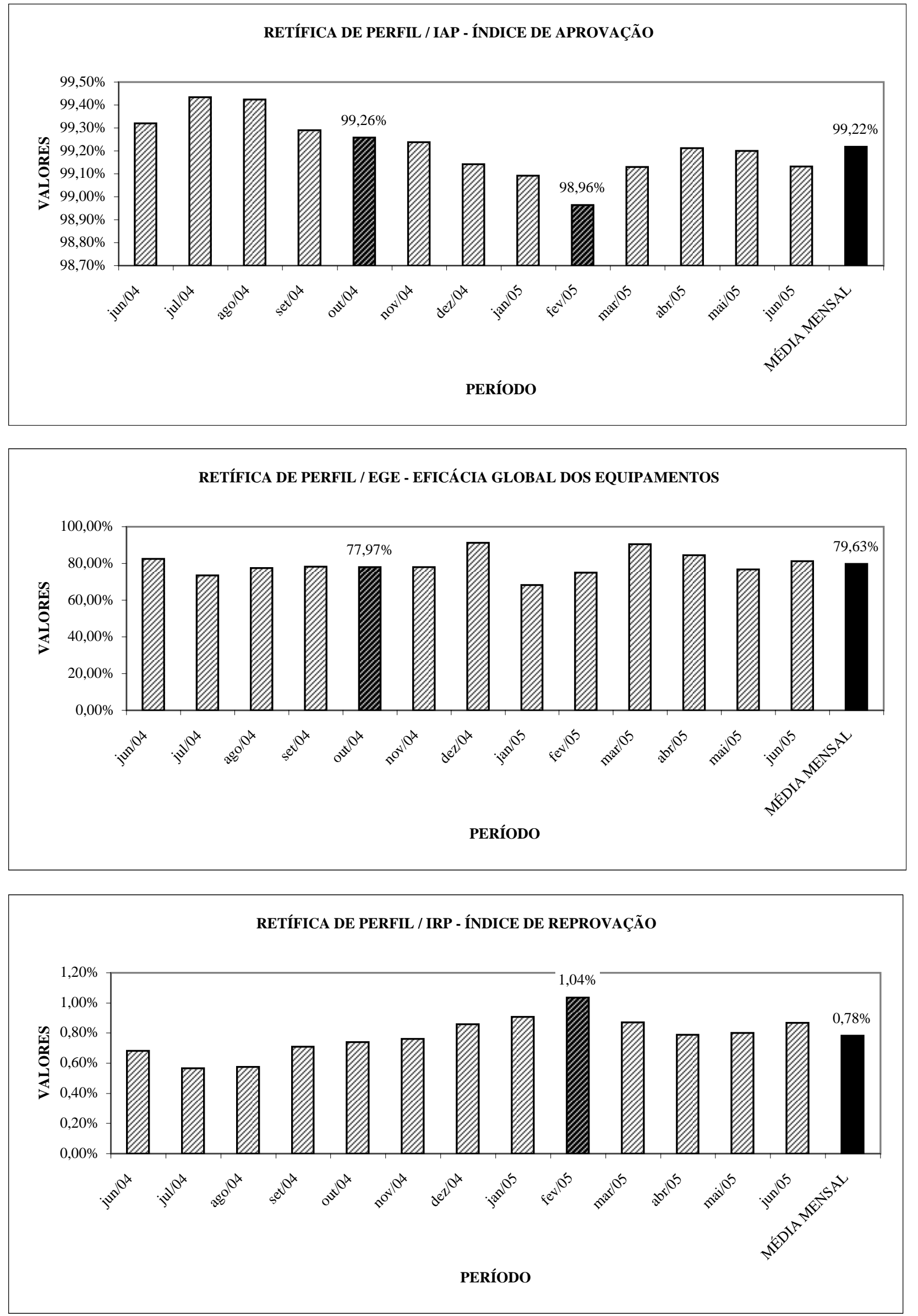

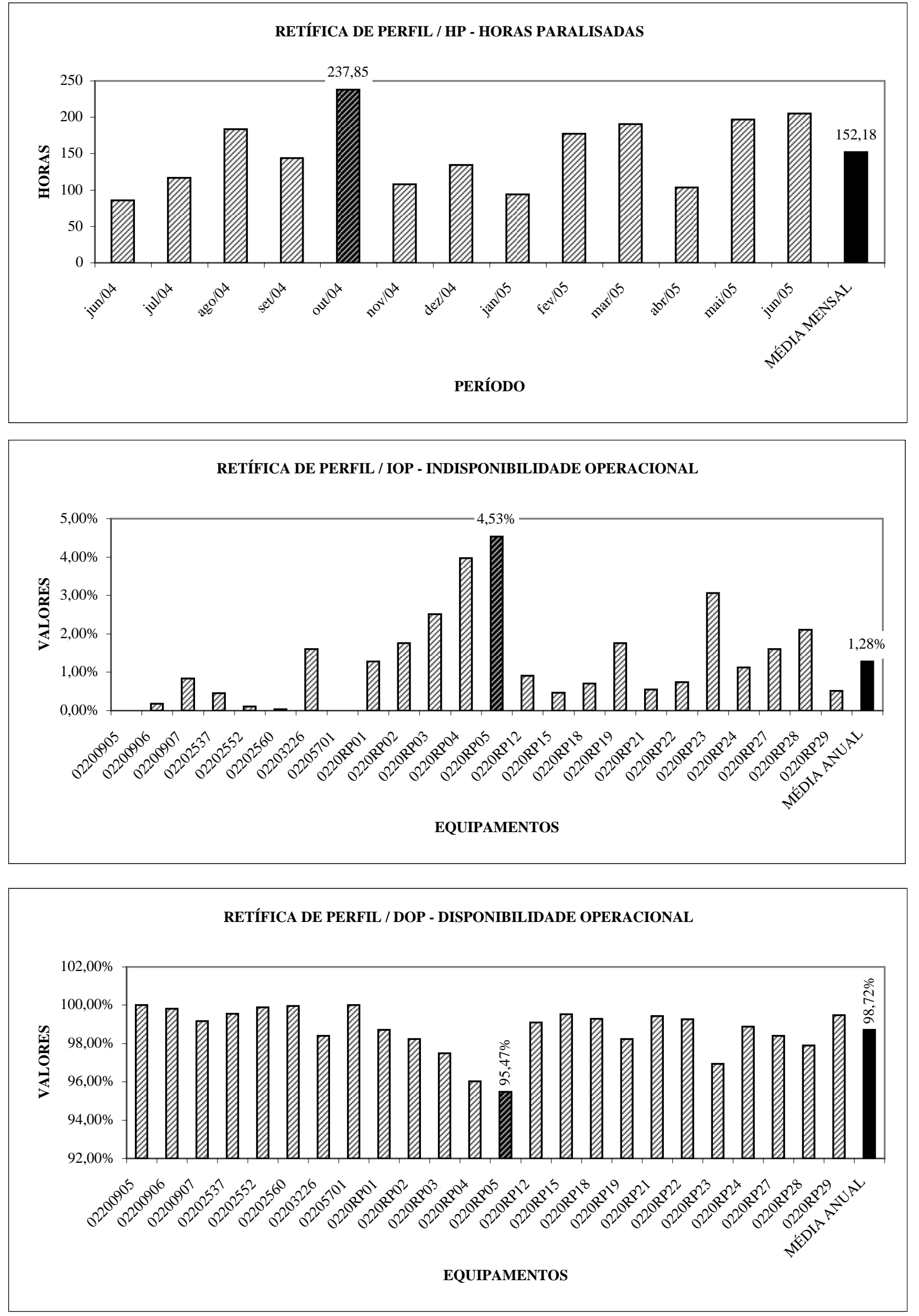

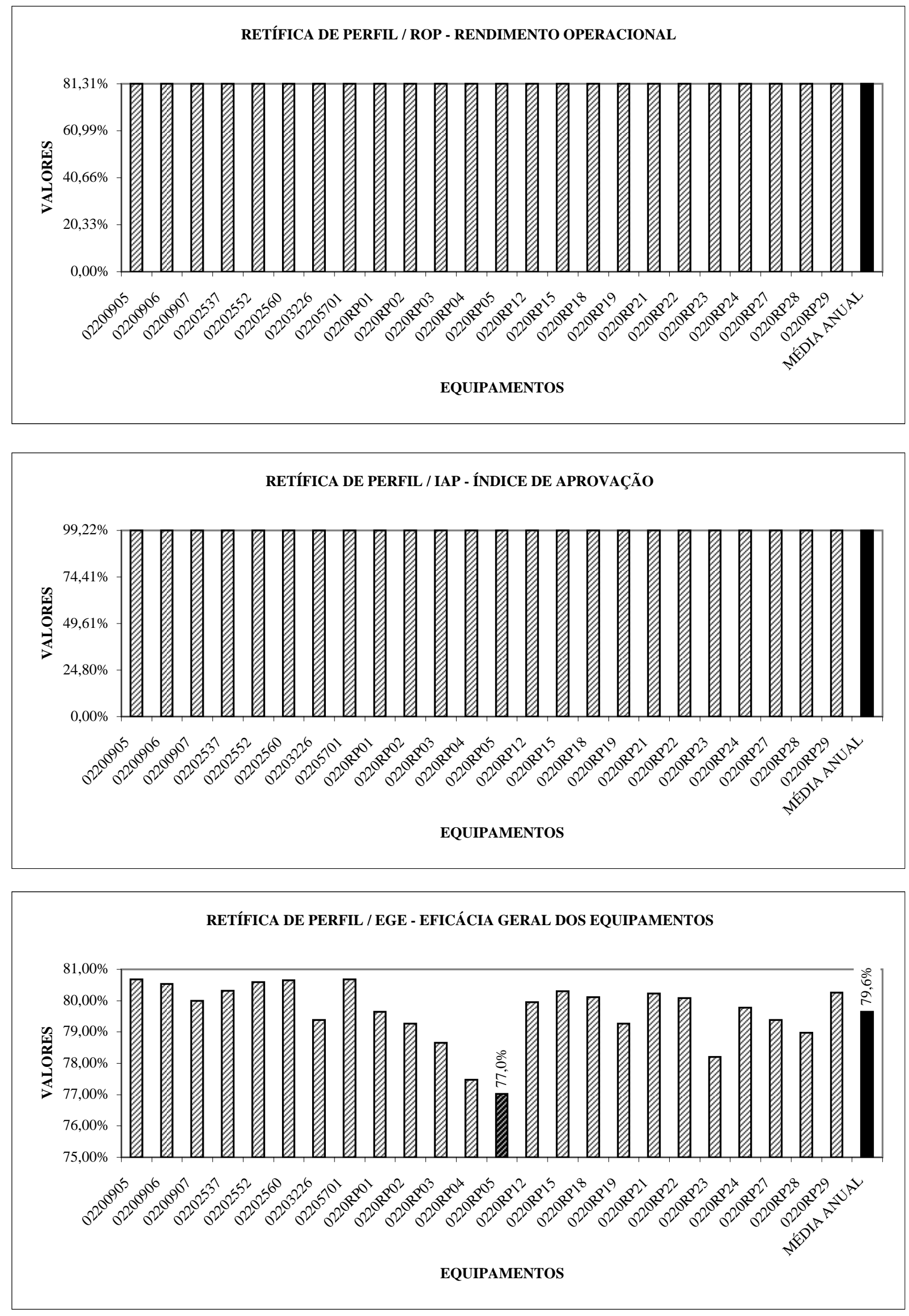


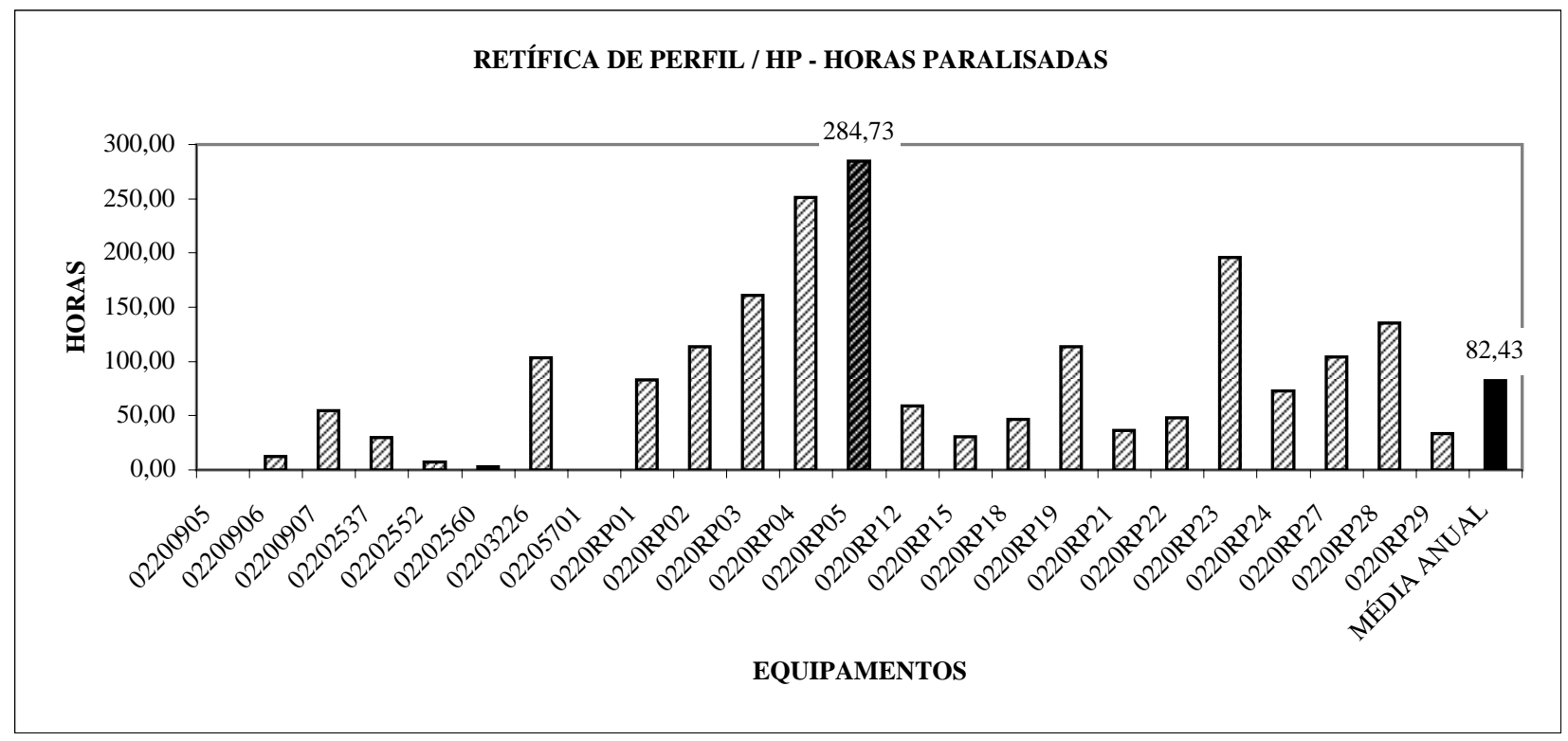



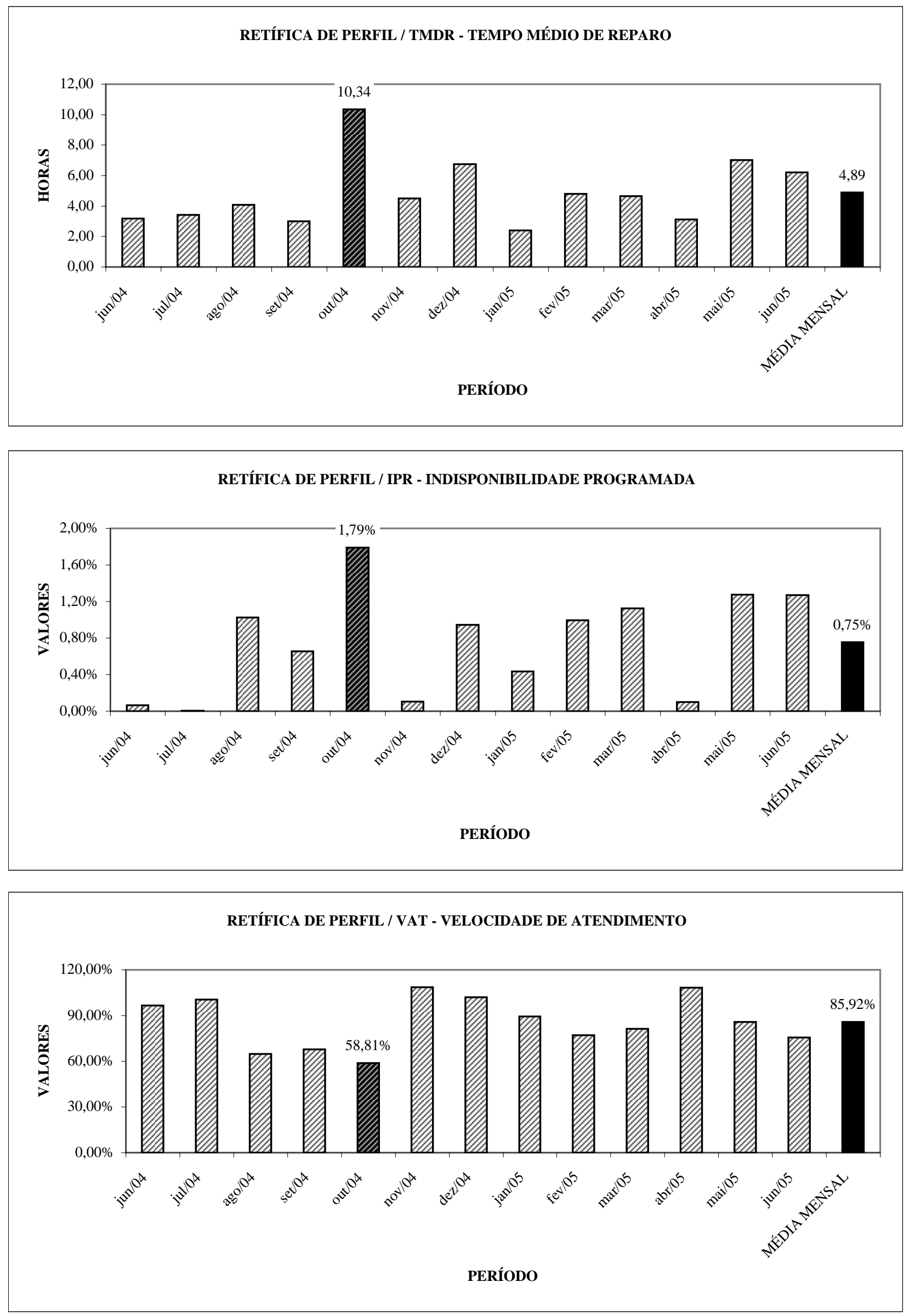

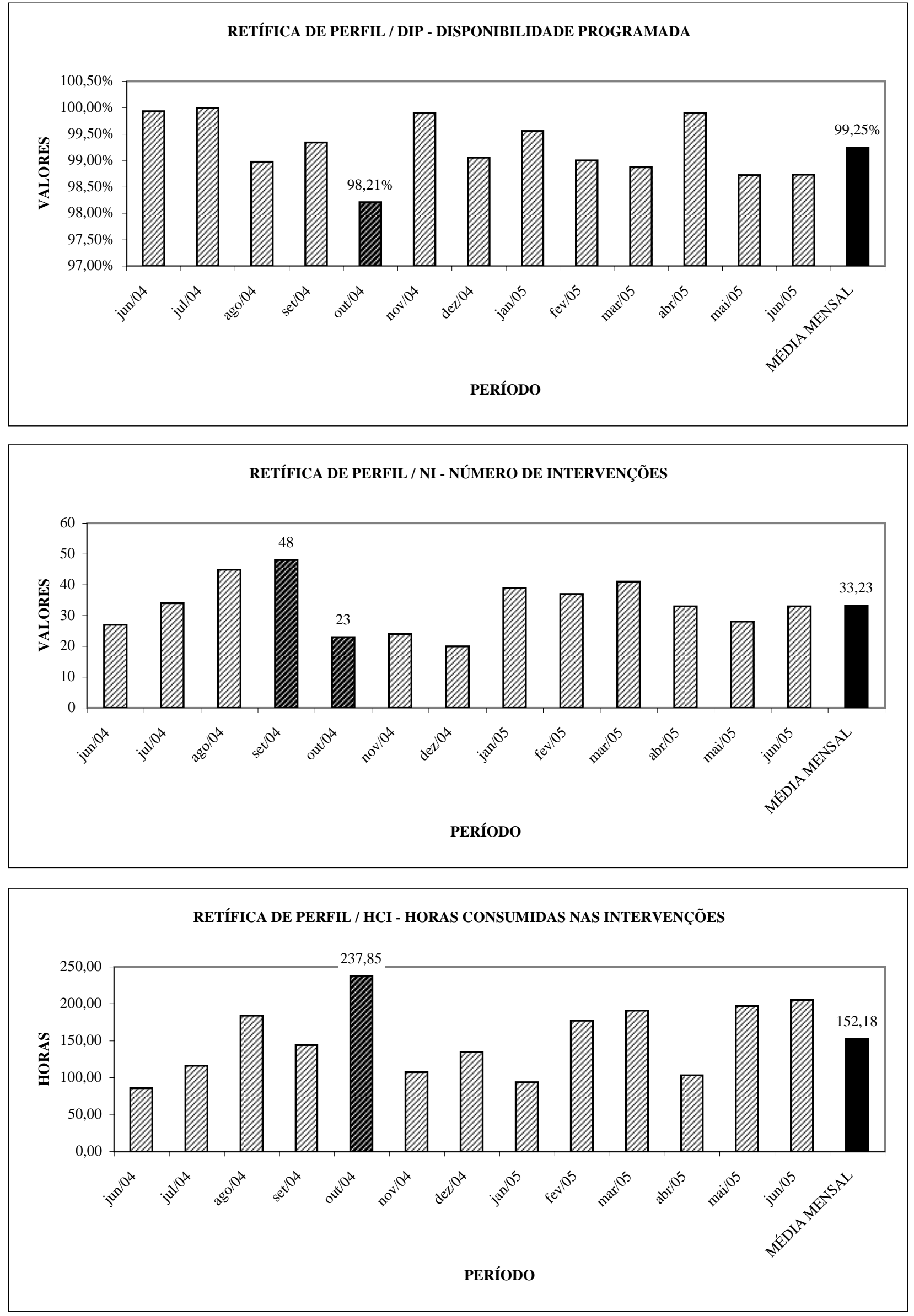

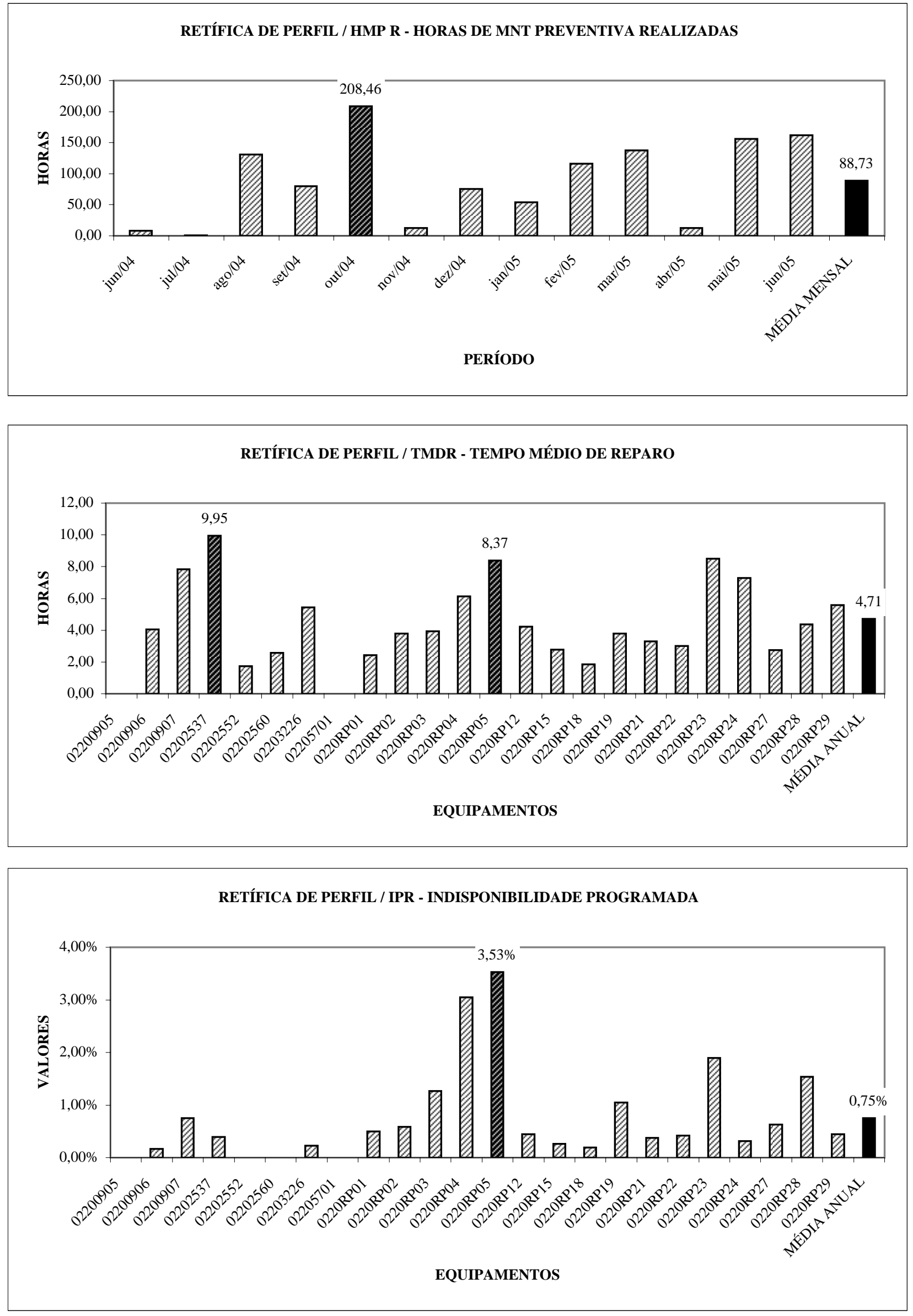

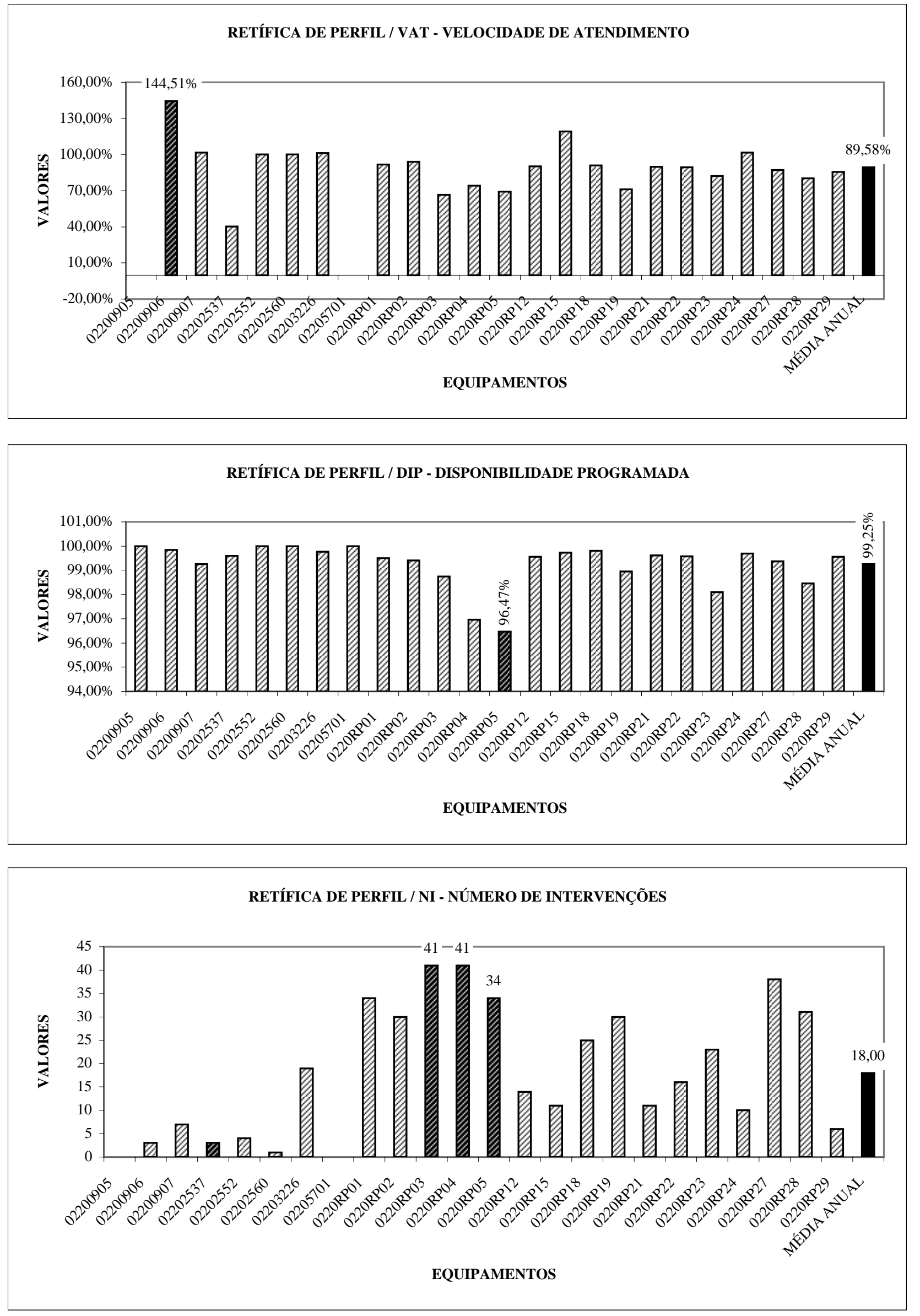

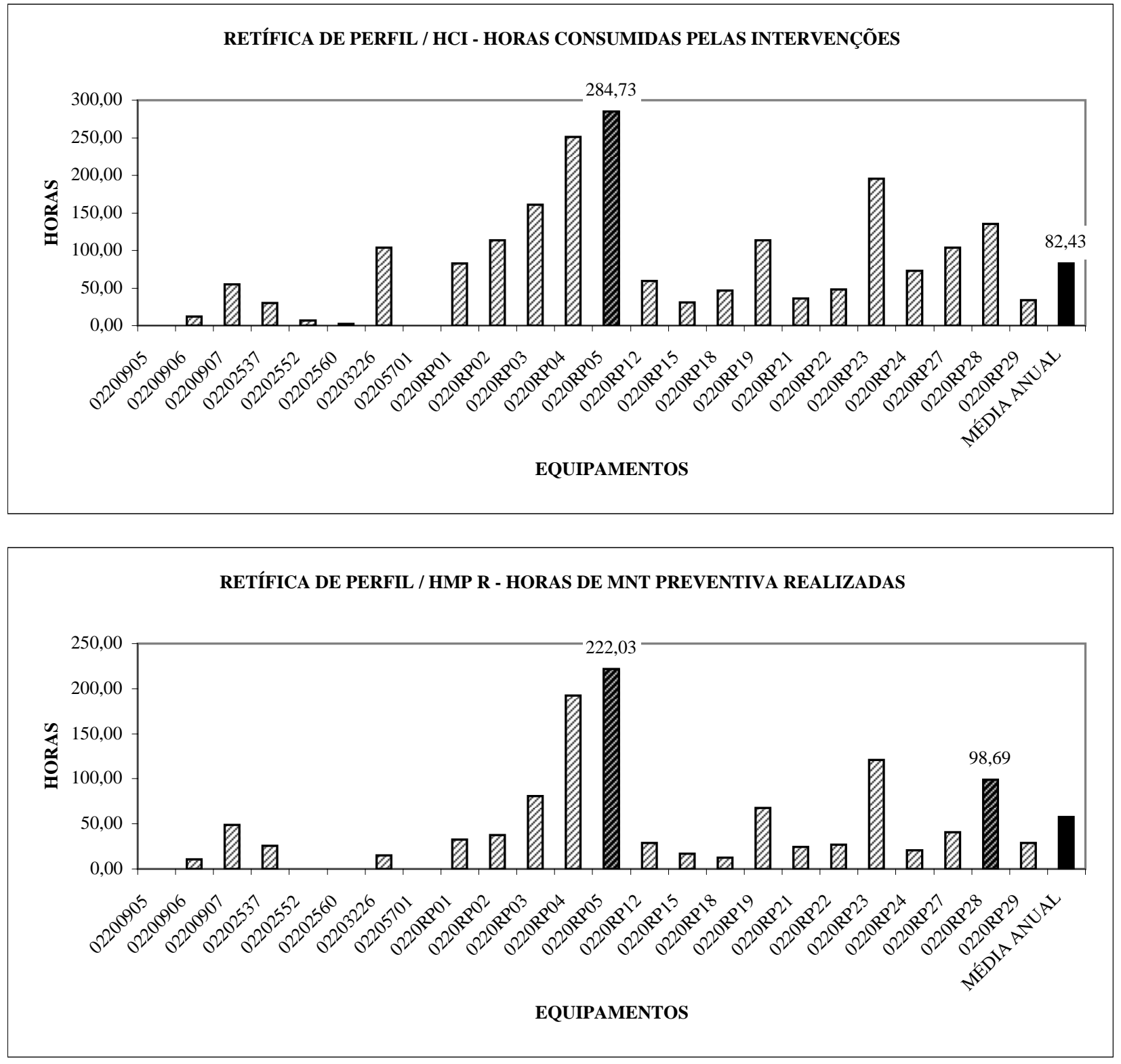

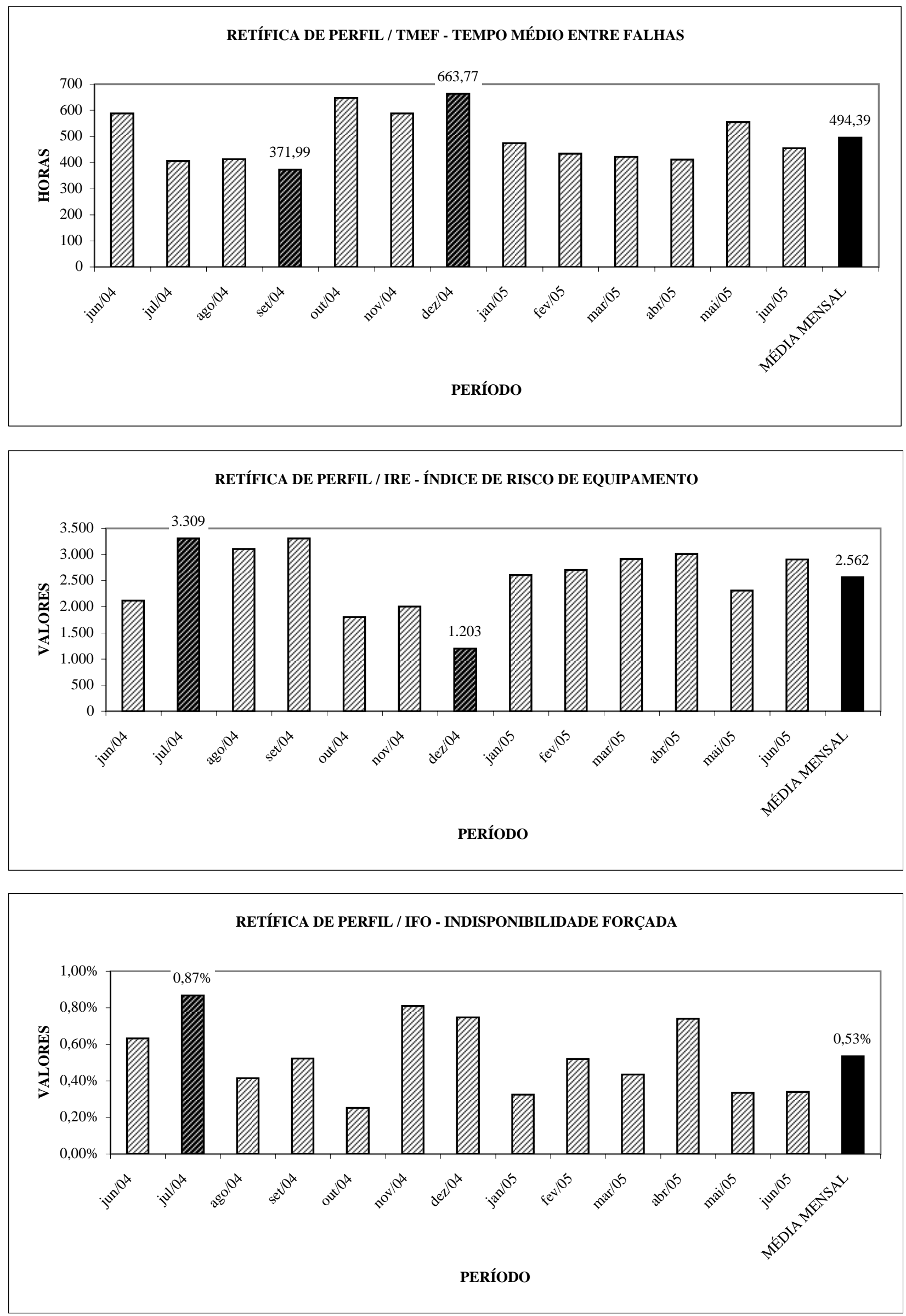

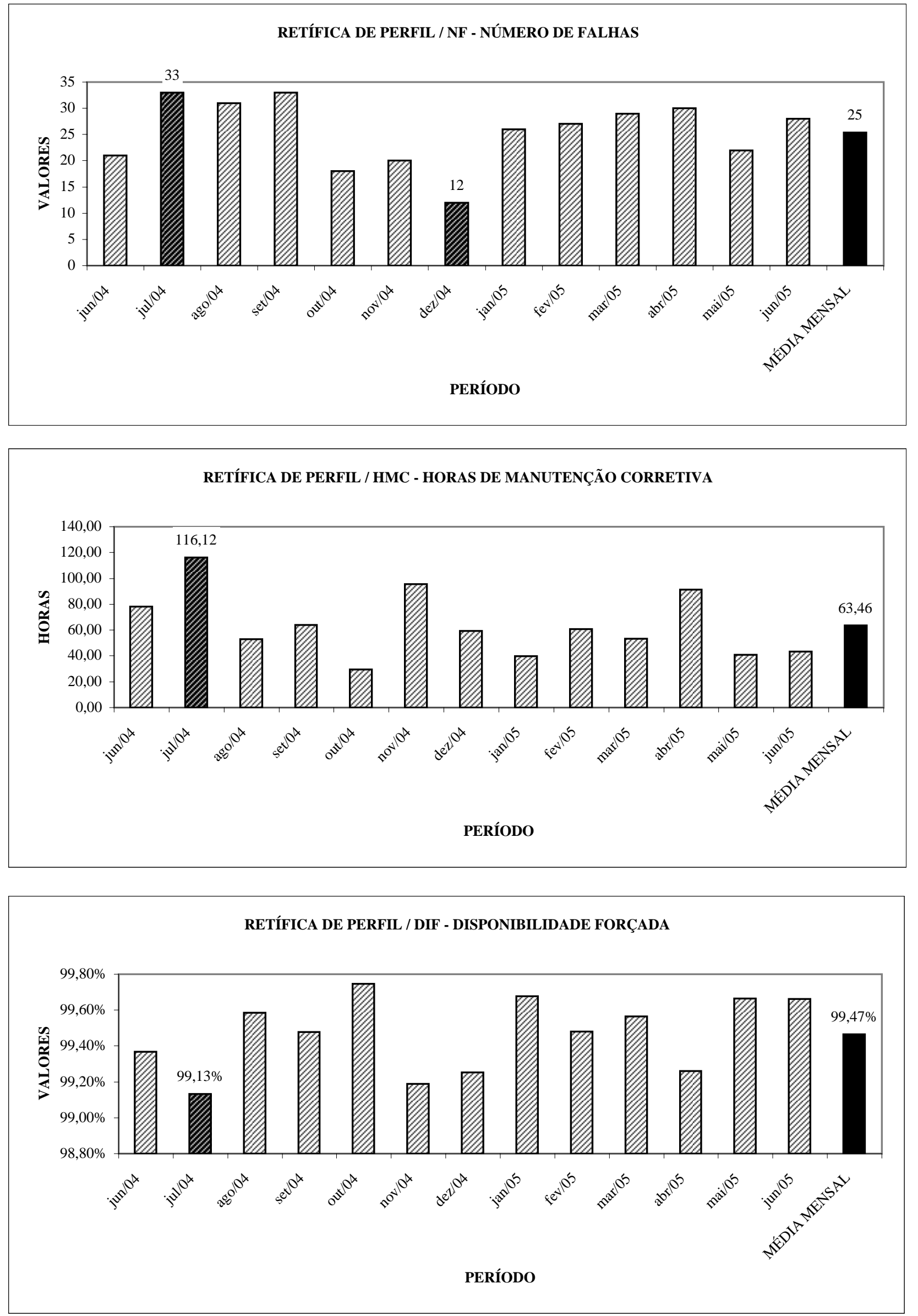

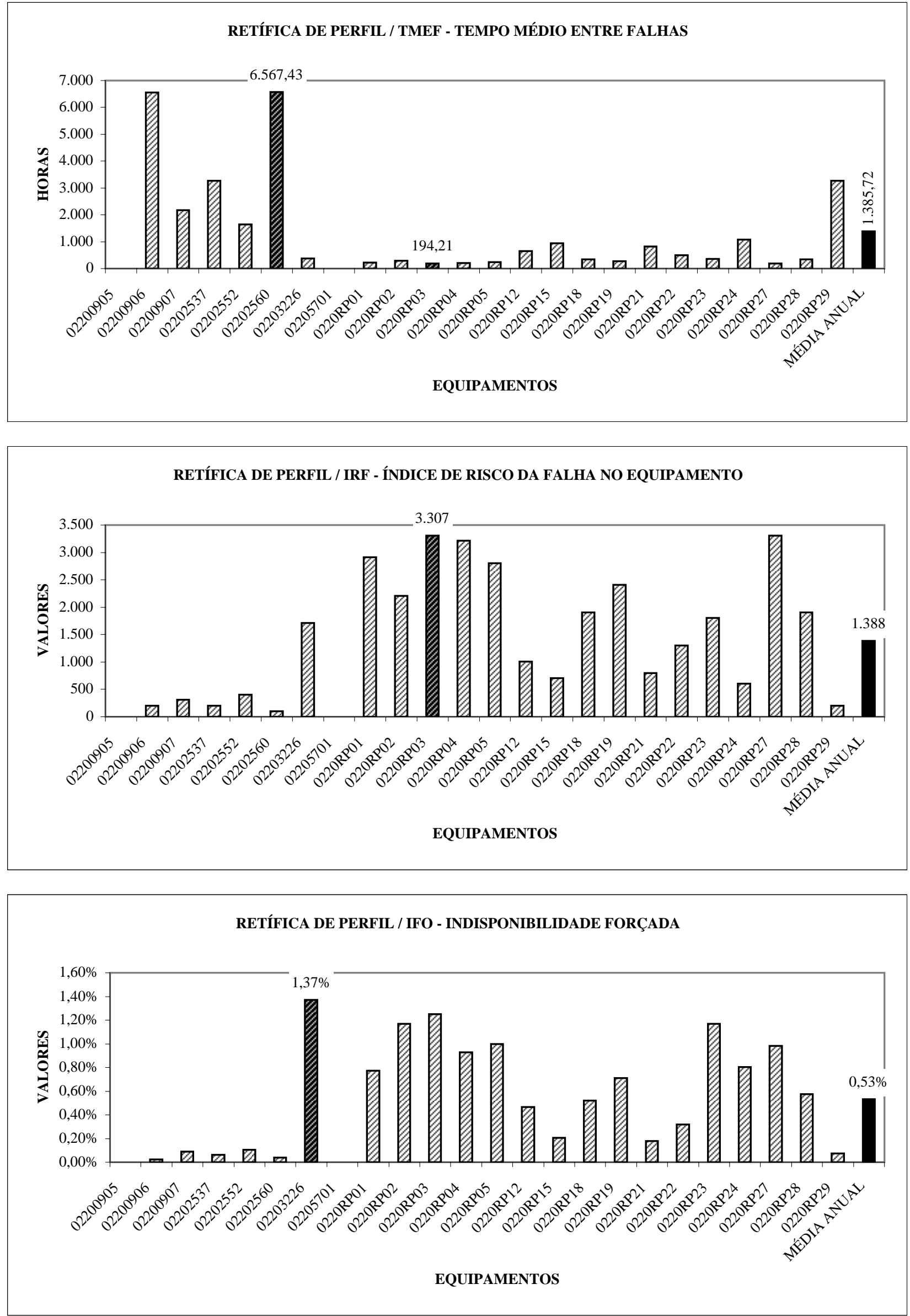

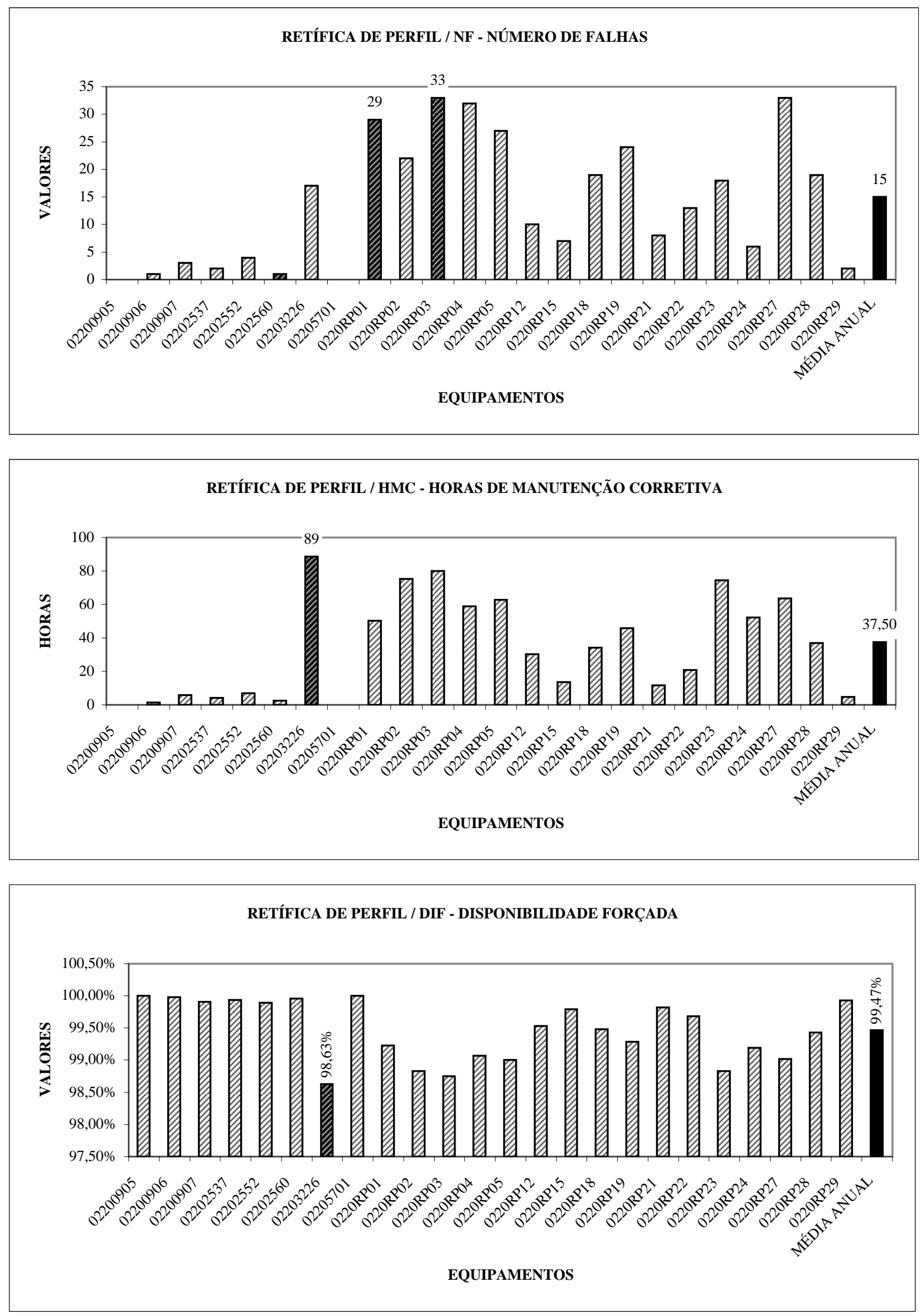

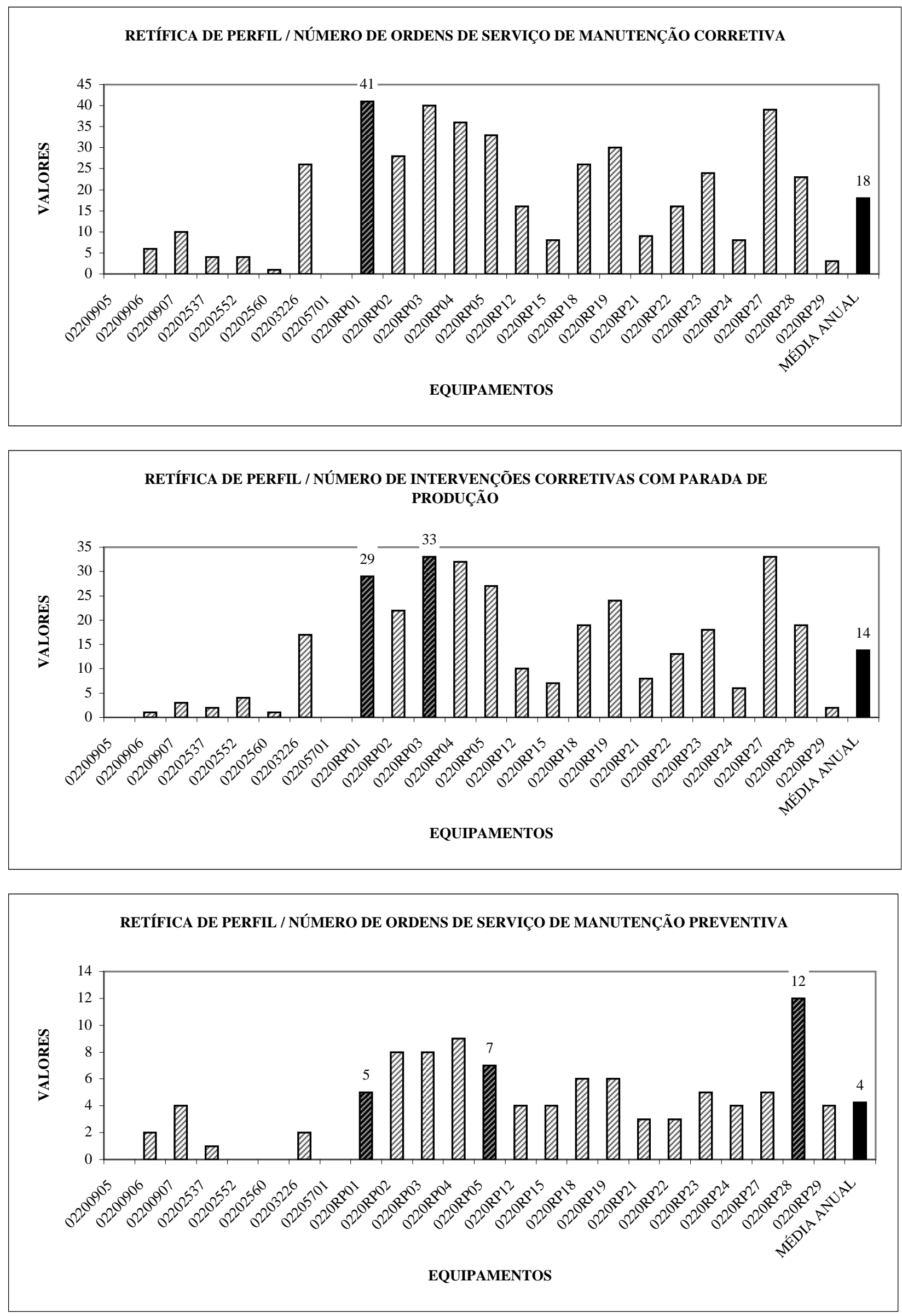

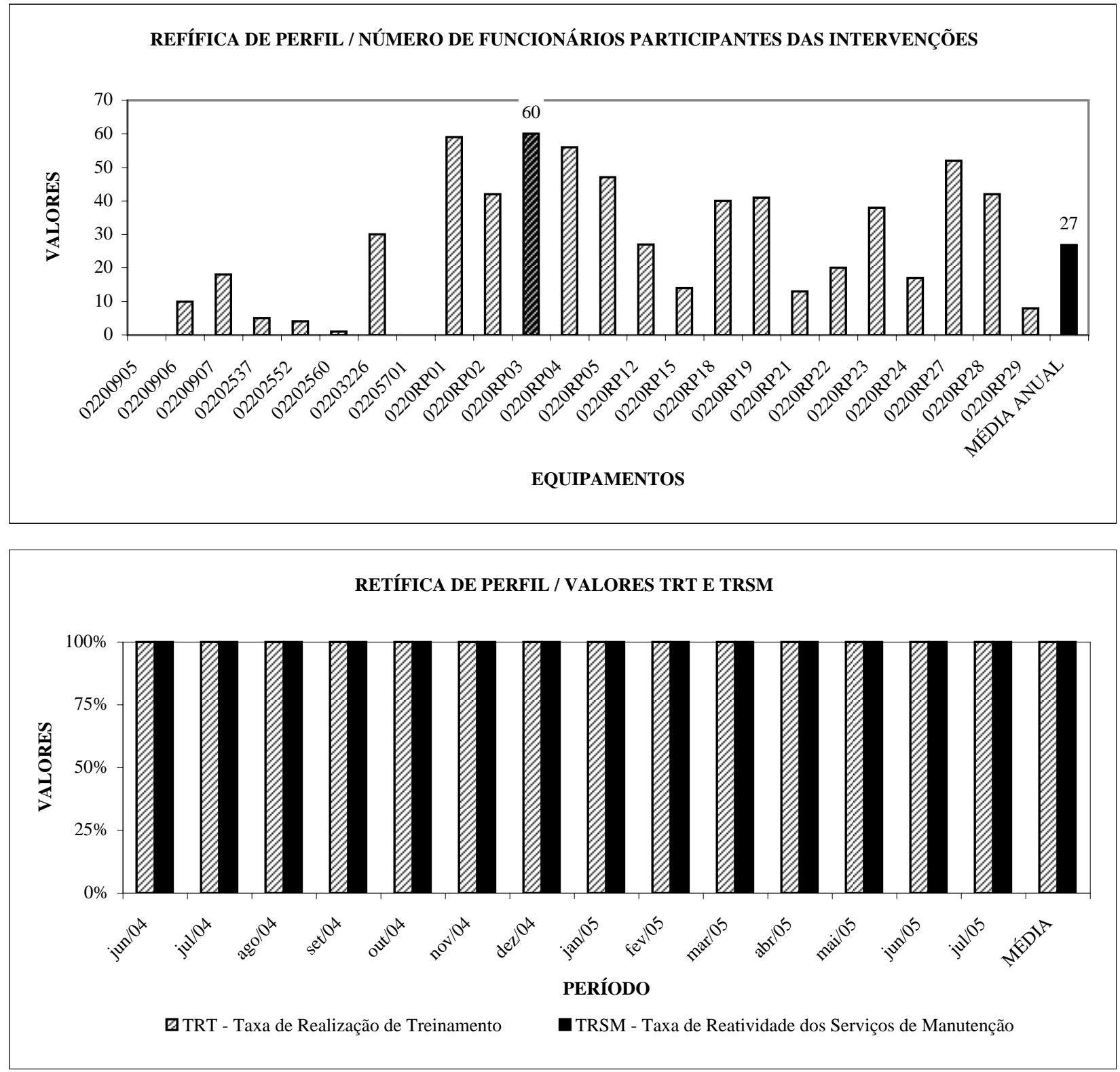

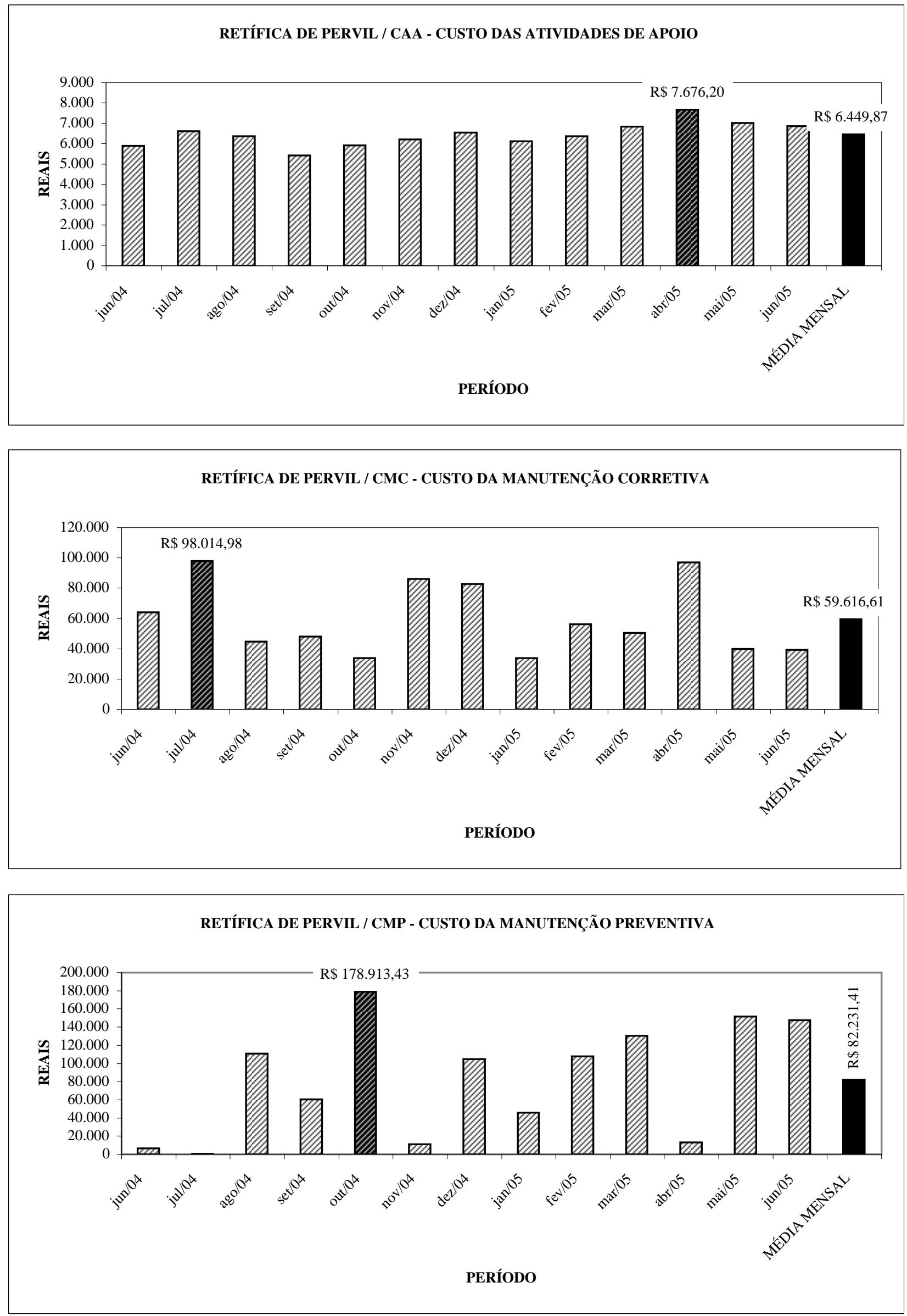

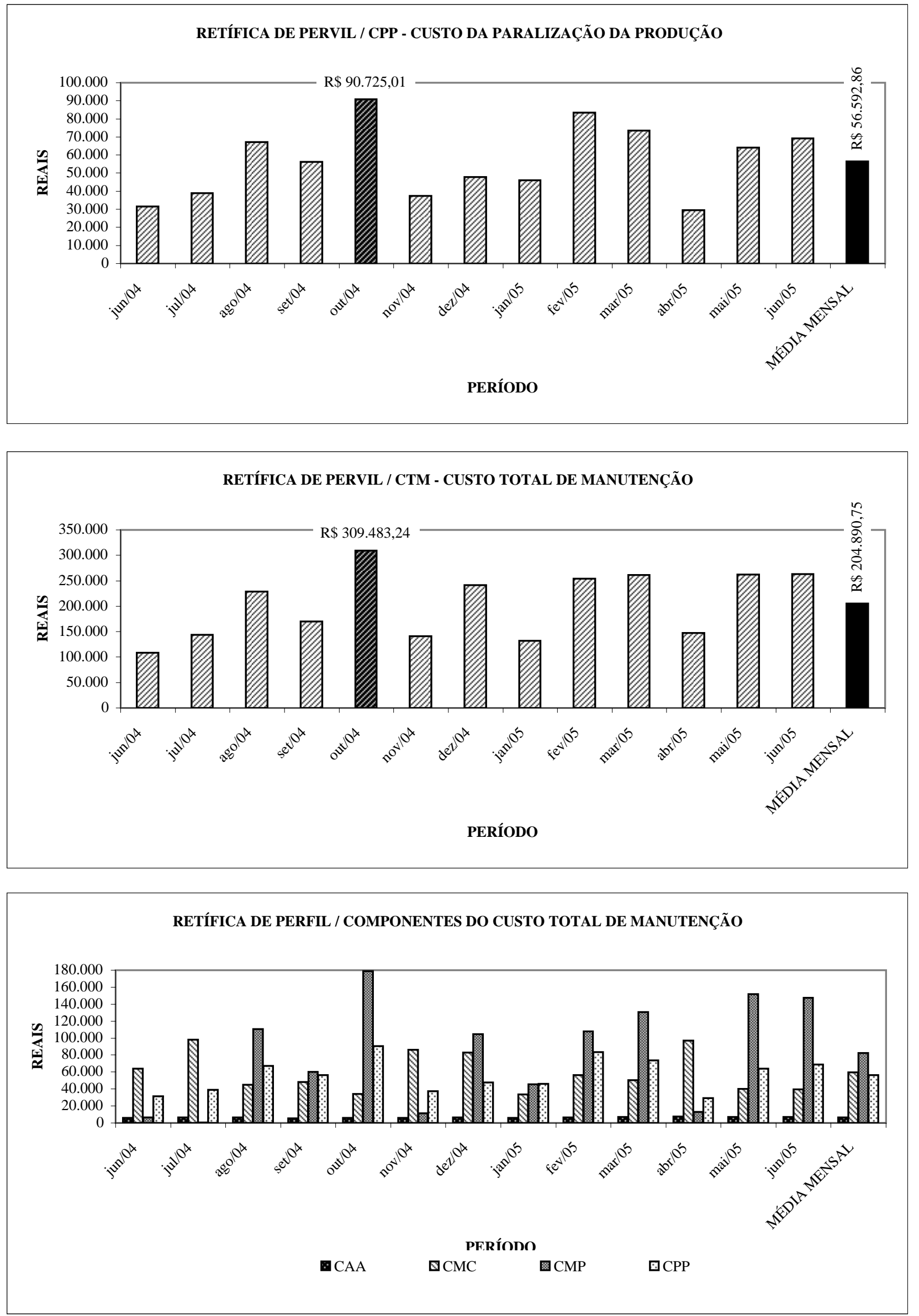

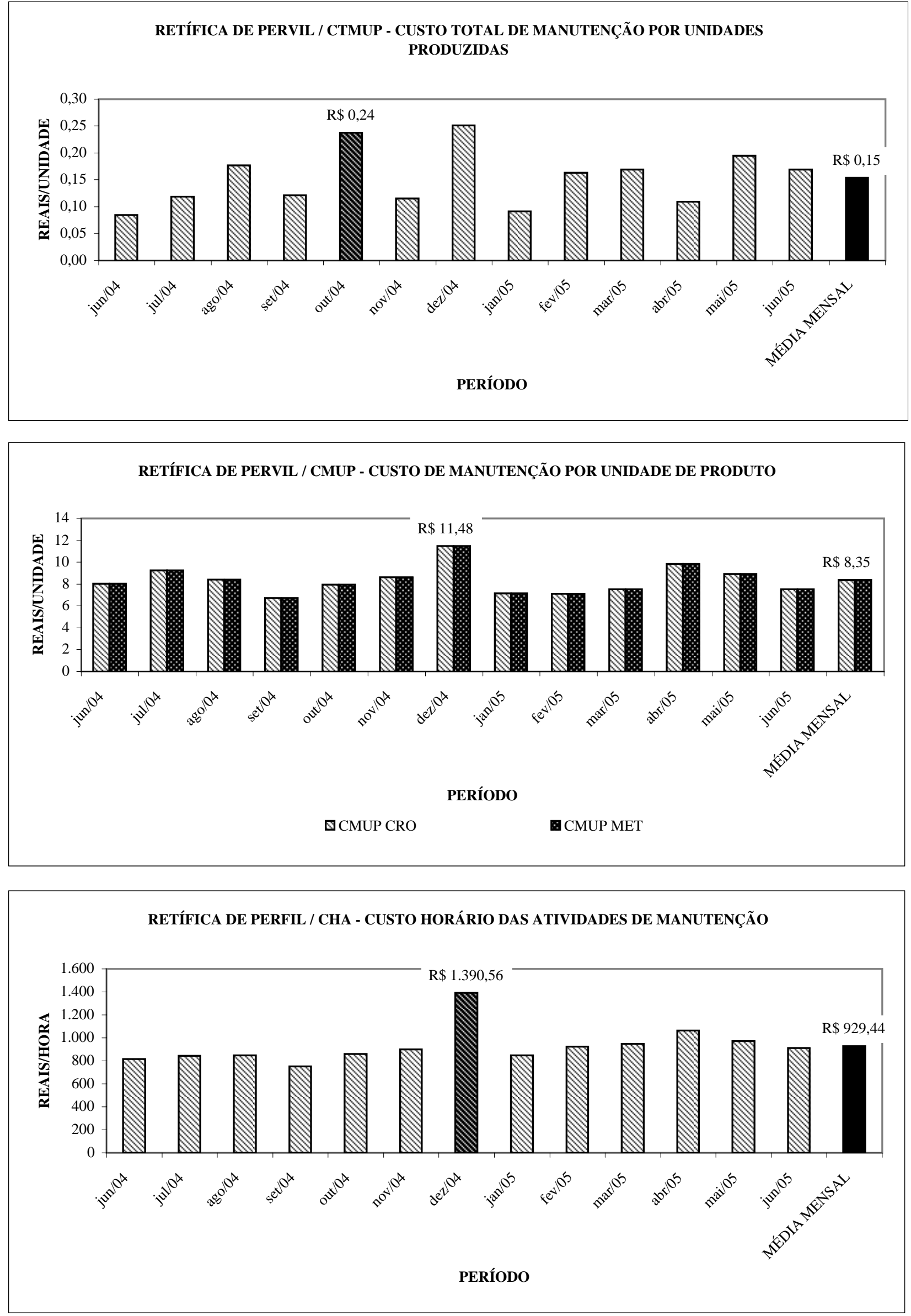


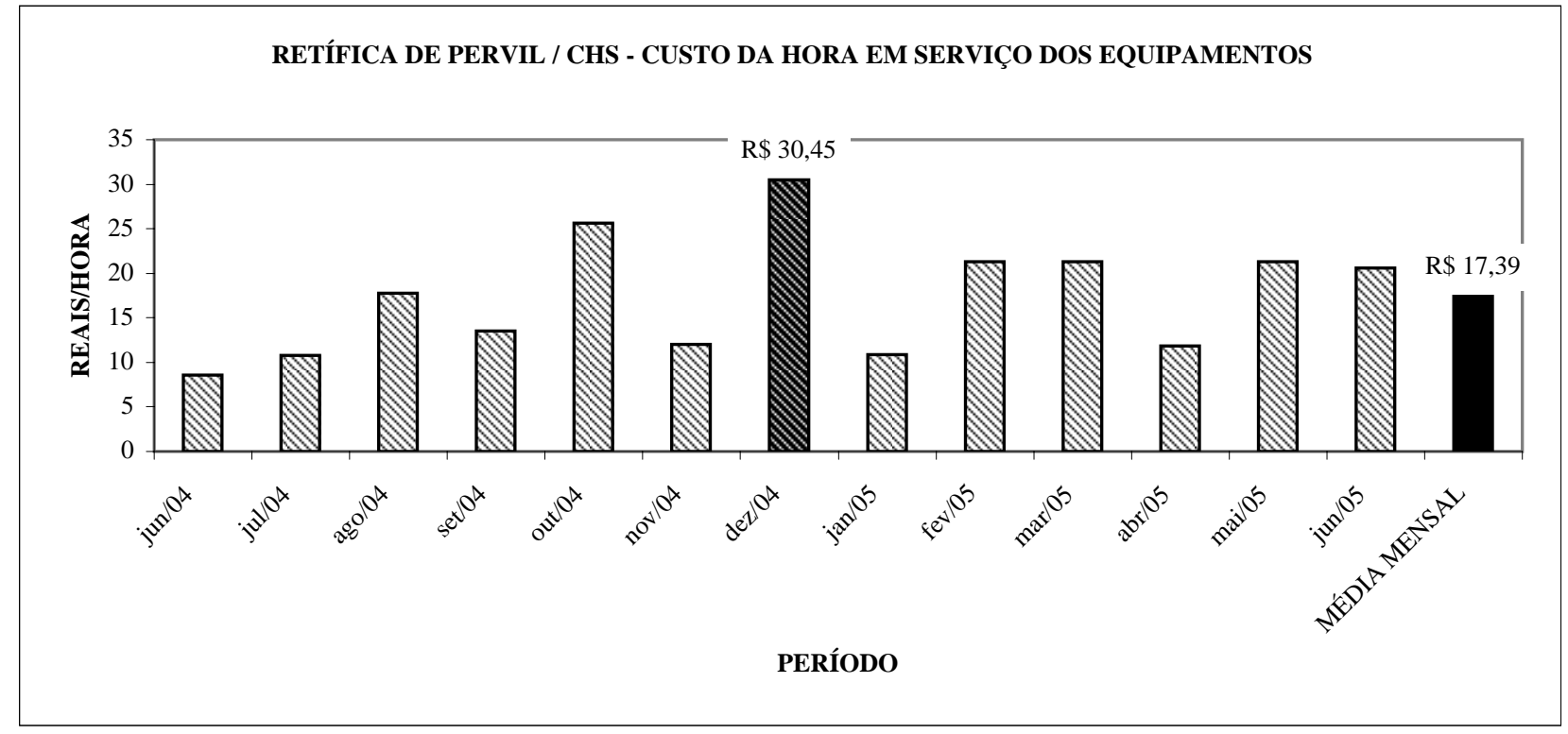




\begin{tabular}{|c|c|c|c|c|c|}
\hline \multirow{2}{*}{ MESES } & \multicolumn{5}{|c|}{ QUALIDADE } \\
\cline { 2 - 6 } & IOP & DOP & ROP & IAP & EGE \\
\hline jun/04 & $0,70 \%$ & $99,30 \%$ & $83,70 \%$ & $99,32 \%$ & $82,55 \%$ \\
\hline jul/04 & $0,87 \%$ & $99,13 \%$ & $74,54 \%$ & $99,43 \%$ & $73,47 \%$ \\
\hline ago/04 & $1,44 \%$ & $98,56 \%$ & $79,11 \%$ & $99,42 \%$ & $77,53 \%$ \\
\hline set/04 & $1,17 \%$ & $98,83 \%$ & $79,65 \%$ & $99,29 \%$ & $78,15 \%$ \\
\hline out/04 & $2,04 \%$ & $97,96 \%$ & $80,19 \%$ & $99,26 \%$ & $77,97 \%$ \\
\hline nov/04 & $0,92 \%$ & $99,08 \%$ & $79,25 \%$ & $99,24 \%$ & $77,93 \%$ \\
\hline dez/04 & $1,69 \%$ & $98,31 \%$ & $93,50 \%$ & $99,14 \%$ & $91,13 \%$ \\
\hline jan/05 & $0,76 \%$ & $99,24 \%$ & $69,32 \%$ & $99,09 \%$ & $68,17 \%$ \\
\hline fev/05 & $1,51 \%$ & $98,49 \%$ & $77,05 \%$ & $98,96 \%$ & $75,09 \%$ \\
\hline mar/05 & $1,56 \%$ & $98,44 \%$ & $92,83 \%$ & $99,13 \%$ & $90,59 \%$ \\
\hline abr/05 & $0,84 \%$ & $99,16 \%$ & $85,92 \%$ & $99,21 \%$ & $84,53 \%$ \\
\hline mai/05 & $1,61 \%$ & $98,39 \%$ & $78,65 \%$ & $99,20 \%$ & $76,76 \%$ \\
\hline jun/05 & $1,61 \%$ & $98,39 \%$ & $83,38 \%$ & $99,13 \%$ & $81,33 \%$ \\
\hline
\end{tabular}

\begin{tabular}{|l|c|c|c|c|c|c|}
\hline \multicolumn{7}{|c|}{ ANÁLISE INTRA INDICADORES - QUALIDADE } \\
\hline Variáveis & r & tn-2 Calc & tn-2 Crit & Comparação & Conclusão & Consistência da Relação \\
\hline IOP x EGE & 0,3033 & 1,0556 & 2,2010 & tn-2 Calc < tn-2 Crit Max & Não há correlação Linear & V \\
\hline DOP x ROP & $-0,3544$ & $-1,2569$ & $-2,2010$ & tn-2 Calc > tn-2 Crit Min & Não há correlação Linear & V \\
\hline DOP x IAP & 0,2628 & 0,9034 & 2,2010 & tn-2 Calc < tn-2 Crit Max & Não há correlação Linear & V \\
\hline ROP x IAP & $-0,1321$ & $-0,4420$ & $-2,2010$ & tn-2 Calc > tn-2 Crit Min & Não há correlação Linear & V \\
\hline
\end{tabular}




\section{RESUMO DOS RESULTADOS: IOP-EGE}

\begin{tabular}{lr}
\hline \multicolumn{2}{c}{ Estatística de regressão } \\
\hline R múltiplo & 0,304994238 \\
R-Quadrado & 0,093021485 \\
R-quadrado ajustado & 0,010568893 \\
Erro padrão & 0,004288102 \\
Observações & 13 \\
\hline
\end{tabular}

\begin{tabular}{|c|c|c|}
\hline $\mathbf{r}$ & tn-2 Calculado & tn-2 Crítico \\
\hline 0,30499 & 1,06216 & 2,20099 \\
\hline \multicolumn{3}{|c|}{ tn-2 Calc < tn-2 Crit Max } \\
\hline \multicolumn{3}{|c|}{ Não há correlação Linear } \\
\hline
\end{tabular}

ANOVA

\begin{tabular}{lccccr}
\hline & gl & SQ & MQ & $F$ & F de significação \\
\hline Regressão & 1 & $2,07448 \mathrm{E}-05$ & $2,07448 \mathrm{E}-05$ & 1,128181455 & 0,31092667 \\
Resíduo & 11 & 0,000202266 & $1,83878 \mathrm{E}-05$ & & \\
Total & 12 & 0,000223011 & & & \\
\hline
\end{tabular}

\begin{tabular}{|c|c|c|c|c|c|c|c|c|}
\hline & Coeficientes & Erro padrão & Stat $t$ & valor-P & 95\% inferiores & 95\% superiores & Inferior 95,0\% & Superior $95,0 \%$ \\
\hline Interseção & $-0,003388216$ & 0,015344957 & $-0,220803255$ & 0,829290535 & $-0,037162238$ & 0,030385805 & $-0,037162238$ & 0,030385805 \\
\hline Variável X 1 & 0,020406377 & 0,01921217 & 1,062158865 & 0,31092667 & $-0,021879324$ & 0,062692078 & $-0,021879324$ & 0,062692078 \\
\hline
\end{tabular}

RESULTADOS DE RESÍDUOS

\begin{tabular}{crrr}
\hline Observação & \multicolumn{1}{c}{ Y previsto } & \multicolumn{1}{c}{ Resíduos } & \multicolumn{1}{c}{ Resíduos padrão } \\
\hline 1 & 0,013457248 & $-0,006457248$ & $-1,572811411$ \\
2 & 0,011604349 & $-0,002904349$ & $-0,707421019$ \\
3 & 0,012432848 & 0,001967152 & 0,479145284 \\
4 & 0,012559367 & $-0,000859367$ & $-0,209318655$ \\
5 & 0,012522636 & 0,007877364 & 1,918713537 \\
6 & 0,012514473 & $-0,003314473$ & $-0,807316265$ \\
7 & 0,015208115 & 0,001691885 & 0,412097605 \\
8 & 0,010522811 & $-0,002922811$ & $-0,711917871$ \\
9 & 0,011934932 & 0,003165068 & 0,77092522 \\
10 & 0,01509792 & 0,00050208 & 0,122293054 \\
11 & 0,013861294 & $-0,005461294$ & $-1,330223937$ \\
12 & 0,012275718 & 0,003824282 & 0,931491853 \\
13 & 0,01320829 & 0,00289171 & 0,704342603 \\
\hline
\end{tabular}

\section{ANÁLISE DE CORRELAÇÃO}

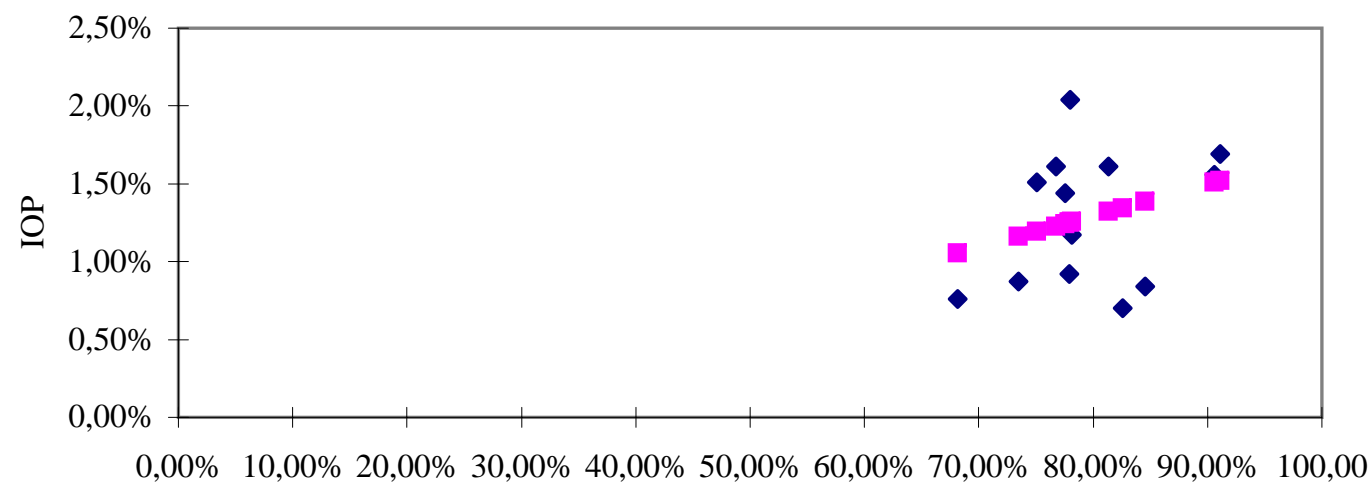

$\%$ 


\section{RESUMO DOS RESULTADOS: IOP-EGE}

\begin{tabular}{lr}
\hline \multicolumn{2}{c}{ Estatística de regressão } \\
\hline R múltiplo & 0,356177112 \\
R-Quadrado & 0,126862135 \\
R-quadrado ajustado & 0,047485965 \\
Erro padrão & 0,004207344 \\
Observações & 13 \\
\hline
\end{tabular}

\begin{tabular}{|c|c|c|}
\hline $\mathbf{r}$ & tn-2 Calculado & tn-2 Crítico \\
\hline$-0,35618$ & $-1,26422$ & $-2,20099$ \\
\hline \multicolumn{3}{|c|}{ tn-2 Calc > tn-2 Crit Min } \\
\hline \multicolumn{3}{|c|}{ Não há correlação Linear } \\
\hline
\end{tabular}

ANOVA

\begin{tabular}{lccccr}
\hline & gl & SQ & MQ & $F$ & F de significação \\
\hline Regressão & 1 & $2,82916 \mathrm{E}-05$ & $2,82916 \mathrm{E}-05$ & 1,598239567 & 0,232284254 \\
Resíduo & 11 & 0,000194719 & $1,77017 \mathrm{E}-05$ & & \\
Total & 12 & 0,000223011 & & & \\
\hline
\end{tabular}

\begin{tabular}{|c|c|c|c|c|c|c|c|c|}
\hline & Coeficientes & Erro padrão & Stat $t$ & valor- $P$ & 95\% inferiores & 95\% superiores & Inferior 95,0\% & Superior 95,0\% \\
\hline Interseção & 1,005742777 & 0,014762293 & 68,12916921 & 8,45597E-16 & 0,973251189 & 1,038234366 & 0,973251189 & 1,038234366 \\
\hline Variável X 1 & $-0,022879424$ & 0,018097732 & $-1,264215$ & 0,232284254 & $-0,062712263$ & 0,016953415 & $-0,062712263$ & 0,016953415 \\
\hline
\end{tabular}

RESULTADOS DE RESÍDUOS

\begin{tabular}{crrr}
\hline Observação & \multicolumn{1}{c}{ Y previsto } & \multicolumn{1}{c}{ Resíduos } & \multicolumn{1}{c}{ Resíduos padrão } \\
\hline 1 & 0,986592699 & 0,006407301 & 1,590601552 \\
2 & 0,988688455 & 0,002611545 & 0,648311741 \\
3 & 0,987642865 & $-0,002042865$ & $-0,507137737$ \\
4 & 0,987519316 & 0,000780684 & 0,193803493 \\
5 & 0,987395767 & $-0,007795767$ & $-1,935285968$ \\
6 & 0,987610834 & 0,003189166 & 0,791705145 \\
7 & 0,984350516 & $-0,001250516$ & $-0,310438407$ \\
8 & 0,98988276 & 0,00251724 & 0,624900451 \\
9 & 0,988114181 & $-0,003214181$ & $-0,797914984$ \\
10 & 0,984503808 & $-0,000103808$ & $-0,025770124$ \\
11 & 0,986084776 & 0,005515224 & 1,369145001 \\
12 & 0,98774811 & $-0,00384811$ & $-0,955286837$ \\
13 & 0,986665913 & $-0,002765913$ & $-0,686633325$ \\
\hline
\end{tabular}

\section{ANÁLISE DE CORRELAÇÃO}

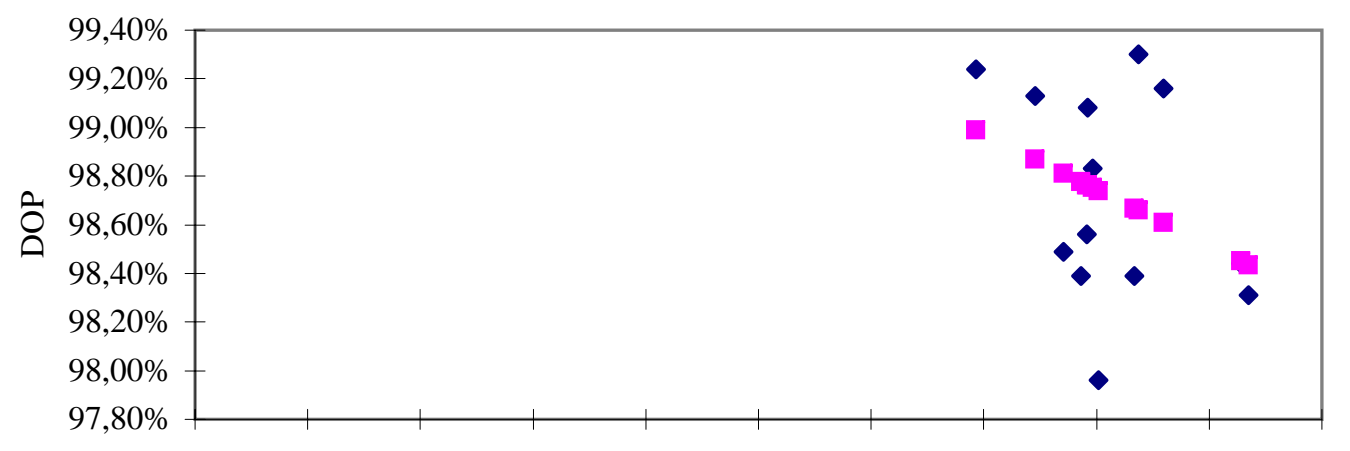

0,00\% 10,00\% 20,00\% 30,00\% 40,00\% 50,00\% 60,00\% 70,00\% 80,00\% 90,00\% 100,00

ROP 


\section{RESUMO DOS RESULTADOS: IOP-EGE}

\begin{tabular}{lr}
\hline \multicolumn{2}{c}{ Estatística de regressão } \\
\hline R múltiplo & 0,261718246 \\
R-Quadrado & 0,06849644 \\
R-quadrado ajustado & $-0,016185702$ \\
Erro padrão & 0,004345691 \\
Observações & 13 \\
\hline
\end{tabular}

\begin{tabular}{|c|c|c|}
\hline $\mathbf{r}$ & tn-2 Calculado & tn-2 Crítico \\
\hline 0,26172 & 0,89937 & 2,20099 \\
\hline \multicolumn{3}{|c|}{ tn-2 Calc < tn-2 Crit Max } \\
\hline \multicolumn{3}{|c|}{ Não há correlação Linear } \\
\hline
\end{tabular}

ANOVA

\begin{tabular}{lccrrr}
\hline & gl & SQ & MQ & \multicolumn{1}{c}{$F$} & F de significação \\
\hline Regressão & 1 & $1,52754 \mathrm{E}-05$ & $1,52754 \mathrm{E}-05$ & 0,80886523 & 0,387720281 \\
Resíduo & 11 & 0,000207735 & $1,8885 \mathrm{E}-05$ & & \\
Total & 12 & 0,000223011 & & & \\
\hline
\end{tabular}

\begin{tabular}{|c|c|c|c|c|c|c|c|c|}
\hline & Coeficientes & Erro padrão & Stat $t$ & valor-P & 95\% inferiores & 95\% superiores & Inferior $95,0 \%$ & Superior $95,0 \%$ \\
\hline Interseção & 0,137853022 & 0,944312957 & 0,145982347 & 0,886576157 & $-1,940565782$ & 2,216271826 & $-1,940565782$ & 2,216271826 \\
\hline Variável X 1 & 0,855988488 & 0,951765242 & 0,899369351 & 0,387720281 & $-1,238832684$ & 2,95080966 & $-1,238832684$ & 2,95080966 \\
\hline
\end{tabular}

RESULTADOS DE RESÍDUOS

\begin{tabular}{crrr}
\hline Observação & \multicolumn{1}{c}{ Y previsto } & \multicolumn{1}{c}{ Resíduos } & \multicolumn{1}{c}{ Resíduos padrão } \\
\hline 1 & 0,988020788 & 0,004979212 & 1,196729651 \\
2 & 0,988962375 & 0,002337625 & 0,561836825 \\
3 & 0,988876777 & $-0,003276777$ & $-0,787557519$ \\
4 & 0,987763992 & 0,000536008 & 0,128827047 \\
5 & 0,987507195 & $-0,007907195$ & $-1,900456341$ \\
6 & 0,987335997 & 0,003464003 & 0,832556397 \\
7 & 0,986480009 & $-0,003380009$ & $-0,81236889$ \\
8 & 0,986052015 & 0,006347985 & 1,525707792 \\
9 & 0,98493923 & $-3,92296 \mathrm{E}-05$ & $-0,00942864$ \\
10 & 0,98639441 & $-0,00199441$ & $-0,479346864$ \\
11 & 0,987079201 & 0,004520799 & 1,08655237 \\
12 & 0,986993602 & $-0,003093602$ & $-0,743532366$ \\
13 & 0,98639441 & $-0,00249441$ & $-0,599519462$ \\
\hline
\end{tabular}

ANÁLISE DE CORRELAÇÃO

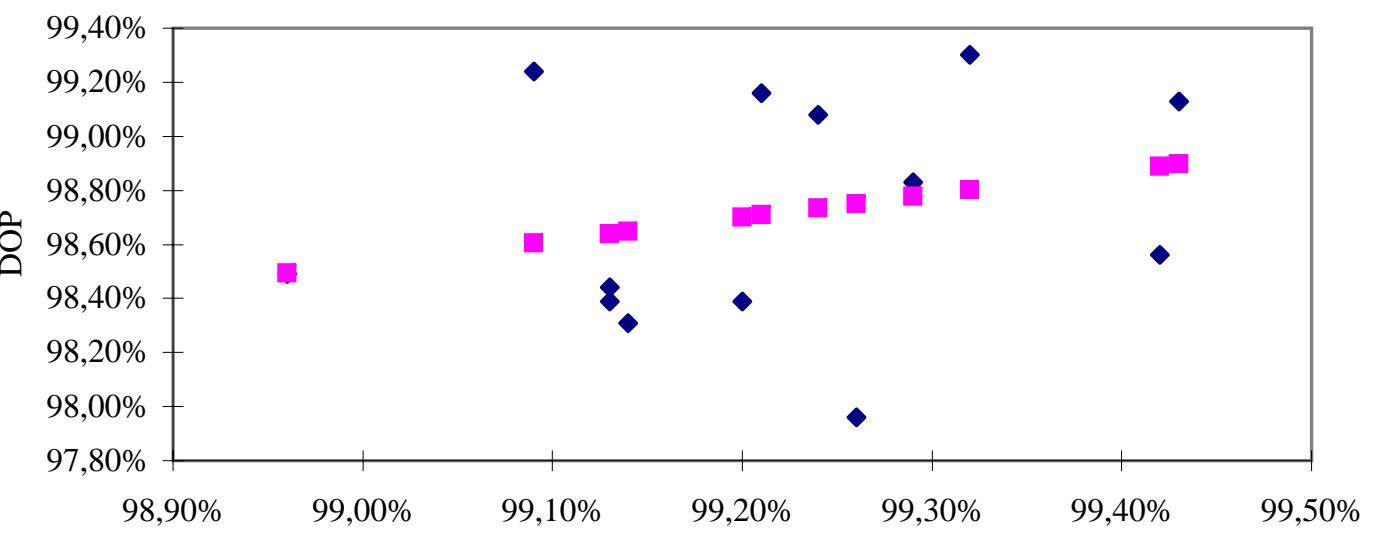

IAP 


\section{RESUMO DOS RESULTADOS: IOP-EGE}

\begin{tabular}{lr}
\hline \multicolumn{2}{c}{ Estatística de regressão } \\
\hline R múltiplo & 0,127144386 \\
R-Quadrado & 0,016165695 \\
R-quadrado ajustado & $-0,073273787$ \\
Erro padrão & 0,069526197 \\
Observações & 13 \\
\hline
\end{tabular}

\begin{tabular}{|c|c|c|}
\hline $\mathbf{r}$ & tn-2 Calculado & tn-2 Crítico \\
\hline$-0,12714$ & $-0,42514$ & $-2,20099$ \\
\hline \multicolumn{3}{|c|}{ tn-2 Calc > tn-2 Crit Min } \\
\hline \multicolumn{3}{|c|}{ Não há correlação Linear } \\
\hline
\end{tabular}

ANOVA

\begin{tabular}{lccccr}
\hline & gl & SQ & $M Q$ & $F$ & F de significação \\
\hline Regressão & 1 & 0,000873699 & 0,000873699 & 0,180744505 & 0,678931766 \\
Resíduo & 11 & 0,053172813 & 0,004833892 & & \\
Total & 12 & 0,054046512 & & & \\
\hline
\end{tabular}

\begin{tabular}{|c|c|c|c|c|c|c|c|c|}
\hline & Coeficientes & Erro padrão & Stat $t$ & valor-P & 95\% inferiores & 95\% superiores & Inferior $95,0 \%$ & Superior $95,0 \%$ \\
\hline Interseção & 7,236144144 & 15,10795175 & 0,47896262 & 0,641344773 & $-26,01623343$ & 40,48852172 & $-26,01623343$ & 40,48852172 \\
\hline Variável X 1 & $-6,473691978$ & 15,22717997 & $-0,42514057$ & 0,678931766 & $-39,98848911$ & 27,04110515 & $-39,98848911$ & 27,04110515 \\
\hline
\end{tabular}

RESULTADOS DE RESÍDUOS

\begin{tabular}{crrr}
\hline Observação & \multicolumn{1}{c}{ Y previsto } & \multicolumn{1}{c}{ Resíduos } & \multicolumn{1}{c}{ Resíduos padrão } \\
\hline 1 & 0,806473271 & 0,030526729 & 0,458591575 \\
2 & 0,79935221 & $-0,05395221$ & $-0,810503782$ \\
3 & 0,799999579 & $-0,008899579$ & $-0,133695037$ \\
4 & 0,808415379 & $-0,011915379$ & $-0,179000261$ \\
5 & 0,810357487 & $-0,008457487$ & $-0,127053642$ \\
6 & 0,811652225 & $-0,019152225$ & $-0,287716679$ \\
7 & 0,818125917 & 0,116874083 & 1,755755437 \\
8 & 0,821362763 & $-0,128162763$ & $-1,925341033$ \\
9 & 0,829778562 & $-0,059278562$ & $-0,890519571$ \\
10 & 0,818773286 & 0,109526714 & 1,645378671 \\
11 & 0,813594333 & 0,045605667 & 0,685116807 \\
12 & 0,814241702 & $-0,027741702$ & $-0,416753162$ \\
13 & 0,818773286 & 0,015026714 & 0,225740677 \\
\hline
\end{tabular}

ANÁLISE DE CORRELAÇÃO

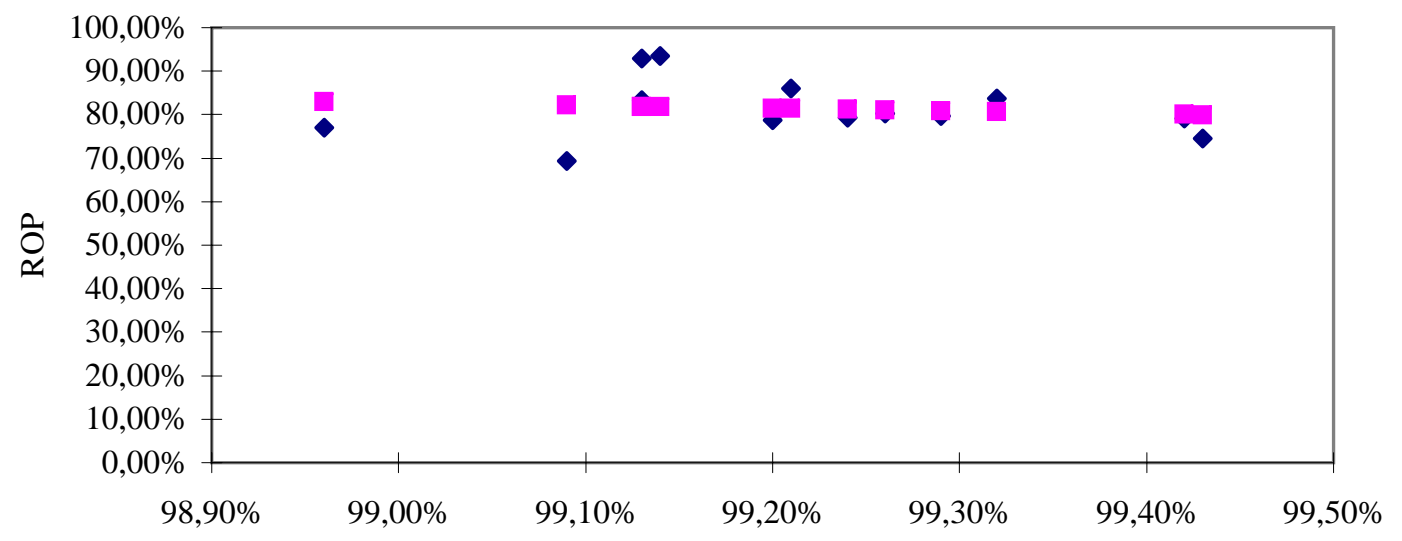




\begin{tabular}{|c|c|r|c|}
\hline \multirow{2}{*}{ MESES } & \multicolumn{3}{|c|}{ VELOCIDADE } \\
\cline { 2 - 4 } & TMDR & VAT & IPR \\
\hline jun/04 & 3,19 & $96,46 \%$ & $0,07 \%$ \\
\hline jul/04 & 3,43 & $100,45 \%$ & $0,00 \%$ \\
\hline ago/04 & 4,09 & $64,73 \%$ & $1,02 \%$ \\
\hline set/04 & 3,01 & $67,94 \%$ & $0,65 \%$ \\
\hline out/04 & 10,34 & $58,81 \%$ & $1,79 \%$ \\
\hline nov/04 & 4,49 & $108,48 \%$ & $0,10 \%$ \\
\hline dez/04 & 6,74 & $102,05 \%$ & $0,94 \%$ \\
\hline jan/05 & 2,41 & $89,45 \%$ & $0,44 \%$ \\
\hline fev/05 & 4,79 & $77,20 \%$ & $0,99 \%$ \\
\hline mar/05 & 4,65 & $81,37 \%$ & $1,12 \%$ \\
\hline abr/05 & 3,13 & $108,44 \%$ & $0,10 \%$ \\
\hline mai/05 & 7,03 & $85,84 \%$ & $1,28 \%$ \\
\hline jun/05 & 6,21 & $75,72 \%$ & $1,27 \%$ \\
\hline
\end{tabular}

\begin{tabular}{|l|c|c|c|c|c|c|}
\hline \multicolumn{7}{|c|}{ ANÁLISE INTRA INDICADORES - VELOCIDADE } \\
\hline \multicolumn{1}{|c|}{ Variáveis } & $\mathbf{r}$ & tn-2 Calc & tn-2 Crit & Comparação & Conclusão & Consistência da Relação \\
\hline TMDR x VAT & $-0,3992$ & $-1,4442$ & $-2,2010$ & tn-2 Calc $>$ tn-2 Crit Min & Não há correlação Linear & V \\
\hline TMDR x IPR & 0,8036 & 4,4787 & 2,2010 & tn-2 Calc $>$ tn-2 Crit Max & Evidências de Correlação Linear Positiva & V \\
\hline VAT x IPR & $-0,7606$ & $-3,8861$ & $-2,2010$ & tn-2 Calc $<$ tn-2 Crit Min & Evidências de Correlação Linear Negativa & V \\
\hline
\end{tabular}




\section{RESUMO DOS RESULTADOS: TMDR x VAT}

\begin{tabular}{lr}
\hline \multicolumn{2}{c}{ Estatística de regressão } \\
\hline R múltiplo & 0,399228597 \\
R-Quadrado & 0,159383472 \\
R-quadrado ajustado & 0,082963788 \\
Erro padrão & 2,107459111 \\
Observações & 13 \\
\hline
\end{tabular}

\begin{tabular}{|c|c|c|}
\hline $\mathbf{r}$ & tn-2 Calculado & tn-2 Crítico \\
\hline$-0,39923$ & $-1,44417$ & $-2,20099$ \\
\hline \multicolumn{3}{|c|}{ tn-2 Calc $>$ tn-2 Crit Min } \\
\hline \multicolumn{3}{|c|}{ Não há correlação Linear } \\
\hline
\end{tabular}

\section{ANOVA}

\begin{tabular}{lccccr}
\hline & $g l$ & $S Q$ & $M Q$ & $F$ & $F$ de significação \\
\hline Regressão & 1 & 9,263100136 & 9,263100136 & 2,085633743 & 0,176563661 \\
Resíduo & 11 & 48,85522294 & 4,441383904 & & \\
Total & 12 & 58,11832308 & & & \\
\hline
\end{tabular}

\begin{tabular}{|c|c|c|c|c|c|c|c|c|}
\hline & Coeficientes & Erro padrão & Stat $t$ & valor-P & 95\% inferiores & 95\% superiores & Inferior 95,0\% & Superior $95,0 \%$ \\
\hline Interseção & 9,424417183 & 3,196887418 & 2,947997834 & 0,013256775 & 2,388115422 & 16,46071894 & 2,388115422 & 16,46071894 \\
\hline Variável X 1 & $-5,282916342$ & 3,658092737 & $-1,444172338$ & 0,176563661 & $-13,33432417$ & 2,768491481 & $-13,33432417$ & 2,768491481 \\
\hline
\end{tabular}

\section{RESULTADOS DE RESÍDUOS}

\begin{tabular}{crrr}
\hline Observação & \multicolumn{1}{c}{ Y previsto } & \multicolumn{1}{c}{ Resíduos } & \multicolumn{1}{c}{ Resíduos padrão } \\
\hline 1 & 4,328685958 & $-1,138685958$ & $-0,564337732$ \\
2 & 4,117485525 & $-0,687485525$ & $-0,340720828$ \\
3 & 6,004555519 & $-1,914555519$ & $-0,948862074$ \\
4 & 5,835447602 & $-2,825447602$ & $-1,400304167$ \\
5 & 6,317302754 & 4,022697246 & 1,993666317 \\
6 & 3,693256363 & 0,796743637 & 0,394869625 \\
7 & 4,033286138 & 2,706713862 & 1,341459207 \\
8 & 4,699019995 & $-2,289019995$ & $-1,134448302$ \\
9 & 5,345916353 & $-0,555916353$ & $-0,275514571$ \\
10 & 5,12574726 & $-0,47574726$ & $-0,235782419$ \\
11 & 3,695553639 & $-0,565553639$ & $-0,280290852$ \\
12 & 4,889457918 & 2,140542082 & 1,060862001 \\
13 & 5,424284976 & 0,785715024 & 0,389403796 \\
\hline
\end{tabular}

ANÁLISE DE CORRELAÇÃO

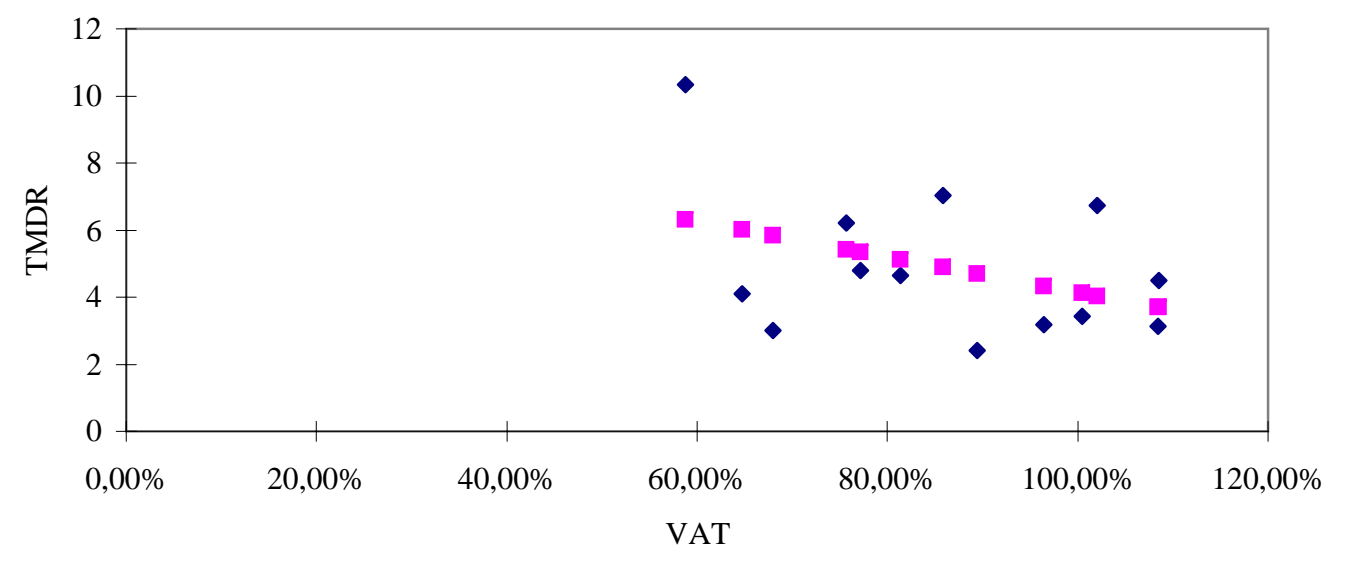




\section{RESUMO DOS RESULTADOS: TMDR x IPR}

\begin{tabular}{lr}
\hline \multicolumn{2}{c}{ Estatística de regressão } \\
\hline R múltiplo & 0,803639123 \\
R-Quadrado & 0,645835841 \\
R-quadrado ajustado & 0,613639099 \\
Erro padrão & 1,36792567 \\
Observações & 13 \\
\hline
\end{tabular}

\begin{tabular}{|c|c|c|}
\hline $\mathbf{r}$ & tn-2 Calculado & tn-2 Crítico \\
\hline 0,80364 & 4,47873 & 2,20099 \\
\hline \multicolumn{3}{|c|}{ tn-2 Calc $>$ tn-2 Crit Max } \\
\hline \multicolumn{3}{|c|}{ Evidências de Correlação Linear Positiva } \\
\hline
\end{tabular}

ANOVA

\begin{tabular}{lccrrr}
\hline & $g l$ & $S Q$ & $M Q$ & $F$ & F de significação \\
\hline Regressão & 1 & 37,53489604 & 37,53489604 & 20,05904341 & 0,000933351 \\
Resíduo & 11 & 20,58342704 & 1,87122064 & & \\
Total & 12 & 58,11832308 & & & \\
\hline
\end{tabular}

\begin{tabular}{|c|c|c|c|c|c|c|c|c|}
\hline & Coeficientes & Erro padrão & Stat $t$ & valor-P & 95\% inferiores & 95\% superiores & Inferior $95,0 \%$ & Superior $95,0 \%$ \\
\hline Interseção & 2,553747682 & 0,644178913 & 3,964345353 & 0,002217479 & 1,135919454 & 3,97157591 & 1,135919454 & 3,97157591 \\
\hline Variável X 1 & 309,7184008 & 69,15313911 & 4,478732344 & 0,000933351 & 157,513368 & 461,9234337 & 157,513368 & 461,9234337 \\
\hline
\end{tabular}

RESULTADOS DE RESÍDUOS

\begin{tabular}{crrr} 
RESULTADOS DE RESİDUOS & \multicolumn{1}{c}{ Y previsto } & \multicolumn{1}{l}{ Resíduos } & \multicolumn{1}{c}{ Resíduos padrão } \\
\hline Observação & 2,755892104 & 0,434107896 & 0,331458733 \\
\hline 1 & 2,564624405 & 0,865375595 & 0,660748862 \\
2 & 5,72581279 & $-1,63581279$ & $-1,249008461$ \\
3 & 4,578461563 & $-1,568461563$ & $-1,197583106$ \\
4 & 8,099449965 & 2,240550035 & 1,710749523 \\
5 & 2,878668703 & 1,611331297 & 1,230315862 \\
6 & 5,479353686 & 1,260646314 & 0,962553858 \\
7 & 3,908085219 & $-1,498085219$ & $-1,143847955$ \\
8 & 5,634589283 & $-0,844589283$ & $-0,644877682$ \\
9 & 6,037093242 & $-1,387093242$ & $-1,059101143$ \\
10 & 2,862294761 & 0,267705239 & 0,204403652 \\
11 & 6,503562649 & 0,526437351 & 0,401955964 \\
12 & 6,482111631 & $-0,272111631$ & $-0,207768109$ \\
13 & & &
\end{tabular}

ANÁLISE DE CORRELAÇÃO

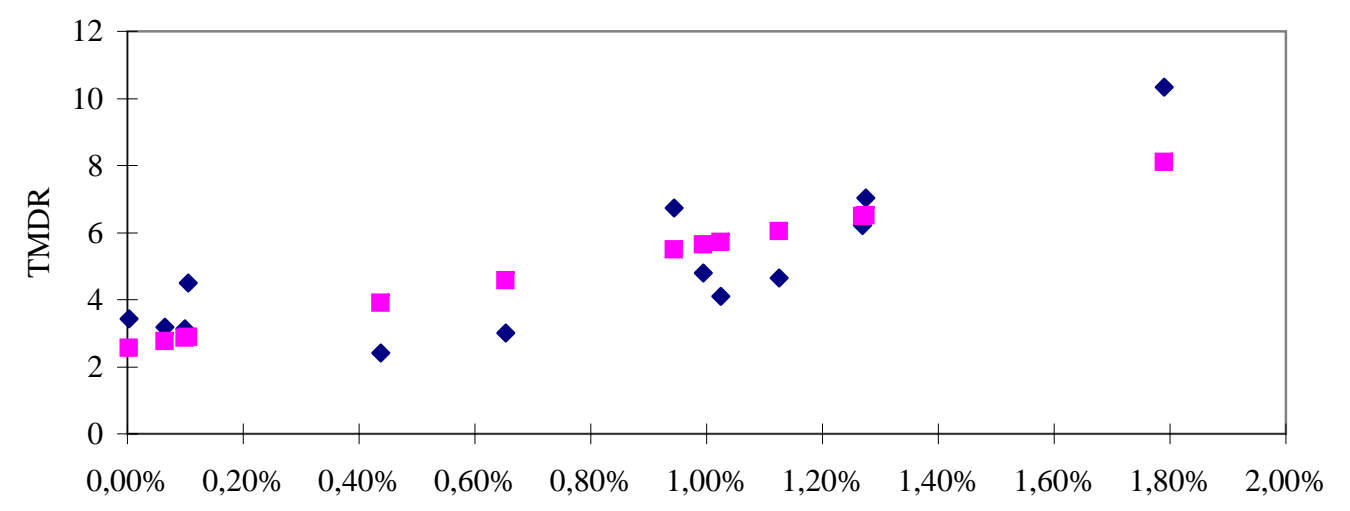

IPR 


\section{RESUMO DOS RESULTADOS: VAT x IPR}

\begin{tabular}{lr}
\hline \multicolumn{2}{c}{ Estatística de regressão } \\
\hline R múltiplo & 0,760638749 \\
R-Quadrado & 0,578571307 \\
R-quadrado ajustado & 0,540259607 \\
Erro padrão & 0,112763917 \\
Observações & 13 \\
\hline
\end{tabular}

\begin{tabular}{|c|c|c|}
\hline $\mathbf{r}$ & tn-2 Calculado & tn-2 Crítico \\
\hline$-0,76064$ & $-3,88609$ & $-2,20099$ \\
\hline \multicolumn{3}{|c|}{ tn-2 Calc $<$ tn-2 Crit Min } \\
\hline \multicolumn{3}{|c|}{ Evidências de Correlação Linear Negativa } \\
\hline
\end{tabular}

ANOVA

\begin{tabular}{|c|c|c|c|c|c|c|c|c|}
\hline & $g l$ & $S Q$ & $M Q$ & $F$ & F de significação & & & \\
\hline Regressão & 1 & 0,192028542 & 0,192028542 & 15,10168737 & 0,002536613 & & & \\
\hline Resíduo & 11 & 0,139872711 & 0,012715701 & & & & & \\
\hline Total & 12 & 0,331901253 & & & & & & \\
\hline & Coeficientes & Erro padrão & Stat $t$ & valor- $P$ & 95\% inferiores & 95\% superiores & Inferior $95,0 \%$ & Superior $95,0 \%$ \\
\hline Interseção & 1,025963876 & 0,053102401 & 19,32047993 & 7,74114E-10 & 0,909086279 & 1,142841472 & 0,909086279 & 1,142841472 \\
\hline Variável X 1 & $-22,15298694$ & 5,70058668 & $-3,886088956$ & 0,002536613 & $-34,69989362$ & $-9,606080259$ & $-34,69989362$ & $-9,606080259$ \\
\hline
\end{tabular}

RESULTADOS DE RESÍDUOS

\begin{tabular}{crrr}
\hline Observação & \multicolumn{1}{c}{ Y previsto } & \multicolumn{1}{c}{ Resíduos } & \multicolumn{1}{c}{ Resíduos padrão } \\
\hline 1 & 1,011505249 & $-0,046937405$ & $-0,434753615$ \\
2 & 1,025185905 & $-0,02064006$ & $-0,191176755$ \\
3 & 0,799078044 & $-0,151734523$ & $-1,405427773$ \\
4 & 0,881143742 & $-0,201789887$ & $-1,86906121$ \\
5 & 0,629300746 & $-0,041156958$ & $-0,381212726$ \\
6 & 1,002723503 & 0,08212442 & 0,760670271 \\
7 & 0,816706333 & 0,203777562 & 1,887471876 \\
8 & 0,929093229 & $-0,034625688$ & $-0,320717412$ \\
9 & 0,805602917 & $-0,033585992$ & $-0,311087314$ \\
10 & 0,77681333 & 0,036879268 & 0,341591004 \\
11 & 1,003894669 & 0,080518404 & 0,745794686 \\
12 & 0,743448535 & 0,114971127 & 1,064910027 \\
13 & 0,744982846 & 0,012199731 & 0,112998941 \\
\hline
\end{tabular}

ANÁLISE DE CORRELAÇÃO

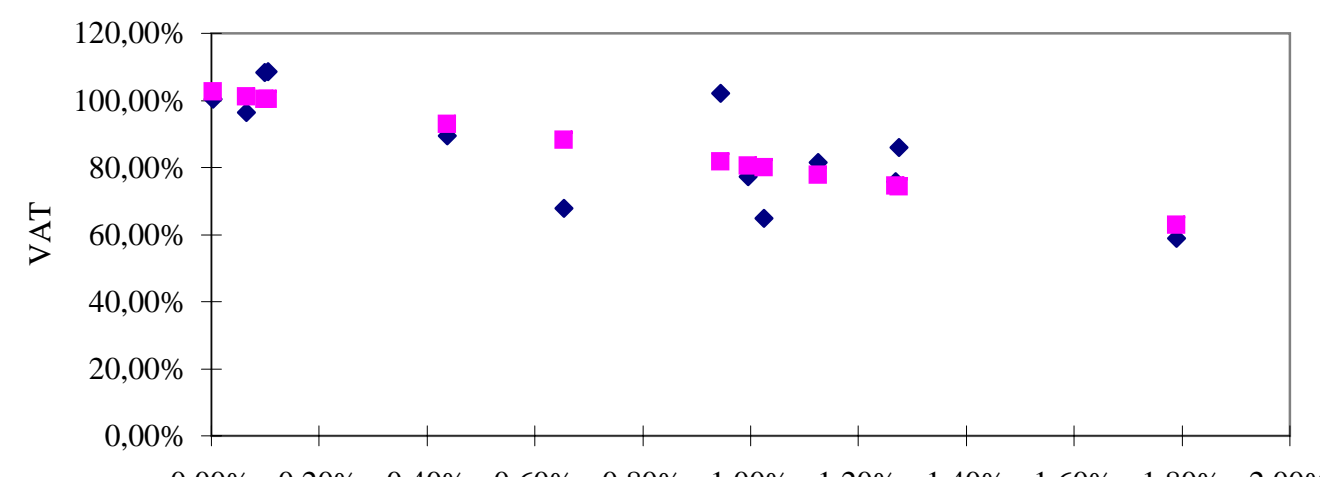

$\begin{array}{llllllllll}0,00 \% & 0,20 \% & 0,40 \% & 0,60 \% & 0,80 \% & 1,00 \% & 1,20 \% & 1,40 \% & 1,60 \% & 1,80 \%\end{array} \quad 2,00 \%$

IPR 


\begin{tabular}{|c|c|c|c|c|}
\hline \multirow{2}{*}{ MESES } & \multicolumn{4}{|c|}{ CONFIABILIDADE } \\
\cline { 2 - 5 } & TMEF & IRE & IFO & NF \\
\hline jun/04 & 587,33 & 2.117 & $0,63 \%$ & 21 \\
\hline jul/04 & 405,56 & 3.309 & $0,87 \%$ & 33 \\
\hline ago/04 & 412,13 & 3.106 & $0,42 \%$ & 31 \\
\hline set/04 & 371,99 & 3.308 & $0,52 \%$ & 33 \\
\hline out/04 & 646,79 & 1.806 & $0,25 \%$ & 18 \\
\hline nov/04 & 588,61 & 2.006 & $0,81 \%$ & 20 \\
\hline dez/04 & 663,77 & 1.203 & $0,75 \%$ & 12 \\
\hline jan/05 & 474,08 & 2.607 & $0,32 \%$ & 26 \\
\hline fev/05 & 433,44 & 2.708 & $0,52 \%$ & 27 \\
\hline $\mathrm{mar} / 05$ & 421,70 & 2.911 & $0,44 \%$ & 29 \\
\hline abr/05 & 410,55 & 3.012 & $0,74 \%$ & 30 \\
\hline mai/05 & 555,59 & 2.309 & $0,34 \%$ & 22 \\
\hline jun/05 & 455,54 & 2.908 & $0,34 \%$ & 28 \\
\hline
\end{tabular}

\begin{tabular}{|c|c|c|c|c|c|c|}
\hline \multicolumn{7}{|c|}{ ANÁLISE INTRA INDICADORES - CONFIABILIDADE } \\
\hline Variáveis & $\mathbf{r}$ & tn-2 Calc & tn-2 Crit & Comparação & Conclusão & Consistência da Relação \\
\hline TMEF x IRE & $-0,9696$ & $-13,1467$ & $-2,2010$ & tn-2 Calc $<$ tn-2 Crit Min & Evidências de Correlação Linear Negativa & $\mathrm{V}$ \\
\hline TMEF $\times$ IFO & $-0,0004$ & $-0,0013$ & $-2,2010$ & tn-2 Calc > tn-2 Crit Min & Não há correlação Linear & $\mathrm{V}$ \\
\hline TMEF x NF & $-0,9730$ & $-13,9888$ & $-2,2010$ & tn-2 Calc $<$ tn-2 Crit Min & Evidências de Correlação Linear Negativa & $\mathrm{V}$ \\
\hline IRE $x$ IFO & $-0,0420$ & $-0,1395$ & $-2,2010$ & tn-2 Calc > tn-2 Crit Min & Não há correlação Linear & $\mathrm{V}$ \\
\hline IRE $x$ NF & 0,9982 & 55,8877 & 2,2010 & tn-2 Calc $>$ tn-2 Crit Max & Evidências de Correlação Linear Positiva & $\mathrm{V}$ \\
\hline IFO X NF & $-0,0180$ & $-0,0596$ & $-2,2010$ & tn-2 Calc > tn-2 Crit Min & Não há correlação Linear & $\mathrm{V}$ \\
\hline
\end{tabular}




\section{RESUMO DOS RESULTADOS: TMEF x IRE}

\begin{tabular}{lr}
\hline \multicolumn{2}{c}{ Estatística de regressão } \\
\hline R múltiplo & 0,96962061 \\
R-Quadrado & 0,940164127 \\
R-quadrado ajustado & 0,934724502 \\
Erro padrão & 25,63037575 \\
Observações & 13 \\
\hline
\end{tabular}

\begin{tabular}{|c|c|c|}
\hline $\mathbf{r}$ & tn-2 Calculado & tn-2 Crítico \\
\hline$-0,96962$ & $-13,14672$ & $-2,20099$ \\
\hline \multicolumn{3}{|c|}{ tn-2 Calc $<$ tn-2 Crit Min } \\
\hline \multicolumn{3}{|c|}{ Evidências de Correlação Linear Negativa } \\
\hline
\end{tabular}

ANOVA

\begin{tabular}{lccccr}
\hline & gl & SQ & $M Q$ & $F$ & F de significação \\
\hline Regressão & 1 & 113538,8979 & 113538,8979 & 172,8362075 & $4,52866 \mathrm{E}-08$ \\
Resíduo & 11 & 7226,07777 & 656,9161609 & & \\
Total & 12 & 120764,9757 & & & \\
\hline
\end{tabular}

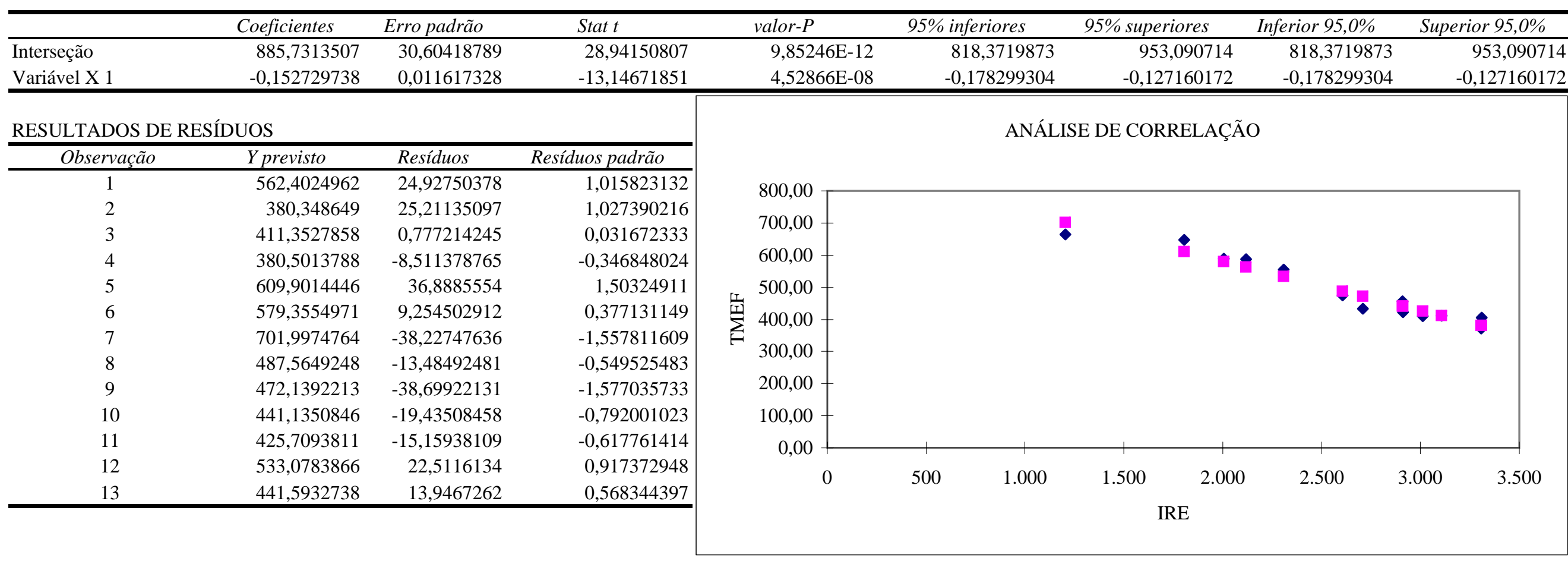




\section{RESUMO DOS RESULTADOS: TMEF x IFO}

\begin{tabular}{lr}
\hline \multicolumn{2}{c}{ Estatística de regressão } \\
\hline R múltiplo & 0,000396974 \\
R-Quadrado & $1,57588 \mathrm{E}-07$ \\
R-quadrado ajustado & $-0,090908919$ \\
Erro padrão & 104,7789694 \\
Observações & 13 \\
\hline
\end{tabular}

\begin{tabular}{|c|c|c|}
\hline $\mathbf{r}$ & tn-2 Calculado & tn-2 Crítico \\
\hline$-0,00040$ & $-0,00132$ & $-2,20099$ \\
\hline \multicolumn{3}{|c|}{ tn-2 Calc $>$ tn-2 Crit Min } \\
\hline \multicolumn{3}{|c|}{ Não há correlação Linear } \\
\hline
\end{tabular}

ANOVA

\begin{tabular}{lccccr}
\hline & $g l$ & $S Q$ & $M Q$ & $F$ & F de significação \\
\hline Regressão & 1 & 0,019031145 & 0,019031145 & $1,73347 \mathrm{E}-06$ & 0,998973069 \\
Resíduo & 11 & 120764,9567 & 10978,63242 & & \\
Total & 12 & 120764,9757 & & & \\
\hline
\end{tabular}

Total 120764,9757

\begin{tabular}{|c|c|c|c|c|c|c|c|c|}
\hline & Coeficientes & Erro padrão & Stat $t$ & valor-P & 95\% inferiores & 95\% superiores & Inferior $95,0 \%$ & Superior 95,0\% \\
\hline Interse & 494,493909 & 83,55370954 & 5,918275942 & 0,000100423 & 310,5934344 & 678,3943837 & 310,5934344 & 678,3943837 \\
\hline Variável X 1 & $-19,29233361$ & 14652,99581 & $-0,001316614$ & 0,998973069 & $-32270,31865$ & 32231,73398 & $-32270,31865$ & 32231,73398 \\
\hline
\end{tabular}

RESULTADOS DE RESÍDUOS

\begin{tabular}{crrr}
\hline Observação & Y previsto & \multicolumn{1}{c}{ Resíduos } & \multicolumn{1}{c}{ Resíduos padrão } \\
\hline 1 & 494,3723673 & 92,95763269 & 0,926627561 \\
2 & 494,3260657 & $-88,76606571$ & $-0,884844854$ \\
3 & 494,4128812 & $-82,28288121$ & $-0,820218666$ \\
4 & 494,3935889 & $-122,4035889$ & $-1,220153049$ \\
5 & 494,4456782 & 152,3443218 & 1,51861061 \\
6 & 494,3376411 & 94,27235889 & 0,939733117 \\
7 & 494,3492165 & 169,4207835 & 1,688833534 \\
8 & 494,4321735 & $-20,35217355$ & $-0,202876132$ \\
9 & 494,3935889 & $-60,95358888$ & $-0,607602343$ \\
10 & 494,4090227 & $-72,70902275$ & $-0,72478378$ \\
11 & 494,3511457 & $-83,80114575$ & $-0,83535315$ \\
12 & 494,4283151 & 61,16168492 & 0,609676702 \\
13 & 494,4283151 & $-38,88831508$ & $-0,387649551$ \\
\hline
\end{tabular}

ANÁLISE DE CORRELAÇÃO

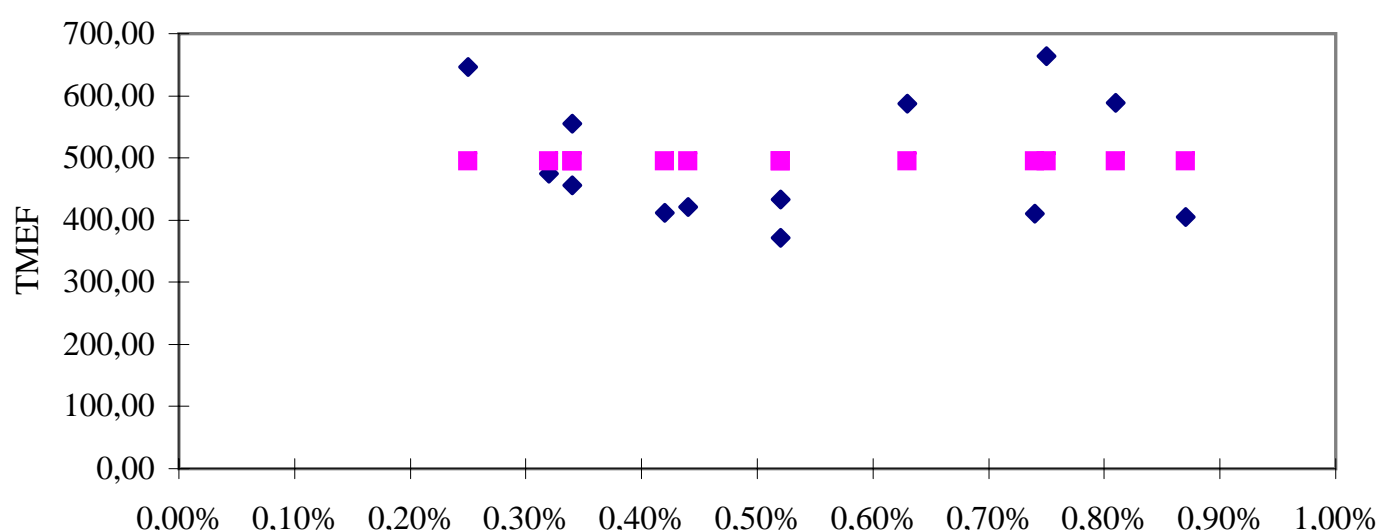

IFO 


\section{RESUMO DOS RESULTADOS: TMEF x NF}

\begin{tabular}{lr}
\hline \multicolumn{2}{c}{ Estatística de regressão } \\
\hline R múltiplo & 0,973025974 \\
R-Quadrado & 0,946779545 \\
R-quadrado ajustado & 0,941941322 \\
Erro padrão & 24,17204795 \\
Observações & 13 \\
\hline
\end{tabular}

\begin{tabular}{|c|c|c|}
\hline $\mathbf{r}$ & tn-2 Calculado & tn-2 Crítico \\
\hline$-0,97303$ & $-13,98883$ & $-2,20099$ \\
\hline \multicolumn{3}{|c|}{ tn-2 Calc $<$ tn-2 Crit Min } \\
\hline \multicolumn{3}{|c|}{ Evidências de Correlação Linear Negativa } \\
\hline
\end{tabular}

ANOVA

\begin{tabular}{lccrrr}
\hline & gl & SQ & MQ & \multicolumn{1}{c}{$F$} & F de significação \\
\hline Regressão & 1 & 114337,8088 & 114337,8088 & 195,6874486 & $2,37046 \mathrm{E}-08$ \\
Resíduo & 11 & 6427,166922 & 584,287902 & & \\
Total & 12 & 120764,9757 & & & \\
\hline
\end{tabular}

\begin{tabular}{|c|c|c|c|c|c|c|c|c|}
\hline & Coeficientes & Erro padrão & Stat $t$ & valor-P & 95\% inferiores & 95\% superiores & Inferior 95,0\% & Superior $95,0 \%$ \\
\hline Interseção & 884,1175167 & 28,65512694 & 30,85372884 & $4,9128 \mathrm{E}-12$ & 821,0480075 & 947,1870258 & 821,0480075 & 947,1870258 \\
\hline Variável X 1 & $-15,35287187$ & 1,097509126 & $-13,98883299$ & 2,37046E-08 & $-17,76847317$ & $-12,93727057$ & $-17,76847317$ & $-12,93727057$ \\
\hline
\end{tabular}

RESULTADOS DE RESÍDUOS

\begin{tabular}{crrr}
\hline Observação & \multicolumn{1}{c}{ Y previsto } & \multicolumn{1}{l}{ Resíduos } & Resíduos padrão \\
\hline 1 & 561,7072074 & 25,62279258 & 1,107152116 \\
2 & 377,472745 & 28,087255 & 1,213640695 \\
3 & 408,1784887 & 3,951511259 & 0,170743452 \\
4 & 377,472745 & $-5,482745005$ & $-0,236907539$ \\
5 & 607,765823 & 39,02417697 & 1,686221358 \\
6 & 577,0600793 & 11,54992071 & 0,499068129 \\
7 & 699,8830542 & $-36,11305423$ & $-1,560432739$ \\
8 & 484,9428481 & $-10,86284808$ & $-0,469379955$ \\
9 & 469,5899762 & $-36,14997621$ & $-1,562028125$ \\
10 & 438,8842325 & $-17,18423248$ & $-0,742524816$ \\
11 & 423,5313606 & $-12,98136061$ & $-0,560920158$ \\
12 & 546,3543356 & 9,235664447 & 0,399069906 \\
13 & 454,2371043 & 1,302895655 & 0,056297676 \\
\hline
\end{tabular}

ANÁLISE DE CORRELAÇÃO

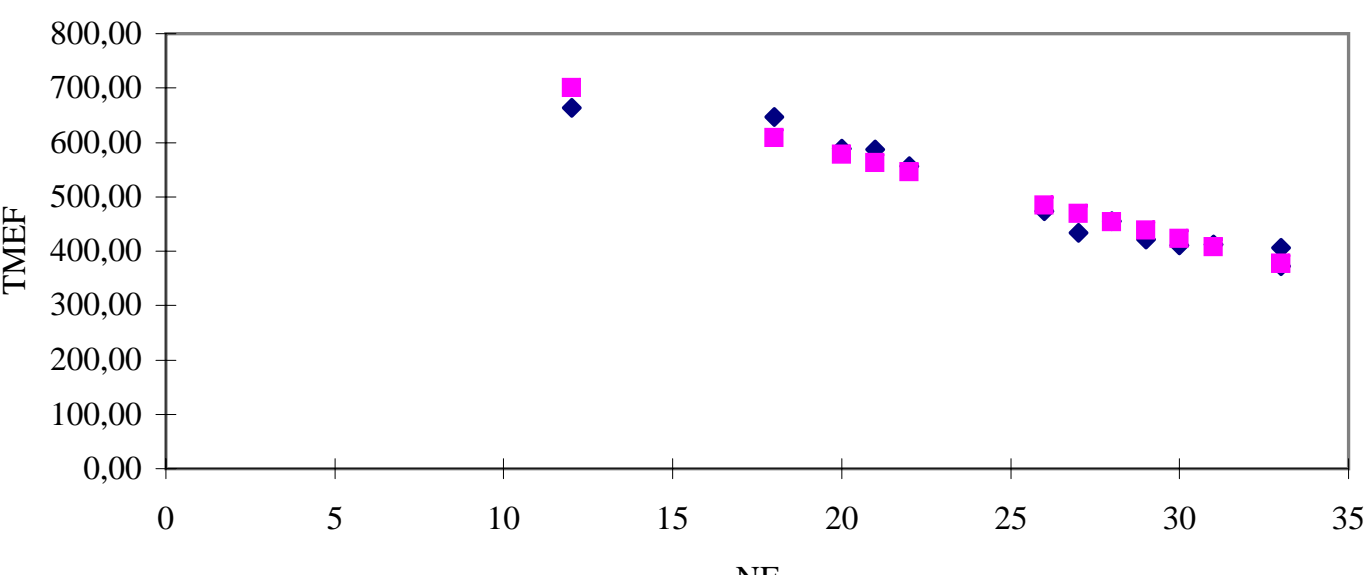




\section{RESUMO DOS RESULTADOS: IRE x IFO}

\begin{tabular}{lr}
\hline \multicolumn{2}{c}{ Estatística de regressão } \\
\hline R múltiplo & 0,042031271 \\
R-Quadrado & 0,001766628 \\
R-quadrado ajustado & $-0,088981861$ \\
Erro padrão & 664,6123872 \\
Observações & 13 \\
\hline
\end{tabular}

\begin{tabular}{|c|c|c|}
\hline $\mathbf{r}$ & tn-2 Calculado & tn-2 Crítico \\
\hline$-0,04203$ & $-0,13953$ & $-2,20099$ \\
\hline \multicolumn{3}{|c|}{ tn-2 Calc $>$ tn-2 Crit Min } \\
\hline \multicolumn{3}{|c|}{ Não há correlação Linear } \\
\hline
\end{tabular}

\section{ANOVA}

\begin{tabular}{lcclcr}
\hline & $g l$ & $S Q$ & $M Q$ & $F$ & F de significação \\
\hline Regressão & 1 & 8598,892305 & 8598,892305 & 0,019467297 & 0,891556927 \\
Resíduo & 11 & 4858805,877 & 441709,6252 & & \\
Total & 12 & 4867404,769 & & & \\
\hline
\end{tabular}

\begin{tabular}{|c|c|c|c|}
\hline & Coeficientes & Erro padrão & Stat $t$ \\
\hline Interseção & 2631,636704 & 529,9806887 & 4,965533198 \\
\hline Variável X 1 & $-12968,01661$ & 92943,86635 & $-0,139525255$ \\
\hline \multicolumn{4}{|c|}{ RESULTADOS DE RESÍDUOS } \\
\hline Observação & Y previsto & Resíduos & Resíduos padrão \\
\hline 1 & 2549,9382 & $-432,9381995$ & $-0,68038034$ \\
\hline 2 & 2518,81496 & 790,1850403 & 1,241808569 \\
\hline 3 & 2577,171034 & 528,8289656 & 0,831076656 \\
\hline 4 & 2564,203018 & 743,7969822 & 1,168907812 \\
\hline 5 & 2599,216663 & $-793,2166627$ & $-1,246572889$ \\
\hline 6 & 2526,59577 & $-520,5957696$ & $-0,818137847$ \\
\hline 7 & 2534,37658 & $-1331,37658$ & $-2,092313523$ \\
\hline 8 & 2590,139051 & 16,86094897 & 0,026497681 \\
\hline 9 & 2564,203018 & 143,7969822 & 0,225982922 \\
\hline 10 & 2574,577431 & 336,4225689 & 0,528702022 \\
\hline 11 & 2535,673381 & 476,3266187 & 0,74856704 \\
\hline 12 & 2587,545448 & $-278,5454477$ & $-0,437745726$ \\
\hline 13 & 2587,545448 & 320,4545523 & 0,503607622 \\
\hline
\end{tabular}

valor- $P \quad 95 \%$ inferiores

$0,00042505 \quad 1465,157074$

$0,891556927 \quad-217536,087$

$95 \%$ sup

\begin{tabular}{lrr} 
superiores & Inferior 95,0\% & Superior 95,0\% \\
\hline 3798,116334 & 1465,157074 & 3798,116334 \\
191600,0538 & $-217536,087$ & 191600,0538 \\
\hline
\end{tabular}

ANÁLISE DE CORRELAÇÃO

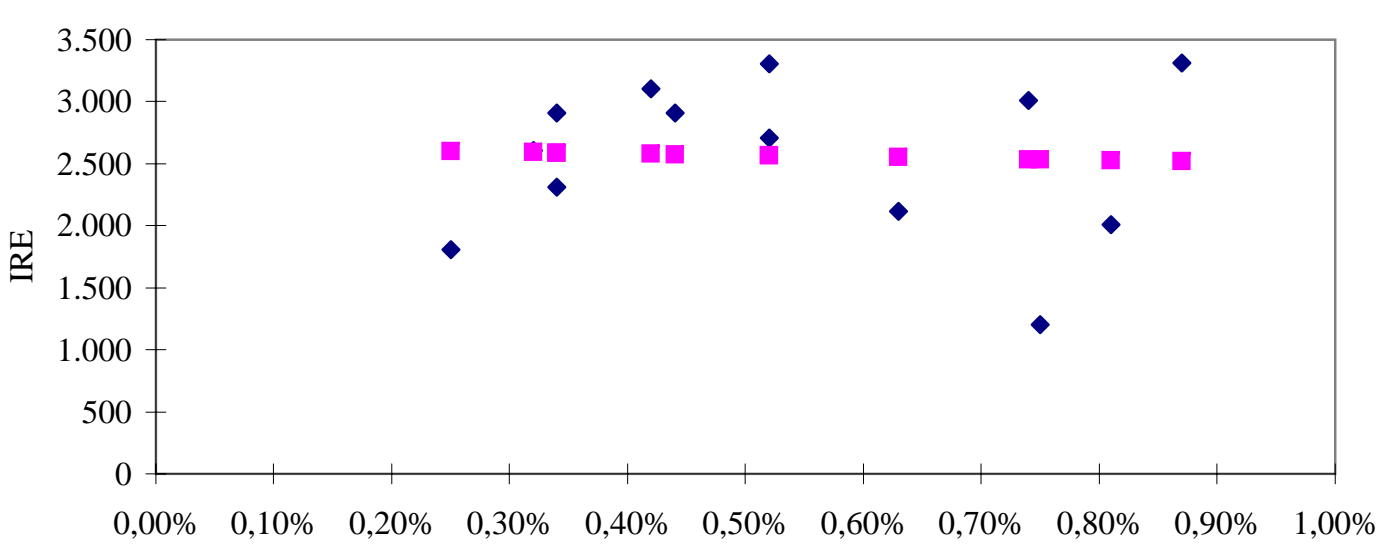

IFO 
RESUMO DOS RESULTADOS: IRE $x$ NF

\begin{tabular}{lr}
\hline \multicolumn{2}{c}{ Estatística de regressão } \\
\hline R múltiplo & 0,998243757 \\
R-Quadrado & 0,996490598 \\
R-quadrado ajustado & 0,996171561 \\
Erro padrão & 39,4066008 \\
Observações & 13 \\
\hline
\end{tabular}

\begin{tabular}{|c|c|c|}
\hline $\mathbf{r}$ & tn-2 Calculado & tn-2 Crítico \\
\hline 0,99824 & 55,88772 & 2,20099 \\
\hline \multicolumn{3}{|c|}{ tn-2 Calc $>$ tn-2 Crit Max } \\
\hline \multicolumn{3}{|c|}{ Evidências de Correlação Linear Positiva } \\
\hline
\end{tabular}

\section{ANOVA}

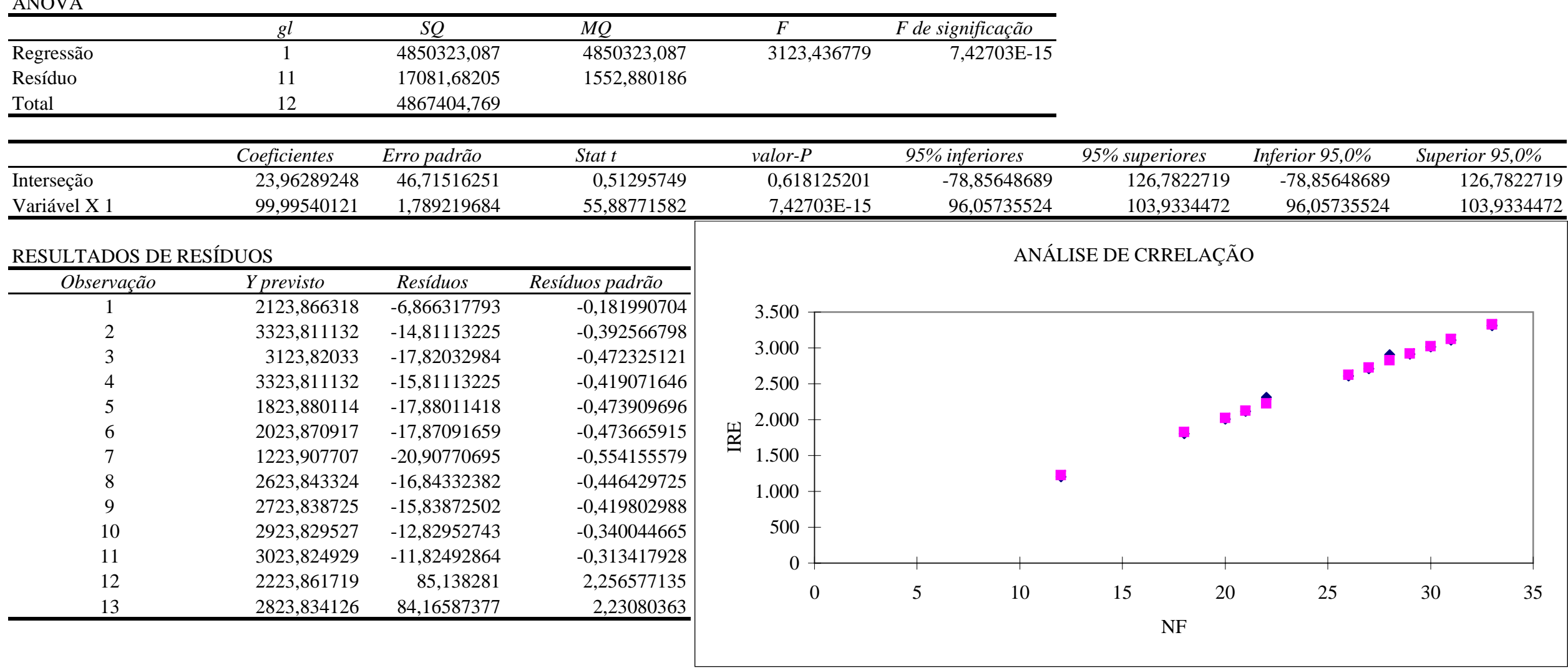




\section{RESUMO DOS RESULTADOS: IFO x NF}

\begin{tabular}{lr}
\hline \multicolumn{2}{c}{ Estatística de regressão } \\
\hline R múltiplo & 0,017974278 \\
R-Quadrado & 0,000323075 \\
R-quadrado ajustado & $-0,090556646$ \\
Erro padrão & 0,002155665 \\
Observações & 13 \\
\hline
\end{tabular}

\begin{tabular}{|c|c|c|}
\hline $\mathbf{r}$ & tn-2 Calculado & tn-2 Crítico \\
\hline$-0,01797$ & $-0,05962$ & $-2,20099$ \\
\hline \multicolumn{3}{|c|}{ tn-2 Calc $>$ tn-2 Crit Min } \\
\hline \multicolumn{3}{|c|}{ Não há correlação Linear } \\
\hline
\end{tabular}

\section{ANOVA}

\begin{tabular}{lccccr}
\hline & $g l$ & $S Q$ & $M Q$ & $F$ & F de significação \\
\hline Regressão & 1 & $1,65196 \mathrm{E}-08$ & $1,65196 \mathrm{E}-08$ & 0,00355497 & 0,953524876 \\
Resíduo & 11 & $5,11158 \mathrm{E}-05$ & $4,64689 \mathrm{E}-06$ & & \\
Total & 12 & $5,11323 \mathrm{E}-05$ & & & \\
\hline
\end{tabular}

\begin{tabular}{|c|c|c|c|}
\hline & Coeficientes & Erro padrão & Stat $t$ \\
\hline Interseção & 0,005494291 & 0,002555466 & 2,150015505 \\
\hline Variável X 1 & $-5,83571 \mathrm{E}-06$ & 9,78759E-05 & $-0,059623569$ \\
\hline \multicolumn{4}{|c|}{ RESULTADOS DE RESÍDUOS } \\
\hline Observação & Y previsto & Resíduos & Resíduos padrão \\
\hline 1 & 0,005371741 & 0,000928259 & 0,449761387 \\
\hline 2 & 0,005301713 & 0,003398287 & 1,646543431 \\
\hline 3 & 0,005313384 & $-0,001113384$ & $-0,539458573$ \\
\hline 4 & 0,005301713 & $-0,000101713$ & $-0,049281972$ \\
\hline 5 & 0,005389248 & $-0,002889248$ & $-1,399903064$ \\
\hline 6 & 0,005377577 & 0,002722423 & 1,319072638 \\
\hline 7 & 0,005424263 & 0,002075737 & 1,005739486 \\
\hline 8 & 0,005342563 & $-0,002142563$ & $-1,038117757$ \\
\hline 9 & 0,005336727 & $-0,000136727$ & $-0,066247142$ \\
\hline 10 & 0,005325056 & $-0,000925056$ & $-0,44820932$ \\
\hline 11 & 0,00531922 & 0,00208078 & 1,008182839 \\
\hline 12 & 0,005365905 & $-0,001965905$ & $-0,952523561$ \\
\hline 13 & 0,005330891 & $-0,001930891$ & $-0,935558392$ \\
\hline
\end{tabular}

$\begin{array}{ccc}\text { valor- } P & \text { 95\% inferiores } & 95 \% \\ 0,054645471 & -0,000130251\end{array}$

$\begin{array}{ll}0,054645471 & -0,000130251 \\ 0,953524876 & -0,000221259\end{array}$

$95 \%$ superiores

$0,011118834 \quad-0,000130251 \quad 0,011118834$

Superior 95,0\%

\begin{tabular}{ll}
0,011118834 & $-0,000130251$ \\
0,000209588 & $-0,000221259$ \\
\hline
\end{tabular}

0,000209588

RESULTADOS DE RESÍDUOS
ANÁLISE DE CORRELAÇÃO

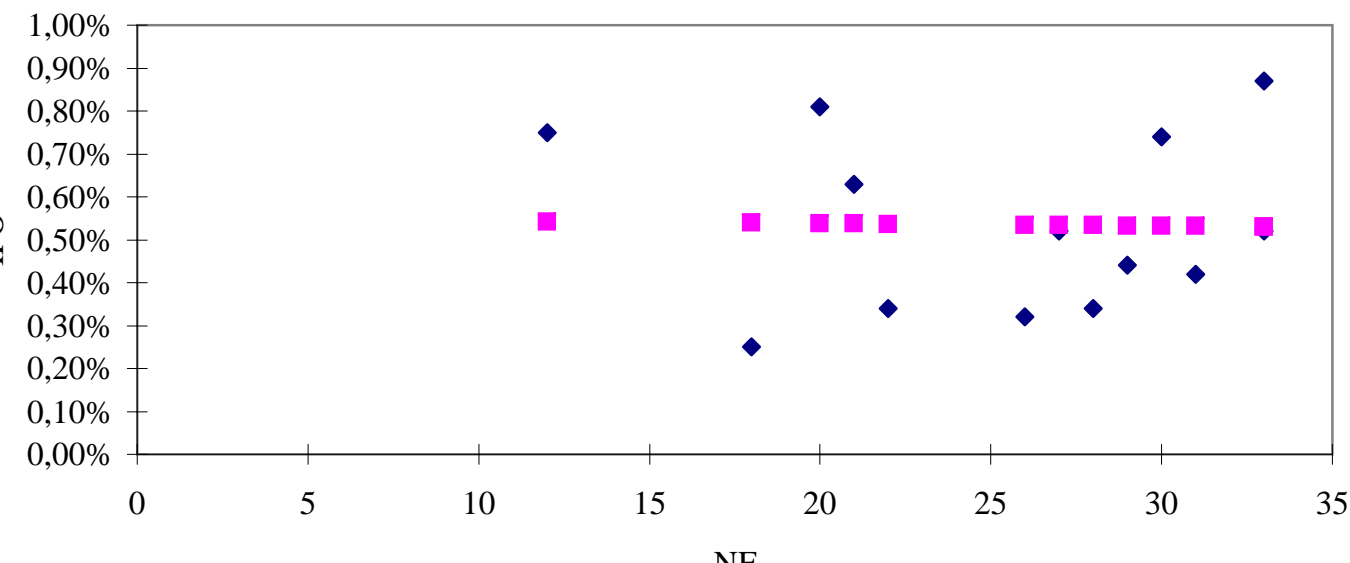




\begin{tabular}{|c|c|c|c|c|c|}
\hline \multirow{2}{*}{$\begin{array}{c}\text { MESES } \\
\text { jun/04 }\end{array}$} & \multirow{2}{*}{$\begin{array}{c}\text { CPP } \\
\mathrm{R} \$ 31.551,47\end{array}$} & \multirow{2}{*}{$\begin{array}{c}\text { СТМ } \\
\mathrm{R} \$ 108.141,31 \\
\end{array}$} & \multicolumn{2}{|c|}{ CTMUP } & CMPU \\
\hline & & & $\mathrm{R} \$$ & 0,08 & $\mathrm{R} \$ \quad 8,05$ \\
\hline $\mathrm{jul} / 04$ & $\mathrm{R} \$ 38.962,95$ & R\$ $143.988,20$ & $\mathrm{R} \$$ & 0,12 & $\begin{array}{ll}\mathrm{R} \$ & 9,27\end{array}$ \\
\hline ago/04 & $\mathrm{R} \$ 67.230,14$ & $\mathrm{R} \$ 229.172,64$ & $\mathrm{R} \$$ & 0,18 & $\mathrm{R} \$ \quad 8,40$ \\
\hline set/04 & R\$ 56.208,13 & $\mathrm{R} \$ 170.288,40$ & $\mathrm{R} \$$ & 0,12 & $\mathrm{R} \$ \quad 6,75$ \\
\hline out/04 & $\mathrm{R} \$ 90.725,01$ & $\mathrm{R} \$ 309.483,24$ & $\mathrm{R} \$$ & 0,24 & 7,95 \\
\hline nov/04 & $\mathrm{R} \$ 37.450,29$ & $\mathrm{R} \$ 140.841,55$ & $\mathrm{R} \$$ & 0,12 & R\$ 8,64 \\
\hline $\mathrm{dez} / 04$ & $\mathrm{R} \$ 47.717,79$ & $\mathrm{R} \$ 241.618,65$ & $\mathrm{R} \$$ & 0,25 & $\mathrm{R} \$ 11,48$ \\
\hline jan/05 & R\$ 46.149,30 & $\mathrm{R} \$ 131.910,27$ & $\mathrm{R} \$$ & 0,09 & $\mathrm{R} \$ \quad 7,15$ \\
\hline $\mathrm{fev} / 05$ & $\mathrm{R} \$ 83.446,91$ & $\mathrm{R} \$ 253.730,77$ & $\mathrm{R} \$$ & 0,16 & 7,09 \\
\hline $\mathrm{mar} / 05$ & $\mathrm{R} \$ 73.630,81$ & R\$2 261.612,77 & $\mathrm{R} \$$ & 0,17 & 7,53 \\
\hline $\mathrm{abr} / 05$ & R\$ 29.522,02 & $\mathrm{R} \$ 147.330,43$ & $\mathrm{R} \$$ & 0,11 & 9,85 \\
\hline mai/05 & $\mathrm{R} \$ 64.002,11$ & R\$ 262.607,76 & $\mathrm{R} \$$ & 0,19 & 8,90 \\
\hline jun/05 & $\mathrm{R} \$ 69.110,22$ & $\mathrm{R} \$ 262.853,79$ & $\mathrm{R} \$$ & 0,17 & 7,51 \\
\hline
\end{tabular}

\begin{tabular}{|c|c|c|c|c|c|c|}
\hline \multicolumn{7}{|c|}{ ANÁLISE INTRA INDICADORES - CUSTOS } \\
\hline Variáveis & $\mathbf{r}$ & tn-2 Calc & tn-2 Crit & Comparação & Conclusão & Consistência da Relação \\
\hline CPР-СТМ & 0,8908 & 6,5029 & 2,2010 & tn-2 Calc $>$ tn-2 Crit Max & Evidências de Correlação Linear Positiva & $\mathrm{V}$ \\
\hline CPP-CTMUP & 0,6487 & 2,8272 & 2,2010 & tn-2 Calc $>$ tn-2 Crit Max & Evidências de Correlação Linear Positiva & $\mathrm{V}$ \\
\hline CPP-CMUP & $-0,4397$ & $-1,6238$ & $-2,2010$ & tn-2 Calc > tn-2 Crit Min & Não há correlação Linear & $\mathrm{V}$ \\
\hline CTM-CTMUP & 0,8805 & 6,1603 & 2,2010 & tn-2 Calc > tn-2 Crit Max & Evidências de Correlação Linear Positiva & $\mathrm{V}$ \\
\hline CTM-CMUP & $-0,0383$ & $-0,1272$ & $-2,2010$ & tn-2 Calc > tn-2 Crit Min & Não há correlação Linear & $\mathrm{V}$ \\
\hline CTMUP-CMUP & 0,3580 & 1,2716 & 2,2010 & tn-2 Calc $<$ tn-2 Crit Max & Não há correlação Linear & $\mathrm{V}$ \\
\hline
\end{tabular}




\section{RESUMO DOS RESULTADOS: CPP x CCTM}

\begin{tabular}{lr}
\hline \multicolumn{2}{c}{ Estatística de regressão } \\
\hline R múltiplo & 0,890826151 \\
R-Quadrado & 0,793571232 \\
R-quadrado ajustado & 0,77480498 \\
Erro padrão & 9417,803382 \\
Observações & 13 \\
\hline
\end{tabular}

\begin{tabular}{|c|c|c|}
\hline $\mathbf{r}$ & tn-2 Calculado & tn-2 Crítico \\
\hline 0,89083 & 6,50286 & 2,20099 \\
\hline \multicolumn{3}{|c|}{ tn-2 Calc > tn-2 Crit Max } \\
\hline \multicolumn{2}{|c|}{ Evidências de Correlação Linear Positiva } \\
\hline
\end{tabular}

ANOVA

\begin{tabular}{|c|c|c|c|c|c|}
\hline & $g l$ & $S Q$ & $M Q$ & $F$ & F de significação \\
\hline Regressão & 1 & 3750659326 & 3750659326 & 42,28714649 & $4,41043 \mathrm{E}-05$ \\
\hline Resíduo & 11 & 975645226 & 88695020,54 & & \\
\hline Total & 12 & 4726304552 & & & \\
\hline
\end{tabular}

\begin{tabular}{|c|c|c|c|}
\hline & Coeficientes & Erro padrão & Stat $t$ \\
\hline Interseção & 1661,219071 & 8841,929527 & 0,1878797 \\
\hline Variável X 1 & 0,268102089 & 0,041228355 & 6,502856794 \\
\hline \multicolumn{4}{|c|}{ RESULTADOS DE RESÍDUOS } \\
\hline Observação & Y previsto & Resíduos & Resíduos padrão \\
\hline 1 & 30654,13014 & 897,3398579 & 0,099517995 \\
\hline 2 & 40264,75622 & $-1301,80622$ & $-0,14437467$ \\
\hline 3 & 63102,8825 & 4127,257503 & 0,457726679 \\
\hline 4 & 47315,89477 & 8892,235231 & 0,986178668 \\
\hline 5 & 84634,32209 & 6090,687909 & 0,675477687 \\
\hline 6 & 39421,13278 & $-1970,842783$ & $-0,218573065$ \\
\hline 7 & 66439,68377 & $-18721,89377$ & $-2,07632072$ \\
\hline 8 & 37026,63796 & 9122,662039 & 1,011733772 \\
\hline 9 & 69686,96844 & 13759,94156 & 1,526023602 \\
\hline 10 & 71800,1491 & 1830,660897 & 0,203026424 \\
\hline 11 & 41160,81506 & $-11638,79506$ & $-1,290781351$ \\
\hline 12 & 72066,908 & $-8064,798$ & $-0,894413108$ \\
\hline 13 & 72132,86916 & $-3022,649157$ & $-0,335221915$ \\
\hline
\end{tabular}

\begin{tabular}{crr} 
valor- $P$ & 95\% inferiores & $95 \%$ \\
0,854391886 & $-17799,73659$ & \\
$4,41043 \mathrm{E}-05$ & 0,177359091 & \\
\hline
\end{tabular}

\begin{tabular}{rrr} 
95\% superiores & \multicolumn{1}{c}{ Inferior 95,0\% } & Superior 95,0\% \\
\hline 21122,17474 & $-17799,73659$ & 21122,17474 \\
0,358845086 & 0,177359091 & 0,358845086 \\
\hline
\end{tabular}

ANÁLISE DE CORRELAÇÃO

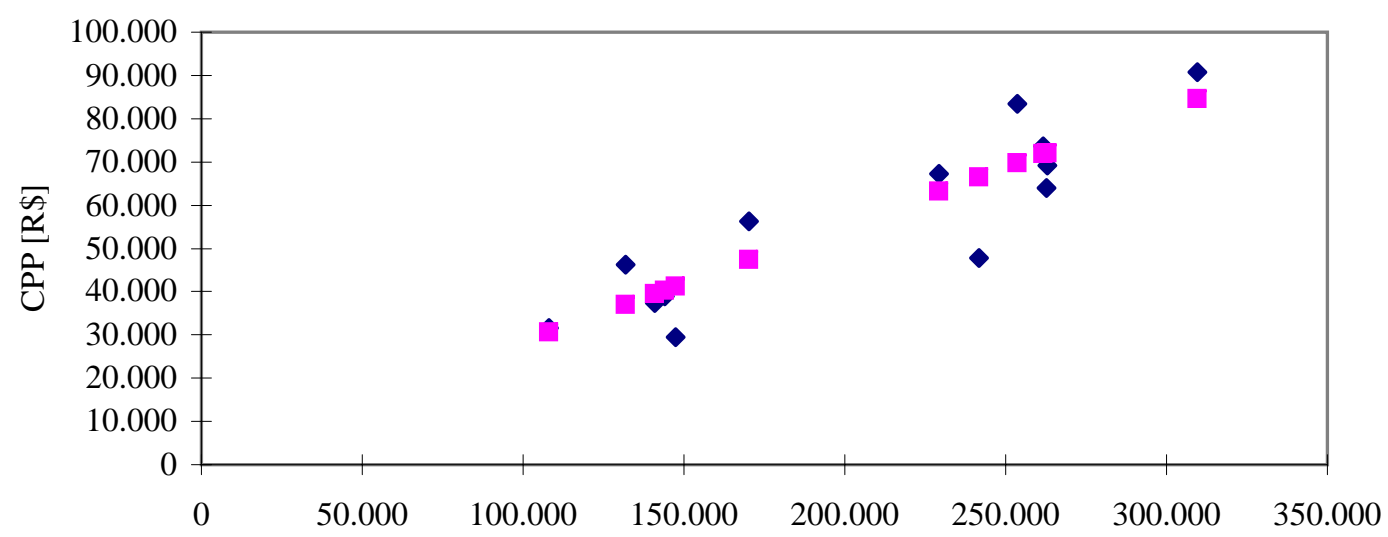

CTM [R $\$]$ 


\section{RESUMO DOS RESULTADOS: CPP x CTMUP}

\begin{tabular}{lr}
\hline \multicolumn{2}{c}{ Estatística de regressão } \\
\hline R múltiplo & 0,648724102 \\
R-Quadrado & 0,420842961 \\
R-quadrado ajustado & 0,368192321 \\
Erro padrão & 15774,75702 \\
Observações & 13 \\
\hline
\end{tabular}

\begin{tabular}{|c|c|c|}
\hline $\mathbf{r}$ & tn-2 Calculado & tn-2 Crítico \\
\hline 0,64872 & 2,82721 & 2,20099 \\
\hline \multicolumn{3}{|c|}{ tn-2 Calc $>$ tn-2 Crit Max } \\
\hline \multicolumn{2}{|c|}{ Evidências de Correlação Linear Positiva } \\
\hline
\end{tabular}

ANOVA

\begin{tabular}{lccccr}
\hline & gl & SQ & MQ & $F$ & F de significação \\
\hline Regressão & 1 & 1989032003 & 1989032003 & 7,993121485 & 0,016454047 \\
Resíduo & 11 & 2737272550 & 248842959,1 & & \\
Total & 12 & 4726304552 & & & \\
\hline
\end{tabular}

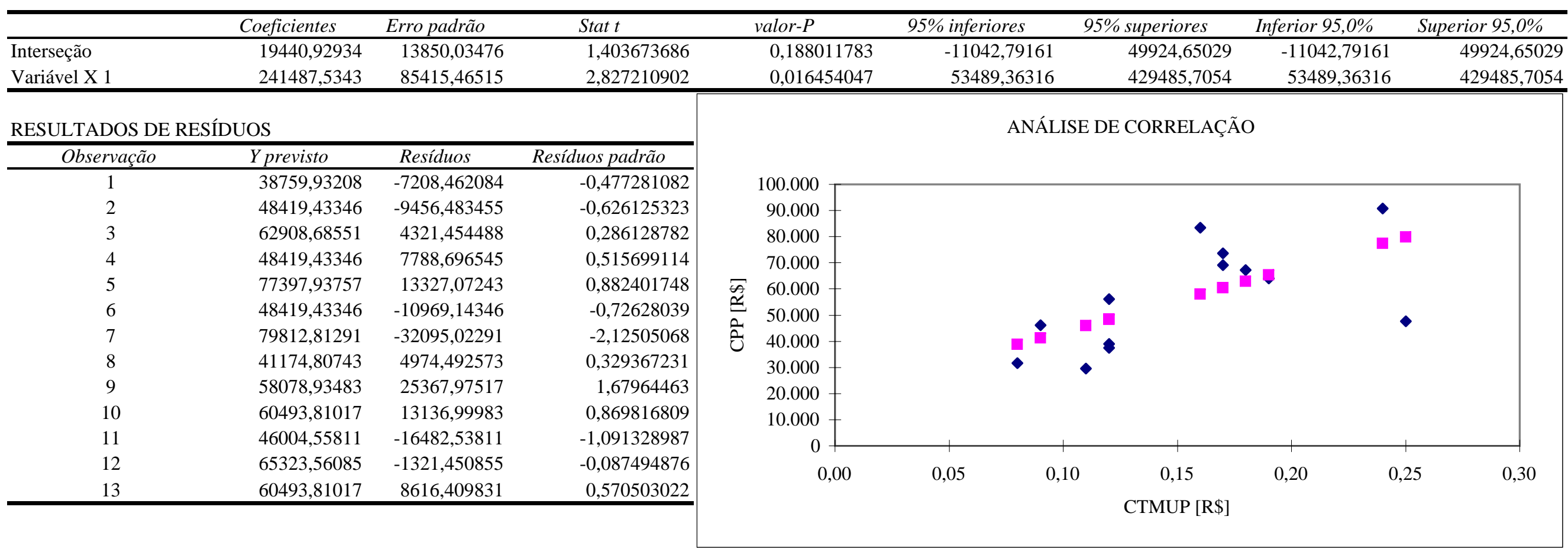




\section{RESUMO DOS RESULTADOS: CPP x CMUP}

\begin{tabular}{lr}
\hline \multicolumn{2}{c}{ Estatística de regressão } \\
\hline R múltiplo & 0,439715245 \\
R-Quadrado & 0,193349496 \\
R-quadrado ajustado & 0,120017632 \\
Erro padrão & 18616,89347 \\
Observações & 13 \\
\hline
\end{tabular}

\begin{tabular}{|c|c|c|}
\hline $\mathbf{r}$ & tn-2 Calculado & tn-2 Crítico \\
\hline$-0,43972$ & $-1,62377$ & $-2,20099$ \\
\hline \multicolumn{3}{|c|}{ tn-2 Calc > tn-2 Crit Min } \\
\hline \multicolumn{3}{|c|}{ Não há correlação Linear } \\
\hline
\end{tabular}

ANOVA

\begin{tabular}{lccccc}
\hline & gl & SQ & MQ & $F$ & F de significação \\
\hline Regressão & 1 & 913828604,7 & 913828604,7 & 2,636636871 & 0,132707899 \\
Resíduo & 11 & 3812475948 & 346588722,5 & & \\
Total & 12 & 4726304552 & & & \\
\hline
\end{tabular}

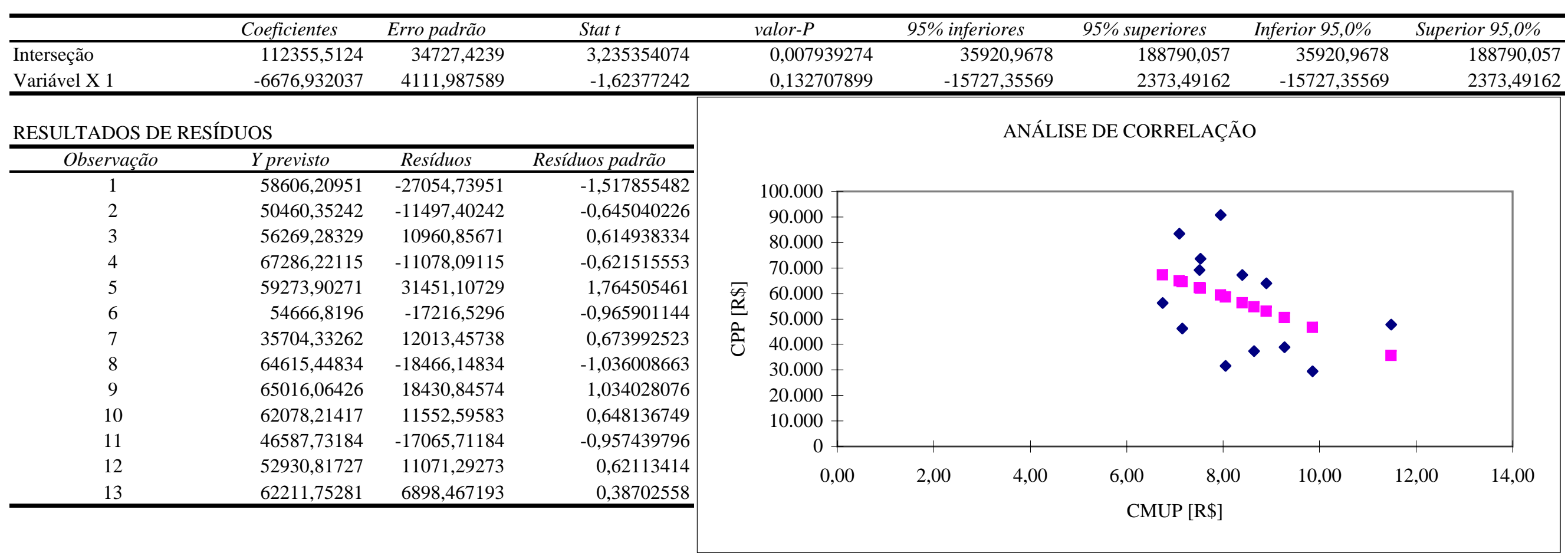




\section{RESUMO DOS RESULTADOS: CTM x CTMUP}

\begin{tabular}{lr}
\hline \multicolumn{2}{c}{ Estatística de regressão } \\
\hline R múltiplo & 0,880498272 \\
R-Quadrado & 0,775277207 \\
R-quadrado ajustado & 0,754847862 \\
Erro padrão & 32649,82304 \\
Observações & 13 \\
\hline
\end{tabular}

\begin{tabular}{|c|c|c|}
\hline $\mathbf{r}$ & tn-2 Calculado & tn-2 Crítico \\
\hline 0,88050 & 6,16029 & 2,20099 \\
\hline \multicolumn{3}{|c|}{ tn-2 Calc > tn-2 Crit Max } \\
\hline \multicolumn{2}{|c|}{ Evidências de Correlação Linear Positiva } \\
\hline
\end{tabular}

ANOVA

\begin{tabular}{|c|c|c|c|c|c|}
\hline & $g l$ & $S Q$ & $M Q$ & $F$ & $F$ de significação \\
\hline Regressão & 1 & 40454258032 & 40454258032 & 37,94919577 & $7,1032 \mathrm{E}-05$ \\
\hline Resíduo & 11 & 11726120391 & 1066010945 & & \\
\hline Total & 12 & 52180378423 & & & \\
\hline
\end{tabular}

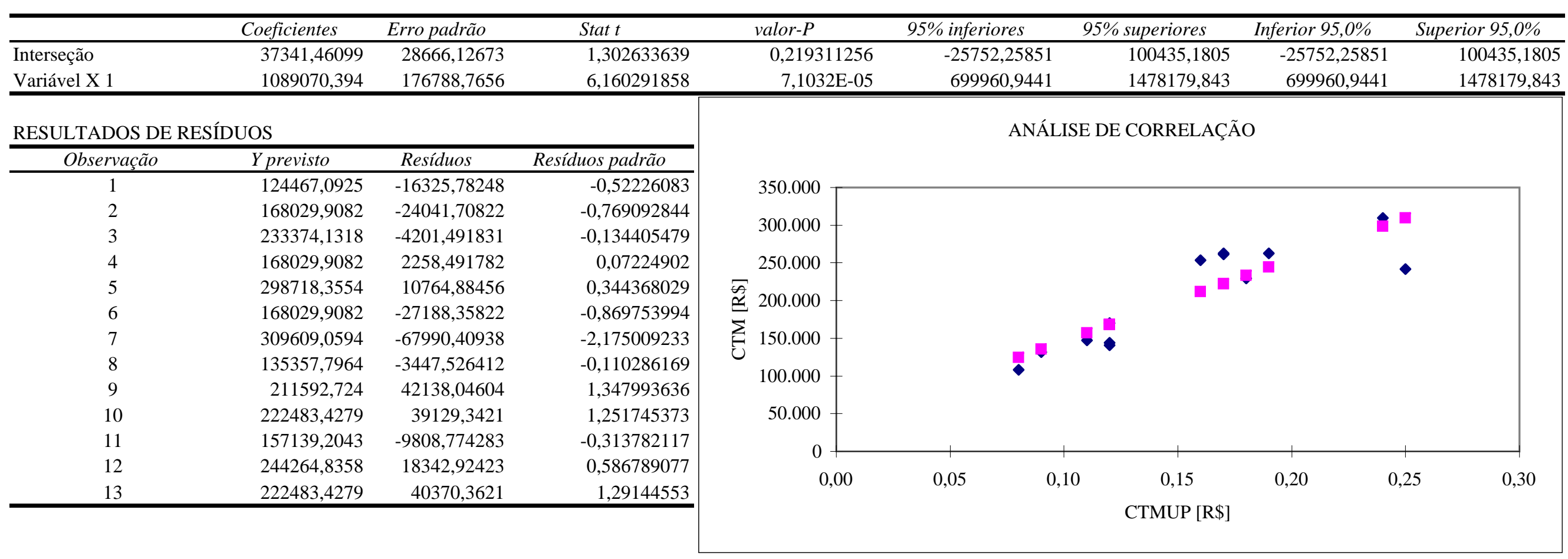




\section{RESUMO DOS RESULTADOS: CTM x CMUP}

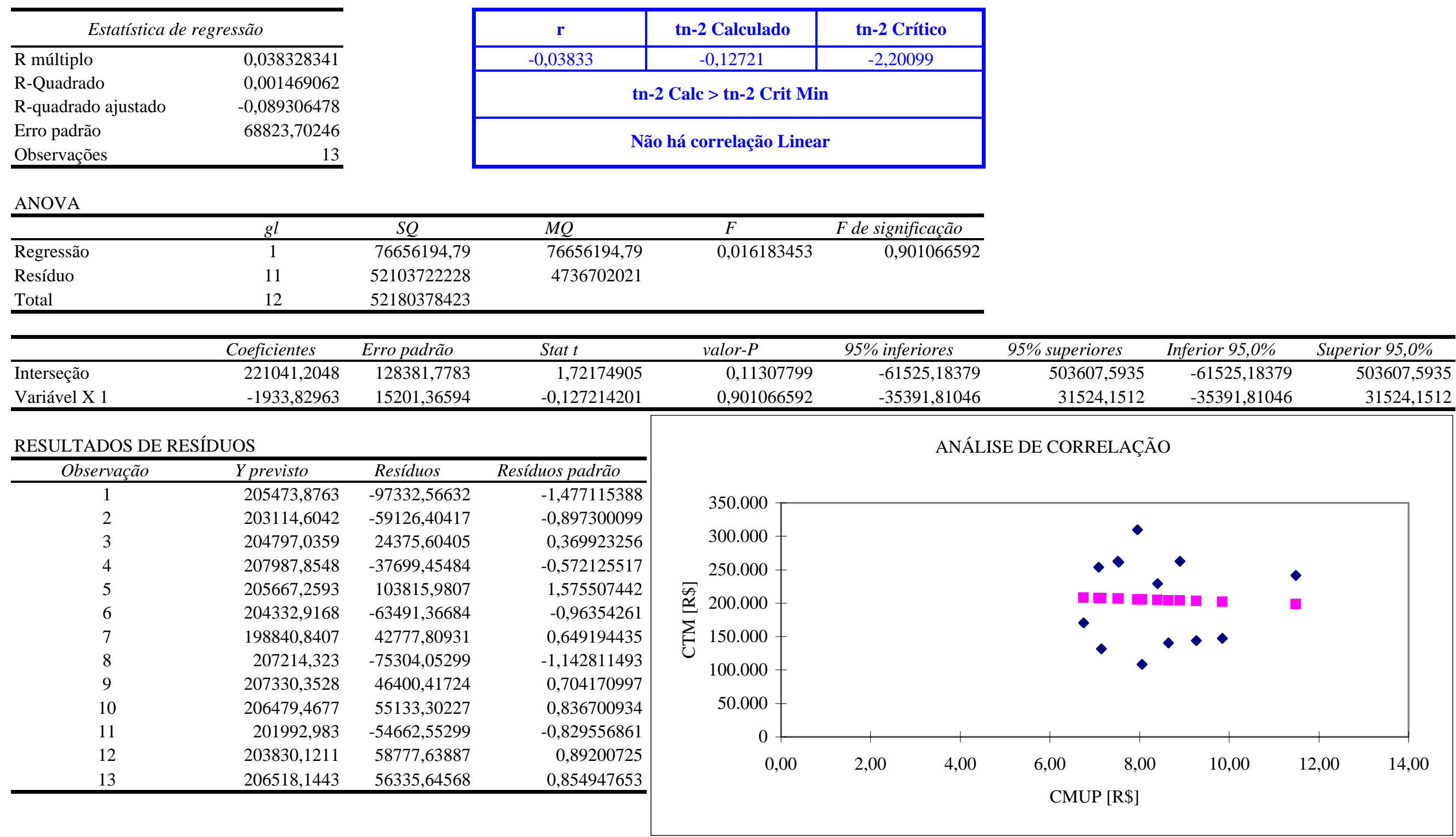




\section{RESUMO DOS RESULTADOS: CTMUP x CMUP}

\begin{tabular}{lr}
\hline \multicolumn{2}{c}{ Estatística de regressão } \\
\hline R múltiplo & 0,357979877 \\
R-Quadrado & 0,128149592 \\
R-quadrado ajustado & 0,048890464 \\
Erro padrão & 0,051993711 \\
Observações & 13 \\
\hline
\end{tabular}

\begin{tabular}{|c|c|c|}
\hline $\mathbf{r}$ & tn-2 Calculado & tn-2 Crítico \\
\hline 0,35798 & 1,27155 & 2,20099 \\
\hline \multicolumn{3}{|c|}{ tn-2 Calc $<$ tn-2 Crit Max } \\
\hline \multirow{3}{|}{ Não há correlação Linear } \\
\hline
\end{tabular}

ANOVA

\begin{tabular}{lccccr}
\hline & gl & SQ & MQ & $F$ & F de significação \\
\hline Regressão & 1 & 0,004370887 & 0,004370887 & 1,616843327 & 0,229759891 \\
Resíduo & 11 & 0,029736805 & 0,002703346 & & \\
Total & 12 & 0,034107692 & & & \\
\hline
\end{tabular}

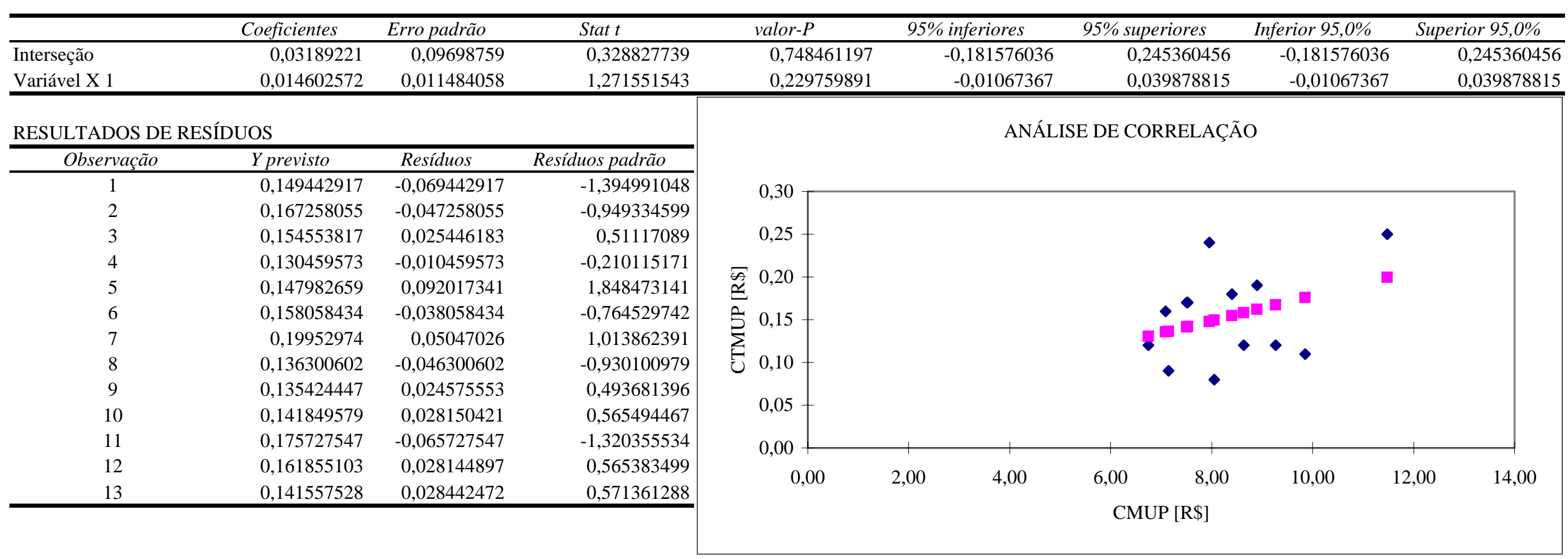




\begin{tabular}{|c|c|c|c|cc|cr|}
\hline \multirow{2}{*}{ MESES } & QUAL & \multicolumn{6}{|c|}{ CUSTOS } \\
\cline { 2 - 8 } & DOP & CPP & CTM & \multicolumn{2}{|c|}{ CTMUP } & \multicolumn{2}{|c|}{ CMUP } \\
\hline jun/04 & $99,30 \%$ & $\mathrm{R} \$ 31.551,47$ & $\mathrm{R} \$ 108.141,31$ & $\mathrm{R} \$$ & 0,09 & $\mathrm{R} \$$ & 8,05 \\
jul/04 & $99,13 \%$ & $\mathrm{R} \$ 38.962,95$ & $\mathrm{R} \$ 143.988,20$ & $\mathrm{R} \$$ & 0,12 & $\mathrm{R} \$$ & 9,27 \\
ago/04 & $98,56 \%$ & $\mathrm{R} \$ 67.230,14$ & $\mathrm{R} \$ 229.172,64$ & $\mathrm{R} \$$ & 0,18 & $\mathrm{R} \$$ & 8,40 \\
set/04 & $98,83 \%$ & $\mathrm{R} \$ 56.208,13$ & $\mathrm{R} \$ 170.288,40$ & $\mathrm{R} \$$ & 0,12 & $\mathrm{R} \$$ & 6,75 \\
out/04 & $97,96 \%$ & $\mathrm{R} \$ 90.725,01$ & $\mathrm{R} \$ 309.483,24$ & $\mathrm{R} \$$ & 0,25 & $\mathrm{R} \$$ & 7,95 \\
nov/04 & $99,08 \%$ & $\mathrm{R} \$ 37.450,29$ & $\mathrm{R} \$ 140.841,55$ & $\mathrm{R} \$$ & 0,11 & $\mathrm{R} \$$ & 8,64 \\
dez/04 & $98,31 \%$ & $\mathrm{R} \$ 47.717,79$ & $\mathrm{R} \$ 241.618,65$ & $\mathrm{R} \$$ & 0,25 & $\mathrm{R} \$$ & 11,48 \\
jan/05 & $99,24 \%$ & $\mathrm{R} \$ 46.149,30$ & $\mathrm{R} \$ 131.910,27$ & $\mathrm{R} \$$ & 0,09 & $\mathrm{R} \$$ & 7,15 \\
fev/05 & $98,49 \%$ & $\mathrm{R} \$ 83.446,91$ & $\mathrm{R} \$ 253.730,77$ & $\mathrm{R} \$$ & 0,17 & $\mathrm{R} \$$ & 7,09 \\
mar/05 & $98,44 \%$ & $\mathrm{R} \$ 73.630,81$ & $\mathrm{R} \$ 261.612,77$ & $\mathrm{R} \$$ & 0,17 & $\mathrm{R} \$$ & 7,53 \\
abr/05 & $99,16 \%$ & $\mathrm{R} \$ 29.522,02$ & $\mathrm{R} \$ 147.330,43$ & $\mathrm{R} \$$ & 0,11 & $\mathrm{R} \$$ & 9,85 \\
mai/05 & $98,39 \%$ & $\mathrm{R} \$ 64.002,11$ & $\mathrm{R} \$ 262.607,76$ & $\mathrm{R} \$$ & 0,20 & $\mathrm{R} \$$ & 8,90 \\
jun/05 & $98,39 \%$ & $\mathrm{R} \$ 69.110,22$ & $\mathrm{R} \$ 262.853,79$ & $\mathrm{R} \$$ & 0,17 & $\mathrm{R} \$$ & 7,51 \\
\hline
\end{tabular}

\begin{tabular}{|c|c|c|c|c|c|c|}
\hline \multicolumn{7}{|c|}{ ANÁLISE ENTRE INDICADORES - QUALIDADE/CUSTOS } \\
\hline Variáveis & $\mathbf{r}$ & tn-2 Calc & tn-2 Crit & Comparação & Conclusão & Consistência da Relação \\
\hline DOP-CPP & $-0,8538$ & $-5,4397$ & $-2,2010$ & tn-2 Calc < tn-2 Crit Min & Evidências de Correlação Linear Negativa & V \\
\hline DOP-CTM & $-0,9818$ & $-17,1244$ & $-2,2010$ & tn-2 Calc $<$ tn-2 Crit Min & Evidências de Correlação Linear Negativa & V \\
\hline DOP-CTMUP & $-0,9414$ & $-9,2558$ & $-2,2010$ & tn-2 Calc $<$ tn-2 Crit Min & Evidências de Correlação Linear Negativa & V \\
\hline DOP-CMUP & $-0,0283$ & $-0,0939$ & $-2,2010$ & tn-2 Calc $>$ tn-2 Crit Min & Não há correlação Linear & V \\
\hline
\end{tabular}


RESUMO DOS RESULTADOS: DOP x CPP

\begin{tabular}{lr}
\hline \multicolumn{2}{c}{ Estatística de regressão } \\
\hline R múltiplo & 0,853814566 \\
R-Quadrado & 0,728999313 \\
R-quadrado ajustado & 0,704362887 \\
Erro padrão & 0,00234869 \\
Observações & 13 \\
\hline
\end{tabular}

\begin{tabular}{|c|c|c|}
\hline $\mathbf{r}$ & tn-2 Calculado & tn-2 Crítico \\
\hline$-0,85381$ & $-5,43970$ & $-2,20099$ \\
\hline \multicolumn{3}{|c|}{ tn-2 Calc < tn-2 Crit Min } \\
\hline \multicolumn{3}{|c|}{ Evidências de Correlação Linear Negativa } \\
\hline
\end{tabular}

ANOVA

\begin{tabular}{lcrrrr}
\hline & $g l$ & $S Q$ & $M Q$ & $F$ & F de significação \\
\hline Regressão & 1 & 0,00016323 & 0,00016323 & 29,59030301 & 0,000203995 \\
Resíduo & 11 & $6,06798 \mathrm{E}-05$ & $5,51634 \mathrm{E}-06$ & & \\
Total & 12 & 0,00022391 & & & \\
\hline
\end{tabular}

\begin{tabular}{|c|c|c|c|c|c|c|c|c|c|c|c|c|c|c|c|}
\hline & Coeficientes & Erro padrão & Stat $t$ & \multirow{3}{*}{\multicolumn{2}{|c|}{$\begin{array}{r}\text { valor-P } \\
3,28554 \mathrm{E}-25 \\
0,000203995 \\
\end{array}$}} & \multicolumn{3}{|c|}{ 95\% inferiores } & \multicolumn{2}{|c|}{ 95\% superiores } & \multicolumn{3}{|c|}{ Inferior $95,0 \%$} & \multicolumn{2}{|c|}{ Superior $95,0 \%$} \\
\hline \multirow{2}{*}{$\begin{array}{l}\text { Interseção } \\
\text { Variável X } 1 \\
\end{array}$} & 0,997649833 & 0,002040209 & 488,9939821 & & & \multicolumn{3}{|c|}{0,993159364} & \multicolumn{3}{|c|}{1,002140303} & \multicolumn{2}{|c|}{0,993159364} & \multicolumn{2}{|c|}{1,002140303} \\
\hline & $-1,8584 \mathrm{E}-07$ & 3,41637E-08 & $-5,43969696$ & & & & $-2,6103$ & $34 \mathrm{E}-07$ & & L,10646E- & -07 & $-2,610$ & $34 \mathrm{E}-07$ & & 1,10646E-07 \\
\hline \multicolumn{4}{|c|}{ RESULTADOS DE RESÍDUOS } & \multicolumn{12}{|c|}{ ANÁLISE DE CORRELAÇÃO } \\
\hline Observação & Y previsto & Resíduos & Resíduos padrão & & & & & & & & & & & & \\
\hline 1 & 0,991786303 & 0,00123457 & 0,549014968 & & $99,40 \%$ & & & & & & & & & & \\
\hline 2 & 0,990408952 & 0,000879517 & 0,391122336 & & $99,20 \%$ & & & $\nabla$ & & $\bullet$ & & & & & \\
\hline 3 & 0,985155774 & 0,000450956 & 0,200540815 & & $99,00 \%$ & & & & & & & & & & \\
\hline 4 & 0,987204106 & 0,001045909 & 0,465117187 & & $98,80 \%$ & & & & & 4 & 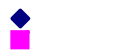 & & & & \\
\hline 5 & 0,980789483 & $-0,001219558$ & $-0,542339372$ & ○े & $98,60 \%$ & & & & & & & & & & \\
\hline 6 & 0,990690065 & 0,000149339 & 0,066411342 & & $98,40 \%$ & & & & & $\bullet$ & & 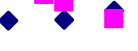 & & & \\
\hline 7 & 0,988781952 & $-0,005697909$ & $-2,533868614$ & & $98,20 \%$ & & & & & 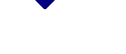 & & & च & n & \\
\hline 8 & 0,989073441 & 0,003315935 & 1,474601192 & & $98,00 \%$ & & & & & & & & & $\bullet$ & \\
\hline 9 & 0,982142047 & 0,002711941 & 1,206004061 & & $97,80 \%+$ & & & & & & & & & & \\
\hline 10 & 0,983966271 & 0,000435049 & 0,193466842 & & $\mathrm{R} \$$ - & $\mathrm{R} \$$ & $\mathrm{R} \$$ & $\mathrm{R} \$$ & $\mathrm{R} \$$ & $\mathrm{R} \$$ & $\mathrm{R} \$$ & $\mathrm{R} \$$ & $\mathrm{R} \$$ & $\mathrm{R} \$$ & $\mathrm{R} \$$ \\
\hline 11 & 0,992163456 & $-0,000560268$ & $-0,249151833$ & & & 10.000, & 20.000 & 30.000, & 40.000, & , 50.000, & 60.000, & , 70.000, & 80.000, & 90.000 & 100.00 \\
\hline 12 & 0,98575567 & $-0,001866176$ & $-0,82989125$ & & & 00 & 00 & 00 & & 00 & 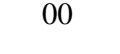 & . & 00 & 00 & 0,00 \\
\hline 13 & 0,984806379 & $-0,000879304$ & $-0,391027672$ & & & & & & & СРР & & & & & \\
\hline
\end{tabular}


RESUMO DOS RESULTADOS: DOP x CTM

\begin{tabular}{lr}
\hline \multicolumn{2}{c}{ Estatística de regressão } \\
\hline R múltiplo & 0,981755998 \\
R-Quadrado & 0,963844839 \\
R-quadrado ajustado & 0,960558006 \\
Erro padrão & 0,000857878 \\
Observações & 13 \\
\hline
\end{tabular}

\begin{tabular}{|c|c|c|}
\hline $\mathbf{r}$ & tn-2 Calculado & tn-2 Crítico \\
\hline$-0,98176$ & $-17,12438$ & $-2,20099$ \\
\hline \multicolumn{3}{|c|}{ tn-2 Calc $<$ tn-2 Crit Min } \\
\hline \multicolumn{3}{|c|}{ Evidências de Correlação Linear Negativa } \\
\hline
\end{tabular}

ANOVA

\begin{tabular}{|c|c|c|c|}
\hline & $g l$ & $S Q$ & $M Q$ \\
\hline Regressão & 1 & 0,000215815 & 0,000215815 \\
\hline Resíduo & 11 & 8,09551E-06 & 7,35955E-07 \\
\hline \multirow[t]{2}{*}{ Total } & 12 & 0,00022391 & \\
\hline & Coeficientes & Erro padrão & Stat $t$ \\
\hline Interseção & 1,000309383 & 0,000805421 & 1241,970446 \\
\hline Variável X 1 & $-6,43112 \mathrm{E}-08$ & 3,75554E-09 & $-17,12437606$ \\
\hline \multicolumn{4}{|c|}{ RESULTADOS DE RESÍDUOS } \\
\hline Observação & Y previsto & Resíduos & Resíduos padrão \\
\hline 1 & 0,993354683 & $-0,00033381$ & $-0,406413731$ \\
\hline 2 & 0,991049326 & 0,000239143 & 0,291156013 \\
\hline 3 & 0,985571009 & 3,57208E-05 & 0,043490042 \\
\hline 4 & 0,989357927 & $-0,001107913$ & $-1,348882714$ \\
\hline 5 & 0,980406136 & $-0,000836212$ & $-1,018086702$ \\
\hline 6 & 0,99125169 & $-0,000412286$ & $-0,50195796$ \\
\hline 7 & 0,984770591 & $-0,001686549$ & $-2,053371776$ \\
\hline 8 & 0,991826072 & 0,000563304 & 0,685822069 \\
\hline 9 & 0,983991646 & 0,000862341 & 1,049899563 \\
\hline 10 & 0,983484745 & 0,000916575 & 1,115929292 \\
\hline 11 & 0,990834383 & 0,000768806 & 0,936020476 \\
\hline 12 & 0,983420756 & 0,000468739 & 0,570688977 \\
\hline 13 & 0,983404934 & 0,000522141 & 0,63570645 \\
\hline
\end{tabular}

\begin{tabular}{cr}
$F$ & F de significação \\
\hline 293,2442556 & $2,80591 \mathrm{E}-09$
\end{tabular}

valor-P 95\% inferiores

1,15826E-29 0,998536663

95\% superiores

\begin{tabular}{lrr} 
superiores & Inferior 95,0\% & Superior 95,0\% \\
\hline 1,002082103 & 0,998536663 & 1,002082103
\end{tabular}

$-5,60453 \mathrm{E}-08$

$-7,25771 \mathrm{E}-08$

$-5,60453 \mathrm{E}-08$

ANÁLISE DE CORRELAÇÃO

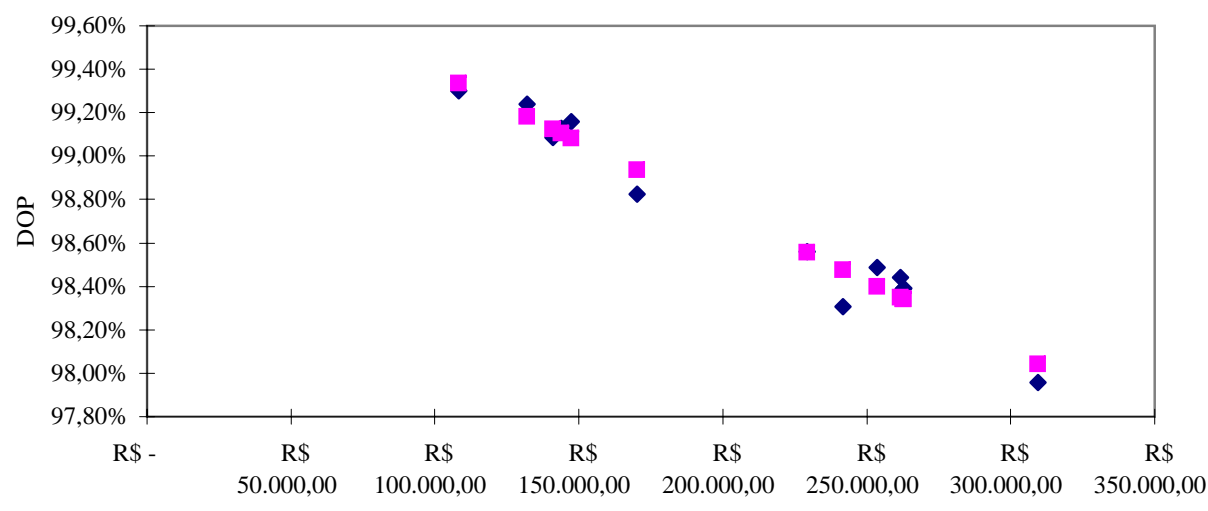

CTM 
RESUMO DOS RESULTADOS: DOP x CTMUP

\begin{tabular}{lr}
\hline \multicolumn{2}{c}{ Estatística de regressão } \\
\hline R múltiplo & 0,941387715 \\
R-Quadrado & 0,88621083 \\
R-quadrado ajustado & 0,875866361 \\
Erro padrão & 0,001521917 \\
Observações & 13 \\
\hline
\end{tabular}

\begin{tabular}{|c|c|c|}
\hline $\mathbf{r}$ & tn-2 Calculado & tn-2 Crítico \\
\hline$-0,94139$ & $-9,25581$ & $-2,20099$ \\
\hline \multicolumn{3}{|c|}{ tn-2 Calc < tn-2 Crit Min } \\
\hline \multicolumn{2}{|c|}{ Evidências de Correlação Linear Negativa } \\
\hline
\end{tabular}

ANOVA

\begin{tabular}{lccccc}
\hline & $g l$ & $S Q$ & $M Q$ & $F$ & F de significação \\
\hline Regressão & 1 & 0,000198432 & 0,000198432 & 85,67000862 & $1,5921 \mathrm{E}-06$ \\
Resíduo & 11 & $2,54785 \mathrm{E}-05$ & $2,31623 \mathrm{E}-06$ & & \\
Total & 12 & 0,00022391 & & & \\
\hline
\end{tabular}

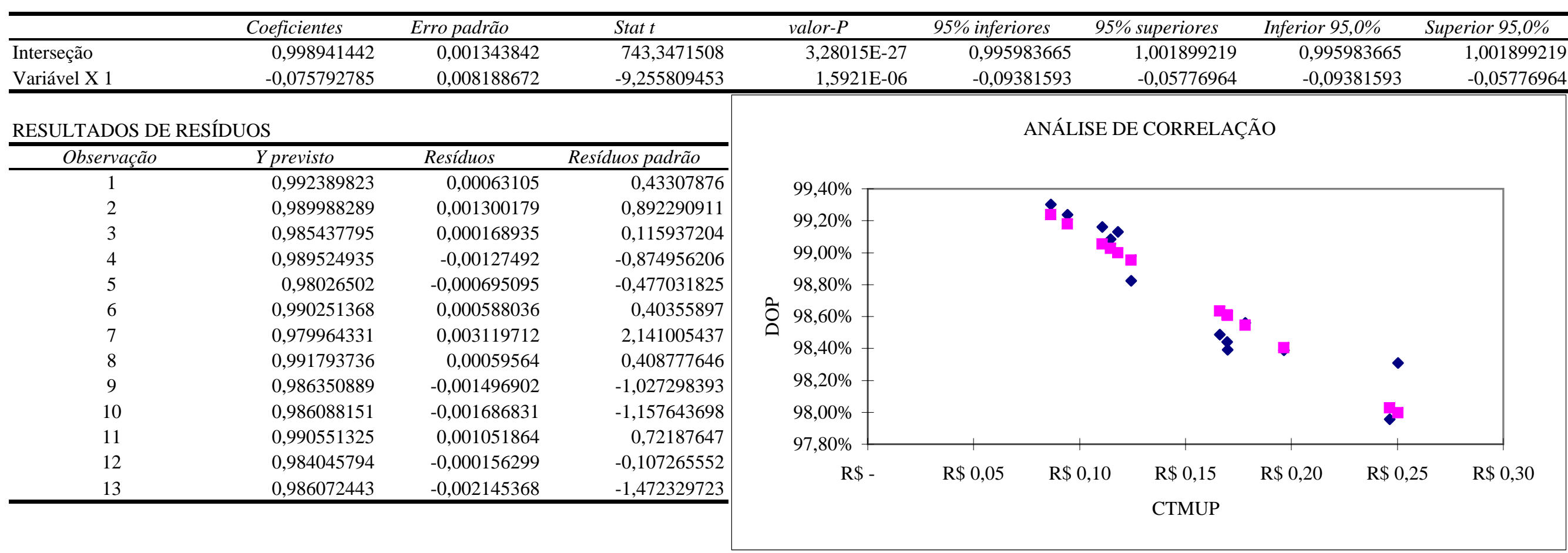




\section{RESUMO DOS RESULTADOS: DOP x CMUP}

\begin{tabular}{lr}
\hline \multicolumn{2}{c}{ Estatística de regressão } \\
\hline R múltiplo & 0,028302321 \\
R-Quadrado & 0,000801021 \\
R-quadrado ajustado & $-0,090035249$ \\
Erro padrão & 0,004509896 \\
Observações & 13 \\
\hline
\end{tabular}

\begin{tabular}{|c|c|c|}
\hline $\mathbf{r}$ & tn-2 Calculado & tn-2 Crítico \\
\hline$-0,02830$ & $-0,09391$ & $-2,20099$ \\
\hline \multicolumn{3}{|c|}{ tn-2 Calc > tn-2 Crit Min } \\
\hline \multicolumn{3}{|c|}{ Não há correlação Linear } \\
\hline
\end{tabular}

ANOVA

\begin{tabular}{lccccr}
\hline & gl & SQ & MQ & F & F de significação \\
\hline Regressão & 1 & $1,79357 \mathrm{E}-07$ & $1,79357 \mathrm{E}-07$ & 0,008818299 & 0,926872639 \\
Resíduo & 11 & 0,000223731 & $2,03392 \mathrm{E}-05$ & & \\
Total & 12 & 0,00022391 & & & \\
\hline
\end{tabular}

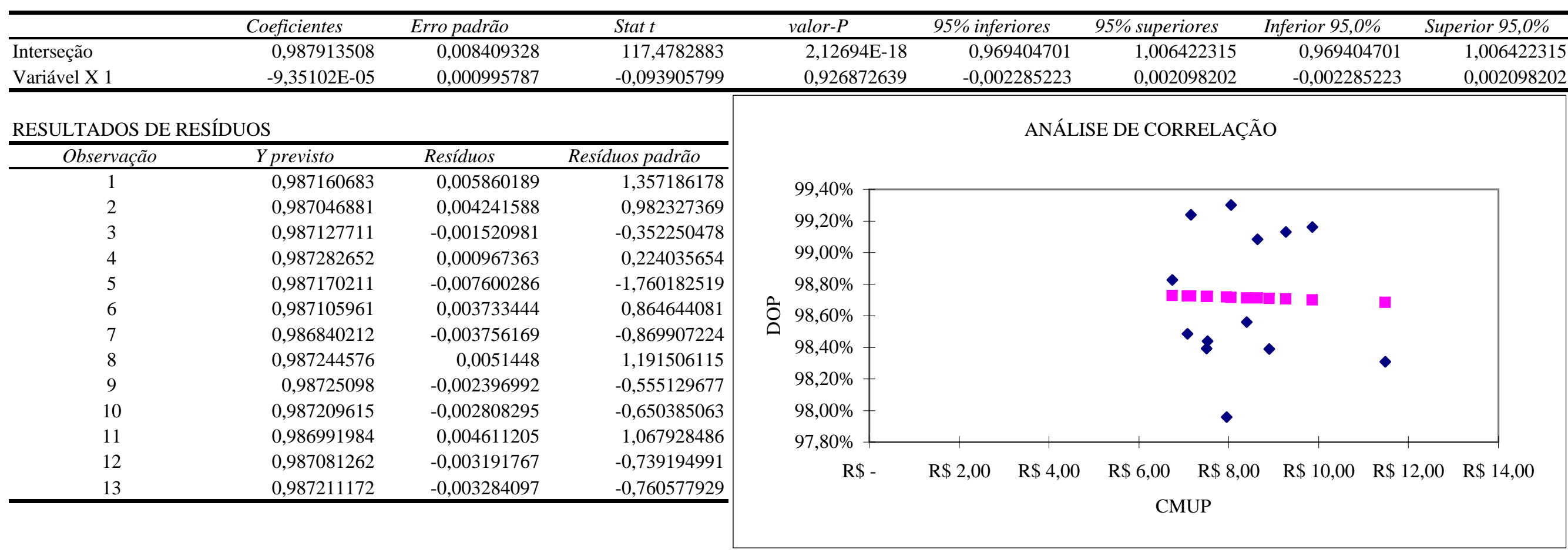




\begin{tabular}{|c|c|c|}
\hline \multirow{2}{*}{ MESES } & QUAL & VEL \\
\cline { 2 - 3 } & DOP & TMDR \\
\hline jun/04 & $99,30 \%$ & 3,19 \\
jul/04 & $99,13 \%$ & 3,43 \\
ago/04 & $98,56 \%$ & 4,09 \\
set/04 & $98,83 \%$ & 3,01 \\
out/04 & $97,96 \%$ & 10,34 \\
nov/04 & $99,08 \%$ & 4,49 \\
dez/04 & $98,31 \%$ & 6,74 \\
jan/05 & $99,24 \%$ & 2,41 \\
fev/05 & $98,49 \%$ & 4,79 \\
mar/05 & $98,44 \%$ & 4,65 \\
abr/05 & $99,16 \%$ & 3,13 \\
mai/05 & $98,39 \%$ & 7,03 \\
jun/05 & $98,39 \%$ & 6,21 \\
\hline
\end{tabular}

\begin{tabular}{|c|c|c|c|c|c|c|}
\hline \multicolumn{7}{|c|}{ ANÁLISE ENTRE INDICADORES - QUALIDADE/VELOCIDADE } \\
\hline Variáveis & $\mathbf{r}$ & tn-2 Calc & tn-2 Crit & Comparação & Conclusão & Consistência da Relação \\
\hline DOP-TMDR & $-0,8619$ & $-5,6373$ & $-2,2010$ & tn-2 Calc $<$ tn-2 Crit Min & Evidências de Correlação Linear Negativa & V \\
\hline
\end{tabular}


RESUMO DOS RESULTADOS: DOP x TMDR

\begin{tabular}{lr}
\hline \multicolumn{2}{c}{ Estatística de regressão } \\
\hline R múltiplo & 0,861896248 \\
R-Quadrado & 0,742865143 \\
R-quadrado ajustado & 0,719489246 \\
Erro padrão & 0,002287815 \\
Observações & 13 \\
\hline
\end{tabular}

\begin{tabular}{|c|c|c|}
\hline $\mathbf{r}$ & tn-2 Calculado & tn-2 Crítico \\
\hline$-0,86190$ & $-5,63730$ & $-2,20099$ \\
\hline \multicolumn{3}{|c|}{ tn-2 Calc < tn-2 Crit Min } \\
\hline \multicolumn{2}{|c|}{ Evidências de Correlação Linear Negativa } \\
\hline
\end{tabular}

ANOVA

\begin{tabular}{|c|c|c|c|c|c|}
\hline & gl & $S Q$ & $M Q$ & $F$ & F de significação \\
\hline Regressão & 1 & 0,000166335 & 0,000166335 & 31,77910864 & 0,000151651 \\
\hline Resíduo & 11 & 5,75751E-05 & 5,2341E-06 & & \\
\hline Total & 12 & 0,00022391 & & & \\
\hline
\end{tabular}

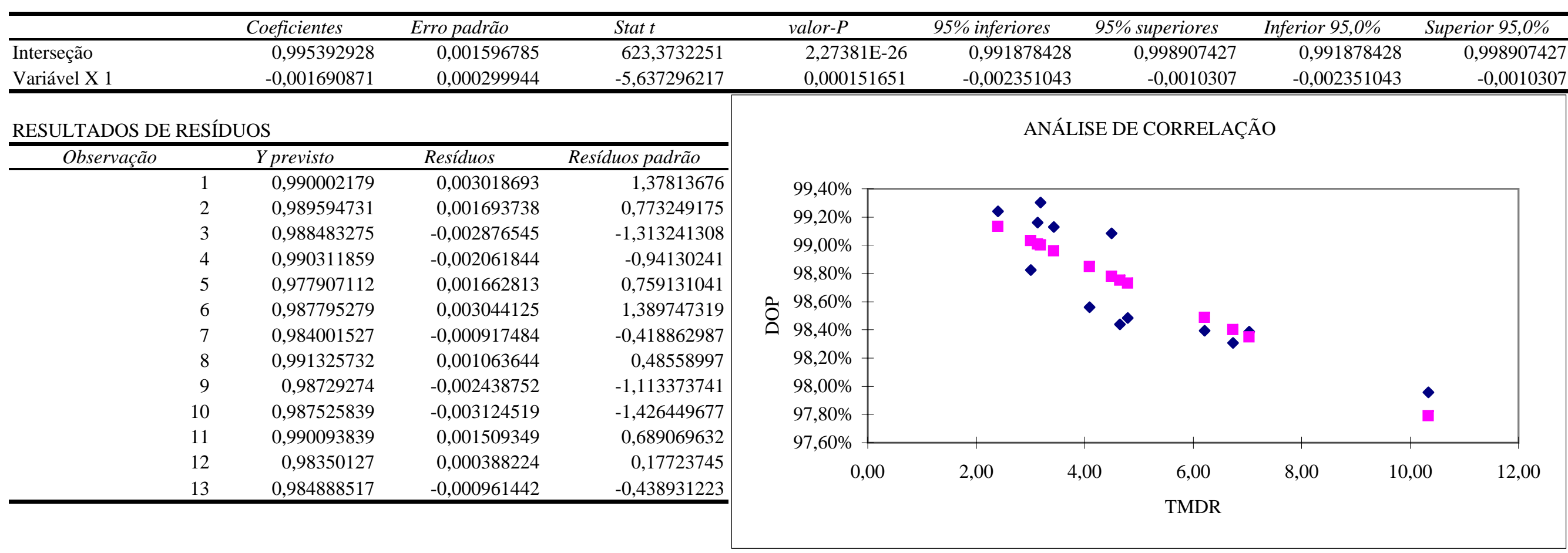




\begin{tabular}{|c|c|c|}
\hline \multirow{2}{*}{ MESES } & QUAL & CONF \\
\cline { 2 - 3 } & DOP & TMEF \\
\hline jun/04 & $99,30 \%$ & 587,33 \\
jul/04 & $99,13 \%$ & 405,56 \\
ago/04 & $98,56 \%$ & 412,13 \\
set/04 & $98,83 \%$ & 371,99 \\
out/04 & $97,96 \%$ & 646,79 \\
nov/04 & $99,08 \%$ & 588,61 \\
dez/04 & $98,31 \%$ & 663,77 \\
jan/05 & $99,24 \%$ & 474,08 \\
fev/05 & $98,49 \%$ & 433,44 \\
mar/05 & $98,44 \%$ & 421,70 \\
abr/05 & $99,16 \%$ & 410,55 \\
mai/05 & $98,39 \%$ & 555,59 \\
jun/05 & $98,39 \%$ & 455,54 \\
\hline
\end{tabular}

\begin{tabular}{|c|c|c|c|c|c|c|}
\hline \multicolumn{7}{|c|}{ ANÁLISE ENTRE INDICADORES - QUALIDADE/CONFIABILIDADE } \\
\hline Variáveis & $\mathbf{r}$ & tn-2 Calc & tn-2 Crit & Comparação & Conclusão & Consistência da Relação \\
\hline DOP x TMEF & $-0,2962$ & $-1,0285$ & $-2,2010$ & tn-2 Calc > tn-2 Crit Min & Não há correlação Linear & V \\
\hline
\end{tabular}




\section{RESUMO DOS RESULTADOS: DOP x TMEF}

\begin{tabular}{lr}
\hline \multicolumn{2}{c}{ Estatística de regressão } \\
\hline R múltiplo & 0,296200977 \\
R-Quadrado & 0,087735019 \\
R-quadrado ajustado & 0,004801838 \\
Erro padrão & 0,004309243 \\
Observações & 13 \\
\hline
\end{tabular}

\begin{tabular}{|c|c|c|}
\hline $\mathbf{r}$ & tn-2 Calculado & tn-2 Crítico \\
\hline$-0,29620$ & $-1,02854$ & $-2,20099$ \\
\hline \multicolumn{3}{|c|}{ tn-2 Calc > tn-2 Crit Min } \\
\hline \multicolumn{3}{|c|}{ Não há correlação Linear } \\
\hline
\end{tabular}

ANOVA

\begin{tabular}{lccccr}
\hline & $g l$ & $S Q$ & $M Q$ & $F$ & F de significação \\
\hline Regressão & 1 & $1,96448 \mathrm{E}-05$ & $1,96448 \mathrm{E}-05$ & 1,057900088 & 0,325780574 \\
Resíduo & 11 & 0,000204265 & $1,85696 \mathrm{E}-05$ & & \\
Total & 12 & 0,00022391 & & & \\
\hline
\end{tabular}

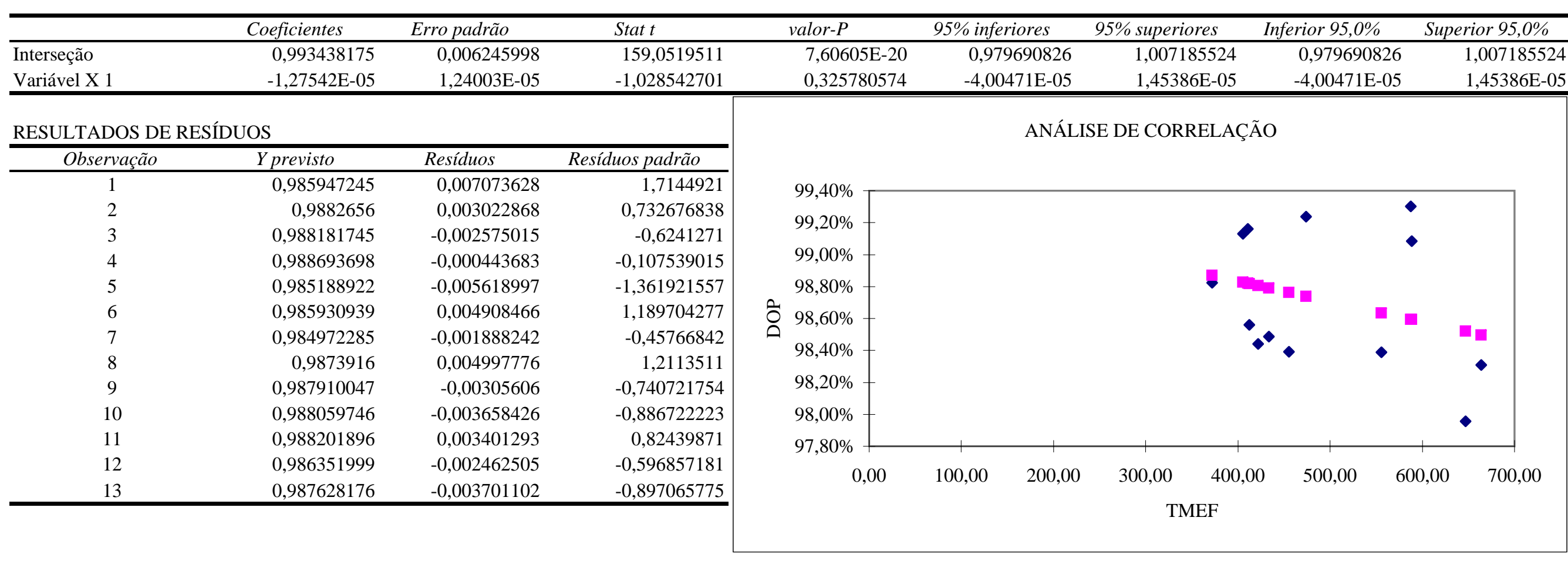




\begin{tabular}{|c|c|c|}
\hline \multirow{2}{*}{ MESES } & VEL & CONF \\
\cline { 2 - 3 } & TMDR & TMEF \\
\hline jun/04 & 3,19 & 587,33 \\
jul/04 & 3,43 & 405,56 \\
ago/04 & 4,09 & 412,13 \\
set/04 & 3,01 & 371,99 \\
out/04 & 10,34 & 646,79 \\
nov/04 & 4,49 & 588,61 \\
dez/04 & 6,74 & 663,77 \\
jan/05 & 2,41 & 474,08 \\
fev/05 & 4,79 & 433,44 \\
mar/05 & 4,65 & 421,70 \\
abr/05 & 3,13 & 410,55 \\
mai/05 & 7,03 & 555,59 \\
jun/05 & 6,21 & 455,54 \\
\hline
\end{tabular}

\begin{tabular}{|c|c|c|c|c|c|c|}
\hline \multicolumn{7}{|c|}{ ANÁLISE ENTRE INDICADORES - VELOCIDADE/CONFIABILIDADE } \\
\hline Variáveis & $\mathbf{r}$ & tn-2 Calc & tn-2 Crit & Comparação & Conclusão & Consistência da Relação \\
\hline TMDR x TMEF & 0,6321 & 2,7053 & 2,2010 & tn-2 Calc > tn-2 Crit Max & Evidências de Correlação Linear Positiva & V \\
\hline
\end{tabular}


RESUMO DOS RESULTADOS: TMDR x TMEF

\begin{tabular}{lr}
\hline \multicolumn{2}{c}{ Estatística de regressão } \\
\hline R múltiplo & 0,632078816 \\
R-Quadrado & 0,39952363 \\
R-quadrado ajustado & 0,344934869 \\
Erro padrão & 1,782103295 \\
Observações & 13 \\
\hline
\end{tabular}

\begin{tabular}{|c|c|c|}
\hline $\mathbf{r}$ & tn-2 Calculado & tn-2 Crítico \\
\hline 0,63208 & 2,70533 & 2,20099 \\
\hline \multicolumn{3}{|c|}{ tn-2 Calc > tn-2 Crit Max } \\
\hline \multicolumn{2}{|c|}{ Evidências de Correlação Linear Positiva } \\
\hline
\end{tabular}

ANOVA

\begin{tabular}{lccccc}
\hline & $g l$ & $S Q$ & $M Q$ & $F$ & F de significação \\
\hline Regressão & 1 & 23,24368498 & 23,24368498 & 7,318789127 & 0,020461079 \\
Resíduo & 11 & 34,93481371 & 3,175892155 & & \\
Total & 12 & 58,17849868 & & & \\
\hline
\end{tabular}

\begin{tabular}{|c|c|c|c|c|c|c|c|c|}
\hline & Coeficientes & Erro padrão & Stat $t$ & valor-P & 95\% inferiores & 95\% superiores & Inferior $95,0 \%$ & Superior 95,0\% \\
\hline Interseção & $-1,973637826$ & 2,583055332 & $-0,76407106$ & 0,460900562 & $-7,658904276$ & 3,711628623 & $-7,658904276$ & 3,711628623 \\
\hline Variável X 1 & 0,013873406 & 0,005128183 & 2,705326067 & 0,020461079 & 0,002586352 & 0,02516046 & 0,002586352 & 0,02516046 \\
\hline
\end{tabular}

\section{RESULTADOS DE RESÍDUOS}

\begin{tabular}{crrr}
\hline Observação & Y previsto & \multicolumn{1}{c}{ Resíduos } & \multicolumn{1}{c}{ Resíduos padrão } \\
\hline 1 & 6,174623152 & $-2,986475004$ & $-1,75033143$ \\
2 & 3,652831309 & $-0,223713662$ & $-0,131115464$ \\
3 & 3,744044818 & 0,342399626 & 0,200675655 \\
4 & 3,187168333 & $-0,182168333$ & $-0,106766324$ \\
5 & 6,999488531 & 3,341815817 & 1,958591734 \\
6 & 6,192359971 & $-1,699026638$ & $-0,995775863$ \\
7 & 7,235136041 & $-0,498136041$ & $-0,2919506$ \\
8 & 4,603525217 & $-2,198140601$ & $-1,28829961$ \\
9 & 4,039584501 & 0,750956039 & 0,440124882 \\
10 & 3,876748808 & 0,775934119 & 0,454764186 \\
11 & 3,72212603 & $-0,588186636$ & $-0,344728$ \\
12 & 5,734350911 & 1,298506232 & 0,761036428 \\
13 & 4,346189161 & 1,866235082 & 1,093774405 \\
\hline
\end{tabular}

ANÁLISE DE CORRELAÇÃO

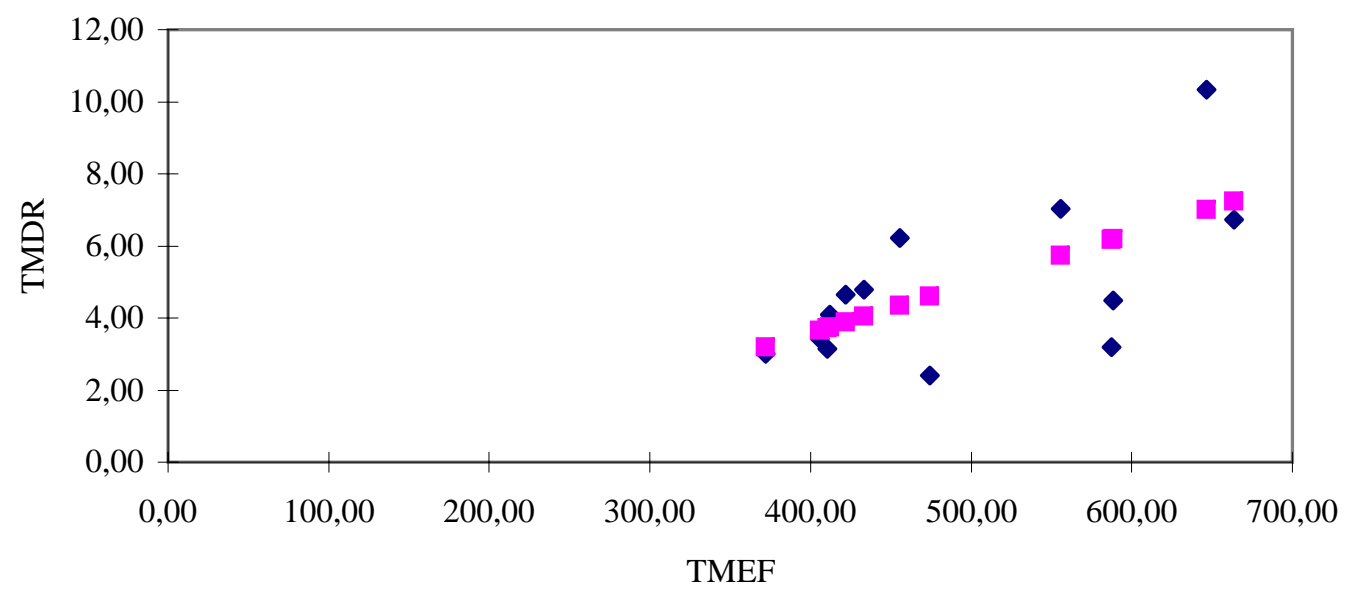




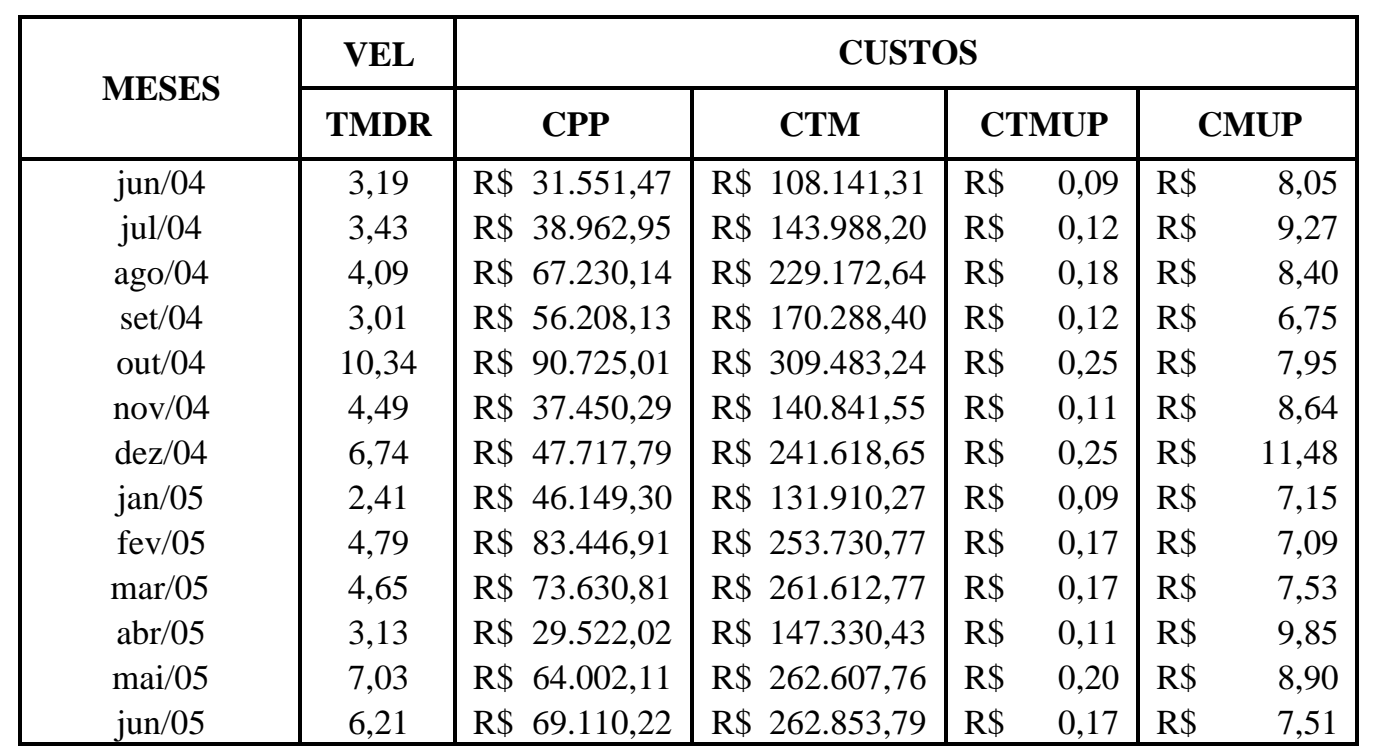

\begin{tabular}{|c|c|c|c|c|c|c|}
\hline \multicolumn{7}{|c|}{ ANÁLISE ENTRE INDICADORES - VELOCIDADE/CUSTOS } \\
\hline Variáveis & $\mathbf{r}$ & tn-2 Calc & tn-2 Crit & Comparação & Conclusão & Consistência da Relação \\
\hline TMDR x CPP & 0,6427 & 2,7824 & 2,2010 & tn-2 Calc > tn-2 Crit Max & Evidências de Correlação Linear Positiva & $\mathrm{V}$ \\
\hline TMDR x CTM & 0,8191 & 4,7358 & 2,2010 & tn-2 Calc > tn-2 Crit Max & Evidências de Correlação Linear Positiva & $\mathrm{V}$ \\
\hline TMDR x CTMUP & 0,8698 & 5,8469 & 2,2010 & tn-2 Calc > tn-2 Crit Max & Evidências de Correlação Linear Positiva & $\mathrm{V}$ \\
\hline TMDR x CMUP & 0,1837 & 0,6198 & 2,2010 & tn-2 Calc $<$ tn-2 Crit Max & Não há correlação Linear & $\mathrm{V}$ \\
\hline
\end{tabular}




\section{RESUMO DOS RESULTADOS: TMDR x CPP}

\begin{tabular}{lr}
\hline \multicolumn{2}{c}{ Estatística de regressão } \\
\hline R múltiplo & 0,642702959 \\
R-Quadrado & 0,413067093 \\
R-quadrado ajustado & 0,359709556 \\
Erro padrão & 1,761891425 \\
Observações & 13 \\
\hline
\end{tabular}

\begin{tabular}{|c|c|c|}
\hline $\mathbf{r}$ & tn-2 Calculado & tn-2 Crítico \\
\hline 0,64270 & 2,78235 & 2,20099 \\
\hline \multicolumn{3}{|c|}{ tn-2 Calc > tn-2 Crit Max } \\
\hline \multicolumn{2}{|c|}{ Evidências de Correlação Linear Positiva } \\
\hline
\end{tabular}

ANOVA

\begin{tabular}{|c|c|c|c|c|c|}
\hline & $g l$ & $S Q$ & $M Q$ & $F$ & $F$ de significação \\
\hline Regressão & 1 & 24,03162334 & 24,03162334 & 7,741494765 & 0,017828686 \\
\hline Resíduo & 11 & 34,14687535 & 3,104261395 & & \\
\hline Total & 12 & 58,17849868 & & & \\
\hline
\end{tabular}

\begin{tabular}{|c|c|c|c|c|c|c|c|c|}
\hline & Coeficientes & Erro padrão & Stat $t$ & valor-P & 95\% inferiores & 95\% superiores & Inferior $95,0 \%$ & Superior 95,0\% \\
\hline Interseção & 0,849790897 & 1,530481415 & 0,555244179 & 0,589840572 & $-2,518775984$ & 4,218357778 & $-2,518775984$ & 4,218357778 \\
\hline Variável X 1 & 7,13068E-05 & 2,56282E-05 & 2,782354177 & 0,017828686 & 1,48994E-05 & 0,000127714 & 1,48994E-05 & 0,000127714 \\
\hline
\end{tabular}

\section{RESULTADOS DE RESÍDUOS}

\begin{tabular}{rrrrr}
\hline Observação & \multicolumn{1}{c}{ Y previsto } & \multicolumn{1}{c}{ Resíduos } & \multicolumn{1}{c}{ Resíduos padrão } \\
\hline 1 & 3,099624159 & 0,088523989 & 0,05247786 \\
2 & 3,628112984 & $-0,198995337$ & $-0,117966322$ \\
3 & 5,64375424 & $-1,557309796$ & $-0,923188007$ \\
4 & 4,857810491 & $-1,852810491$ & $-1,09836362$ \\
5 & 7,319097565 & 3,022206783 & 1,791592824 \\
6 & 3,520249987 & 0,973083346 & 0,57685303 \\
7 & 4,252392033 & 2,484607967 & 1,472899151 \\
8 & 4,140547743 & $-1,735163127$ & $-1,028621147$ \\
9 & 6,800119719 & $-2,009579179$ & $-1,191297583$ \\
10 & 6,100165742 & $-1,447482815$ & $-0,858081532$ \\
11 & 2,954910654 & 0,17902874 & 0,106129934 \\
12 & 5,413574376 & 1,619282767 & 0,959926171 \\
13 & 5,777817089 & 0,434607154 & 0,25763924 \\
\hline
\end{tabular}

ANÁLISE DE CORRELAÇAO

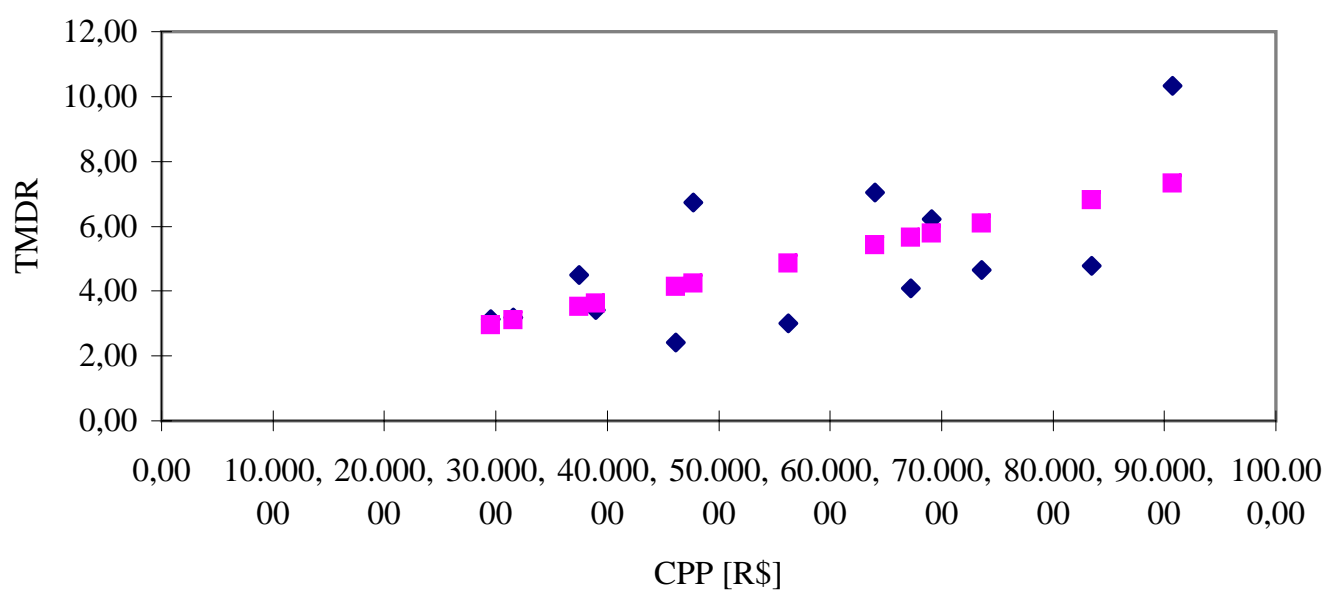




\section{RESUMO DOS RESULTADOS: TMDR x CTM}

\begin{tabular}{lr}
\hline \multicolumn{2}{c}{ Estatística de regressão } \\
\hline R múltiplo & 0,819105394 \\
R-Quadrado & 0,670933646 \\
R-quadrado ajustado & 0,641018523 \\
Erro padrão & 1,319248631 \\
Observações & 13 \\
\hline
\end{tabular}

\begin{tabular}{|c|c|c|}
\hline $\mathbf{r}$ & tn-2 Calculado & tn-2 Crítico \\
\hline 0,81911 & 4,73581 & 2,20099 \\
\hline \multicolumn{3}{|c|}{ tn-2 Calc > tn-2 Crit Max } \\
\hline \multicolumn{2}{|c|}{ Evidências de Correlação Linear Positiva } \\
\hline
\end{tabular}

ANOVA

\begin{tabular}{|c|c|c|c|c|c|}
\hline & gl & $S Q$ & $M Q$ & $F$ & $F$ de significação \\
\hline Regressão & 1 & 39,03391223 & 39,03391223 & 22,42790856 & 0,000613574 \\
\hline Resíduo & 11 & 19,14458646 & 1,740416951 & & \\
\hline Total & 12 & 58,17849868 & & & \\
\hline
\end{tabular}

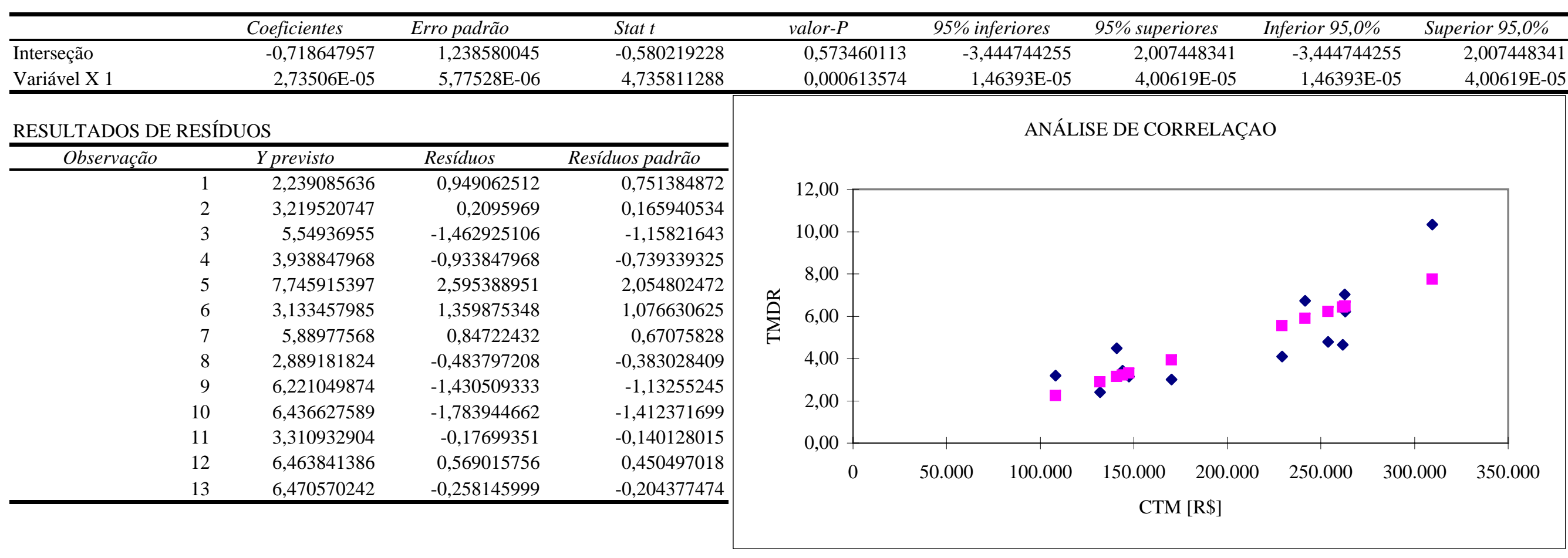


RESUMO DOS RESULTADOS: TMDR x CTMUP

\begin{tabular}{lr}
\hline \multicolumn{2}{c}{ Estatística de regressão } \\
\hline R múltiplo & 0,869804764 \\
R-Quadrado & 0,756560328 \\
R-quadrado ajustado & 0,734429449 \\
Erro padrão & 1,134698783 \\
Observações & 13 \\
\hline
\end{tabular}

\begin{tabular}{|c|c|c|}
\hline $\mathbf{r}$ & tn-2 Calculado & tn-2 Crítico \\
\hline 0,86980 & 5,84686 & 2,20099 \\
\hline \multicolumn{3}{|c|}{ tn-2 Calc > tn-2 Crit Max } \\
\hline \multicolumn{2}{|c|}{ Evidências de Correlação Linear Positiva } \\
\hline
\end{tabular}

ANOVA

\begin{tabular}{|c|c|c|c|c|c|}
\hline & gl & $S Q$ & $M Q$ & $F$ & F de significação \\
\hline Regressão & 1 & 44,01554407 & 44,01554407 & 34,18573297 & 0,000111399 \\
\hline Resíduo & 11 & 14,16295462 & 1,287541329 & & \\
\hline Total & 12 & 58,17849868 & & & \\
\hline
\end{tabular}

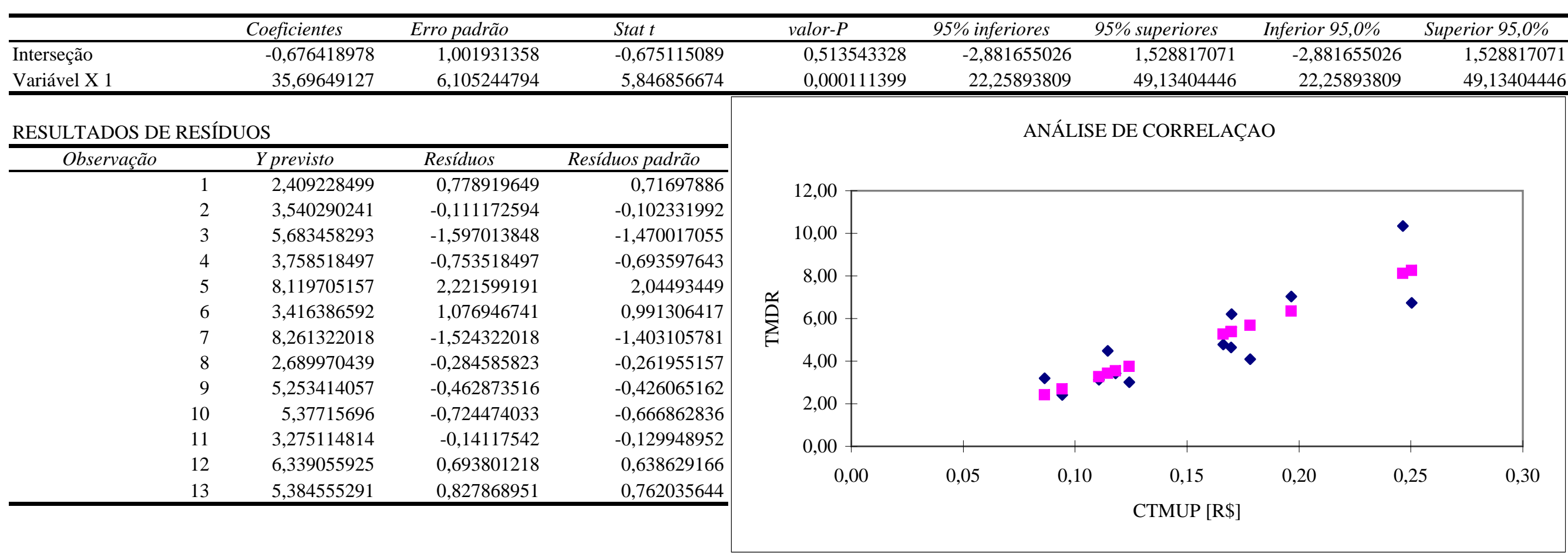


RESUMO DOS RESULTADOS: TMDR x CMUP

\begin{tabular}{lr}
\hline \multicolumn{2}{c}{ Estatística de regressão } \\
\hline R múltiplo & 0,183692382 \\
R-Quadrado & 0,033742891 \\
R-quadrado ajustado & $-0,054098664$ \\
Erro padrão & 2,260639249 \\
Observações & 13 \\
\hline
\end{tabular}

\begin{tabular}{|c|c|c|}
\hline $\mathbf{r}$ & tn-2 Calculado & tn-2 Crítico \\
\hline 0,18369 & 0,61979 & 2,20099 \\
\hline \multicolumn{3}{|c|}{ tn-2 Calc < tn-2 Crit Max } \\
\hline \multicolumn{3}{|c|}{ Não há correlação Linear } \\
\hline
\end{tabular}

ANOVA

\begin{tabular}{|c|c|c|c|c|c|}
\hline & $g l$ & $S Q$ & $M Q$ & $F$ & $F$ de significação \\
\hline Regressão & 1 & 1,963110748 & 1,963110748 & 0,38413358 & 0,548022702 \\
\hline Resíduo & 11 & 56,21538794 & 5,110489812 & & \\
\hline Total & 12 & 58,17849868 & & & \\
\hline
\end{tabular}

\begin{tabular}{|c|c|c|c|c|c|c|c|c|}
\hline & Coeficientes & Erro padrão & Stat $t$ & valor-P & 95\% inferiores & 95\% superiores & Inferior $95,0 \%$ & Superior $95,0 \%$ \\
\hline Interseção & 2,301740754 & 4,21527663 & 0,546047379 & 0,595934033 & $-6,976020549$ & 11,57950206 & $-6,976020549$ & 11,57950206 \\
\hline Variável X 1 & 0,30936586 & 0,499150199 & 0,619785108 & 0,548022702 & $-0,78925632$ & 1,407988039 & $-0,78925632$ & 1,407988039 \\
\hline
\end{tabular}

\section{RESULTADOS DE RESÍDUOS}

\begin{tabular}{rrrrr}
\hline Observação & \multicolumn{1}{c}{ Y previsto } & \multicolumn{1}{c}{ Resíduos } & \multicolumn{1}{c}{ Resíduos padrão } \\
\hline 1 & 4,792359654 & $-1,604211506$ & $-0,741181625$ \\
2 & 5,168860565 & $-1,739742918$ & $-0,803800171$ \\
3 & 4,901443462 & $-0,814999018$ & $-0,376547789$ \\
4 & 4,388842656 & $-1,383842656$ & $-0,639366283$ \\
5 & 4,760839909 & 5,580464439 & 2,578299486 \\
6 & 4,973402124 & $-0,480068791$ & $-0,221802527$ \\
7 & 5,852596635 & 0,884403365 & 0,408614151 \\
8 & 4,514812213 & $-2,109427597$ & $-0,974602768$ \\
9 & 4,493625837 & 0,296914704 & 0,137181239 \\
10 & 4,630474098 & 0,022208829 & 0,010260976 \\
11 & 5,350478389 & $-2,216538995$ & $-1,024090631$ \\
12 & 5,055115217 & 1,977741926 & 0,91376104 \\
13 & 4,625326024 & 1,587098218 & 0,733274903 \\
\hline
\end{tabular}

ANÁLISE DE CORRELAÇAO

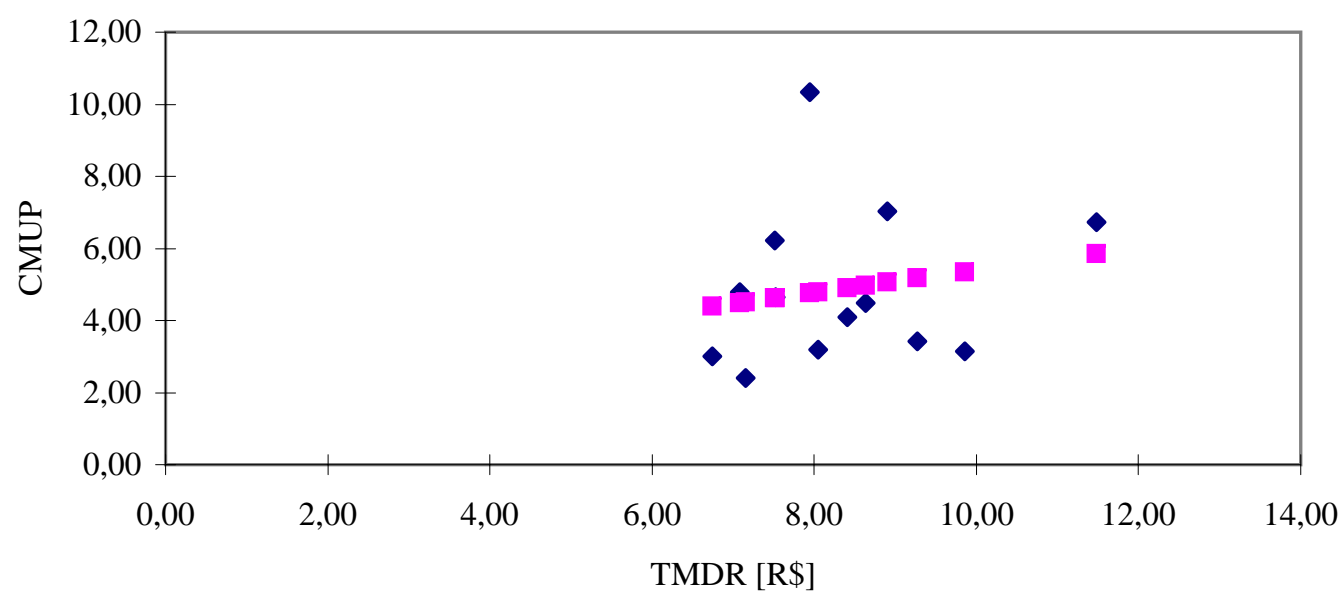




\begin{tabular}{|c|c|c|c|c|c|}
\hline \multirow{2}{*}{ MESES } & \multicolumn{4}{|c|}{ CUSTOS } & \multirow{2}{*}{$\frac{\text { CONF }}{\text { TMEF }}$} \\
\hline & CPP & СТM & CTMUP & CMUP & \\
\hline jun/04 & $\mathrm{R} \$ 31.551,47$ & $\mathrm{R} \$ 108.141,31$ & $\mathrm{R} \$ 0,09$ & 8,05 & 587,33 \\
\hline $\mathrm{jul} / 04$ & $\mathrm{R} \$ 38.962,95$ & $R \$ 143.988,20$ & $\mathrm{R} \$ 0,12$ & 9,27 & 405,56 \\
\hline ago/04 & $\mathrm{R} \$ 67.230,14$ & R\$2 229.172,64 & $\mathrm{R} \$ 0,18$ & 8,40 & 412,13 \\
\hline set/04 & $\mathrm{R} \$ 56.208,13$ & $\mathrm{R} \$ 170.288,40$ & $\mathrm{R} \$ 0,12$ & 6,75 & 371,99 \\
\hline out/04 & $\mathrm{R} \$ 90.725,01$ & $\mathrm{R} \$ 309.483,24$ & $\mathrm{R} \$ 0,25$ & 7,95 & 646,79 \\
\hline nov/04 & $\mathrm{R} \$ 37.450,29$ & $\mathrm{R} \$ 140.841,55$ & $\mathrm{R} \$ 0,11$ & 8,64 & 588,61 \\
\hline dez/04 & $\mathrm{R} \$ 47.717,79$ & R\$ 241.618,65 & $\mathrm{R} \$ 0,25$ & 11,48 & 663,77 \\
\hline jan/05 & $\mathrm{R} \$ 46.149,30$ & $\mathrm{R} \$ 131.910,27$ & $\mathrm{R} \$ 0,09$ & 7,15 & 474,08 \\
\hline fev/05 & R\$ 83.446,91 & R\$ 253.730,77 & $\mathrm{R} \$ 0,17$ & 7,09 & 433,44 \\
\hline $\mathrm{mar} / 05$ & R\$ 73.630,81 & $\mathrm{R} \$ 261.612,77$ & $\mathrm{R} \$ 0,17$ & 7,53 & 421,70 \\
\hline abr/05 & $\mathrm{R} \$ 29.522,02$ & $\mathrm{R} \$ 147.330,43$ & $\mathrm{R} \$ 0,11$ & 9,85 & 410,55 \\
\hline mai/05 & $\mathrm{R} \$ 64.002,11$ & $\mathrm{R} \$ 262.607,76$ & $\mathrm{R} \$ 0,20$ & 8,90 & 555,59 \\
\hline jun/05 & $\mathrm{R} \$ 69.110,22$ & $\mathrm{R} \$ 262.853,79$ & $\mathrm{R} \$ 0,17$ & 7,51 & 455,54 \\
\hline
\end{tabular}

\begin{tabular}{|c|c|c|c|c|l|c|}
\hline \multicolumn{7}{|c|}{ ANÁLISE ENTRE INDICADORES - CUSTOS/CONFIABILIDADE } \\
\hline Variáveis & $\mathbf{r}$ & tn-2 Calc & tn-2 Crit & Comparação & Conclusão & Consistência da Relação \\
\hline CPP x TMEF & $-0,0051$ & $-0,0168$ & $-2,2010$ & tn-2 Calc > tn-2 Crit Min & Não há correlação Linear & V \\
\hline CTM x TMEF & 0,1924 & 0,6501 & 2,2010 & tn-2 Calc < tn-2 Crit Max & Não há correlação Linear & V \\
\hline CTMUP x TMEF & 0,4680 & 1,7563 & 2,2010 & tn-2 Calc < tn-2 Crit Max & Não há correlação Linear & V \\
\hline CMUP x TMEF & 0,4317 & 1,5874 & 2,2010 & tn-2 Calc < tn-2 Crit Max & Não há correlação Linear & V \\
\hline
\end{tabular}




\section{RESUMO DOS RESULTADOS: CPP x TMEF}

\begin{tabular}{lr}
\hline \multicolumn{2}{c}{ Estatística de regressão } \\
\hline R múltiplo & 0,005066929 \\
R-Quadrado & $2,56738 \mathrm{E}-05$ \\
R-quadrado ajustado & $-0,090881083$ \\
Erro padrão & 20728,07295 \\
Observações & 13 \\
\hline
\end{tabular}

\begin{tabular}{|c|c|c|}
\hline $\mathbf{r}$ & tn-2 Calculado & tn-2 Crítico \\
\hline$-0,00507$ & $-0,01681$ & $-2,20099$ \\
\hline \multicolumn{3}{|c|}{ tn-2 Calc > tn-2 Crit Min } \\
\hline \multicolumn{3}{|c|}{ Não há correlação Linear } \\
\hline
\end{tabular}

ANOVA

\begin{tabular}{lcclrr}
\hline & gl & SQ & $M Q$ & $F$ & F de significação \\
\hline Regressão & 1 & 121342,0458 & 121342,0458 & 0,000282419 & 0,986892869 \\
Resíduo & 11 & 4726183092 & 429653008,3 & & \\
Total & 12 & 4726304434 & & & \\
\hline
\end{tabular}

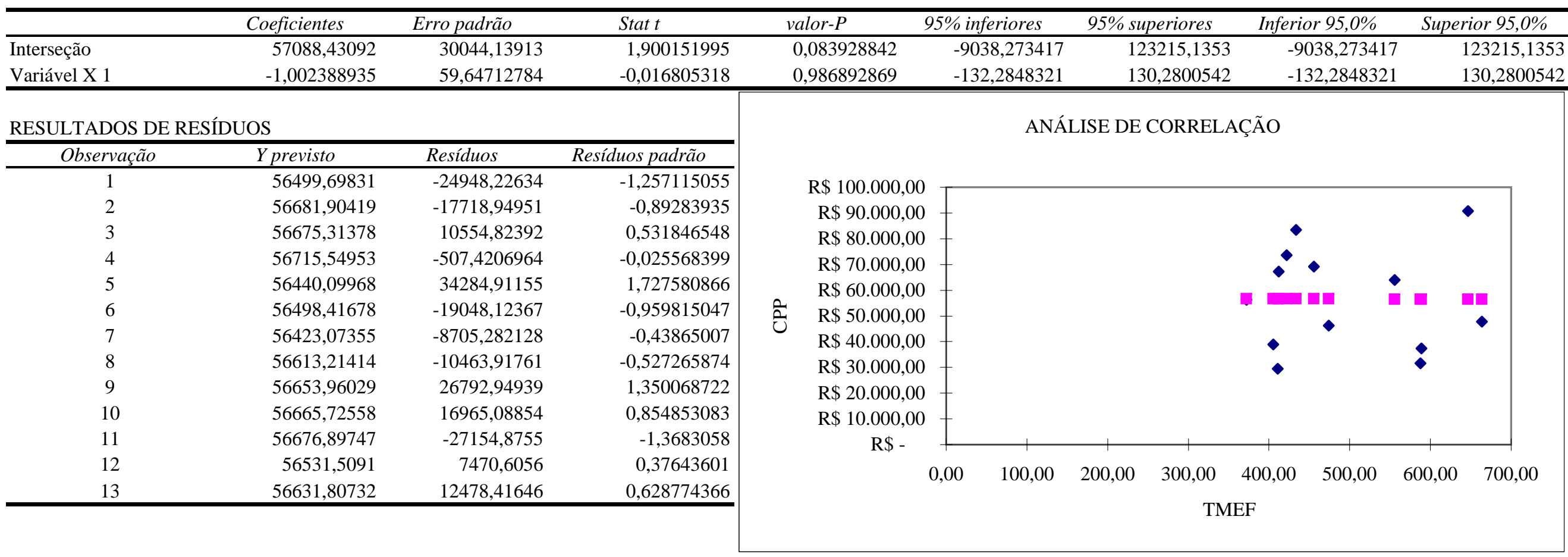




\section{RESUMO DOS RESULTADOS: CTM x TMEF}

\begin{tabular}{lr}
\hline \multicolumn{2}{c}{ Estatística de regressão } \\
\hline R múltiplo & 0,192358313 \\
R-Quadrado & 0,037001721 \\
R-quadrado ajustado & $-0,050543577$ \\
Erro padrão & 67588,06706 \\
Observações & 13 \\
\hline
\end{tabular}

\begin{tabular}{|c|c|c|}
\hline $\mathbf{r}$ & tn-2 Calculado & tn-2 Crítico \\
\hline 0,19236 & 0,65012 & 2,20099 \\
\hline \multicolumn{3}{|c|}{ tn-2 Calc < tn-2 Crit Max } \\
\hline \multicolumn{3}{|c|}{ Não há correlação Linear } \\
\hline
\end{tabular}

ANOVA

\begin{tabular}{lcccrr}
\hline & gl & $S Q$ & $M Q$ & $F$ & F de significação \\
\hline Regressão & 1 & 1930763796 & 1930763796 & 0,422658001 & 0,528957466 \\
Resíduo & 11 & 50249614899 & 4568146809 & & \\
Total & 12 & 52180378695 & & & \\
\hline
\end{tabular}

\begin{tabular}{|c|c|c|c|c|c|c|c|c|}
\hline & Coeficientes & Erro padrão & Stat $t$ & valor-P & 95\% inferiores & 95\% superiores & Inferior $95,0 \%$ & Superior $95,0 \%$ \\
\hline Interseção & 142378,4586 & 97964,98185 & 1,453360741 & 0,174050228 & $-73241,01251$ & 357997,9297 & $-73241,01251$ & 357997,9297 \\
\hline Variável X 1 & 126,4431134 & 194,4915036 & 0,650121528 & 0,528957466 & $-301,6297996$ & 554,5160264 & $-301,6297996$ & 554,5160264 \\
\hline
\end{tabular}

RESULTADOS DE RESÍDUOS

\begin{tabular}{crrr}
\hline Observação & Y previsto & \multicolumn{1}{c}{ Resíduos } & \multicolumn{1}{c}{ Resíduos padrão } \\
\hline 1 & 216642,2322 & $-108500,9221$ & $-1,676708952$ \\
2 & 193658,4595 & $-49670,26389$ & $-0,767574824$ \\
3 & 194489,7853 & 34682,85782 & 0,535968332 \\
4 & 189414,3772 & $-19125,98059$ & $-0,29556157$ \\
5 & 224160,1082 & 85323,13015 & 1,318533091 \\
6 & 216803,8867 & $-75962,33686$ & $-1,173876939$ \\
7 & 226307,8148 & 15310,83256 & 0,236604533 \\
8 & 202323,1448 & $-70412,874$ & $-1,088118828$ \\
9 & 197183,3529 & 56547,41479 & 0,873850238 \\
10 & 195699,2579 & 65913,50988 & 1,018588321 \\
11 & 194290,016 & $-46959,58891$ & $-0,725685659$ \\
12 & 212629,5627 & 49978,20196 & 0,772333516 \\
13 & 199977,7674 & 62876,01915 & 0,97164874 \\
\hline
\end{tabular}

\section{ANÁLISE DE CORRELAÇÃO}

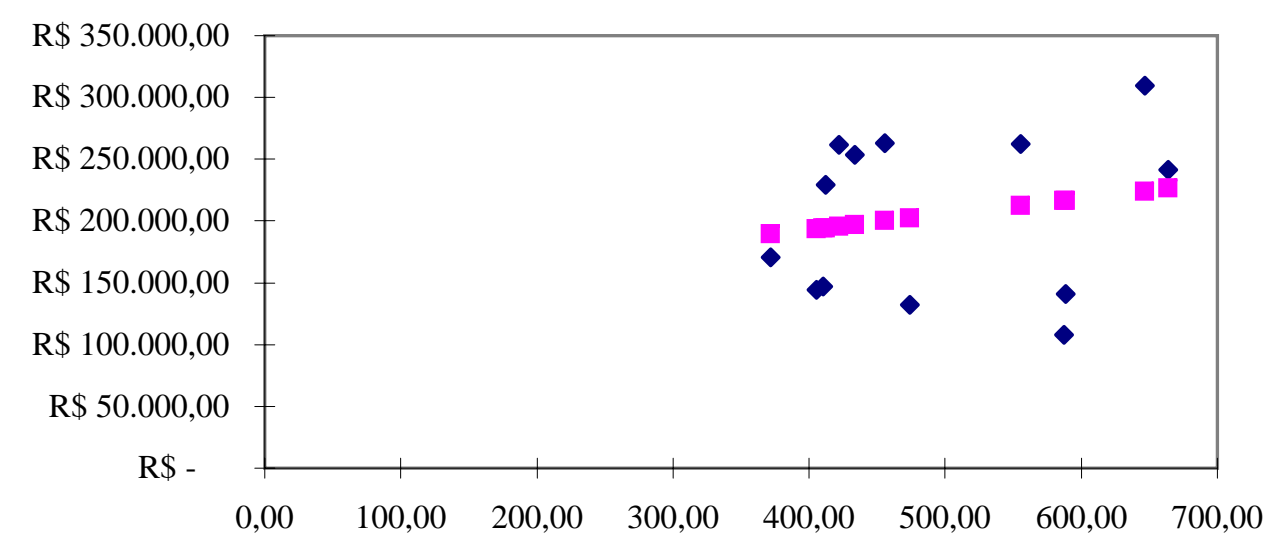

TMEF 


\section{RESUMO DOS RESULTADOS: CTMUP x TMEF}

\begin{tabular}{lr}
\hline \multicolumn{2}{c}{ Estatística de regressão } \\
\hline R múltiplo & 0,467969478 \\
R-Quadrado & 0,218995432 \\
R-quadrado ajustado & 0,147995017 \\
Erro padrão & 0,049523115 \\
Observações & 13 \\
\hline
\end{tabular}

\begin{tabular}{|c|c|c|}
\hline $\mathbf{r}$ & tn-2 Calculado & tn-2 Crítico \\
\hline 0,46797 & 1,75625 & 2,20099 \\
\hline \multicolumn{3}{|c|}{ tn-2 Calc < tn-2 Crit Max } \\
\hline \multicolumn{3}{|c|}{ Não há correlação Linear } \\
\hline
\end{tabular}

ANOVA

\begin{tabular}{lcclrr}
\hline & gl & $S Q$ & $M Q$ & $F$ & F de significação \\
\hline Regressão & 1 & 0,007564671 & 0,007564671 & 3,084424667 & 0,106810539 \\
Resíduo & 11 & 0,026977928 & 0,002452539 & & \\
Total & 12 & 0,034542599 & & & \\
\hline
\end{tabular}

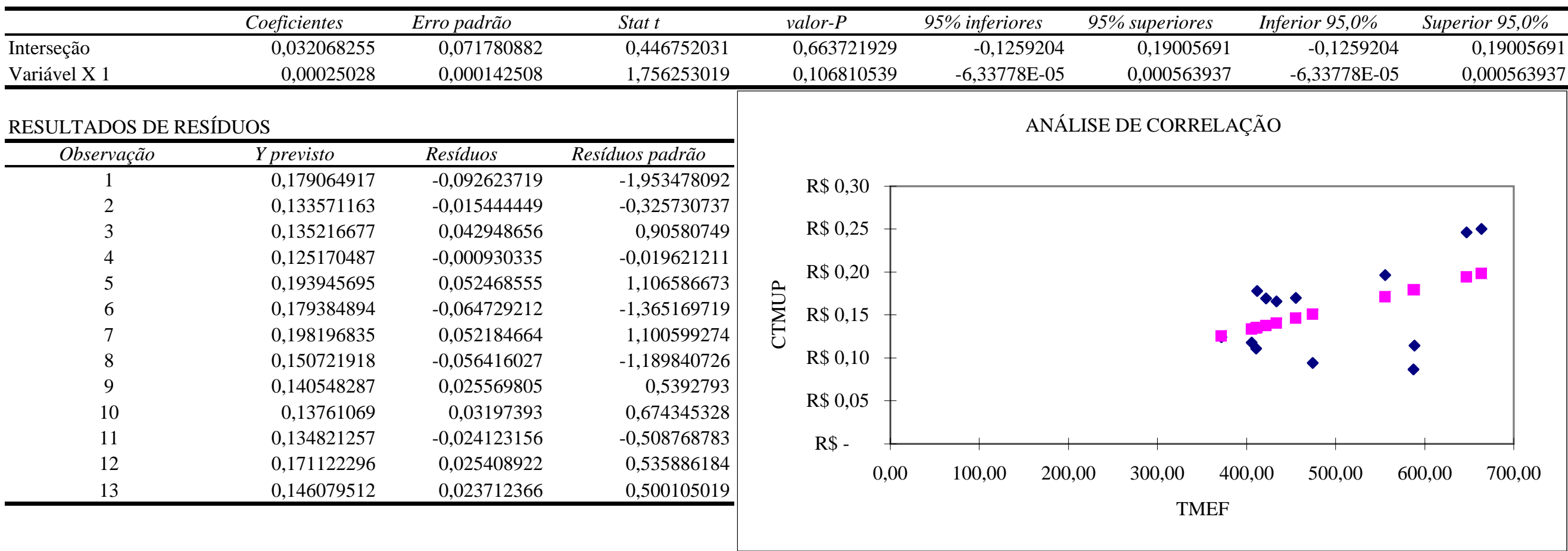




\section{RESUMO DOS RESULTADOS: CMUP x TMEF}

\begin{tabular}{lr}
\hline \multicolumn{2}{c}{ Estatística de regressão } \\
\hline R múltiplo & 0,431713967 \\
R-Quadrado & 0,186376949 \\
R-quadrado ajustado & 0,112411218 \\
Erro padrão & 1,231729363 \\
Observações & 13 \\
\hline
\end{tabular}

\begin{tabular}{|c|c|c|}
\hline $\mathbf{r}$ & tn-2 Calculado & tn-2 Crítico \\
\hline 0,43171 & 1,58738 & 2,20099 \\
\hline \multicolumn{3}{|c|}{ tn-2 Calc < tn-2 Crit Max } \\
\hline \multicolumn{3}{|c|}{ Não há correlação Linear } \\
\hline
\end{tabular}

ANOVA

\begin{tabular}{lcclrr}
\hline & gl & $S Q$ & $M Q$ & $F$ & F de significação \\
\hline Regressão & 1 & 3,822893762 & 3,822893762 & 2,519774289 & 0,140733888 \\
Resíduo & 11 & 16,68872945 & 1,517157223 & & \\
Total & 12 & 20,51162321 & & & \\
\hline
\end{tabular}

\begin{tabular}{|c|c|c|c|c|c|c|c|c|}
\hline & Coeficientes & Erro padrão & Stat $t$ & valor-P & 95\% inferiores & 95\% superiores & Inferior $95,0 \%$ & Superior $95,0 \%$ \\
\hline Interseção & 5,569350803 & 1,785320248 & 3,119524808 & 0,009758258 & 1,639887434 & 9,498814172 & 1,639887434 & 9,498814172 \\
\hline Variável X 1 & 0,00562635 & 0,003544426 & 1,587379693 & 0,140733888 & $-0,002174879$ & 0,013427579 & $-0,002174879$ & 0,013427579 \\
\hline
\end{tabular}

RESULTADOS DE RESÍDUOS

\begin{tabular}{crrr}
\hline Observação & \multicolumn{1}{c}{ Y previsto } & \multicolumn{1}{c}{ Resíduos } & \multicolumn{1}{c}{ Resíduos padrão } \\
\hline 1 & 8,873872096 & $-0,823148913$ & $-0,69800317$ \\
2 & 7,851161255 & 1,416570525 & 1,201205154 \\
3 & 7,888152827 & 0,5151749 & 0,436851349 \\
4 & 7,662311974 & $-0,915924696$ & $-0,776673979$ \\
5 & 9,208395649 & $-1,25955748$ & $-1,068063263$ \\
6 & 8,88106525 & $-0,245136997$ & $-0,207868101$ \\
7 & 9,303962324 & 2,173890735 & 1,843387752 \\
8 & 8,236714475 & $-1,08314084$ & $-0,918467762$ \\
9 & 8,008008729 & $-0,922918334$ & $-0,782604353$ \\
10 & 7,941970833 & $-0,414529554$ & $-0,351507411$ \\
11 & 7,879263678 & 1,975532957 & 1,675186889 \\
12 & 8,69532001 & 0,204739176 & 0,173612078 \\
13 & 8,132352025 & $-0,621551477$ & $-0,527055184$ \\
\hline
\end{tabular}

ANÁLISE DE CORRELAÇÃO

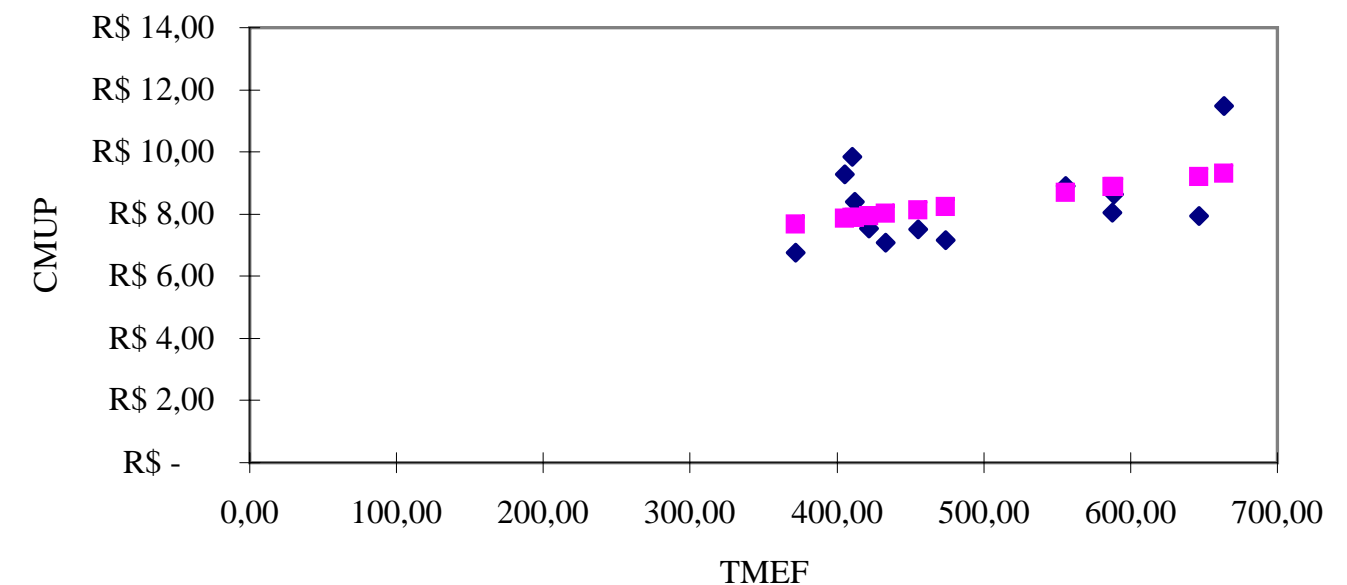


DISTRIBUIÇÃO BI-CAUDAL DE STUDENT

SIGNIFICÂNCIA

\begin{tabular}{|c|c|c|c|c|c|c|c|c|c|c|}
\hline G L & $5 \%$ & $10 \%$ & $15 \%$ & $20 \%$ & $25 \%$ & $30 \%$ & $35 \%$ & $40 \%$ & $45 \%$ & $50 \%$ \\
\hline 1 & 12,7062 & 6,3138 & 4,1653 & 3,0777 & 2,4142 & 1,9626 & 1,6319 & 1,3764 & 1,1708 & 1,0000 \\
\hline 2 & 4,3027 & 2,9200 & 2,2819 & 1,8856 & 1,6036 & 1,3862 & 1,2096 & 1,0607 & 0,9313 & 0,8165 \\
\hline 3 & 3,1824 & 2,3534 & 1,9243 & 1,6377 & 1,4226 & 1,2498 & 1,1045 & 0,9785 & 0,8664 & 0,7649 \\
\hline 4 & 2,7764 & 2,1318 & 1,7782 & 1,5332 & 1,3444 & 1,1896 & 1,0573 & 0,9410 & 0,8364 & 0,7407 \\
\hline 5 & 2,5706 & 2,0150 & 1,6994 & 1,4759 & 1,3009 & 1,1558 & 1,0305 & 0,9195 & 0,8191 & 0,7267 \\
\hline 6 & 2,4469 & 1,9432 & 1,6502 & 1,4398 & 1,2733 & 1,1342 & 1,0133 & 0,9057 & 0,8079 & 0,7176 \\
\hline 7 & 2,3646 & 1,8946 & 1,6166 & 1,4149 & 1,2543 & 1,1192 & 1,0014 & 0,8960 & 0,8000 & 0,7111 \\
\hline 8 & 2,3060 & 1,8595 & 1,5922 & 1,3968 & ,2403 & 1,1081 & 0,9925 & 0,8889 & 0,7942 & 0,7064 \\
\hline 9 & 2622 & 1,8331 & 1,5737 & 1,3830 & 1,2297 & 1,0997 & 0,9858 & 0,8834 & 0,7897 & 0,7027 \\
\hline 10 & 2,2281 & 1,8125 & 1,5592 & 1,3722 & 1,2213 & 1,0931 & 0,9804 & 0,8791 & 0,7862 & 0,6998 \\
\hline 11 & 2,2010 & 1,7959 & 1,5476 & 1,3634 & 1,2145 & 1,0877 & 0,9761 & 0,8755 & 0,7833 & 0,6974 \\
\hline 12 & 2,1788 & 1,7823 & 1,5380 & 1,3562 & 1,2089 & 1,0832 & 0,9725 & 0,8726 & 0,7809 & 0,6955 \\
\hline 13 & 2,1604 & 1,7709 & 1,5299 & 1,3502 & 1,2041 & 1,0795 & 0,9695 & 0,8702 & 0,7789 & 0,6938 \\
\hline 14 & 2,1448 & 1,7613 & 1,5231 & 1,3450 & 1,2001 & 1,0763 & 0,9669 & 0,8681 & 0,7772 & 0,6924 \\
\hline 15 & 2,1314 & 1,7531 & 1,5172 & 1,3406 & 1,1967 & 1,0735 & 0,9647 & 0,8662 & 0,7757 & 0,6912 \\
\hline 16 & 2,1199 & 1,7459 & 1,5121 & 1,3368 & 1,1937 & 1,0711 & 0,9627 & 0,8647 & 0,7744 & 0,6901 \\
\hline 17 & 2,1098 & 1,7396 & 1,5077 & 1,3334 & 1,1910 & 1,0690 & 0,9610 & 0,8633 & 0,7732 & 0,6892 \\
\hline 18 & 2,1009 & 1,7341 & 1,5037 & 1,3304 & 1,1887 & 1,0672 & 0,9595 & 0,8620 & 0,7722 & 0,6884 \\
\hline 19 & 2,0930 & 1,7291 & 1,5002 & 1,3277 & 1,1866 & 1,0655 & 0,9582 & 0,8610 & 0,7713 & 0,6876 \\
\hline 20 & 2,0860 & 1,7247 & 1,4970 & 1,3253 & 1,1848 & 1,0640 & 0,9570 & 0,8600 & 0,7705 & 0,6870 \\
\hline 21 & 2,0796 & 1,7207 & 1,4942 & 1,3232 & 1,1831 & 1,0627 & 0,9559 & 0,8591 & 0,7698 & 0,6864 \\
\hline 22 & 2,0739 & 1,7171 & 1,4916 & 1,3212 & 1,1815 & 1,0614 & 0,9549 & 0,8583 & 0,7691 & 0,6858 \\
\hline 23 & 2,0687 & 1,7139 & 1,4893 & 1,3195 & 1,1802 & 1,0603 & 0,9540 & 0,8575 & 0,7685 & 0,6853 \\
\hline 24 & 2,0639 & 1,7109 & 1,4871 & 178 & 1,1789 & 1,0593 & 0,9532 & 0,8569 & 0,7680 & 0,6848 \\
\hline 25 & 2,0595 & 1,7081 & 1,4852 & 1,3163 & 1,1777 & 1,0584 & 0,9524 & 0,8562 & 0,7675 & 0,6844 \\
\hline
\end{tabular}

Fonte: Microsoft Office Excel 2003 